Facultad de Arquitectura y Urbanismo Universidad Nacional de La Plata
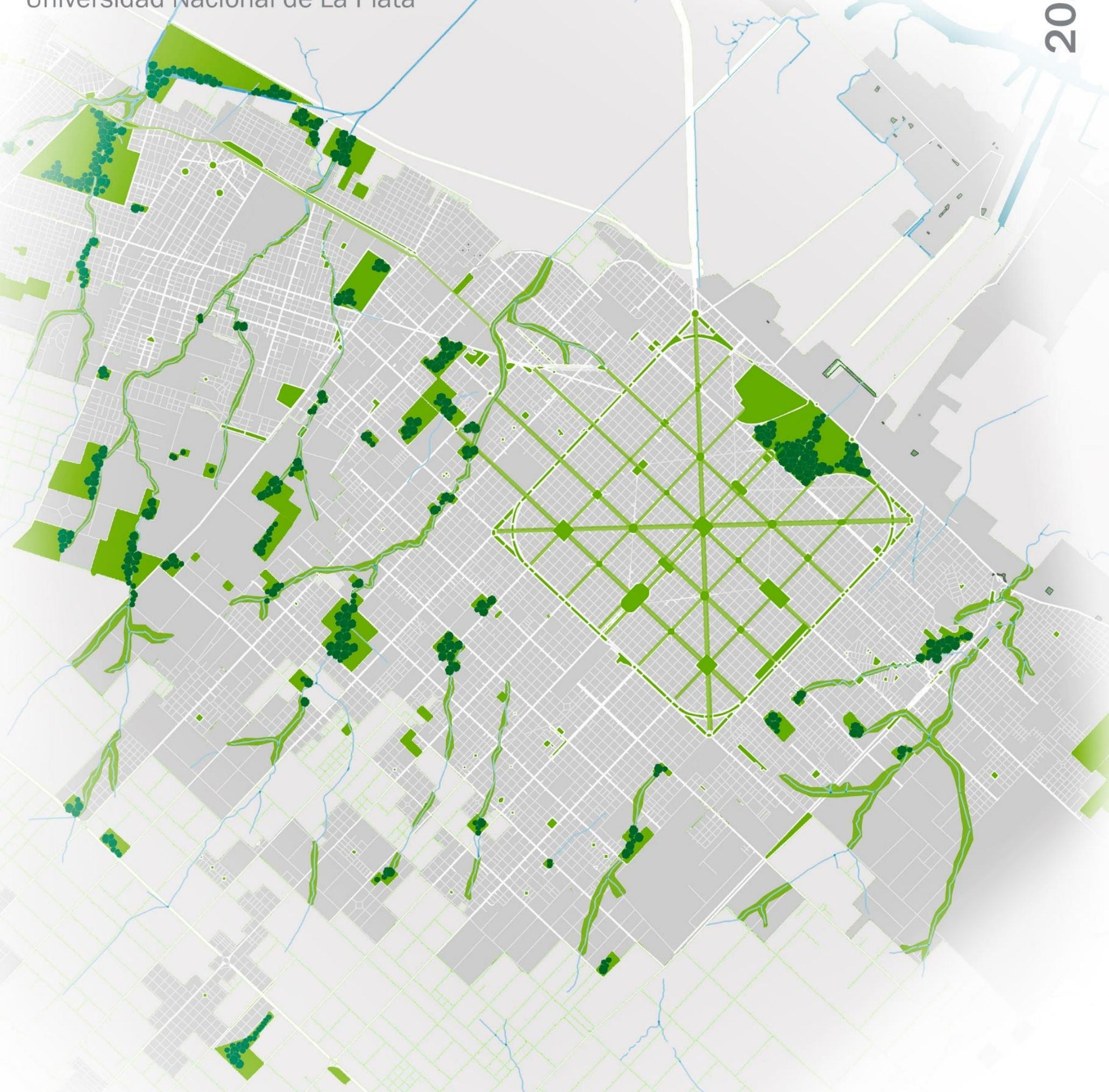

\title{
PAISAJES VACANTES
}

El paisaje y los espacios verdes en la periferia platense 


\title{
PAISAJES VACANTES
}

El paisaje y los espacios verdes en la periferia platense

Tesis doctoral presentada por

\section{KARINA JENSEN}

\author{
ante la \\ Facultad de Arquitectura y Urbanismo de la \\ Universidad Nacional de La Plata \\ para acceder al grado académico de \\ DOCTOR EN ARQUITECTURA Y URBANISMO
}

Directora: Prof. Arq. Olga Ravella

Codirectora: Dr. Geog. Julieta Frediani

La Plata, Argentina

Julio, 2018 


\section{INDICE}

INDICE DE FIGURAS

INDICE DE TABLAS $\quad 7$

ABREVIATURAS

INTRODUCCION 11

ESTRUCTURA DE LA TESIS 14

PARTE I EL PAISAJE, LOS ESPACIOS VERDES Y LAS TIERRAS VACANTES EN LA EXPANSIÓN URBANA

CAPITULO 1 I APROXIMACIONES TEÒRICO CONCEPTUALES

1.1| Antecedentes del tema

Paisaje, implementación y gestión territorial

1.2 | Aproximación teórica conceptual de la cuestión urbana desde la perspectiva del paisaje

Las periferias como nuevas formas de ocupación

La expansión urbana y las transformaciones en los espacios verdes a partir de la década del '90 55

Los espacios verdes como elemento esencial del derecho a la ciudad 61

$\begin{array}{ll}\text { El verde como infraestructura urbana } & 67\end{array}$

1.3 I El cambio climático y la resiliencia urbana 69

1.4 I Las tierras vacantes como espacios de oportunidad 73

1.5 | Paisajes vacantes 76

CAPITULO 2 I ABORDAJE METODOLÓGICO

$2.1 \mid$ El nivel superior de análisis, matriz contextual 85

2.2 | El nivel de análisis focal, matriz de anclaje 96

2.3 | El nivel inferior de análisis, matriz de componentes 101

PARTE II LA PERIFERIA PLATENSE Y LOS ESPACIOS VERDES

CAPITULO 3 I MAS ALLA DEL CASCO FUNDACIONAL. TRANSFORMACIONES EN LA PERIFERIA PLATENSE

3.1 La región de estudio

3.2 Los espacios verdes en la conformación de la ciudad

El arbolado urbano como elemento estructurador en la ciudad:

La evolución en el tiempo

3.3 | El avance de la frontera urbana

3.4 | La periferia platense

La fragmentación urbana 
4.1 Los espacios verdes y el paisaje en la periferia platense. Relevamiento de los espacios verdes.

Tipos de paisaje

4.2 | La falta de espacios verdes de uso público 149

Radios de cobertura 156

Áreas criticas 159

PARTE III LOS NUEVOS ESPACIOS VERDES DE USO PÚBLICO

\section{CAPITULO 5 I LOS NUEVOS ESPACIOS VERDES DESDE ELPAISAJE}

5.1 | Tipos de espacios verdes Públicos

Espacios flexibles como herramientas para la diversidad

5.2 | Las tierras vacantes como Espacios verdes potenciales

5.3 | Calidad de paisaje de las tierras vacantes aptas para ser incorporadas como espacios verdes

CAPITULO 6 I HACIA UN SISTEMA DE ESPACIOS VERDES EN LA PERIFERIA PLATENSE

6.1 | Los espacios verdes como resiliencia al cambio climático

6.2 | Categorías de intervención y recuperación para las tierras vacantes

6.3 | Criterios de diseño

CAPITULO 7 I CONCLUSIONES

7.1 I Consideraciones finales

Aspectos teórico-conceptuales

Aspectos metodológicos

Aspectos empíricos o referidos al caso de estudio

7.2 I Reflexiones del proceso y futuras líneas de trabajo

ANEXO 1

ANEXO 2

ANEXO 3 


\section{RESUMEN}

Con el propósito de establecer lineamientos para conformar un sistema de espacios verdes, en la presente tesis doctoral se aborda el estudio del proceso de expansión urbana en la periferia platense desde el concepto de paisaje. Para tal fin se propone indagar sobre el rol de las tierras vacantes y los espacios verdes como elementos clave en los procesos de expansión urbana ya que le brindan calidad y cualidad a la ciudad con incidencia sobre la vida colectiva. La hipótesis que guía la investigación plantea que la integración de las tierras vacantes a un sistema de espacios verdes, permite mejorar la calidad la calidad del paisaje urbano colaborando con la mitigación de los efectos del cambio climático. Para dar respuesta a los objetivos e hipótesis, la metodología propone un abordaje sistémico donde se concibe a la ciudad como un sistema complejo y se adopta como método la triangulación metodológica. Con el fin de incorporar las tierras vacantes a un sistema de espacios verdes que mejore la calidad del paisaje urbano como así también contribuya a mitigar los efectos del cambio climático se elaboran categorías de recuperación e intervención en base a la calidad de paisaje.

\section{ABSTRACT}

With the purpose of establishing guidelines to form a system of green spaces, in the present doctoral thesis the study of the process of urban expansion in the platense periphery from the concept of landscape is addressed. For this purpose, it is proposed to investigate the role of vacant lands and green spaces as key elements in urban expansion processes, since they provide quality and quality to the city with an impact on collective life. The hypothesis that guides the research proposes that the integration of vacant lands into a system of green spaces, allows to improve the quality of the urban landscape quality, collaborating with the mitigation of the effects of climate change. In order to respond to the objectives and hypotheses, the methodology proposes a systemic approach where the city is conceived as a complex system and methodological triangulation is adopted as a method. In order to incorporate vacant lands into a system of green spaces that improve the quality of the urban landscape as well as contribute to mitigate the effects of climate change, recovery and intervention categories are elaborated based on the quality of the landscape. 


\section{INDICE DE FIGURAS}

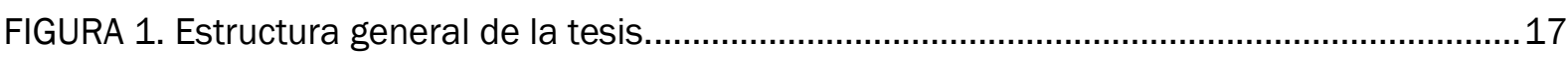

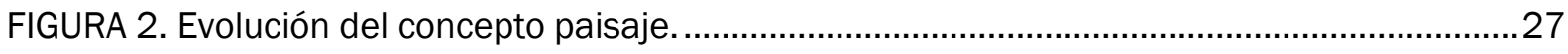

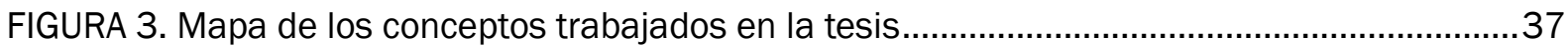

FIGURA 4. El modelo de desarrollo estructural de la ciudad latinoamericana...............................37

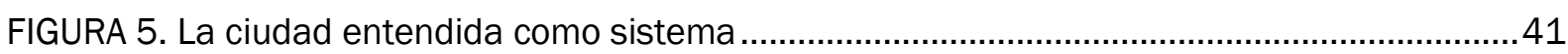

FIGURA 6. Relaciones de los subsistemas de la ciudad. ............................................................ 42

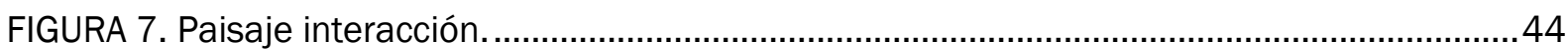

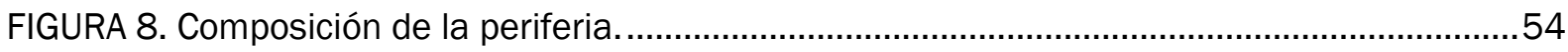

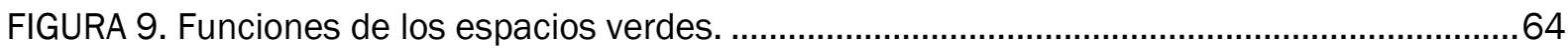

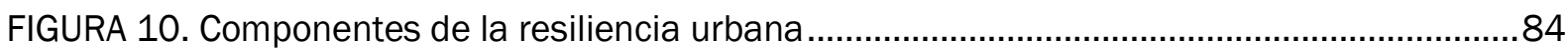

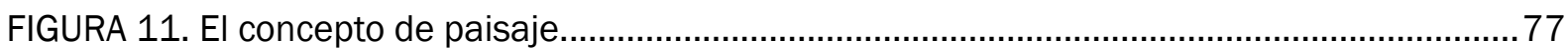

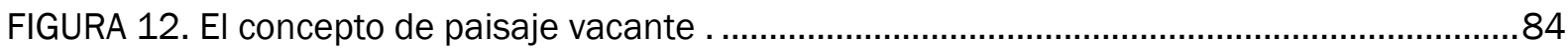

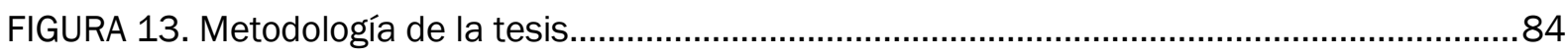

FIGURA 14. Metodologia y universo de analisis de la encuesta..................................................86

FIGURA 15. Secuencia cronológica del proceso de crecimiento de la Ciudad de La Plata. ...........86

FIGURA 16. Unidades de paisaje y tipo de paisaje.................................................................. 88

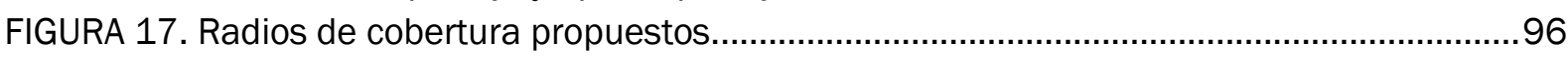

FIGURA 18. Parámetros para la selección de tierras vacantes. ....................................................98

FIGURA 19. La región de estudio en relación al territorio nacional.............................................. 106

FIGURA 20. LA PLATA: circunvalación - eje monumental - red ortogonal de avenidas - sistema de

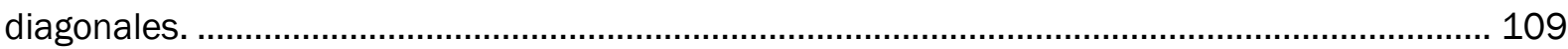

FIGURA 21. Secuencia cronológica del proceso de crecimiento de la Ciudad de La Plata. ........ 110

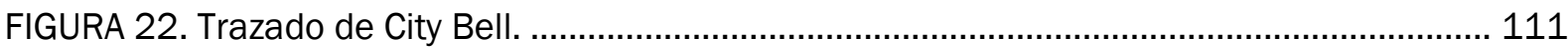

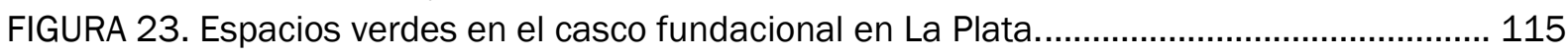

FIGURA 24. Análisis de los tipos de espacio verde en el casco fundacional. ............................... 117

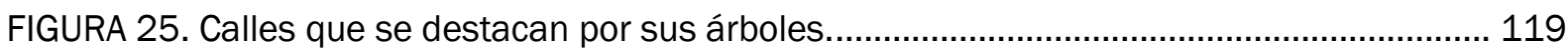

FIGURA 26. La pérdida del arbolado urbano en La Plata.......................................................... 120

FIGURA 27. Relación cantidad de habitantes por cada árbol en el caso fundacional platense. 120

FIGURA 28. Loteo Altos de Dos Carlos I en las calles 507 y 137 loteo en una zona que era productiva

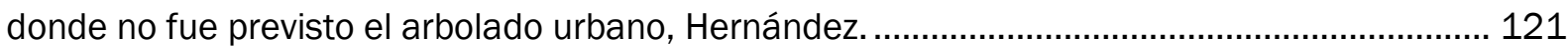

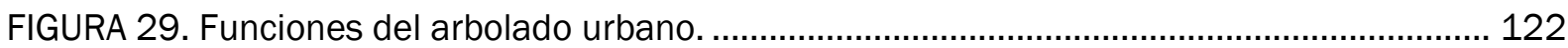

FIGURA 30. Relación espacio lleno y vacío en la trama urbana y los edificios públicos............... 123

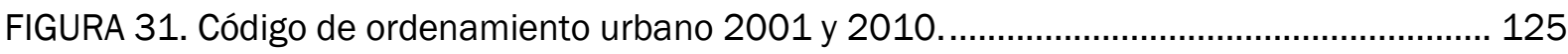

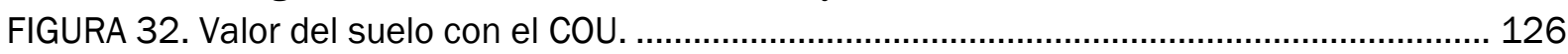

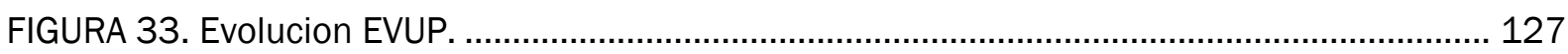

FIGURA 34. Plano de la ciudad de La Platacon la mancha urbana que propone el código y la mancha

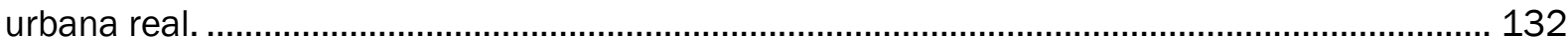

FIGURA 35. El corrimiento del cinturón frutihortícola platense. ................................................. 133

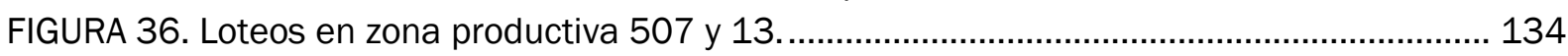

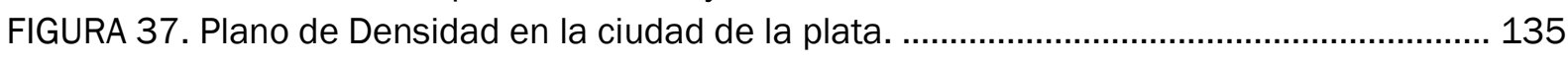

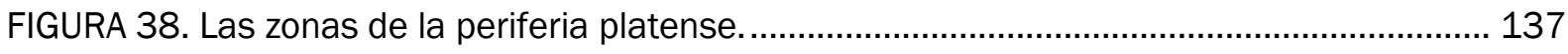

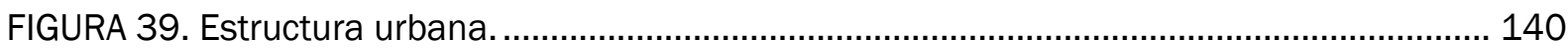

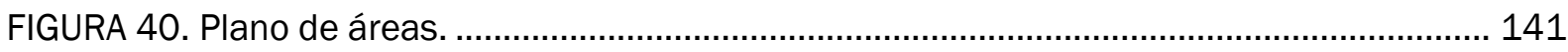

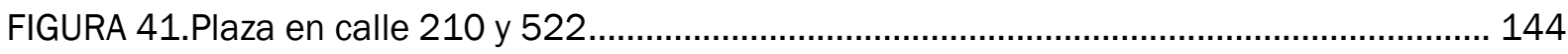

FIGURA 42. Espacios verdes de uso público............................................................................ 146

FIGURA 43. m2 de área verde por habitante según zona de la periferia.................................... 146 
FIGURA 44. Relación de áreas de EVUP, área urbana y rural por delegación. .............................. 147

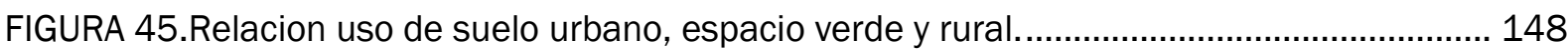

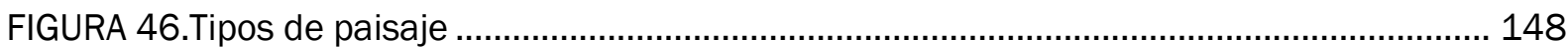

FIGURA 47. m2 de espacio verde por habitante en disferentes ciudades del mundo. ............... 151

FIGURA 48. Plano con las zonas de la periferia y los EVUP total y a escala urbana. .................... 155

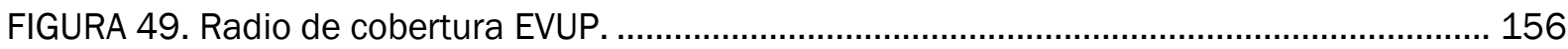

FIGURA 50. Distancia maxima para acceder a un espacio verde caminando adoptada............. 157

FIGURA 51. Cuadras que caminaría una persona para llegar a un espacio verde, datos obtenidos

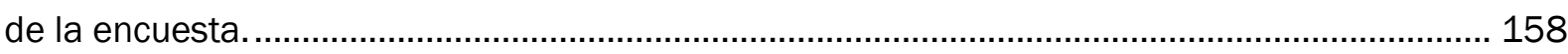

FIGURA 52. Radios de cobertura de áreas verdes en la periferia. ............................................. 158

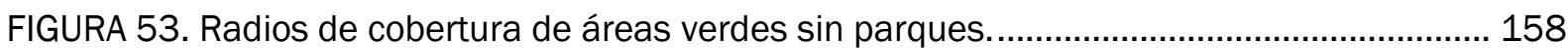

FIGURA 54. Zonas sin cobertura de áreas verdes en la periferia................................................. 160

FIGURA 55. Porcentaje de la población sin cobertura de EVUP por zona de la periferia............. 161

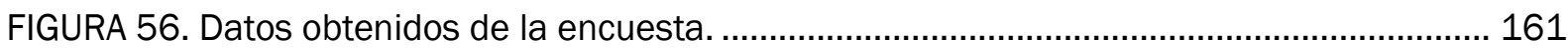

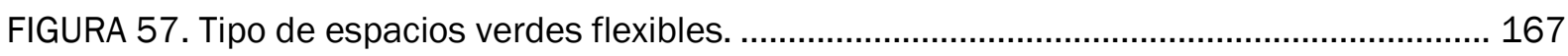

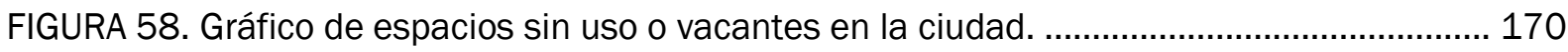

FIGURA 59. Plano con los espacios sin uso o vacantes de la ciudad reconocidos...................... 170

FIGURA 60. La cantera de Gorina.

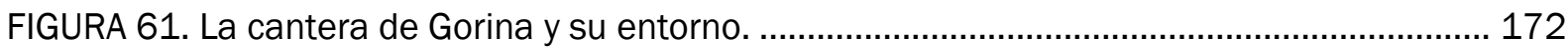

FIGURA 52. Las TV en zona urbana en la periferia platense. .................................................... 174

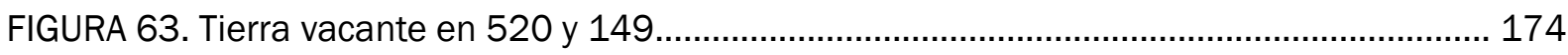

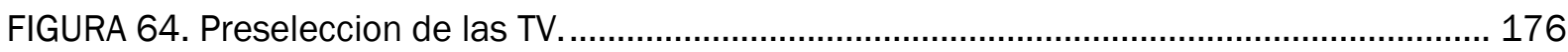

FIGURA 65. Tierras vacantes como espacios verdes potenciales y radios de cobertura............. 177

FIGURA 66. Tierras vacantes como espacios verdes potenciales y radios de cobertura. El estado

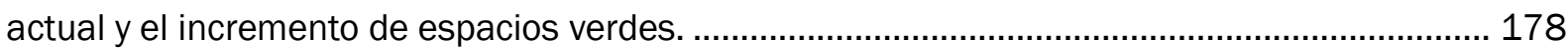

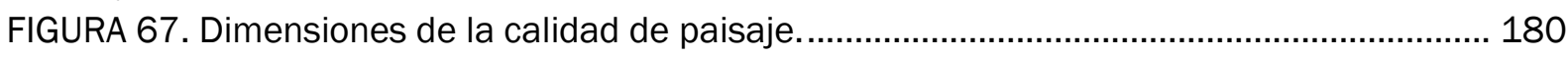

FIGURA 68. Calidad de paisaje en las tierras vacantes seleccionadas. ...................................... 182

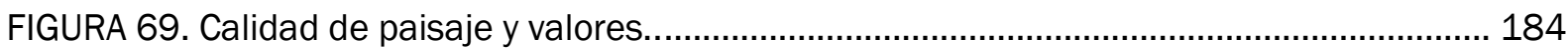

FIGURA 70. Sistema de espacios verdes dinámico que se adapta a los cambios en el tiempo. 187

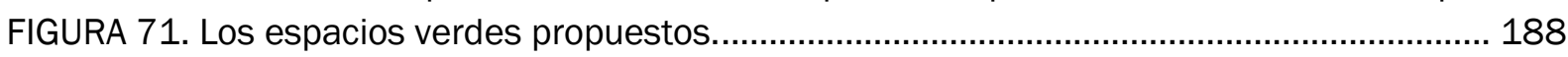

FIGURA 72. Las tierras vacantes según calidad de paisaje y tipos de paisaje............................ 192

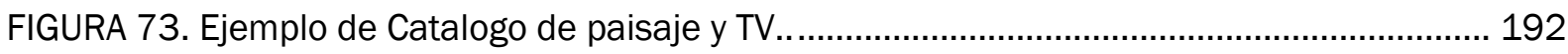

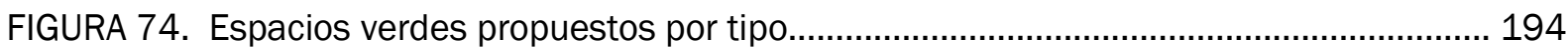

FIGURA 75. Superficie de suelo absorbente mínima ................................................................. 195

FIGURA 76. Zona desborde tipos de espacios verdes propuestos.............................................. 196

FIGURA 77. Zona del eje NO tipos de espacios verdes propuestos. .......................................... 197

FIGURA 78. Zona del eje NO tipos de espacios verdes propuestos ........................................... 198

FIGURA 79. La diversidad de usuarios de los espacios verdes. .................................................. 199

FIGURA 80. Fases propuestas para la intervención en tierras vacantes. .................................... 201

FIGURA 81. Fases según la cobertura de vegetación en las tierras vacantes y los años............ 202

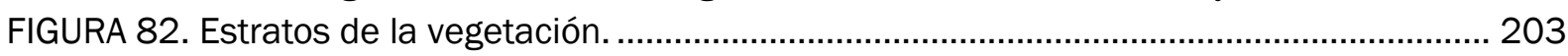

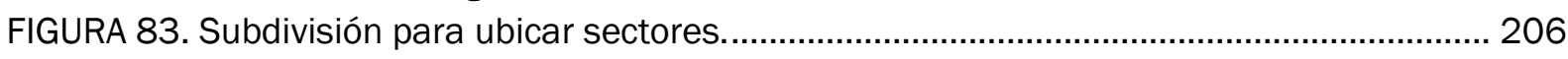

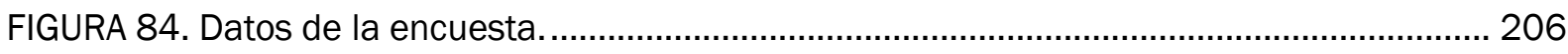

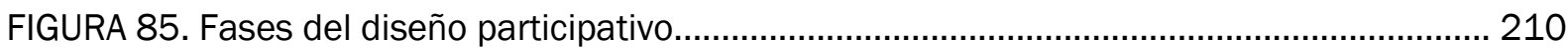

FIGURA 86. Experiencia de diseño participativo en el 2013 con el grupo de investigación (IIPAC) de un parador ecológico en la posada Samborombón (Brandsen) en el marco del proyecto PIT-AP Parador ecológico en la autovía 2 ......................................................................................... 210 FIGURA 87. Cartelería en el High Line en Nueva York donde se manifiestan las intenciones de

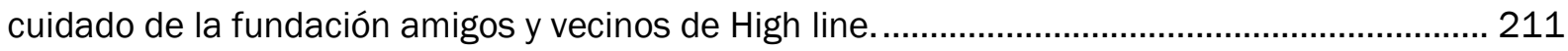


FIGURA 88. Comparación de la situación actual y la propuesta con el sistema de espacios verdes

FIGURA 89. Tabla resumen de conclusiones obtenidas.

\section{INDICE DE TABLAS}

TABLA 1. Población por zonas y cantidad de áreas verdes..............................................................8

TABLA 2. Matriz para la el relevamiento y clasificación de espacios verdes de uso público...........91

TABLA 3. Asignación de valores numéricos a cada valor del indicador. ...........................................92

TABLA 4. Superficie mínima de áreas verdes por habitante..........................................................93

TABLA 5. Antecedentes de casos donde se ha aplicado el radio de cobertura................................94

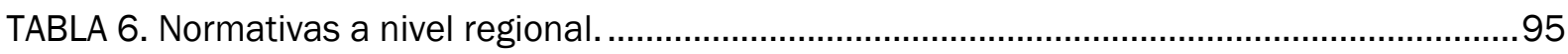

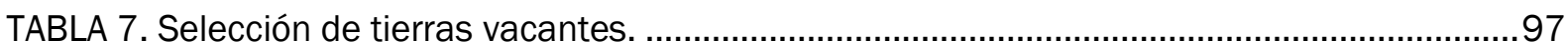

TABLA 8. La expansión urbana en la Región del Gran La Plataen los últimos 30 años............... 131

TABLA 9. Porcentaje de crecimiento en las distintas zonas de la periferia. ................................. 137

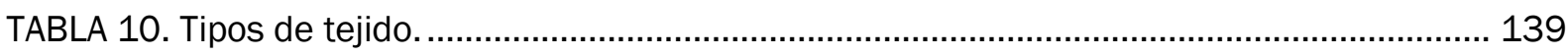

TABLA 11. Recomendaciones sobre la superficie de áreas verdes. .......................................... 152

TABLA 12. M2 de áreas verdes por habitante y áreas verdes a escala urbana sin parques

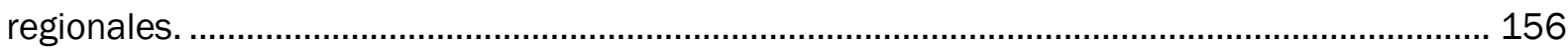

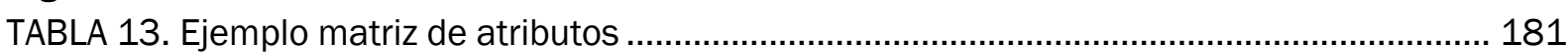

TABLA 14. Criterios de intervención según calidad de atributos................................................. 190

TABLA 15. Ejemplo de aplicación tabla de asociaciones. ........................................................... 193

TABLA 16. Tipos de espacios verdes propuestos y cantidad por zona....................................... 195 


\section{ABREVIATURAS}

Art.- Articulo

Av. - Avenida

CEMAT- Conferencia Europea de Ministros responsables de ordenación del territorio

CEP- Convenio Europeo del Paisaje

diag.- Diagonal

EPA- Environmental Protection Agency

EVUP- Espacio Verde de Uso Publico

FAU- Facultad de Arquitectura y Urbanismo

GIS- Sistema de información geográfica (SIG en español o GIS en inglés)

Ha.- Hectárea

Hab.- Habitantes

IPCC- Panel Intergubernamental sobre el Cambio Climático

IFLA- Iniciativa Latinoamericana del Paisaje

IIPAC- CONICET- Instituto de investigaciones y políticas del ambiente construido.

LALI- Latin american landscape initiative

RAP- Red Argentina del Paisaje

INDEC- Instituto Nacional de Estadística y Censos

OMS- Organización Mundial de la Salud

ONU- Organización de las Naciones Unidas

PMC- Maestría Paisaje, Medio Ambiente y Ciudad

NO- Noroeste

Unesco- La Organización de las Naciones Unidas para la Educación, la Ciencia y la Cultura.

M2 - Metro Cuadrado

TP- Tipo de Paisaje

TV- Tierra Vacante

UNLP- Universidad Nacional de La Plata 
GRACIAS!

A la Universidad Nacional de La Plata

A todos aquellos que de alguna u otra manera formaron parte de este proceso, A mis directoras Olga y Julieta por la confianza, el apoyo, la paciencia y dedicación, a mi director de beca...

En especial a mi familia, mis abuelos, mis hermanas de la vida, a las arquis de mi vida y a mi otro yo paisajístico por acompañarme en este camino...

En particular al apoyo incondicional de mi pequeña gran familia: a Javi mi compañero de vida y a mi hijo Benjamín que ya desde que estaba en la panza me acompaño en este largo proceso...

"Tarda en llegar y al final, al final hay recompensa..." 
Si pudiera elegir mi paisaje de cosas memorables, mi paisaje de otoño desolado, elegiría, robaría esta calle que es anterior a mi y a todos.

Ella devuelve mi mirada inservible, la de hace apenas quince o veinte años cuando la casa verde envenenaba el cielo. Por eso es cruel dejarla recién atardecida con tantos balcones como nidos a solas y tantos pasos como nunca esperados.

Aquí estarán siempre, aquí, los enemigos, los espías aleves de la soledad, las piernas de mujer que arrastran a mis ojos lejos de la ecuación de dos incógnitas.

Aquí hay pájaros, lluvia, alguna muerte, hojas secas, bocinas y nombres desolados, nubes que van creciendo en mi ventana mientras la humedad trae lamentos y moscas.

Sin embargo existe también el pasado con sus súbitas rosas y modestos escándalos con sus duros sonidos de una ansiedad cualquiera y su insignificante comezón de recuerdos.

Ah si pudiera elegir mi paisaje elegiría, robaría esta calle, esta calle recién atardecida en la que encarnizadamente revivo y de la que sé con estricta nostalgia el número y el nombre de sus setenta árboles.

Elegir mi paisaje (Benedetti, M., 1994, p.37) 


\section{INTRODUCCION}

El presente trabajo se propone comprender las características paisajísticas de las tierras vacantes ${ }^{1}$ de la periferia de La ciudad de La Plata entendidas como "paisajes vacantes". A efectos de incorporar las tierras vacantes como espacios verdes ${ }^{2}$ se determinan lineamientos generales y criterios de diseño a partir de la calidad paisajística en relación a las dimensiones geográfico urbanística, biofísica, estructural y estética con el fin de conformar un sistema de espacios verdes contribuyendo a la mitigación de los efectos del cambio climático.

La elaboración y presentación de esta tesis es el resultado de un período de formación intenso que se llevó a cabo en el contexto del Grupo IV del Instituto de Investigaciones y Políticas del Ambiente Construido (IIPAC) 3 que impulsa abordar la interrelación paisaje, ambiente y ciudad desde una visión integral. Este período comenzó con una beca de entrenamiento de la FAU4 (2012) "Concepciones de sustentabilidad ambiental como integradoras de variables en el proyecto Parador Ecológico en Brandsen" donde se reflexionó acerca del concepto de paisaje ligado a la sustentabilidad ambiental, luego una

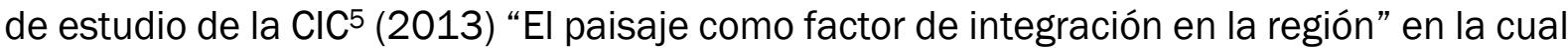
se delimitaron unidades de paisaje para la región, culminando con una beca doctoral del CONICET6 (2014-2019) “El paisaje como factor de mitigación de la degradación socio ambiental del Gran La Plata". Desarrollos realizados a partir de los marcos teóricos de los proyectos de investigación y extensión, que abordaban la reflexión e indagación en la interrelación de conceptos tales como: desarrollo urbano, espacios verdes y tierras vacantes desde el paisaje. La elección del tema de estudio se fundamenta en el creciente y renovado interés por "orientar nuestra disciplina hacia el diseño de los espacios, con improntas ambientales y sociales, con sumo compromiso ético ya que allí es donde estamos haciendo falta" (Márquez, 2011). Para lograr estos criterios se requiere adquirir métodos e instrumentos que permitan concebir las intervenciones espaciales desde una perspectiva sistémica ${ }^{7}$ e integrada.

\footnotetext{
1 Tierras que se encuentran vacías o sin uso en zona urbana.

2 Áreas o espacios donde predomina el suelo absorbente. A partir de ahora voy a hablar de "espacios verdes", "espacios verdes de uso público", "zonas verdes", "zonas verdes urbanas" o "áreas verdes" de forma indistinta para referirme a estos espacios en zona urbana.

3 Instituto de investigaciones y políticas del ambiente construido CONICET-UNLP.

${ }_{4}^{4}$ Facultad de Arquitectura y Urbanismo, Universidad Nacional de La Plata.

5 Comisión de investigaciones científicas de la provincia de buenos aires - CIC.

${ }^{6}$ Consejo Nacional de Investigaciones Científicas y Técnicas - CONICET.

${ }^{7}$ Como una forma de ver y observar la realidad.
} 
Este proceso de conocimiento teórico - metodológico se fue profundizando en la formación de posgrado en la Maestría “Paisaje, Medioambiente y Ciudad” y también en el Doctorado de "Arquitectura y Urbanismo". En este sentido, la presente tesis resulta una instancia significativa en el proceso de formación académica y en investigación, en la cual se intentan plasmar los conocimientos adquiridos sobre paisaje con el fin de lograr una visión integradora. En este contexto, se plantea como objetivo principal contribuir a la construcción de un conjunto de criterios sobre el tratamiento de las tierras vacantes como espacios verdes desde la perspectiva del paisaje, a fin de contribuir al mejoramiento de la calidad de vida urbana y a mitigar los efectos del cambio climático.

El paisaje es hoy objeto de atención en la agenda de las diferentes instituciones tanto internacionales como nacionales. Se constituye como un factor fundamental en el desarrollo urbano y regional desde la visión sistémica y en la mitigación de los efectos del cambio climático. Es entendido como una pieza fundamental de muchas políticas de ordenamiento territorial e, incluso, de políticas de carácter social, cultural y económico (Nogué y Sala, 2008). La valoración social del paisaje lo ha convertido en un recurso económico, en un factor de calidad de vida y de identidad cultural. Todas estas razones que convergen en el concepto de paisaje como intereses colectivos sobre la naturaleza y la cultura explican por qué se lo postula como una de las dimensiones que coadyuvan a la recuperación de tierras vacantes y al aumento de la resiliencia al cambio climático.

El análisis del proceso de desarrollo urbano tanto de aquellos realizados a partir de planes urbanos, como de aquellos productos de la improvisación permite explicar la inexistencia de la creación de nuevos espacios verdes concebidos desde la visión del paisaje. El proceso de expansión de las ciudades iniciado en los noventa ha provocado por una parte una homogeneización y especialización funcional de los centros históricos y por otra parte la dispersión y fragmentación territorial, carente de espacios verdes de uso público a pesar de la existencia de numerosas tierras vacantes. En el contexto de los proyectos de investigación y de la maestría "Paisaje, medio ambiente y Ciudad” y la Red Argentina del Paisaje, se han formulado proyecto de leyes y normativas para la planificación y gestión del paisaje en los procesos de planificación, tomando como base antecedentes latinoamericanos, europeos y nacionales.

A pesar de la existencia de estos criterios, lineamientos y propuestas proyectuales específicas, las políticas de desarrollo urbano en la región de estudio no los incorporan, 
provocando una mayor vulnerabilidad urbana, con el crecimiento de la contaminación y problemas de inundaciones.

El "paisaje" se constituye como una categoría relacional que recompone el vínculo entre cultura y naturaleza, entre sujeto y objeto, entre la razón y sentimiento. Desde este enfoque, se entiende al paisaje como la representación o el efecto de la relación entre medio natural y cultura, y en el caso de las ciudades, entre medio urbano y cultura, a través de un proceso histórico y dinámico por el cual el hombre reconoce el medio y genera las formas para adaptarlo y adaptarse.

Por tanto, el paisaje es el principal recurso para la progresiva adaptación de la ciudad a las nuevas condiciones requeridas para un desarrollo equilibrado y resiliencia a los efectos del cambio climático. Es en este contexto que la investigación propuesta implica un avance en el conocimiento sobre la incorporación de tierras vacantes como espacios verdes y el diseño de estos nuevos espacios desde la calidad del paisaje.

El presente trabajo toma como recorte temporal desde 1990 a la actualidad. Se toma como punto de partida la década del '90 ya que marca un punto de inflexión en las transformaciones territoriales y, en particular, en los procesos de urbanización de la región.

A través de la investigación realizada en esta tesis se intenta aportar al conocimiento y la comprensión de los espacios verdes y las tierras vacantes en la expansión urbana, considerándolas como PAISAJES VACANTES, "espacios que esperan ser mirados". Y tratados desde la noción de paisaje. 


\section{ESTRUCTURA DE LA TESIS}

Con el fin de facilitar la lectura de la tesis se estructura en tres apartados principales y un total de seis capítulos (Ver figura 1 - Estructura General de la Tesis).

\section{PARTE I}

La Primera Parte, titulada El paisaje, los espacios verdes y las tierras vacantes en la expansión urbana, consta de dos capítulos donde se constituye el abordaje teóricoconceptual y el metodológico. Los antecedentes y el marco teórico conceptual permiten orientar la aproximación conceptual a la cuestión urbana desde el paisaje determinando el enfoque de la tesis. Asimismo, se establece el abordaje metodológico de esta, el recorte temporal y espacial, como así también las técnicas utilizadas para la recolección de datos.

\section{PARTE II}

La Segunda Parte, denominada La periferia platense y los espacios verdes, se compone de dos capítulos en los que se aborda el diagnóstico de la periferia platense desde el paisaje y el relevamiento de los espacios verdes. Se identifican las principales transformaciones urbanas de la periferia, la evolución de los espacios verdes y la expansión urbana. A su vez, se relevan los espacios verdes de uso público que hay en la periferia y se los caracteriza, con el fin de identificar las zonas que carecen de los mismos desde el concepto de radio de cobertura.

\section{PARTE III}

Finalmente, la Tercera Parte, denominada Los nuevos espacios verdes de uso público, comprende dos capítulos en los que se realiza el relevamiento, la catalogación y la caracterización de las tierras vacantes y, además se establecen criterios de diseño desde el paisaje para los nuevos espacios verdes. Se indaga acerca de los nuevos espacios verdes y como deberían conformarse para adaptarse a los cambios de la sociedad. Se exponen los resultados obtenidos al aplicar el procedimiento metodológico para determinar criterios de intervención, recuperación y diseño para las tierras vacantes.

En el primer capítulo, se realiza en una breve presentación de los antecedentes entorno a la temática abordada. Se analiza el concepto de paisaje desde sus orígenes y los cambios en el significado que ha tenido en el tiempo desde las principales visiones. Asimismo, se efectúa una aproximación teórica conceptual de la cuestión urbana desde la perspectiva 
del paisaje donde se analizan las transformaciones territoriales en la conformación de la ciudad Latinoaméricana. Se hace énfasis en la periferia como una nueva forma de ocupación del territorio y las transformaciones de los espacios verdes, entendiendo a los espacios verdes como elemento esencial del derecho a la ciudad debido a las funciones ambientales, estéticas, psicologías y sociales que brindan.

Para concluir, se aborda el concepto propuesto de paisaje vacante desde el cual el paisaje es entendido como el reconocimiento del mundo poniendo de manifiesto la relevancia de la imagen, es decir se entiende como la representación del espacio. En este contexto se plantea comprender a las tierras vacantes como espacios de oportunidad desde el reconocimiento de los habitantes de estas.

En el segundo capítulo, se describe el abordaje metodológico de la tesis propuesto desde el método de la triangulación metodológica. La aplicación de esta propuesta teóricometodológica se basa en el concepto de matrices de datos de Juan Samaja (1996).

En este caso se propone un nivel superior de análisis donde se plantea realizar una caracterización urbano-territorial de la ciudad desde el paisaje y los espacios verdes desde la dimensión urbano territorial y paisajística. Un nivel de análisis focal donde se establece como unidad de análisis las tierras vacantes y se comienza con el análisis para su posterior caracterización mediante la construcción de un inventario de estas que fueron determinados en el marco del paisaje y tomando la dimensión geográfico urbanística, biofísica, estructural y estética. Por último, un nivel inferior de análisis donde se cierra el proceso estableciendo lineamientos y criterios de diseño para la conformación de un sistema de espacios verdes. Además, teniendo en cuenta la calidad del paisaje de las tierras vacantes se determinan las medidas de intervención y los tipos de espacios verdes.

En el capítulo tres, se presenta la evolución histórica de la configuración urbana del Partido desde su fundación a la actualidad. Para ello, se resume dicho proceso en tres períodos históricos estrechamente vinculados con los diferentes ciclos económicos o modelos político-económicos por los que ha atravesado nuestro país: un primer período o etapa fundacional, desde 1882 a 1930, una segunda etapa desde 1930 a 1970, y una última etapa, desde 1970 a nuestros días.

Se profundiza además en las transformaciones urbanas producidas en el Partido, fundamentalmente desde la década del '90 hasta la actualidad, y en particular en el avance de la frontera urbana, los cambios en el paisaje y la evolución de los espacios 
verdes. Se analiza la periferia platense con el fin de comprender la fragmentación urbana en cuanto al tejido y la configuración paisajística de esta.

En el capítulo cuatro, se relevan los espacios verdes en la periferia desde la dimensión social, urbana y paisajística. Se determina la cantidad de espacio verde por metro cuadrado y se plantea la falta de espacio verde que hay en las distintas zonas de la periferia. Se propone trabajar desde la dimensión espacial con el concepto propuesto de radio de cobertura pensando en los espacios verdes como una infraestructura más de los que brinda la ciudad.

Además, se determinan áreas críticas donde no hay cobertura de espacios verdes y se identifican las tierras vacantes que se encuentran en estas áreas.

En el capítulo cinco, se profundiza en el concepto de espacio verde y se reflexiona acerca de cómo deberían ser los nuevos espacios verdes. Se propone trabajar e incorporar el concepto de espacio flexible donde el vacío y la vegetación estructuren el espacio.

Se seleccionan las tierras vacantes susceptibles a ser incorporadas como espacios verdes de uso público y se las caracteriza. En base a la caracterización se identifica la calidad de paisaje desde la dimensión geográfico urbanística, biofísico, estructural y estética. Una vez determinada la calidad de paisaje se establecen criterios para la recuperación e intervención de las tierras vacantes.

Finalmente, en el capítulo seis, se construye una tipología de espacios verdes de uso público en tierras vacantes donde se toma como variables la calidad de paisaje y el tipo de paisaje donde se localiza la tierra vacante. Se establecen criterios de diseño para los nuevos espacios verdes propuestos y se plantean dos fases que tengan en cuenta las características en relación a la vegetación de las tierras vacantes identificando elementos estructurales y elementos de uso.

Se señalan las reflexiones finales a las que hemos arribado en estos años de investigación sobre el tema, y que permiten la contrastación de las hipótesis planteadas. 


\section{PAISAJES VACANTES}

El paisaje y los espacios verdes en la periferia platense.

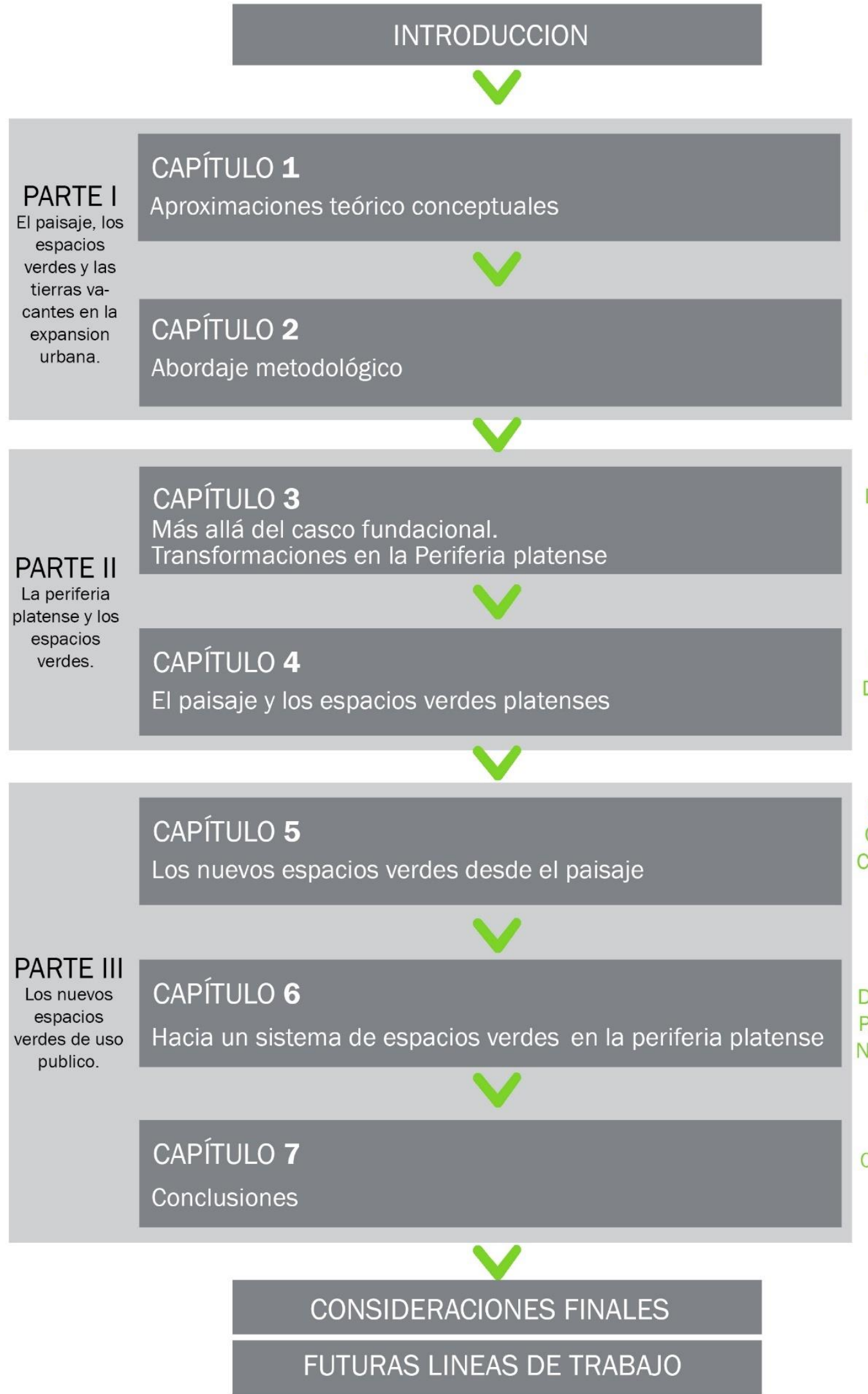

ABORDAJE

TEORICO-

CONCEPTUAL

ABORDAJE METODOLOGICO

DIAGNOSTICO DE LA PERIFERIA PLATENSE

RELEVAMIENTO DE LOS ESPACIOS VERDES

RELEVAMIENTO, CATALOGACION Y CARACTERIZACION DE LAS TV

CRITERIOS DE DISEÑO DESDE EL PAISAJE PARA LOS NUEVOS ESPACIOS VERDES

CONSIDERACIONES FINALES REFLEXIONES

Figura 1. Estructura general de la tesis. Fuente: elaboración propia, 2018. 


\section{OBJETIVOS E HIPÓTESIS}

\section{PROBLEMA}

El problema de investigación es la falta de espacios verdes públicos, la calidad del espacio verde existente y la proliferación de tierras vacantes en la periferia platense.

La pregunta que guía la investigación:

¿Qué estrategias se pueden proponer desde la concepción de paisaje para revalorizar las tierras vacantes en áreas con falta de espacio verde e incorporarlas como espacios verdes de uso público en la periferia platense?

Preguntas derivadas:

¿Cómo se conforma espacialmente la periferia platense?

¿Cuál sería la cantidad y distribución optima de espacios verdes de uso público en la periferia platense?

¿Cómo deberían ser estos nuevos espacios verdes de la periferia y que deberían contemplar?

¿Cuál es la calidad de paisaje de las tierras vacantes?

¿Cuál es la percepción de los habitantes de la periferia en relación a la cantidad y calidad de espacios verdes públicos?

¿Cómo podemos contribuir a la resiliencia al cambio climático desde los espacios verdes?

OBJETIVOS

\section{Objetivo general:}

Contribuir al conocimiento de los espacios verdes y tierras vacantes desde el paisaje con el fin de establecer lineamientos para conformar un sistema de espacios verdes en pos de mejorar la calidad del paisaje urbano y contribuir a la mitigación de los efectos del cambio climático.

\section{Objetivos Particulares:}

- Indagar los diferentes marcos teóricos y metodológicos que integren las prácticas urbanísticas y el rol del paisaje. 
- Analizar las transformaciones territoriales derivadas del modo de producción del espacio urbano en busca de comprender los procesos que dan origen a la falta de espacios verdes de uso público.

- Explorar acerca de la percepción de los habitantes de la periferia en relación a la cantidad y calidad de espacios verdes públicos en pos de relacionar las diferentes visiones con la localización espacial según la zona de la periferia.

- Indagar y analizar sobre las nuevas tipologías de espacios verdes en relación a las actividades y funciones requeridas en pos de conformar la base del sistema de espacios verdes.

- Elaborar categorías de intervención y recuperación para la incorporación de tierras vacantes que permitan formular estrategias de intervención paisajística para los nuevos espacios verdes.

- Formular lineamientos que integren las prácticas urbanísticas referidas a las tierras vacantes y el rol del paisaje tendientes a conformar un sistema de espacios verdes.

\section{HIPÓTESIS}

\section{Hipótesis general:}

La integración de las tierras vacantes a un sistema de espacios verdes permite mejorar la calidad del paisaje urbano.

\section{Hipótesis derivadas:}

La estructuración del paisaje del sistema de espacios verdes con elementos resilientes contribuye a mitigar los efectos del cambio climático. 
Aproximación teórico conceptual

1.1| Antecedentes del tema

1.2 | Aproximación teórica conceptual de la cuestión urbana desde la perspectiva del paisaje

1.3 I El cambio climático y la resiliencia urbana

1.4 I Las tierras vacantes como espacios de oportunidad 


\section{CAPITULO 1}

“El paisaje es a la vez, una realidad física y la representación que culturalmente nos hacemos de ella; la fisonomía externa y visible de una determinada porción de la superficie terrestre y la percepción individual y social que genera. Un tangible geográfico y su interpretación intangible. Es al mismo tiempo significante y significado, el continente y el contenido, la realidad y la ficción."

(Nogué, 2007, p.378)

\section{1| Antecedentes del tema}

Existe una significativa producción literaria que aborda el estudio del paisaje haciendo foco sobre la relación entre cultura y naturaleza, los conflictos ambientales y sociales, como así también de la planificación territorial y el ordenamiento del territorio. En su gran mayoría los autores que trabajan con el término paisaje resaltan los múltiples significados del término, ya que éste designa tanto a un conjunto de objetos reales, una porción de territorio, y también su imagen y representación gráfica (Silvestri, 2001; Roger, 2007; Santos, 2000).

En los estudios sobre paisaje se observan dos tendencias teóricas fuertes: la idealista y la materialista. La primera tendencia es la de los que afirman que el paisaje es representación y, en contraposición, la materialista que es la de los que aseveran que el paisaje no representa, es.

Al respecto, es necesario analizar de dónde proviene el concepto de paisaje, por lo que se retoma de dónde surge y cuándo se comenzó a utilizar. En relación a esto último, se puede decir que es un viejo concepto empleado por la geografía clásica que se rescata y resignifica en la geografía contemporánea, al igual que ha sucedido con otros como el de lugar, región o territorio. De esta manera Cosgrove (2002) sugiere que:

"Su uso ha pasado de ser una referencia a lo tangible, un conjunto mensurable de formas materiales en un área geográfica determinada, una representación de esas formas en medios variados como son los cuadros, los textos, las fotografías o las 
representaciones teatrales hasta llegar a convertirse en los espacios deseados, recordados y somáticos de la imaginación y los sentidos". (p.64)

Es indispensable comprender las dos tendencias con el fin de apreciar la concepción desde las que han sido abordadas y cuál es la visión que propone esta tesis. En cuanto a la visión materialista, el paisaje también se refiere al producto visual de una cierta disposición de elementos físicos en una parte de la superficie terrestre, es una porción material del ambiente natural y su representación. Esta forma de concebir al paisaje tuvo su origen en la geografía alemana del siglo XIX y a comienzos del siglo sería introducida en Estados Unidos por Carl Sauer y la Escuela de Berkeley. El alemán Hommeyerem fue el primero en introducir el término, al utilizar el vocablo alemán “landschaft”, entendido como el conjunto de elementos observables desde un punto alto. En este caso, estas disciplinas intentan excluir las valencias estéticas del término ya que lo artístico o sensible no era considerado racional por tanto quedaba fuera del ámbito científico. El geógrafo Carl Sauer (1889-1975), fue quien a principios del siglo XX acuñó y desarrolló el término Paisaje Cultural, para referirse a la incidencia de los procesos de poblamiento y las formas de producción y movilidad sobre el medio natural en la determinación del carácter del paisaje. Según Sauer, "La cultura es el agente, lo natural, el medio; el paisaje cultural el resultado" (Sabaté, 2004). Por otro lado, Von Humboldt presenta al paisaje como la estructura de una forma coherente de la superficie terrestre, y afirma que cada paisaje tiene su fisonomía particular. Farinelli (1999 citado en Souto, 2011) plantea que fue Alexander Von Humboldt el primero que indujo la transformación del concepto de paisaje como concepto científico. Apropiándose de la duplicidad semiótica del concepto de la que se hablaba anteriormente, Humboldt habría logrado que pase de ser un conocimiento pictórico y poético a servir para el desarrollo de una descripción científica del mundo. Para este autor, el paisaje representaba una "impresión de la naturaleza”, lo cual constituía el primer paso para el proceso de conocimiento científico.

En contraposición, la teoría idealista se presenta de la mano del arte. Hasta el siglo XVIII la naturaleza apareció escasamente en obras pictóricas valorada por sí misma o como paisaje. Esta teoría tiene como argumento que el paisaje es una construcción mental y/o cultural; y que disfrutar estéticamente de un paisaje es reconocer en él algo artístico dentro de las coordenadas en las que se nos ha educado.

Más adelante, el mayor representante de esta teoría, Alain Roger (2007), sostiene que no existe paisaje desde un punto de vista exclusivamente físico: "hablar de paisaje implica 
necesariamente un tipo de apreciación estética, en la que la mirada está guiada por ciertos criterios relativos a la representación artística postulado en su libro "Breve tratado del paisaje". Es decir, el paisaje por sí mismo no existe, sino que es una construcción cultural. El espacio vivido o visto se transformó, por medio de la representación artística pictórica, en un paisaje contemplado y percibido, en lo que Roger denomina un proceso de "artealización", de asignación de un carácter artístico o estético a un objeto cotidiano, un proceso que se consolida alrededor del siglo XVI, pero que continúa en constante producción.

En este sentido, en la geografía contemporánea durante la década del `70, los geógrafos humanistas retoman el concepto de paisaje, pero esta vez más asociado a otro concepto clave de la geografía: el lugar. Desde esta perspectiva, el paisaje constituye un lugar, sin que esta asociación implique privilegiar ninguna escala de análisis en particular. Cualquier ámbito en el que los seres humanos construyan vínculos, aspiraciones, significados, emociones puede constituirse en objeto de interpretación: una casa, un parque, una autopista, un paisaje rural, una ciudad.

Desde este enfoque, J. B. Jackson, D. W. Meinig, David Sopher o Yi Fu Tuan trabajan el concepto en la obra The Interpretation of Ordinary Landscapes (1979). Estos autores desarrollan un enfoque hermenéutico, es decir, una interpretación del paisaje como un texto que puede ser leído desde la tradición humanista en la que se rescata el valor simbólico de los paisajes "vernáculos", pero sin perder de vista su calidad de entidades materiales (Wylie, 2007). La mayor contribución de la interpretación de esta corriente de geógrafos consistió en trasladar el eje desde la observación de las apariencias de la superficie externa del paisaje que había predominado en el tratamiento del paisaje en la geografía clásica, hacia la interpretación de sus significados y de la experiencia del paisaje para los sujetos que lo habitan o para los observadores externos. Esta mirada fue trabajada posteriormente y profundizada con el desarrollo de una serie de estudios del paisaje desde la denominada "nueva geografía cultural” que comienza a difundirse a fines de la década del `80, inspirada por los estudios culturales desarrollados desde una perspectiva materialista-histórica.

En la década del `80, el paisaje se encuentra dentro de la reivindicación de los valores ecológicos y naturales. Por primera vez, se registra un esfuerzo de armonización de políticas y procesos en principio por parte de la Comunidad Europea, de esta manera hacen su aparición las evaluaciones de impacto ambiental, con mayor o menor 
repercusión paisajística. luego en la década posterior, las leyes y ordenanzas se dirigen más específicamente al paisaje.

Posteriormente a la canonización de paisajes sobresalientes, los cuales en un principio eran los únicos que llaman la atención, se pasa a una visión totalizadora la cual ve al paisaje en todos lados. Esta nueva mirada sitúa al paisaje en la larga duración y extiende el ámbito de atención hasta cubrir todo el territorio, ampliándose tanto en lo espacial como en lo temporal. De esta manera, se renuevan los presupuestos teóricos y metodológicos del análisis y la praxis del paisaje.

A finales del siglo XX los términos del debate han ido cambiando, gracias al desarrollo de una visión del paisaje que ha superado las oposiciones y dualismos propios de la fase anterior. Latour publica en 1991 en su libro "nunca fuimos modernos" la abolición de las dicotomías tradicionales naturaleza cultura. Se retoma de esta manera el tema del paisaje como señala Silvestri (2011), ya que alcanza un auge inédito porque remite a uno de los problemas más notables de los últimos años, la conflictiva relación entre el hombre y la naturaleza.

En la actualidad, se puede seguir esta línea en aquellos que postulan una visión del paisaje que lo considera un objeto científico más, para cuyo estudio hay que adoptar una perspectiva holística, cada vez más integradora, capaz de ajustarse a los tiempos y capaz de dar cuenta de la complejidad de los sistemas y subsistemas que forman un paisaje. Es desde esta visión donde se posiciona esta investigación la cual propone abordar desde una mirada integral la periferia entendiendo al paisaje como un factor principal en la expansión urbana8.

Se puede decir que el estudio del paisaje en relación a la forma urbana comenzó siendo estudiado en 1960 con Lynch el cual en su libro "La imagen de la ciudad" aborda cuestiones perceptivas de la forma urbana al tratar las imágenes de la ciudad como un problema interpretativo. Si bien trata con cuestiones como la legibilidad, y la estructuración de la ciudad, todavía no llega a denominarla como paisaje. Para Lynch todos los espacios se pueden analizar teniendo en cuenta los elementos que lo componen.

${ }^{8}$ La expansión urbana asociada al crecimiento sobre el territorio asociado a la insustentabilidad ambiental, la fragmentación territorial y la segregación socio espacial. 
Gordon Cullen (1961) en su libro “El paisaje urbano" realiza un análisis de los fenómenos visuales, perceptivos y constructivos de la ciudad, entendiendo al entorno urbano como paisaje, lo que luego Maderuelo (2010) retoma trabajándolo como "paisaje urbano".

De esta manera, incorporar la noción de paisaje en el estudio del ordenamiento del territorio es substancial, para lo cual es necesario tener presente a partir de cuándo se comienzan a desarrollar estudios sobre la relación del paisaje y el ordenamiento del territorio. En el año 1992 en Europa se redacta la Carta del Paisaje Mediterráneo, donde se establece al paisaje como la "manifestación formal de la relación sensible de los individuos y las sociedades, en el espacio y en el tiempo, con un territorio más o menos modelado por los factores sociales, económicos y culturales." Estos estudios se realizan “...con objeto de hacer frente a su creciente deterioro y desarrollar una función pública que se ocupe adecuadamente de él..." (Zoido Naranjo, 2002, p.21) empezando a pensar en un territorio planificado desde la mirada del paisaje.

Desde esta perspectiva, se puede mencionar el trabajo realizado por los franceses en el "Atlas de paisaje" de Francia donde propone unidades de paisaje y su descripción y caracterización y la iniciativa británica “Landscape Character Assesment" (The Countryside Agency, 2002) elabora una metodología para la identificación y evaluación del paisaje. En este sentido, se puede decir que proponen un nuevo interés por el paisaje y cuyos resultados han sentado precedente para los catálogos de paisaje que se desarrollaran posteriormente.

Tras una época en la que la política en relación al paisaje estaba ligada a la protección, se produce un cambio a un nuevo modelo de intervención, cuyas líneas de fuerza son las tres componentes descriptas por el Convenio Europeo del Paisaje: no solo la protección sino también la gestión y ordenación. El Convenio Europeo del Paisaje ${ }^{9}$ - CEP (Florencia, 20 de octubre de 2000), aprobado por el Consejo de Europa y marco de referencia europeo para el diseño de políticas de protección, gestión y ordenación del paisaje en toda Europa, propone la elaboración de catálogos de paisaje considerando los objetivos y principios de sostenibilidad formulados en convenios europeos e internacionales, como la Cumbre de Río de Janeiro en 1992 o la Estrategia Europea de Desarrollo Sostenible. El Convenio de

\footnotetext{
9 El Convenio Europeo del Paisaje o Convenio de Florencia es un tratado internacional, que trata de promover el papel que el paisaje desempeña por su interés general en los campos cultural, ecológico, medioambiental y social, y que constituye un recurso favorable para la actividad económica y que su protección, gestión y ordenación pueden contribuir a la creación del empleo. Este convenio fue elaborado por el Consejo de Europa, que lo aprobó en el año 2000 en Florencia (Italia). (Consel de l'Europe, 2000).
} 
la Unesco ${ }^{10}$ para la Preservación del Patrimonio Cultural Inmaterial (París, 17 de octubre de 2003) o los Principios Directores para el Desarrollo Territorial Sostenible del Continente Europeo de la CEMAT.

Al adoptarse la Convención Europea del Paisaje se profundizaron los estudios en relación al paisaje e incluso se han puesto en funcionamiento varios planes territoriales en países como Francia y España. Reconociendo que el paisaje es:

Un factor de identidad cultural, un factor de calidad de vida y un factor de mejora y profundización en la democracia... en todas las Partes, un elemento importante de la calidad de vida de las poblaciones, tanto en los medios urbanos como rurales, en los territorios degradados como en los de gran calidad, en los espacios singulares como en los cotidianos como así también que este participa de manera importante en el interés general, en el aspecto cultural, ecológico, ambiental y social, y que constituye un recurso favorable para la actividad económica, con cuya protección, gestión y ordenación adecuadas se puede contribuir a la generación de empleo, aclarando que este concepto se aplica a todo el territorio de las partes y trata de los espacios naturales, rurales, urbanos y periurbanos. Incluye los espacios terrestres, las aguas interiores y marítimas. Concierne tanto a los espacios que pueden ser considerados notables como a los paisajes cotidianos y a los paisajes degradados (López Geta, Pulido Bosch, y Baquero Úbeda, 2005, p.47).

EI CEP ha permitido desarrollar un concepto de integración del paisaje que llega no sólo a los paisajes singulares, naturales o rurales, sino también a los urbanos y periurbanos, así como a los cotidianos, a esos paisajes de cada día, de cualquier lugar. Todo ello producto de una mayor sensibilización social hacia el paisaje; las personas cada vez sienten más inquietud con respecto a la calidad de su entorno sea natural, sea rural o urbano.

La ampliación y complejización del concepto de paisaje conlleva cambios tanto en lo temporal como en lo espacial (figura 2). Respecto a lo primero, además de la mirada hacia el legado paisajístico la cual se concreta con las manifestaciones heredadas del pasado, se hace hincapié en la necesidad de ofrecer a los paisajes del presente una gestión, la cual se concreta en objetivos para el futuro y así tomar la iniciativa para dirigir la evolución del territorio mediante la ordenación y gestión del paisaje. De esta manera, el paisaje

10 La Organización de las Naciones Unidas para la Educación, la Ciencia y la Cultura es un organismo especializado de las Naciones Unidas. 
queda en la dimensión totalmente temporal donde se estimula a la acción proactiva del paisaje ayudando a superar la actitud defensiva basada solo en la protección. En cuanto a la segunda la concepción que impone el CEP donde todo el territorio es paisaje busca la dignificación de cualquier espacio incluido los paisajes ordinarios, cotidianos o degradados.

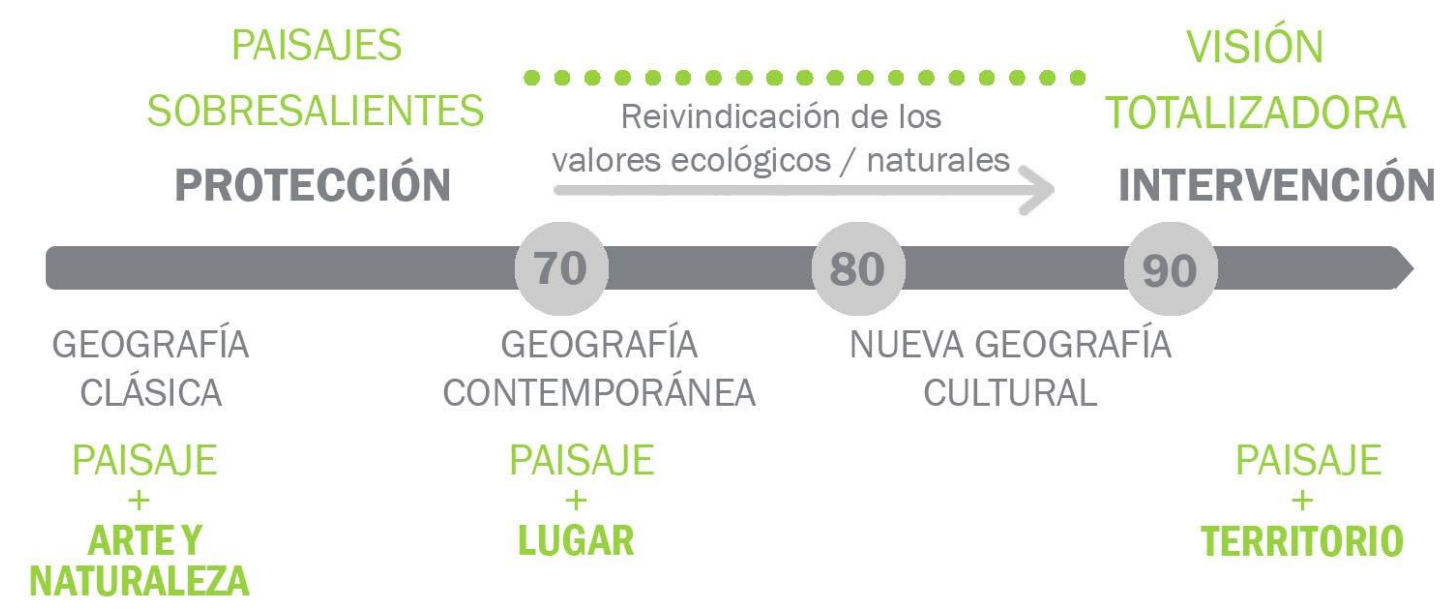

Figura 2. Evolución del concepto paisaje.

Fuente: Elaboración propia, 2017.

Se supone un punto de inflexión a partir de la Convención Europea del Paisaje y de la nueva mirada desde el territorio. Se puede decir que el Paisaje es un elemento relevante para el ordenamiento del territorio ya que alude a la posibilidad de la identificación de los lugares adecuados para los diferentes usos y actividades en el territorio, relacionado a la contribución al diagnóstico territorial teniendo en cuenta “...la valoración del paisaje que tienen las personas que lo perciben,...debe ser considerado como factor que coadyuva a la participación ciudadana, que permite opinar y decidir sobre la propuesta de ordenamiento territorial..." (Zoido Naranjo, 2002, p.24). A partir de ella, se asume plenamente el sentido territorial de la cuestión referida al paisaje, es decir la idea renovadora desde el punto de vista jurídico y político, que todo territorio es paisaje, de que cada territorio se manifiesta en la especificidad de su paisaje, independientemente de su calidad y aprecio que merezca.

Asimismo, el propósito de la Convención Europea del Paisaje en general es establecer un marco para la protección, gestión y planificación de los paisajes europeos. Su objetivo es la instrumentación de políticas, metodologías e intervenciones impregnadas de una concepción de paisaje entendido como atributo de la totalidad del territorio en búsqueda de conservar y mejorar su calidad, propone desde el diagnóstico urbano y territorial profundizar en el conocimiento del territorio. El Convenio reconoce todas las formas de los 
paisajes europeos: naturales, rurales, urbanos y periurbanos, y tanto los emblemáticos como los cotidianos y degradados. Si bien, algunos de los aportes teóricos en relación a la temática del paisaje son discutibles, el Convenio Europeo del Paisaje ha sido un factor decisivo en la consolidación y difusión del término "paisaje" y ha contribuido a salvar las diferencias en cuanto a la terminología.

Respecto a la vinculación de los conceptos de paisaje, sustentabilidad y planificación territorial Gómez Orea (2004) desde su enfoque incorpora el concepto de ambiente reconociendo:

“Un paisaje bello, la manifestación del ambiente sano que subyace, no es indisociable de una correcta planificación del territorio, y siendo esta la proyectación espacial del modelo de sociedad, hay que entender tal paisaje como testimonio de una buena gestión del estilo de desarrollo económico y social. Mientras que un ambiente degradado evidencia una desidia en la gestión del desarrollo y de una imagen externa: el orden del territorio. En síntesis, la calidad ambiental evidencia el comportamiento de las autoridades, la gestión de los agentes socioeconómicos y el grado de compromiso social de la población en general". (p.34)

De este modo, se comienza a hablar de ambiente degradado y como se corresponde la dimensión paisajística con la correcta planificación del territorio. Otro antecedente a tener en cuenta son los catálogos de paisaje que nacen en un momento en el que resulta transcendental implantar una nueva cultura de la ordenación territorial basada en la gestión prudente y sostenible de los recursos naturales, en un tratamiento nuevo e imaginativo del suelo no urbanizable y del paisaje en su conjunto, en una nueva forma de gobierno y de gestión del territorio basada en el diálogo y la concertación social. La Conselleria de infraestructuras, territorio y medio ambiente de la comunitat Valenciana en su "Guía metodológica de estudios de paisaje" (2012) expresa la importancia de la incorporación del paisaje en la planificación territorial haciendo un análisis exhaustivo de la calidad de paisaje ${ }^{11}$.

Es de gran aporte al momento de indagar en la temática estudiar la labor del Observatorio del Paisaje, el cual es una entidad de asesoramiento de la administración catalana y de concientización de la sociedad en general en materia de paisaje, constituida legalmente

${ }^{11}$ Es definida a partir de la consideración de aquellos aspectos que determinan en mayor medida el carácter de un paisaje. Dicho paisaje será estudiado y evaluado a partir de los siguientes criterios: interés de su conservación, representatividad, singularidad, integridad, función de un paisaje integral, calidad de la escena. 
en el 2004. Es significativo resaltar que desde el 2005, el Observatorio ha centrado su actividad en identificar y caracterizar los paisajes de Cataluña, en desplegar las herramientas previstas en la Ley del Paisaje y en contribuir a conseguir que Cataluña sea uno de los referentes europeos en las políticas de esta materia. Con estas líneas prácticamente ya consolidadas, el Observatorio inicia una nueva etapa y marca una nueva hoja de ruta bajo el nombre de Catpaisatge 2020. El Observatorio ha publicado dos colecciones las cuales plantean un enfoque similar al que se propone abordar en esta investigación, como así también documentos como "La planificación del paisaje en el ámbito local en Europa. Los casos de Alemania, Francia, Países Bajos, Reino Unido, Suiza y la región de Valonia, en Bélgica" donde se explica cómo se implementa y cuáles son los primeros casos.

A su vez, se pueden mencionar en España a los Mapas de los paisajes de Aragón realizados por la Dirección General de Ordenación del Territorio (Departamento de Política Territorial e Interior Gobierno de Aragón) y al Inventario de paisajes realizado por el Departamento de Ordenación del Territorio y Urbanismo de la Comunidad Autónoma de la Rioja. De la misma manera, en Bélgica el Landschapsatlas que ofrece información sobre el paisaje flamenco a su vez, en Francia se puede mencionar al Atlas des Paysages du Territoire de Belfort y el Inventaire des paysages de Poitou-Charentes los cuales ponen de manifiesto la evolución del paisaje. En Reino Unido se puede nombrar al Landscape of Hertfordshire que busca visualizar las declaraciones publicadas de la autoridad local de Hertfordshire en temas de paisaje, así como las estrategias y directrices paisajísticas para diferentes áreas del condado.

En cuanto al paisaje tratado desde una manera global se puede mencionar el trabajo que lleva a cabo La Federación Internacional de Arquitectos del Paisaje (IFLA) la cual hace foco en la arquitectura del paisaje entendiéndola como la profesión para un futuro mejor. Esta federación representa setenta y seis asociaciones nacionales de África, las Américas, Europa y Asia Pacífico, y una región emergente en Oriente Medio. Tiene como misión crear ambientes de vida globalmente sostenibles y equilibrados para el beneficio de la humanidad en todo el mundo.

En el contexto latinoamericano, recién comienza a gestarse la incorporación del paisaje en el ordenamiento territorial a fines del siglo XX, de esta manera algunas ciudades han 
comenzado impulsar intervenciones que buscan la revalorización ${ }^{12}$, reconstrucción ${ }^{13}$ y remediación ${ }^{14}$ de los paisajes.

La problemática de la planificación enfocada en los fenómenos urbanos y las problemáticas ambientales la aborda Kullock (1998) en su libro "Planificación ambiental urbana". De esta manera la entiende como un proceso en la cual "confluyen cuestiones de orden fenomenológico (la ciudad en sí misma), de orden ideológico (problemáticas que la sociedad ha identificado) y de orden disciplinario (respuestas que a nivel profesional ha ido dando)".

Al respecto, pueden destacarse estrategias territoriales como el Plan de Renovación Urbana de Bogotá entre 1997 y 2004 (con tareas de recuperación de humedales, creación de paseos litorales y espacios de marcado interés social), el plan para la ciudad de Medellín, intervenciones a escala más chica como los parques Micaela Bastidas y Mujeres Argentinas en Buenos Aires, el Parque de los Pies Descalzos en Medellín, como ejemplos que comienzan a manifestar el carácter del paisaje latinoamericano. Estas intervenciones muchas veces no difieren de las europeas, están ligadas al turismo o a la proyección de una imagen global. Asimismo, en algunas se identifica el reconocimiento de las características del territorio local y su particular conformación cultural.

En este contexto, Tardín (2010) realiza en su libro “Espacios libres: sistema y proyecto territorial" un análisis del proyecto territorial y cómo influyen los espacios libres en él, tomando como caso de estudio la metrópoli de Rio de Janeiro. La mirada esta puesta en hacer énfasis en el análisis y valorización en base a los atributos que poseen estos espacios con el fin de reestructurar el territorio. Al respecto, Battle (2011) en su libro "EI jardín de la metrópoli”. Del paisaje romántico al espacio libre para una ciudad sostenible” establece los "principios" de ese nuevo espacio libre a través del análisis de varios modelos históricos y de algunos ejemplos contemporáneos: desde jardines o parques hasta sistemas de espacio público e híbridos urbanos. Propone el jardín de la metrópoli como "un sistema de espacios exteriores capaz de resolver las disfunciones evidentes entre la nueva cuidad dispersa y sus espacios libres".

\footnotetext{
12 Dotación o recuperación del valor que cierto paisaje había perdido.

${ }^{13}$ Reparación o nueva construcción de una cosa destruida, deteriorada o dañada.

${ }^{14}$ Entendida el conjunto de actividades a ser llevadas a cabo para recuperar sitios degradados.
} 
A escala latinoamericana, pese a que existe una declaración de principios para la gestión sostenible del paisaje (LALI: Latin American Landscape Initiative) ${ }^{15}$ no hay acuerdos multinacionales como el Convenio Europeo. LALI es una declaración de principios éticos fundamentales para promover el reconocimiento, la valoración, la protección, la gestión y la planificación sostenible del paisaje latinoamericano, mediante la adopción de convenios que reconozcan la diversidad y los valores locales, nacionales y regionales, tanto tangibles como intangibles del paisaje, así como los principios y procesos pertinentes para salvaguardarlo. Esta iniciativa se inspira en las discusiones de una Convención Internacional del Paisaje, adelantadas en reuniones convocadas por la UNESCO y la Federación Internacional de Arquitectos Paisajistas (IFLA), en la Convención Europea del Paisaje y con apoyo en la Declaración de Florencia sobre el Paisaje.

En Argentina, la problemática planteada para esta investigación se ha trabajado desde distintos enfoques. Se realizaron estudios en la Región Metropolitana de Buenos Aires que abordan la problemática de los espacios verdes y la importancia como sistema para mejorar la calidad de vida de los habitantes, como lo es el libro "Biodiversidad urbana" de Garay y Fernández (2006). Este libro trabaja desde la complejidad con la normativa, el diagnóstico y las propuestas en la búsqueda de un sistema integrado de áreas verdes.

Desde la mirada de la antropología, Segura (2015) en su libro "Vivir afuera, antropología de la experiencia urbana" afirma que, a partir de los usos y representaciones cambiantes del territorio, el espacio se vuelve heterogéneo y singular, y en él las unidades territoriales no siempre coinciden. Analiza la ciudad como objeto que se mira (imagen), la ciudad como experiencia corporal/ individual y la ciudad como experiencia pública de vincularse con otros. El trabajo, además, aporta conceptos y miradas interesantes sobre la periferia de La Plata. Por otro lado, también en la ciudad de La Plata, pero sólo en el área correspondiente al casco urbano, Domínguez (2013) en su libro “Valoración del Patrimonio Cultural. Plazas platenses", realizado a partir de su tesis doctoral, elabora una metodología que evalúa y establece una valoración de los distintos componentes de las plazas y parques en el casco fundacional de la ciudad.

\footnotetext{
15 Es una declaración de principios éticos para promover la gestión sostenible del paisaje latinoamericano, mediante la adopción de convenios (leyes-acuerdos-decretos-ordenanzas) que reconozcan la diversidad y los valores locales, nacionales y regionales, tanto tangibles como intangibles del paisaje, así como los principios y procesos pertinentes para salvaguardarlo (IFLA-UNESCO). http://lali-iniciativa.com/que-es-lali/.
} 
Márquez (2011) en su libro, “Planificación diseño y gestión participativa del paisaje” afirma que:

“Planificar el territorio desde el paisaje debe permitirnos resolver los niveles y modos de antropización, establecer los criterios de preservación natural y cultural, definir los nuevos usos del suelo, recalificar las áreas degradadas y organizar sistemas buscando respuestas a través de preguntarnos los dónde, cómo, qué, cuándo y porqué, de cada acción a desarrollar en el paisaje”. (p.26)

Se debe destacar el trabajo que lleva adelante desde el 2008 la Red Argentina del Paisaje (RAP) ${ }^{16}$ y los documentos elaborados con el objetivo principal de la protección del paisaje ya que es un bien que debe ser jurídicamente protegido, poniendo en valor los aspectos ambientales, culturales, históricos, económicos y perceptivos de éste, que lo convierte en un derecho inalienable para la población que se reconoce en él. El paisaje es un recurso que si no se planifica su uso, se agota, de ahí la importancia de la presente ley teniendo en cuenta que Argentina cuenta con una gran variedad de paisajes debido a su morfología territorial, su diversidad climática y sus distintos paisajes culturales, profundamente identitarios, extensa y muy rica en recursos naturales.

También se puede mencionar el Catálogo del Paisaje del río Suquía en la ciudad de Córdoba (Períes, Ojeda, Kesman y Perazzolo, 2016) donde se realiza un estudio paisajístico que se concreta en un documento de información múltiple. Permite conocer los recursos tangibles e intangibles con los que cuenta un sector de ciudad, como también, comprender su dimensión histórica, determinar sus caracteres y sus valores; con la finalidad de establecer el tipo de paisaje que se pretende, así como los medios para lograrlo, como por ejemplo las consideraciones de calidad paisajística. Este catálogo es de gran relevancia ya que es un ejemplo a nivel nacional de cómo determinar la calidad paisajística, donde se contempla el paisaje como modo vivencial, en su totalidad y temporalidad, permitiendo trabajar sobre los aspectos tangibles e intangibles, con especial atención en la fisonomía del paisaje y su dinámica, identificando sus valores y desvalores.

16 La fuerza de la Red está en su base, que son los grupos que se constituyen por situación geográfica, temática o afinidad personal. Estos grupos deben darse la organización propia que consideren más conveniente y la relación con los demás grupos de la Red se establece en diferentes planos y escalas. http://www.redargentinadelpaisaje.com/index.php?b=r 
En cuanto a trabajos de carácter proyectual e investigativo que trabajan en la región de La Plata se tienen en cuenta los desarrollados en el marco de la maestría "Paisaje, Medio Ambiente y Ciudad" (PMC) ${ }^{17}$, los cuales abordan los temas urbanos desde la mirada del paisaje que se propone esta investigación. También se pueden mencionar trabajos de investigación en el IIPAC como el proyecto acreditado de paisaje ${ }^{18}$ que busca mitigar la degradación socio ambiental desde el concepto de paisaje a cargo del Mg. Arq. Leandro Varela. También se pueden mencionar los trabajos realizados en el CIUT'19 por la Arq. Isabel López y el Dr. Juan Carlos Etulain, los cuales han llevado a cabo proyectos acreditados por la UNLP20 que han profundizado sobre la definición de unidades de paisaje en el Gran La Plata y también han establecido una serie de Paisajes de Atención Especial, en base a aquellos que resultaron más reconocidos por parte de los habitantes.

Los trabajos de paisaje en los cuales se hace énfasis en los antecedentes detallados anteriormente, toman a la calidad del paisaje como una variable para tener en cuenta en el ordenamiento del territorio.

En este contexto, muchos de estos antecedentes han sentado precedentes de interés y, por consiguiente, resultan un insumo para el encuadre de la tesis. Es trascendental destacar aquellos que en materia de reflexión han contribuido al conocimiento de la problemática desde un abordaje integral y sistémico, considerando la dimensión paisajística. Estos antecedentes desde distintos puntos de vista se complementan permitiendo plantear una nueva mirada desde una perspectiva que integre dichos temas, entendiendo a la calidad de paisaje no solo desde la conformación estética, sino desde sus atributos físicos y ambientales, permitiendo avanzar en el tema como así también sentar precedente para próximos estudios.

\section{Paisaje, implementación y gestión territorial}

El estudio de paisaje hoy en día tiene dos visiones, por un lado, la reivindicación como expresión de la relación entre la sociedad y el ambiente, entendido como un indicador de

\footnotetext{
${ }^{17}$ La maestría "Paisaje, Medio ambiente y Ciudad" Categoría CONEAU Resolución 1316/12 (2012) con sede en la Facultad de Arquitectura y Urbanismo- UNLP.

${ }^{18}$ El paisaje como factor de mitigación de la degradación socio-ambiental en la región del Gran La Plata (20142017).

${ }^{19} \mathrm{CIUT}$ - Centro de Investigaciones Urbanas y Territoriales tiene su sede en la Facultad de Arquitectura y Urbanismo de la Universidad Nacional De La Plata.

${ }^{20}$ El Paisaje Cultural en la Región del Gran La Plata: enfoques, estrategias e instrumentos. Cod. 11/U086 (20062009) y Ordenamiento, Diseño y Gestión del Paisaje en el Gran La Plata. Estrategias y escalas de Intervención. Cod. 11/U110 (2010-2013).
} 
la calidad de vida de los habitantes y, por el otro lado, ocupando un rol destacado en la planificación y gestión del territorio con el fin de incidir en la recuperación de la identidad territorial.

El entendimiento del territorio a través del paisaje implica la articulación de los aspectos culturales y naturales, asumiendo la interacción continua entre ambos. La concepción territorial del paisaje demanda políticas paisajísticas para todo el territorio, por eso las normativas y los planes de ordenamiento territorial se convierten en un marco adecuado para la incorporación de objetivos y criterios paisajísticos, así como los proyectos de paisaje toman escala territorial. El conocimiento sobre el paisaje debe apuntar a la acción, a frenar la pérdida de identidad y calidad paisajística del territorio, y para ello los métodos de diagnóstico deben abocarse a identificar (desde un enfoque interdisciplinar) los valores del paisaje. Valorar los paisajes significa según Scazzosi (2007) “interpretar y comunicar las diferencias y las especificidades que los distinguen entre sí, subrayando asimismo los problemas y potencialidades" (citado en Caron, 2017, p.117).

En relación a la implementación el Parlamento catalán aprobó el 8 de junio de 2005 la Ley $8 / 2005^{21}$ de protección, gestión y ordenación del paisaje, planteando la ordenación y gestión del paisaje desde la perspectiva del planeamiento territorial. En busca de promover la integración de criterios paisajísticos en el planeamiento territorial, urbanístico y sectorial, el desarrollo de actuaciones ejemplares de restauración y mejora del paisaje basadas en la educación y sensibilización social hacia el paisaje crea los catálogos de paisaje como un instrumento nuevo para la introducción de objetivos paisajísticos en la planificación territorial en Cataluña. Como instrumento de organización la ley introduce la figura de Observatorio del Paisaje, entidad de apoyo y colaboración con la administración en todas las cuestiones relacionadas con la elaboración, aplicación y gestión de las políticas de paisaje (Art. $13^{\circ}$, Ley 8/2005). Su creación responde a la necesidad de estudiar el paisaje, elaborar propuestas e impulsar medidas de protección, gestión y ordenación en el marco de un desarrollo sostenible.

En Argentina, en la legislación aún se ve el paisaje desde una concepción proteccionista, distinguiendo entre paisajes de interés cultural y natural, en la que se preservan valores arquitectónicos, históricos y áreas de interés natural, pero aún no se vislumbra una verdadera integración entre ambos (Jensen y Birche, 2018 b).

\footnotetext{
${ }^{21}$ Ley de protección, gestión y ordenación del paisaje. Año 2005. Parlamento de Cataluña
} 
Al respecto en la Provincia de Buenos Aires, la ley más relevante de protección del paisaje es la $N^{\circ} 12704 / 01$, que establece y regula las condiciones para que un sitio sea declarado "paisaje protegido de interés provincial" o "espacio verde de interés provincial". Los paisajes protegidos se definen como “ambientes naturales o antropizados con valor escénico, científico, sociocultural, ecológico u otros, conformados por especies nativas y/o exóticas de la flora y fauna, o recursos ambientales a ser protegidos" (art. $2^{\circ}$ ); mientras que los espacios verdes de interés provincial son "áreas urbanas o peri urbanas que constituyen espacios abiertos, forestados o no, con fines ambientales, educativos, recreativos, urbanísticos y/o eco-turísticos" (art. $3^{\circ}$ ). Para que un sitio sea declarado como paisaje protegido de interés provincial, además de la biodiversidad y los beneficios ambientales que genera, se prioriza que posea rasgos paisajísticos relevantes para la comunidad, y consenso para la implementación de mecanismos de conservación (Decreto 2314/1122, art. $2^{\circ}$ ). Asimismo, un espacio verde de interés provincial debe cumplir una función ambiental relevante para una población y en él deben poder desarrollarse actividades educativas, recreativas o eco turísticas (Decreto 2314/11 art. $3^{\circ}$ ). Actualmente existe un espacio verde de interés provincial y nueve paisajes protegidos, de los cuales uno sólo corresponde a la cuenca de un arroyo: el Paisaje Protegido de la Cuenca del Arroyo El Pescado, Localidades de La Plata y Berisso ${ }^{23}$ ).

Para finalizar, se pude mencionar la preservación de las áreas de interés natural que está entre los objetivos y principios del decreto-ley 8912/7724, pero también la preservación de áreas con valor paisajístico, histórico o turístico, ligado al mejoramiento de la calidad ambiental. Asimismo, la Ley Nacional General del Ambiente ${ }^{25}$ tiene entre sus objetivos fundamentales asegurar la preservación, conservación, recuperación y mejoramiento de la calidad ambiental, tanto de los recursos naturales como culturales. Estos objetivos se llevan parcialmente a la práctica debido a la carencia de instrumentos específicos de regulación y gestión vinculados al paisaje dentro de los distintos niveles de gobierno, pero especialmente de los municipios que son las instituciones que tienen obligación de regular y ordenar el uso del suelo. Por lo tanto, es posible afirmar que en Argentina la normativa no contempla aún la gestión y el ordenamiento de los paisajes ya que está orientada a la conservación y preservación de los recursos naturales. De esta forma, la legislación se

\footnotetext{
22 Reglamentación de la Ley 12704 De "Paisaje Protegido De Interés Provincial" y/o "Espacio Verde De Interés Provincial". Cámara de Diputados de la Provincia de Buenos Aires. Año 2012

${ }^{23}$ Ley 12274. Cámara de Diputados de la Provincia de Buenos Aires. Año 1999.

${ }^{24}$ Art. N ${ }^{\circ}$ 2. Decreto-ley 8912: Ley de Ordenamiento Territorial y Uso del Suelo de la Provincia de Buenos Aires. Año 1977.

25 Ley 25.675. Congreso de la Nación Argentina. Año 2002.
} 
enfoca en paisajes de características extraordinarias y no existe regulación para los paisajes cotidianos. La figura de espacio verde de interés provincial es la más innovadora en materia de ponderación del paisaje cotidiano, sin embargo, se registra un sólo reconocimiento en toda la provincia 26.

\section{2 | Aproximación teórica conceptual de la cuestión urbana desde la perspectiva del paisaje}

Para profundizar en los procesos de producción del espacio urbano, la configuración del paisaje y el rol de los espacios verdes en el crecimiento de la ciudad, es necesario comprender algunas visiones sobre los conceptos de territorio, ciudad y la noción de paisaje (figura 3). Se busca hacer foco en la importancia de la dimensión paisajística en el proceso de producción de la ciudad y la planificación territorial.

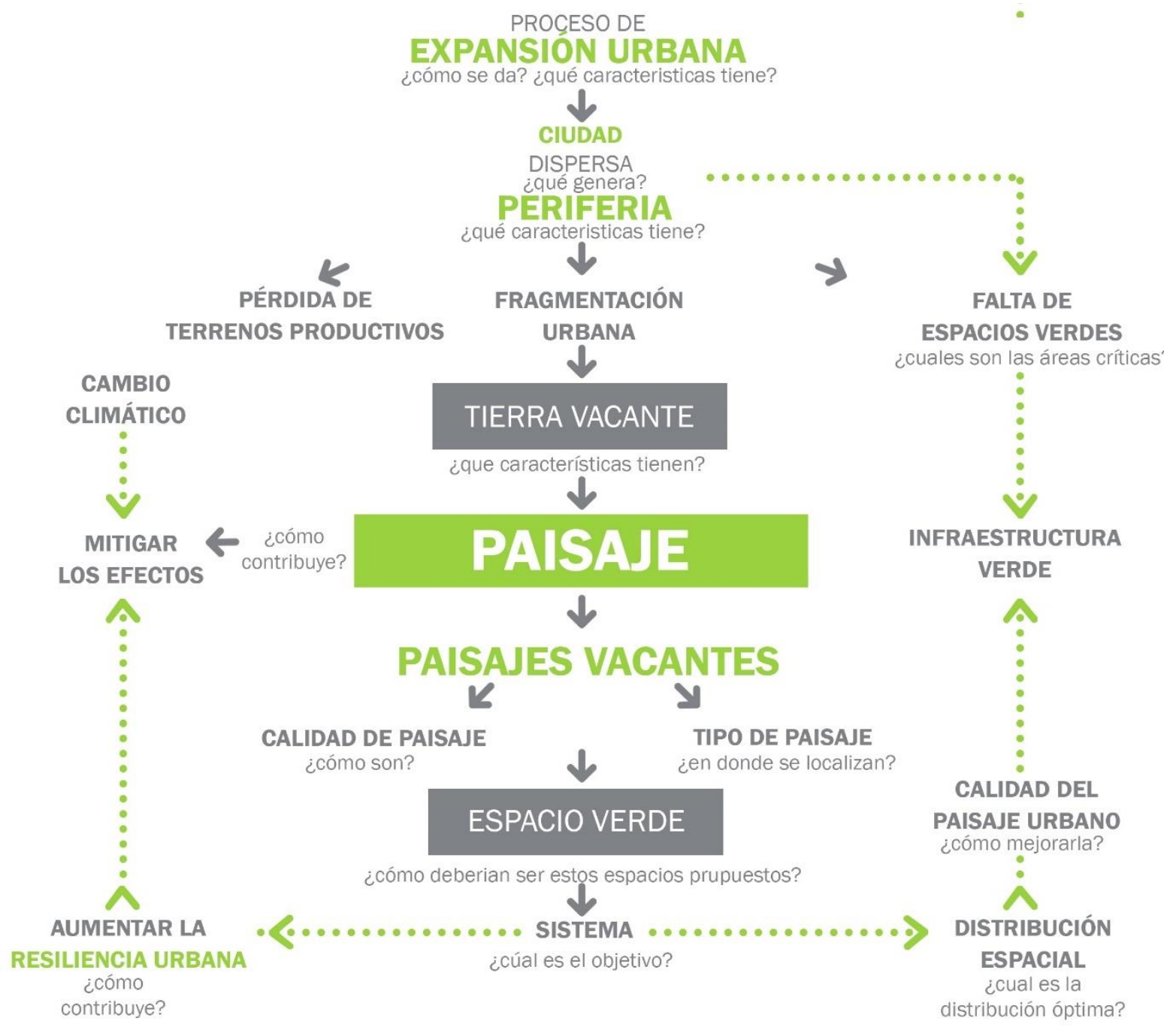

Figura 3. Mapa de los conceptos trabajados en la tesis. Fuente: elaboración propia, 2017.

\footnotetext{
${ }^{26}$ Ley N 14.546. Espacio Verde "Monte del Hospital Dr. Raúl Alfonsín", Partido de Gral. Rodríguez.
} 
El proceso de transformación y conformación de las ciudades latinoamericanas conlleva comprender la estructura urbana. El geógrafo alemán Borsdorf (figura 4) realiza un análisis de las tendencias urbanísticas y modelos de las últimas décadas. Plantea que la transformación urbana de la ciudad latinoamericana se podría modelar en cuatro momentos, de acuerdo a las condiciones históricas y a los procesos económicos. Identifica el período de la ciudad colonial entre 1500 y 1820, la ciudad sectorial en la primera fase de urbanización entre 1820 y 1920, la ciudad polarizada como la segunda fase de urbanización entre 1920 y 1970; y finalmente, la ciudad fragmentada a partir de 1970 hasta hoy, dando como resultado una estructuración espacial específica. Se puede decir entonces que en Latinoamérica se da un proceso de modernización urbana y (a la vez) se da un cambio y se pasa de "las grandes aldeas a las metrópolis masificadas".

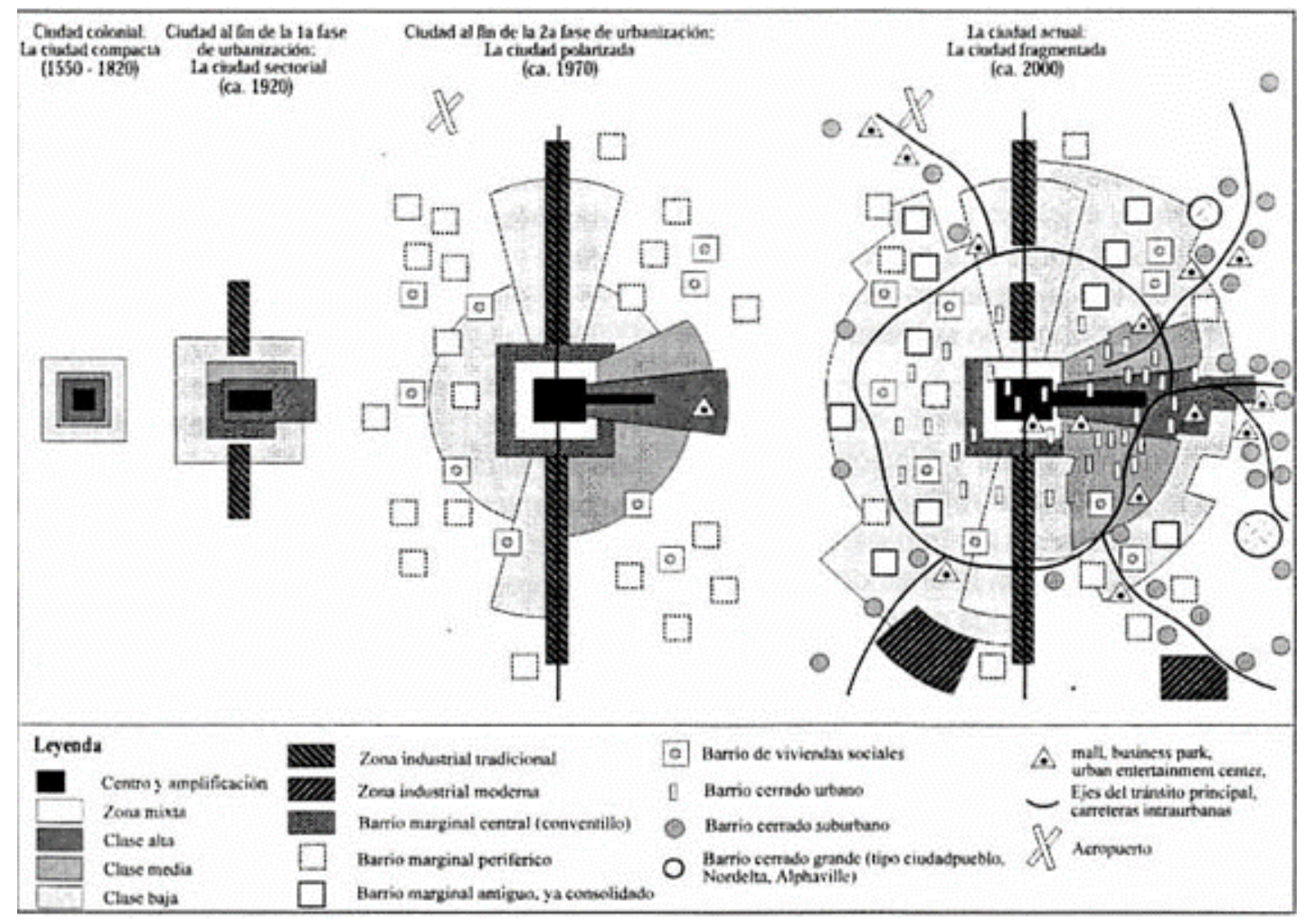

Figura 4. El modelo de desarrollo estructural de la ciudad latinoamericana.

Fuente: Borsdorf, Bahr y Janoschka (2002)

De esta manera, se debe entender los cambios a que son sometidas las ciudades, así según Tulio Halperin Donghi (1969):

" (...) Las sociedades latinoamericanas eran estructuralmente agrarias y los procesos de industrialización muy débiles y dependientes. ¿Cómo se dio este proceso acelerado 
de urbanización? Y qué tipo de "urbanización". Ya que la modernidad latinoamericana ha creado ciudades en las que lo "moderno se arcaiza" y lo "arcaico se moderniza”. De allí que no sea contradictorio hablar de "ciudades de campesinos", sobre todo cuando ese proceso de urbanización comienza a partir de los años 30, en que el "cerco silencioso" de los migrantes internos, modificó profundamente las ciudades, generalmente las capitales, que tenían un "inequívoco "acento francés", convirtiéndolas en ciudades masivas, complejas multicolores, polifónicas." (p.1)

En este sentido, dentro de la transformación de las ciudades latinoamericanas se comienza a observar la influencia de las tendencias urbanísticas europeas y cómo son interpretadas en el territorio latinoamericano. Entre estos se puede destacar desde el haussmanismo en sus distintos momentos, al modernismo corbusierano o el Stadtbau racionalista de Hegemann, los cuales sirvieron de aporte para el desarrollo de las primeras oficinas de urbanismo en la región y dieron forma a los primeros planes urbanos, mientras consolidaron el urbanismo en los medios académicos y profesionales. En este contexto, además de la transformación de las ciudades se ubican las llamadas ciudades planificadas, las cuales surgen del diseño de las mismas en un plano y se implantan sobre el territorio.

Si para el pensamiento europeo el concepto de ciudad es bastante posterior a la existencia del "hecho urbano" (De Certeau, 2000), esta relación se invierte en el caso de América. Como sostuvo Ángel Rama, desde la remodelación de Tenochtitlán hasta la inauguración de Brasilia,

“(...) la ciudad latinoamericana ha venido siendo un parto de la inteligencia, pues quedó inscripta en un ciclo de la cultura universal en que la ciudad pasó a ser el sueño de un orden y encontró en las tierras del Nuevo Continente, el único sitio propicio para encarnar" (Rama, 1984, p.9).

Estas ciudades surgen de la mano de las corrientes de pensamiento europeo mencionadas anteriormente e impregnaron a la clase política de la época; las ideas de orden y progreso rondaron constantemente en las decisiones de los gobernantes. Las principales ciudades de Latinoamérica planificadas fueron construidas a través de las ideas del higienismo que 
comenzaba a tomar importancia en esa época, llevado adelante por hombres formados en los ideales de la ciencia positivista ${ }^{27}$ y el racionalismo ${ }^{28}$.

Esta corriente surge en el contexto de la incipiente implantación del liberalismo a mediados del siglo XIX cuando los gobernantes comenzaron a considerar la posibilidad de gestionar las zonas urbanas de un modo más sustentable en el área de saneamiento de las grandes ciudades. Esto implica un mejoramiento en las condiciones de salubridad que buscaban evitar el hacinamiento y la propagación de enfermedades y epidemias que venían castigando los grandes aglomerados urbanos europeos (como lo fueron el cólera y la fiebre amarilla). Esta corriente tuvo gran difusión y aceptación durante finales del siglo XIX fue uno de los ejes que sostuvo de forma teórica la planificación de la cuidad.

Las ciudades planificadas ${ }^{29}$ en su mayoría surgen "de la nada" como resultado de una preparación para un propósito específico, es decir en un terreno no urbanizado se plantea la concepción de una nueva ciudad. Este desarrollo urbano responde principalmente a la gestión administrativa y no de un proceso natural de desarrollo urbano, es decir de un asentamiento espontáneo. Estas ciudades son creadas atendiendo un propósito o un objetivo político o económico, o por el simple motivo de poblar un espacio rural. En este contexto, la ciudad de La Plata se convierte en el paradigma de la planificación urbanista de finales del siglo XIX, al igual que la ciudad de Belo Horizonte en Brasil, correspondiéndose una misma filosofía en la construcción y similitudes en el trazado de las mismas: cuadricula perfecta, diagonales, plaza central y numerosos espacios verdes.

En Argentina, el trazado urbano adquirió una identidad propia aun antes de que se funde la ciudad propiamente dicha, de esta manera se puede remarcar "la identificación de una ciudad prácticamente sin existencia física (puro gesto político, expediente administrativo) con una imagen previa de lo que sería" (Gandolfi y Gentile, s/f).

\footnotetext{
${ }^{27}$ El positivismo es un pensamiento filosófico que afirma que el conocimiento auténtico es el conocimiento científico y que tal conocimiento solamente puede surgir de la afirmación de las hipótesis a través del método científico.

28 Teoría epistemológica que, frente al empirismo, considera la razón como fuente principal y única base de valor del conocimiento humano en general.

${ }^{29}$ Se denomina como ciudad planificada, ciudad planeada o ciudad de nueva planta a una ciudad creada desde la nada, en terreno previamente no urbanizado o muy escasamente poblado, con un propósito determinado, y de acuerdo con unos planes urbanísticos globales. Su desarrollo depende por lo tanto de una decisión administrativa, y no del movimiento natural de la población.
} 
A esto ayudo la condición geomorfológica de la pampa ${ }^{30}$, esa llanura extensa, una superficie natural e incivilizada sobre la cual se imprimiría una nueva cultura. La gran extensión de esta llanura sin límites en cuanto a niveles permitía superponer el trazado de la futura ciudad sin ningún tipo de condicionante en relación al relieve.

De ahí surge un interrogante ¿Cómo dar forma a la pampa?, la ausencia de límites y obstáculos dificultaba la delimitación.

“La cuadrícula intenta llenar el vacío de la pampa, intenta fundar ciudad sobre la nada. Porque ve la naturaleza como amenaza material y cultural, funda una forma abstracta, homogénea, regular: pura cultura (...) pero en esa regularidad el culturalismo denuncia el triunfo de la naturaleza (...), porque lo que aparece como principal abstracción es la propia inmensidad de la llanura, su ausencia de organicidad”. (Gorelik, 1998, p.34)

En este contexto, la ciudad estaba sometida a lo que la pampa imponía prolongando indefinidamente un trazado en cuadrícula que no encontraba obstáculos para su expansión, es por ello que el plano fundacional proponía límites precisos y claros que hagan hincapié en la diferencia entre el adentro y el afuera, lo urbano y lo rural entendido de otra forma en la cultura y la naturaleza.

Por otro lado, hay concepciones que se refieren a la ciudad, como la materialización de procesos sociales y, por tanto, el foco está en comprender las relaciones humanas y cómo ellas influyen en el espacio. En este contexto, Castells (1978) considera el espacio como la expresión de la estructura social en la cual el sistema político, económico e ideológico, así como las prácticas derivadas de ellos, son elementos fundamentales para su análisis.

Actualmente, las ciudades son consideradas como un punto de concentración de los poderes o fuerzas económicas, políticas, físicas y culturales. Desde el enfoque económico que plantea Sassen (2005), las ciudades son consideradas como nodos que interactúan en una red global, dentro de la cual es posible ser o no competitivo y tener ventajas sobre otras.

\footnotetext{
${ }^{30}$ La Pampa, o región pampeana, es un área geográfica situada en el centro-este de Argentina, en Uruguay, y el sur de Brasil. Se caracteriza por ser un relieve llano con algunas ondulaciones y sistemas de sierras.
} 
Desde la perspectiva de esta investigación, la ciudad es entendida como un "sistema abierto, multidimensional, de alto orden de complejidad" (Karol, Ravella y Aón, 2012), definida por sus componentes y las relaciones que existen entre ellos.

La ciudad como un sistema ${ }^{31}$ de realidad compleja, resultado de la interrelación, de al menos tres aspectos (figura 5), el espacio urbano "urbs", el hecho social o los ciudadanos que la habitan "civis" y el hecho institucional y político que la gestiona "polis y en la que cada una de sus partes se interrelaciona a través de flujos materiales o virtuales.

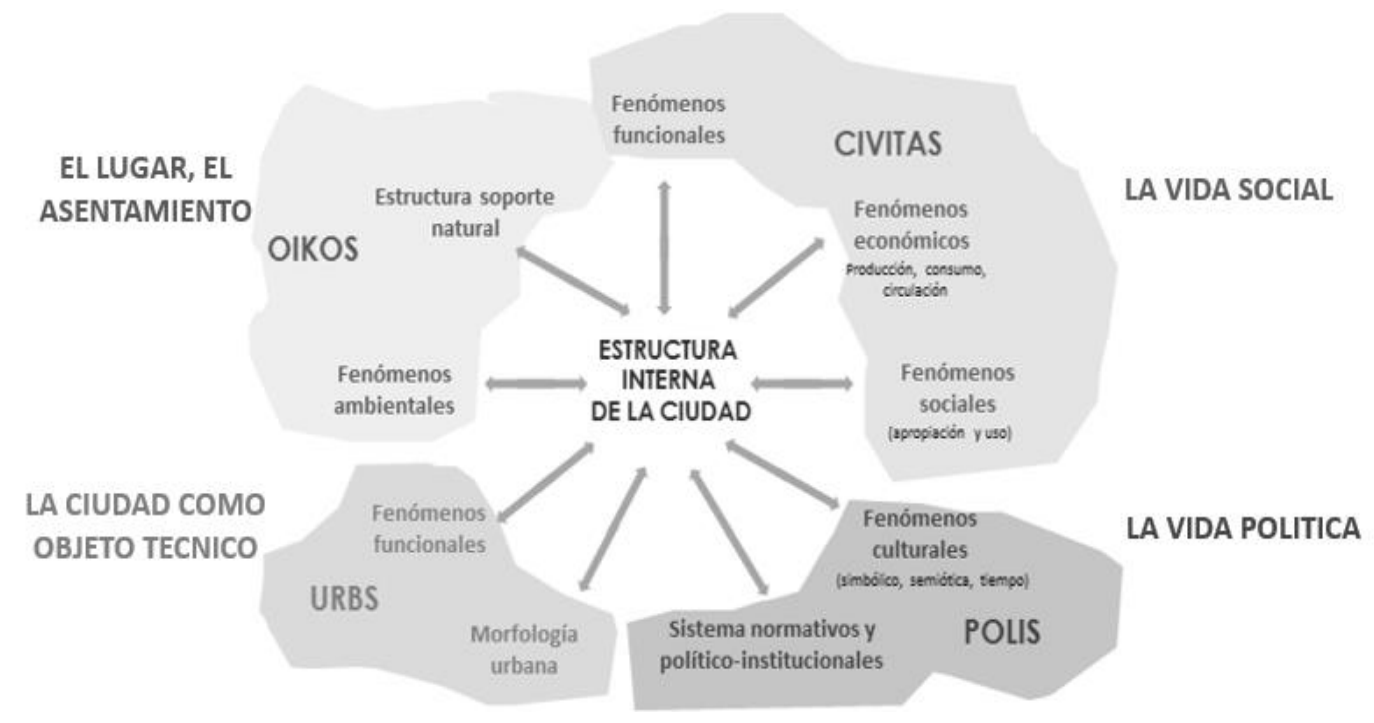

Figura 5. La ciudad entendida como sistema

Fuente: planeamiento físico Ravella, Karol - Fau-Unlp

Esto se debe a que la estructura de la ciudad comprende componentes del soporte natural, fenómenos ambientales y funcionales, morfología urbana, estructura y procesos económicos, sociales, culturales, atributos físicos, sistemas normativos y políticoinstitucionales, los cuales se articulan implicándose universalmente, bajo condiciones sistémicas en un espacio geográfico (Karol, 2013).

Entonces esta visión de la ciudad desde la complejidad “implica avanzar más allá de la simple relación causa efecto, para intentar comprender la evolución, la organización y el comportamiento de los actores, cuyas relaciones conflictivas definen las características del hecho urbano" (Ravella, 2010).

En base a estas relaciones Kullock (1998) interpreta a la ciudad como la relación del ambiente y la sociedad poniendo de manifiesto los efectos y relaciones que los sistemas

${ }^{31}$ Conjunto de elementos relacionados o interactuando de manera tal que formen una unidad. 
ejercen mutuamente y en el contexto que se dan. Propone una serie de aspectos y fenómenos a indagar en relación a la ciudad, donde se pueden observar las diferentes relaciones que se dan entre los subsistemas y las demandas que le genera uno a otro.

Esto nos permite comprender que los problemas que se dan en el subsistema natural y construido se debe a la demanda ambiental que ejerce el subsistema social y productivo. Es decir, estas relaciones y demandas se ven reflejadas en la ciudad y permiten comprender las problemáticas que en ella encontramos y los orígenes de estos problemas. Kullock (1998) mediante un cuadro (figura 6) propone poner de manifiesto estas relaciones y el contexto en el que se dan.

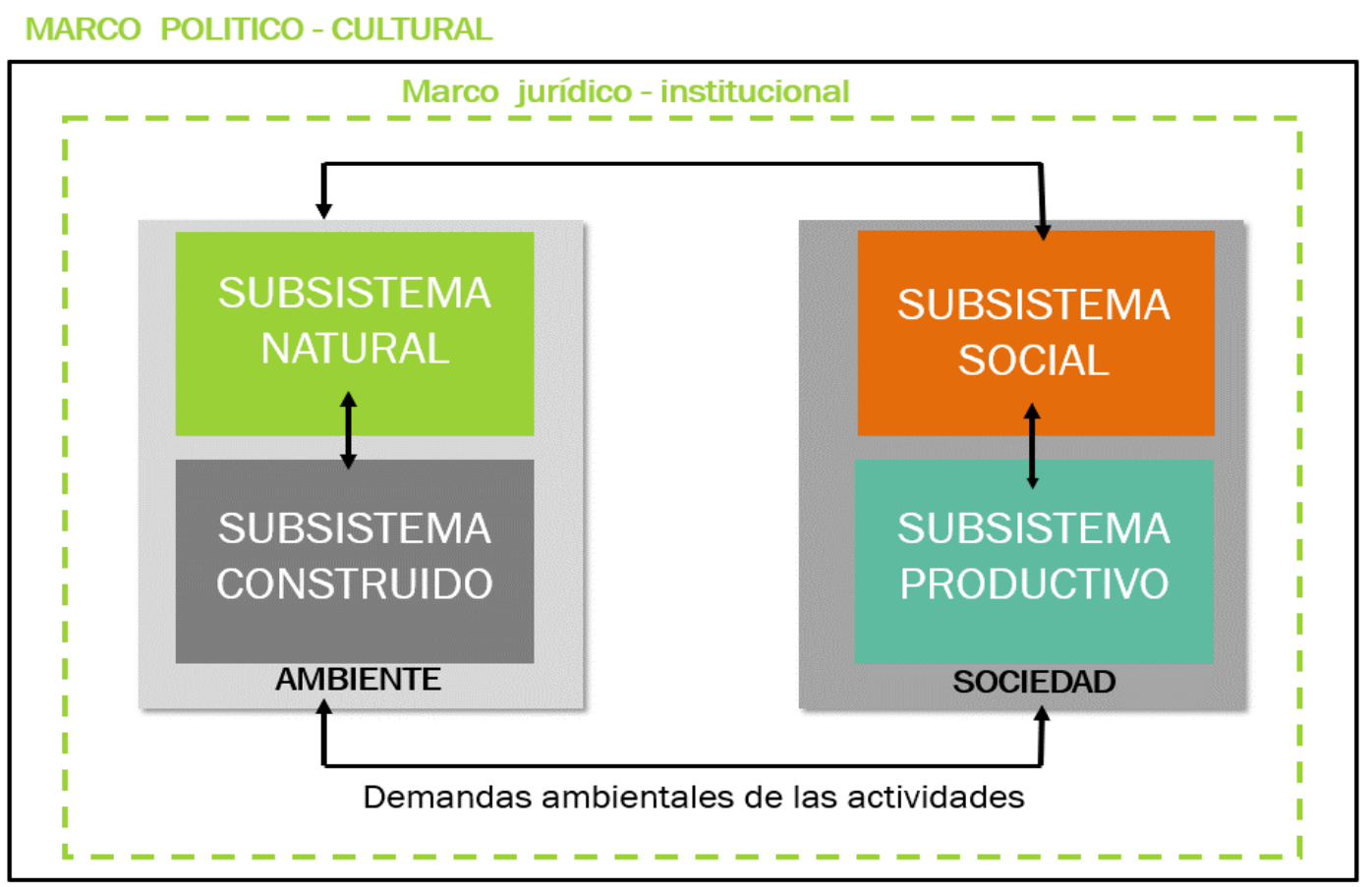

Figura 6. Relaciones de los subsistemas de la ciudad.

Fuente: Kullock, 1998.

El término paisaje proviene de 'país' y se introduce en nuestro idioma a principios del siglo XVIII, como resultado de las francesas paisaje y pays. En efecto, país significa también la pintura en la que están pintados lugares, villas y campiñas. El Paisaje puede definirse, así como "un pedazo de país en la pintura" (Bedoya, 1996). Existen aproximaciones semánticas, fonéticas y conceptuales de las palabras francesas pays y paysage; italianas: paese y paesaggio, inglesas: land y landscape; catalanas: pays y paisatge; y alemanas: land y landschaft (Gastó-Coderch et al., 2010). 
Desde estas aproximaciones conceptuales se puede observar la relación entre la cultura y la naturaleza que como resultante arrojan al paisaje. También se logra visualizar el vínculo estrecho que hay entre las artes y el paisaje. Dicen Silvestri y Aliata (2001):

“Para que exista un paisaje no basta que exista 'naturaleza'; es necesario un punto de vista y un espectador; es necesario, también, un relato que dé sentido a lo que se mira y experimenta; es consustancial al paisaje, por lo tanto, la separación entre el hombre y el mundo. No se trata de una separación total, sin embargo, sino de una ambigua forma de relación, en donde lo que se mira se reconstruye a partir de recuerdos, pérdidas, nostalgias propias y ajenas, que remiten a veces a larguísimos períodos de la sensibilidad humana, oras a modas efímeras". (p.0)

En referencia a la dimensión paisajística, esta depende de la disciplina desde la que se considere. Si bien muchas disciplinas abordan la temática del paisaje, en este trabajo, se toma como punto de referencia a la Convención Europea del Paisaje que lo define como: "Cualquier parte del territorio, tal y como es percibida por las poblaciones, cuyo carácter resulta de la acción de los factores naturales y humanos y de sus interrelaciones" (Consel de l'Europe, 2000).

Con esta definición propuesta por el Convenio Europeo del Paisaje, se hace referencia al hecho objetivo de que es todo paisaje, donde es importante resaltar el vínculo que se establece entre paisaje y población al mencionar "tal y como es percibida por las poblaciones". En este caso, se promueve el conocimiento sensible más que el conocimiento puro, a lo subjetivo. Asimismo, existe una clara referencia a la construcción social del paisaje cuando se mencionan los factores humanos: "cuyo carácter resulta de la acción de los factores naturales y humanos y de sus interrelaciones". Se pueden nombrar como factores humanos: los asentamientos y sus actividades, prácticas agrícolas, ganaderas, forestales y de extracción de recursos naturales, todas ellas siendo constituidas desde la cultura misma de esa sociedad. Esta última parte refleja la idea de que los paisajes evolucionan a lo largo del tiempo, como resultado de la actuación de las fuerzas naturales y humanas, y destacando que un paisaje forma un todo, cuyos componentes naturales y culturales se toman de forma conjunta y no de forma separada.

Ahora bien, al hablar de interrelaciones se entiende al paisaje como el "resultado" de la interacción entre el hombre y la naturaleza, es decir entre la cultura y la naturaleza (figura 7). El termino paisaje para Graciela Silvestri (2011) “alude simultáneamente a un 
ambiente predominantemente natural y a las formas de ser interpretado, representado o transformado".

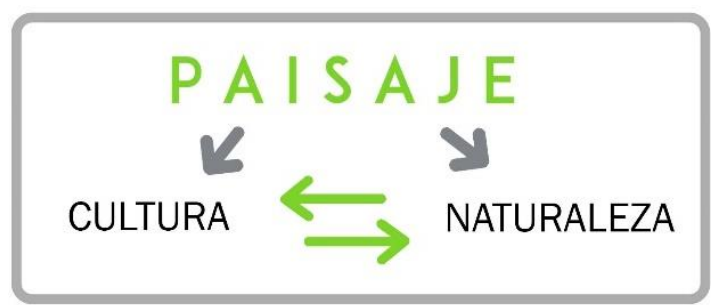

Figura 7. Paisaje interacción.

Fuente: elaboración propia, 2014.

Los factores que influyen en la conformación del paisaje y su expresión actual son numerosos e interrelacionados, y pueden producirse múltiples combinaciones que pueden ser casi ilimitadas. Sin embargo, existen semejanzas, características comunes, que hermanan diversos paisajes y que están en estrecha relación con los factores causales que los determinan.

Desde un enfoque social, Nogué (2007) define el paisaje como un producto social, como la proyección cultural de una sociedad en un espacio determinado, producto de una relación entre el hombre y la naturaleza, que se establece a partir de un conjunto de sistemas técnicos y simbólicos. Símbolos que expresan las relaciones que se dan en el territorio, y a su vez contribuyen a configurar el mismo territorio. Esta perspectiva entiende al paisaje como una construcción social, una forma de ver el mundo, que se corresponde con una ideología y con una determinada forma de apropiación del espacio, es un reflejo del poder en el territorio y una herramienta para establecer y legitimar relaciones sociales. De la misma manera lo definen Aliata y Silvestri (2001) donde expresan que "Para que exista un paisaje no basta con que exista "naturaleza"; es necesario un punto de vista y un espectador; un relato que de sentido a lo que se mira y experimenta como actor y como espectador."

En este contexto la noción de Paisaje se constituye como una categoría relacional recomponiendo la relación entre cultura y naturaleza, entre sujeto y objeto, entre la razón y sentimiento, separada por el paradigma moderno dualista. La conceptualización de paisaje en la actualidad desde una visión sistémica y relacional se distancia de los enfoques esteticistas o naturalistas. Desde este modo se entiende al paisaje como la representación de la relación entre medio natural y cultura, y en el caso de las ciudades entre medio urbano y cultura, a través un proceso histórico y dinámico por el cual el 
hombre reconoce el medio y genera las maneras para adaptarlo y adaptarse. Esta dialéctica entre construcción material del ambiente y construcción de códigos culturales, es lo que Berque (2006) define como trayección, el vaivén entre el hombre y su entorno, donde en hombre modifica su entorno y este a su vez este modifica al hombre. El paisaje es un estado intermediario y dinámico, no puede reducirse a ninguno de estos polos teóricos, ni al físico ni al social, sino que está precisamente entre los dos, como lo define el autor, es trayectivo.

Roger (2007) sostiene que no existe paisaje desde un punto de vista exclusivamente físico: hablar de paisaje implica necesariamente un tipo de apreciación estética, en la que la mirada este guiada por ciertos criterios relativos a la representación artística, por eso distingue el país del paisaje. El primer término se referiría a lo que se puede denominar como ambiente, o bien territorio: un ámbito considerado desde el punto de vista de sus características físicas, de asentamientos humanos, de actividad económica. En tanto, el termino paisaje implica necesariamente un proceso de actualización, es decir de asignación de cualidades estéticas.

Santos (2000) afirma al hablar de paisaje que es:

“El conjunto de formas que, en un momento dado, expresa las herencias que representan las sucesivas relaciones localizadas entre el hombre y la naturaleza.(...) el paisaje es solo la porción de configuración territorial que es posible abarcar con la visión(...) El paisaje es transtemporal, juntando objetos pasados y presentes, una construcción transversal (...) El paisaje existe a través de sus formas, creadas en momentos históricos diferentes, aunque coexistiendo en el momento actual(...)una especie de palimpsesto donde, mediante acumulaciones y sustituciones, la acción de diferentes generaciones se superpone". (p. 86,87)

En contraposición según Fontanari (2011) “El paisaje no existe; es el hombre quien pone en el acto de calificar a un lugar como paisaje" aporta así al conocimiento y propuestas de producción de paisajes poniéndole atención a la relación entre los objetos ya sean los muertos o estáticos como una piedra como así también los dinámicos y móviles como el hombre. El hombre es el verdadero generador del paisaje.

Entonces el paisaje puede ser comprendido como la imagen multidimensional de un proceso histórico-cultural en un territorio específico. Esta categoría combina dimensiones que incluyen aspectos físicos y simbólicos que caracterizan esa relación entre cultura y 
naturaleza. Según esta visión la ciudad puede entenderse como la define Lefebvre (1974) como "un particular modo histórico de vivir juntos", comprendiéndola como un fenómeno social, espacial e histórico. Es así donde el paisaje toma relevancia como categoría de análisis, no solo por la reconstrucción de memoria del proceso histórico-cultural de la conformación de la ciudad, sino por la significativa importancia que éste tiene en los procesos de producción del espacio urbano.

Se puede decir entonces que los paisajes evolucionan a lo largo del tiempo, como resultado de la actuación de las fuerzas naturales y humanas, y se destaca que un paisaje forma un todo, cuyos componentes naturales y culturales se toman de forma conjunta, y no de forma separada. Como indica Nogué (2008), "El paisaje es, a la vez, una realidad física y la representación que culturalmente nos hacemos de ella; la fisonomía externa y visible de una determinada porción de la superficie terrestre y la percepción 32 individual y social que genera; un tangible geográfico y su interpretación intangible" (p.138). La adjudicación de un valor tiene una connotación espacial y temporal, social, cultural, histórica y ecológica, a la vez que está determinada por la naturaleza de quien observa, sus capacidades, conocimiento, educación, experiencias pasadas, nivel socio económico, edad, sexo, estado de ánimo y expectativas.

La percepción del paisaje es de gran importancia en la creación de un sistema de espacios verdes de uso público ya que es un elemento esencial para el mantenimiento de la calidad visual de un lugar, con repercusiones sobre el desarrollo de la calidad de vida de la población y la preservación del su patrimonio natural y artificial (Zoido Naranjo, 2002).

En cuanto a los métodos e instrumentos que permitan concebir las intervenciones espaciales desde una perspectiva sistémica e integrada y considerando que uno de los desafíos presentes es "el de orientar nuestra disciplina hacia el diseño de los espacios, con improntas ambientales y sociales, con sumo compromiso ético ya que allí es donde estamos haciendo falta" (Márquez, 2011), en este contexto se propone trabajar desde el concepto de paisaje como una visión integral del territorio.

De esta manera, el diseño y la planificación del paisaje funcionan a modo de instrumento para la puesta en valor de un espacio. Los estudios de paisaje son los instrumentos de ordenación paisajística que tienen como función coadyuvar, en materia de paisaje, a la

\footnotetext{
${ }^{32}$ Ésta se utiliza para comprender y valorar la percepción del público hacia el paisaje así como las relaciones físicas y psicológicas entre los usuarios con las áreas verdes y espacios abiertos (van den Berg y van Winsum-Westra, 2010).
} 
planificación territorial y urbanística. Estos instrumentos de dinamización y de mejora de la calidad del territorio son una herramienta muy útil para orientar los futuros desarrollos urbanísticos y territoriales, preservando la identidad de cada lugar y contribuyendo a la funcionalidad de la infraestructura verde del territorio.

Es indispensable comprender las dinámicas urbanas en las que se encuentran insertos, la importancia que tuvieron los espacios en la organización de la unidad territorial de referencia y las consecuencias que sufrieron a causa de la ocupación urbana y la forma en que se llevó a cabo. Estos, además, establecen criterios para zonificar el suelo no urbanizable y para la catalogación y conservación de los elementos estructurales del territorio que definen en mayor medida el carácter de un paisaje.

Es de suma importancia valorizar los espacios cuyos atributos favorezcan el desarrollo de los procesos biofísicos y visuales, que puedan tener un importante papel en la reestructuración espacial y funcional del territorio.

Para comenzar a hablar de calidad de paisaje se puede incorporar el concepto acuñado por Auge (1992) de "no lugar" entendiendo que un lugar puede definirse como lugar de identidad, relacional e histórico, un espacio que no puede definirse ni como espacio de identidad ni como relacional ni como histórico, definirá un no lugar. Este concepto desde el enfoque del paisaje podría acercarse a lo que es un área degradada social y ambientalmente y como se convierte en ese lugar que carece de identidad.

En cuanto al fin de evaluar la calidad de paisaje es necesario tomar de referencia el trabajo realizado en la Maestría PMC titulado “Hacia la conformación de un marco jurídico sobre el paisaje fundamentos para la elaboración de un proyecto de ley de presupuesto mínimos sobre paisaje", donde se aborda la problemática haciendo hincapié en:

"La inexistencia de mecanismos y medios específicos de gestión, así como, de control y seguimiento integral del paisaje, se convierte en una de las principales trabas para adoptar políticas eficaces, justas y decisivas sobre este particular. [...] Por tal razón, resulta importante la adopción de medidas que nos acerquen a países con mayor tradición paisajística, que tienen más experiencias en una buena gestión, protección y desarrollo endógeno de las políticas de paisaje, sin dejar de lado nuestro contexto latinoamericano, sus problemáticas y posibilidades en el marco cultural, económico, político, social y ambiental". (Varela y Sahaniuk Coord., 2008, p.4). 
En cuanto al ordenamiento del territorio, la noción de paisaje resulta clave. En este sentido, sostiene Francisco Zoido (2002), los paisajes resultan un instrumento útil en una triple dimensión:

1. Como hecho que contribuye a la correcta localización y disposición de los elementos y usos del territorio, así como de las estructuras o sistemas que lo conforman.

2. Ayuda a realizar el diagnóstico territorial, pues contiene y muestra en sus formas los aciertos y disfunciones en el uso del espacio geográfico, al mismo tiempo permite comprender y explicar sus formas, tarea imprescindible para ordenarlo con conocimiento de las causas que las han producido.

3. La valoración del paisaje que tienen las personas que lo perciben, especialmente aquellas para las que es su espacio vivido de forma cotidiana, su lugar de trabajo o de residencia. Esta valoración debe ser considerada como factor que coadyuva a la participación ciudadana, que permite opinar y decidir sobre las propuestas de ordenación territorial.

En el siglo XXI, se puede decir que es indiscutible que el paisaje se encuentra mediado por las tecnologías de visión. La imagen tiene un poderoso impacto en la mente humana a nivel de experiencia. Sin embargo, la arquitectura y el arte ya no comunican nada si no van acompañados por las claves para ser interpretados. No pudieron abandonar la tradición del siglo XX en que el arte es entendido como un fenómeno inminentemente intelectual, donde la teoría toma un rol fundamental. En este sentido, se puede definir el paisaje como una realidad observada (no existe, es resultado de una experiencia) que se define a través de una representación y da como resultado una imagen. Se puede decir también que conocemos a través de la experiencia directa o a través de imágenes. Por lo tanto, la teoría del paisaje es una teoría de los medios, es decir de cómo conocemos (Silvestri, 2011).

Según Ravella (2013), planificar las acciones en el territorio se convierte en un instrumento esencial para reequilibrar las relaciones entre los hombres y entre la sociedad y la naturaleza. Desde la ciudad, a través del uso eficiente de la energía como factor de desarrollo; el paisaje como factor de mitigación de la degradación y un sistema de movilidad que integre actividades, uso de suelo y transporte. 


\section{Las periferias como nuevas formas de ocupación}

Habiendo recorrido las diferentes visiones del concepto de paisaje a lo largo de la historia se puede identificar la estrecha relación que hay entre este concepto y las dinámicas urbanas en las que se inserta.

Mientras que la urbanización industrial generó concentración de población e industrias en grandes ciudades, los nuevos procesos de urbanización postindustriales cambian el sentido de los movimientos migratorios de campo-cuidad a ciudad-campo impulsando el movimiento desde las áreas centrales hacia la periferia, propiciando a una urbanización difusa. Estas migraciones generan una nueva concepción de cuidad. Como explica Harvey (2004), a partir de finales de los años 1960, el desarrollo inmobiliario pasa a ser un campo de gran importancia para la acumulación capitalista, directa o indirectamente, y las instituciones financieras comenzaron a involucrarse en el desarrollo urbano ${ }^{33}$, que convirtió a la construcción en una de las fuerzas motrices de la economía. Estas políticas de densificación se insertan en el proceso de globalización de la economía mundial, que va acompañado de una desterritorialización política y económica, separando a los actores locales de la toma de decisiones.

En relación a las nuevas formas de conformación de la cuidad, Dematteis (1996) considera que:

“Los recientes procesos de difusión de la ciudad están dando origen a periferias urbanas de un tipo muy distinto de aquellas que se han formado en Europa desde la revolución industrial hasta la década de 1960. Estas nuevas periferias son el resultado de profundos cambios en las estructuras territoriales urbanas, en las tecnologías de la comunicación y de la información, en la organización y en la regulación social, que han transformado a los países industrializados a partir de finales de la década de 1960" (p.17).

Hacia la década de los `70, el modelo fordista estaba agotado, entonces, se comenzaron a ver los procesos que generaban una nueva alternativa, el toyotismo, que tuvo clara influencia en los noventa con el neoliberalismo, y nació en la forma de producción japonesa, este modelo se diferencia por su idea de trabajo flexible, el trabajo combinado

\footnotetext{
${ }^{33}$ Se entiende "el desarrollo urbano como un proceso que tiene como objetivos eficiencia económica, equidad social y equilibrio ambiental; ya que la eficiencia dará competitividad al territorio, la equidad facilitará cohesión social a través de la distribución de la riqueza y el equilibrio permitirá la conservación del sostén de todas las actividades." (R. Cotorruelo Menta, 2001)
} 
y aumento de la producción por organización y gestión. La polarización social que significa el pasaje del fordismo al posfordismo, tiene que ver con un cambio fundamental en la economía mundial.

Los nuevos procesos de urbanización han generado cambios estructurales en la conformación, configuración y ordenamiento del territorio. Entendiendo al territorio como el lugar donde se desarrollan procesos naturales y donde se despliegan procesos sociales (Bozzano, 2004 citado en: Frediani, 2010), es decir, como una construcción social que expresa la organización que las sociedades realizan sobre un marco natural, a través de mediaciones, en las que intervienen las representaciones de los actores sociales. Este territorio corresponde a las huellas del hombre, el artificio humano sobre la naturaleza; como afirma Folch (2003), el territorio que un día fue territorio de la naturaleza, pasa a ser en gran medida, el territorio del hombre, donde conviven el artificio en sí mismo y la naturaleza "artificializada".

De los cambios que se vinieron manifestando en los últimos años, Maristella Svampa (2004, citado en: Méndez Mihura, 2011) plantea que:

“Una de las expresiones más claras de esta dinámica global excluyente fue la consolidación de un patrón socio-espacial el fenómeno es de tal envergadura que los estudiosos del tema como S. Sassen, M. Castells o Meter Marcase, sostienen que asistimos a la emergencia de una nueva configuración urbana (la "ciudad postfordista", la "ciudad global”, la "ciudad cuarteada") caracterizada- entre otras cosaspor la expansión de una nueva periferia, que presenta enormes contrastes respecto del modelo anterior, visibles en el aumento de la segregación interna y en los procesos de dualización espacial...Estos cambios socioespaciales están presentes en grados diferentes en todas las sociedades. En términos más esquemáticos, el actual proceso urbano ha sido descripto como el desplazamiento de un modelo de "ciudad abierta", básicamente europeo, centrado en la noción de espacio público y en valores como la ciudadanía política y la integración social, hacia un régimen de "ciudad cerrada", más asociado al tipo norteamericano, marcado por la afirmación de una ciudadanía patrimonialista centrada en la figura del contribuyente". (p.3)

Los territorios actuales presentan una estructura espacial discontinua y extendida donde los centros son compactos y se mezclan con asentamientos dispersos combinando el medio natural, rural y urbano. En las áreas de expansión la producción del suelo urbano 
se realiza a través de amanzanamientos, loteos y de vías de circulación, en tanto la ocupación del suelo se concreta en continuar el tejido urbano, a medida que avanza la construcción de edificaciones y comienzan a desarrollarse los usos vinculados a las actividades urbanas y periurbanas. La ocupación del espacio depende de los actores que intervienen en el proceso de crecimiento urbano y de la aplicación de políticas urbanas orientadas a partir de la priorización de la lógica económica arrojando como resultando la pérdida de paisaje y de calidad de vida ${ }^{34}$ urbana. Como señala Bozzano (1990), "el avance de la ciudad, en su expansión horizontal, transforma los espacios rurales adyacentes en un proceso que se relaciona con "las diferentes condiciones generales de valorización de capitales que se generan en unos y otros ámbitos; asimismo, el espacio periurbano se estructura para la ciudad porque sus procesos, directa o indirectamente, están en función de ella" (p.269).

Esta tendencia se continuó de esa manera, tal es así que para el año 2008, más de la mitad de la población mundial se encuentra viviendo en ciudades. Según el Banco Mundia| ${ }^{35}$ se estima que para el año 2030 el 60\% de la población vivirá en ciudades. Además, cabe destacar que en Argentina y en América Latina, la urbanización supera en la mayoría de los casos el 90\%. En el país, este acelerado proceso de producción de la ciudad se ha llevado a cabo con escasa regulación por parte del Estado siguiendo principalmente las líneas impuestas por el mercado inmobiliario.

Los procesos de crecimiento urbano se pueden distinguir según tres fases de desarrollo, por expansión, consolidación y densificación (Frediani, 2010). La expansión de las ciudades se da con barrios que van ocupando la periferia con un patrón de baja densidad sobre los territorios rurales. Esta expansión va dejando grandes vacíos intersticiales, este proceso se completa con el de consolidación. En las áreas centrales, las cuales cuentan con todos servicios y equipamientos, se da el proceso de densificación, donde el valor del suelo es mayor.

Estos procesos se pueden dar de a uno o en simultáneo ya que el patrón de crecimiento de las ciudades latinoamericanas responde a un crecimiento desordenado de extensión de la mancha urbana y al mismo tiempo en las áreas centrales de valorización y

\footnotetext{
${ }^{34}$ Calidad de vida es una construcción compleja y multifactorial sobre la que pueden desarrollarse algunas formas de medida objetivas a través de una serie de indicadores, pero donde tiene un importante peso específico la vivencia que el sujeto. (Rueda, 1996)

${ }^{35}$ El Banco Mundial es una fuente fundamental de asistencia financiera y técnica para los países en desarrollo de todo el mundo, ofrece ayuda mediante asesoramiento sobre políticas, investigación, análisis y asistencia técnica.
} 
densificación del suelo. Este patrón de crecimiento combina el modelo de ciudad difusa y el modelo de ciudad compacta.

Al respecto de los modelos de ciudad, Salvador Rueda (2003) expresa que el funcionamiento complejo se basa un modelo compacto de ciudad, diversa en usos y con una población heterogénea. De esta manera, la compacidad permite concentrar y multiplicar los vínculos que, como señala el autor, son la esencia de la ciudad como hecho colectivo; al mismo tiempo que reduce las distancias, el transporte y el consumo de energía derivado, permite mayor intercambio entre factores. Para garantizar una ciudad multifuncional, socialmente heterogénea y diversa, es esencial un grado de diversidad de factores.

Por oposición, define el modelo de ciudad difusa como tendiente a aumentar el tamaño y la complejidad de funcionamiento del conjunto urbano, a partir de la adición de partes de complejidad mínima. Se trata de una forma de crecimiento basada en el incremento del consumo de suelo, que tiende a configurar sectores urbanos homogéneos y monofuncionales, que requieren vincularse entre sí. De esta manera, el modelo difuso no logra un aumento de la complejidad equivalente a la cantidad de recursos consumidos. Asimismo, este modelo produce una fragmentación funcional que, dentro de un contexto urbano condicionado por el mercado inmobiliario, incrementa la segregación urbana por niveles de ingresos y capacidad de acceso, fomentando el vínculo solo entre semejantes; fenómeno que deteriora los lazos de vecindad, los mecanismos de regulación de convivencia, y la estabilidad social del conjunto (Rueda, 2006).

El periodo periferización, como lo define Carrión (2010), implicó no solo la extensión de la superficie urbana sino también un proceso de pérdida de población residente de las áreas centrales, que está ligado tanto a sus aspectos cuantitativos (valores de los inmuebles, dimensión) como a aspectos cualitativos (los factores que inducen a la gente a decidir por la compra de departamentos) (citado en Duarte y Blascovi, 2006).

Se reconocen procesos que intervienen en la expansión urbana como lo son el de periurbanización y suburbanización, la tesis tiene como objeto de estudio las periferias urbanas. Dematteis (1996) expresa que éste se caracteriza por "una dilatación de las coronas y de las ramificaciones radiales de las ciudades, que puede asociarse con una difusión reticular para dar lugar a áreas metropolitanas extensas y policéntricas". Este proceso conlleva el avance de la frontera urbana sobre tierras rurales y genera un nuevo 
espacio o anillo de transición en el cual se observan usos de suelo mezclados y diversos. La diferencia entre ambos modelos de ocupación radica en la base territorial sobre la que se llevan a cabo: mientras que la suburbanización implica la creación de tejidos mixtos residenciales y productivos, el crecimiento periurbano se produce sobre una base de desarrollo más pobre en servicios y en actividad productiva, mediante la dilatación progresiva de las coronas urbanas externas y a partir de ramificaciones radiales (Dematteis, 1998).

Al margen de las particularidades que pueda presentar la periurbanización frente a otras formas de suburbanización, lo cierto es que todas ellas impulsan la disolución del modelo de ciudad compacta idealizada. En su lugar se establece un modelo expansivo de ciudad dispersa caracterizada por la baja densidad, importantes infraestructuras viarias y grandes extensiones de espacios libres; pero también por la presencia de áreas industriales, equipamientos deportivos y de usos semiurbanos (Monclus, 1997). Se crea de esta manera un mosaico discontinuo de fragmentos autónomos, entre los cuales aparecen espacios baldíos intersticiales (tierras vacantes), que termina por adquirir una fisionomía urbana aun careciendo de todos los rasgos físicos y morfológicos que definen la ciudad tradicional, esto es, intensidad, densidad y límites.

Ahora bien, se puede decir entonces que el éxodo de los habitantes de los núcleos urbanos propone una nueva concepción de ciudad, la cual está ligada a la dispersión. Esta dispersión es la característica principal de los procesos de urbanización en las ciudades latinoamericanas, superando la dicotomía urbano- rural, planteando una nueva forma de ver la periferia como una oportunidad.

Esta visión de la periferia como oportunidad no se da ni desde el punto de vista de un desarrollo económico sustentable, ni de la cohesión social, ni de la sustentabilidad ambiental, pero de todos modos la dispersión urbana en el territorio es un fenómeno deseable (Esteban, 2006 citado en Torroja y Camagni, 2006). Este se debe a que en los últimos años ha cambiado la visión sobre estos espacios y se ha comenzado un periodo de valorización desde una perspectiva multifuncional de la periferia. El periurbano se define como un espacio de transición urbano-rural, que es asimilada sólo en parte por el proceso de dispersión urbana y que conserva atributos típicamente rurales. La periferia emerge como resultado del proceso de crecimiento urbano, que efectúa avances irregulares entre distintos puntos de la ciudad, generando así un patrón incoherente de usos del suelo que suele caracterizar a esta franja (Carter, 1972). 
La periferia empieza a cobrar importancia cuando se la asocia al espacio periurbano el cual Valenzuela Rubio define como una zona transitoria entre lo urbano y lo rural, de predominio urbano, que ofrece una amplia gama de recursos tan dispares como grandes equipamientos y parques, polígonos industriales, ciudades dormitorio y urbanizaciones de baja densidad de edificación con espacios de agricultura residual (Valenzuela, 1986 citado en Frediani, 2010). El periurbano puede definirse entonces como una zona de contacto entre dos ambientes -el urbano y el rural-, adquiriendo así los rasgos particulares de una zona de transición, este espacio sirve de apoyo a la periferia y es susceptible a ser tomado por la misma (figura 8). De esta manera, la periferia se caracteriza por ser un espacio de carácter dinámico, con grandes contrastes y mutaciones rápidas. Está en continuo proceso de cambio ya sea morfológicos, funcionales y de población.

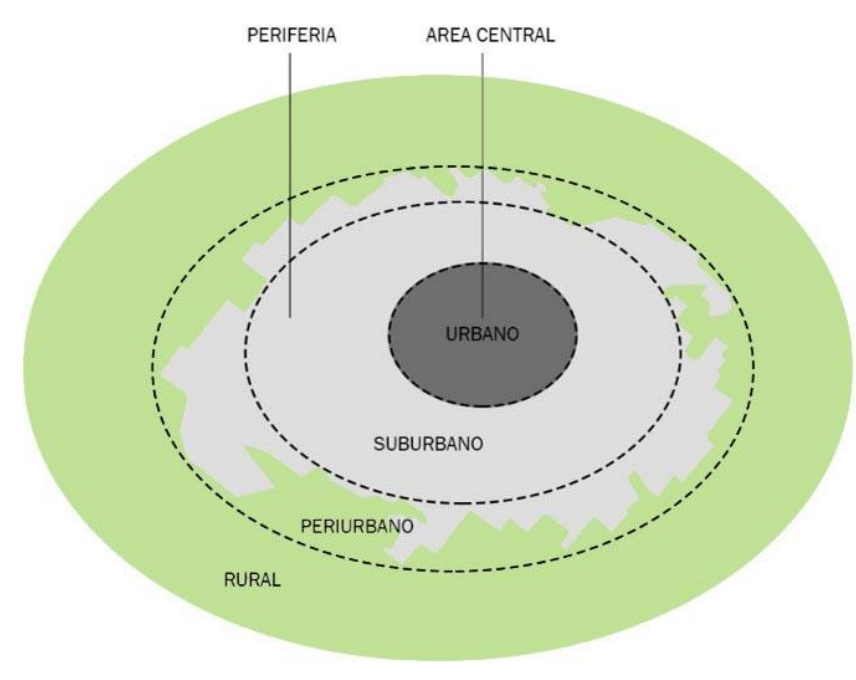

Figura 8. Composición de la periferia.

Fuente: elaboración propia, 2016.

En este contexto, se puede decir que el avance de la ciudad hacia áreas rurales, con las consecuentes variaciones en los usos del suelo, da origen a un nuevo tejido urbano, flexible y disperso, donde los límites se tornan cada vez más imprecisos. Como señala Bozzano (1990), el avance de la ciudad -en su expansión horizontal-, transforma los espacios rurales adyacentes en un proceso que se relaciona con "las diferentes condiciones generales de valorización de capitales que se generan en unos y otros ámbitos; asimismo, el espacio periurbano se estructura para la ciudad porque sus procesos, directa o indirectamente, están en función de ella". 
Según Arias Sierra (2003) se pueden reconocer tres tipos de periferia dependiendo de la cercanía del área central. La primera se podría definir como la periferia de lo suburbial donde es la más cerca del área central urbana, como segunda se define la periferia metropolitana en expansión y por último la periferia en las áreas rururbanas.

En las áreas de expansión la producción de suelo urbano se realiza a través de amanzanamientos, nuevos loteos y vías de circulación, continuando el tejido urbano y albergando nuevas actividades según la demanda existente. Estas van a depender de los intereses de los actores intervinientes. De este modo, el espacio periurbano asume la condición de suelo en espera, incorporándose al mercado inmobiliario mucho antes de que se lleve a cabo su reclasificación (Rueda, 2012). En Latinoamérica se trata de un espacio de uso residencial donde se pueden encontrar barrios muy heterogéneos.

De esta forma, la periferia ha constituido el emplazamiento natural de los procesos de crecimiento urbano, lo que permite considerar su complejidad como realidad urbana y territorial.

La ciudad necesita del espacio periurbano, en particular, y de la periferia, en general, donde la oportunidad se ve reflejada en la indefinición de usos que los caracteriza la cual le da un valor en sí mismo. En su Manifiesto del tercer paisaje, el arquitecto-paisajista Gilles Clément trata de definir un espacio distinto al arquetípico urbano y rural que aparece como residuo inherente de la actividad planificadora. Clément no trata a este residuo de una manera despectiva, sino que lo considera la antesala de la naturalización hacia un paisaje secundario caracterizado por una dinámica poderosa y caótica (Clément, 2007). En este mismo sentido, desde una óptica menos abstracta, Naredo y Fariña (2010) defienden la creación de espacios libres sin uso: espacios abiertos no urbanizables que no tengan un uso específico asignado y que no precisen de excesiva atención por parte de la administración.

La periferia entonces es el lugar donde todavía estamos a tiempo en ciertas zonas de revertir tendencias, de pensar como debe ser la ciudad y que debe contemplar. Es el territorio de lo posible por eso son espacios de oportunidad.

La expansión urbana y las transformaciones en los espacios verdes a partir de la década del ${ }^{\top} 90$

Hace algunos pocos años, los habitantes de la ciudad de La Plata podían acceder en pocos minutos al campo abierto y al contacto directo con la naturaleza. Hoy en día, se requiere 
algunas horas para poder encontrarse finalmente con un ambiente rural degradado y una vida animal y vegetal muchas veces deteriorada.

En este gran continuo urbano periférico, los espacios verdes públicos han tenido que encontrar nuevas formas de adaptación que den respuesta a las demandas de los habitantes. Han perdido la formalidad del dominio público y encontrado nuevos lugares de uso colectivo que constituyen nuevos ámbitos de apropiación social cuyo carácter público puede resultar equivoco por alejarse de la noción convencional de lo público (Arroyo, 2011)

Los procesos de expansión llevan consigo cambios en el paisaje, de esta manera, como señala Joan Nogué (2007), "nunca habíamos transformado el territorio a la velocidad en la que lo hemos hecho en los últimos decenios". Si bien esta afirmación la hace en relación al contexto español, se puede generalizar para describir las transformaciones a nivel global y en particular la de las ciudades de Latinoamérica, donde se han experimentado transformaciones que se dan en el marco del proceso de reestructuración del sistema capitalista del último cuarto de siglo XX.

Como señala Clichevsky (2001), a partir de finales del siglo XX, el Estado modifica sus acciones en pos de posibilitar y facilitar grandes inversiones en la ciudad, de capitales nacionales y extranjeros. Para ello se iniciaron procesos de desregulación políticoadministrativa del suelo urbano, que incrementaron la participación del mercado en la configuración de las ciudades.

En las últimas décadas las ciudades latinoamericanas sufren grandes transformaciones, las cuales comienzan en la década del `90. Las ciudades en un contexto de economías mundiales integradas son lugares de disputa para atraer inversiones, en pos de esto buscan concentrar innovaciones, brindar servicios como así también recursos humanos capacitados para el desarrollo de actividades económicas. Por otro lado, en cuanto a lo ambiental se busca brindar una buena calidad ambiental a los habitantes como a los visitantes. Se reorganizan los territorios a partir de "ejes por los cuales se producen flujos de mercancías, personas, capitales e información" (Ravella, 2010).

Las ciudades deben resistir en el largo plazo los efectos de la lógica cortoplacista, que por un lado suman el incremento de población, de espacio construido, de automóviles, de actividades y de estrés urbano. Y por otro, resta cantidad de espacios verdes públicos, de espacios colectivos, de espacios para los peatones, de asoleamiento, de superficies de suelo absorbente, de vegetación. La aplicación de políticas urbanas orientadas a partir de 
la priorización de la lógica económica arroja como resultante la pérdida de paisaje y de calidad de vida urbana. Como señala Rueda (1996) el desarrollo sustentable implica la mejora de la calidad de vida ${ }^{36}$ dentro de los límites de los ecosistemas. Así mismo resalta que los niveles de satisfacción, de calidad de vida, se encuentran en los aspectos donde los sujetos muestran mayor grado de apropiación, ya que la noción de calidad de vida implica un proceso relacional, para el que se puede aplicar el concepto de apropiación de espacio, que permite relacionar la realidad urbana, el paisaje, con la identificación, a nivel cognitivo, afectivo, funcional y satisfactorio.

El cambio en la dinámica del paisaje ya sea inducido por la acción humana o por causas naturales altera la estructura y función de este. El paisaje va a ser el protagonista de las profundas transformaciones sociales y morfológicas de la expansión urbana.

Al desarrollo mundial, se le suma como señala García (2009) la crisis ambiental y civilizatoria contemporánea que influye directamente en el deterioro del ambiente, se reconocen numerosos problemas ambientales que abarcan todas las escalas y se entiende que los mismos no surgen de manera aislada, sino que se relacionan como emergentes de un sistema de desarrollo humano a nivel mundial.

Los impactos negativos que se generan sobre el ambiente han crecido a mayor velocidad en los últimos años y sus consecuencias ya se empezaron a visualizar. Al respecto, muchas personas han empezado a tomar conciencia del problema y de lo que esto conlleva.

\section{En este sentido:}

“En la medida que los daños causados al ambiente y a la sociedad por determinadas intervenciones antrópicas no son remediados tras su abandono, desmantelamiento, o cambio de actividad, puede suceder que sus efectos tiendan a permanecer en el tiempo e incluso a constituirse en factores de degradación aún más complejos o en condicionantes para nuevos desarrollos económicos o sociales" (Garay y Fernández, 2007, p.264).

Lynch (2005) hace énfasis en cómo históricamente, la planificación urbana no se ha preocupado mucho por los sistemas naturales, orientándose en cambio hacia las

\footnotetext{
${ }^{36}$ Calidad de vida entendida como la capacidad de un individuo para experimentar el ambiente dependiendo de la valoración de su entorno. (Ardila, 2003)

Calidad de vida es una construcción compleja y multifactorial sobre la que pueden desarrollarse algunas formas de medida objetivas a través de una serie de indicadores, pero donde tiene un importante peso específico la vivencia que el sujeto. (Rueda, 1996)
} 
transformaciones artificiales del entorno. Al parecer, se daba por supuesto que la tecnología y la planificación podrían resolver todos los problemas y superar las restricciones naturales, pero las limitaciones de la tecnología se han hecho demasiado evidentes en el esfuerzo de lograr el abastecimiento de agua a ciudades en climas áridos, ya sea en la depuración de residuos tóxicos que contaminan las provisiones de agua urbana o en la reconstrucción de ciudades asoladas por catástrofes naturales. En contraposición al desarrollo histórico de la planificación esta tesis propone incorporar el concepto de paisaje.

En este contexto, el concepto y uso de los espacios públicos cambia acompañando los cambios que se vienen dando en relación a la cultura. Este cambio se relaciona a la evolución y complejización de la ciudad como así también al incremento de los habitantes en dichas ciudades. La globalización impone nuevas prácticas que están ligadas a la tecnología y a la comunicación. Los habitantes de estas nuevas ciudades globalizadas usan menos la plaza y las calles como espacios de intercambio y comunicación directa.

En las ciudades argentinas el espacio de uso público puede reconocerse en la etapa colonial, a través de las Plazas Mayores, fundadas en base a las Leyes de Indias, que le otorgaban forma y carácter a la ciudad, al tiempo que la convertían en símbolo del poder. En torno a ellas se situaba la iglesia mayor, el cabildo, el fuerte, la casa real, las tiendas. Posteriormente nacieron otras plazas denominadas "menores", que fueron concebidas como "vacíos urbanos" y utilizadas como baldíos, como altos de carretas, como mercados, mataderos o basurales. A principios del siglo XX, las plazas fueron concebidas como espacios de encuentro e interacción social y como elementos urbanos de control: las "plazas secas" o "plazas grises" dan cuenta de ello. Es decir que la idea de "plaza" ha ido cambiando de paradigmas en función de sus prácticas, de su valor simbólico y de su carácter cívico-institucional.

A partir del desarrollo de un nuevo modelo de cuidad producto de las nuevas formas de crecimiento urbano se modificó la relación centro-periferia. El territorio es entendido como paisaje artificializado, lugar de la naturaleza y el humano, es decir, espacio sujeto a ser visto, interpretado, adaptado y transformado a lo largo del tiempo (Tardín, 2010, p. 21).

De esta manera, para afrontar la complejidad urbana actual antes mencionada desde la perspectiva que propone la investigación, es necesario analizar los espacios verdes desde sus atributos ecológicos y socioculturales como así también a partir de la función que 
pueden cumplir en la estructura urbana pensando en estrategias de intervención como propone Battle (2011).

Es así como:

"Los espacios públicos constituyen uno de los elementos para la patrimonialización afectiva de la ciudad. Se entiende aquí por patrimonialización afectiva la capacidad de generar unos vínculos afectivos estables de identificación y apego con la ciudad. Sin estos espacios públicos la ciudad pierde la capacidad de generar un patrón de actividad simbólica y significativa que favorezca la implicación de los ciudadanos en el espacio urbano y con el resto de los pobladores que lo ocupan. Y gran parte de los riesgos que hacen vulnerable los espacios urbanos derivan de la escasez y/o baja calidad de estos". (Corraliza, 2009, p.3)

Esto nos lleva a reflexionar acerca de ¿cuáles son los lugares de encuentro para esta nueva sociedad? Se podría decir que cambian los lugares de reunión para pasar a ser en lugares de dominio privado y de uso público, como lo son los grandes centros comerciales, bares, boliches como así también grandes eventos como recitales y eventos deportivos. Es decir, los nuevos espacios públicos están ligados al capital, al mercado inmobiliario donde es difícil diferenciar que es público y que es privado. Cerasi (1990) denomina a estos espacios como "espacios colectivos".

Es así como el habitante de estas ciudades globalizadas pasa de ser ciudadano a ser un consumidor. Donde al generarse un consumo de "bienes culturales globales" se comienza a perder lo de carácter local de las ciudades latinoamericanas ligado a la cultura, identidad y la memoria. Los espacios públicos no se pierden, siguen siendo los preponderantes en la ciudad, pero empiezan a competir con estos nuevos espacios, el espacio que da identidad y carácter a una ciudad, el que permite reconocerla y vivirla.

Es decir, "con la apertura de las fronteras se difunden y asimilan bienes y mensajes de otras culturas; conformándose un mundo nuevo y diversificado. Se debilita el sentido integral de pertenencia a la ciudad, para dar paso a sitios de pertenencia e interacción de subgrupos" (Perahia, 2007, p. 4).

La sociedad postindustrial comienza a cambiar rápidamente dando lugar a nuevas actividades o espacios en el territorio. Aparecen entonces barrios cerrados y una nueva gestión público / privada de los espacios urbanos públicos y/o semipúblicos. Estos barrios 
generan el intercambio y relación de los habitantes dentro de este sin interactuar con la ciudad. Se puede decir que predominan:

- Los grandes complejos comerciales, recreativos y de servicios, con fuertes inversiones inmobiliarias en áreas centrales o en la periferia, en áreas de nueva centralidad, en correspondencia con los nodos de autopistas y rutas de vinculación regional, con un espacio verde controlado y seguro.

- Las urbanizaciones cerradas como forma de hábitat suburbano que privatizan lo urbano y gestionan su propio espacio privado de uso público.

- Los complejos recreativos y las áreas de nueva centralidad.

Estas actividades como los centros comerciales buscan localizarse en áreas centrales compitiendo con los espacios comerciales abiertos o en zonas de la periferia donde son impulsados por la mejora de la red de accesibilidad a través de la disponibilidad la red de autopistas y las nuevas tecnologías de comercialización, se constituyen en el nuevo equipamiento de consumo y diversión. Estos complejos conforman las áreas de nueva centralidad con formas de sociabilidad muy diferentes a las que ofrecen los centros comerciales y de esparcimiento tradicionales, muchos de los cuales perdieron usuarios y vida urbana.

Las ciudades actualmente se encuentran en un proceso de desarrollo paulatino invariable, donde por desgracia el medio ambiente es el primer afectado. Lo cual por consiguiente viene a cambiar el paisaje que rodea al habitante urbano, y la calidad de vida de este, "de forma paralela, el paisaje que embellece y mejora la calidad del aire, es transformado en un paisaje urbano de características radicalmente distintas, el cual deja de ser interpretable en términos espaciales y ecológicos, para convertirse en objeto de análisis desde un punto de vista casi exclusivamente arquitectónico" (Ramos, 2005).En este contexto, se puede decir que "estas lógicas diferentes, a veces casi antagónicas, generan dispersión y atentan contra la calidad y una imagen integral de la ciudad; aportan poco al concepto de identidad y de orientación, de leer el espacio urbano como algo cotidiano y seguro" (Perahia, 1999, p.2).

Los espacios verdes o los espacios vacantes son lugares con gran potencial de transformación para la planificación y el diseño del paisaje en los procesos de crecimiento urbano; son áreas con potencial para mitigar la degradación ambiental gracias a la 
flexibilidad que poseen dentro de la estructura territorial. De esta manera constituyen una oportunidad para la estructuración del territorio desde el paisaje. Estas áreas generalmente no poseen valor y no son reconocidos por el planeamiento siendo amenazados por la ocupación urbana. En este contexto, estos espacios pueden funcionar de diferente manera dependiendo de las necesidades y requerimientos de los habitantes del lugar, ya sea como lugar de esparcimiento, reservas de biodiversidad, reservorios, área de reserva urbana entre otros. El espacio verde "se vive como la preexistencia que da lugar a la experiencia particular y propia, experiencia de acción que lo modifica dando lugar a episodios de lo público" (Arroyo 2011, p. 167).

\section{Los espacios verdes como elemento esencial del derecho a la ciudad}

El derecho a la ciudad y a los espacios de uso público surge a partir de un clásico de la sociología y antropología moderna, Marcel Mauss, de orientación socialdemócrata, acuñó el término de "droit de cité", equivalente a derecho a la ciudad entendida como ámbito de ciudadanía. Posteriormente se lo vincula a Henri Lefebvre que en la década del `60, escribió un libro con ese título, como uno de los derechos fundamentales del ser humano y de la ciudadanía, un derecho que implica la motivación de la sociedad civil para re-crear la ciudad como parte de una 'misión' común y colectiva. El derecho a la ciudad, publicado a principios de 1968 reveló sus pensamientos sobre la ciudad y la urbanización, anticipándose a los cambios que se iban a producir.

En este contexto, se puede decir que surge el concepto, pero la generalización del mismo y la relación con el "espacio público" (entendiéndolo como espacio urbano) es más reciente ya que se comenzó a hablar en esta última década. Esto se da por la tendencia a la disolución de la ciudad en las nuevas y discontinuas periferias y la voluntad de los movimientos sociales de integrar en este concepto a los derechos sectoriales urbanos y socio-políticos. David Harvey (2003), a lo largo de los últimos 30 años, ha desarrollado un análisis crítico de la ciudad en el capitalismo desarrollado y lo ha culminado con la recuperación del concepto de "derecho a la ciudad" como por ejemplo en "espacios de esperanza". En la primera parte de esta obra se dedica a interpretar la globalización, habla de los desarrollos geográficos desiguales, mientras que la segunda parte hace más referencia a ese espacio personal, que él denomina como los cuerpos y las personas en el espacio global. Para finalmente hablar de los espacios de la utopía y la definición de un hábitat social sostenible. 
Actualmente, se ha estimulado el pensamiento crítico sobre la urbanización, donde diversos autores han tratado la temática en relación al tema, a su vez en el marco del Foro Urbano Mundial de Rio de Janeiro (abril 2010) HIC-Hábitat internacional Coalition presentó un libro con el título "Ciudades para todos".

También en 2010 se ha publicado la "Carta por el Derecho a la Ciudad de la Ciudad de México" elaborada mediante un interesante proceso participativo comandado por HIC América Latina. Y, más recientemente, el Foro Urbano Mundial de Naciones Unidas celebrado en Rio de Janeiro se convocó con el lema "El Derecho a la Ciudad: Uniendo el urbano dividido".

Como afirma Jordi Borja (1998):

“La ciudad es ante todo el espacio público, el espacio público es la ciudad. Es a la vez condición y expresión de la ciudadanía, de los derechos ciudadanos. La crisis del espacio público se manifiesta en su ausencia o abandono o en su degradación, en su privatización o en su tendencia a la exclusión. Sin espacio público potente, integrador socialmente, articulador física y simbólicamente, la ciudad se disuelve, la democracia que se pervierte, el proceso histórico que hace avanzar las libertades individuales y colectivas se interrumpe o retrocede, la reducción de las desigualdades y la supremacía de la solidaridad y la tolerancia como valores ciudadanos se ven superados por la segregación y por la codicia, por el egoísmo y la exclusión" (p.1)

El espacio verde de uso público es entendido como una de las dimensiones para desarrollar la democracia política y social, expresada en su dimensión territorial, el espacio colectivo y de intercambio. En este es dónde la sociedad se escenifica, se representa a sí misma, se muestra como una colectividad que convive, que muestra su diversidad y sus contradicciones y expresa sus demandas y sus conflictos. Es donde se construye la memoria colectiva y se manifiestan las identidades múltiples y las fusiones en proceso. El espacio público democrático es un espacio expresivo, significante, polivalente, accesible, evolutivo. Es un espacio que relaciona a las personas y que ordena las construcciones, un espacio que marca a la vez el perfil propio de los barrios o zonas urbanas y la continuidad de las distintas partes de la ciudad.

Estos son espacios de historia, de identificación con el pasado de toda ciudad, que expresa identidades y orígenes comunes, donde se ve la historia de los habitantes. En este sentido, "el derecho al espacio público es en última instancia el derecho a ejercer como ciudadano 
que tienen todos los que viven y que quieren vivir en las ciudades" (Borja y Muxi 2003). Es decir, el factor beneficio no debe por tanto ver clase social, y se debe de plantearse para toda la sociedad que vive, disfruta y sufre su transitar por la ciudad, dando réplica a las demandas sociales de la actualidad; buscando evitar la sustracción del espacio verde público y haciendo generalizado el vínculo de la sociedad con el medio ambiente, facilitando el contacto a dichos espacios.

El espacio verde de uso público en la esencia de lo urbano, desde la antigüedad hasta nuestros días, es el espacio del encuentro y el intercambio, enriquece las prácticas urbanas y alienta la participación de los ciudadanos y su interés por las cuestiones comunitarias. Una ciudad sin plazas, ni parques, ni espacios para el encuentro casual, no solo sería pobre ambientalmente sino también en los aspectos socio urbanísticos. Estos espacios, tal como lo mencionamos anteriormente, están en crisis y con ello se ve disminuida la capacidad de los ciudadanos de ejercer el derecho a la ciudad. Esta crisis se debe a la tendencia de debilitar y privatizar los espacios públicos. Esto deriva en la pérdida del diálogo entre la administración pública como propietaria jurídica del territorio (que faculta el dominio del suelo y garantiza su uso), y la ciudadanía que ejerce un uso real del mismo, otorgándole carácter de dominio público (apropiación cultural colectiva).

"Hay una crisis del espacio público en sus dos dimensiones: como elemento ordenador y polivalente, como lugar de intercambio y de vida colectiva, en cada zona o barrio, y también como elemento de continuidad, de articulación de las distintas partes de la ciudad, de expresión comunitaria, de identidad ciudadana". (Borja, 2001, p. 21)

Hoy en día las ciudades se urbanizan sin tener en cuenta los espacios verdes y sin importar la necesidad que los habitantes tienen, es así que en muchos casos la población se apropia de espacios donde el dominio es privado, pero los usan como espacios públicos. En la conferencia de Hábitat III37 (2016) se retomó el concepto de derecho a la ciudad incorporándolo en la nueva agenda urbana; esta inclusión lo volvió a poner en escena asociándolo a la calidad de vida en las urbes. Este es un gran paso a la transversalidad porque este acuerdo lo han firmado países de todo tipo.

El derecho a la ciudad no es tan solo el derecho a usarla sino también el derecho a identificarnos con ella, a apropiarnos, aunque sea simbólicamente de sus espacios, de

${ }^{37}$ Es la conferencia de las Naciones Unidas sobre vivienda y desarrollo urbano sostenible, se celebró en Quito, Ecuador, del 17 al 20 de octubre de 2016. Estas conferencias sobre vivienda, denominadas Hábitat, se realizan cada 20 años. 
manera fluida, espontánea y creativa. Es el derecho a gozar de ambientes sanos, verdes de calidad paisajística y que todos los ciudadanos puedan gozar de los mismos derechos.

De esta manera los espacios verdes se constituyen como un elemento esencial a la hora de pensar en el derecho a la ciudad. Estos constituyen un papel fundamental en la ciudad y son indispensables para la vida. Es decir, tenemos derecho como ciudadanos a acceder y tener espacios verdes que nos brinden los beneficios que estos generan.

\section{Funciones de los espacios verdes}

Entre las funciones que cumplen los espacios libres y verdes se destacan las siguientes (Falcón, 2007; Palomo, 2003) (figura 9):

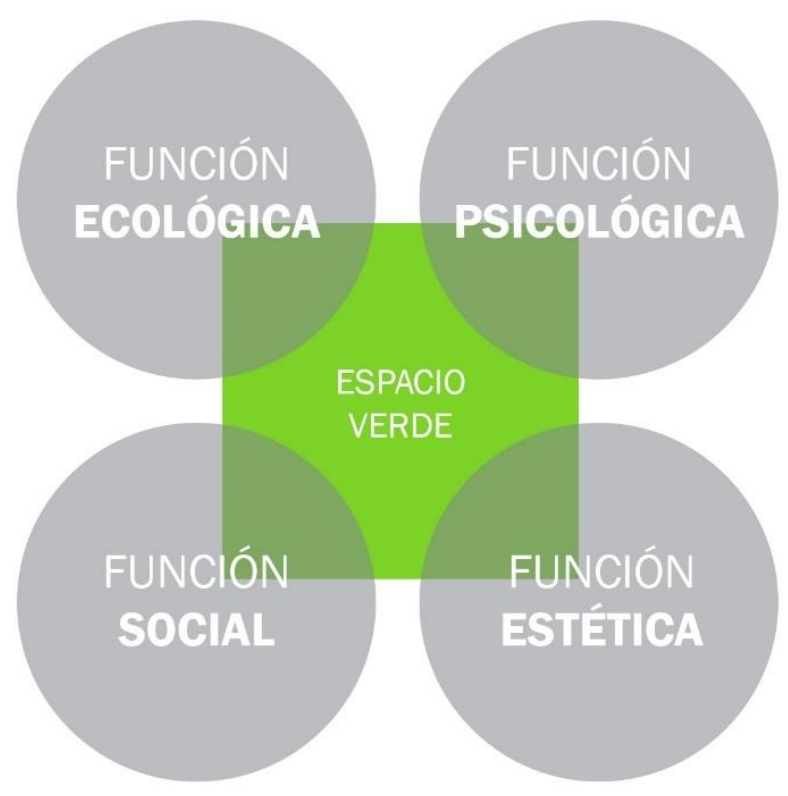

Figura 9. Funciones de los espacios verdes. Fuente: Elaboración propia, 2017.

UNA FUNCIÓN SOCIAL

Ofrecer espacios destinados al paseo, al encuentro, la contemplación, los juegos, el contacto con la naturaleza indispensable para todos los hombres.

- Recreación física y mental: Los espacios verdes públicos son importantes lugares para recreación ya que aportan beneficios psicológicos relevantes para la población, permitiendo el intercambio y encuentro entre la ciudadanía y la naturaleza. El lugar donde vivimos condiciona y determina nuestras actitudes. 
Los espacios verdes públicos tienen una atribución de equilibrio entre los habitantes urbanos contribuyendo a la sensación de bienestar del usuario. Producir un vacío en la trama construida, una discontinuidad, un pulmón verde necesario para la oxigenación del aire. Un elemento fundamental en la conformación del paisaje urbano, un elemento de identidad para los habitantes.

- Minimizan impactos de urbanización. Una ciudad dotada de espacios verdes, jardines, arbolado urbano ordenado y planificado, plantas manejadas convenientemente, exaltan el valor de las ciudades ya que tienen una correlación directa en los beneficios ambientales atrayendo persistentemente al habitante urbano que lo habita y el turismo que le visita, logrando un equilibrio entre lo natural y lo edificado.

\section{UNA FUNCIÓN ECOLÓGICA}

Los espacios verdes y la vegetación son necesarios en el sistema de la ciudad; es el hábitat de la fauna y actúa como reguladora del microclima urbano.

- Regulador climático: el asentamiento de una ciudad modifica el estado del entorno natural debido a que las superficies de edificación y pavimentos urbanos atraen y reproducen las radiaciones solares. Esto conlleva a una atmosfera más seca, que descontrola el clima que le circunscribe, donde en verano aumenta inherentemente la temperatura ambiental, y en invierno lleva a temperaturas más bajas. Las concentraciones de espacios verdes compensan los valores de temperatura y de humedad, contribuyendo al equilibrio ambiental. El contraste térmico entre una calle sin espacios verdes y otra con arbolado urbano puede cambiar de $2^{\circ} \mathrm{C}$ a $4^{\circ} \mathrm{C}$. El follaje absorbe las emisiones de onda corta que se convierte en rayos infrarrojos al tocar el suelo.

La humedad relativa se produce por la transpiración de los árboles, que, al tiempo que genera humedad, absorbe calor al evaporarse, la cual puede ser superior hasta en un $10 \%$ en las calles arboladas. En este orden, la vegetación de baja altura, aunque no proyecta sombra, de igual manera interviene en la temperatura ambiente por medio de la evaporación y eliminación de reflexión de rayos solares.

- Absorben el dióxido de carbono que contamina la atmosfera: Uno de los trascendentales problemas ambientales de las ciudades son las emisiones de gases que causan el efecto invernadero, como el dióxido de carbono (CO2). Las hojas de los árboles atrapan el bióxido 
de carbono de la atmósfera a través de la fotosíntesis, realizando un proceso bioquímico inverso al de la respiración humana, convirtiéndolo en oxígeno, mejorado y purificado.

- Filtran los vientos: La vegetación de las áreas verdes sirve para fijar las partículas de polvo y los gases contaminantes que se encuentran suspendidos en la atmósfera, como el plomo, el flúor o el ácido sulfúrico. Quedando estas partículas retenidas, en las partes aéreas de las plantas, puesto que están diseñadas para que el aire pase a través de ellas filtrando esporas y polen, además de los polvos, cenizas, humos y demás impurezas que arrastra el viento, favoreciendo una atmosfera más limpia. De este modo, cuanto mayor sea el volumen vegetal, mayor será la retención y por ende el nivel de purificación de aire.

- Disminuyen el ruido: La principal fuente de ruido en las ciudades es el trafico el cual sumado a la densidad de los edificios en calles estrechas multiplica este efecto. Los espacios verdes con arbolado urbano funcionan como pantallas acústicas que disminuyen el impacto de las ondas sonoras en calles, parques y zonas industriales.

- Reducen la velocidad de viento: No detienen desastres naturales, sin embargo, su presencia disminuye velocidad a la corriente del aire y tormentas, disipando su potencia y optimizando el medio ambiente.

\section{FUNCIÓN PSICOLÓGICA}

En investigaciones realizadas desde un ámbito diferente como es el de la psicología ambiental, se obtienen evidencias de la importancia que para el bienestar humano tiene la contemplación de la naturaleza (Maussner, 1995 y Kaplan, 1995 citados en Corraliza 2015). Diversos estudios psicológicos afirman que un espacio verde nos permite explorar lo incierto, nos lleva a asumir riesgos y adaptarnos a las circunstancias del entorno. Es decir "nos pone frente al vacío, a la nada".

Se ha comprobado que en los espacios verdes los niños proponen un juego mucho más creativo que en un espacio que no es flexible. Estos juegos poseen significación cultural y mítica. La diferencia está en que en espacios cerrados hay un exceso de recursos altamente estructurados que los inducen a determinadas acciones mientras que los espacios al aire libre no contienen expectativas ni establecen formas predeterminadas para el juego, no condicionan la actividad a realizar la dejan libre imaginación, donde la oferta que brindan estos espacios es infinita. 
Los espacios verdes influyen en la persona. La topografía, la luminosidad, el color, los aromas, los sonidos, la vegetación, son los elementos que producen esa sensación de relajación. Estudios han demostrado que en las grandes ciudades lo que más influye es el color, la vegetación produce una relajación cerebral.

\section{FUNCIÓN ESTÉTICA}

Los espacios verdes embellecen las ciudades contribuyendo al disfrute del habitante urbano, que transita ya sea caminando o en auto. Estos espacios organizan el territorio e integran entre ellas de manera eficiente diferentes zonas urbanas.

Los espacios verdes ayudan contrarrestar el efecto de dureza que nos brinda lo construido, dotando de color y de vida a las ciudades. A su vez, su diseño en base a los diferentes estratos arbóreos y especies generan diferentes sensaciones en el habitante.

\section{El verde como infraestructura urbana}

El término infraestructura verde se comenzó a utilizar a fin de la década del `90, de la mano del servicio de bosques de EEUU. Este concepto del verde como infraestructura se ha ido ampliando, hoy se entiende "como todo el sistema natural que soporta la vida posibilitando los procesos ecológicos, sosteniendo la flora y la fauna y manteniendo los recursos" (Fariña, 2012).

De esta manera, la naturaleza aparece como el soporte para la existencia de áreas urbanizadas, sobre todo en las áreas periurbanas donde se entiende mejor el significado del verde como infraestructura. Aquellas funciones o elementos de la naturaleza necesarios para el funcionamiento de las áreas urbanizadas probablemente deberían de formar parte de esta infraestructura verde.

De esta manera, la infraestructura verde o green infrastructure es entendida como una red interconectada de espacios verdes (urbanos, periurbanos, rurales y silvestres) que conserva y aporta funciones ecosistémicas y servicios ambientales para la población humana, a nivel de provisión de agua limpia, mejoramiento de la calidad del aire, mitigación de efectos de isla de calor, biodiversidad y vida silvestre, recreación, belleza escénica y protección ante desastres, entre otros beneficios. (Benedict y McMahon, 2006)

Las áreas urbanizadas tendrían espacios dedicados al esparcimiento, la socialización, la realización de ejercicio físico 0 el contacto con la naturaleza. Los espacios verdes traen beneficios físicos y mentales para los habitantes, como así 
también desde este punto de vista el espacio de recreo, socialización, de necesidad de contacto con la naturaleza para el equilibrio mental y realización de ejercicio físico. La función que cumplen estos espacios desde la biología es conocida como lo es la función de las hojas de los árboles relacionada con la fijación de determinados tipos de contaminación aérea limpiando el aire. Y por supuesto, la capacidad de los suelos para absorber, retener, filtrar y purificar el agua. 0 las posibilidades de reducir la contaminación acústica o aumentar el confort de zonas concretas del microclima urbano.

Entender las zonas verdes urbanas como infraestructura va más allá del primer concepto, donde se plantea que no es necesaria la conexión física de estos espacios para conformar una red. Se entiende entonces como "conjunto de elementos o servicios que se consideran necesarios para el funcionamiento de aspectos concretos de la ciudad”.(Fariña, 2012).

Según plantea Fariña (2012) las zonas verdes urbanas se componen de la siguiente manera:

“En primer lugar, son verdaderos equipamientos urbanos con sus requisitos propios y específicos que deberían atender al esparcimiento, la socialización, la realización de ejercicio físico o el contacto con la naturaleza de la población. En segundo lugar, de forma similar a la infraestructura gris, se comportan como una auténtica infraestructura (en este caso verde), es decir, como el conjunto de elementos naturales puestos al servicio del funcionamiento de aspectos concretos de la ciudad. Y, por último, la función ecológica, no sólo como memoria que nos recuerde a qué hemos renunciado para recluirnos en un hábitat distinto al natural, sino también, por ejemplo, como aumento de la biodiversidad o para garantizar la continuidad y disponibilidad de la flora y de la fauna". (Fariña, 2012)

De esta manera, el concepto de infraestructura verde comprende una aproximación estratégica para la conservación del paisaje y sus componentes, en el marco de las iniciativas de ordenamiento y planificación sustentable del territorio. El enfoque en que se basa la planificación y el diseño de ésta es multiescalar, identificando y analizando todos los espacios.

Para finalizar se puede decir que la configuración de la infraestructura verde se entiende como una red sinérgica y articulada, permite la provisión de servicios ecológicos, culturales, sociales y/o estéticos, que contribuyen a la resiliencia de los sistemas de vida y al bienestar general de personas, comunidades y economías. La infraestructura verde en 
el tejido urbano, entendida como una red interconectada de ecosistemas que conserva sus valores y sus funciones y proporciona beneficios a las poblaciones humanas, conforma un sistema urbano de soporte a la vida.

\subsection{I el cambio climático y la resiliencia urbana}

Los estudios disponibles indican que las consecuencias del cambio climático afectarán a la mayoría de las ciudades y en especial a las costeras. De este modo, el Panel Intergubernamental sobre el Cambio Climático (IPCC) prevé que sigan aumentando la intensidad, duración y frecuencia de las lluvias torrenciales, las inundaciones, las olas de calor y las sequías de larga duración. Asimismo, asegura que se agudizará el efecto isla de calor urbano. Por tanto, aquellas ciudades que quieran conservar o mejorar la calidad de vida que ahora ofrecen a sus habitantes, deberán aprender a adaptarse.

Se entiende al cambio climático como una modificación del clima atribuido directo o indirectamente a la actividad humana que altera la composición de la atmósfera, a lo que se suma la variabilidad natural del clima observada durante períodos de tiempo comparables. Este cambio trae como consecuencia efectos adversos. Los cambios en el medio ambiente resultantes del cambio climático tienen efectos nocivos significativos en la composición, la capacidad de recuperación o la productividad de los ecosistemas naturales o sujetos a ordenación, o en el funcionamiento de los sistemas socioeconómicos, o en la salud y el bienestar humanos (Naciones Unidas, 1992).

El informe Stern (2006) afirma que hay "un abrumador cuerpo de evidencias científicas nos indican claramente que el cambio climático es un asunto serio y urgente". Evidenciándose en las variaciones que se han producido en los ciclos de lluvias, mayor intensidad en los fenómenos ambientales (lluvias, inundaciones, huracanes, tsunamis, sequias, etc.) afectando a todos los habitantes. Según el acuerdo de kyoto se ha estimado que en lo que queda de este siglo la temperatura aumentaría entre 2 y $5^{\circ} \mathrm{C}$, representando el mayor cambio en los últimos 10.000 años, Ese incremento se verá reflejado en temperaturas medias anuales más altas, lo que agudizará el efecto de isla de calor. Este efecto consiste en la formación de un domo o cúpula de aire cálido debido a la presencia de edificios y superficies pavimentadas, que irradian calor incluso después de la puesta del sol (Jensen y Birche, 2018).

En las últimas cuatro décadas se constató el crecimiento lineal del número global de casos de inundación y tormentas frente al comportamiento estacionario de otras amenazas, 
tales como terremotos o sequías prolongadas (IPCC TAR WG3, 2001). Esto coloca a las inundaciones como el principal generador de desastres en el planeta, independientemente de las causas posibles de su génesis, pero con una tendencia confirmada que prácticamente obliga a replantear las intervenciones urbanas. Esto implica comenzar a tener en cuenta intervenciones que no solo permitan disminuir las inundaciones sino también afrontar las consecuencias durante la misma y poseer capacidad de recuperación de los efectos nocivos y daños que las mismas provocan.

En 2005 en la reunión de Naciones Unidas en Hyogo se da comienzo al programa mundial de reducción de desastres (decenio 2005-2015). Según el Proyecto Impactos del Cambio Global en las áreas costeras del Río de La Plata (IACC LA 26), Ilevado adelante por investigadores de la Universidad de Buenos Aires y científicos de Uruguay, el nivel medio del río aumenta 1,7mm. por año, aunque desde 1970 esta tendencia se habría acelerado. Para finales de este siglo, los modelos hidrodinámicos proyectaron un aumento del nivel medio de $50 \mathrm{~cm}$ en su valor máximo. Las principales causas son la mayor frecuencia de vientos con componente del Este y eso hace que se acumule más agua sobre el margen de la provincia de Buenos Aires, otra causa es el ascenso del nivel del mar que también significa niveles de agua cada vez más altos. Frente a este escenario, las ciudades costeras deben empezar un periodo de adaptación frente al cambio climático, para lo cual se propone minimizar los efectos en cuanto a las inundaciones desde el concepto de paisaje incorporando los espacios verdes a modo de reservorios y espacios de superficie absorbente al sistema hídrico.

En este contexto, en el libro La Argentina y el cambio climático (2016) se expresa que "Un aspecto negativo de las crecientes precipitaciones de las últimas décadas son las cada vez más frecuentes inundaciones. Éstas constituyen las catástrofes de origen natural que mayores daños económicos y sociales causaron en la Argentina en los últimos tiempos". De esta manera, la problemática de las inundaciones y sus consecuencias resulta de gran relevancia en el territorio argentino existen grandes zonas afectadas

Estas zonas, configuran un nuevo plano de vulnerabilidad al cambio climático y se posicionan como áreas de intervención prioritarias. Al respecto, la vulnerabilidad según IPCC es definida como:

“Nivel al que un sistema (natural o humano) es susceptible, o no es capaz de soportar, los efectos adversos del cambio climático, incluidos la variabilidad climática y los 
fenómenos extremos. La vulnerabilidad está en función del carácter, magnitud y velocidad de la variación climática al que se encuentra expuesto un sistema, su sensibilidad, y su capacidad de adaptación." (p.1)

Estas nuevas configuraciones obligan a re-pensar sobre la capacidad que poseen las poblaciones para adaptarse al impacto del cambio climático, entendiendo que algunos de los factores más importantes que determina la capacidad de adaptación de las personas, hogares y comunidades, es el acceso y control que puedan tener sobre los recursos naturales, humanos, sociales, físicos y financieros.

Se puede decir entonces que la adaptación o resiliencia es un proceso enfocado a reducir la vulnerabilidad (figura 10), implica fortalecer la capacidad de resiliencia, en especial de aquellas personas más vulnerables (CARE y The International Institute for Sustainable Development, 2010).

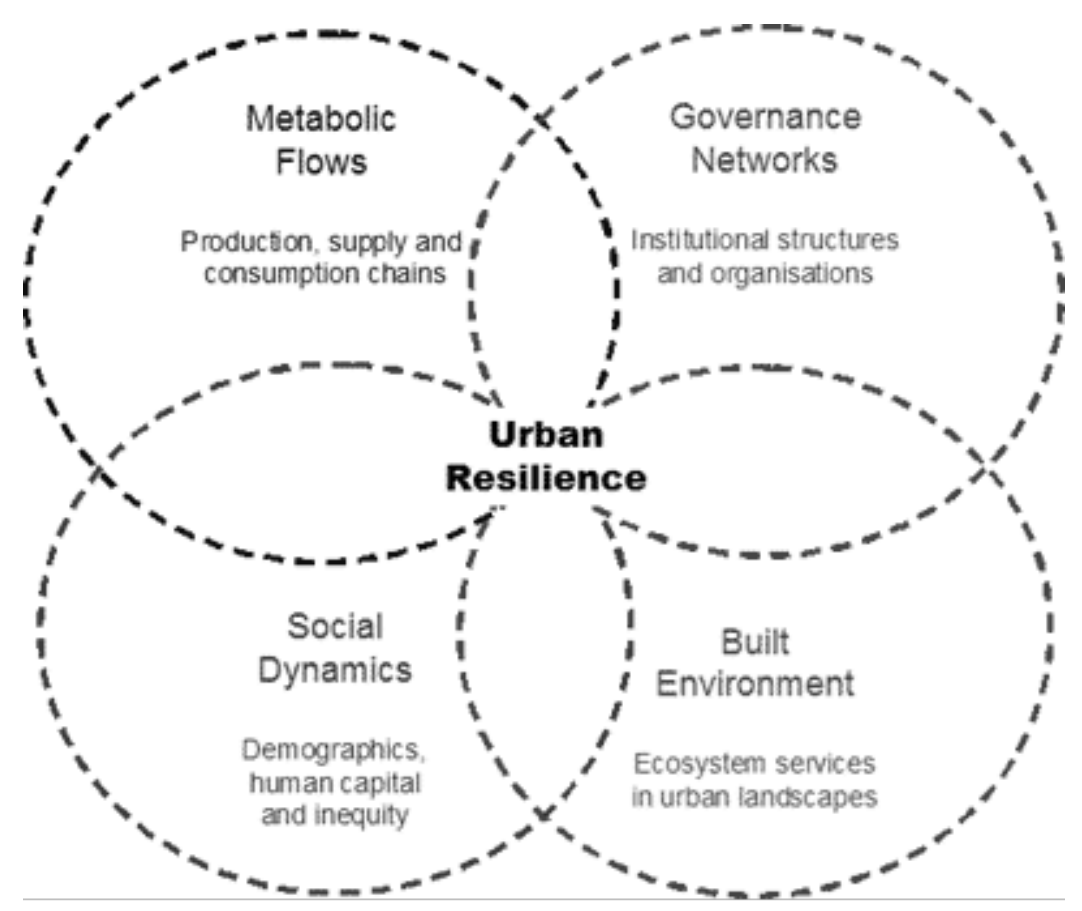

Figura 10. Componentes de la resiliencia urbana.

Fuente: https://www.resalliance.org

En este contexto, hay que empezar a pensar en la Resiliencia al cambio climático, la cual es entendida como "la capacidad de un sistema socio-ecológico para absorber o soportar las perturbaciones y otros factores estresantes, de modo que el sistema pueda mantener esencialmente su estructura y funciones. Describe el grado en que el sistema es capaz de 
generar auto-organización, aprendizaje y adaptación". (Holling 1973; Gunderson y Holling 2002)

Al mejorar la capacidad de recuperación o pensar en las acciones o intervenciones futuras colaboraría a aumentar la resiliencia disminuyendo la vulnerabilidad de los habitantes.

En los diversos estudios realizados en base a proyectos se puede decir que las medidas de adaptación más importantes se pueden clasificar en tres grandes categorías (Del Pozo, 2016):

- Las que tratan de atenuar la escasez del agua

- Las relativas a combatir las lluvias torrenciales

- Las destinadas a suavizar el efecto del aumento de la temperatura.

De este modo, se hace necesario pensar ¿cómo podríamos revertir estas consecuencias al cambio climático? En primer lugar, desde nuestro punto de vista de esta tesis se puede decir que concebir y dar forma a nuestro entorno pensando de manera integral y con medidas de intervención creativas, ecológicas y sociales pensando como trabajar estos paisajes vacantes para convertirlos en un elemento funcional a la adaptación de la ciudad al cambio climático.

Es por ello que como grandes medidas en base a las categorías planteadas se pueden pensar en las siguientes medidas. Para revertir la escasez del agua en optimizar el ciclo de agua, resultando fundamental recoger el agua de pluviales o utilizar pavimentos que favorezcan la recarga de aguas subterráneas y de acuíferos. Como así también, pensar en la reutilización de las aguas de lluvia o de las aguas sucias para otras actividades.

En el caso del aumento de la temperatura que se viene dando en las últimas décadas desde nuestra visión se pueden crear más zonas de sombras y pensar en especies que sean funcionales y se adapten a nuestro clima.

En cuanto al aumento de las precipitaciones sería necesario comenzar a gestionar mejor las aguas superficiales, en particular en las calles, incorporando elementos que retarden la velocidad de escurrimiento capturando el agua en momentos de flujo máximo y la liberándola lentamente como los jardines verticales, terrazas jardín o espacios con superficies de suelo absorbente. Estas medidas también tienen que estar ligadas a las de combatir la escasez de agua donde se puede reutilizar el agua de lluvia para otras actividades. 
Esta tesis propone entonces pensar como estrategia de resiliencia al cambio climático un sistema de espacios verdes de uso público convirtiendo espacios vacantes de la ciudad en espacios verdes que funcionen como reservorios. Este sistema contribuiría a mejorar la resiliencia al cambio climático como a mejorar la calidad del paisaje urbano con el fin de optimizar las condiciones de los habitantes.

\subsection{Las tierras vacantes como espacios de oportunidad}

Como se mencionó anteriormente los espacios verdes adquieren un papel relevante en la ciudad y en muchos casos se puede identificar la ausencia o falta de estos. En este contexto es donde la tierra vacante adquiere un papel preponderante en el crecimiento urbano, ya sea desde sus aspectos negativos como positivos. La existencia de tierras vacantes sin uso evidencia la falta de continuidad en el área urbana como así también inequidad e irracionalidad en el acceso a la tierra, trae aparejado un incremento de los costos económicos y socio-ambientales de urbanización, lo que dificulta además la integración entre los barrios. Asimismo, es vista desde sus aspectos positivos como una potencialidad para la utilización e incorporación a la trama urbana. Se puede decir entonces que "posee un papel importante en las formas de producir ciudad (debido a las nuevos oferentes y demandantes, con diferentes pautas culturales y posibilidades económicas)" (Clichevsky, 2007).

En Latinoamérica, la tierra vacante constituye un porcentaje importante de las áreas urbanizadas, en las cuales podría asentarse población sin acceso al suelo urbano como así también, poder convertir estas en espacios para la recreación, cultura, entre otros. Clichevsky (2002) señala que en "Río de Janeiro significan cerca del 44\% de la superficie del Municipio. En Quito, aproximadamente el 21.7\%. En San Salvador, aunque actualmente el número de predios baldíos no representa más que el $4.65 \%$ del área total del Distrito Comercial Central, existe tierra vacante latente, constituida por numerosas edificaciones que están a la espera de ser demolidas. Este tipo de tierra puede llegar al $40 \%$ del total de esta área. En Lima, representa el 10\%. En Buenos Aires alrededor del $32 \%$ de la superficie urbanizada del ÁMBA".

Se puede decir que existen múltiples causas que provocan su generación y permanencia. La principal causa es la no regulación del mercado de suelo, ligado a comportamientos especulativos de los agentes productores de suelo y la demanda de suelo. Por otro lado, las políticas aplicadas que impactan en la valorización de espacios urbanos influyen en la permanencia como así también los factores socioculturales, políticos y legales 
relacionados con la posesión de inmuebles; como así también problemáticas vinculadas al riesgo ambiental (Fausto Brito, 2005).

La especulación del precio del suelo en relación a las expectativas al respecto que tengan los consumidores en un determinado momento trae aparejados procesos de urbanización de difícil regulación y se convierte en fuente de inequidades. Esta es una de las causas de la existencia de tierras vacantes; pero, como se mencionó anteriormente, existe una amplia gama de factores causales, que van desde la escasez de recursos para desarrollar la tierra hasta condicionantes ambientales, como inductores de la creación de espacios urbanos sin uso definido, sin obviar los impedimentos de orden jurídico y presiones políticas (Larangeira, 2004).

En este sentido, Clichevsky (2002) define a las tierras vacantes como aquellas permanentemente desocupadas que se localizan dentro de los límites urbanos, excluyendo los parques, las plazas o las áreas de protección ecológica destinadas a usos públicos. Del mismo modo, Fausto Brito y Rábago (2001) definen la tierra vacante como los terrenos remanentes a la dinámica urbana, que permanecen vacíos o subutilizados; o que todavía reconocidos como urbanos y servidos directamente o muy próximos a infraestructuras ya instaladas, no se desarrollan en la plenitud de su potencial, contrariando el principio de función social de la propiedad (como se cita en Frediani, 2014, p.264). Por otro lado, Larangeira (2004) señala que "las denominaciones pueden ser tantas como son los tipos, tamaños, ubicaciones y motivos determinantes de que tramos de suelo urbano permanezcan sin uso efectivo, o no alcancen su mejor potencial de utilización, haciendo difícil el establecimiento de una definición única. De hecho, son múltiples las posibilidades de interpretar los orígenes del fenómeno y de desarrollar estrategias y acciones para mitigar sus consecuencias negativas o, mejor aún, sacarle partido".

Según el INDEC ${ }^{38}$, se considera tierra vacante tanto a aquella tierra privada no utilizada y que se encuentra subdividida en parcelas denominadas urbanas según la legislación vigente dentro del perímetro de una aglomeración, como a la tierra de propiedad fiscal que ha sido desafectada de sus anteriores usos (Mignaqui y Arias, 2008 citado en Frediani,2014).

38 El Instituto Nacional de Estadística y Censos (INDEC) es un organismo público, de carácter técnico, que unifica la orientación y ejerce la dirección superior de todas las actividades estadísticas oficiales que se realizan en el territorio de la República Argentina. 
En las ciudades que poseen pocos espacios abiertos, se designa a los terrenos rurales como "vacantes", como si la tierra no tuviera aprovechamiento legítimo actual y estuviese simplemente esperando ser "desarrollada”. Este que Solà-Morales (1996) llama terrain vague en las cuales "se focaliza en las áreas abandonadas, en los espacios y edificios obsoletos e improductivos, a menudo indefinidos y sin límites determinados...".

En este contexto, se va a tomar como tierra vacante en esta investigación a las tierras que se encuentran permanentemente desocupadas y que se localizan dentro de los límites urbano. Las tierras vacantes conforman una ciudad de sentidos inciertos. Se refieren a una ciudad que no puede reconocerse desde un concepto de estructura funcional, son los territorios que desconocen cualquier integración sistémica a la ciudad como fenómenos autodeterminados, generalmente exteriores a la planta urbana. Las tierras vacantes manifiestan la privación de algún tipo de urbanidad, se presenta "como vacío que, habiendo sido parte de la ciudad, está actualmente despojado y en estado de incertidumbre" (Arroyo, 2011)

Si bien la problemática de las tierras vacantes resulta fundamental en la planificación del entorno urbano, se debe poder analizar correctamente los distintos ecosistemas asociados a ellas, para poder establecer criterios adecuados de intervención sobre las mismas. Es así como el estudio de las dinámicas y gestión de la tierra vacante resulta en una línea de investigación fundamental para la tesis ya que estos lugares pueden plantearse como espacios verdes de uso público. Los vacíos urbanos de la ciudad aún pueden re valorizar el espacio verde publico siendo una "oportunidad para producir ciudadanía ya su vez un test de desarrollo de la misma" (Gorelik, 1998).

En este contexto, las tierras vacantes en la periferia son el centro de atención y son disputadas por todos los sectores de la población, ya sea de bajo como de alto nivel socioeconómico. Clichevsky (1990) señala que "la tierra más que un bien de uso, es un capital especial del cual se pueden obtener beneficios extraordinarios por el solo hecho de poseerla; es una inversión improductiva para la sociedad en su conjunto y lucrativa para su dueño". Esta ocupación del suelo da como resultado, una trama urbana discontinua donde proliferan las tierras vacantes. Espacios que se encuentran insertos en la ciudad pero que no forman parte de ella, es decir que no participan activamente y no se reconocen por la sociedad como posibles potenciales. 
Si bien las tierras vacantes son consideras, como ya se mencionó anteriormente, como un problema (ya que la modalidad de producción de suelo urbano dispersa y con grandes vacíos intersticiales incrementa los costos económicos y socio-ambientales de urbanización, dificultando además la integración entre los barrios), en este caso vamos a considerarlos fundamentalmente como "espacios de oportunidad".

Estos espacios se identifican como plantea Carabajal, Servetti y Souto (2011) "como un espacio de oportunidad; transformando el concepto de ausencia en promesa, como espacio de lo posible." Pueden reconocerse como espacios de oportunidad con un importante potencial social y de uso para las diversas actividades urbanas, dado que su disponibilidad constituye una oportunidad de crecimiento, de contar con suelo para urbanizar, de localizar y construir la demanda de vivienda, de realizar proyectos urbanos de gran envergadura, de construir nuevas centralidades. Se puede decir que son indispensables para poder (re)orientar la forma de estructuración, crecimiento y desarrollo urbano (Larangeira, 2004). Es decir “asumir la vacancia urbana es asumir un tiempo de oportunidades y un espacio de potencialidades, fundados en sus valores estratégicos por su rentabilidad, funcionalidad, capital paisajístico, cualidad ambiental, etc."(Arroyo 2011, p.24).

Estas tierras representan un punto estratégico en el control del crecimiento urbano expansivo y en la conformación de un espacio urbano consolidado. De esta manera, "constituyen espacios de oportunidad que, bien aprovechados, desde los parámetros de la racionalidad urbanística, nos ayudarán a recomponer y ordenar la ciudad en su conjunto". Por dicho motivo, considerar la problemática de la vacancia de tierra constituye una instancia básica e indispensable para definir estrategias tendientes a un desarrollo urbano más sustentable. El uso o la reutilización racional de estas tierras podrían contribuir a recomponer y ordenar la ciudad en su totalidad y favorecer la integración socioterritorial. El potencial de oportunidad dependerá de la importancia de reutilizar dicho espacio, de su carácter estratégico en función de la ubicación, proximidad a arterias principales o a servicios circundantes que dicho suelo presenta (Frediani, 2016).

\section{5 | Paisajes vacantes}

La conformación estética del paisaje parte de las leyes de la forma y la disposición de los materiales. Como afirma Milani (2006 citado en Nogué ,2008): 
“El paisaje es una gran experiencia de la emoción, de la visión y de la contemplación, pero asimismo del trabajo humano sobre el territorio y el ambiente. Es un resultado cultural, no intelectual porque la naturaleza, de la que constituye una revelación en el ámbito de las formas, es vivida, sentida y modificada por el hombre en el transcurso de la historia" (p.55)

Entonces se puede decir, que el paisaje entendido como el reconocimiento del mundo pone de manifiesto la relevancia de la imagen como el reconocimiento del espacio. El paisaje es entonces, como afirman Silvestri y Aliata (2001), el espacio de mediación entre el hombre y el mundo, para que este exista es necesario un punto de vista, un observador y un relato que otorgue sentido a lo que mira (figura 11). Es decir, ya antes de aproximarnos al paisaje hay conciencia de la forma y esta se lleva a la representación a través de la imagen.

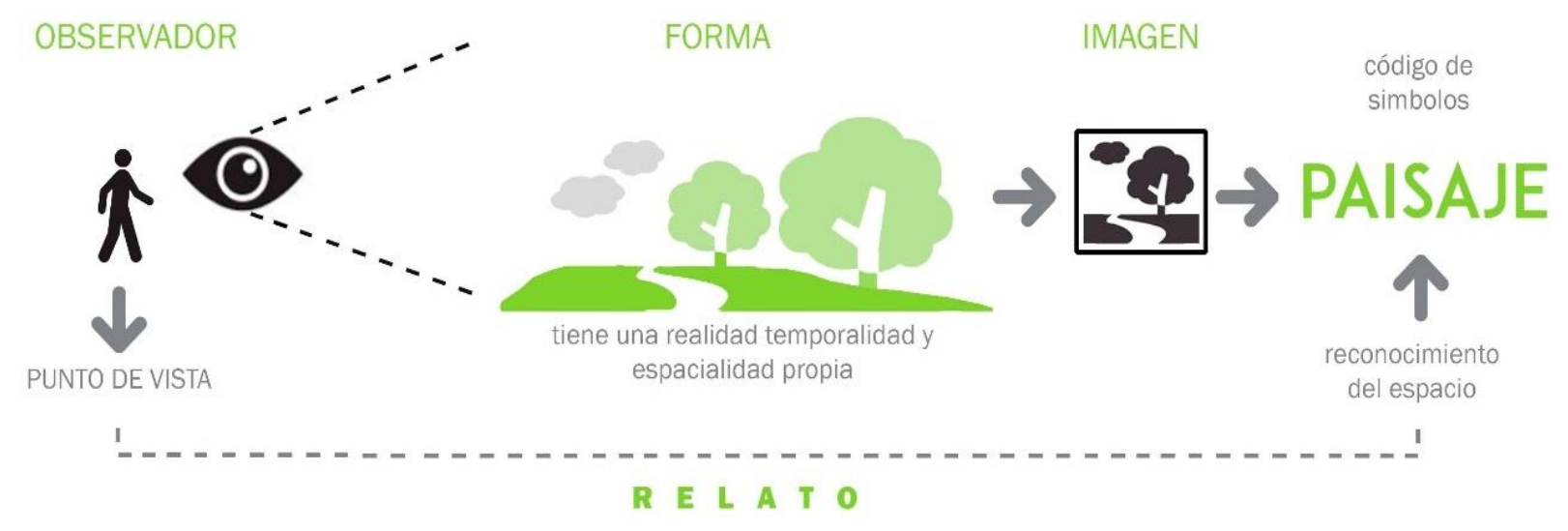

Figura 11. El concepto de paisaje.

Fuente: elaboración propia, 2017.

El paisaje tiene un papel relevante en la cultura contemporánea ya que "es la proyección cultural de una sociedad en un espacio determinado y reconocen en el mismo dos dimensiones intrínsecamente relacionadas: dimensión física, material y objetiva y otra perceptiva, cultural y subjetiva" (Nogué, 2008, p.11).

De acuerdo con Punter (1982), la percepción del paisaje es un proceso que se compone de tres etapas consecutivas y cíclicas: 1) experiencia; 2) cognición; y 3) evaluación o preferencia. La experiencia del paisaje es individual debido a que cada persona tiene particularidades propias, es dinámica porque éstas varían por una nueva experiencia y es fisiológica porque se adquiere a través de los sentidos, siendo la vista el más importante. La cognición es individual y subjetiva, pues el conocimiento adquirido es una 
representación o abstracción de la realidad, que está influenciada por experiencias, asociaciones y recuerdos del individuo (Cakci-Kaymaz, 2012).

Asimismo, como se mencionó anteriormente, se reconoce al hombre como el observador, sin la observación no existe la posibilidad de paisaje ya que no hay relato. Esto nos permite empezar a pensar ¿qué pasa con los espacios donde no hay un observador que arme un relato de estos? Espacios que están en continuo contacto con los habitantes, pero siguen sin ser vistos. Estos espacios están esperando poder ser mirados, para convertirse en paisaje.

Smithson (citado en Ábalos, 2008) habla del paisaje postindustrial haciendo énfasis en lo que hubo y lo que hay, una nueva y extraña belleza como cuando se observa una cantera. De esta manera introduce a la noción de paisaje a los denominados lugares entrópicos los cuales son entendidos como "un vasto conjunto de lugares marcados por la huella erosiva de las industrias modernas que había sido condenado al espacio de lo invisible mientras su destrucción como lugares vivos se estaba produciendo". A estos espacios los califica como invisibles haciendo énfasis en que "pueden y deben adquirir una visibilidad equivalente a la que el pintoresquismo introdujo en los lugares modificados por la acción de la naturaleza y el hombre".

De esta manera, Smithson asume la posición de paisajero (observador del paisaje) antropizado, solo es posible el paisajismo donde hay ausencia de él, donde es necesario:

"dar cuenta y operar sobre una melancolía que surge precisamente cuando las sociedades pierden sus vínculos naturales, traer a la esfera del ciudadano la huella de aquello de lo que se ha despegado, organizada ahora como una experiencia estética, una experiencia sustancialmente construida como un desplazamiento". (p. 217)

En este contexto es que proponemos llamar "paisajes vacantes" a estos espacios que esperan ser mirados y que podrían convertirse en paisaje mediante el reconocimiento del espacio en base a la imagen (figura12). Estos espacios están a la espera de que los habitantes los miren los vean como paisaje, es decir que los reconozcan y se identifiquen con ellos. 

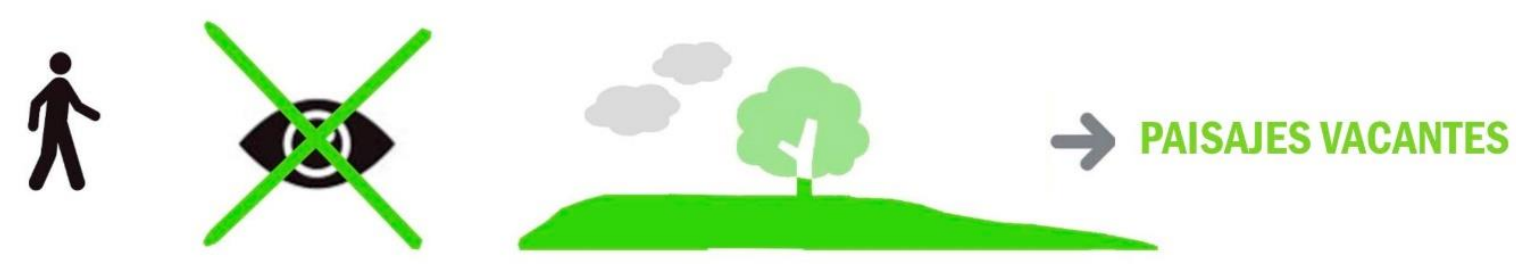

Figura 12. El concepto de paisaje. Fuente: elaboración propia, 2017

De esta manera, se recompone la fractura entre la visión científica y la visión artística del mundo. Desde la percepción del paisaje como una experiencia sensorial compleja, se mira al espacio como construcción de imágenes y practicas colectivas, abarcando su dimensión estética, social y cultural para la lectura e intervención del territorio (Lynch, 1998; Roger, 2007).

En relación a la investigación que se propone realizar en la presente tesis, las tierras vacantes serían entonces estos "paisajes vacantes" que se encuentran a la espera de que sus habitantes los miren. De este modo, los criterios de intervención o de diseño de estos permitirían cambiar la mirada que existe sobre estos espacios para comenzar a incorporarlos a la ciudad permitiendo mejorar la calidad del paisaje urbano.

Esta categoría propuesta permitiría reconocer las tierras vacantes que estén en esta condición y pensar ¿cómo se pueden incorporar a la ciudad estos paisajes vacantes? o ¿que deberían ser? Esto nos da la pauta para empezar a pensar y a reflexionar acerca de la mirada de los habitantes de estos espacios.

En síntesis, en su mayoría aparecen como espacios residuales, abandonados, los cuales contribuyen a la fragmentación del tejido. Sin embargo, estos espacios representan una oportunidad para la ciudad, paisajes que esperan ser paisaje, en otras palabras, paisajes vacantes.

El desafío entonces de esta tesis este puesto en "hacer que unos elementos, juzgados a priori como muy negativos, se vean de forma muy positiva, ya sea por inversión o por exceso, se trata de provocar una retroversión del desencanto del que el lugar ha sido testigo" (Nouvel, citado en Druot et al., 2007). En otras palabras, pensar cómo estas tierras vacantes o "paisajes vacantes" puedan transformarse en espacios verdes de uso público.

De esta manera, dotar de espacio público a tramas consolidadas que carecen de ellos como así también a sectores en consolidación, implica pensar en un nuevo tipo de espacio común. Reivindicar el uso de las tierras vacantes existentes en la ciudad, se convierte en 
un derecho del ciudadano, que puede por fin acceder a unos servicios de los que se ve privado en su entorno. Los vacíos urbanos son "una oportunidad para crear ciudad" (Fernández Áñez, 2011). 
Abordaje metodológico

2.1 | El nivel superior de análisis, matriz contextual

2.2 | El nivel de análisis focal, matriz de anclaje

2.3 | El nivel inferior de análisis, matriz de componentes 


\section{CAPITULO 2}

La metodología de la investigación es una ciencia que provee al investigador de una serie de conceptos, principios y leyes que le permiten encauzar, de un modo eficiente y tendiente a la excelencia, el proceso de la investigación científica.

(Bunge, 1997)

El procedimiento metodológico de esta tesis es entendido como el "conjunto de métodos que se siguen en una investigación científica para cumplir con un determinado objetivo" (Becerra, 1997), considerando al paisaje como la manifestación externa o imagen de los procesos que tienen lugar en el territorio, ya sea correspondiendo al ámbito natural o humano, entendiéndolo como el resultado de la acción entre el hombre y la naturaleza. La región es condicionada por las características del medio y la participación de los actores políticos, económicos y sociales que configuran el territorio y cada uno de los subsistemas que lo componen. Es el producto de la reelaboración de distintos métodos en un intento de producir una innovación teórica metodológica para abordar el objetivo planteado: "Contribuir al conocimiento de los espacios verdes y tierras vacantes desde el paisaje con el fin de establecer lineamientos para conformar un sistema de espacios verdes en pos de mejorar la calidad del paisaje urbano y contribuir a la mitigación de los efectos del cambio climático".

La aplicación de criterios metodológicos basados en la triangulación ${ }^{39}$ metodológica ha posibilitado construir una visión integral que constituye un avance para comprender desde nuestra disciplina la relación ciudad, espacios verdes y paisaje y que se concretó guiada por la propuesta teórico-metodológica de Samaja (1996) organizada a partir de un conjunto de matrices de datos (por lo menos tres). Al respecto, en esta investigación se propone la siguiente estructuración (figura 13):

MATRIZ CONTEXTUAL (Nivel supraunitario) Caracterización urbano territorial de la ciudad desde el paisaje y los espacios verdes.

\footnotetext{
39 La triangulación se asume como el uso de múltiples métodos en el estudio de un mismo objeto. Denzin, N.
} (1989) 
MATRIZ DE ANCLAJE (Nivel Focal de Análisis) Variables y dimensiones de los espacios verdes y las tierras vacantes desde el paisaje

MATRIZ DE COMPONENTES (Nivel subunitario) variables y dimensiones de los criterios de diseño para la conformación de un sistema de espacios verdes.

El enfoque desde donde se estudia y analiza el paisaje desde el sentido estético, como combinación de las formas y colores del territorio. Interesa como expresión espacial y visual del medio, como conjunto de los caracteres físicos del medio físico y biótico, perceptibles con la vista. Se concreta en lo que el observador es capaz de percibir de ese territorio y parte de una base, la realidad territorial, que constituye el objeto de estudio (Smardon et al., 1986; Johnston y Naiman, 1990; Amir y Gidali-Zon, 1990; Al-Kodmany, 1999).

Se distinguen dos métodos para la valoración del paisaje desde lo estético, donde se pueden identificar los directos y los indirectos:

- Métodos directos de valoración de la calidad visual: este grupo de métodos se caracteriza porque la evaluación se realiza por medio de la contemplación del paisaje, en forma directa o por medios visuales. El paisaje se valora subjetivamente, con calificativos, escalas de rango o de orden (Fines, 1978).

-Métodos indirectos de valoración de la calidad: son métodos cualitativos y cuantitativos que evalúan el paisaje analizando y describiendo sus componentes o a través de categorías estéticas Los primeros utilizan la desagregación de las características físicas del paisaje, tales como, topografía, uso del suelo, agua, etc., a las que se le asigna un valor parcial, el que luego es sumado a los demás valores parciales obteniéndose un valor final de la calidad (Fernández Cañadas, 1977; Gómez Orea, 1979; Wrigth, 1974).

En este caso se va a utilizar el segundo donde se destaca el método estético-formal, en el que se valora el paisaje en términos de cualidades estéticas referidas a propiedades formales (Linton, 1968). Estos métodos no son totalmente objetivos, debido a que las variables a considerar deben ser elegidas, pero son menos subjetivos que los directos o visuales (Fairbanks y Benn, 2000).

En cada uno de los niveles de análisis se busca dar respuesta a los objetivos planteados en la tesis. 

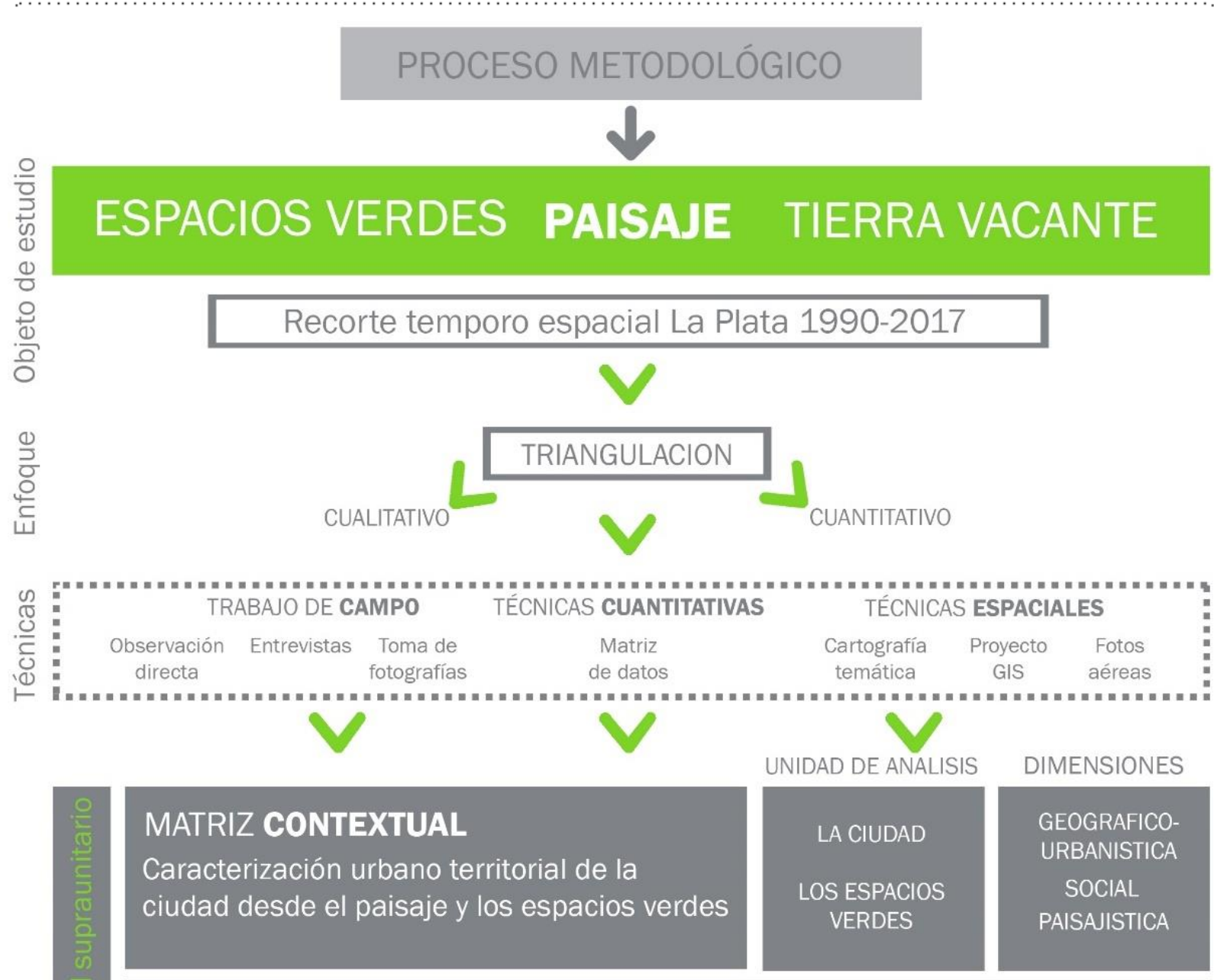

DIMENSIONES

Diagnostico urbano territorial. Relevamiento espacios verdes
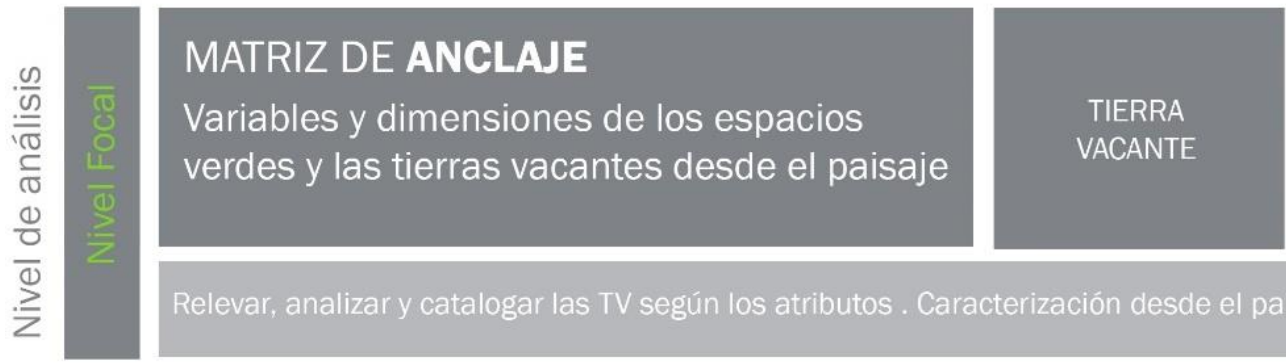

GEOGRAFICO-

URBANISTICA

BIOFISICA

ESTRUCTURAL

ESTETICA

Relevar, analizar y catalogar las TV según los atributos. Caracterización desde el paisaje.

\section{MATRIZ DE COMPONENTES}

Variables y dimensiones de los criterios de

diseño para la conformación de un sistema

de espacios verdes
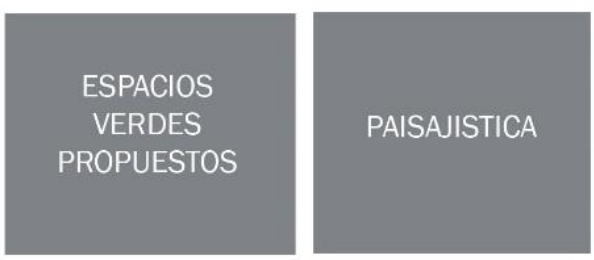

Elaborar categorias, medidas de intervención y recuperación para la incorporación de TV como EVUP.

LIneamientos y criterios de diseño para la conformación de un sistema de espacios verdes

Figura 13. Metodología de la tesis.

Fuente: Elaboración propia, 2017. 


\section{1 | El nivel superior de análisis, matriz contextual}

En este nivel superior de análisis se va a realizar una caracterización urbano-territorial de la ciudad desde el paisaje y los espacios verdes abordándola desde dos aproximaciones.

- APROXIMACIÓN URBANO-TERRITORIAL: vincula al desarrollo de la ciudad, los espacios verdes de uso público y el paisaje desde la historicidad, definido por cortes que nos permiten comprender el crecimiento de la ciudad en base a Ravella et al. (2006).

- APROXIMACIÓN PAISAIÍSTICA: aborda los tipos de paisaje reconocidos en base al estudio que propone la guía para estudios del paisaje de la Comunidat Valenciana (2012) y la valoración de los espacios verdes de uso público como así también la importancia de ellos en la ciudad.

Con el fin de responder al objetivo que propone "explorar acerca de la percepción de los habitantes de la periferia en relación a la cantidad y calidad de espacios verdes públicos en pos de relacionar las diferentes visiones con la localización espacial según la zona de la periferia", se diseñó una encuesta ${ }^{40}$ (figura14), que fue implementada a través de una plataforma Web (https://goo.gl/C5YR3r) y que también se realizó en persona, la cual se desglosó por temas organizados por preguntas y por un conjunto de fotografías a valorar (Ver anexo 1).

Al respecto, el conjunto de preguntas se determinó para garantizar la orientación del entrevistado apuntando a conocer la mirada de los habitantes de estos espacios: el tipo de vínculo entre las personas y los espacios verdes. En relación a este nivel de análisis se buscó indagar sobre:

- el grado de reconocimiento de los espacios verdes

- el uso de los espacios verdes

- La identificación de los habitantes con un espacio a escala barrial

A su vez, al entrevistado se le pidió que asigne la esquina más cercana a su vivienda con el fin de poder georreferenciar las respuestas y poder analizar estas espacialmente incorporando los datos a un plano en GIS.

Mientras que, la valoración por medio de fotografías se desarrolla siguiendo la técnica de evaluación de los ambientes realizada por Corraliza (2009) mediante las dimensiones

\footnotetext{
${ }^{40} \mathrm{El}$ universo de estudio es la periferia platense. Es un cuestionario estructurado con preguntas abiertas y cerradas sobre el paisaje y los espacios verdes. La modalidad de contacto fue presencial y on-line, la toma de muestra de las zonas se realizó de L. a V. en los centros comerciales y los fines de semana en los espacios verdes. El tamaño de la muestra es de 514 personas, donde el Nivel de confianza $95.68 \%$ y el porcentaje de error $4.32 \%$. La muestra es representativa del universo de análisis, permite su generalización ya que se verifica de manera espacial.
} 
afectivas del ambiente. Fueron adoptados del modelo teórico el factor de agrado de los espacios verdes.

El factor de agrado se refiere a contenidos emocionales relacionados con: agradabilidad, sugestión, interés. Se interpreta como una dimensión de atracción, donde se valora el atractivo o agrado que produce en los sujetos un determinado lugar o situación, reflejando en este caso la estética del paisaje.

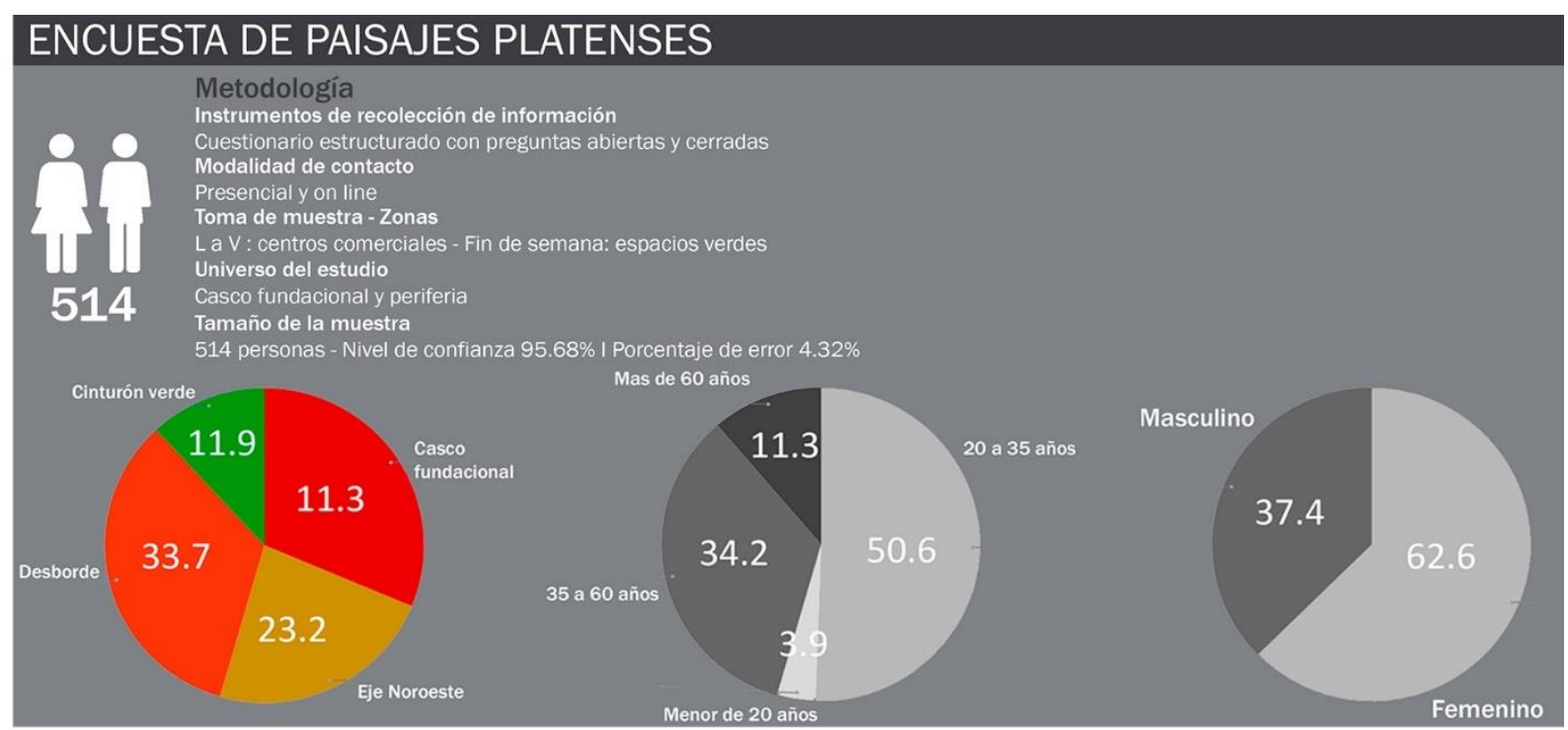

Figura 3. Metodología y universo de análisis de la encuesta

Fuente: Elaboración propia, 2017.

1- En este contexto, se van a analizar las transformaciones territoriales derivadas del modo de producción del espacio urbano en busca de comprender los procesos que dan origen a la falta de espacios verdes de uso público. Para abordar la región y su conformación se propone trabajar con el período o etapa fundacional, que va desde 1882 a 1930; una segunda etapa desde 1930 a 1970, y una tercera y última etapa, que se extiende desde 1970 a nuestros días (Ravella et al., 2006).
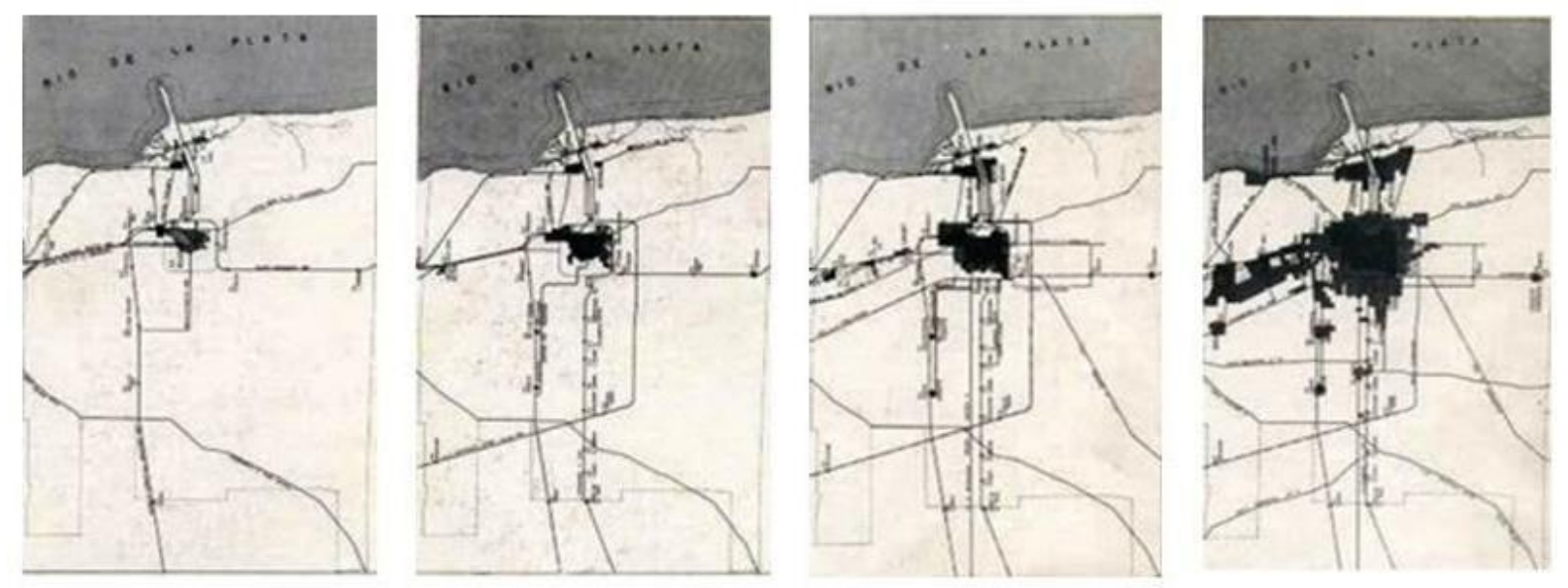

Figura 15. Secuencia cronológica del proceso de crecimiento de la Ciudad de La Plata.

Fuente: La Plata, Ciudad Nueva-Ciudad Antigua. UNLP 
Una vez comprendida la conformación de la región y su evolución (figura 15) se toma como recorte temporal el periodo 1990 a 2017 ya que es el periodo con mayor crecimiento de las ciudades en Argentina al igual que en toda América Latina, producto del flujo de inmigración interna de zonas rurales hacia zonas urbanas debido a condiciones económicas y sociales desfavorables, desde la ciudad compacta hacia una ciudad dispersa. Los profundos cambios que se produjeron a nivel económico, político y social en nuestro país, entre los que cabe destacar la implementación de la Ley de Reforma del Estado y de Emergencia Económica (1989), y al Plan de Convertibilidad puesto en marcha desde 1991, señalan el inicio de la reactivación de la industria de la construcción y el mercado inmobiliario prácticamente estancados durante los ochenta, contribuyendo así a generar un nuevo espacio urbano y periurbano.

Particularmente, en la región de estudio desde fines de los años ' 80 , se observa un notable cambio en la morfología de la ciudad como consecuencia de las transformaciones urbanas que se vienen produciendo en el Partido de La Plata. La ciudad de La Plata se ha desbordado de los tejidos originales hacia la periferia, siguiendo las vías de comunicación, fundamentalmente las que la conectan con Buenos Aires. Paralelamente con este crecimiento, se verifican transformaciones en la estructura periférica, con nuevas actividades comerciales, de servicios y recreativas, que ha cobrado mayor autonomía respecto del centro tradicional (Frediani y Matti, 2006).

Este recorte temporal nos va a permitir hacer foco en la conformación de la periferia desde el paisaje y los espacios verdes con el fin de comprender el crecimiento de la población, de la mancha urbana como así también de los espacios verdes y su relación en el crecimiento urbano. Dentro del recorte temporal se va a separar en tres periodos, los cuales corresponden al los que establece el Censo de Población y Vivienda en Argentina realizado por el INDEC, donde se divide en 1990-2001, 2001-2010 y del 2010 a la actualidad 2017.

Se van a tomar como variables de análisis:

- La mancha urbana: la extensión del uso residencial real relevado de fotos satelitales de los periodos establecidos.

- La población: Se incorporan los datos del censo INDEC de 1991, 2001 y 2010 desglosando por zona de análisis y se realiza una proyección de la población estimada al año 2017. Con estos datos se pudo calcular la tasa de crecimiento de las últimas tres 
décadas lo cual se va a complementar con los m2 de área verde por zona de análisis, obtenidos del relevamiento de los espacios verdes en la región de estudio (tabla 1).

\begin{tabular}{|c|c|c|c|c|c|}
\hline Zonas de análisis & $\begin{array}{c}\text { Población Censo } \\
\text { Habitantes }\end{array}$ & $\begin{array}{c}\text { Población Censo } \\
\text { Habitantes }\end{array}$ & $\begin{array}{c}\text { Población Censo } \\
2010 \\
\text { Habitantes }\end{array}$ & $\begin{array}{c}\text { Población estimada } \\
2017 \\
\text { Habitantes }\end{array}$ & $\begin{array}{c}\text { Crecimiento } \\
1991-2017 \\
\text { (\% Habitantes) }\end{array}$ \\
\hline Casco & $207,434.0$ & $181,402.0$ & $191,075.0$ & $211,744.9$ & 102.1 \\
\hline Desborde & $202,294.0$ & $220,156.0$ & $228,538.0$ & $253,259.0$ & 125.2 \\
\hline Eje Noroeste & $62,648.0$ & $104,751.0$ & $159,783.0$ & $177,066.3$ & 282.6 \\
\hline Cinturón Verde & $69,529.0$ & $70,614.0$ & $80,939.0$ & $89,691.4$ & 129.0 \\
\hline TOTAL LP & 541,905 & 574,223 & 660,335 & 731,783 & 35.0 \\
\hline
\end{tabular}

Tabla 1. Población por zonas y cantidad de áreas verdes.

Fuente: Jensen y Birche, 2017.

- Los espacios verdes: Se relevan en relación a los periodos en las fotos satelitales y luego se va a completar con el relevamiento mediante trabajo de campo realizado en año 2016 para la catalogación y clasificación según tipo y configuración.

2- Aproximación desde el paisaje. Se va a estudiar y analizar la región desde el paisaje identificando los tipos de paisaje que se observan. Estos son áreas que poseen un mismo carácter paisajístico, en cuanto a su configuración estructural y funcional. Permiten sintetizar las características de un paisaje. Es así como diferentes unidades de paisaje pueden pertenecer a un mismo tipo de paisaje. Por ejemplo, en el siguiente esquema (Figura 16) aparecen cuatro unidades de paisaje, pero solo tres tipos de paisaje:

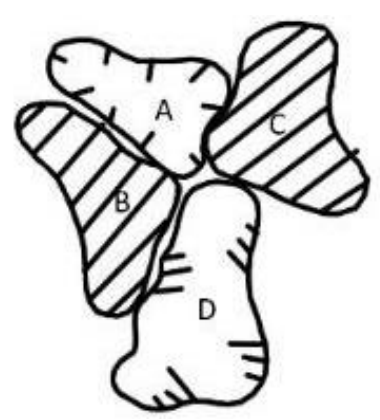

Figura 16. Unidades de paisaje y tipo de paisaje.

Fuente: Elaboración propia, 2017.

De esta forma, cada tipo se conforma por diferentes unidades de paisaje que comparten el mismo tipo. Se denomina unidad de paisaje al área geográfica con una configuración estructural, funcional o perceptivamente diferenciada, que presentan un carácter paisajístico diferenciado. Se puede decir entonces que "las unidades de paisaje son porciones del territorio con un mismo carácter, es decir, están caracterizadas por un 
conjunto de elementos que contribuyen a que un paisaje sea diferente de otro, y no por ello mejor o peor" (Nogué y Sala, 2008).

Las seis variables paisajísticas que sirven para delimitar los tipos de paisaje son:

- Los factores fisiográficos y, en especial, el relieve.

- Los usos y las cubiertas del suelo, cuyo estudio permite identificar la disposición espacial característica de cada paisaje.

- La dimensión histórica del paisaje, es decir el factor humano como principal agente transformador del paisaje desde una perspectiva histórica. El paisaje es un reflejo de las funciones que secularmente se le han ido otorgando. Se fundamenta en las formas y estructuras paisajísticas que hemos heredado, como por ejemplo los patrones urbanos, la estructura parcelaria y de la propiedad, las tipologías de asentamiento en el territorio, la distribución histórica de determinadas actividades productivas, las infraestructuras hidráulicas, o la red de caminos antiguos u otras infraestructuras de comunicación y transporte. La pervivencia de estas huellas en el territorio contribuye a definir el carácter de un determinado paisaje y la identidad de un territorio y son elementos básicos que deberán tenerse en cuenta en la ordenación posterior del paisaje.

- La estructura del paisaje debería ser analizada desde la ecología del paisaje

- El estudio de visibilidades y, por lo tanto, la visión del paisaje. Este aspecto es muy importante para la definición de las unidades de paisaje, ya que la observación y comprensión del paisaje está fuertemente condicionada por la existencia de unos ciertos puntos de observación y de recorridos visuales que son los que en mayor medida contribuyen a la percepción del paisaje.

- Detección de dinámicas recientes y tendencias inmediatas. La definición de las unidades se debe basar también en elementos paisajísticos perdurables en el tiempo.

- La identidad del lugar. El paisaje es mucho más que un conjunto de componentes naturales, estéticos o el resultado de unos factores históricos y socioeconómicos que han intervenido sobre el territorio. El paisaje es, en gran medida, un elemento vivencial, es decir, que está configurado a partir de la suma de experiencias vividas a lo largo de los años y en el que arraigan sentimientos de pertenencia e identidad. La relación social y económica ancestral establecida entre distintas poblaciones de un territorio, o entre un pueblo y un río cercano, el uso de ciertas técnicas y prácticas de manejo de los cultivos, la denominación de los lugares, la existencia de un dialecto hablado en un pequeño territorio o el reconocimiento especial de ciertos paisajes son, entre otros, algunos factores que nos identifican con un determinado paisaje. 
3- Relevar, analizar y clasificar los espacios verdes de uso público.

Para la identificación de los espacios verdes de uso público en la periferia platense se ha elaborado una metodología basada en la fotointerpretación de imágenes satelitales de Google Earth (año 2016) y una posterior visita a campo, con el fin de incorporar estos datos obtenidos en un plano en GIS41.

En este contexto una vez definida la unidad de análisis ${ }^{42}$, se definen macro variables ${ }^{43} \mathrm{a}$ partir de establecer diferentes dimensiones o enfoques que se quieren abordar en el análisis (Ynoub, 2015). Estas variables están en relación con el marco teórico utilizado para el desarrollo de la metodología propuesta, el cual parte del concepto de paisaje como el resultado de la acción entre el hombre y la naturaleza, y se expresa en la imagen de los procesos que tienen lugar en el territorio. El territorio es entendido como paisaje artificializado, lugar de la naturaleza y el humano, es decir, espacio sujeto a ser visto, interpretado, adaptado y transformado a lo largo del tiempo (Tardín, 2010). De esta forma, se establecen tres dimensiones las cuales se componen de sus respectivas variables: la dimensión urbana, que pretende estudiar la relación entre los espacios verdes de uso público (EVUP) ${ }^{44}$ y el medio urbano, la dimensión social, que pretende entender el tipo de acercamiento que tienen los habitantes con estos espacios y la dimensión paisajística que pretende rescatar las valencias estéticas del lugar.

De esta forma, se tienen:

- DIMENSIÓN URBANA: en esta dimensión se tomaron tres variables para analizar, el tipo de espacio verde, la propiedad pública o privada y por último el porcentaje de suelo absorbente que posee el EVUP en relación a la proporción de verde y de solado.

- DIMENSIÓN SOCIAL: en esta dimensión se tomaron dos variables de análisis, el alcance, relacionado al área de influencia o nivel de atracción, y el mobiliario, que hace referencia a si el espacio verde posee el mobiliario necesario en relación al tipo de espacio.

41 Sistema de información geográfico.

42 La unidad de análisis es la "sustancia" o materia de la investigación. Una unidad de análisis es concebida como un "individuo" (miembro de un sistema o universo) y al mismo tiempo como un "colectivo" (esto quiere decir, ítems, cualidades particulares).

43 El término variable, concepto tomado de las matemáticas, significa la propiedad que tienen las personas, los hechos, fenómenos y procesos de tomar ciertos valores cualitativos o cuantitativos.

44 El termino EVUP se utiliza para denominar a los espacios verdes de uso público sin importar si el dominio es público o privado, haciendo énfasis en el uso. 
- DIMENSIÓN PAISAJÍSTICA: en esta dimensión se toma como variables de análisis el arbolado, que está en relación a la proporción de especies vegetales en relación al área total de un espacio verde de uso público, y la presencia de agua superficial, como una variable clave respecto a la calidad paisajística de un sitio.

Consecuentemente para cada una de las dimensiones y las variables que las componen, se elaboraron los siguientes indicadores ${ }^{45}$ que permiten catalogar los EVUP (tabla 2):

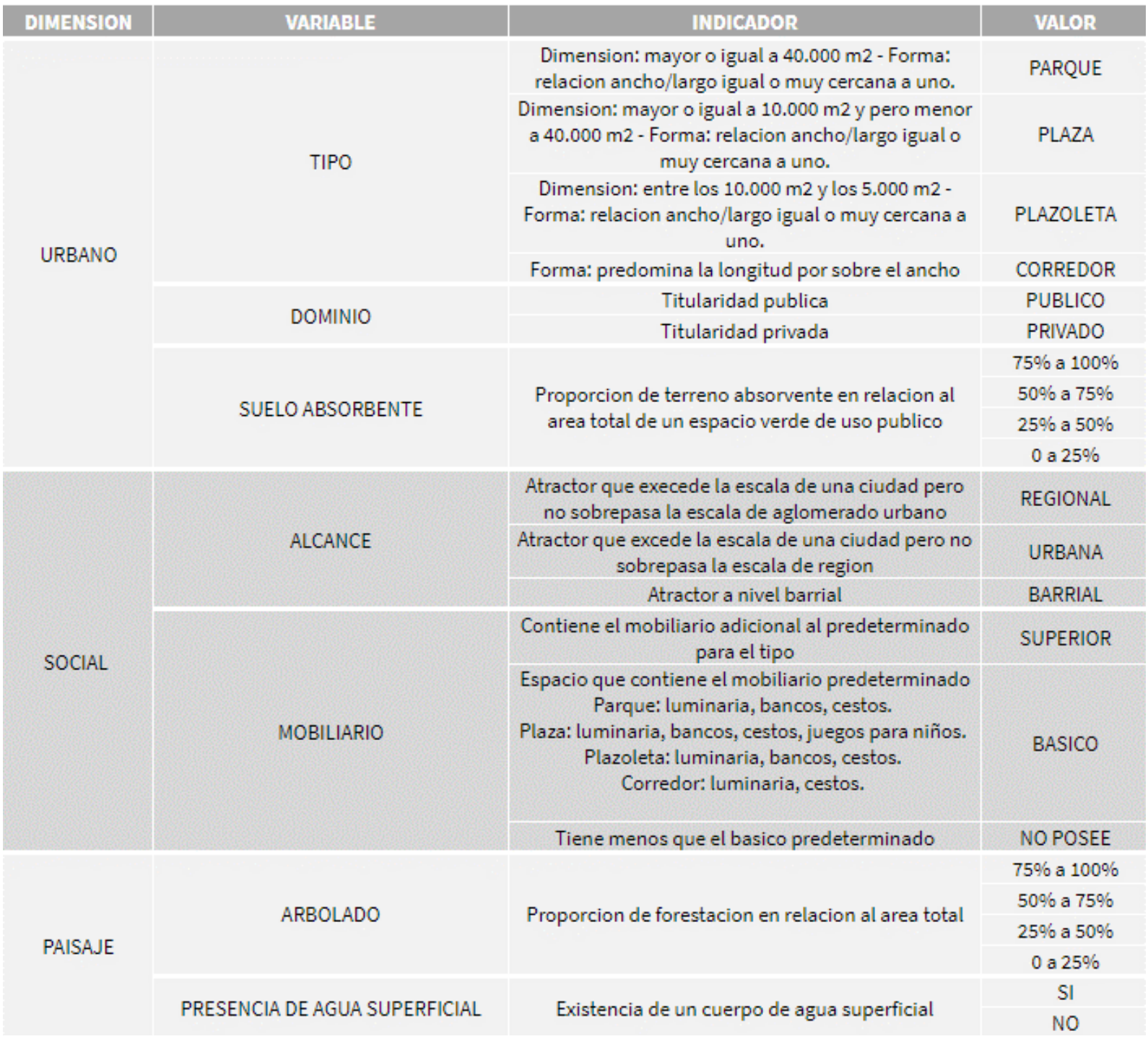

Tabla 2. Matriz para la el relevamiento y clasificación de espacios verdes de uso público.

Fuente: Jensen y Birche, 2017.

\footnotetext{
45 Los indicadores representan un ámbito específico de una variable o de una dimensión de ésta. El indicador nos "indica" la situación de una variable, siendo un valor mensurable que permite seguir la evolución de un proceso para identificar el logro de un objetivo. Los indicadores son, por tanto, herramientas que nos proporcionan información sintética sobre una realidad compleja como la que nos rodea.
} 
Para la recolección de datos se procedió a la elaboración de una matriz de análisis donde se le asigna un valor numérico a cada variable y se lo inserta en una tabla. De esta manera la matriz de datos reconoce un lugar análogo, organizada a través de una estructura invariante compuesta por la unidad de análisis, las variables y los valores.

La matriz se elabora con las variables anteriormente descriptas las cuales permiten relevar los EVUP a través de observación indirecta por Google Earth, realizando posteriormente la corroboración en campo (tabla 3). Para referenciar cada uno de los EVUP relevados se le asigna un valor numérico como así también, a cada uno de los valores de los indicadores, el cual permite insertarlo en un SIG y poder operacionalizar los datos.

\begin{tabular}{|c|c|c|c|}
\hline DIMENSION & VARIABLE & VALOR & VALOR NUMERICO \\
\hline \multirow{10}{*}{ URBANO } & \multirow{4}{*}{ TIPO } & PARQUE & 1 \\
\hline & & PLAZA & 2 \\
\hline & & PLAZOLETA & 3 \\
\hline & & CORREDOR & 4 \\
\hline & \multirow{2}{*}{ DOMINIO } & PUBLICO & 1 \\
\hline & & PRIVADO & 2 \\
\hline & \multirow{4}{*}{ SUELO ABSORBENTE } & $75 \%$ a $100 \%$ & 1 \\
\hline & & $50 \%$ a $75 \%$ & 2 \\
\hline & & $25 \%$ a $50 \%$ & 3 \\
\hline & & 0 a $25 \%$ & 4 \\
\hline \multirow{6}{*}{ SOCIAL } & \multirow{3}{*}{ ALCANCE } & REGIONAL & 1 \\
\hline & & URBANA & 2 \\
\hline & & BARRIAL & 3 \\
\hline & \multirow{3}{*}{ MOBILIARIO } & SUPERIOR & 1 \\
\hline & & BASICO & 2 \\
\hline & & NO POSEE & 3 \\
\hline \multirow{6}{*}{ PAISAJE } & \multirow{4}{*}{ ARBOLADO } & $75 \%$ a $100 \%$ & 1 \\
\hline & & $50 \%$ a $75 \%$ & 2 \\
\hline & & $25 \%$ a $50 \%$ & 3 \\
\hline & & 0 a $25 \%$ & 4 \\
\hline & \multirow{2}{*}{ PRESENCIA DE AGUA SUPERFICIAL } & SI & 1 \\
\hline & & NO & 2 \\
\hline
\end{tabular}

Tabla 3. Asignación de valores numéricos a cada valor del indicador.

Fuente: Jensen y Birche, 2017 


\section{CANTIDAD DE EVUP POR HABITANTE}

Para determinar la cantidad mínima de EVUP por habitante se recurre a tomar como parámetro lo que propone la OMS, la ONU46 y la ley 8912. Estas organizaciones establecen la superficie mínima de áreas verdes por habitante en metros cuadrados y en el caso particular de la OMS no solo propone la superficie mínima, sino que establece cual sería la superficie óptima. Por otro lado, la ley 8912 que es la ley de ordenamiento territorial y uso del suelo que se encuentra vigente en la provincia de Bs. As. no solo establece la superficie mínima de áreas verdes por habitante, sino que también los desglosa por tipo de espacio verde. Es decir que se tiene en cuenta no solo la cantidad de espacio verde como así también la cantidad según el tipo, haciendo énfasis en las distintas escalas.

Se relevo lo siguiente (tabla 4):

\begin{tabular}{|c|c|c|c|c|c|}
\hline Fuente & $\begin{array}{c}\text { Superficie mínima } \\
\text { de Areas verdes } \\
M 2 / \text { hab. }\end{array}$ & $\begin{array}{c}\text { Superficie óptimna } \\
\text { de Areas verdes } \\
\text { M2/hab. }\end{array}$ & \multicolumn{2}{|c|}{$\begin{array}{l}\text { Según tipo } \\
\text { M2/ hab. }\end{array}$} & $\begin{array}{c}\text { Radio de } \\
\text { cobertura } \\
\mathrm{Km}\end{array}$ \\
\hline OMS & 9 & 15 & \multicolumn{2}{|l|}{-} & - \\
\hline ONU & 16 & - & \multicolumn{2}{|l|}{-} & - \\
\hline \multirow{3}{*}{$\begin{array}{l}\text { Ley } 8912, \text { Provincia de } \\
\text { Buenos Aires, } 1977\end{array}$} & \multirow{3}{*}{10} & \multirow{3}{*}{-} & $\begin{array}{l}\text { Plazoletas, plazas } 0 \\
\text { espacios vecinales }\end{array}$ & 3,5 & - \\
\hline & & & $\begin{array}{l}\text { Parques urbanos y } \\
\text { comerciales }\end{array}$ & 2,5 & - \\
\hline & & & Parques regionales & 4 & 60 \\
\hline
\end{tabular}

Tabla 4. Superficie mínima de áreas verdes por habitante.

Fuente: Jensen y Birche, 2017.

Estos parámetros dejan por fuera la cobertura espacial de cada espacio verde, es decir no se tiene en cuenta el acceso que tienen los habitantes a estos.

4- Relevar y determinar las áreas críticas de la periferia en cuanto a la cantidad población y los espacios verdes de uso público por metro cuadrado. Determinar áreas críticas sin cobertura de espacios verdes.

Para determinar las áreas críticas se propone indagar en el concepto de radio de influencia de los espacios verdes como se viene trabajando en otros lugares del mundo (tabla 5), como así también ver en las normativas a nivel regional (tabla 6).

\footnotetext{
${ }^{46}$ La Organización Mundial de la Salud (OMS) y la Organización de las Naciones Unidas (ONU) son organismos a nivel internacional que establecen parámetros mínimos de espacio verde por habitante.
} 


\begin{tabular}{|c|c|c|c|c|}
\hline Fuente & Tipo & $\begin{array}{l}\text { Radio de } \\
\text { cobertura } \\
\text { M. }\end{array}$ & $\begin{array}{l}\text { Superficie } \\
\text { mínima } \\
\text { Ha. }\end{array}$ & $\begin{array}{l}\text { Superficie minima de } \\
\text { Areas verdes } \\
\text { M2/hab. }\end{array}$ \\
\hline \multirow{3}{*}{$\begin{array}{c}\text { Plan Especial Verde } \\
\text { de Valencia, } 1992\end{array}$} & Parque regional & 5000 & $>200$ & _ \\
\hline & Parque urbano & 1000 & 10 & 5 \\
\hline & Plaza & $100-1000$ & $>0,1$ & 1.5 \\
\hline \multirow{3}{*}{$\begin{array}{c}\text { Van Herzele \& } \\
\text { weidemann, } 2003\end{array}$} & Parque urbano & 3200 & 60 & - \\
\hline & Plaza & 400 & 1 & - \\
\hline & Plazoleta & 150 & - & - \\
\hline Oh \& Jeong, 2007 & Parque urbano & 1000 & - & - \\
\hline \multirow{4}{*}{ Palomo, 2003} & Parque regional & 5000 & $5-10$ & - \\
\hline & Parque urbano & 1000 & 10 & - \\
\hline & Plaza & 250 & 1 a 5 & - \\
\hline & Plazoleta & 100 & 0.01 & - \\
\hline \multirow{4}{*}{$\begin{array}{l}\text { Garay y Fernandez, } \\
2013\end{array}$} & Parque regional & & $>2$ & - \\
\hline & Parque urbano & 2000 & $4-10$ & - \\
\hline & Plaza & 800 & $1-3$ & - \\
\hline & Plazoleta & $100-500$ & $0,1-0,5$ & - \\
\hline \multirow{4}{*}{$\begin{array}{l}\text { Plan de indicadores } \\
\text { de sostenibilidad de } \\
\text { Vitoria-Gasteiz. } \\
\text { Actividad urbanística } \\
\text { de Sevilla, } 2010\end{array}$} & Parque regional & $<4000$ & $>10$ & - \\
\hline & Parque urbano & $<2000$ & $>1$ & - \\
\hline & Plaza & $<750$ & $>0,5$ & - \\
\hline & Plazoleta & $<200$ & $>0,1$ & - \\
\hline \multirow{4}{*}{ Turín, 1980} & Parque regional & $2500-3000$ & - & - \\
\hline & Parque urbano & $500-800$ & - & - \\
\hline & Plaza & $500-600$ & - & - \\
\hline & Plazoleta & 200 & - & - \\
\hline \multirow{3}{*}{$\begin{array}{l}\text { CAT-MED. Modelos } \\
\text { urbanos sostenibles, } \\
2011\end{array}$} & Parque urbano & 900 & 1 & - \\
\hline & Plaza & 500 & $0,5-1$ & - \\
\hline & Plazoleta & 300 & $0,1-0,5$ & - \\
\hline \multirow{3}{*}{ Málaga } & Parque urbano & 500 & $>0,3$ & - \\
\hline & Plaza & 300 & $0,15-0,3$ & - \\
\hline & Plazoleta & 100 & $<0,15$ & - \\
\hline \multirow{4}{*}{ IAURIF, 1991} & Parque regional & 1000 & $>30$ & - \\
\hline & Parque urbano & 500 & 10 a 30 & - \\
\hline & Plaza & 250 & 1 a 10 & - \\
\hline & Plazoleta & 50 & & - \\
\hline \multirow{4}{*}{$\begin{array}{l}\text { Francisco Bascuñán } \\
\text { Walker, Paz Walker } \\
\text { Fernández, Juan } \\
\text { Mastrantonio Freitas. } \\
\text { Universidad de la } \\
\text { Serena, } 2007\end{array}$} & Parque regional & - & 45 & 5 \\
\hline & Parque urbano & $800-1000$ & 15 & 5 \\
\hline & Plaza & 500 & 2 & 2 \\
\hline & Plazoleta & 200 & 0.15 & 1 \\
\hline
\end{tabular}

Tabla 5. Antecedentes de casos donde se ha aplicado el radio de cobertura.

Fuente: Jensen y Birche, 2017. 
Este concepto permite incorporar la dimensión espacial, es decir no solo tener en cuenta si está cubierta la superficie mínima de áreas verdes por habitante, sino además tener en cuenta la cercanía de éstos a los habitantes para fomentar su uso y aprovechamiento de las funciones que brindan. Estos radios se adoptan en función de determinar la distancia máxima que puede ser recorrida a pie por un habitante para acceder a un espacio verde.

Para determinar la distancia máxima se realiza un relevamiento de los casos más representativos en donde se ha aplicado este concepto de área o radio de influencia, pero entendido como radio de cobertura ya que se propone entender la ciudad desde los habitantes reforzando la idea de cuáles zonas están desprovistas o descubiertas de EVUP.

\begin{tabular}{|c|c|c|c|c|c|}
\hline \multirow{2}{*}{ Fuente } & \multirow{2}{*}{ Tipo } & \multicolumn{2}{|r|}{ Definición } & \multirow{2}{*}{$\begin{array}{l}\text { Radio de } \\
\text { cobertura } \\
\text { M. }\end{array}$} & \multirow{2}{*}{$\begin{array}{l}\text { Superficie mínima de } \\
\text { Areas verdes } \\
\text { M2/hab. }\end{array}$} \\
\hline & & Superficie & Condicion urbana & & \\
\hline \multirow{3}{*}{$\begin{array}{c}\text { Ley } 8912 \text {, Provincia de } \\
\text { Buenos Aires, } 1977\end{array}$} & $\begin{array}{l}\text { Plazoletas, plazas o } \\
\text { espacios vecinales }\end{array}$ & - & - & - & 3.5 \\
\hline & $\begin{array}{l}\text { Parques urbanos y } \\
\text { comerciales }\end{array}$ & - & - & - & 2.5 \\
\hline & Parques regionales & _ & _- & 60,000 & 4 \\
\hline \multirow{4}{*}{$\begin{array}{c}\text { Código Espacio } \\
\text { Público, Ord. } 9880 \\
\text { Municipalidad de La } \\
\text { Plata, } 2004\end{array}$} & Parque & $>4$ Has. & _proporción cuadrada/similar & _ & _ \\
\hline & Plaza & $<4$ Has. & _proporción cuadrada/ similar & _ & - \\
\hline & Rambla & - & $\begin{array}{l}\text { _proporción longitudinal } \\
\text { _separa carriles vehiculares }\end{array}$ & - & - \\
\hline & Jardin & - & $\begin{array}{l}\text { _perimetral a los edificios } \\
\text { fundacionales } \\
\text { uso real/ disfrute visual }\end{array}$ & - & - \\
\hline \multirow{4}{*}{ Propuesta } & Parque regional & $>4$ Has. & _proporción cuadrada/ similar & 2000 & _- \\
\hline & Plaza & $<4$ Has. & _proporción cuadrada/ similar & 800 & - \\
\hline & Plazoleta & $<1$ Has. & _proporción cuadrada/ similar & 400 & - \\
\hline & Parque lineal/Rambla & - & $\begin{array}{l}\text { _proporción longitudinal } \\
\text { _separa carriles vehiculares }\end{array}$ & 400 & - \\
\hline \multirow{4}{*}{$\begin{array}{l}\text { Garay y Fernandez, } \\
2013\end{array}$} & Parque regional & $>2$ & - & & _ \\
\hline & Parque urbano & $4-10$ & _ & 2000 & - \\
\hline & Plaza & $1-3$ & _ & 800 & - \\
\hline & Plazoleta & $0,1-0,5$ & - & $100-500$ & _ \\
\hline
\end{tabular}

Tabla 6. Normativas a nivel regional.

Fuente: Jensen y Birche, 2017.

Se propone adoptar para el Partido de La Plata las siguientes distancias (Figura 17) máximas en base a las propuestas por Garay y Fernández (2013) para la Región Metropolitana de Buenos Aires, ya que es el ejemplo más cercano a la región, que toma y trabaja las distancias máximas que un habitante debe estar de un espacio verde. Por otro lado, esto se corrobora con la encuesta realizada (ver anexo 1) donde los habitantes manifiestan que caminarían en promedio unas diez cuadras ${ }^{47}$ para llegar a un espacio

\footnotetext{
47 Se entiende por cuadra a las cuadras de 100 metros de largo en promedio.
} 
verde, por lo que la determinación de hasta $800 \mathrm{~m}$ sería una distancia aceptada por los habitantes.

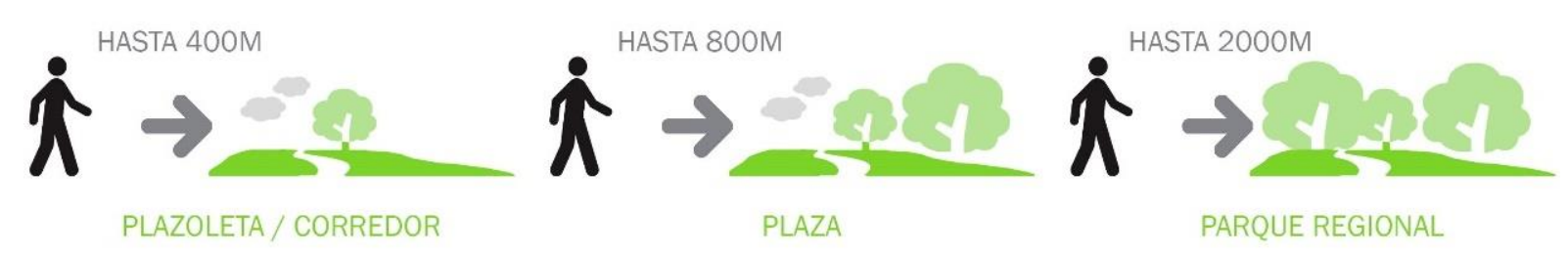

Figura 4. Radios de cobertura propuestos.

Fuente: Jensen y Birche, 2017.

De esta forma, una persona tiene que hacer como máximo hasta $400 \mathrm{~m}$ caminando para llegar a una plazoleta o corredor, $800 \mathrm{~m}$ para llegar a una plaza y hasta $2000 \mathrm{~m}$ para acceder a un parque local. Las zonas que queden por fuera de estos radios de cobertura de escala barrial van a conformar las zonas críticas donde no hay cobertura de espacios verdes.

\section{2 | El nivel de análisis focal, matriz de anclaje}

En el nivel de análisis focal se establece como unidad de análisis las tierras vacantes, y se comienza con el análisis para su posterior caracterización mediante la construcción de un inventario de estas. Para la conformación de este inventario, se toma la dimensión geográfica urbanística, biofísica, estructural y estética. Es por ello que para la identificación de tierras vacantes en la periferia platense en zona urbana se ha elaborado una metodología basada en la fotointerpretación de imágenes satelitales de Google Earth (año 2016) y una posterior visita a campo, utilizando 1 hectárea $\left(10.000 \mathrm{~m}^{2}\right)$ como unidad de análisis mínimo.

En la encuesta mencionada anteriormente (ver anexo 1) uno de los temas en los que se indagó fue en tierras vacantes donde el conjunto de preguntas se determinó para garantizar la orientación del entrevistado apuntando a identificar qué reconocimiento tiene el habitante de estos espacios vacantes.

Al respecto, el conjunto de preguntas se determinó para garantizar la orientación del entrevistado apuntando a conocer la mirada de los habitantes de estos espacios:

- El grado de reconocimiento de tierras vacantes en la ciudad

- Si le agradaría convertir estos espacios en espacios verdes.

1- Relevar, analizar y clasificar las tierras vacantes según las causas que la generan, su ubicación y dimensiones. 
Para llevar a cabo el relevamiento y la posterior identificación de las tierras vacantes se adoptan como parámetros el tamaño, la ubicación, dominio, tipo y área (tabla 7) a través de los cuales las tierras que no cumplan con los mismos quedarán por fuera de la primera selección.

Para clasificar las tierras vacantes se ha utilizado la tipología desarrollada por Carabajal, Servetti y Souto (2011), quienes distinguen: vacíos indefinidos (Obras inacabadas), vacíos residuales (Edificios abandonados), vacíos latentes (Solares vacantes), y vacíos obsoletos (Infraestructuras públicas en desuso).

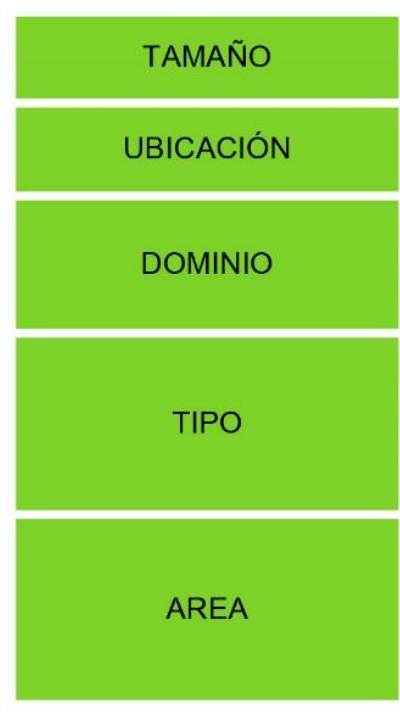

\begin{tabular}{|c|}
\hline superficie mayor a 1 hectarea \\
\hline superficie menor a 1 hectarea \\
\hline Localizacion dentro de la region \\
\hline Titularidad publica \\
\hline Titularidad privada \\
\hline Titularidad desconocida \\
\hline Obras inacabadas \\
\hline Edificios abandonados \\
\hline Solares vacantes \\
\hline Infraestructuras públicas en desuso \\
\hline Áreas según el decreto-Ley $8912 / 77$ \\
\hline
\end{tabular}

Tabla 7. Selección de tierras vacantes.

Fuente: Elaboración propia, 2017. mas de una hectarea menos de una hectarea Centro Periferia Publico privado Desconocido Vacio indefinido Vacios residuales Vacio latente Vacio obsoleto Complementaria

\begin{tabular}{|c|}
\hline Publico \\
\hline privado \\
\hline Desconocido \\
\hline Vacio indefinido \\
\hline Vacios residuales \\
\hline Vacio latente \\
\hline Vacio obsoleto \\
\hline Complementaria \\
\hline urbana \\
\hline rural \\
\hline uso especifico \\
\hline
\end{tabular}


Por otro lado, dentro del área urbana se van a seleccionar las que se encuentren en áreas críticas definidas anteriormente (áreas sin cobertura de espacios verdes) donde se va a hacer otra pequeña selección donde haya más de una en el área priorizando en este caso las que estén cerca de las principales vías de circulación, las que estén fuera del área de cobertura de parques y las de mayor tamaño.

A continuación, se detallan los parámetros (figura 18):

\section{TIERRAS VACANTES}

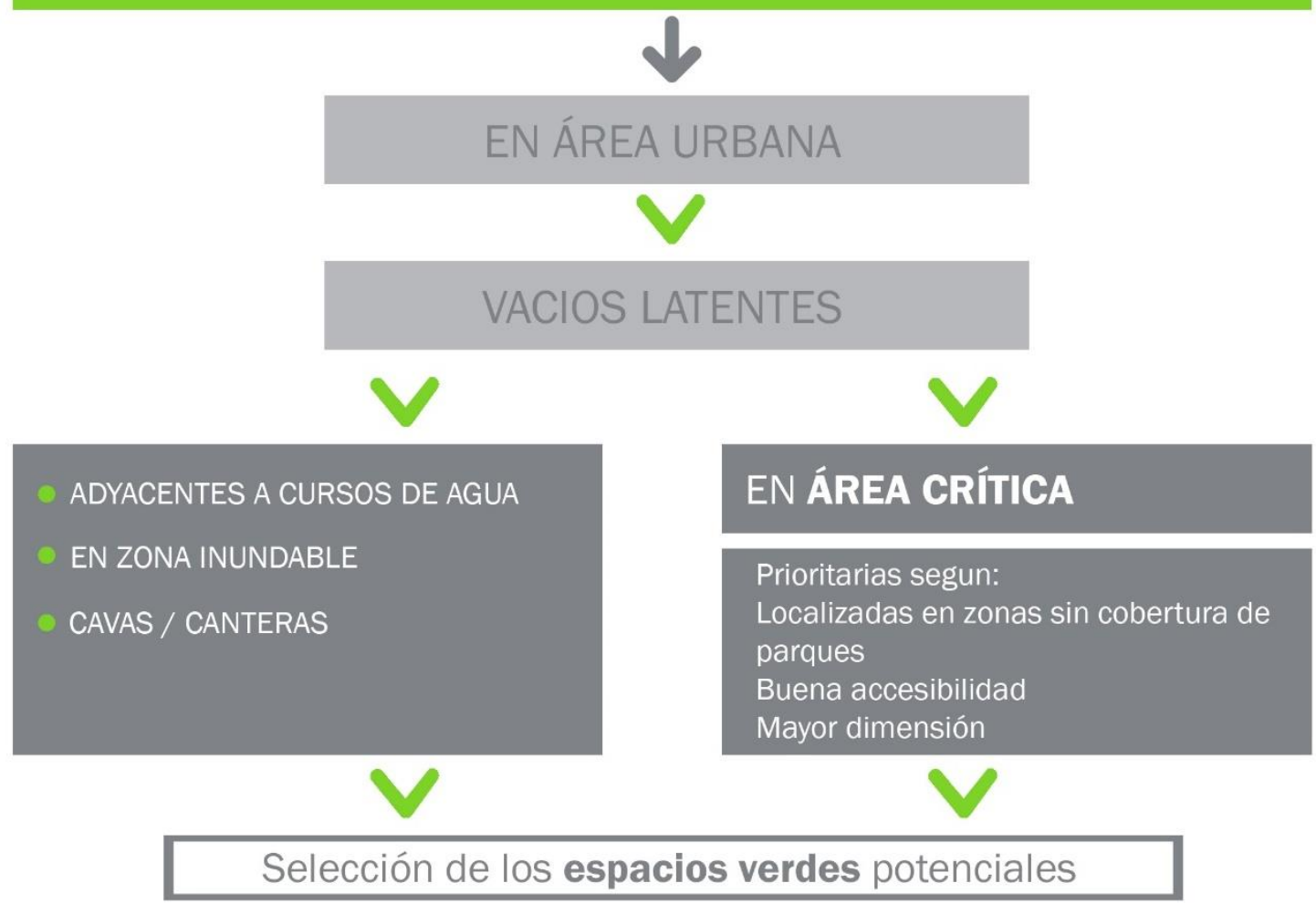

Figura 5. Parámetros para la selección de tierras vacantes.

Fuente: Elaboración propia, 2018.

2- Catalogar las tierras vacantes según los atributos geográficos urbanísticos, biofísicos, estructurales y estéticos. Caracterización de las tierras vacantes desde el paisaje.

En su mayoría, en los estudios de paisaje se tienen en cuenta las dimensiones estética, ecológica y cultural (Tesser, 2000). Se pone así de manifiesto que un paisaje se integra a partir de varios componentes: "el paisaje natural como el medio, el ser humano como organismo y el paisaje cultural como resultado" (Gómez, 2010, p. 96) que, combinados, contribuyen al análisis integral del paisaje a partir de su descripción, interpretación y valoración, lo cual nos permite llegar a una aproximación del modelo de indicadores que 
contribuyan a alimentar la idea de calidad visual del paisaje en las tierras vacantes. Peña (1998, citado en: Navarro, 2003) clasifica el paisaje a partir de tres relaciones: "paisaje como naturaleza disponible para el hombre; paisaje como producto social y paisaje como construcción simbólica".

A partir de la identificación de los diferentes tipos de estudios del paisaje se proponen una serie de variables e indicadores que buscan evaluar el estado de la calidad visual del paisaje urbano por medio de los valores culturales de las tierras vacantes, relacionados con el estudio morfológico y perceptual del paisaje, lo que finalmente llevaría al mejoramiento de la calidad en los espacios (Escribano et al., 1991, citado por Tesser, 2000). Entonces para determinar la calidad de paisaje se consideran estas tres dimensiones que se consideran en los estudios anteriormente mencionados las cuales se determinan en base a la percepción visual de éste.

En este caso se propone incorporar la dimensión geográfica urbanística, que desde el campo de la arquitectura es la que le da el marco al espacio analizado, nos dice como es su entorno y qué características tiene. Esto nos permite determinar en los siguientes momentos metodológicos cuál va a ser el tipo de espacio verde que debería haber en ese lugar.

En este contexto una vez definida la unidad de análisis y las dimensiones con el fin de establecer diferentes enfoques que se quieren abordar en el análisis. Estas variables están en relación con el marco teórico utilizado para el desarrollo de la metodología propuesta, para las cuales se elabora un indicador y se le asigna un valor.

- DIMENSION GEOGRÁFICO-URBANÍSTICA: Está en relación a las características del entorno, el tipo predominante del entorno y la posibilidad de los habitantes de acceder a la tierra vacante en relación a las principales vías de comunicación y los medios de transporte público. 


\begin{tabular}{|c|c|c|c|}
\hline DIMENSION & VARIABLE & INDICADOR & VALOR \\
\hline \multirow{11}{*}{$\begin{array}{l}\text { GEOGRAFICO } \\
\text { URBANISTICA }\end{array}$} & \multirow{3}{*}{ ENTORNO } & \multirow{3}{*}{$\begin{array}{l}\text { Caracteristica del entorno en cuanto a perfil urbano y } \\
\text { los usos predominantes }\end{array}$} & Singular \\
\hline & & & Homogeneo \\
\hline & & & Heterogeneo \\
\hline & \multirow{5}{*}{ TIPO RESIDENCIAL } & \multirow{5}{*}{ Tipo residencial predominante del entorno } & $\begin{array}{l}\text { Areas centrales y barrios } \\
\text { consolidados } \\
\text { loteo formal con diferentes } \\
\text { grados de ocupacion }\end{array}$ \\
\hline & & & grandes parcelas residenciales \\
\hline & & & $\begin{array}{c}\text { urbanizaciones residenciales } \\
\text { cerradas }\end{array}$ \\
\hline & & & viviendas sociales \\
\hline & & & villa y asentamiento \\
\hline & \multirow{3}{*}{ ACCESIBILIDAD } & \multirow{3}{*}{$\begin{array}{l}\text { La posibilidad de los habitantes de acceder en } \\
\text { relacion a las principales vias de comunicación y los } \\
\text { medios de transporte publico }\end{array}$} & Buena \\
\hline & & & Mala \\
\hline & & & Regular \\
\hline
\end{tabular}

- DIMENSION BIOFISICA: Se encuentra en relación a las características físicas como lo son la rugosidad del suelo, el tipo de cuerpo de agua, la vegetación que posee el borde o ribera de agua, la abundancia de agua, el movimiento de esta, la calidad y característica visual. Por otro lado, se analiza la vegetación en cuanto a la cobertura, temporalidad, la diversidad de flora y el follaje predominante.

\begin{tabular}{|c|c|c|c|}
\hline \multirow{38}{*}{ BIOFISICA } & \multirow{3}{*}{ SUELO } & \multirow{3}{*}{ Rugosidad del suelo en relacion a la pendiente } & Suelo Rugoso \\
\hline & & & Suelo medio \\
\hline & & & Suelo liso \\
\hline & \multirow{15}{*}{ AGUA } & \multirow{3}{*}{ Tipo de cuerpo de agua } & rio \\
\hline & & & humedal \\
\hline & & & arroyo \\
\hline & & \multirow{3}{*}{$\begin{array}{c}\text { La ribera o borde posee vegetacion en todo la } \\
\text { extension } \\
\begin{array}{c}\text { La ribera o borde posee vegetacion en algunes } \\
\text { sectores de la extension } \\
\text { La ribera o borde no posee vegetacion }\end{array}\end{array}$} & Mucha Vegetacion \\
\hline & & & Con Vegetacion \\
\hline & & & Sin Vegetacion \\
\hline & & \multirow{3}{*}{ Movimiento que posee el cuerpo de agua } & Rapido \\
\hline & & & Ligero \\
\hline & & & ninguno \\
\hline & & \multirow{3}{*}{$\begin{array}{l}\text { Abundancia de agua presente en relacion a la } \\
\text { superficie }\end{array}$} & Alta \\
\hline & & & Media \\
\hline & & & Baja \\
\hline & & \multirow{3}{*}{ La calidad y caracteristica visual del cuerpo de agua } & limpia \\
\hline & & & Turbia \\
\hline & & & Sucia \\
\hline & \multirow{14}{*}{ VEGETACION } & La cobertura es mayor a $75 \%$ & Alta \\
\hline & & La cobertura es mayor a $25 \%$ y menor a $75 \%$ & media \\
\hline & & La cobertura es menor que el $25 \%$ & baja o nula \\
\hline & & \multirow{2}{*}{ La temporalidad de la vegetacion } & Permanente \\
\hline & & & Estacional \\
\hline & & \multirow{3}{*}{ diversidad de flora } & Alta \\
\hline & & & Media \\
\hline & & & Baja \\
\hline & & estratificación mayor a la magnitud $x$ & Arboreo \\
\hline & & estratificación entre la magnitud $\mathrm{x} y \mathrm{x}$ & Arbusto \\
\hline & & estratificación menor a la magnitud $x$ & Herbaceo \\
\hline & & & Mixto \\
\hline & & El follaje predomianate de la vegetacion & Perenne \\
\hline & & & Caduco \\
\hline & & & Alta \\
\hline & & presencia de especies & Media \\
\hline & FAUNA & & baja o nula \\
\hline & & & Alta \\
\hline & & diversidad de especies & Media \\
\hline & & & baja o nula \\
\hline
\end{tabular}


- DIMENSION ESTRUCTURAL: Está relacionada con las características que estructuran ese paisaje como por el ejemplo el grado de antropización o la diversidad paisajística en relación a la heterogeneidad y al grado de singularidad.

\begin{tabular}{|c|c|c|c|}
\hline \multirow{3}{*}{ ESTRUCTURAL } & NATURALIDAD & El grado de antropizacion del ambiente & $\begin{array}{c}\text { Alta } \\
\text { Media } \\
\text { baja o nula }\end{array}$ \\
\hline & \multirow{2}{*}{$\begin{array}{l}\text { DIVERSIDAD } \\
\text { PAISAJISTICA }\end{array}$} & $\begin{array}{l}\text { Grado de heterogeneidad en relacion a los } \\
\text { elementos que componen el paisaje }\end{array}$ & $\begin{array}{c}\text { Alta } \\
\text { Media } \\
\text { baja o nula }\end{array}$ \\
\hline & & $\begin{array}{l}\text { Grado de singularidad del paisaje en base a sus } \\
\text { componentes }\end{array}$ & $\begin{array}{c}\text { Alta } \\
\text { Media } \\
\text { baja o nula }\end{array}$ \\
\hline
\end{tabular}

- DIMENSION ESTÉTICA: Esta dimensión está en relación a la percepción del paisaje, en relación a las características estéticas como la forma, color y la textura.

\begin{tabular}{|c|c|c|c|}
\hline \multirow{15}{*}{ ESTETICA } & \multirow{3}{*}{ FORMA } & \multirow{3}{*}{$\begin{array}{l}\text { Diversidad de formas en los elementos que } \\
\text { componen el espacio }\end{array}$} & Alta \\
\hline & & & Media \\
\hline & & & baja \\
\hline & \multirow{6}{*}{ COLOR } & \multirow{3}{*}{ Contraste de colores } & Alta \\
\hline & & & Media \\
\hline & & & baja \\
\hline & & \multirow{3}{*}{ Diversidad de colores en los elementos compositivos } & Alta \\
\hline & & & Media \\
\hline & & & baja \\
\hline & \multirow{6}{*}{ TEXTURA } & \multirow{3}{*}{$\begin{array}{l}\text { La relación entre } \\
\text { la luz y sombra de la superficie }\end{array}$} & Grueso \\
\hline & & & Medio \\
\hline & & & Fino \\
\hline & & \multirow{3}{*}{ Diversidad de granulometria } & Alta \\
\hline & & & Media \\
\hline & & & baja \\
\hline
\end{tabular}

El valor numérico asignado a cada indicador nos permite elaborar una matriz, a partir de la cual determinar la calidad de paisaje.

\section{3 | El nivel inferior de análisis, matriz de componentes}

En este nivel se cierra el proceso estableciendo lineamientos y criterios de diseño para la conformación de un sistema de espacios verdes. Teniendo en cuenta la calidad del paisaje de las tierras vacantes se determinan las medidas de intervención y los tipos de espacios verdes. De este modo, se establecen criterios para su diseño en relación a dos grandes fases, una primera fase en donde se van a determinar los elementos estructurales como lo es la vegetación y luego, una segunda fase en donde se va a realizar un proceso participativo con los habitantes para el diseño del espacio verde en relación a las necesidades. Se van a dejar planteados criterios para los sectores. Este proceso participativo se va a realizar en base a los criterios propuestos pero este proceso no es parte del objeto de estudio de esta tesis. 
En la encuesta mencionada anteriormente (ver anexo 1) uno de los temas abordados fue el equipamiento que poseía el espacio verde y que creía el habitante que necesitaban estos se indago acerca de:

- Cuál es la necesidad que plantean los habitantes de equipamiento de los espacios verdes

- $\quad$ La preferencia de un espacio verde en base a que elemento está relacionada.

1- El objetivo que se va a tomar en este nivel de análisis tiene como fin "elaborar categorías o medidas de intervención y recuperación para la incorporación de tierras vacantes que permitan formular estrategias de intervención paisajística para los nuevos espacios verdes". Para lo cual mediante el análisis y relevamiento realizado anteriormente se proponen los siguientes criterios:

CRITERIOS DE INTERVENCIÓN SEGÚN CALIDAD DE ATRIBUTOS:

- GEOGRÁFICOS URBANÍSTICOS

ALTA - Intensidad o grado de modificación posible del entorno baja o nula.

MEDIA - Intensidad o grado de modificación posible del entorno media. Culminar las obras inacabadas o poner en valor las infraestructuras públicas en desuso.

BAJA - Intensidad o grado de modificación posible del entorno alta. Recuperar edificios abandonados.

\section{- BIOFÍsICOS}

ALTA - Preservación activa

MEDIA - completamiento forestal - purificación del agua

BAJA - vegetación - saneamiento curso de agua

Estructurales

ALTA - Preservación activa

MEDIA - puesta en valor

BAJA - recuperación - Remediación / mitigación de un hábitat degradado

- ESTÉTICOS

ALTA - Preservación activa

MEDIA - puesta en valor

BAJA - recuperación 
2- Siguiendo estos criterios propuestos se busca dar respuesta al objetivo que propone “Formular lineamientos que integren las prácticas urbanísticas referidas a las tierras vacantes y el rol del paisaje tendientes a conformar un sistema de espacios verdes. La calidad de paisaje de cada una de las tierras vacantes se va a complementar con los tipos de paisaje identificados (fluvial, urbano y periurbano)".

Se establecieron lineamientos y criterios de diseño según el tipo de espacio verde determinado en base a las dimensiones anteriormente descriptas y los tipos de paisaje reconocidos en la región. A continuación, se presentan los criterios propuestos en función del tipo de espacio verde:

\section{- CALIDAD ALTA EN TIPO DE PAISAJE URBANO:}

Tipo 1: Parque urbano. Reserva de biosfera.

Posibilidad de modificación y de intervención del espacio: baja.

Suelo absorbente: $>90 \%$

Vegetación: >90\% - Preservación y reposición de las especies vegetales.

- CALIDAD MEDIA EN TIPO DE PAISAJE URBANO.

Tipo 2: Parque urbano. Espacio recreativo.

Posibilidad de modificación y de intervención del espacio: media.

Suelo absorbente: entre 70 y $90 \%$

Vegetación: entre 70 y 90\% - Preservación y reposición de las especies vegetales.

- CALIDAD BAJA EN TIPO DE PAISAJE uRBANO.

Tipo 3: Parque urbano. Espacio recreativo.

Posibilidad de modificación y de intervención del espacio: alta.

Suelo absorbente: $>50 \%$

Vegetación: >50 \%. Completamiento de especies vegetales.

- CALIDAD ALTA EN TIPO DE PAISAJE FLUVIAL.

Tipo 4: Parque fluvial. Reservorio.

Posibilidad de modificación y de intervención del espacio: baja.

Suelo absorbente: $>90 \%$

Vegetación: >90\% - Preservación y reposición de las especies vegetales.

- CALIDAD MEDIA EN TIPO DE PAISAJE FLUVIAL

Tipo 5: Parque fluvial. Reservorio. 
posibilidad de modificación y de intervención del espacio: media.

Suelo absorbente: entre 70 y $90 \%$

Vegetación: entre 70 y 90\% - Completamiento de especies vegetales - purificación del agua.

- CALIDAD BAJA EN TIPO DE PAISAJE FLUVIAL

Tipo 6: Parque fluvial. Reservorio.

posibilidad de modificación y de intervención del espacio: alta. Reservorio.

Posibilidad de modificación y de intervención del espacio: alta.

Suelo absorbente: $>50 \%$

Vegetación: >50 \%. - Completamiento de especies vegetales - saneamiento del agua

- CALIDAD ALTA EN TIPO DE PAISAJE PERIURBANO.

Tipo 7: Parque de transición. Reserva de biosfera. Huerta urbana.

posibilidad de modificación y de intervención del espacio: Baja

Suelo absorbente: $>90 \%$

Vegetación: >90\% - Preservación y reposición de las especies vegetales.

- CALIDAD MEDIA EN TIPO DE PAISAJE PERIURBANO.

Tipo 8: Parque de transición. Espacio recreativo. Huerta urbana.

posibilidad de modificación y de intervención del espacio: media.

Suelo absorbente: entre 70 y $90 \%$

Vegetación: entre 70 y 90\% - Preservación y reposición de las especies vegetales.

- CALIDAD BAJA EN TIPO DE PAISAJE PERIURBANO.

Tipo 9: Parque de transición. Espacio recreativo. Huerta urbana.

posibilidad de modificación y de intervención del espacio: alta.

Suelo absorbente: $>50 \%$

Vegetación: >50 \%. Completamiento de especies vegetales.

Estos lineamientos y criterios de diseño desde la noción de paisaje permiten llevar a cabo acciones en el territorio desde una mirada integral, teniendo en cuenta los diversos aspectos que caracterizan a los espacios verdes. 


\section{CAPÍTULO 3 \\ Más allá del casco fundacional Transformaciones en la Periferia platense}

3.1 | La región de estudio

3.2 | Los espacios verdes en la conformación de la ciudad

3.3 | El avance de la frontera urbana

3.4 | La periferia platense 


\section{CAPITULO 3}

“El simple contacto del hombre con la Naturaleza, esta influencia de los grandes espacios, o del "aire libre" ...ejercen una acción de sosiego, aplacan el dolor y calman las pasiones, al tiempo que el alma se siente intimamente agitada. Esta benéfica influencia la recibe el hombre en todas partes, cualquiera sea la zona que habite y cualquiera sea el grado de cultura intelectual que haya alcanzado..."

(Alexandre Von Humboldt, 1874)

\subsection{La región de estudio}

Como primera aproximación a la región de estudio desde el paisaje podemos identificar que esta se ubica en lo que se llama "pampa" esta gran unidad de paisaje está dividida en distintos tipos de pampa las cuales poseen distintas características de acuerdo a su ubicación. Esta se encuentra en lo que se denomina Pampa Ondulada (figura 19), la cual se extiende desde el sur de la provincia de Santa Fe hasta el norte de la provincia de Buenos Aires.
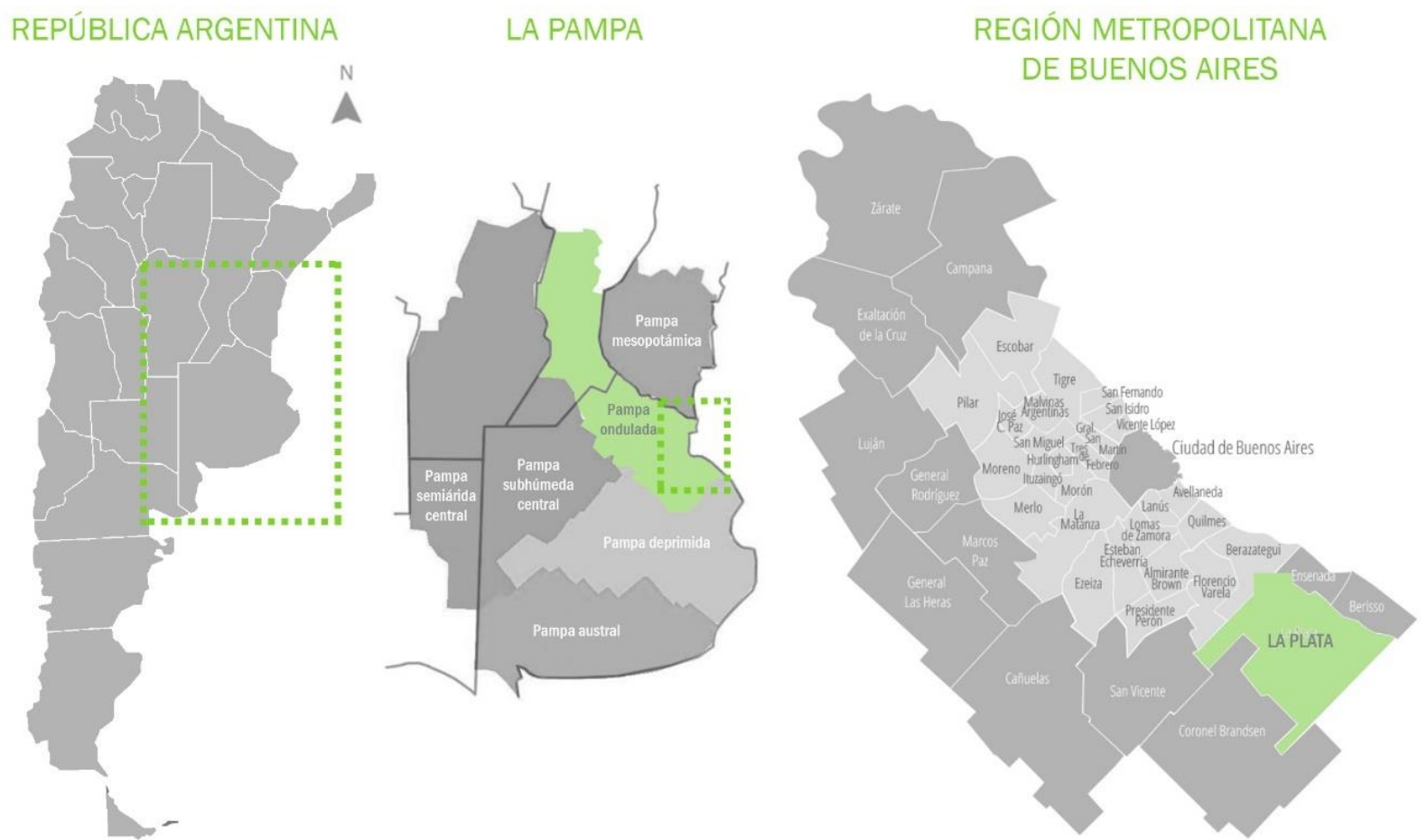

Figura19. La región de estudio en relación al territorio nacional.

Fuente: Elaboración propia, 2016 en base a http://www.cienciahoy.org.ar/In/hoy68/sustentabilidad.htm 
La característica principal de esta región es la suave ondulación del terreno debido a la erosión de los ríos y una leve elevación del basamento cristalino, por lo que se pueden distinguir en esta zona barrancas, bajos y terrazas fluviales.

La región del Gran La Plata es el sexto aglomerado más poblado del país y se encuentra localizada en la región metropolitana de Buenos Aires. Esta es un área geográfica conformada por la Ciudad de Buenos Aires, el Gran Buenos Aires y un conjunto de partidos aledaños, que incluyendo al Gran La Plata con un total de cuarenta municipios. Conforma hoy la conurbación más extensa y polinuclear de la República Argentina cuyo espacio periférico se ha urbanizado rápidamente en las últimas dos décadas, verificando la existencia de las dinámicas y transformaciones.

La ciudad de La Plata es el centro de la llamada Región Gran La Plata la cual está formada por los partidos limítrofes de Ensenada al noroeste y Berisso al noreste (incluyendo la jurisdicción de del Puerto de La Plata entre ambos) y el Partido de La Plata.

Las localidades de la Plata, Berisso y Ensenada en conjunto conforman un conglomerado, de aproximadamente 800.000 habitantes $^{49}$, en el que La Plata se posiciona como el Partido cabecera de esta micro - región.

La Plata es una ciudad planificada "ex novo" con un sistema de espacios verdes que materializaba las teorías sanitaristas de fines del siglo XIX. El trazado del casco fundacional de la ciudad, proyectado en 1882 fue diseñado desde su origen con criterios estéticos y paisajísticos del Urbanismo Barroco Europeo del siglo XVII, y en base a fundamentos ambientales y funcionales propios del Higienismo del siglo XIX. Su trazado racionalista en cuadrícula, con diagonales y plazas cada seis cuadras (en la intersección de avenidas) responde a criterios de orden, organización y equilibrio entre el espacio construido y el espacio público en pos de una distribución equitativa de actividades y circulación. Además del reconocimiento obtenido en su propia época como un ejemplo de modernidad urbana, que incluye una distinción en la Exposición Universal de París de 1889, el valor patrimonial del casco fundacional de La Plata fue reconocido tempranamente; en 1949 normas locales establecieron su carácter histórico y el compromiso de las autoridades en su protección y conservación.

49 Censo 2010. Fuente: http://www.censo2010.indec.gov.ar/ INDEC - Instituto Nacional de Estadística y Censos. 
Es concebida a fines del siglo XIX en el marco de un contexto externo de innovaciones tecnológicas, que contemplaban las escalas regional y local incluyendo al ferrocarril y al tranvía como ejes estructuradores. Su trazado vial jerarquizado posibilitó la incorporación posterior de los automotores sin graves inconvenientes hasta hace pocos años. Su emplazamiento decidido por la proximidad de un puerto, la existencia de infraestructura ferroviaria y de caminos hacia la capital del país y el interior de la provincia, definió desde sus orígenes el carácter integrador con el país y el exterior.

La analogía organicista y las políticas higienistas impregnaron el diseño de la ciudad de La Plata fue proyectada a fin de que la disposición de las diagonales favoreciera la circulación del aire y el acceso a las plazas ubicadas regularmente en la cuadrícula; la avenida de circunvalación sería un boulevard arbolado que actuaría como un anillo purificador del aire, entre otros elementos destacables. Pero, además, el paisaje de la ciudad planificada debía ser expresión del orden republicano: escala imponente y fácil acceso desde cualquier punto para los edificios públicos, edificaciones bajas y con una disposición regular para las zonas residenciales (Vallejo, 1998). Este ejemplo permite, nuevamente, visualizar los cruces entre las miradas estéticas y científicas sobre el paisaje, y el modo en que tales miradas influyen en la producción material de determinadas configuraciones territoriales

El diseño de la ciudad estaba compuesto por tres elementos básicos (figura 20):

EL CASCO URBANO50: fue trazada a partir del cuadrado como forma básica y dominante y reconoce dos conceptos generadores en su composición formal: la geometría y la simetría, que se unifican con la base productiva, tecnológica y organizativa de la ciudad industrial del siglo XIX.

ZONA DE CHACRAS Y QUINTAS: estaban destinadas al aprovisionamiento de la ciudad y se ubicaron en el área circundante al casco.

EL PUERTO: Estaba conformado por un canal central y dos canales lateras que iban desde el casco urbano hasta el Rio de La Plata, donde se habían pensado cuatro diques para que lleguen las barcazas, pero solo se construyó uno.

\footnotetext{
50 En la tesis se usan los conceptos de casco urbano (como lo denomina el cogido de espacio público, 2004) y casco fundacional (como se propone llamarlo en la tesis) para referirnos al trazado fundacional de la ciudad definido por la avenida de circunvalación.
} 


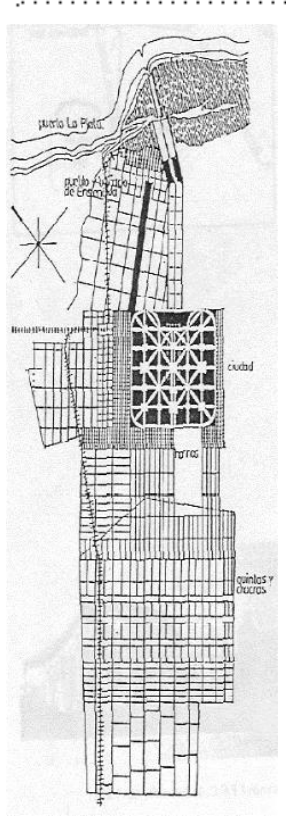

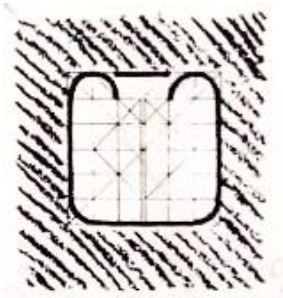

circunvalación

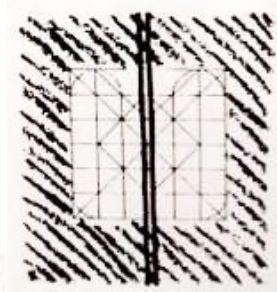

eje monumental

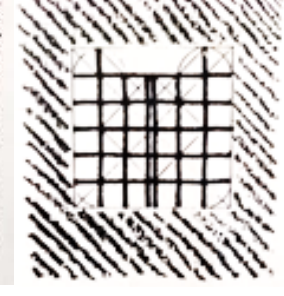

avenidas

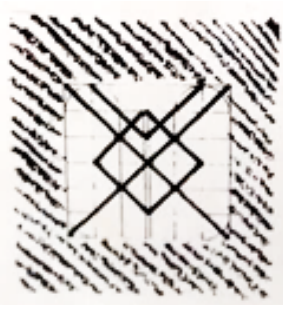

diagonales.

Figura 20. LA PLATA: circunvalación - eje monumental - red ortogonal de avenidas sistema de diagonales.

Fuente: GARNIER, A. (1992)

La Plata configuró su perfil desde tres ejes: las actividades productivas (puerto y frigoríficos), las actividades administrativas, como capital de la Provincia de Buenos Aires y nexo entre la pampa húmeda y la gran metrópolis y las actividades culturales educativas, a través de una red de escenarios artísticos de alcance internacional y de la Universidad como polo de educación, investigación y transferencia.

La región se constituyó históricamente con características propias, desde las más elementales ocupaciones productivas en la época colonial, hasta las más recientes, actuales y complejas actividades industriales, agropecuarias, de servicios y administrativas. Una red de comunicación y transporte apropiada a cada época complementa la producción y circulación de bienes y productos elaborados en la región. Esta red permitió identificar ejes comunes de crecimiento que contribuirían a su identificación actual

El territorio de la región se fue transformando a medida que se incorporaron infraestructuras y actividades productivas, que fueron caracterizando y consolidando los distintos paisajes de la zona.

Se pueden distinguir etapas históricas en el espacio geográfico que conforma la Región Gran La Plata, cada una de ellas caracterizada por:

- una actividad productiva principal

- una administración institucional

- un sistema de comunicación acorde a sus necesidades 
El proceso de configuración espacial de la ciudad de La Plata se puede estructurar en tres grandes etapas (figura 21), a partir del reconocimiento de los procesos políticoseconómicos en los que se inscribe, y de la acción de los actores, Estado mercado y sociedad civil, intervinientes en dichos procesos. De esta manera, se puede determinar un primer período o etapa fundacional, que va desde la fundación en 1882 a 1930; una segunda etapa desde 1930 a 1970, y una tercera y última etapa, que se extiende desde 1970 a nuestros días. (Ravella et al., 2006)

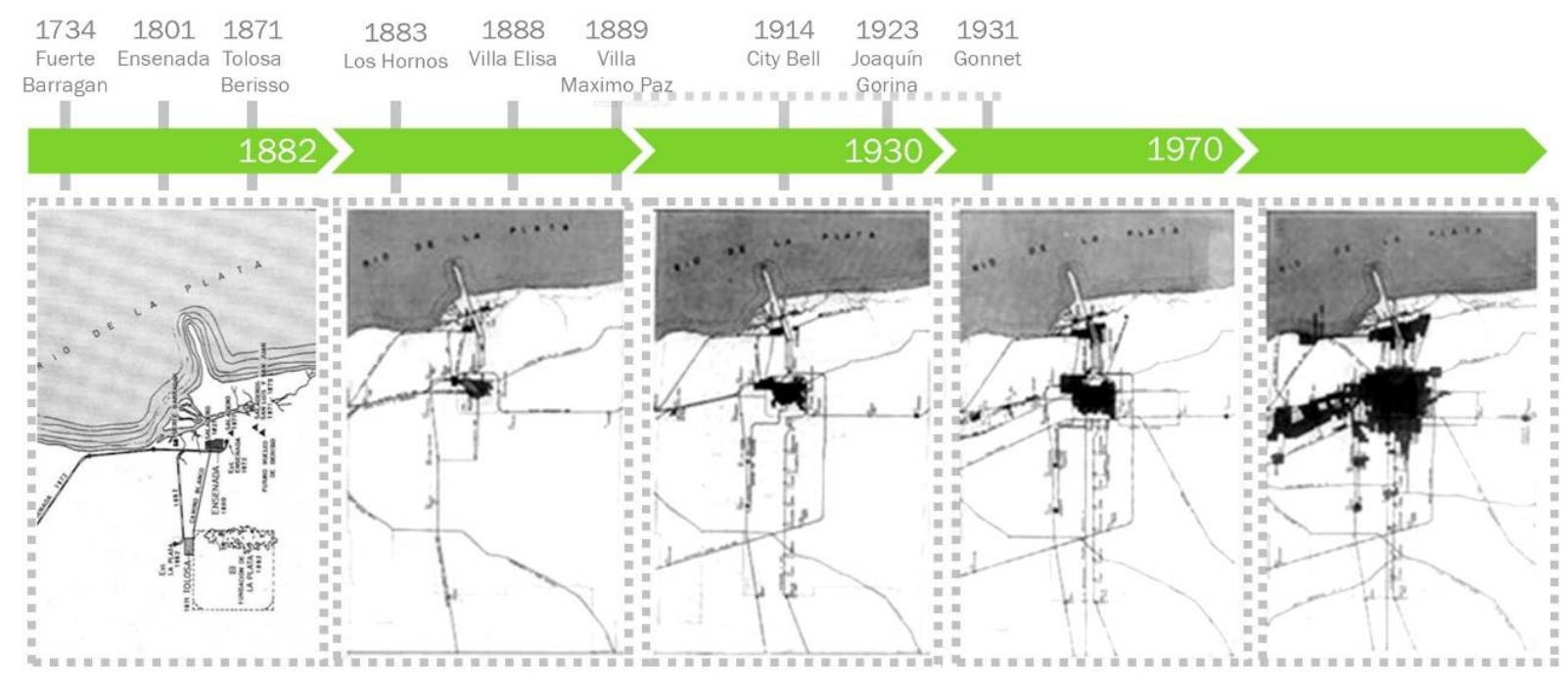

Figura 21. Secuencia cronológica del proceso de crecimiento de la Ciudad de La Plata.

Fuente: La Plata, Ciudad Nueva-Ciudad Antigua. UNLP

En la etapa fundacional de la ciudad luego de la fundación de La Plata en 1883 luego del traslado de los Hornos de ladrillo a la parte sureste del casco se denominó al nuevo poblado "Los Hornos". Unos años más tarde, con la construcción del empalme del ferrocarril en Pereyra en 1888 se aprobó el trazado para el barrio de Villa Elisa en tierras que pertenecían a la estancia de Pereyra y Jorge Bell. Solo un año más tarde en 1889 se anuncia la inauguración de Villa Máximo Paz y del otro lado de las vías del FFCC Castells lotea sus tierras, lo que en 1931 paso a llamarse Manuel B. Gonnet y Villa Castells. Lo quedaba entre lo que era Villa Elisa y lo que era Villa Máximo Paz se pide gobierno provincial una autorización para destinar esas tierras a un asentamiento poblacional en 1914, donde se destinaron tierras a emprendimientos hortícolas, mediante arrendamientos a familias de horticultores. Esta nueva iniciativa terminó consolidando un pequeño núcleo poblacional en la zona, hecho al que también contribuyó la inauguración de la estación City Bell del entonces Ferrocarril Sud. 
City Bell al igual que La Plata posee un trazado urbano planificado influenciado por el diseño de La Plata (figura 22), donde se pensó en una cuadrícula de manzanas de $100 \mathrm{x}$ 100 metros a partir de dos hitos: la línea definida por el ferrocarril y el cruce de las dos avenidas preexistentes (sobre el que planteó la plaza principal del pueblo: la San Martín). Todas las manzanas de la planta urbana se mantuvieron de $100 \mathrm{~m}$ de lado, pero hubo que dejar de respetar el criterio en las últimas manzanas laterales y ajustarlas a los límites externos, midiendo $180 \mathrm{~m}$. Se definió una zona de quintas con manzanas son más largas que miden $215 \mathrm{~m}$.

Aparecen como reseña de la ciudad de La Plata tres diagonales a $45^{\circ}$ donde para la distribución de las tres plazas circulares se utilizó un criterio similar al usado en La Plata: aunque forman un triángulo, hay 6 cuadras de separación entre los centros de las tres.

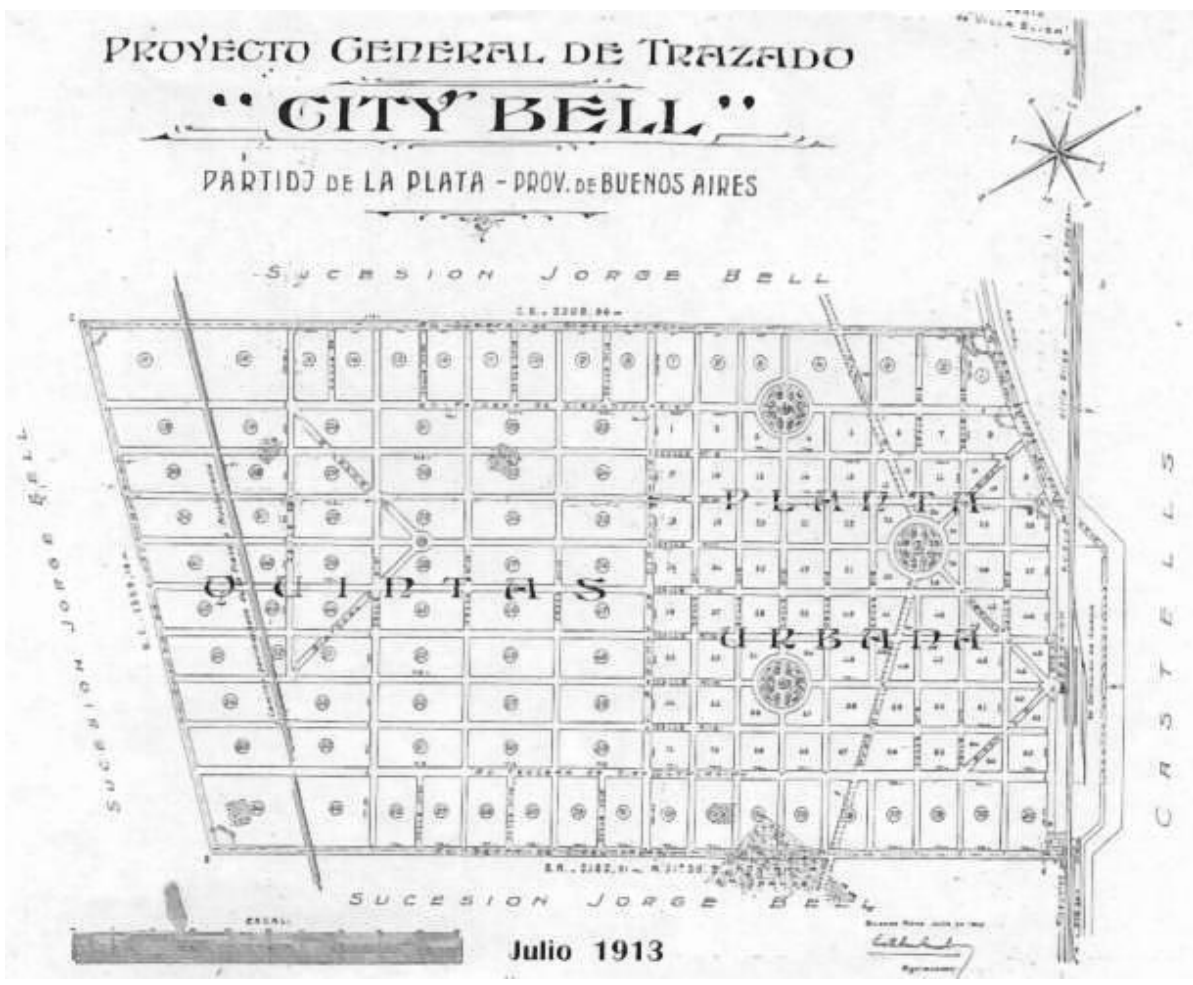

Figura 22. Trazado de City Bell.

Fuente: http://www.citybellviva.com.ar/orient7.htm

Terminando la etapa fundacional de la ciudad aparece Joaquín Gorina con la construcción de un ferrocarril provincial que uniera La Plata con Avellaneda en 1923.

Se puede decir que con la fundación de La Plata y el FFCC se fueron conformando los barrios de alrededor con subdivisiones de tierras que pertenecían a grandes estancias destacando City Bell con un trazado planificado como el de la ciudad de La Plata, donde 
no solo se tuvo en cuenta el trazado para lo urbano y la zona de quintas, sino que también se tuvieron en cuenta los espacios verdes de uso público.

\subsection{Los espacios verdes en la conformación de la ciudad}

Desde la visión que propone abordar la tesis, la ciudad es entendida como un sistema complejo en el la cual interactúan elementos de distintas escalas, susceptibles a establecer relaciones de diferente naturaleza entre sí y con su entorno. Tradicionalmente, en nuestras ciudades, el Espacio Público fue concebido como el espacio de la expresión y la apropiación social por excelencia, es el espacio que alberga el cotidiano transcurrir de la vida colectiva. Es el espacio que da identidad y carácter a una ciudad, el que permite reconocerla y vivirla. Es el sitio que conserva la memoria de sus habitantes en sus espacios naturales, culturales, patrimoniales.

Estos espacios presentan diversidad de formas, dimensiones, funciones y características ambientales. Sin embargo, el espacio verde de uso público es percibido como un vacío "con forma", es decir conformado por los elementos que lo bordean como los espacios de circulación y tránsito.

La esencia de lo urbano está en el espacio público, desde la antigüedad hasta nuestros días. Es un espacio para el encuentro y el intercambio, enriqueciendo las practicas urbanas y alentando a la participación ciudadana esto que Lefebvre (1974) llamaba "un particular modo histórico de vivir juntos...". Es muy difícil pensar en Una ciudad sin parques, plazas y espacios de uso público ya que sería muy pobre ambientalmente y en los aspectos socio urbanísticos. Según Heidegger (1951) "La manera según la cual los Hombres somos en la tierra es el Habitar. Ser Hombre significa estar en la tierra como mortal, significa Habitar".

En este sentido José Antonio Corraliza (2009), manifiesta en su artículo Emoción y espacios públicos: La experiencia humana de los escenarios urbanos. Los espacios públicos instituyen los elementos claves más importantes para el desarrollo afectivo de la ciudad. Donde, sin los espacios públicos la ciudad desaprovechara la capacidad de crear una norma de acción explicativa y simbólica que beneficie la implicación de los habitantes en el espacio urbano y con el resto de la sociedad que lo ocupan. Gran parte de los conflictos que hacen sensible a los espacios urbanos emanan de la insuficiencia y/o baja calidad de estos espacios públicos.

Los principios higienistas de la época proponían como primordial la necesidad de espacios destinados a la mejora de la salud de la población de la época, para ello había estudios de 
cuáles eran los adecuados índices de habitabilidad, absorción del agua de lluvia, generación de clorofila; condiciones de iluminación, ventilación y asoleamiento. Estos requerimientos se siguen verificando su importancia hoy en día, corrientes que vinieron después replantean el papel que desempeñan los espacios verdes en las ciudades y amplían el concepto al de espacios libres.

Respecto a esto último se les llama espacios libres a los espacios urbanos al aire libre de usos predominante peatonal, pensados para el descanso, paseo, el deporte, el recreo y el entretenimiento en sus horas de ocio. Estos espacios tienen como función principal la de reguladores del medio ambiente, como equilibrantes del sistema ambiental, actuando como pulmones de la ciudad. Se incorpora el tratamiento paisajístico del espacio público a lo largo de las vías de circulación como avenidas, boulevares, ejes ferroviarios como así también en el borde los cursos de agua o en los espacios intersticiales entre los grandes equipamientos y las vías de circulación (Tardín, 2010).

Las Políticas sanitaristas y jardines públicos, como así también la parquizacion de los grandes espacios públicos buscaban ofrecer lugares de recreo y esparcimiento para la población en general, así como un contacto con la naturaleza (producida y artealizada) constituyendo a tales espacios como "pulmones" de la ciudad. Este fenómeno se dio en la mayoría de las grandes ciudades: el Central Park en Nueva York, el Bois de Boulogne en París, el Hyde Park en Londres, los bosques de Palermo en Buenos Aires o el Paseo del Bosque en La Plata. Esta tendencia mundial de fines del siglo XIX, no solo era expresión de determinados gustos estéticos sino también de las crisis sanitarias experimentadas por muchas ciudades en esos años (Venturi Ferriolo, 2008 en Nogué, 2008, p.133). El hacinamiento, la falta de servicios básicos, las viviendas inadecuadas, la presencia de industrias contaminantes dentro de las ciudades, entre otros factores, desencadenaron epidemias de tifus, cólera o fiebre amarilla. Ante esta situación, las clases medias y altas se desplazaron hacia zonas de mejor calidad ambiental dentro de la ciudad, o bien hacia los suburbios, donde existía la posibilidad de contar con una quinta o un jardín.

A fines del siglo XX, se empieza a actuar sobre los espacios públicos ya sea en la creación de nuevos espacios como en el mantenimiento, recuperación, puesta en valor y mejora de los espacios existentes, también se comienza con la renovación de áreas degradadas renacionalizando grandes áreas con actividades obsoletas y convirtiendo en peatonales las calles en cascos antiguos y áreas centrales (a veces inclusive con la reducción y/o anulación de las superficies destinadas al tránsito y el estacionamiento vehicular). Este 
proceso se sigue llevando a cabo hoy en día y cada vez se observa más la reconversión de áreas que quedaron marginadas por un cambio de uso y se transforman en parques urbanos. Estas intervenciones se llevan a cabo con criterios diversos según el lugar donde se estén implementando ya sean monumentales, tradicionales (ligadas a la cultura local) o intervenciones foráneas.

Las intervenciones realizadas en las ciudades en relación a los espacios públicos buscan una accesibilidad igual para todos como así también mejorar la calidad de vida de los habitantes.

Teniendo en cuenta que la figura de los espacios verdes públicos en las ciudades, no sólo cumplen con una función ornamental, sino que coadyuvan a optimizar la calidad del aire correspondiendo que una significativa absorción de Oxido de Carbono (CO2), el cual toma el papel de moderador de intercambio de aire, calor y humedad en el paisaje urbano; al mismo tiempo que pasa a tomar un papel perceptual paisajístico que participa como deleite visual y por consiguiente mejora la calidad de vida urbana. Los beneficios ambientales que resultan de los espacios verdes son diversos, otorgando intangibles mejoras a los habitantes, por lo cual la Organización Mundial de la Salud (OMS) los contempla considerando como una recomendación ineludible para una mejor calidad de vida urbana, que la ciudades deberán cumplir mínimamente con $9 \mathrm{~m} 2$ de áreas verdes por habitante, cifra que a su vez la Organización de las Naciones Unidas (ONU) indica que corresponderán contar con una superficie no menor de $12 \mathrm{~m} 2$ de áreas verdes por habitante, todo ello con el fin de brindar la normatividad necesaria para proteger la permanencia y equilibrio de la calidad de vida de los habitantes en la ciudades, puesto que día con día, estos espacios verdes se convierten en lugares olvidados.

En este sentido se enuncia a Jordi Borja quien del mismo modo hace un análisis expresando "el derecho al espacio público es en última instancia el derecho a ejercer como ciudadano que tienen todos los que viven y que quieren vivir en las ciudades" (Borja 2001). Es decir, el factor beneficio no debe por tanto ver clase social, y se debe de plantearse para toda la sociedad que vive, disfruta y sufre su transitar por la ciudad, dando réplica a las demandas sociales de la actualidad; buscando evitar la sustracción del espacio verde público y haciendo generalizado el vínculo de la sociedad con el medio ambiente, facilitando el contacto a dichos espacios. 
En este contexto, el estudio del espacio verde público toma un impensado encaminado hacia la conservación del espacio abierto, el cual "es mucho más que establecer contacto con la naturaleza. Puede ser lugares donde uno adquiera una preparación, o un hobby, descubra una nueva carrera, experimente el pasado o el futuro o unas formas de vida diferente el hacer esto posible requiere nuevas maneras de manejar el espacio abierto y también de diseñarlo" (Lynch 1998).

Si la ciudad es el lugar de encuentro por excelencia, más que cualquier otra cosa, la ciudad es un espacio público peatonal. Los seres humanos no pueden estar en el espacio de los automóviles, ni en los espacios privados que no les pertenecen. La cantidad y la calidad del espacio público peatonal determinan la calidad urbana de una ciudad. Gehl (2006) señala que un espacio público es bueno cuando en él tienen lugar muchas actividades no indispensables, cuando la gente sale al espacio público como un fin en sí mismo, a disfrutarlo.

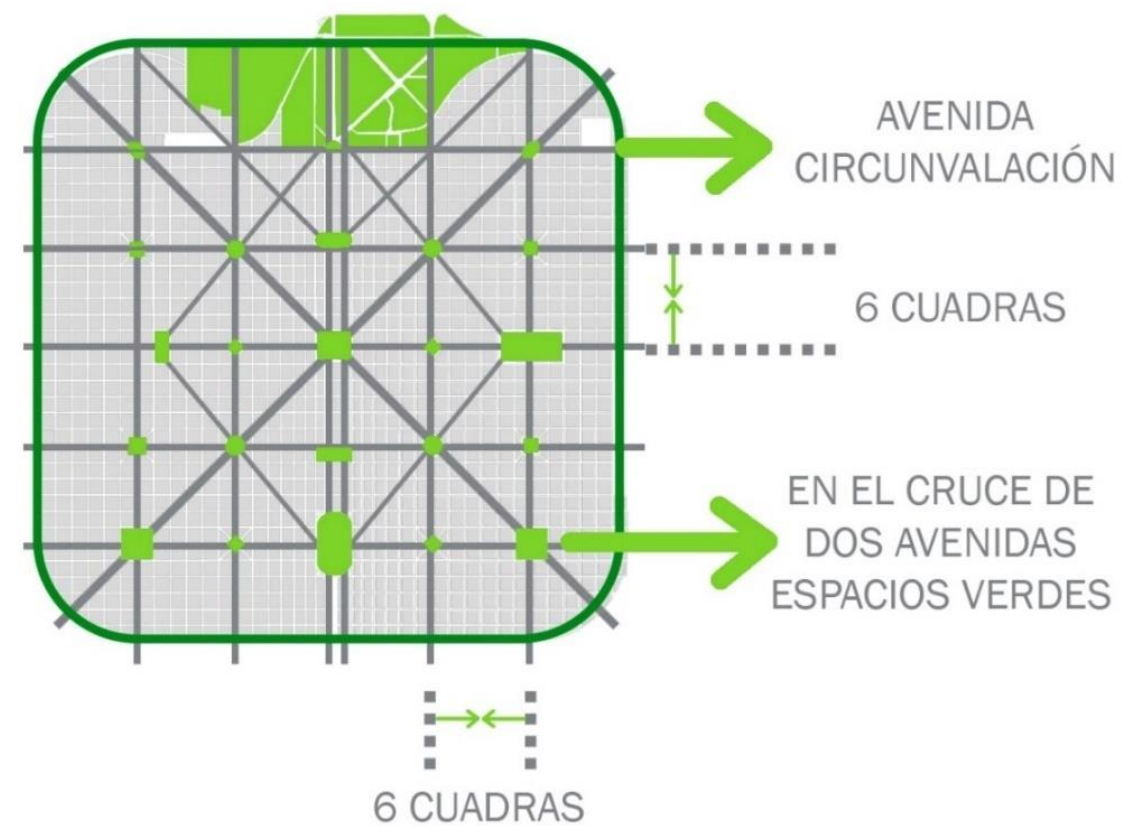

Figura 23. Espacios verdes en el casco fundacional en La Plata.

Fuente: elaboración propia, 2017.

El sistema de espacios públicos juega un papel fundamental en la identidad urbana (figura 23). La ciudad es diseñada con todos los criterios de modernidad urbana de la época, desarrollando una estructura jerarquizada que permitía poner en valor la imagen de la ciudad neoclásica como centro político administrativo provincial, a la vez que posibilitaba el desarrollo de sistemas de transporte integrados al ferrocarril, como símbolo de modernidad de ese momento histórico. Asimismo, se destaca el componente estético- 
paisajístico, el cual es tenido en cuenta en el diseño articulado de las plazas, parques y monumentos como remates visuales y funcionales de sus avenidas y boulevares.

La Plata es una ciudad planificada desde su origen con un sistema de espacios verdes que materializaba, las teorías sanitaristas de fines del siglo XIX. El proyecto comprendía:

- tres parques urbanos, actuales Saavedra, Belgrano y Vucetich

- dieciséis plazas ubicadas en las intersecciones de sus avenidas y diagonales

- plazoletas que surgen del encuentro de la trama ortogonal y las diagonales principales

- jardines en torno a sus edificios públicos

- un boulevard de circunvalación del casco urbano

- el arbolado de sus vías de circulación

- un entorno inmediato de chacras y quintas

El diseño histórico determinaba una distribución equilibrada de sus espacios verdes en el área urbana, de manera de brindar una dotación homogénea de equipamiento público recreativo de fácil accesibilidad para los habitantes. A esta generosa provisión de áreas libres públicas se sumaba un sistema parcelario en el que el tamaño de los lotes facilitaba la creación de amplios jardines privados (Domínguez, 2013).

Sobre el borde nordeste de La Plata, Benoit proyectó el Paseo del Bosque y hacia su izquierda el Hipódromo de La Plata. El Bosque es el principal parque platense y el pulmón de la cuidad.

La estética urbana y paisajística se visualiza también en la arquitectura neoclásica de viviendas y edificios institucionales, en los jardines de los edificios públicos y en el bosque platense. Los atributos del diseño original han resistido el paso de más de un siglo, conservando hasta hoy la calidad de sus espacios verdes públicos que constituyen lugares de intenso intercambio social y económico en la ciudad del siglo XXI. Las casi 300 hectáreas de parque y plazas son además un componente importante de la matriz ambiental urbana con que la ciudad da respuesta a las necesidades de espacio verde de uso público para los habitantes del casco. 
Sin embargo, hoy la ciudad se ha expandido hacia la periferia y en este sentido la calidad urbana y paisajística original del casco fundacional cobra una mayor relevancia al comparar la situación dentro y fuera del casco. En el marco del actual proceso de crecimiento y densificación de la ciudad, es indispensable pensar en el diseño, gestión y planificación de los espacios verdes públicos para lograr un desarrollo equilibrado de todos los barrios que componen el partido, en pos de mejorar la calidad de vida de los habitantes.

El espacio público, y en este caso los espacios verdes, no han acompañado el crecimiento de la ciudad. Alicia Novick (2004) comprende al "espacio público", pensado como plural y condensador del vínculo entre la sociedad, el territorio y la política ha quedado rezagado frente al capital.

En este contexto, las plazas constituyen un subconjunto de los espacios públicos verdes de la ciudad y en relación a estas características, a su historia y su disposición espacial, pueden tener diferentes roles dentro de la estructura urbana, entre los cuales se destaca lo social y ambiental (figura 24). En este sentido, puede decirse que las plazas son parte del bien común de los habitantes, presentan un alto significado social y contribuyen a mejorar la calidad de vida de los ciudadanos al favorecer la sociabilidad, la convivencia y el intercambio en la vida urbana. Se establece su rol social en tanto que son los principales articuladores de la vida colectiva, creando oportunidades de encuentro, organización e intercambio socio-cultural y económico, definiendo ámbitos de la vida comunitaria muy importantes para el ejercicio de la democracia, la manifestación y expresión de intereses y conflictos sociales.

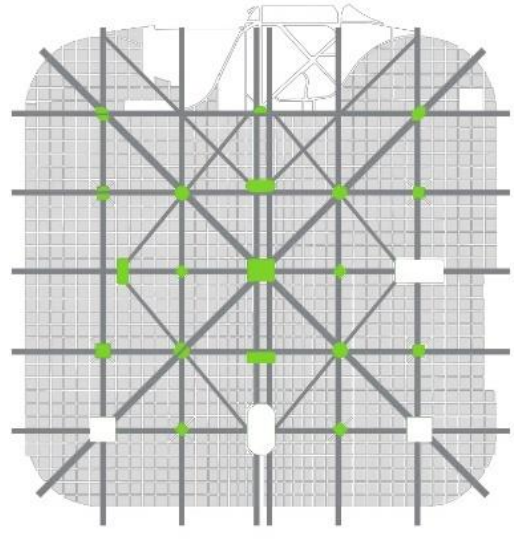

PLAZAS

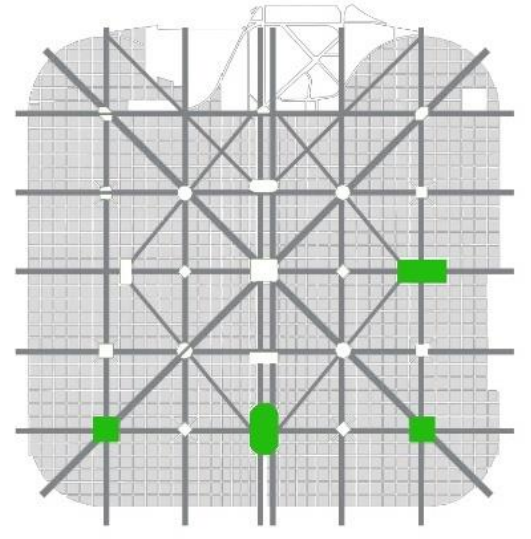

PARQUES

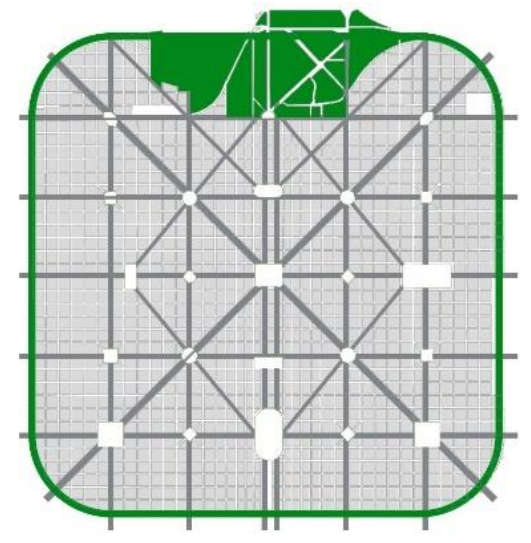

BOSQUE

CIRCUNVALACIÓN

Figura 6. Análisis de los tipos de espacio verde en el casco fundacional.

Fuente: Elaboración propia, 2017. 
Respecto de su rol ambiental, los espacios verdes, a través de su vegetación, operan como pulmones de las áreas centrales urbanas, oxigenando la ciudad, mitigando los efectos del ruido y brindando un componente paisajístico y estético al ambiente urbano. A su vez el espacio verde tiene un peso importante en la regulación del escurrimiento de aguas de lluvia, por la superficie de suelo absorbente que aportan al área urbana. Como espacios de ocio y recreación, las plazas y parques de nuestra ciudad cumplen además una importante función en la salud física y emocional de los habitantes. Mientras que, en la escala barrial, las plazas cumplen un rol social e identitario muy fuerte, que permite y admite el despliegue de procesos de apropiación y pertenencia por parte de sus habitantes. Por este motivo resulta relevante asegurar el mantenimiento de estos espacios como garantía de la sustentabilidad urbano-barrial.

\section{El arbolado urbano como elemento estructurador en la ciudad:}

En el casco fundacional de La Plata, la presencia más característica es, sin duda, la del árbol. Las sensaciones que su existencia provoca en el hombre de la ciudad, son varias y todas gratificantes puesto que suavizan la rigidez de la edificación moderna; otorga un efecto de continuidad a la construcción y sobre todo oxigenan el aire.

El arbolado urbano viene de la mano de la historia de la ciudad, comenzando el 1900 el intendente de aquel entonces Carlos Lavalle arbolo numeras calles y plazas y en los años sucesivos se foresto la plaza Rivadavia, y se plantaron Plátanos en la avenida 7. Cuando se realiza el empedrado de esa vía el ingeniero agrónomo encargado en ese momento Juan Ramón de la Llosa trasladó los plátanos desde esa calle hacia las avenidas 51 y 53 y en su reemplazo plantó los tilos que otorgaron una fisonomía tan particular a esa vía central y a toda la ciudad. Estas plantas de tilo habían sido importadas desde Alemania.

El ingeniero Llosa realizo una ardua labor en la forestación urbana, organizo un jardín botánico en el parque Saavedra. Años más tarde en la década del 20 se plantan los Jacaranda lo largo de la diagonal 73 los cuales le dan un color particular a esta vía desde Plaza Rocha hacia el barrio de La Loma con sus flores de color cobalto y sus frutos que recuerdan las castañuelas.

Se prosiguió de esa manera con la forestación y planificación botánica de la ciudad la cual fue realizada para que las personas con minusvalías visuales pudieran orientarse a través del aroma de los árboles. Para esto se usaron estratégicamente diferentes tipos de árboles para diferenciar las calles, avenidas y diagonales (ver anexo 2). Se pueden encontrar tilos, 
jacarandas, arces americanos, naranjos, palos borrachos, entre otros, cada uno en zonas o vías específicas.

Estos distintos tipos de árbol nos permiten poder reconocer las diferentes vías y asociarlas a alguna especie, por ejemplo "la diagonal de los jacaranda" se le llama comúnmente a la diag. 73 la cual es muy característica sobre todo en época de floración o "la calle de los naranjos" a la calle 47. Los plátanos que son característicos en las veredas platenses, los tilos, los ginkgos en la entrada al museo, en la ciudad podemos encontrar muchos lugares donde se caracterizan por la vegetación (figura 25).

El reconocimiento por parte de los habitantes del cambio de especies en relación a los diferentes lugares se da a menudo, es decir que se aprecia por la gente que vive el espacio el tipo de vegetación propuesta.

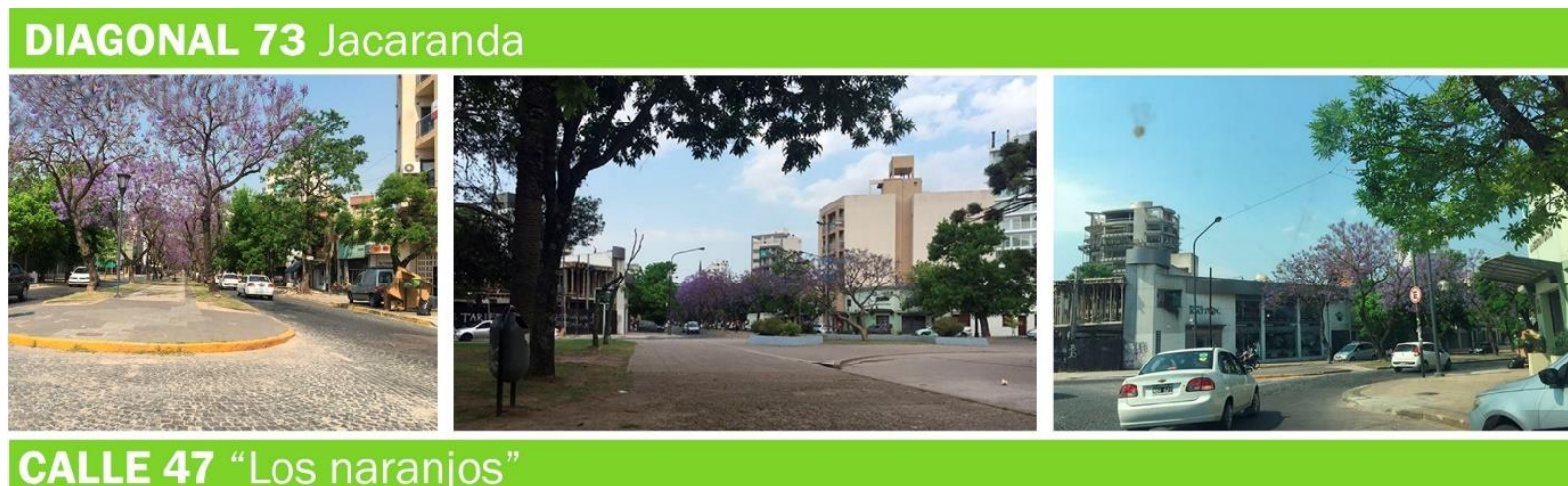

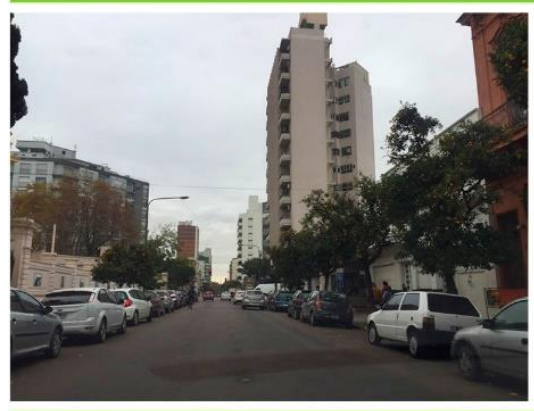

AVENIDA 1. Plátanos

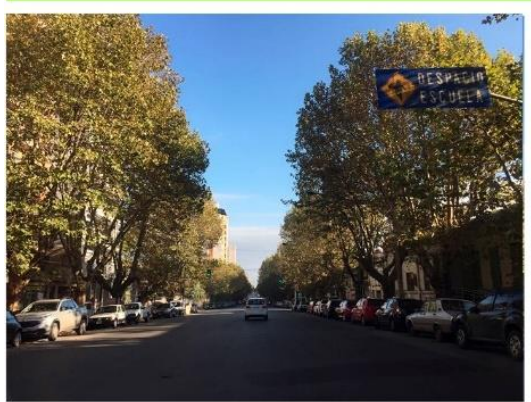

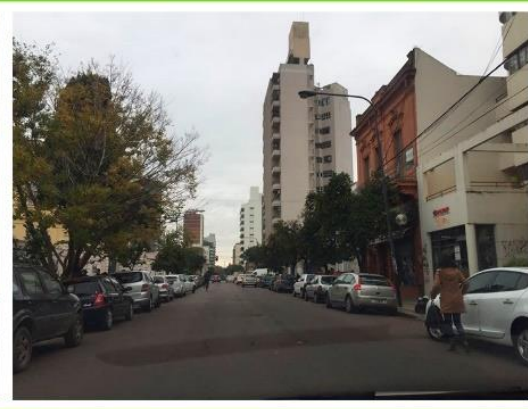

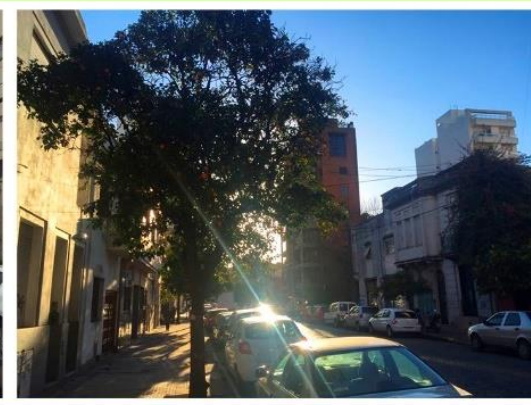

AVENIDA 53 Tilos y Plátanos
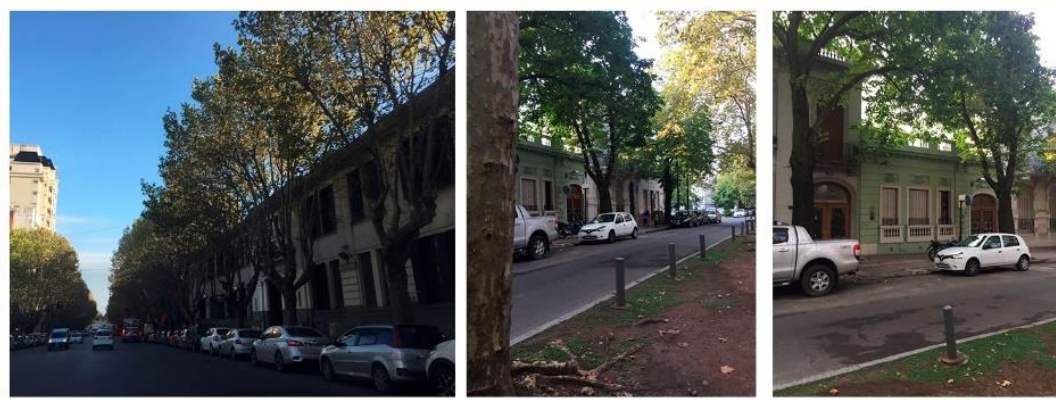

Figura 7. Calles que se destacan por sus árboles.

Fuente: Imágenes del autor, 2017. 
Hoy en día recorriendo el caso fundacional se pueden observar las malas condiciones de algunos árboles, escasa presencia de ejemplares jóvenes, poco éxito de las esporádicas plantaciones, cazuelas vacías o ausentes, paños verdes erosionados. A esto se le suma la plantación por parte de los vecinos de especies que no son aptas para arbolado urbano, las cuales impiden las visuales, impiden la libre circulación o generan riesgo por las condiciones de su fisonomía (figura 26).

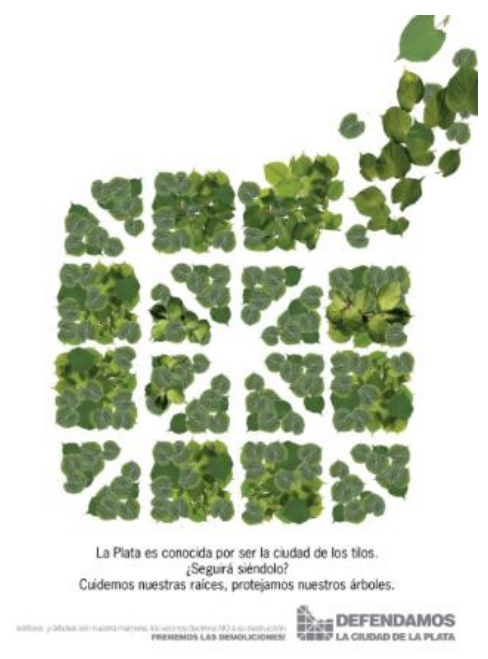

Figura 8. La pérdida del arbolado urbano en La Plata.

Fuente: http://defendamoslaplata.blogspot.com/

Pero a pesar de esto, según el censo elaborado en 2008 por la cátedra de Silvicultura de la facultad de Ciencias Agrarias y Forestales de la UNLP, el casco fundacional cuenta con casi 81.000 árboles con una población estimada es de poco más de 210.000 habitantes. Esto implica la existencia de un árbol cada tres vecinos (figura 27), mejorando la relación mínima recomendada por la OMS para los ambientes urbanos, que es de ocho; en la ciudad autónoma de Buenos Aires, las cifras apenas llegan a ese mínimo.

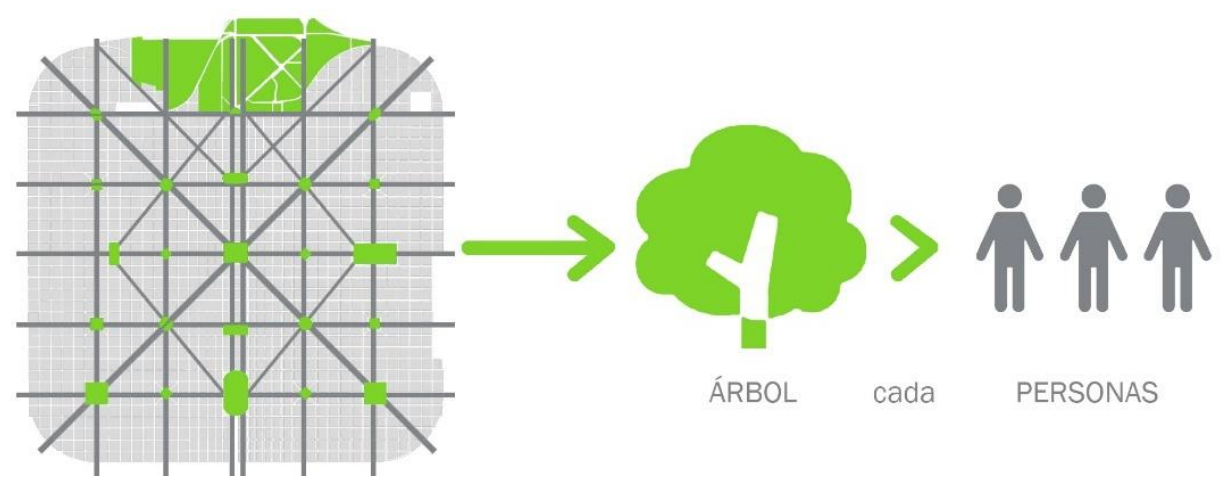

Figura 9. Relación cantidad de habitantes por cada árbol en el caso fundacional platense.

Fuente: Elaboración propia en base a los datos de la cátedra de silvicultura de la facultad de Ciencias Agrarias y Forestales de la UNLP 
Este número supera ampliamente las relaciones de habitantes por árbol que hay en ciudades como Barcelona donde hay un árbol cada 10 habitantes, en Curitiba hay un árbol cada 12 habitantes y en Nueva York hay un árbol por cada 14 habitantes (https://www.lanacion.com.ar/1840338-la-ciudad-tiene-un-arbol-cada-ocho-personas-elminimo-de-lo-sugerido).

Ahora cuando nos alejamos del casco fundacional planificado y arbolado nos encontramos con otra realidad. La periferia no mantiene todas estas premisas establecidas para el casco fundacional, en la mayoría de los sectores no hay especies que caractericen zonas, como así tampoco para ser un tejido más abierto donde predomina el verde no hay tantos árboles.

A esto se le suma que en la periferia es donde se localizan los nuevos loteos en los que se subdividen la tierra, se lotea, se colocan luminarias, se asfaltan calles, pero no se piensa en la vegetación, estos loteos en su mayoría no contemplan el arbolado urbano (figura 28). Los que contemplan poner arboles ponen las especies que les agradan a los dueños de las viviendas o a los que administran los loteos sin ningún tipo de criterio.

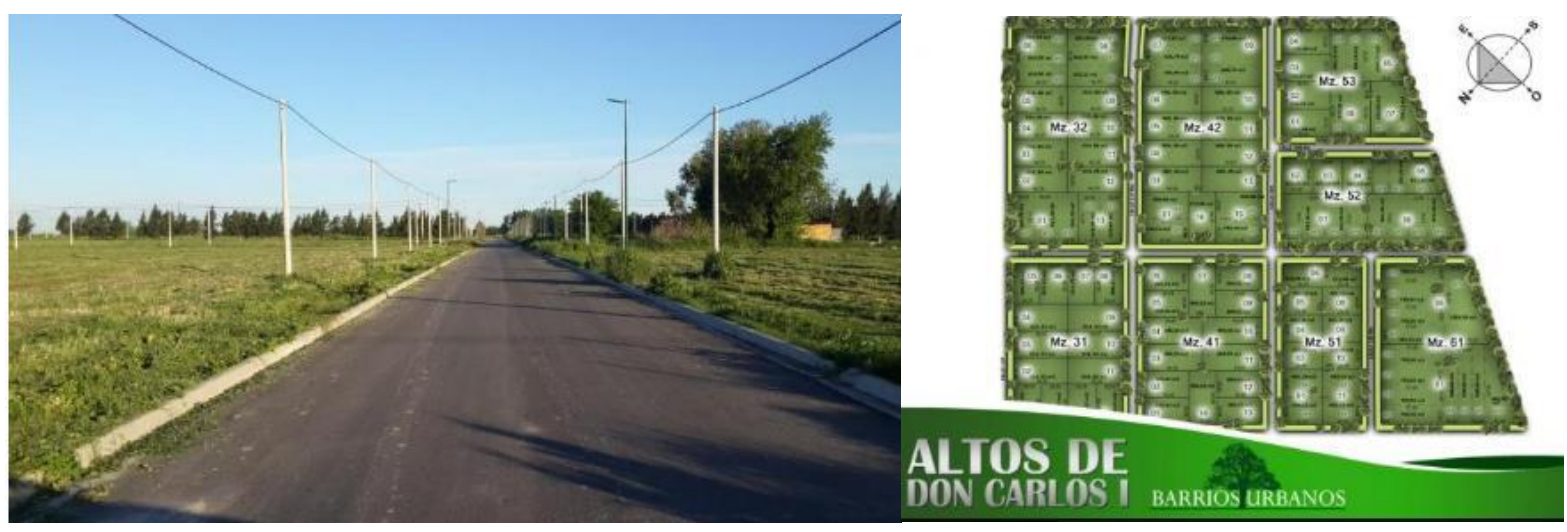

Figura 10. Loteo Altos de Dos Carlos I en las calles 507 y 137 loteo en una zona que era productiva donde no fue previsto el arbolado urbano, Hernández.

Fuente: fotos del autor, 2016.

¿Cómo se configura entonces el paisaje urbano de un barrio que no contempla el arbolado urbano?, es un espacio sin identidad, sin ningún tipo de característica. En el caso del ejemplo del loteo Altos de Don Carlos I es un barrio que se loteo en el 2011 con el cambio de código los lotes se encuentran un 50\% vendidos y solo tienen árboles plantados en la vereda cuatro casas. Si el propietario del loteo hubiera invertido en la plantación de árboles en esas veredas como invirtió en el asfalto, la luz, el gas hoy en día esos árboles hubieran alcanzado un tamaño considerable brindándole servicios ecosistémicos y configurando el 
paisaje urbano. Este es uno de los ejemplos observados, pero como este caso hay muchos casos en la periferia platense.

El arbolado urbano es importante en la ciudad porque brinda funciones ecosistémicas como la purificación del aire, conservación del agua y reducción de la erosión del terreno, combaten el efecto invernadero, reducen la contaminación del aire, reducen la contaminación acústica, retardan el escurrimiento del agua entre otros (figura 29). Como así también generan beneficios los arboles de la vereda como colaboran con el aislamiento térmico con espacios se sol y sombra, el aislamiento térmico y acústico, reducen vientos, aumentan la humedad en climas secos, a su vez le dan un marco al peatón que circula por estas calles arboladas generando un espacio singular.

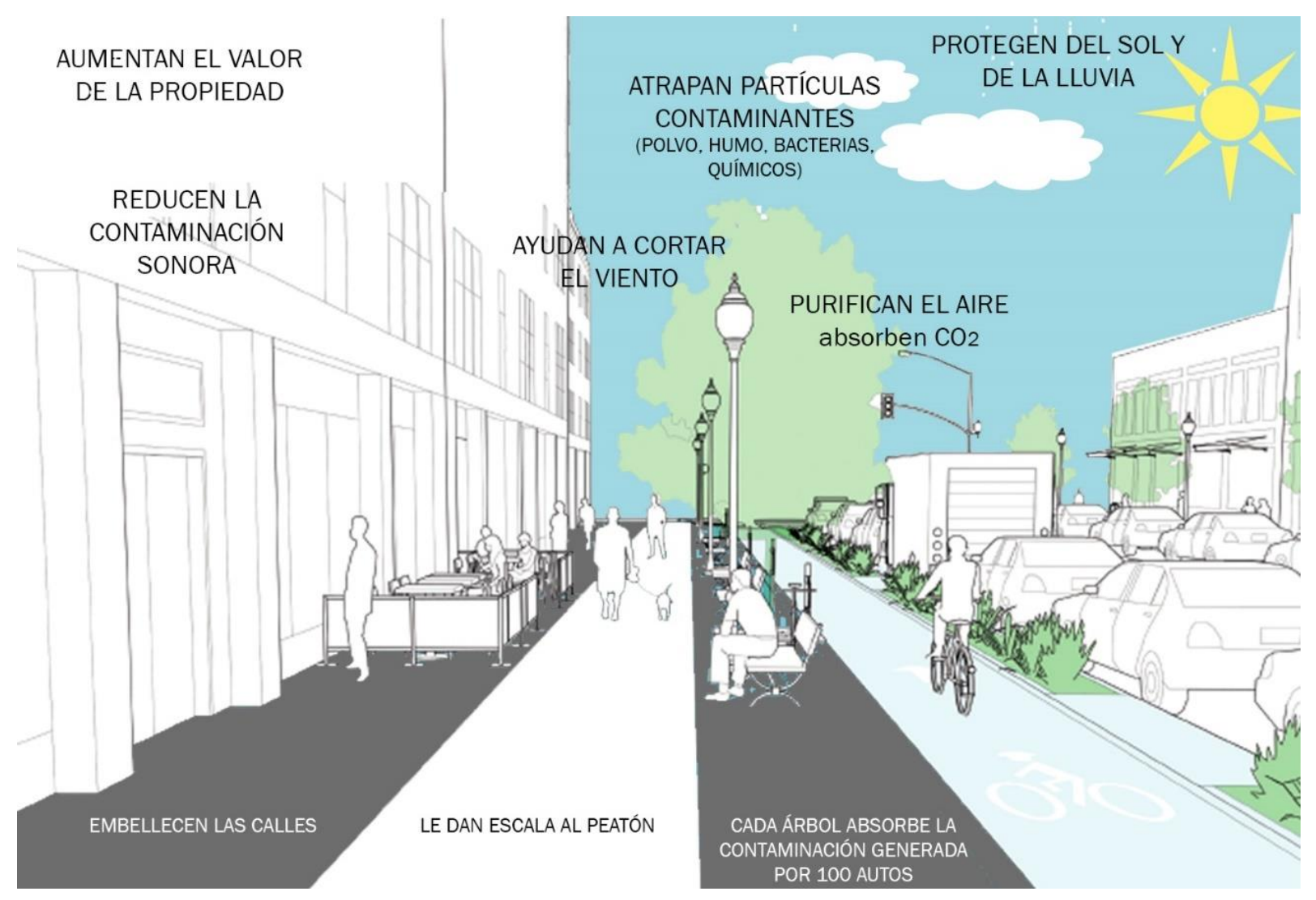

Figura 11. Funciones del arbolado urbano.

Fuente: elaboración propia en base a Global Street Design Guide ,2017.

Entonces es necesario reflexionar acerca de cómo se configura la periferia, una periferia en construcción sin árboles, una periferia donde la calidad de paisaje se ve disminuida como así también la calidad de vida de las personas. No basta con tener árboles en el interior de los jardines de las viviendas es indispensable la vegetación en los espacios verdes como en las vías de circulación. El arbolado urbano estructura la ciudad, le brinda cualidades y confort contribuyendo a un paisaje urbano característico. 


\section{La evolución en el tiempo}

En su evolución en el tiempo, el trazado fundacional del casco urbano no ha pasado más que por mínimas o escasas modificaciones, pero si lo han pasado los espacios verdes públicos, más allá de que mantengan la localización y dimensiones han sido afectados para otros usos.

Se puede destacar en primer lugar, la desafectación de más del 50\% del bosque para su dedicación a otros usos (campus universitario y dependencias oficiales) y la reducción de uno de los parques menores, cuyas tres cuartas partes fueron sustraídas. Se observan, no obstante, otros tipos de intervenciones que, en el tiempo, cambiaron los rasgos de estos espacios en relación a su concepción original. Respecto a las vías y espacios de circulación, los cambios más notables se dan en el sistema de avenidas, muchas de ellas estaban dotadas de una rambla central, que permitía la existencia de árboles, a efectos de facilitar y agilizar la circulación vehicular, muchas ramblas desaparecieron o fueron reducidas notablemente en su ancho como lo es el caso de la avenida 60, la diagonal 73 entre otras.

El cambio más significativo en la calidad del espacio público proviene, sin embargo, de las sustanciales modificaciones del tejido urbano, particularmente en el área central de la ciudad. Los cambios más importantes se dan en el área central y afectan a la calidad de estos espacios. La ciudad fue pensada para tener dos situaciones básicas de ocupación las manzanas construidas respetando la línea municipal y con un corazón de manzana verde y los edificios públicos los cuales se ubicaban en el eje fundacional y eran el negativo de las manzanas donde el edificio se ubicaba en el centro de la manzana y lo demás quedaba libre (figura 30). Todo esto conformaba, en conjunto, una morfología en la que los edificios públicos se desatacaban por sus dimensiones y lenguaje arquitectónico respecto a un tejido residencial homogéneo en términos de volumen y expresión.

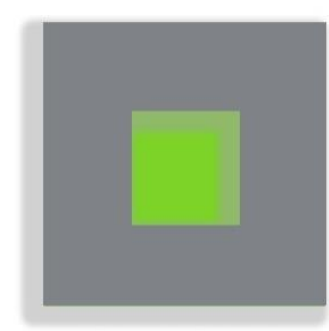

TEJIDO RESIDENCIAL

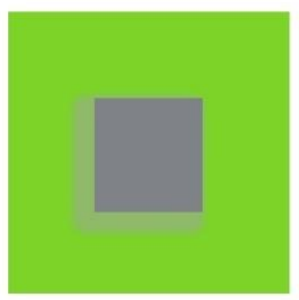

EDIFICIOS PÚBLICOS

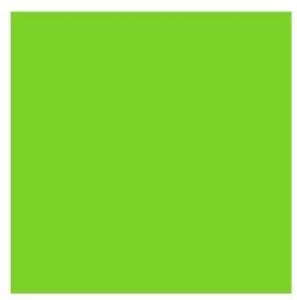

ESPACIOS VERDES

Figura 30. Relación espacio lleno y vacío en la trama urbana y los edificios públicos.

Fuente: elaboración propia, 2017. 
El corazón de manzana representaba un gran porcentaje del espacio verde del casco, es decir estos corazones eran parte del verde de la ciudad.

A partir de la década del cincuenta esta situación comenzó a cambiar la altura de los edificios que no superaba los dos pisos cambia por edificios de mayor altura transformando notablemente las condiciones de escala, asoleamiento e iluminación, temas significativos en la concepción higienista original de la ciudad. La escala de algunos espacios libres de mayores dimensiones, como plazas, ha sido también modificada por la mayor altura de los edificios que las rodean y enmarcan, como así también se han perdido los corazones de manzana.

Parte del proceso evolutivo puede considerarse natural, en el sentido que la ciudad es un organismo vivo en cambio permanente, pero generando un cambio irreversible en la identidad y característica de la ciudad. Esto se verifica en las evaluaciones técnicas realizadas en las dos ocasiones en que el casco fundacional fue presentado a la Lista de Patrimonio Mundial de UNESCO51 hicieron hincapié en la alteración irreversible de algunos atributos esenciales que incidían en la identidad de la ciudad y en la autenticidad de su trazado fundacional.

En este contexto donde ya se observa en la ciudad un cambio en cuanto a la configuración del paisaje urbano, en el año 2010 fue aprobado un nuevo Código de Ordenamiento Urbano $^{52}$ (COU). Por su parte, el código anterior del 2001 buscaba fortalecer el modelo fundacional de ciudad compacta y poli-nuclear (figura 31). Reforzando la idea de que la ciudad de La Plata fue diseñada para tener un casco urbano de densidad 53 media, capaz de absorber la demanda de habitación de la zona, con un sistema de núcleos barriales (a modo de centralidades) y un gran eje monumental. Este sistema contemplaba un fuerte cinturón verde, en principio hortícola, que además de abastecer a la ciudad puede y debe proyectarse a las localidades vecinas. Este modelo se fortalecía equilibrando la densidad en la totalidad del casco, organizando las alturas a partir de la estructura urbana de calles, avenidas y plazas.

\footnotetext{
51 El casco fundacional de La Plata fue presentado ante la UNESCO por el gobierno nacional con el proyecto de declarar a La Plata como patrimonio cultural de la humanidad. El 30 de junio de 1999.

52 COU ordenanza 10703/10

53 Densidad de Población: Es la forma de medir la cantidad de población con respecto al territorio. Se calcula dividiendo el número de habitantes entre el área considerada (hab./Ha, hab./km2).
} 
Este nuevo COU del 2010 retrocede en cuanto a lo propuesto en el código del 2001 ya que promueve la densificación del área central de la ciudad en mayor medida de lo que hacían ordenanzas anteriores de usos del suelo.

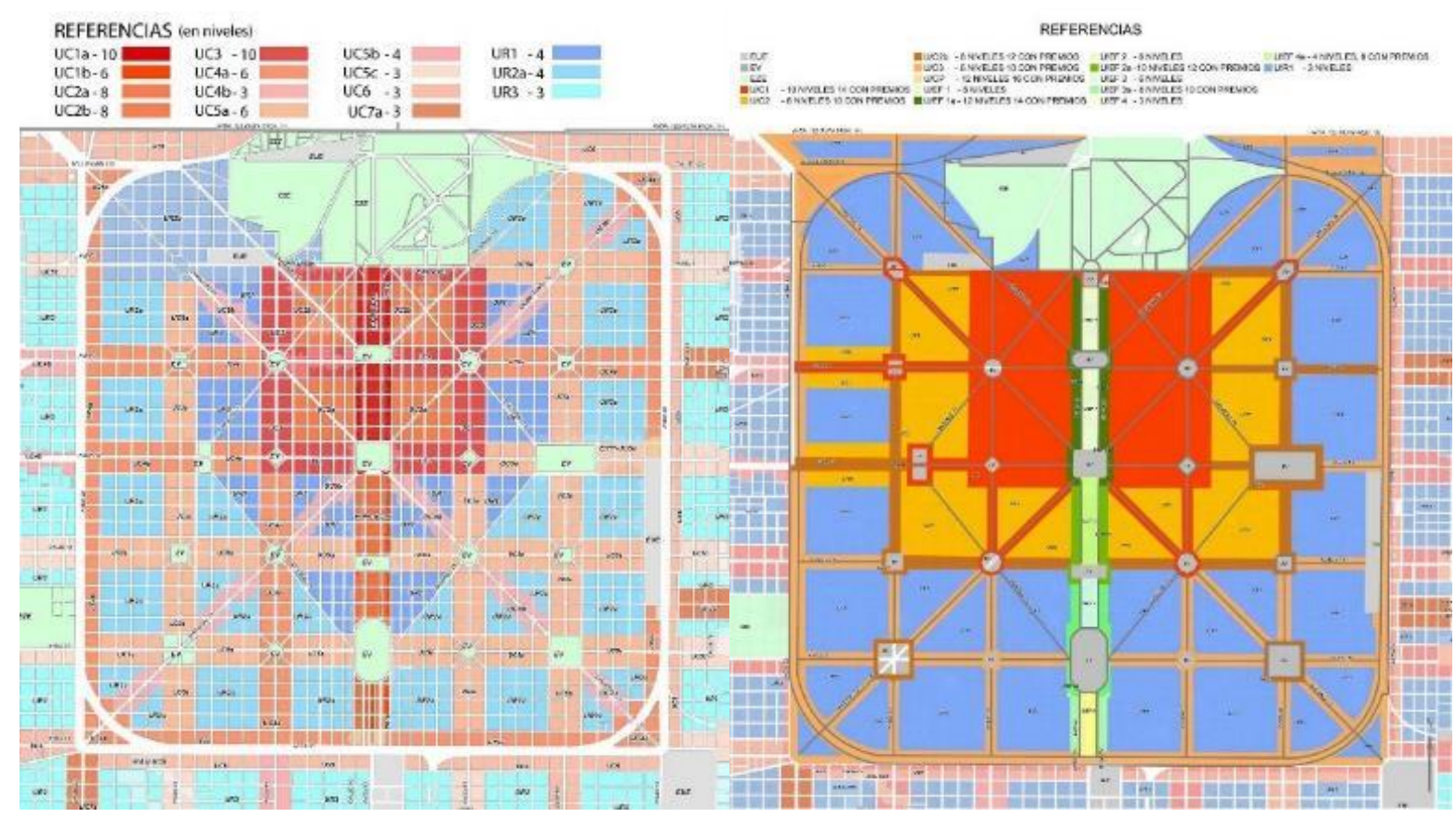

Figura 31. Código de ordenamiento urbano 2001 y 2010.

Fuente: https://habitar-arq.blogspot.com.ar/2010/05/la-desestructuracion-de-la-ciudad-de-la.html Más allá de la pérdida irreversible del patrimonio edilicio, que se agrava día a día en La Plata, la implementación de este nuevo Código pone en riesgo la calidad de vida de sus habitantes y, con ello, uno de los componentes más caros del patrimonio inmaterial de la ciudad. La ciudad en la actualidad vive una situación complicada respecto al patrimonio y a cuál será el futuro del casco fundacional, producto del enfrentamiento entre intereses económicos, sociales y culturales diversos y opuestos. Un acuerdo social en que todas las voces sean escuchadas y tenidas en cuenta aparece como una condición necesaria para equilibrar las presiones desarrollistas con la preservación de identidad de la ciudad expresada en su patrimonio y su paisaje. Este COU permite la subdivisión de lotes en área rural y complementaria, yendo en contra de la función original que era la producción en esos terrenos.

Por otro lado, esta posibilidad de aumento de los niveles genera un aumento en el valor del lote provocando una presión inmobiliaria sobre los propietarios (figura 32). 


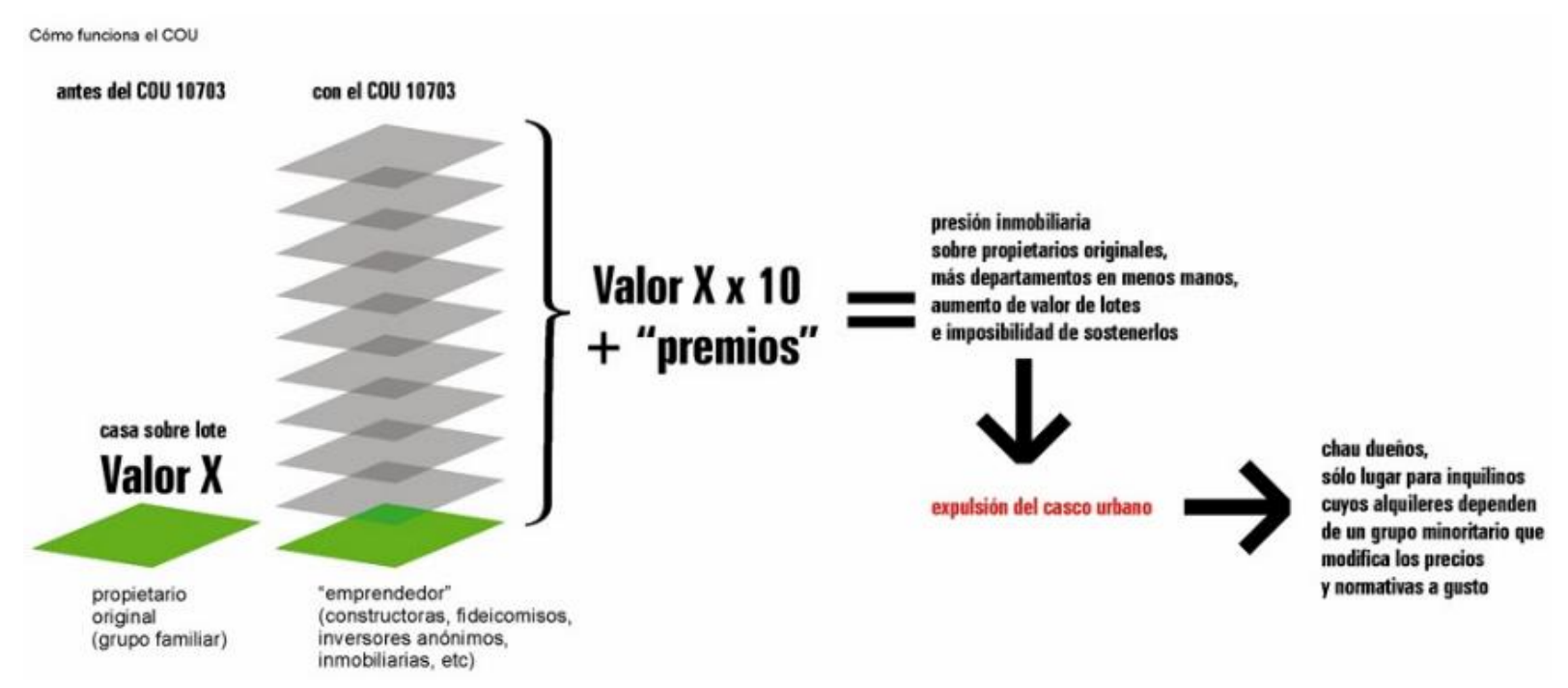

Figura 32. Valor del suelo con el cou.

Fuente: http://defendamoslaplata.blogspot.com.ar/2014_02_24_archive.html

A su vez unos años antes, en el 2004 se había aprobado el Código de Espacio Público54 (CEP) en el cual se definen las intervenciones urbanísticas autorizadas en el Partido de La Plata sobre las componentes del espacio público. Este código busca ser un instrumento regulatorio de las actuaciones sobre el espacio público.

Hace una discriminación de las tipologías urbanas de espacio público donde las clasifica en espacios verdes, espacio vial y peatonal y centralidad, caracterizándolos de la siguiente manera:

- Espacios verdes: Son los espacios de uso colectivo que actúan como reguladores del equilibrio ambiental. Constituyen un espacio libre cuyo paisaje se caracteriza por el alto predominio de suelo natural y vegetación, destinado a la recreación, deporte, contemplación y esparcimiento para todos los habitantes del partido.

- Espacio vial y peatonal: Son los espacios destinados a la conexión intra e interurbana para el desplazamiento de vehículos y peatones. Son el soporte funcional básico de la movilidad urbana. Sus límites quedan definidos por las Líneas Municipales.

- Centralidad: Es el ámbito o sitio en sé que concentran una multiplicidad de actividades ligadas a los servicios en general y residencia multifamiliar, de alta densidad, y alto nivel de movilidad peatonal y tránsito vehicular, vinculadas a la disponibilidad de transporte, comunicación e infraestructura.

Si bien sumado al CEP se han realizado mejoras y remodelaciones de los centros comerciales tradicionales y en las principales vías estas acciones no terminan de

\footnotetext{
54 Código del Espacio Público ordenanza 9880, 29 de diciembre del 2004
} 
conformar una base sólida sobre la cual el espacio verde se consolide como estructurador de la ciudad, especialmente en las zonas periféricas.

Respecto de los espacios verdes en particular, distintas leyes han impulsado la preservación de estos espacios. Es el caso de la Ley 11544 que establece a las selvas del Rio de La Plata como Reserva Provincial en Punta Lara y la ley 12756 (2001) que declara paisaje protegido a la zona costera de Ensenada y Berisso. En 2007 se sanciona la ley que declara al paseo del bosque como Paisaje Protegido de Interés Provincial. Sin embargo, tanto las cuestiones paisajísticas como aquellas que refieren al uso de estos lugares como espacio público no han sido reglamentadas eficientemente.

En este contexto, el rol del Estado en la evolución de los espacios públicos como planificador cobra una importancia fundamental, ya que es quien debiera hacer frente a esta situación promoviendo la mejora de aquellos lugares de uso público que estén asociados a la identidad y al paisaje de la ciudad y propicien el encuentro con el otro, donde los ciudadanos se reconozcan como iguales (figura 33).

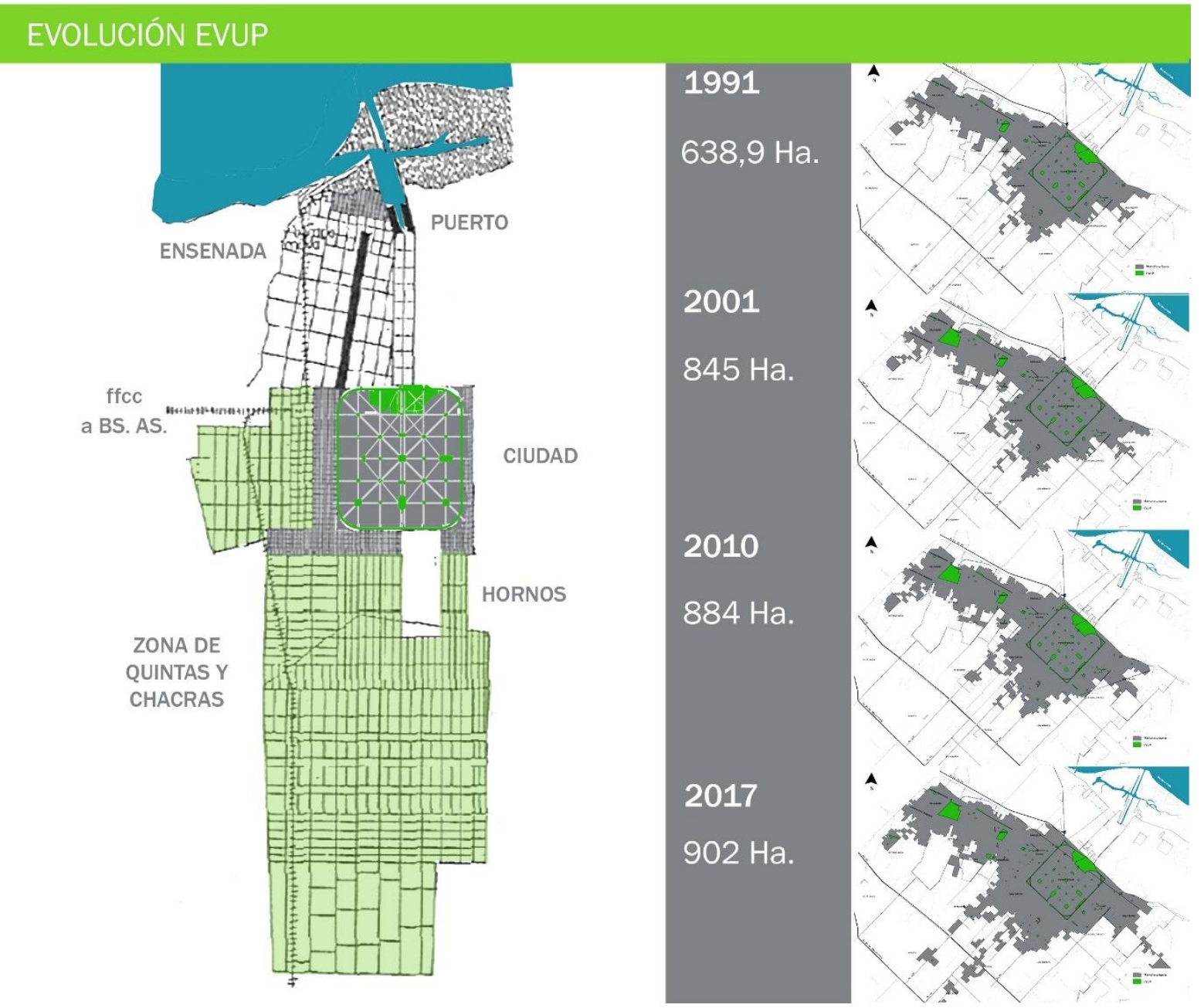

Figura 33. Evolución de los espacios verdes. Fuente: Elaboración propia en GIS, 2018. 


\section{3 | El avance de la frontera urbana}

El corrimiento de los límites de la frontera urbana hacia la periferia se dio a medida que se comenzó a incrementar la población. En otras palabras,

“El diseño fundacional de la ciudad de La Plata, con su énfasis de distinguir usos, jerarquizar funciones, atribuir ubicaciones, delinear circuitos, establecer ejes, en suma con su objetivo de traducir un tipo deseado de sociedad en una forma espacial específica, pretendientemente racional, y diseñada de tal modo que sus habitantes puedan (al menos en teoría) identificar tales jerarquías y usos especializados...no pudo resistir a los procesos urbanos del siglo XX." (Segura 2015, p.81)

El proceso de crecimiento y suburbanización comenzó muy tempranamente debido a la preexistencia del poblado de Tolosa, el cual se ubicaba en el límite norte del casco fundacional y la posterior formación del poblado de Los Hornos ${ }^{55}$, adyacente al límite oeste del trazado fundacional. En el trazado original el límite de lo urbano y lo rural era definido por la avenida de circunvalación y cuando lo urbano comienza a avanzar sobre lo rural se empieza a reconocer la suburbanización. Al respecto, se puede decir que el crecimiento de la periferia urbana no se debió a que el casco estuviese colmado, sino que, este se dio, aunque en el casco fundacional había espacios vacíos.

Respecto a esto último, se observan dos espacios urbanos muy diferentes los cuales se encuentran separados por la avenida circunvalación, se ve el contraste que hay no solo de la densidad de población, sino que también, de la rigurosidad del trazado de calles y avenidas como de los espacios verdes.

La tendencia a la suburbanización adquirió importancia a partir de la década de 1940, expandiéndose la ciudad en todas las direcciones, con preponderancia de desarrollo del eje que une la ciudad con Buenos Aires, actualmente por cuatro vías: ferrocarril, caminos Belgrano y Centenario, y autopista Buenos Aires - La Plata (Segura, 2009). El suburbano platense se encuentra compuesto por 18 centros comunales distribuidos en la periferia del casco fundacional muy heterogéneos entre sí. De esta manera se puede reconocer un patrón de segregación espacial marcado del tipo centro-periferia donde se pueden visualizar las diferencias en cuanto a infraestructura urbana y de servicios del casco con la periferia.

\footnotetext{
55 Nombre que hace referencia a los hornos donde se elaboraron los ladrillos con los que se levantó la ciudad.
} 
Retomando la desigualdad de las condiciones urbanas y socioeconómicas que tienen los habitantes por fuera del casco fundacional es necesario realizar una distinción ya que no todos los sectores de dicha periferia son iguales ni poseen las mismas características. Es así como se puede destacar el sector nor-oeste, que se da sobre el eje con sentido noroeste donde se encuentran las vías que conectan la ciudad con Buenos Aires las cuales se desarrollan paralelas al rio el cual posee mejores condiciones que el resto, pero sin llegar a igualar al casco fundacional.

Si bien hay un proceso muy marcado y cada vez más acelerado de crecimiento y expansión por fuera del casco fundacional se siguen manteniendo los limites fundacionales, es así que la Avenida circunvalación como se la conoce hoy en día (corresponde a los cuatro lados, las avenidas 32, 72, 31 y 122 y delimitan el cuadrado con extremos redondeados boulevares del casco fundacional formando un corredor continuo de 100 metros de ancho y alrededor de 20 kilómetros de largo) se culminó recién durante la década de ` 70 y `80, a partir de los restos de ramales ferroviarios que existían en tres de los cuatro lados, que fueron desactivados en las décadas del ` 60 y`70. Es decir, la ciudad se desbordaba por el crecimiento y a su vez se reforzaban los límites del casco fundacional.

A principios de los `90 en la región de La Plata se observa un considerable cambio en la morfología como consecuencia de las transformaciones urbanas que se vienen produciendo. La expansión urbana ha desbordado el casco fundacional de la ciudad hacia la periferia siguiendo las vías de comunicación especialmente las que conectan la ciudad con Buenos Aires. Si bien desde la fundación la ciudad ha dependido de la conexión con Buenos Aires, inicialmente se pensó en una ciudad capital con un puerto propio que compitiera con el de Buenos Aires, pero sin embargo La Plata adquirió un perfil administrativo y universitario y, en lugar de competir con Buenos Aires, se ha trasformado en uno de sus tantos satélites.

Respecto a esto último, el eje fundacional y de circulación principal según la idea original era el compuesto por las avenidas 51 y 53 el cual es perpendicular al Rio de La Plata y tenía intenciones de vincular la pampa con el puerto. Sin embargo, en la actualidad, el eje principal de circulación se desarrolla sobre la autopista y los caminos Belgrano y Centenario que conectan a la ciudad con el conurbano y la Ciudad Autónoma de Buenos Aires. Este nuevo eje de circulación se da en sentido perpendicular al anterior y favoreció la expansión de la ciudad en dicho sentido. De esta manera, se remarca un segundo rasgo urbanístico el sentido de expansión hacia el conurbano el cual se encuentra discontinuado 
por la presencia de un gran espacio verde y vacío urbano como lo es el Parque Provincial Pereira Iraola que actúa como un pulmón verde.

Esta expansión del área urbana en la región La Plata se produjo de manera vertiginosa en Ios últimos veinte años, transformando la periferia. El crecimiento de la ciudad se dio con un uso predominantemente residencial el cual fue dejando espacios residuales o terrenos vacantes que no fueron ocupados, generando una fragmentación.

Este fenómeno, es impulsado por los mecanismos del mercado, sumado a la imposibilidad de acceso al suelo urbano, produce una expulsión de la población hacia terrenos más alejados del centro los cuales son suelo productivo ya que es parte del cinturón frutihortícola, lo que favorece la expansión de las periferias y la consolidación de los barrios más alejados. Hay factores que influyeron también a la urbanización como lo fue el decrecimiento de actividades productivas y el auge de las nuevas formas de consumo, como así también los cambios en las tendencias de producción del espacio residencial en relación a los tipos de viviendas y la localización requerida.

Estos procesos de urbanización no constituyen en la actualidad una forma conveniente para conformar un entorno urbano que garantice la calidad de vida de la población. E crecimiento de las periferias, sin ninguna forma de regulación, conlleva a distintos sectores de la población a vivir en zonas sin los servicios o infraestructuras adecuadas. Se ha producido un gran crecimiento del cinturón el cual se ve acompañado por la expansión de la mancha urbana, demostrando que la urbanización no solo se manifiesta a través de la cantidad de personas que viven en áreas urbanas sino también a partir de una relación que estas establecen con las áreas rurales.

En el casco fundacional residen 191.075 habitantes en 2807 ha, es decir el 28,9\% de la población total del partido se localiza en el 3,15\% de la superficie total, que como centro urbano cuenta con todos los servicios e infraestructura, transporte, espacios públicos, equipamientos, entre otros (tabla 8). Mientras que en la periferia es donde residen los 469.260 habitantes restantes (71,1\% de la población total) en 86.080 ha (96,7\%). Se observa entonces el desequilibrio espacial en cuento a la ocupación del territorio y a la cantidad de habitantes. 


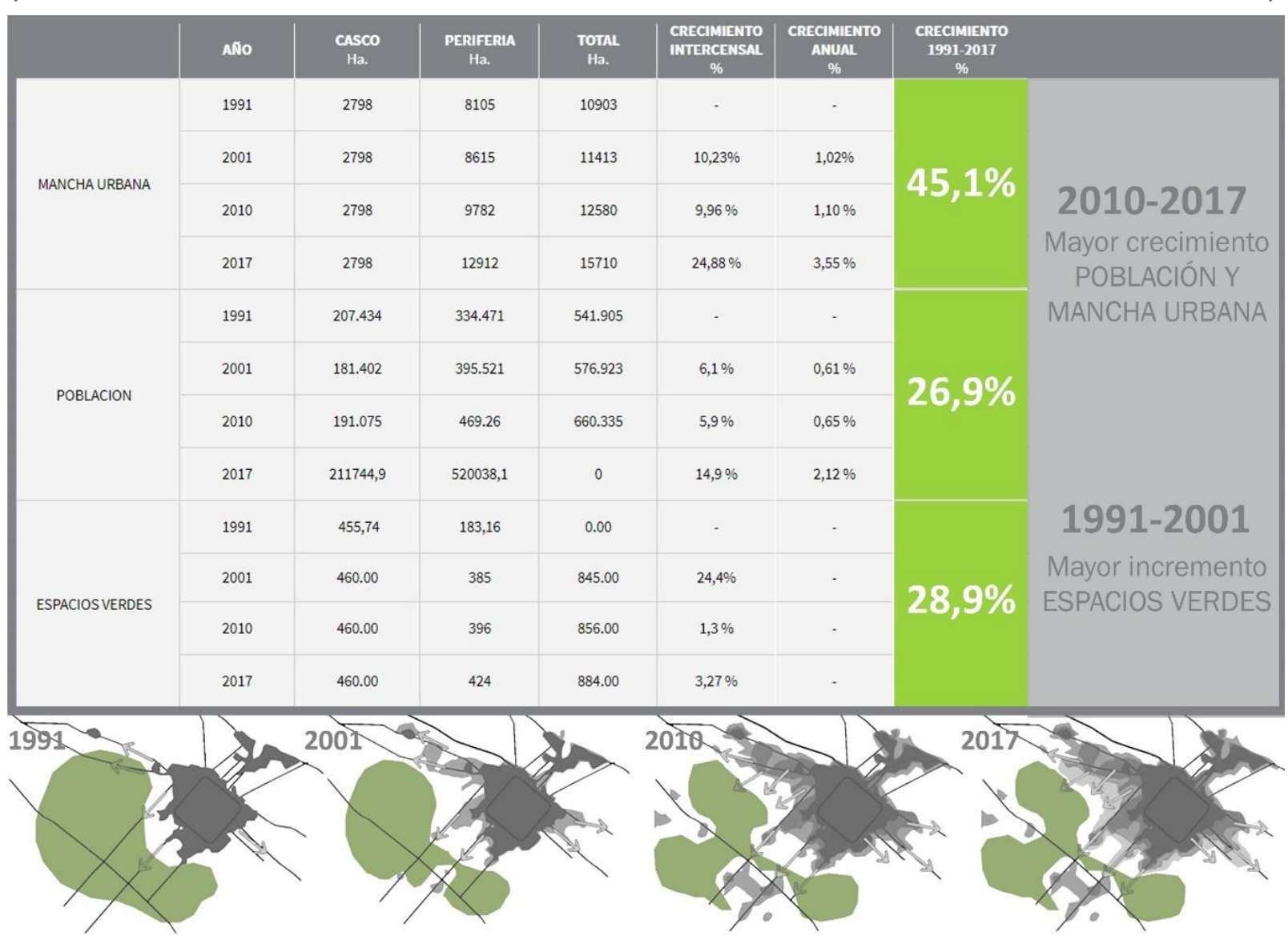

Tabla 8. La expansión urbana en la Región del Gran La Plata en los últimos 30 años.

Fuente: elaboración propia en base a UTDT -CIPUV, Centro de Investigación de Políticas Urbanas y de Vivienda, Atlas de Crecimiento Urbano (2013).

En este contexto, se debe señalar que además de la expansión de la ciudad por fuera del casco en los últimos años debido al cambio del Código de Ordenamiento Urbano se ha densificado el casco fundacional donde la edificación en altura ha tomado gran preponderancia, alterando el equilibrio deseado por los planificadores del trazado fundacional entre la edificación privada (homogénea y continua) y los edificios públicos (singulares, monumentales y discontinuos), relación que posibilitaba que estos últimos se constituyeran en hitos urbanos.

Por la acción combinada de todos estos factores, el urbanista suizo Alain Garnier sostuvo a inicios de la década de 1990 en su análisis de la ciudad el cual titula "El cuadrado Roto" que:

“La Plata es hoy una ciudad desfigurada. La geometría perfecta de la organización de los espacios urbanos (...) no ha sabido resistir las dificultades del siglo XX (...) Las torres de veinte pisos han reemplazado las casas de patio, las exigencias vehiculares han transformado las avenidas plenas de verde en pistas asfálticas, los límites de la ciudad 
han desaparecido y los hitos simbólicos del eje monumental han sido ahogados por el caos de las construcciones modernas." (Garnier, 1992, p.102)

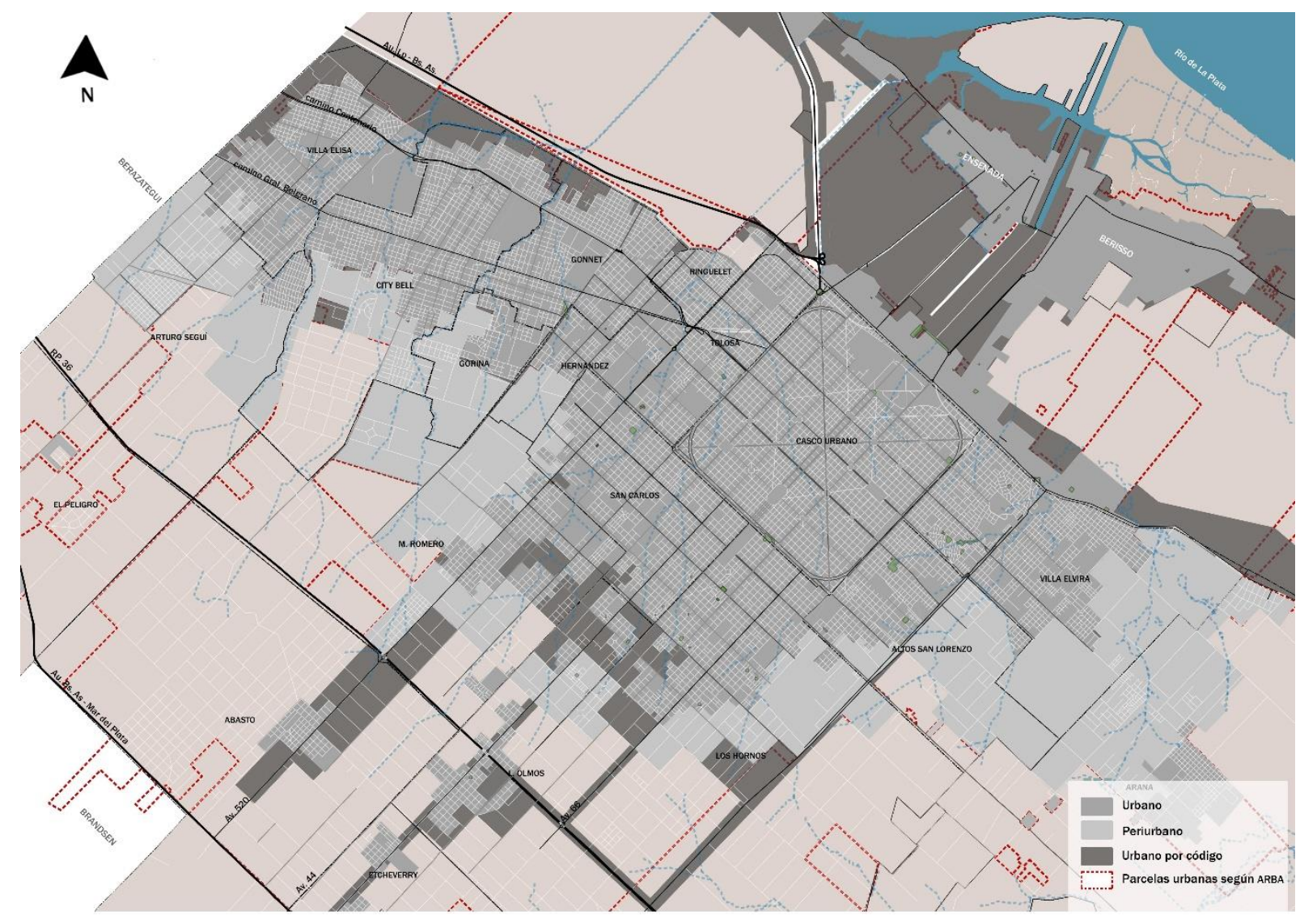

Figura 34. Plano de la ciudad de La Plata con la mancha urbana que propone el código y la mancha urbana real. Fuente: Elaboración propia en base a Jensen y Birche en GIS, 2017.

En la última década, la población que vivía en el casco fundacional a comenzado a emigrar a la periferia en busca de un nuevo hábitat (figura 35). Este crecimiento se da sobre tierras que eran destinadas a explotaciones primarias intensivas, presentando un nuevo uso de suelo propio del área urbana. Esta situación respecto del uso de suelo provoca un cambio en el precio de la tierra el cual ha ido variando a lo largo de la última década y presenta diferencias según la zona del partido. Desde el punto de vista socio-territorial este cambio ha llevado a nuevas formas de fragmentación, estratificación, generando una estructura económica desigual. Una nueva ocupación de la periferia caracterizada por la acentuación de la segregación socio espacial existente. (Pintos, 1993 citado en Frediani, 2010)

Por otra parte, el desarrollo de la cuidad en estos términos conforma grandes zonas donde solo el uso es residencial sin tener en cuenta la demanda de actividades culturales o de esparcimiento de los habitantes del lugar. Sin mencionar la falta de infraestructura, servicios o transporte público. Contar con espacios libres y ambientes sanos es 
indispensable para mejorar la calidad de vida de la población como así también para pensar en un futuro desarrollo sustentable de la región.

De esta manera al comenzar a agotarse las tierras en el sentido noroeste en los últimos años debido a la proliferación de barrios cerrados de clase alta provocando el corrimiento del cinturón frutihortícola y expansión urbana de clase media-baja se comenzó a dar en el sentido sudeste y sudoeste. En este sentido, Barsky (2007) denomina a estos espacios como "cinturones de especulación inmobiliaria", al considerar que no hay lugar donde la tierra se valorice más.

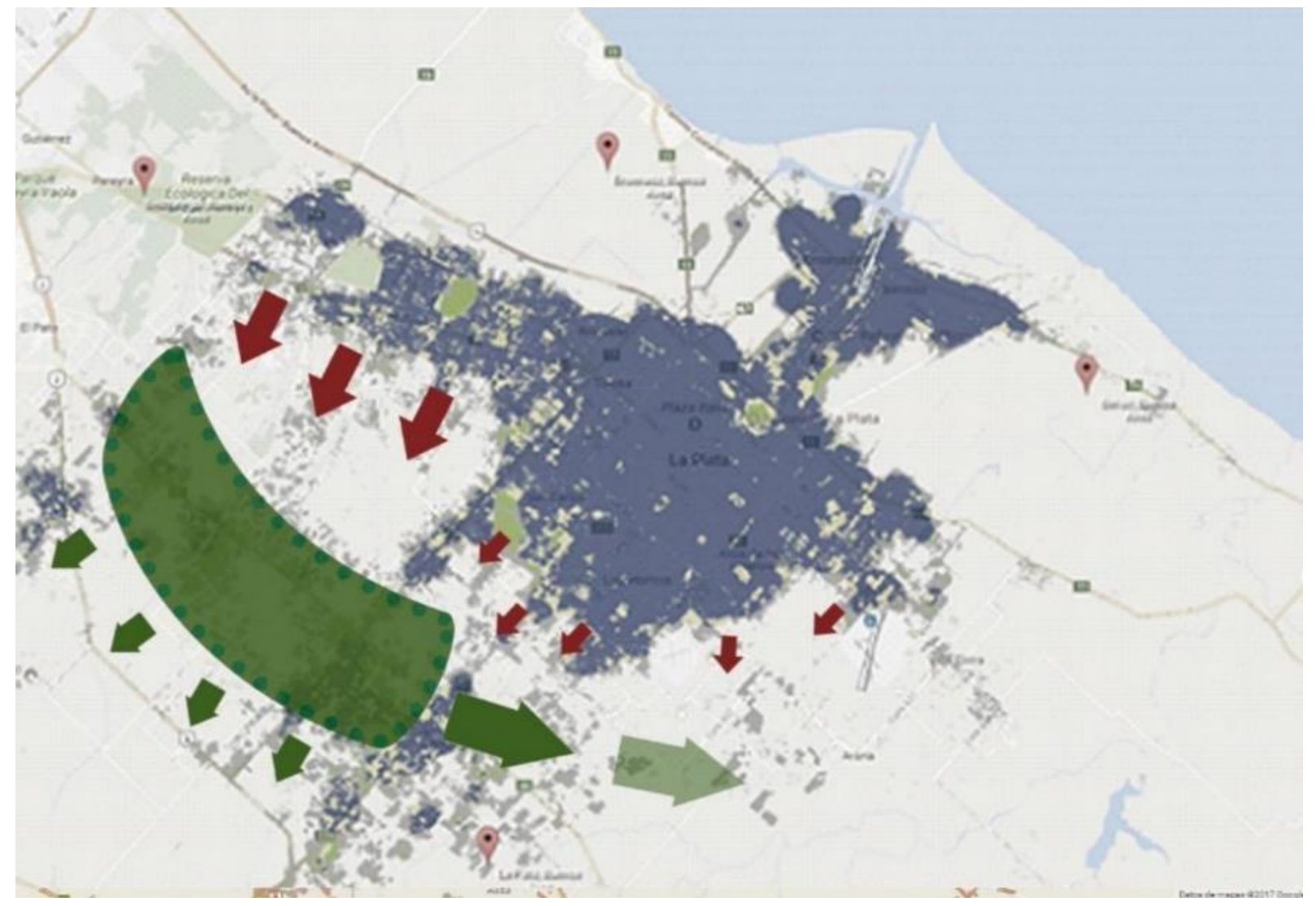

Figura 12. El corrimiento del cinturón frutihortícola platense.

Fuente: Elaboración propia, 2016

Este crecimiento hacia los terrenos productivos de la ciudad (figura 35), configura espacios urbanos fragmentados, que ya evidencian una baja calidad urbana y paisajística en estas nuevas zonas periféricas. Esta pérdida de terrenos productivos cobra relevancia por la importancia y dimensiones de este cinturón, el partido de La Plata es el primer productor hortícola ${ }^{56}$ de la Argentina. La Plata se destaca a nivel nacional en algunos productos como el tomate, el alcaucil, el apio, la lechuga, la frutilla, entre otros, como así también el sector

56 Censo Provincial Hortiflorícola (CPHF, 2005) pone de manifiesto que este contiene a 1.000 productores y 5.308 hectáreas cultivadas. http://www.estadistica.ec.gba.gov.ar/dpe/Estadistica/chfba/censohort.htm. 
florícola del partido (Frediani, 2010).

En el periurbano se empieza a ver como la residencia convive con la producción, es decir, empieza a desmaterializarse la zona urbana y se encuentra con la productiva. Suelos que eran aptos para la producción son loteados y vendidos para viviendas (figura 36).
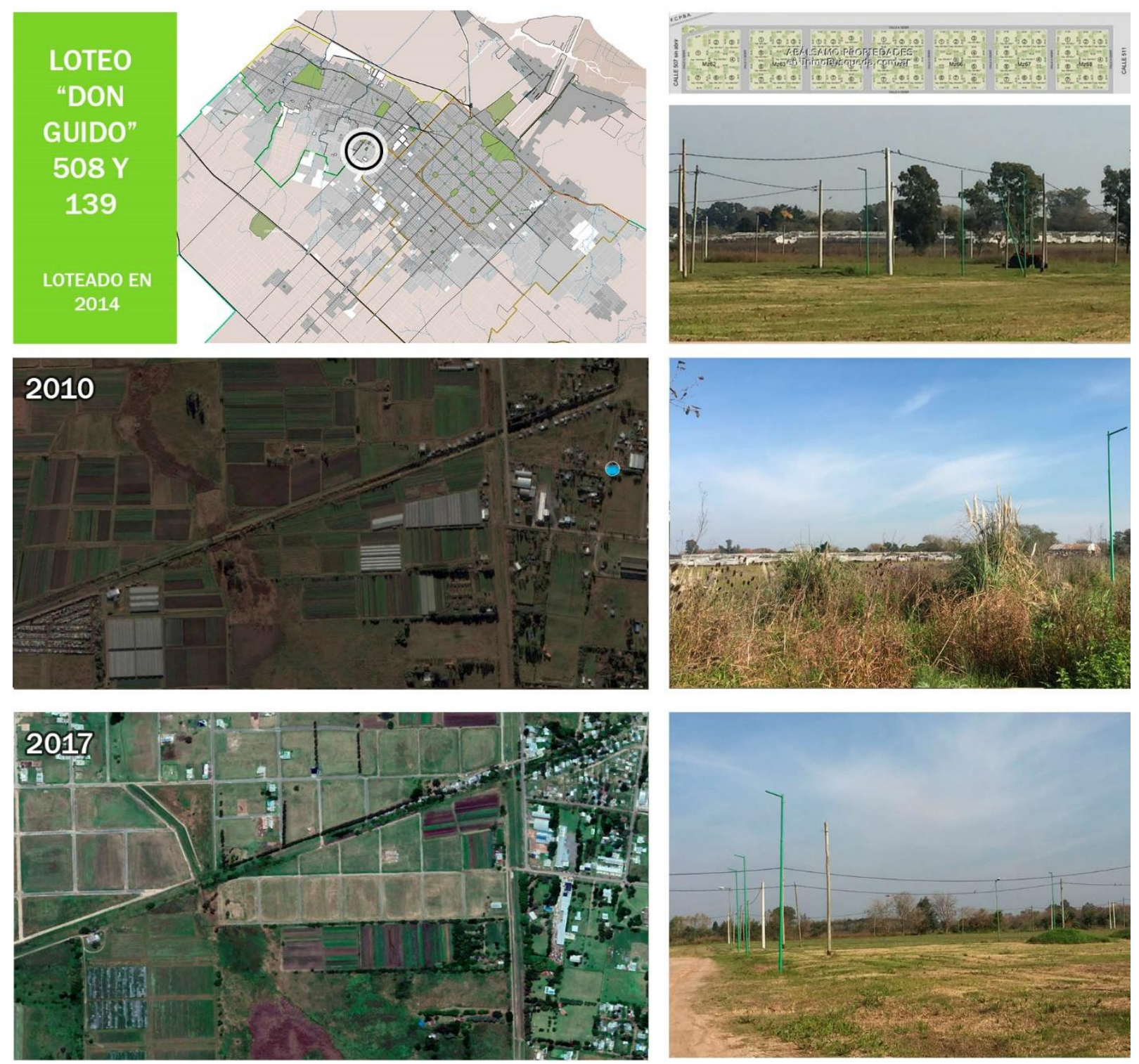

Figura 13. Loteos en zona productiva 507 y 13.

Fuente: Fotos del autor, 2015.

Esta situación, en adición a la falta de planificación y la carencia de espacios verdes públicos genera un fuerte contraste con el paisaje que se configura por dentro del casco urbano (Jensen y Birche, 2017).

A su vez, se evidencia un cambio en la tendencia de decrecimiento que se venía 
experimentando desde la década del 80. De esta manera la densidad media es de 69 $\mathrm{Hab} / \mathrm{ha}$, llegando a máximas de $290 \mathrm{Hab} / \mathrm{ha}$. Esta densificación está relacionada con la lógica de los sectores inmobiliarios y privados y el cambio del código (figura 37).

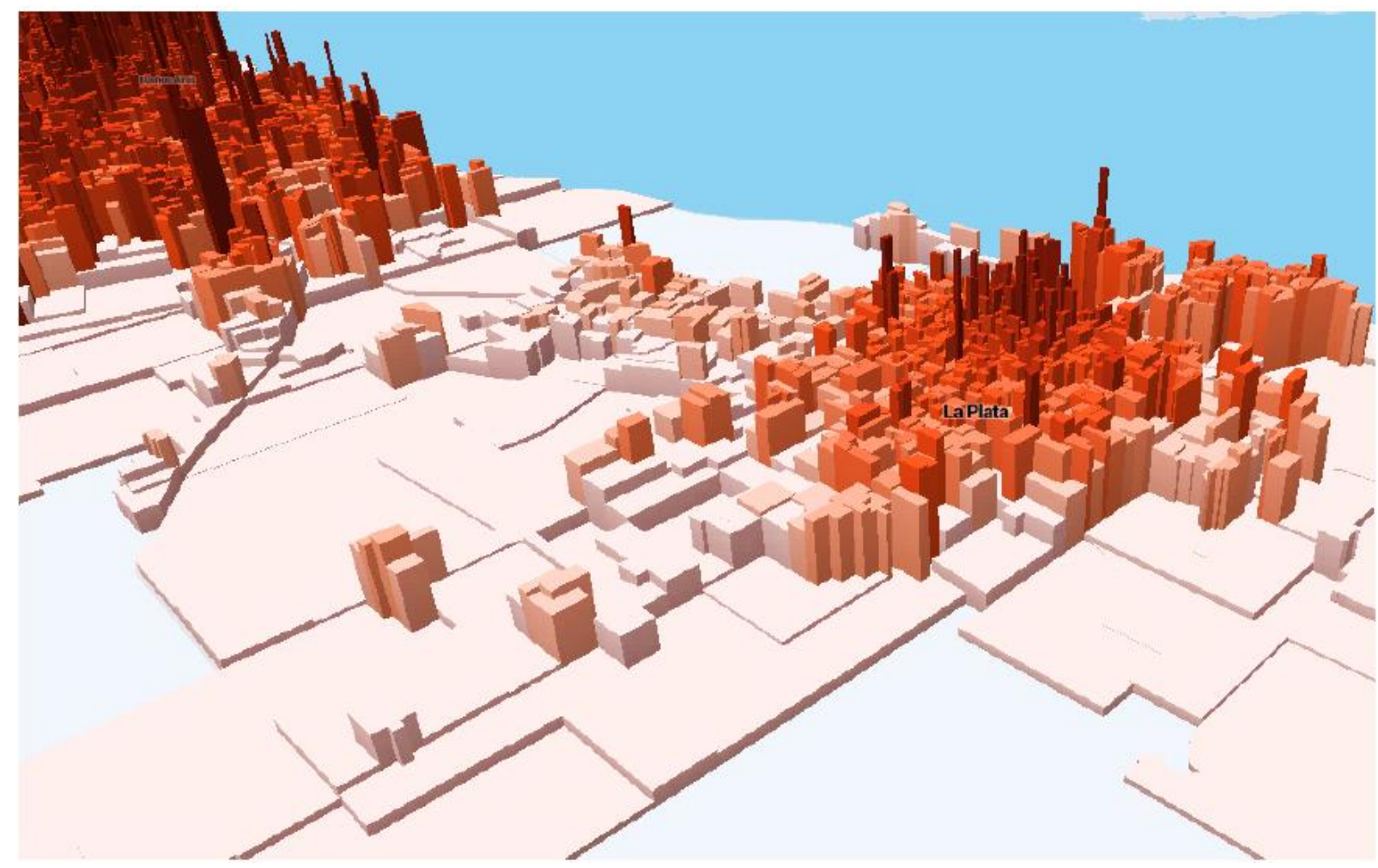

Figura 14. Plano de Densidad en la ciudad de la plata.

Fuente:https://datos.gob.ar.github.io/densidad-poblacion/\#/inicio. FECHA DE CAPTURA:11/04/2017

Se puede decir entonces que la ciudad de La Plata no solo ha crecido en extensión, sino que también se ha densificado, incrementando la cantidad de habitantes tanto en el centro como en la periferia.

\section{4 | La periferia platense}

De los tipos de expansión urbana que se pueden identificar, en la ciudad de La Plata se observa la formal abierta, formal cerrada e informal abierta donde se observan los distintos tipos de lógicas. Como señala Frediani (2010) en su tesis “En este sentido, el periurbano es escenario de distintas lógicas que permitirían diferenciar una "periferia por opción" (Terreno, 2008), destinada a la población de ingresos altos y medio-altos, territorio distintivo y característico de la denominada "privatópolis inmobiliaria" (Hidalgo et al., 2008), de una "periferia por necesidad" o "precariópolis", destinada a la población de más bajos ingresos y a los excluidos del mercado de trabajo. 
El partido de La Plata se encuentra dividido en 18 centros comunales además del casco urbano. Las delegaciones administrativas que conforman el Partido de La Plata terminaron de conformarse como tales en el año 1999 durante el mandato del intendente Julio Alak, ya que anteriormente estaban constituidas como tales sólo siete de ellas (Villa Elisa, City Bell, Gonnet, Los Hornos, Villa Elvira, Tolosa y Romero). Estas delegaciones conforman límites administrativos que se consideran al momento de conformar las cuatro zonas de análisis propuestas por esta investigación. Se decide adoptar cuatro zonas de análisis, respetando las tres zonas propuestas por el Código de Espacio Público de La Plata (2004) en su art. 10, pero subdividiendo la tercera zona que comprende el eje Noroeste y las localidades rurales del cinturón verde platense, entendiendo que responden a realidades y procesos de formación diferentes. Estas zonas, servirán para abordar el estudio de los espacios verdes y las tierras vacantes en el área urbana del partido de La Plata, permitiendo mantener una relación de los espacios verdes identificados con la estructura urbana y el modelo de crecimiento de la ciudad.

De esta forma, se adoptan las siguientes zonas (figura 38):

- EL CASCO FUNDACIONAL: delimitado por la Av. Circunvalación de acuerdo al diseño establecido desde su fundación.

- LA ZONA DE DESBORDE: generada a partir de los primeros procesos de crecimiento por fuera del casco fundacional, se compone por las delegaciones adyacentes al casco urbano: Tolosa, San Carlos, Los Hornos, Altos de San Lorenzo y Villa Elvira.

- EL EJE DE CRECIMIENTO NO: entendido a partir del crecimiento en torno a las principales vías de conectividad de la ciudad con la ciudad de Buenos Aires. Incluye las localidades de Villa Elisa, City Bell, Gonnet, Ringuelet, Gorina y Hernández.

- EL CINTURÓN VERDE: 57 se conforma por la Reserva Urbana del Área Complementaria y por el sector de la Zona Rural Intensiva. Se conforma a partir de las localidades de Arturo Seguí, Melchor Romero, El Peligro, Abasto, Etcheverry y L. Olmos

\footnotetext{
57 Según Barsky (2005) "en Argentina, se denomina cinturón verde al espacio periurbano conformado por una trama de quintas o huertas familiares -y otras de características más empresariales- que rodean a las grandes ciudades, cuya producción se destina especialmente a verduras de hoja y hortalizas de estación".
} 


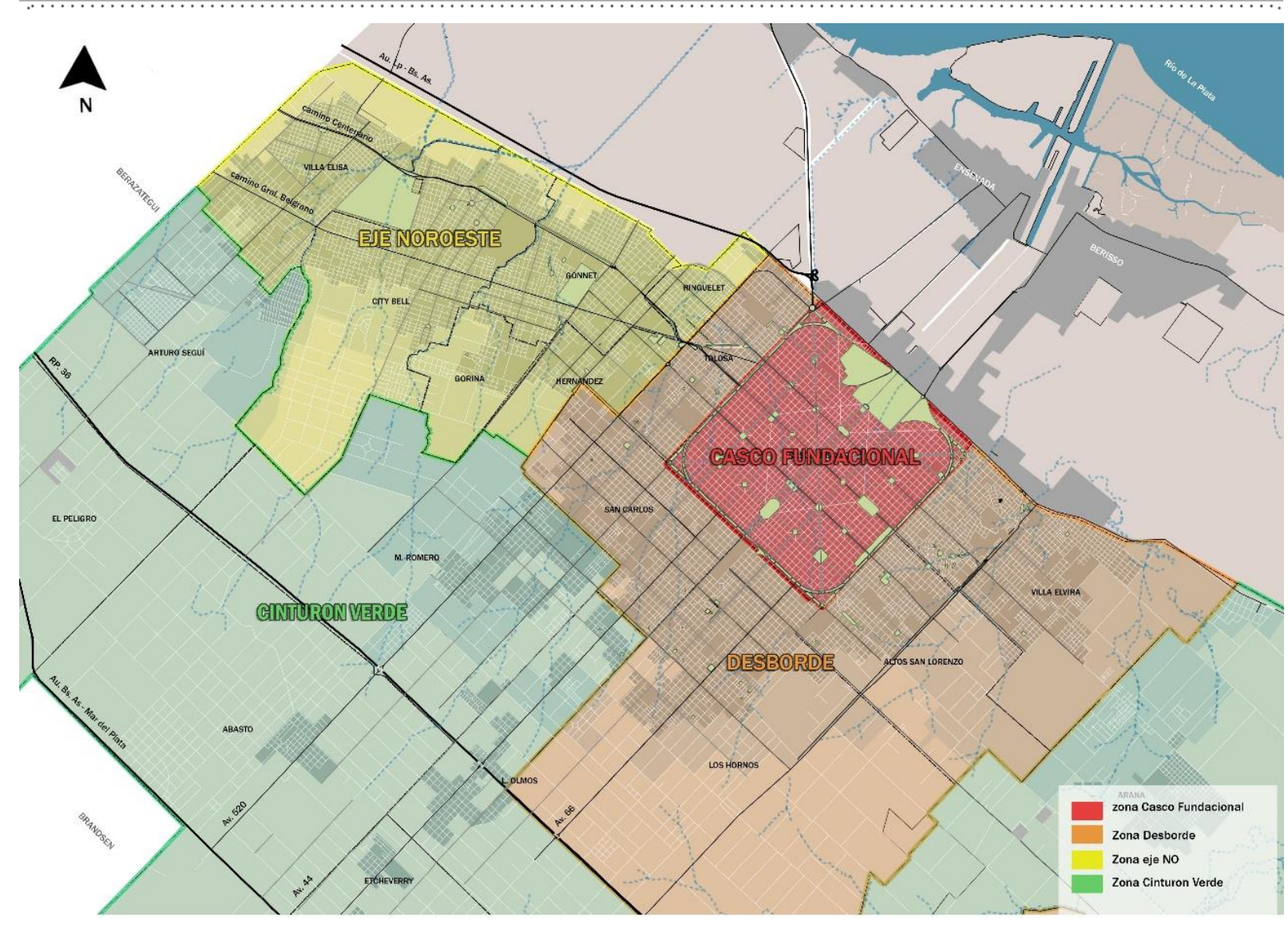

Figura38. Las zonas de la periferia platense.

Fuente: Elaboración propia en base Jensen y Birche en GIS, 2017.

Las tres zonas de la periferia tienen características muy distintas, empezando por la población (tabla 9) donde según el censo 2010 la zona con mayor cantidad de habitantes es la zona de desborde seguida por el casco, el eje noroeste y por último el cinturón verde. A su vez en el casco urbano se observó un decrecimiento de la población entre el 1991 y el 2010 el cual coincide con la migración de la población del casco a la periferia. Esto se evidencia en la región noroeste donde la tasa de crecimiento es la más alta.

\begin{tabular}{|c|c|c|c|c|c|}
\hline Zonas de análisis & $\begin{array}{c}\text { Población Censo } \\
1991 \\
\text { Habitantes }\end{array}$ & $\begin{array}{c}\text { Población Censo } \\
\text { Habitantes }\end{array}$ & $\begin{array}{c}\text { Población Censo } \\
\text { Habitantes }\end{array}$ & $\begin{array}{c}\text { Población estimada } \\
2017 \\
\text { Habitantes }\end{array}$ & $\begin{array}{c}\text { Crecimiento } \\
1991-2017 \\
\text { (\% Habitantes) }\end{array}$ \\
\hline Casco & $207,434.0$ & $181,402.0$ & $191,075.0$ & $211,744.9$ & 102.1 \\
\hline Desborde & $202,294.0$ & $220,156.0$ & $228,538.0$ & $253,259.0$ & 125.2 \\
\hline Eje Noroeste & $62,648.0$ & $104,751.0$ & $159,783.0$ & $177,066.3$ & 282.6 \\
\hline Cinturón Verde & $69,529.0$ & $70,614.0$ & $80,939.0$ & $89,691.4$ & 129.0 \\
\hline TOTAL LP & 541,905 & 574,223 & 660,335 & 731,783 & 35.0 \\
\hline
\end{tabular}

Tabla 9. Porcentaje de crecimiento en las distintas zonas de la periferia.

Fuente: Jensen y Birche en GIS, 2017. 
Por otro lado, se puede mencionar que estas zonas son distintas en cuanto a la accesibilidad y movilidad debido a las principales vías de comunicación. Como así también en la característica socio-económica de la población y las actividades y equipamientos que se encuentran en una y en otra.

La zona noroeste se define por la comunicación de la ciudad con la región metropolitana, la zona de desborde se caracteriza por ser la continuidad del tejido del casco urbano y la zona del cinturón verde por la zona frutihortícola platense.

\section{La fragmentación urbana}

Las ciudades difusas, se caracterizan por un modelo de ciudad ligado a la insustentabilidad ambiental, la fragmentación territorial, y la segregación socio espacial. En la periferia de la ciudad se identifica por una producción del espacio urbano caracterizada por una fuerte fragmentación socio territorial, debido a las diferentes formas de ocupación residencial. Estas ocupaciones se dan en relación a los distintos sectores de la población, representando de una modalidad de producción del espacio urbano representada por una fuerte fragmentación socio territorial

En este sentido, se puede decir como afirma Frediani (2010) que "la fragmentación territorial puede definirse como el proceso por el cual se transforma la organización del territorio tanto en su aspecto físico como social, producto de la inacción política, la falta de medidas jurídico normativas y de procesos de cambio de carácter económico y sociocultural" (p. 30).

En esta periferia fragmentada conviven diferentes usos y tipos de tejido residencial como así también grupos de distintos niveles sociales. La trama urbana es la que le da continuidad al paisaje y la que refleja las características de este. Los usos del suelo configuran distintos vínculos entre la trama urbana, el tejido residencial, los espacios verdes, las urbanizaciones cerradas y los espacios del agua. En este sentido, los cursos de agua pueden entenderse como elementos descriptores del paisaje, y particularmente como elementos estructurales, debido a su permanencia en el tiempo. Estos condicionan y organizan la estructura formal del paisaje, la configuración de las áreas residenciales y de la estructura viaria. Como ya se ha mencionado, la región pampeana posee escasas pendientes de escurrimiento hacia el río y se caracteriza por sus grandes llanuras, lo cual resalta la impronta de cada uno de los arroyos que atraviesan perpendicularmente el área urbana, conformando lugares característicos. 
Para comprenden como se encuentra conformada la región de estudio necesitamos determinar los tipos de tejido urbano y como lo vamos a relevar. Es por ello que según lo que propone argentina urbana (2011) en cuanto a los tipos de tejido se plantea la siguiente clasificación, para la cual se establecen dimensiones e indicadores (tabla 10).

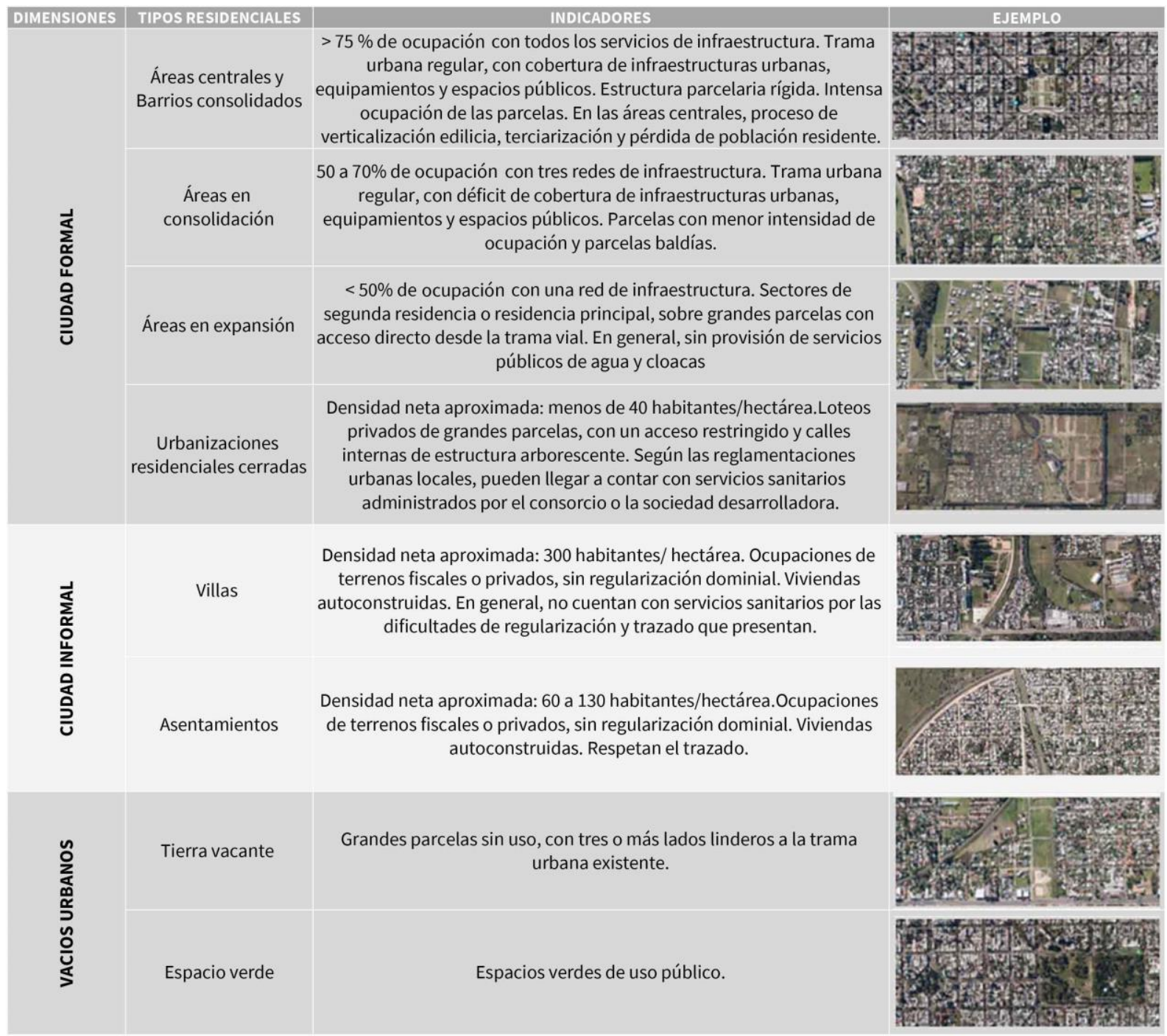

Tabla 10. Tipos de tejido.

Fuente: Jensen y Birche, 2016.

A partir de comprender e identificar los distintos tipos de tejidos, se observa que la ciudad está compuesta por estas "piezas” que evidencian la fragmentación que existe en el área urbana. Se elabora un plano (figura 39) en donde se observan los tres tipos de consolidación del área residencial, las urbanizaciones cerradas, villas y asentamientos y los grandes vacíos urbanos. Una configuración territorial diversificada y fragmentada, caracterizada por la disminución del suelo apto para usos productivos y la localización de asentamientos informales en planicies de inundación natural. 
La ciudad fragmenta surge como resultado de la transformación de la ciudad compacta tradicional, en este caso de la expansión del casco fundacional. Esta expansión y cambios en el tejido se da como consecuencia de los procesos de suburbanización recientes. Según Frediani (2010):

"El modelo de ciudad fragmentada surge en el marco del cambio de nuestros países a un nuevo paradigma económico, basado en el neoliberalismo y una fuerte influencia de la globalización. La reestructuración económica y social que se operó en la década de los '80 en casi todos los países latinoamericanos trajo aparejada la retirada del Estado, la privatización y la desregulación, permitiendo a los inversores, planificadores y ciudadanos mayores libertades, que se reflejan en la estructura de las ciudades. "(p.30)

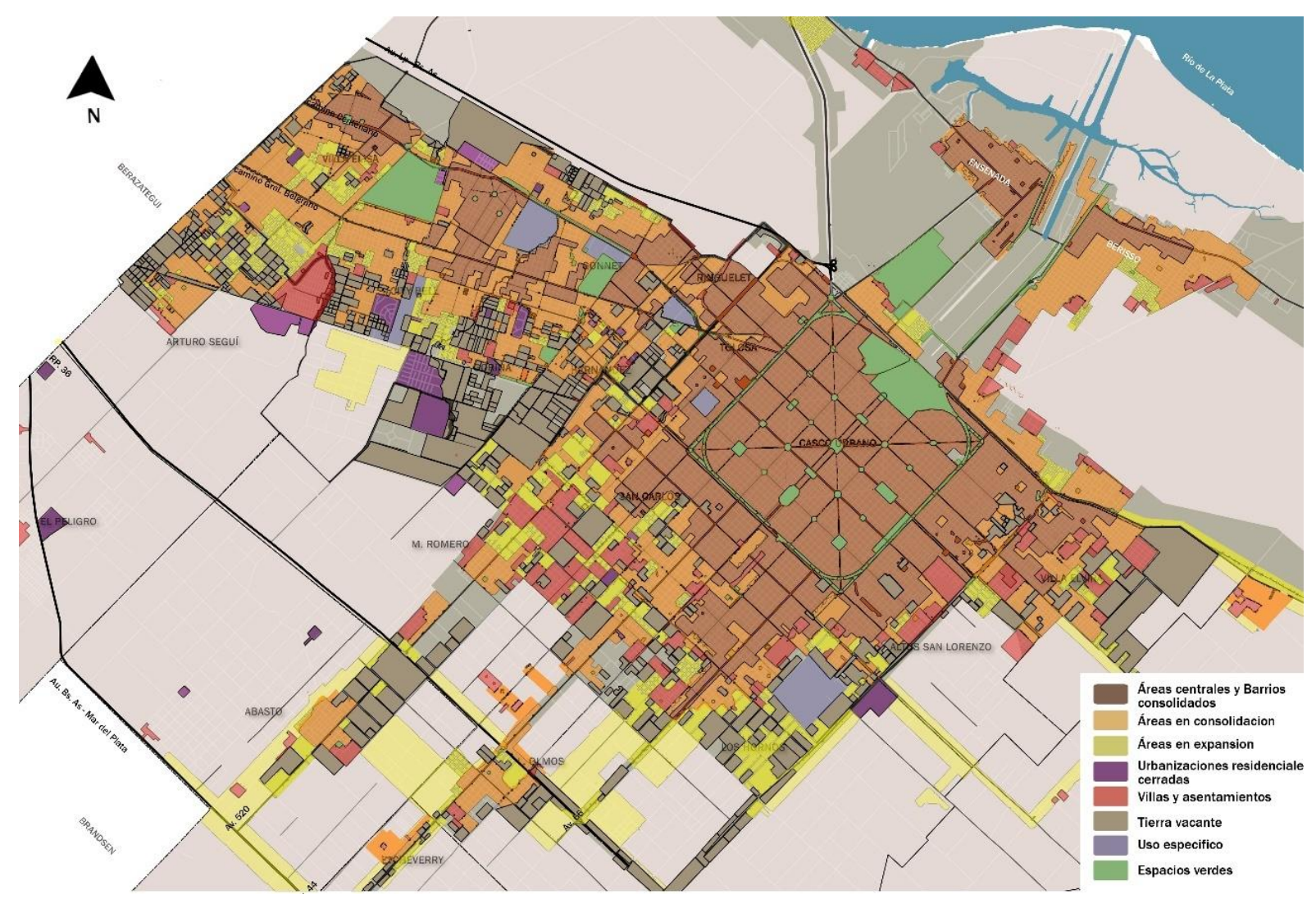

Figura 15. Estructura urbana.

Fuente: Elaboración propia en base a Jensen y Birche en GIS, 2017.

Se puede decir entonces que no se observa un crecimiento equilibrado ni tampoco compacto y que el área urbana se encuentra fragmentada, exceptuando el casco fundacional que presenta una situación más homogénea y consolidada como así también el primer anillo de desborde de este. Al observar la periferia se evidencia la fragmentación existente y se identifican zonas donde predominan las villas y asentamientos como lo es el sector sur este y zonas donde predominan las urbanizaciones cerradas como lo es el eje 
noroeste. En cuanto a los vacíos urbanos se observa la falta de espacios verdes que hay la periferia y la presencia de tierras vacantes.

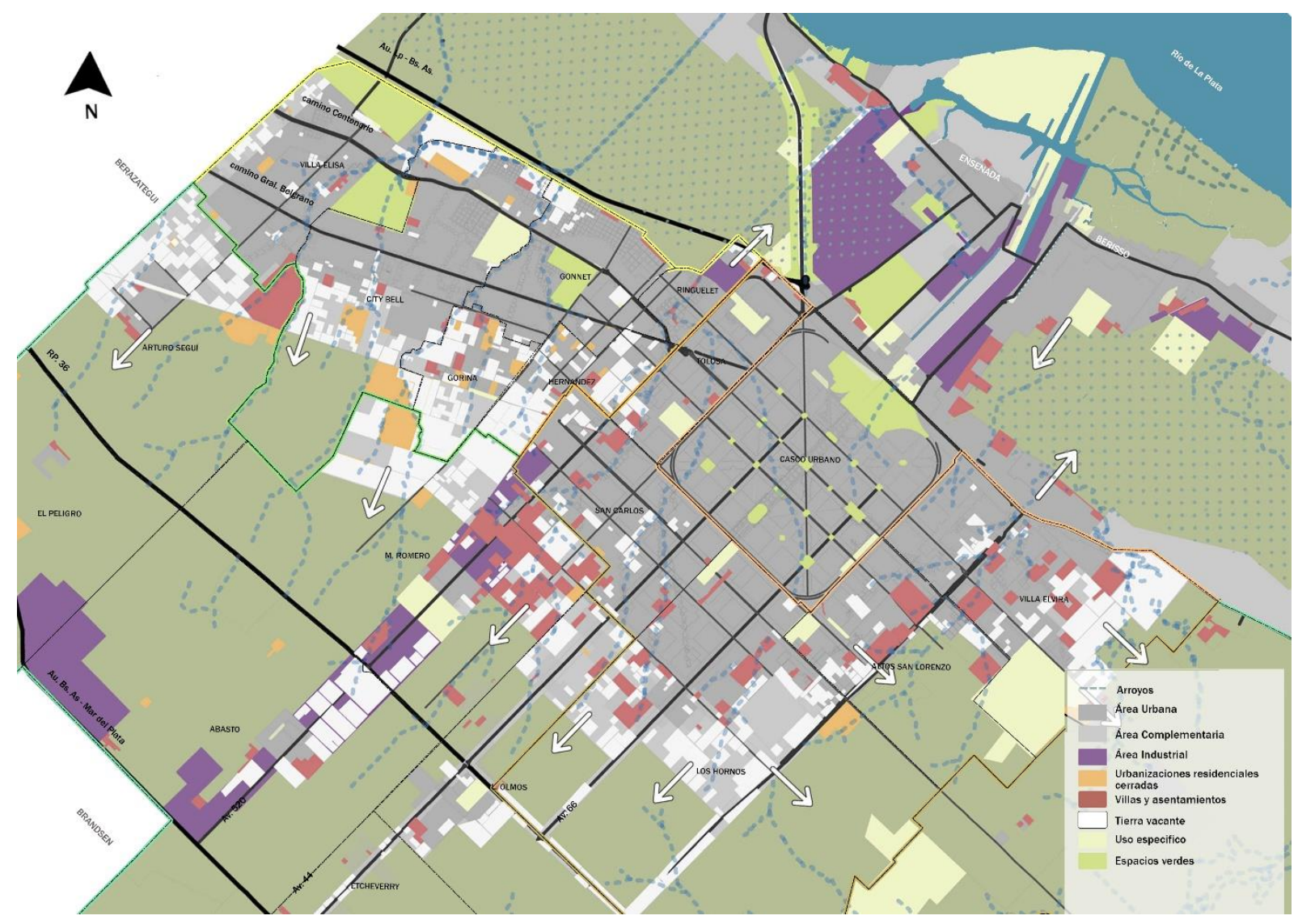

Figura 40. Plano de áreas.

Fuente: Jensen y Birche en GIS, 2018.

El tejido va perdiendo densidad a medida que se aleja de las vías vehiculares que estructuran la región. Se ve interrumpido por los arroyos y también por grandes equipamientos como hipermercados, barrios cerrados, clubs y también por grandes espacios verdes como la tradicional República de los Niños o el Parque Ecológico Municipal. Estos espacios constituyen hitos en un paisaje de casas de uno o dos niveles separadas en muchos casos por medianeras de poca altura y veredas arboladas, que configuran un paisaje tranquilo dentro de la cuadrícula ortogonal que forman sus calles, donde el verde se adueña tanto de los espacios públicos como privados (Figura 40). 


\section{CAPÍTULO 4}

El paisaje y los espacios verdes platenses

4.1 | Los espacios verdes de uso público y el paisaje en la periferia platense.

Relevamiento de los espacios verdes

4.2 | La falta de espacios verdes de uso público 


\section{CAPITULO 4}

“En la actual situación de nuestras metrópolis, sólo un elemento como el espacio libre puede ser capaz de articular, organizar, definir, explicar y dar sentido a la forma de la ciudad".

Enric Batlle58

\subsection{Los espacios verdes y el paisaje en la periferia platense. Relevamiento de los espacios verdes.}

Se entiende que el estudio del paisaje en un territorio complejo, debe ser abordado desde su conceptualización como sistema, es decir como un territorio que está conformado por diferentes patrones o sistemas territoriales interdependientes. Desde este punto de vista, para estudiar el paisaje de las periferias, se han diferenciado las configuraciones urbanas del área de estudio según su grado de consolidación y los patrones de ocupación predominantes (capitulo 2), y que por consecuencia tienen diferentes paisajes: centros periféricos urbano-rurales, periferias en construcción, periferias en consolidación y centros periféricos urbanos.

Los espacios verdes dentro de la ciudad se los diferencia según el estudio realizado en cuanto a su tamaño, al uso, el alcance, la vegetación y el equipamiento. De esta forma, se plantea estudiar aquellos espacios que tomando como base la definición de la Ley 8912/77 permitan incluir los espacios verdes de uso público de dominio privado y cumplan con las siguientes premisas (figura 41):

1- Poseer como función y destino el esparcimiento, recreación o la práctica de los deportes o juegos por parte de los habitantes, así como también el goce de cualidades estéticas del lugar.

2- Poseer una estructura en donde el elemento fundamental y característico generalmente sea la vegetación. Estos espacios ser portadores de elementos distintivos a nivel del paisaje circundante, como así también por la posibilidad de ofrecer desde el propio espacio, vistas generales del entorno

\footnotetext{
${ }^{58}$ En Colafranceschi, 2007 p. 130.
} 
3- Acceso libre y gratuito, es decir que no existan restricciones de acceso.

A partir de estos parámetros de relevamiento, la presente tesis pretende constituirse como una oportunidad para la estructuración del territorio desde la mirada del paisaje, identificando y poniendo en valor ciertos elementos que constituyen el paisaje urbano tales como el arbolado o la presencia de agua en los espacios verdes. Estos pueden adquirir diferentes funciones dependiendo de las necesidades y requerimientos de los habitantes del lugar, ya sea como lugar de esparcimiento y recreación, pero también como reservas de biodiversidad, corredores ecológicos (Armenteras y Vargas, 2015),

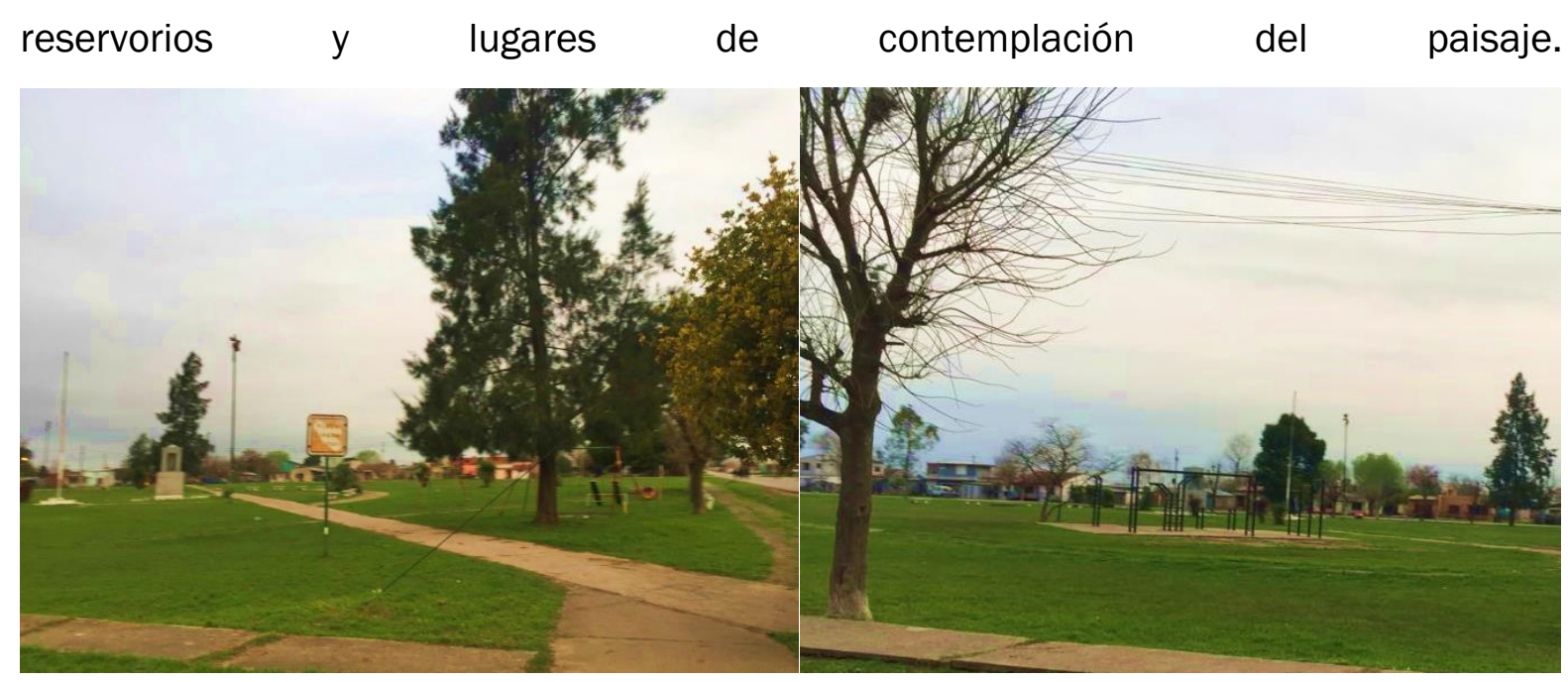

Figura 41. Plaza en calle 210 y 522.

Fuente: Imágenes del autor, 2017.

De esta forma, elementos como el arbolado y el agua cobran relevancia dentro del relevamiento de los espacios verdes si incorporamos variables que reflejan características del paisaje urbano. Según Appleton (1984, 1975), la relación del sujeto humano con el entorno percibido es comparable a la relación de un animal con su hábitat. La preferencia humana innata por las características del paisaje es una reacción espontánea al paisaje como hábitat. Para decirlo simplemente: preferimos aquellos paisajes que ofrecieron a nuestros ancestros primitivos las mejores posibilidades de supervivencia (Appleton, 1975; Orians, 1986). Nos gusta ver sin ser visto: preferimos paisajes que nos permitan escondernos, así como también explorar el entorno.

Además de los espacios semiabiertos, se considera que una abundancia de vegetación y una abundancia de agua son propiedades paisajísticas para las cuales tenemos una preferencia innata. Estas preferencias innatas son fáciles de explicar: necesitamos agua para sobrevivir, y la presencia de vegetación a menudo indica la presencia de comida, agua y un lugar donde esconderse (Birche y Jensen, 2018). 
La metodología propuesta parte de considerar al paisaje como el resultado de la acción entre el hombre y la naturaleza, que se expresa en la imagen de los procesos que tienen lugar en el territorio, ya sea correspondiendo al ámbito natural o humano aplicando métodos lógicos y empíricos. Los primeros a efectos de deducir, analizar y sintetizar el conocimiento existente, mientras que los segundos se aproximan al conocimiento del objeto a través de la observación empírica.

Como se mencionó anteriormente, se plantea como unidad de análisis a los espacios verdes de uso público de la periferia platense, sobre los cuales se focaliza la presente investigación. Estos espacios, se señalan como espacios estratégicos de estudio por constituirse naturalmente como atractores para la población, ser parte inherente de la estructura y la morfología urbana desde la fundación de la ciudad de La Plata y por estar constituidos a partir de la vegetación como elemento fundamental y característico, componente básico para el desarrollo de la vida. Estos espacios también son portadores de elementos distintivos a nivel del paisaje urbano circundante y ofrecen vistas generales del entorno, lo que los convierte en espacios estratégicos al momento de hablar de paisaje.

Según la metodología propuesta detallada anteriormente en el capítulo 2 apartado "el nivel superior de análisis, matriz contextual se prosiguió a relevar los espacios verdes mediante la matriz de análisis.

Se obtuvo un plano en gis donde se volcaron los diferentes valores en una tabla (ver anexo 3) para realizar el siguiente plano (figura 42):

A su vez se los desagrego por las variables propuestas para el relevamiento.

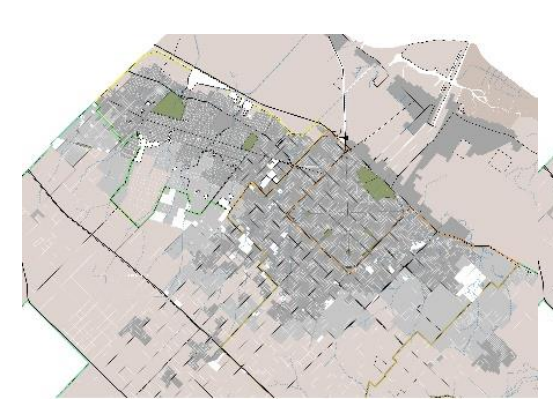

PARQUES

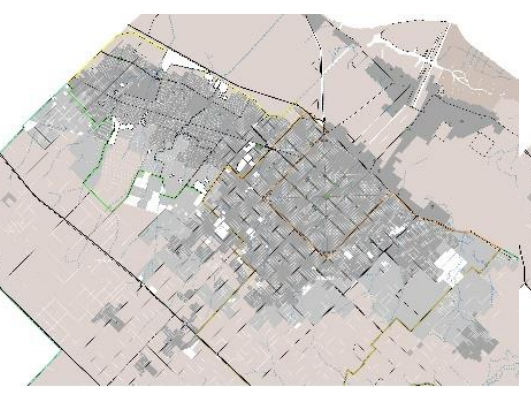

PLAZAS

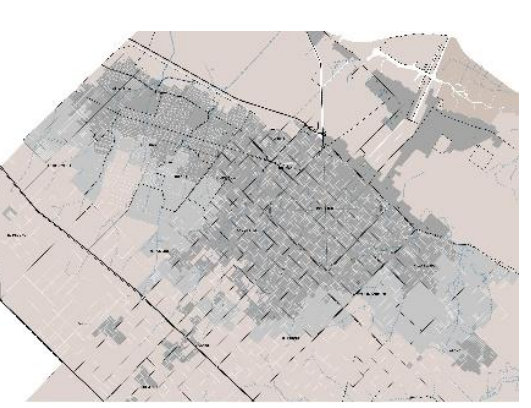

PLAZOLETAS 


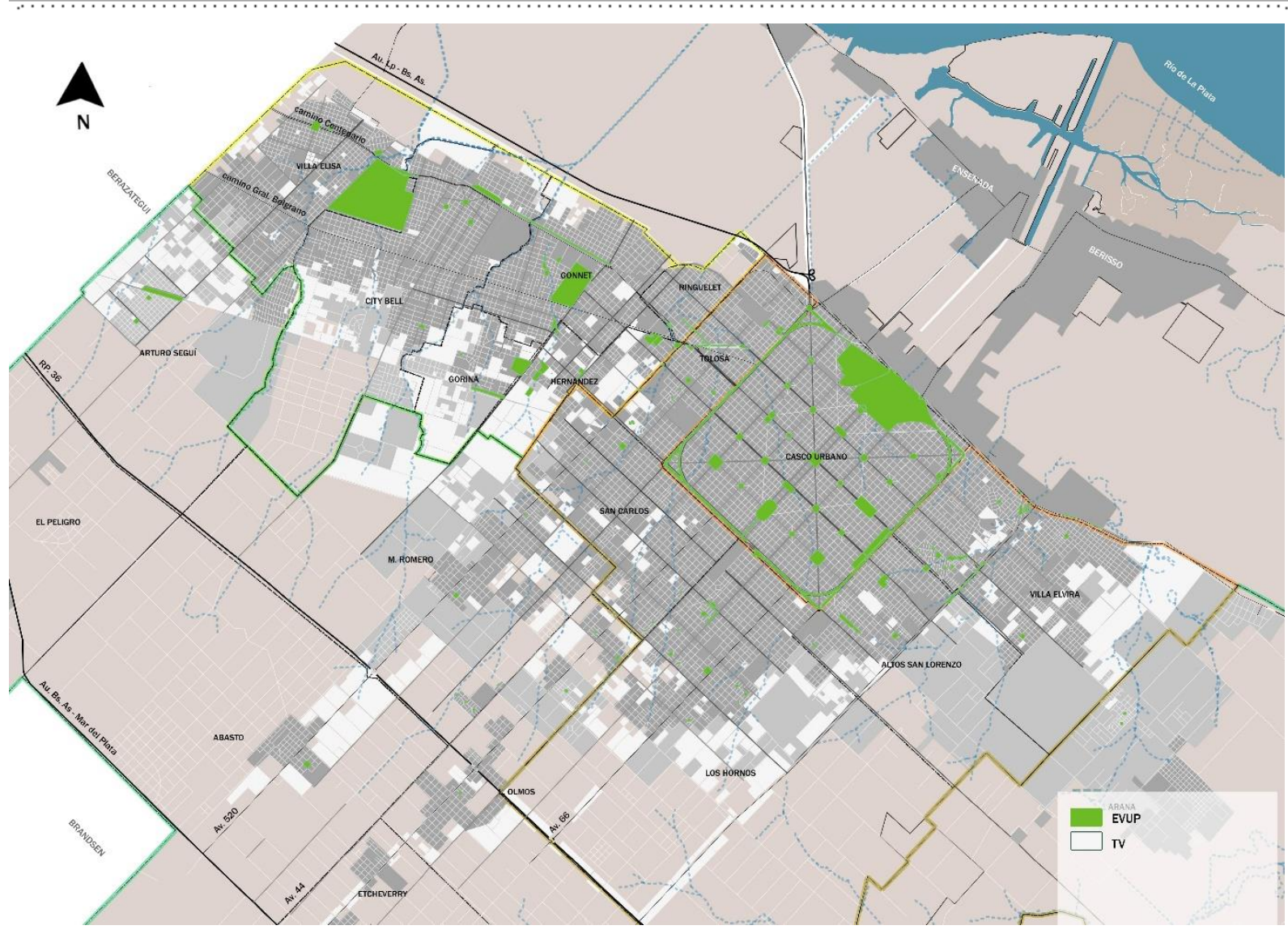

Figura 42. Espacios verdes de uso público. Fuente: Elab. propia en base a Jensen y Birche en GIS, 2016.

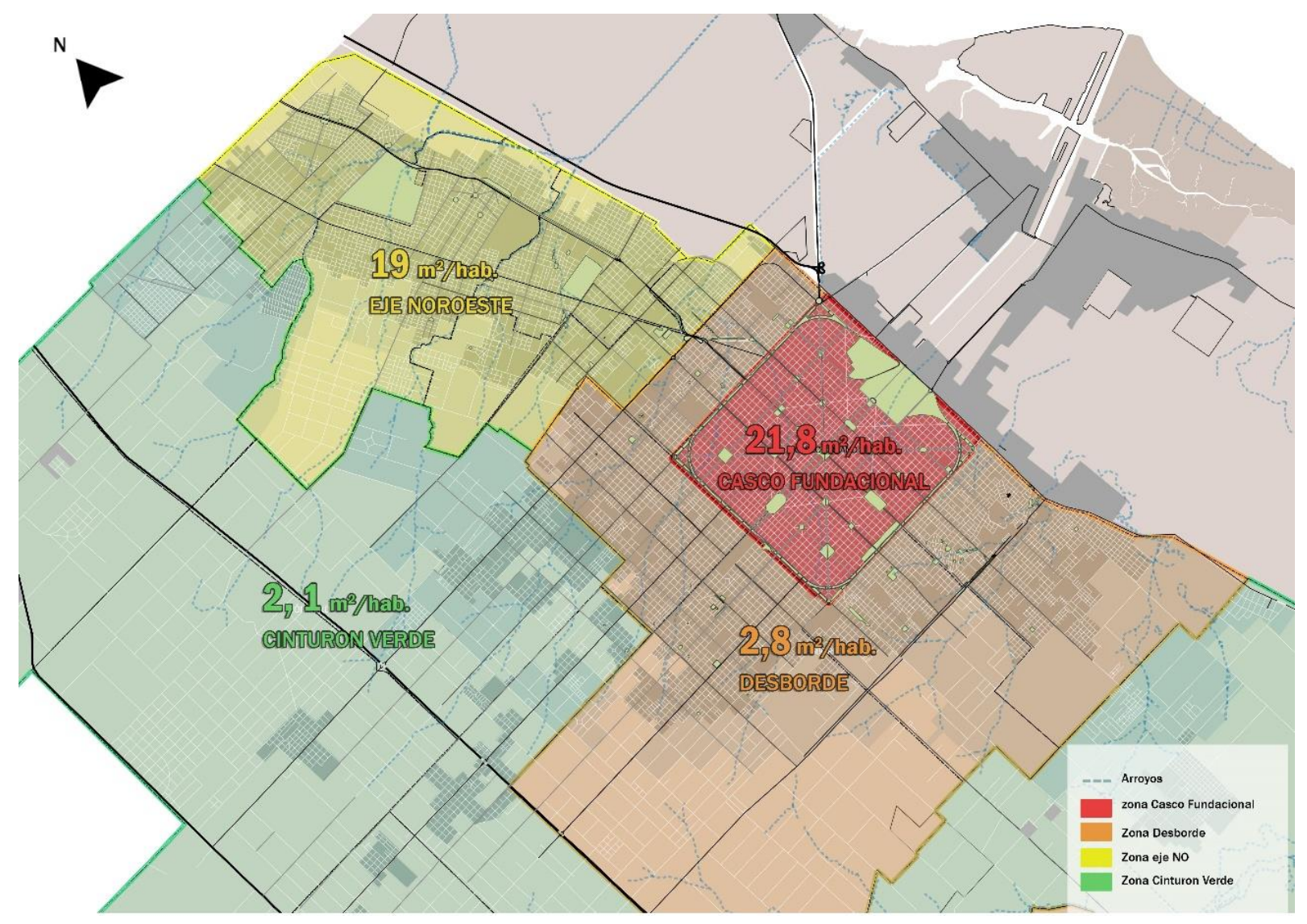

Figura 43.m2 de evup por hab. s/zona periferia. Fuente: Elab. propia en base a Jensen y Birche en GIS, 2017. 


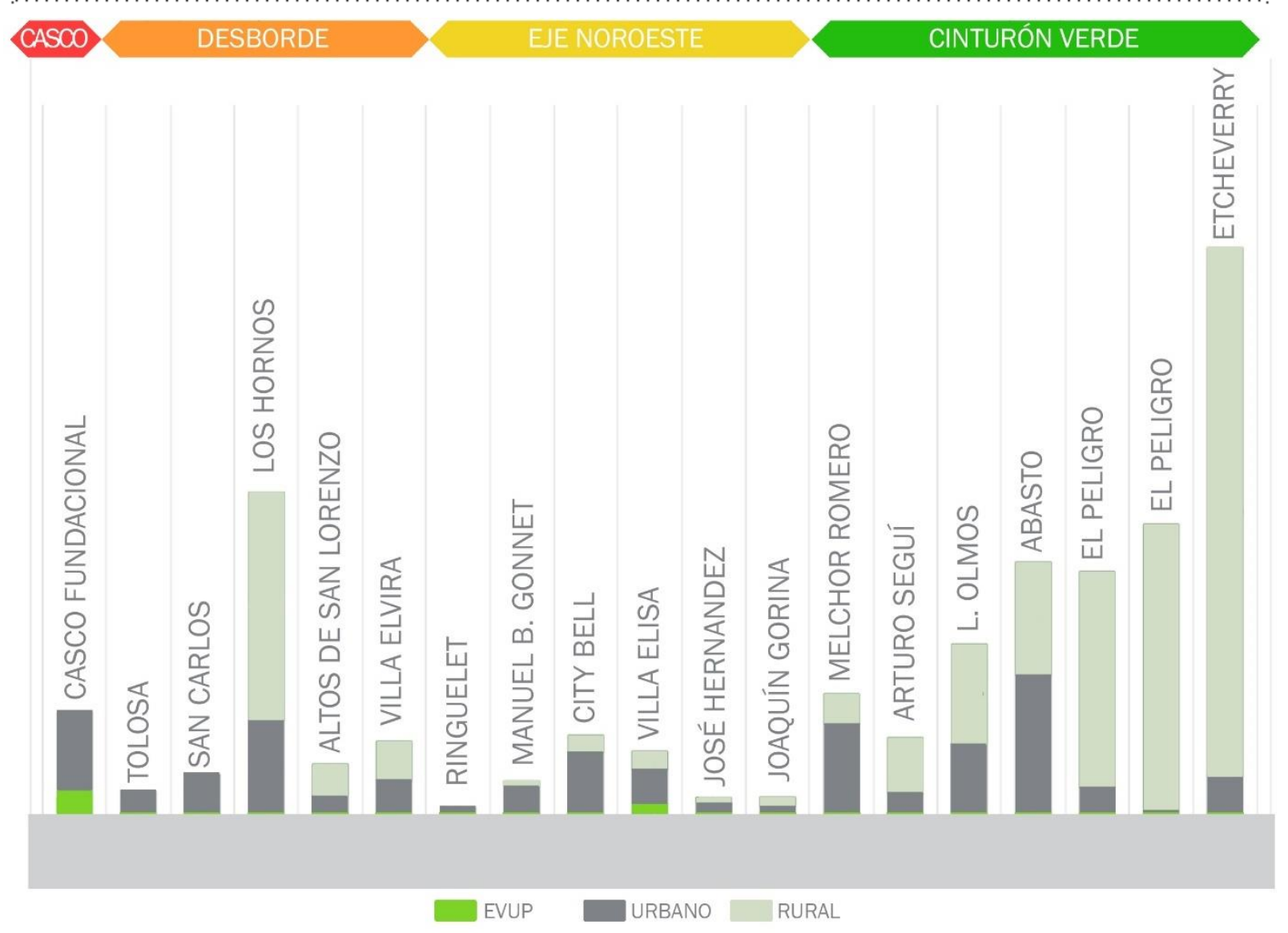

Figura 44. Relación de áreas de EVUP, área urbana y rural por delegación.

Fuente: elaboración propia, 2017.

De acuerdo a la zona de la periferia que se observe se ve la diferencia que hay en cuento a la relación de área urbana, área rural y EVUP59 (figura 44, 45). De esta manera se puede visualizar en el grafico como el casco posee un equilibrio en cuanto al área urbana y al área determinada para EVUP pero cuando se ven las distintas zonas de la periferia este porcentaje cambia. Aparece equilibrado en el eje noroeste pero en el desborde y en el cinturón verde los números cambian. En estos últimos predomina el área rural y lo destinado a área urbana es mucho menor.

Se puede observar entonces como se encuentran compuestas las zonas de la periferia en relación a la superficie urbana, espacio verde y la rural. Se evidencia lo distintas que son las zonas de la periferia y en cuales hay mayor porcentaje de suelo rural, mientras que en las zonas más urbanizadas el porcentaje de suelo rural disminuye.

${ }^{59}$ EVUP se refiere a espacio verde de uso público. Con esto se hace hincapié en el uso porque hay en la periferia espacios verdes de dominio privado y eso publico. 


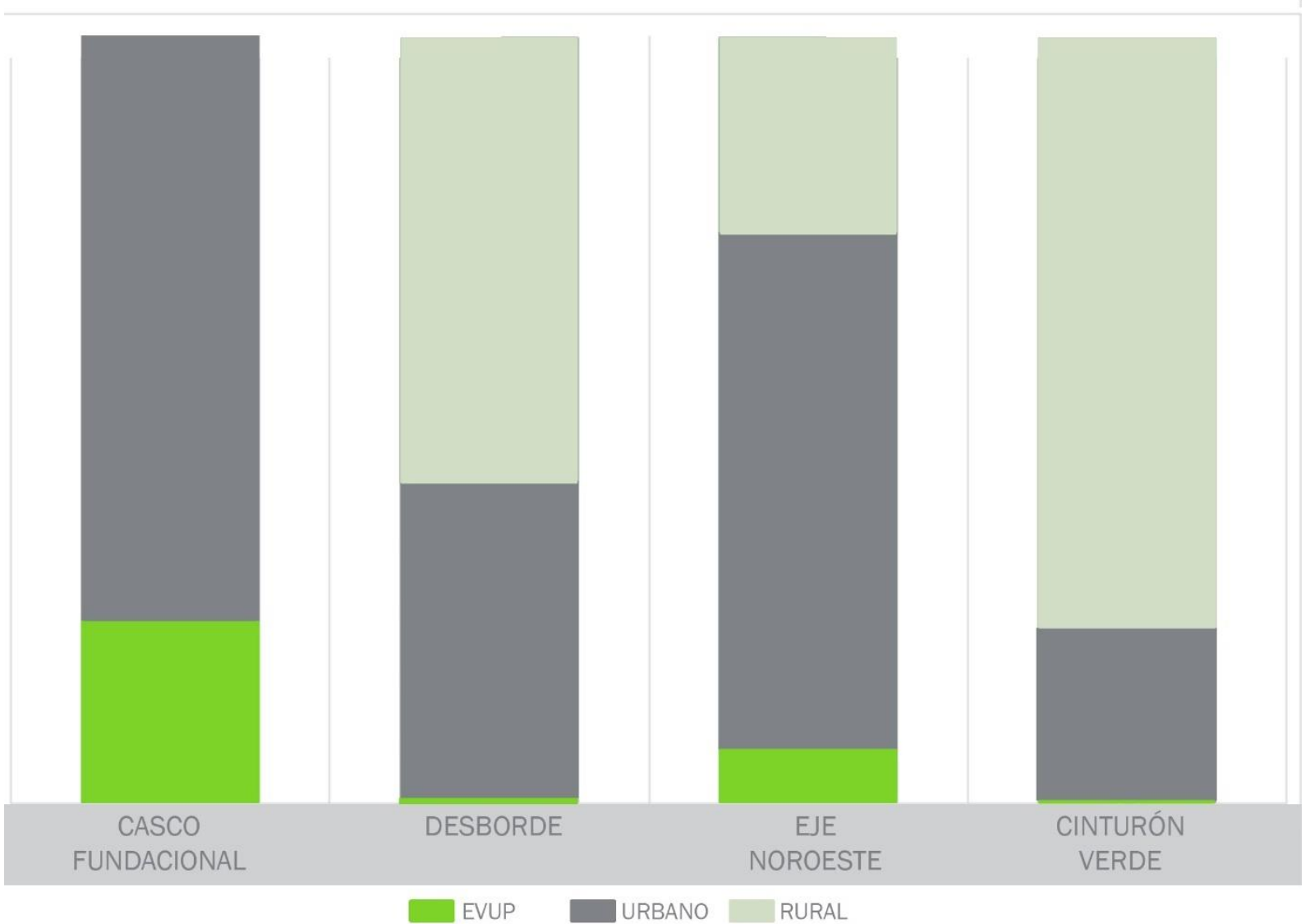

Figura 45. Relación uso de suelo urbano, espacio verde y rural.

Fuente: elaboración propia, 2017.

\section{Tipos de paisaje}

La división de un territorio en tipos de paisaje permite obtener mayor información sobre sus características y facilitar su tratamiento. A partir de aquí, se procedió a la delimitación de los tipos de paisaje presentes en la región. El concepto de tipo de paisaje sirve para diferenciar o comparar dos paisajes desde el punto de vista estructural. Es decir que permiten el entendimiento del territorio a través del paisaje y la articulación de los aspectos culturales y naturales, asumiendo la interacción continua entre ambos.

El concepto de tipo de paisaje también permite diferenciar unidades dentro de un mismo tipo de paisaje que posean algún tipo de protección o distinción. Entre ellas, se puede nombrar a la Reserva Natural Punta Lara, al Paseo del Bosque, la Cuenca del Arroyo El Pescado y el Monte Ribereño Isla Paulino, Isla Santiago.

En el Gran La Plata, los tipos de paisaje identificados se pueden agrupar en:

1 | Costa: es el área comprendida por el Río de la Plata hasta la costa de este. 
2 | Fluvial: comprende todos los canales y arroyos de la región, su respectivo cauce y planicie de inundación.

3 | Humedal: área comprendida entre el albardón costero y la terraza alta. Se caracteriza por ser zona de bañados.

4 | Urbano: comprende la zona urbana de la ciudad de La Plata, Berisso y Ensenada.

5 | Periurbano: área comprendida entre el patrón urbano y el frutihortícola.

6 | Frutihortícola: es un área extraurbana, que forma parte del cordón frutihortícola.

7 | Industrial: Comprende a el área donde se localizan la mayoría de las industrias en la región, principalmente distribuida entre el puerto y la ruta 36 .

En el plano (Figura 46) se pueden observar los tipos de paisaje identificados en la región y las zonas protegidas.

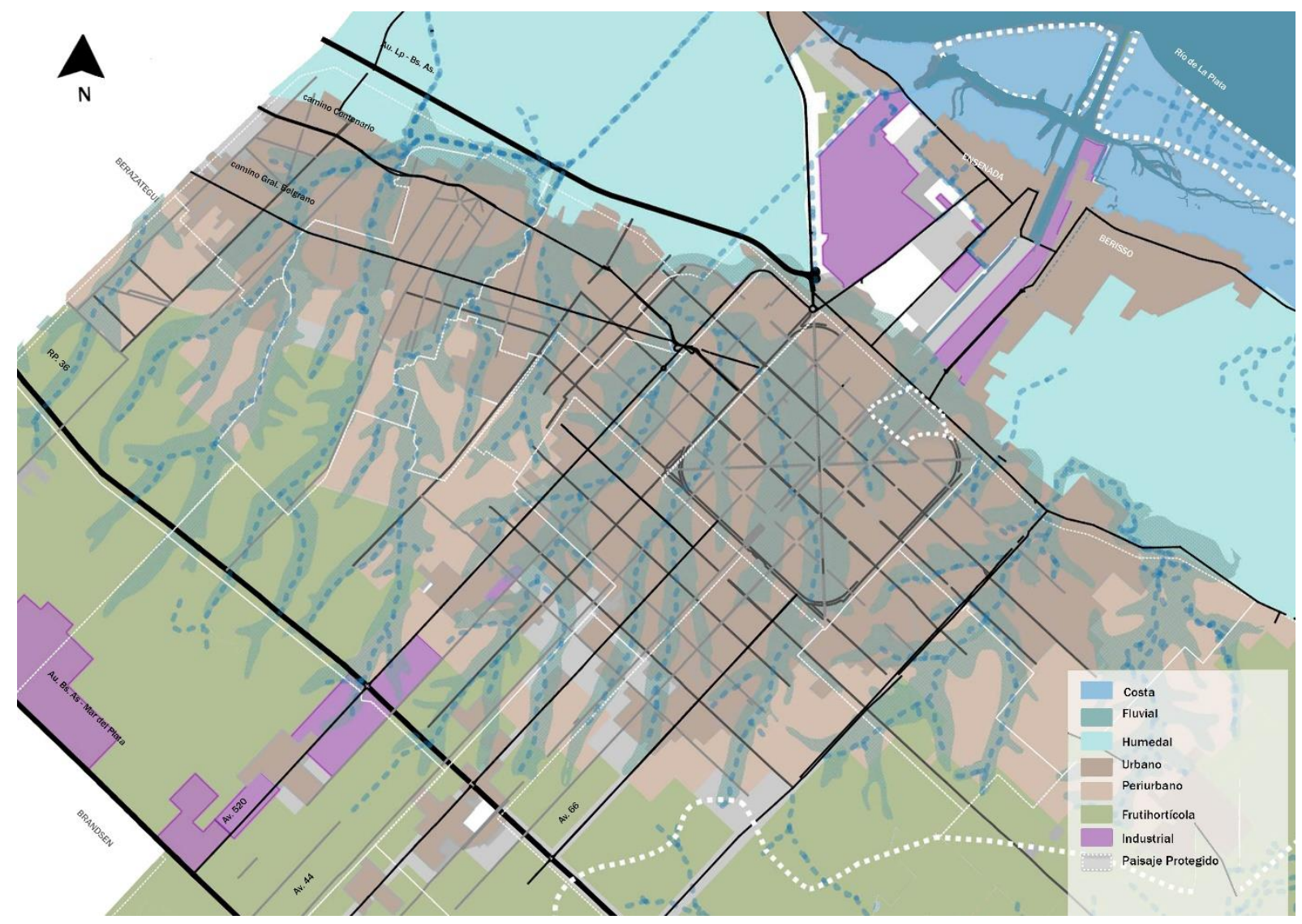

Figura 46. Tipos de paisaje.

Fuente: Elaboración propia en base a Jensen y Birche en GIS, 2018.

\section{2 | La falta de espacios verdes de uso público}

La región metropolitana de Buenos Aires tiene, en promedio, apenas 2,3 metros cuadrados de espacios verdes por habitante, en la zona sur los metros cuadrados de espacio verde por habitante suben por la presencia del Parque Pereyra. Como excepción se encuentra el casco fundacional de ciudad de La Plata donde se encuentra el mínimo de 
espacio verde por habitante que propone la Organización Mundial de la Salud (OMS) que es estipula entre 10 y $15 \mathrm{~m} 2$ por habitante. En este contexto, la ciudad siempre fue identificada desde su origen e historia temprana por las ideas de avanzada en materia urbanística y ambiental, pero actualmente enfrenta el desafío de recobrar parte de aquella impronta perdida. Por fuera del casco fundacional, en la periferia platense no se encuentran los espacios verdes de uso público mínimos y la mayoría están degradados.

El cuadrado fundacional representa una suerte de oasis y es uno de los valores del plano fundacional la presencia, cada seis cuadras, de una plaza, a cada una de las cuales, además, se dotó de un rico patrimonio forestal que se extendió también a lo largo de todas las calles del casco urbano, disponiéndose desde entonces de un recurso natural que el sólo transcurso de los años encarece cada vez más. Pero aquel lineamiento previsto de los fundadores no se respetó, cuando el crecimiento urbanístico superó los límites del plano original, generándose y permitiéndose en la periferia una expansión que dejó de prever la disponibilidad de espacios verdes en los barrios, perdiéndose por consiguiente no sólo esa identidad sino privándose a los vecinos de la alternativa de contar con lugares de esparcimiento. Este crecimiento sin tener en cuenta espacios verdes de uso público alteró profundamente los principios que planteaba la creación de una ciudad de vanguardia, que había puesto su acento en respetar la relación equilibrada que debe existir entre los espacios verdes y la cantidad de habitantes.

Como se mencionó anteriormente, la periferia ha constituido el emplazamiento natural de los procesos de crecimiento urbano60, lo que permite reflexionar sobre su complejidad como realidad urbana y territorial. En el contexto latinoamericano, las cifras que contabilizan la cantidad de espacio verde por habitante resultan insuficientes al compararlas con los parámetros que sugiere la OMS. La OMS sugiere un mínimo de $10 \mathrm{~m}^{2}$ por persona y una situación óptima de $15 \mathrm{~m}^{2}$ por persona. Exceptuando el caso de Santiago de Chile que cuentan con el mínimo de $10 \mathrm{~m}^{2}$ y la excepcional situación de Curitiba con $52 \mathrm{~m}^{2}$ de espacio verde por habitante, la mayoría de las grandes metrópolis (figura 47) no cumplen con estos estándares como es el caso de Bogotá con 5,9 m², San Pablo 4,2 $\mathrm{m}^{2}$, Lima $2 \mathrm{~m}^{2}$ y Buenos Aires con 1,9 $\mathrm{m}^{2}$.

\footnotetext{
${ }^{60} 80 \%$ de la población de América Latina vive en ciudades, lo cual expresa contundentemente el nivel alcanzado por los procesos de urbanización.
} 


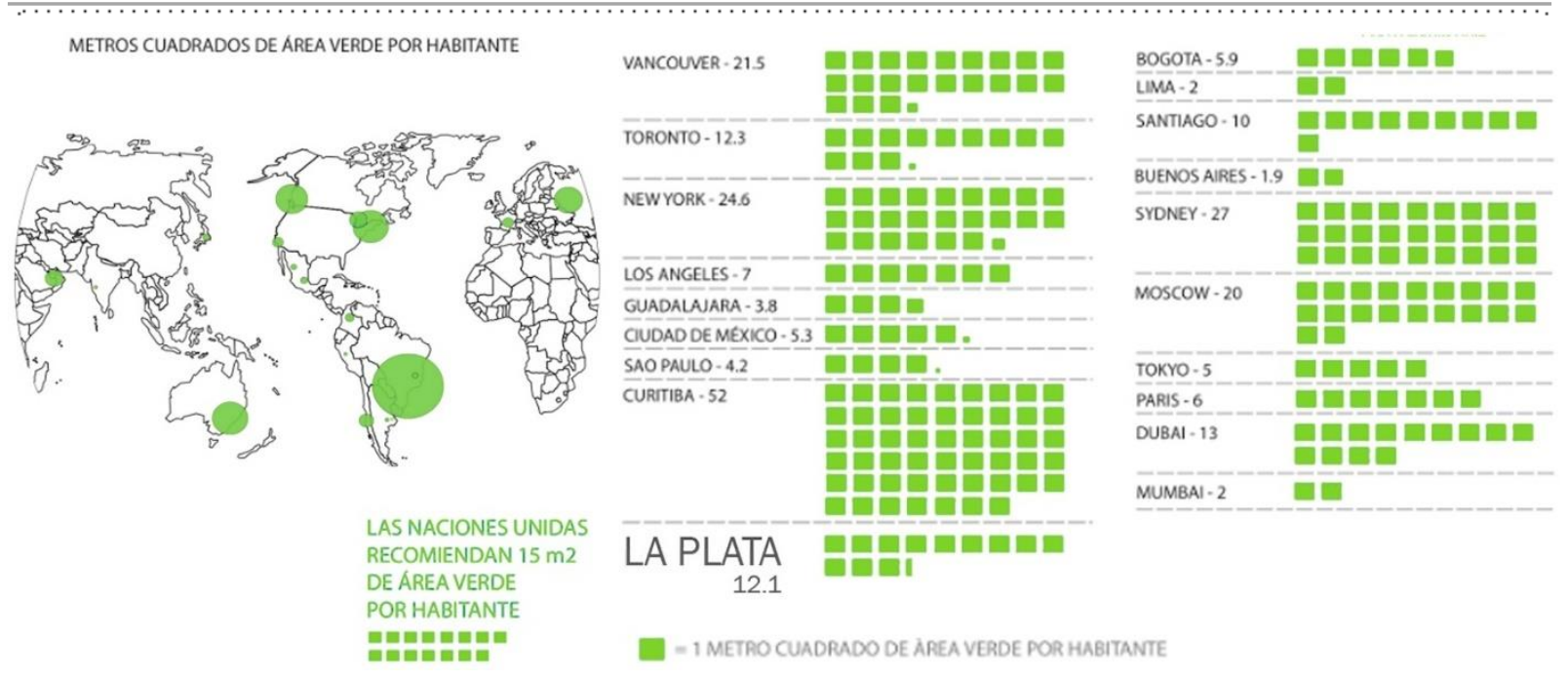

Figura 47. m2 de espacio verde por habitante en diferentes ciudades del mundo.

Fuente: Elaboración propia en base a http://taller13.com/blog/metros-cuadrados-de-areas-verdes-porhabitante/\#prettyPhoto

En este contexto, la Ciudad de La Plata61 se ubica por encima del mínimo establecido llegando a contar con $12,1 \mathrm{~m}^{2}$ por habitante.

Siguiendo las recomendaciones de la OMS, la Organización de las Naciones Unidas recomienda a los países que las ciudades deben tener al menos $16 \mathrm{~m}^{2}$ de área verde por persona. Sin embargo, si analizamos la ubicación espacial de los espacios verdes, las cifras pueden resultar un tanto engañosas, como es el caso de la ciudad de La Plata, que desarrollaremos más adelante, incorporando el concepto de radio de cobertura de manera de trabajar con la dimensión espacial.

Considerando la situación expuesta, la falta de espacios verdes a nivel generalizado y particularmente en las áreas periféricas, los espacios verdes públicos han tenido que encontrar nuevas formas de adaptación que den respuesta a las demandas de los habitantes. Han perdido la formalidad del dominio público y encontrado nuevos lugares de uso colectivo que constituyen nuevos ámbitos de apropiación social cuyo carácter público puede resultar equivoco por alejarse de la noción convencional de lo público (Arroyo, 2011)

En este sentido, el concepto de espacio de uso público o espacio colectivo refiere a aquellos lugares englobados en el territorio urbanizado que como plantea Cerasi (1990), tienen una incidencia sobre la vida colectiva, definen un uso común para amplios estratos de la población y que constituyen la sede y los lugares de su experiencia colectiva. Esta

\footnotetext{
${ }^{61}$ Capital de la provincia de Buenos Aires, Argentina. La ciudad constituye el centro del sexto aglomerado urbano con más habitantes del país con 787.294 habitantes según el Censo Nacional de Población, Hogares y Viviendas 2010.
} 
diferenciación, si bien define un objeto de estudio más amplio y complejo, permitirá captar los nuevos ámbitos de apropiación urbana específicamente en la periferia de La Plata, aportando un componente original al trabajo que le permitirá diferenciarse de otras investigaciones referidas a espacios verdes.

En la bibliografía en general y en el ordenamiento jurídico argentino se denomina como espacio público a aquel que es de dominio público, es decir que el Estado es propietario de la parcela en cuestión. La Ley 8912/77 de Ordenamiento Territorial y Usos del Suelo de la Provincia de Buenos Aires, establece en su Art. 8 que los espacios verdes y libres públicos son aquellos sectores públicos en los que predominan la vegetación y el paisaje y cuya función principal es servir a la recreación de la comunidad y contribuir a la depuración del medio ambiente, agrega además en su Art. 13 que debe existir un mínimo de $10 \mathrm{~m}^{2}$ de estos espacios por habitante, computando las plazoletas, plazas y parques públicos, ya sean comunales o regionales (tabla 11). Particularmente en la ciudad de La Plata, el Código de Espacio Público de la Municipalidad define a los espacios verdes como espacios de uso colectivo, definición que resulta confusa si se tiene en cuenta que previamente define al espacio público como la red de espacios conformada por el conjunto de espacios abiertos de dominio público y uso social. De esta forma, se reconoce el carácter colectivo de estos espacios, pero el término se ve restringido por el carácter dominial de la propiedad, como se explica más adelante. Respecto de las áreas verdes, solo se cuantifica la cantidad que debe haber por habitante sin incluir otros parámetros como el área de influencia. En la ley 8912, se distingue una proporción según el tipo de espacio verde.

\begin{tabular}{|c|c|c|c|c|c|}
\hline Fuente & $\begin{array}{c}\text { Superficie mínima } \\
\text { de Areas verdes } \\
\mathrm{M}^{2} / \text { hab. }\end{array}$ & $\begin{array}{c}\text { Superficie óptimna } \\
\text { de Areas verdes } \\
\mathrm{M}^{2} / \mathrm{hab} .\end{array}$ & \multicolumn{2}{|c|}{$\begin{array}{l}\text { Según tipo } \\
\mathrm{M}^{2} / \mathrm{hab} \text {. }\end{array}$} & $\begin{array}{c}\text { Radio de } \\
\text { cobertura } \\
\mathrm{Km}\end{array}$ \\
\hline OMS & 9 & 15 & \multicolumn{2}{|l|}{-} & - \\
\hline ONU & 16 & - & \multicolumn{2}{|l|}{-} & - \\
\hline \multirow{3}{*}{$\begin{array}{l}\text { Ley } 8912 / 77 \\
\text { Provincia de } \\
\text { Buenos Aires }\end{array}$} & \multirow{3}{*}{10} & \multirow{3}{*}{ - } & $\begin{array}{l}\text { Plazoletas, plazas o } \\
\text { espacios vecinales }\end{array}$ & 3,5 & - \\
\hline & & & $\begin{array}{l}\text { Parques urbanos y } \\
\text { comerciales }\end{array}$ & 2,5 & - \\
\hline & & & Parques regionales & 4 & 60 \\
\hline
\end{tabular}

Tabla 11. Recomendaciones sobre la superficie de áreas verdes.

Fuente: Jensen y Birche, 2017. 
El déficit de espacios verdes públicos constituye una de las principales problemáticas de las ciudades argentinas. Una ciudad que no puede ofrecer a sus ciudadanos suficiente cantidad de espacios verdes, de acceso público y distribución homogénea, proporcional al número de habitantes, ejerce una enorme presión adicional sobre los espacios verdes existentes, sobre su entorno periurbano y sobre el ambiente.

En general, cuando estos espacios fueron creados, estaban dirigidos a un radio de usuarios determinado y con expectativas de uso específicas. Al aumentar la densidad urbana, desbordan su capacidad de carga y requiere la generación de nuevos.

Uno de las amenazas que presentan hoy los espacios verdes públicos en las ciudades es convertirse en vacíos urbanos, en espacios sin función y sin uso, dejando de ser espacios convocantes y dinamizadores de actividad urbana para convertirse en focos de degradación e inseguridad. Por otra parte, ante el crecimiento extremo de los niveles de inseguridad en la sociedad, los espacios públicos tienden a encerrarse tras rejas o muros, con delimitaciones físicas y/o simbólicas, que los fragmenta y que los desarticula del resto de la ciudad.

En este contexto, se puede decir que una de las consecuencias de la falta de estos espacios son los efectos perjudiciales de las acciones no planificadas, que no consideran su incidencia sobre el paisaje, se manifiestan a través de la degradación de sus características distintivas, de la disminución de los valores naturales o culturales, y del debilitamiento del vínculo entre la comunidad y la tierra (Castelli y Sapallasso, 2007).

De esta forma, se puede sostener que los espacios verdes otorgan calidad y cualidad a la ciudad y, por ende, deben constituir uno de los ejes de acción en el marco de las políticas públicas. En esa línea, cabe preguntarse ¿dónde y cómo actuar para revertir los procesos de degradación, para dinamizar los procesos de su reconversión desde la noción del paisaje y propiciar la creación de un sistema de espacios verdes que atiendan a nuevas demandas de la población? Es por esto que los planes, programas y proyectos articulados y formalmente reconocidos con base en datos válidos construidos sobre una base metodológica que integre cuestiones interdisciplinarias desde distintos enfoques, conforman en la actualidad los instrumentos centrales de la gestión urbana para planificar y operar sobre la complejidad del ambiente construido.

El avance de la frontera urbana y la expansión más allá del tejido que establecía el proyecto original para la ciudad han desequilibrado la relación entre espacio libre, espacio 
construido y habitantes. En este contexto, se empiezan a desarrollar proyectos que ofrecen como ventaja la provisión de áreas verdes en zonas alejadas al casco fundacional. Mas allá de los espacios verdes de uso público que se encuentran dentro del casco las nuevas actividades requieren de espacios complementarios.

La Plata posee un sistema de espacios verdes de trascendencia patrimonial cuya puesta en valor, en base a estudios de carácter científico, enriquecería el ámbito público con la disposición de testimonios singulares del pasado, para el goce de la población actual y futura.

"La reconquista, o simplemente la conquista, de una identidad urbana platense y de toda reconstrucción de toda una cultura urbana local deberá pasar por un redescubrimiento del plano de 1882 y por una reapropiación de los espacios públicos. Toda tentativa de mejorar la apropiación de la ciudad y de valorizar una cultura urbana de los espacios públicos necesitará a la vez un trabajo de información histórica, al que se podría llamar reconquista de la memoria colectiva, y de reanimación de un sentido simbólico olvidado." (Garnier, 1992, p.21)

La situación expuesta se verifica si se incluyen los datos correspondientes al Censo Nacional de Población, Hogares y Viviendas 2010 y su proyección poblacional al año 2017. Esto último, permite establecer una cantidad de metros cuadrados por habitante según las zonas adoptadas, identificando como la zona más crítica a la zona de desborde urbano.

Si partimos de considerar que en la zona de desborde urbano residen más de 250.000 personas (constituyendo la zona con mayor cantidad de habitantes, superando incluso al casco urbano), resulta coherente preguntarse qué tipo de planificación respecto a los espacios verdes han tenido lugar en estas zonas periféricas. Particularmente en esta zona, la adyacencia al casco fundacional se convierte en una presencia ilusoria que no hace más que crear un fuerte contraste entre un diseño ideal (avenidas y plazas cada seis cuadras) y la realidad urbana del sector.

Las desigualdades entre sectores sociales significan acceso desigual a la vivienda, infraestructura y servicios urbanos y también al espacio público, conforman una distancia y por lo tanto devienen en segregación socio espacial (Segura, 2014). Esta desigualdad de acceso a infraestructuras y servicios se evidencia en la periferia platense donde la posibilidad no es la misma en todas las zonas y el nivel socio económico de la población es muy diferente. 


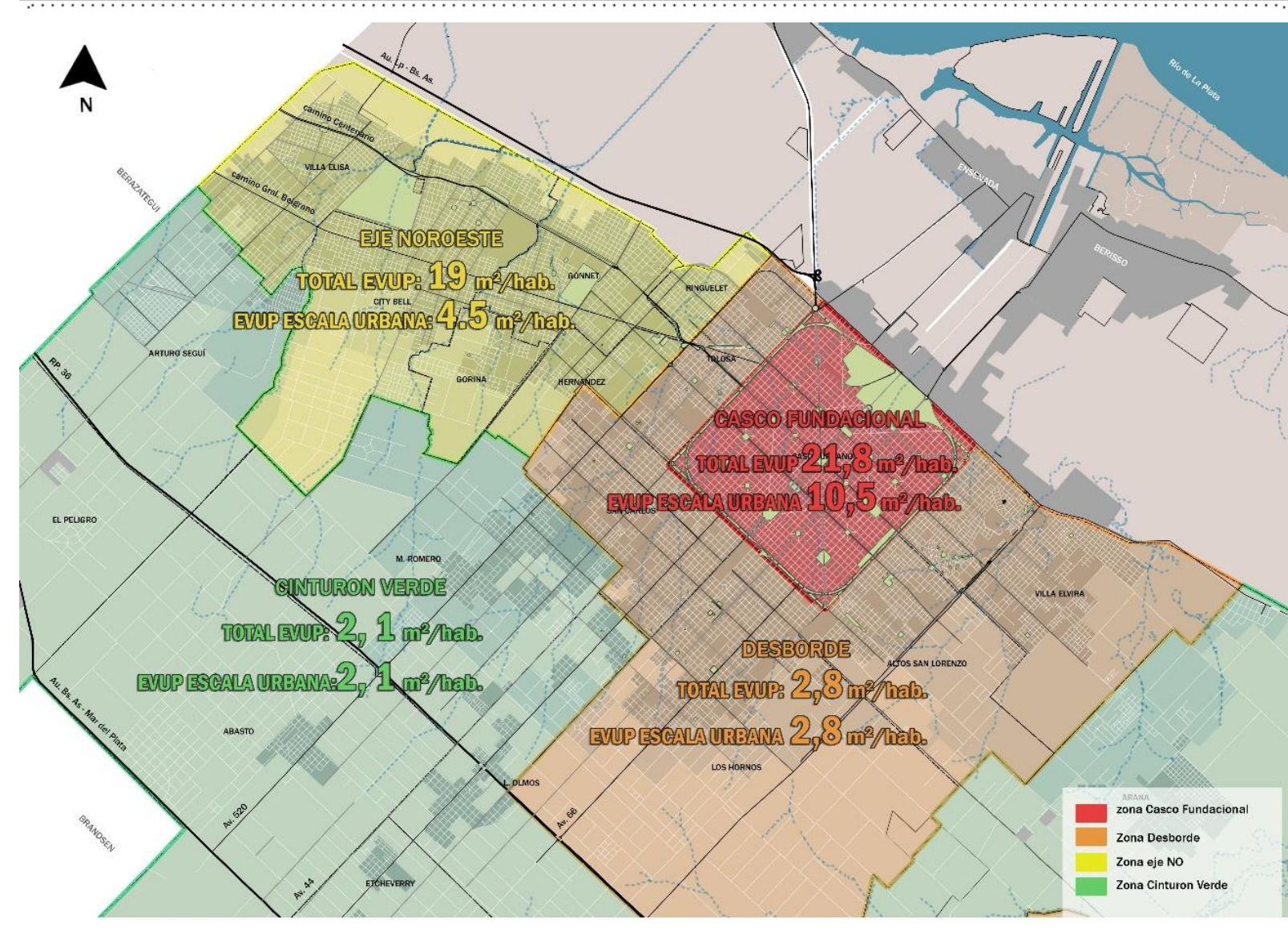

Figura 16. Plano con las zonas de la periferia y los EVUP total y a escala urbana.

Fuente: Jensen y birche, 2017.

Los números de espacio verde por habitante en las zonas de cinturón verde y eje noroeste están por encima del mínimo que requiere la OMS. Sin embargo, esto no se verifica desde la distribución espacial de los espacios verdes resulta discontinua y no logra conformar un sistema como si sucede dentro del casco urbano. Es decir, lo que se pretende mostrar es la falta de cobertura espacial de espacios verdes, el mínimo requerido en relación habitante por metro cuadrado da pero no se corrobora a nivel espacial cuando solo hablamos de los espacios urbanos. De este modo, las zonas que están por encima de lo que recomienda la OMS cuando le restamos los parques regionales, los espacios que no son de escala barrial, descienden considerablemente.

En base al relevamiento realizado (figura 48), se puede observar que si bien la zona del eje noroeste y del cinturón verde supera el mínimo de espacios verde por habitante la zona no ofrece una cobertura suficiente del área urbana, dejando grandes sectores sin acceso a espacios verdes. Por otra parte, la situación más crítica se observa en la zona de desborde donde la superficie de espacios verde por habitante es de 2,8 m². 


\begin{tabular}{|c|c|c|c|}
\hline Zonas de análisis & $\begin{array}{c}\text { Areas Verdes } \\
\text { M2 }\end{array}$ & $\begin{array}{c}\text { Areas Verdes } \\
\text { M2/hab. }\end{array}$ & $\begin{array}{c}\text { Area verde X Hab. } \\
\text { sin parques } \\
\text { regionales M2 / } \\
\text { Hab }\end{array}$ \\
\hline Casco & $4,607,812.9$ & 21.8 & 10.5 \\
\hline $\begin{array}{c}\text { Desborde } \\
\text { Eje Noroeste }\end{array}$ & $702,438.9$ & 2.8 & 2.8 \\
\hline Cinturón Verde & $3,355,559.6$ & 19.0 & 4.5 \\
\hline TOTAL LP & $\mathbf{1 8 5 , 1 4 9 . 0}$ & 2.1 & 2.1 \\
\hline
\end{tabular}

Tabla 12. M2 de áreas verdes por habitante y áreas verdes a escala urbana sin parques regionales.

Fuente: elaboración propia, 2017.

Si tomamos lo que propone la ley 8912/77 que establece un mínimo de espacio verde por habitante, pero lo separa según la cantidad de acuerdo al tipo de espacio verde y se le restan los parques regionales solo verifica el casco con $10.5 \mathrm{~m} 2$ ya que de espacios verdes a nivel barrial propone un mínimo de $6 \mathrm{~m} 2$ (tabla 12).

\section{Radios de cobertura}

Para incorporar la dimensión espacial, se parte de incorporar el concepto de área de influencia62, que en este caso se propone una reelaboración del concepto trabajándolo como radio de cobertura. Entendiendo a este como las zonas que poseen cobertura de espacios verdes (figura 49), pensando en los espacios verdes como una infraestructura o un servicio más de los que brinda la ciudad.

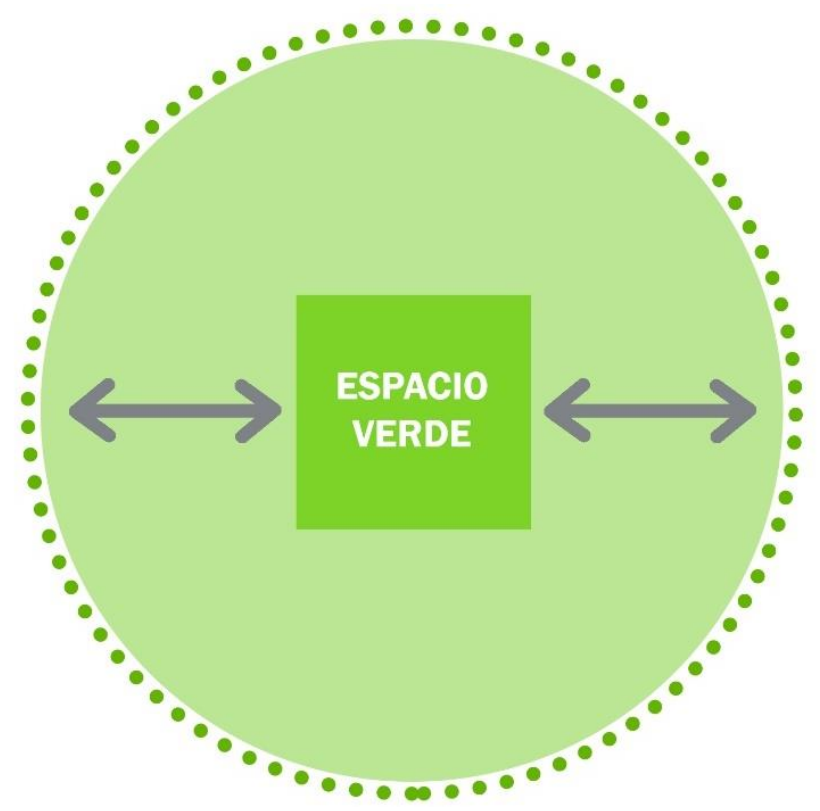

Figura 17. Radio de cobertura EVUP.

Fuente elaboración propia, 2017.

62Una esfera de influencia o zona de influencia es un área o región en la cual una organización o estado ejerce cierta clase de indirecta dominación cultural, económica, militar o política. 
De esta manera, se pone como elemento principal al hombre o a los habitantes donde no se habla de la influencia que tienen los espacios verdes sobre el territorio, sino que habitantes están cubiertos y pueden gozar de estos espacios. Se incorpora al habitante y a la dimensión urbana, permitiendo identificar las áreas por fuera de estos radios y por lo tanto no poseen acceso a áreas verdes.

Para determinar estos radios, se analizó la legislación local y también investigaciones que trabajan con estos conceptos como se observó en el capítulo 3 apartado 3.3. Para suplir la falta de especificaciones en cuanto a las reglamentaciones legales, se toman parámetros del Plan verde de Valencia (1992), del Plan especial de indicadores de sostenibilidad ambiental de la actividad urbanística de Sevilla (2010) y del libro Biodiversidad Urbana (2013), de Garay y Fernández, lo que permite definir al radio de cobertura como la distancia máxima que una persona puede recorrer en pos de acceder a un espacio verde, según su tipo y adoptar medidas acordes para cada tipo (figura 50).

Según plantea Garay y Fernandez (2006) una persona caminando debe estar a no más de 2000m de un parque local, a $800 \mathrm{~m}$ de una plaza y siguiendo esta lógica se estima que a $400 \mathrm{~m}$ de una plazoleta o corredor. De esta manera, teniendo en cuenta lo que plantean ellos y los datos recabados en la encuesta se determinan los radios de cobertura de los EVUP donde se manifiesta claramente que zonas urbanas no poseen cobertura de estos.

En la encuesta (ver anexo 1) se pudo contrastar que la gente caminaría en promedio unas diez cuadras para llegar a un espacio verde, por lo que la determinación de hasta $800 \mathrm{~m}$ sería una distancia aceptada por los habitantes (figura 51).

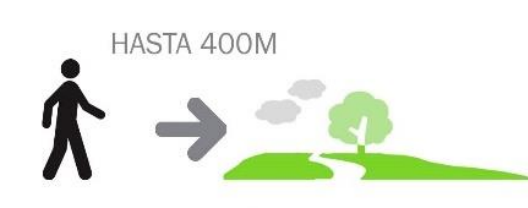

PLAZOLETA / CORREDOR

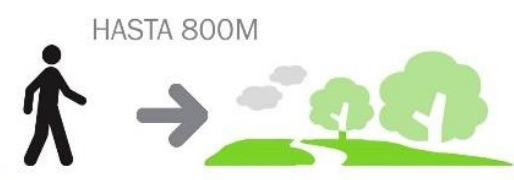

PLAZA

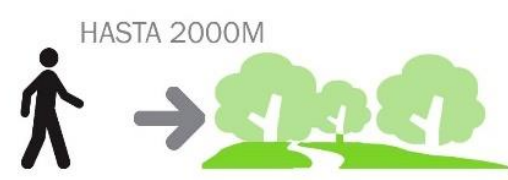

PARQUE REGIONAL

Figura 50. Distancia máxima para acceder a un espacio verde caminando adoptada Fuente: Elaboración propia, 2017 


\section{¿Hasta cuantas cuadras caminaría usted para llegar a una plaza o parque?}

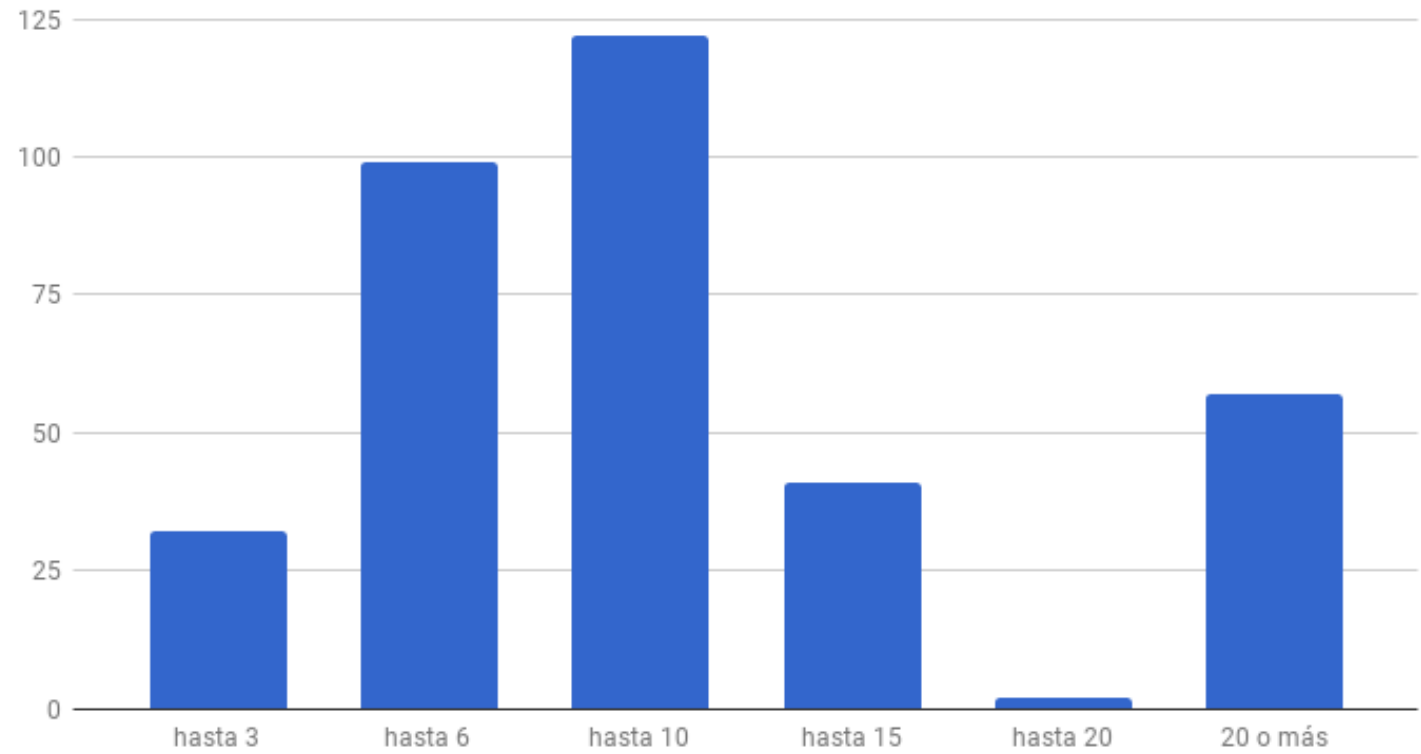

Figura 51. Cuadras que caminaría una persona para llegar a un espacio verde, datos obtenidos de la encuesta.

Estos radios se cobertura se los mapea en una cartografía realizada en gis donde se puede observar la cobertura de cada tipo de espacio verde (figura 52).

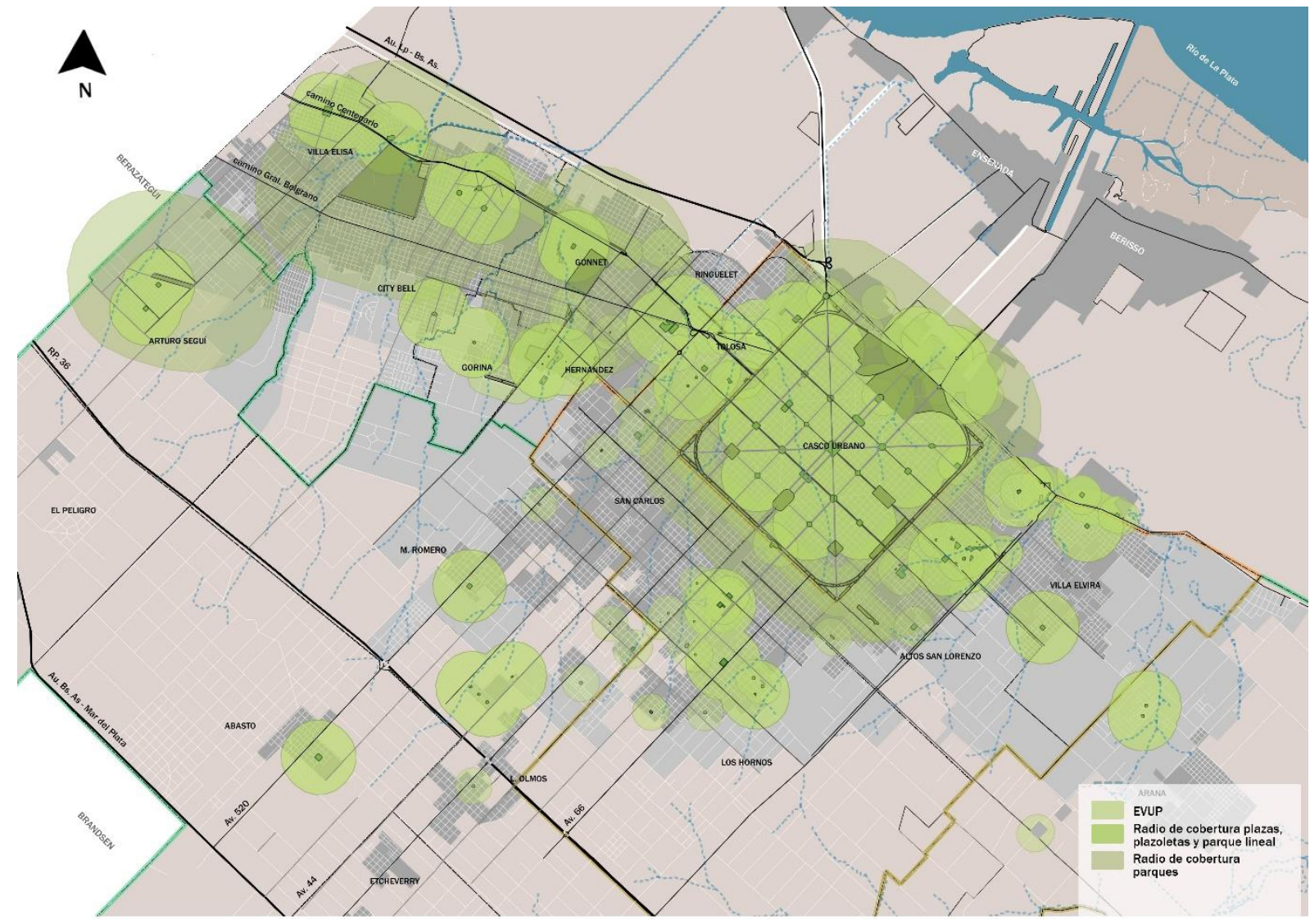

Figura 52. Radios de cobertura de áreas verdes en la periferia.

Fuente: Elaboración propia en base a Jensen y Birche en GIS, 2017. 
De esta manera, se observa como el casco se encuentra cubierto por los EVUP pero cuando se observa que pasa en la periferia esto mismo no se verifico. En la periferia los espacios verdes no cubren toda la zona urbana, de este modo el número de metros cuadrados por habitante es menor que el que se observa en el casco.

Respecto a la incorporación de la noción de paisaje, no existe una definición de paisaje en el ordenamiento jurídico a nivel nacional y sus apariciones en normativas o legislación, por lo general resulta ambigua. Si bien en algunos casos se ha incorporado la noción de paisaje a algunos proyectos urbanos, estos ejemplos son muy reducidos y por lo general de un abordaje conceptual acotado.

\section{Áreas criticas}

Luego del análisis realizado en el que se visualiza la falta de EVUP según la zona de la periferia seguimos con la determinación de las áreas críticas. Estas áreas son las que se encuentran en el área urbana y que están desprovistas de EVUP (figura 53), es decir según los radios de cobertura planteados estas áreas no poseen cobertura de EVUP a escala barrial, sino que algunas poseen cobertura a escala urbana, esto quiere decir que algunas áreas tienen cobertura de parques, pero no de plazas.

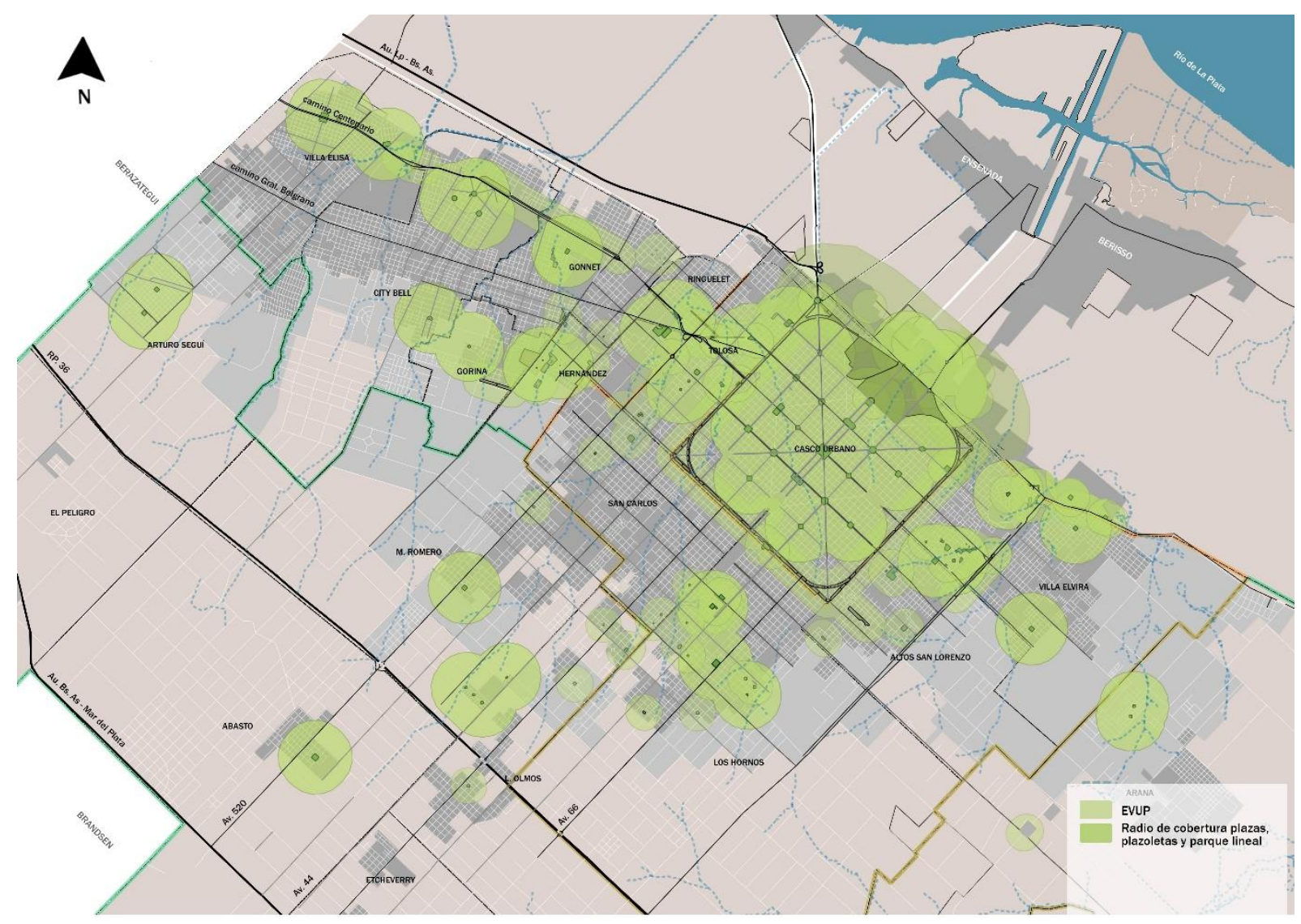

Figura 53. Radios de cobertura de EVUP. Fuente: Elab. Propia en base a Jensen y Birche en GIS, 2017. 
Esta tesis propone poner el acento en la cobertura espacial de los espacios verdes como así también en la cobertura de espacios a escala barrial, de esta manera todas las zonas que están en área urbana por fuera del radio de cobertura de los espacios verdes forman parte de esa área critica. Ahora ¿qué es un área critica? Es este caso se denomina áreas críticas a las áreas donde no hay cobertura de espacios verdes las cuales deberían ser las primeras en intervenir. Es decir que son áreas que hoy en día no gozan de los beneficios sociales y ambientales que brindan los espacios verdes de uso público, a su vez, son áreas prioritarias de intervención porque son áreas urbanas donde vive la población.

En cuanto al paisaje son áreas donde hay que poner especial atención ya que no esos habitantes no gozan de la misma calidad de paisaje que los que si poseen cobertura de espacios verdes, es decir la calidad de estas zonas se ve disminuida (figura 54).

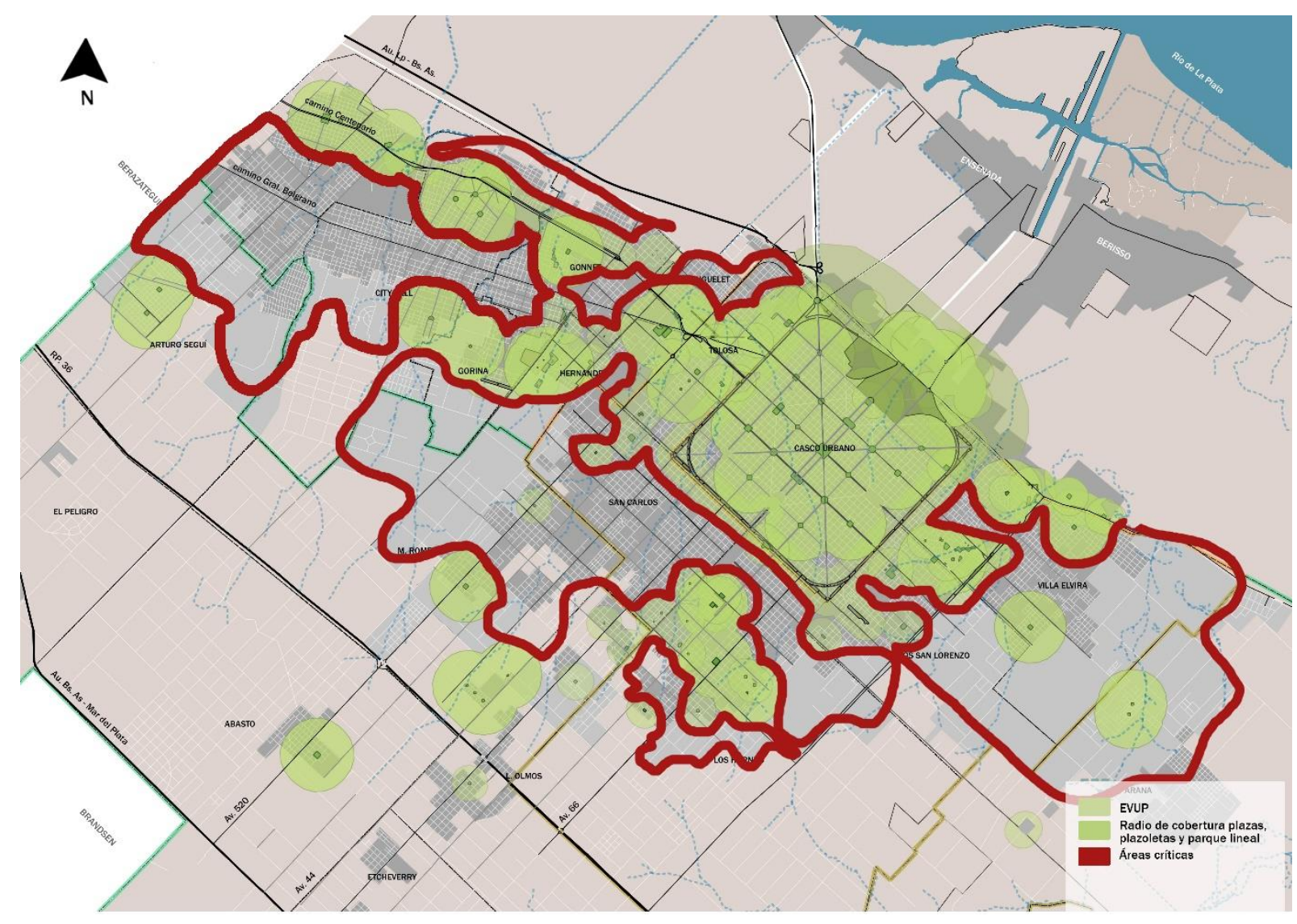

Figura 54. Zonas sin cobertura de áreas verdes en la periferia.

Fuente: elaboración propia, 2017.

De esta forma, sobre el plano realizado en GIS se delimitan las áreas críticas (figura 54) donde se puede observar como la zona de la periferia que corresponde al desborde y al cinturón verde presenta casi un $80 \%$ de la superficie sin cobertura de espacios verdes, seguidas por la zona del eje noroeste con casi el 55\% de la superficie urbana sin cobertura 
de espacios verdes. Se propone entonces determinar (figura 55) por cada zona de la periferia cual es el porcentaje de habitantes desprovisto sin cobertura de espacios verdes desde la dimensión espacial.

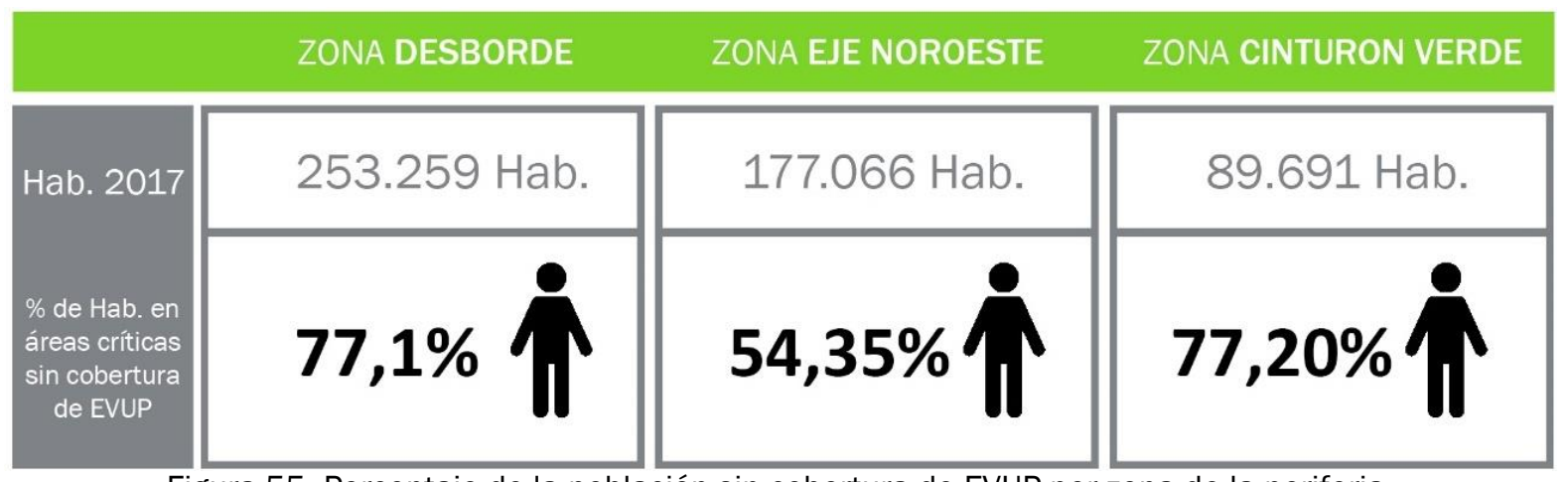

Figura 55. Porcentaje de la población sin cobertura de EVUP por zona de la periferia.

Fuente: Elaboración propia en base a los planos realizados en GIS, 2017.

Esto pone de manifiesto como la ciudad ha ido creciendo sobre tierras productivas sin contemplar el espacio verde, es decir si observamos los espacios verdes son los mismos no hay un incremento de estos en relación a la densidad o a la expansión del área urbana.

Esto coincide además, con las características del tejido, un tejido abierto con predominancia del verde, lo cual es inversamente proporcional a la cantidad de espacio verde de uso público. Este dato nos llama a reflexionar acerca de si ¿la gente que posee un parque en su casa no usa los espacios públicos?, se puede decir que eso no es correcto una encuesta que realizamos pone de manifiesto que la gente que vive en zonas de la periferia usa los espacios verdes de uso público y le gustaría que estos se incrementen (figura 56).

\section{¿Cree que es necesario que existan más espacios verdes en la ciudad?}

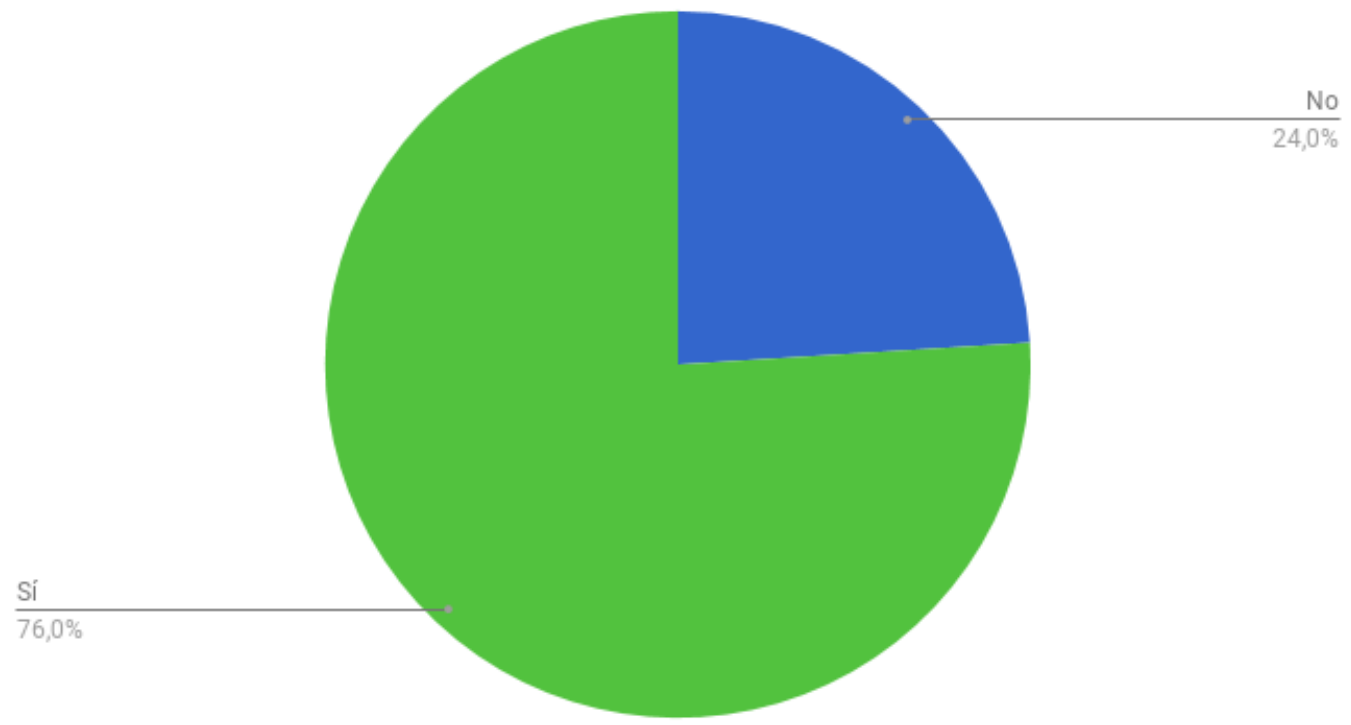

Figura 56. Datos obtenidos de la encuesta. 
El 70\% de la población cree que es necesario que existan más espacios verdes de uso público, y cuando se les pregunta si algún espacio sin uso sea convertido en un espacio verde el 90\% contesto que sí. Esto remarca la falta de espacio verde que hay en la periferia platense, pero también, de acuerdo a la zona de la periferia estos números cambian, como por ejemplo en City Bell en su mayoría la gente contesto que no creen necesario más espacios verdes, en cambio en San Carlos ocurrió lo opuesto. 


\section{CAPÍTULO 5 \\ Los nuevos espacios verdes desde el paisaje}

5.1 | Tipos de espacios verdes Públicos

5.2 | Las tierras vacantes como Espacios verdes potenciales

5.3 | Calidad de paisaje de las TV aptas para ser incorporadas como espacios verdes 
CAPITULO 5

“Hacer que elementos, juzgados a priori como muy negativos, se vean de forma muy positiva, ya sea por inversión o por exceso, se trata de provocar una retroversión del desencanto del que el lugar ha sido testigo"

(Nouvel, citado en Druot et al., 2007)

\section{1 | Tipos de espacios verdes Públicos}

Después de un análisis exhaustivo de la conformación de la ciudad y el rol de los espacios verdes y el paisaje, surge como interrogante ¿cómo deberían ser esos espacios verdes de uso Público? ¿que deberían contemplar? ¿Cuáles son los usuarios? Para dar respuesta a estos interrogantes comenzamos a pensar criterios para el diseño y su entorno desde el concepto de paisaje.

Se puede decir que los espacios verdes, como se planteó en la metodología de relevamiento, se diferencian según su escala, su dimensión y según relación de ancho y largo distinguiendo entre parques, parque lineal, plazas y plazoletas. La función está ligada a la forma, y las actividades que se desarrollan en él. El diseño de una plaza, de un parque, de un bulevar o de cualquier otro espacio verde público tiene como propósito fomentar las actividades sociales y el intercambio.

La sociedad ha cambiado a lo largo de los últimos años, usa los centros comerciales, bares y sitios de reunión, grandes paseos de compra y entretenimiento, los mega eventos deportivos, los masivos encuentros musicales como lugares de encuentro. Se hace difícil diferenciar la propiedad y uso de los espacios públicos pues hay numerosos espacios privados, en los que el consumo desempeña el papel preponderante, que actúan como puntos de encuentro o nuevos hitos de la ciudad, y que son utilizados libremente por el público.

Como resultado nos encontramos con propuestas cada vez más aceptadas por los mismos ciudadanos

“...durante varias décadas las políticas urbanas y territoriales han abandonado los espacios públicos (salvo para sus usos como espacios de ocio y de consumo cultural). Las ofertas privadas (desde centros comerciales a grandes eventos) se han convertido 
en el sucedáneo de los espacios públicos: permiten experiencias colectivas pero no la participación y usos abiertos." (Freire citado en Domenico di Siena, 2014)

Los tradicionales espacios verdes han quedado un poco de lado, sin embargo, persiste el concepto de lo público como el carácter predominante de la vida urbana en las ciudades, como espacio de reencuentro y de reunión es por esto que por lo cual es necesario preguntarnos ¿los espacios verdes públicos se adaptan a las necesidades de los habitantes de hoy en día?

Esta tesis propone poner al hombre como el elemento principal del espacio y su relación con la naturaleza desde el concepto de paisaje. Partimos entonces de entender que en el ser humano no hay nada natural, en el sujeto humano todo es cultural, la visión del espacio mediada por la cultura, el paisaje como esa relación cultura (hombre) y naturaleza.

Pensar en el diseño de los nuevos espacios verdes de uso público con el hombre como protagonista implica incorporar los nuevos usos y funciones de estos espacios, que la función deje de estar ligada a la forma o que la forma no condicione las actividades.

“Los proyectos y la gestión de los espacios públicos y de los equipamientos colectivos son a la vez una oportunidad de producir ciudadanía y un test del desarrollo de la misma. Su distribución más o menos desigual, su concepción articuladora o fragmentadora del tejido urbano, su accesibilidad y su potencial de centralidad, su valor simbólico, su polivalencia, la intensidad de su uso social, su capacidad de crear empleo, la importancia de los nuevos públicos de usuarios, la autoestima y el reconocimiento social, su contribución a dar sentido a la vida urbana... son siempre oportunidades que nunca se deberían desaprovechar para promover los derechos y deberes (políticos, sociales, cívicos) constitutivos de la ciudadanía. (...) Las Administraciones públicas en un Estado democrático tienen que asumir como una de las fuentes de su legitimidad el promover una política de ciudad que produzca espacios públicos ciudadanos. No son por lo tanto admisibles grandes proyectos urbanos que no integren objetivos sociales y ambientales que amplían la ciudadanía en cantidad y calidad." (Borja,1998)

De esta forma, proponer criterios de diseño para espacios públicos flexibles que se adapten a los nuevos usos de la población otorgándoles espacios que puedan funcionar para diversos usos y una escala específica, definiendo integralmente los criterios de sustentabilidad dónde se vinculan las perspectivas sociales y económicas en un marco territorial donde la ciudad y su entorno se convierten en uno. 
Respecto de los criterios de diseño de los espacios verdes, el Ing. Benassi (Tella y Potocko, 2009) sostiene que una propuesta de intervención desde el paisaje debe estar basada en tres principios básicos:

- Relación con el sistema mayor de pertenencia: debe perdurar y desarrollarse el conjunto funcional de espacios verdes en relación a un sistema mayor de pertenencia.

- Relación con el funcionamiento biológico del sistema: los espacios verdes deben vincularse y complementar recreativamente $y$, al mismo tiempo, articular el funcionamiento biológico del sistema.

- Relación con una nueva noción del tiempo libre social: finalmente, la calidad del tiempo libre lo brinda la calidad del paisaje en todas las escalas del territorio, proporcionar una nueva noción del tiempo libre social.

Estos principios hacen referencia a la relación entre los espacios verdes dándole fuerza a la idea de un sistema de espacios verdes, donde todos se encuentren interrelacionados entendiendo al sistema como un conjunto de componentes que se relacionan con al menos algún otro componente.

En este contexto, para Fabio Márquez (2011) el espacio verde público debe ser integrador e inclusivo. Pone de manifiesto que los criterios para el diseño deberán permitir diferentes usos sin dejar de tener en cuenta la estética de estos, teniendo de esta manera espacios de encuentro sin importar cuestiones etarias, culturales, étnicas o sociales.

\section{Espacios flexibles como herramientas para la diversidad}

En el marco del crecimiento urbano, la configuración de las ciudades y la sociedad hoy en día es necesario recapacitar a cómo deben ser los espacios verdes, que características deben poseer.

Pensar en nuevos espacios verdes públicos constituye hoy un desafío importante para las administraciones públicas locales, en los procesos actuales de consolidación, densificación y crecimiento de las ciudades. Particularmente, la capacidad de articular herramientas, mecanismos y políticas en espacios de gestión multiactorales y plurirepresentados, a fin de dirigir recursos para obtener los mayores beneficios de cualquier intervención (figura 57). 


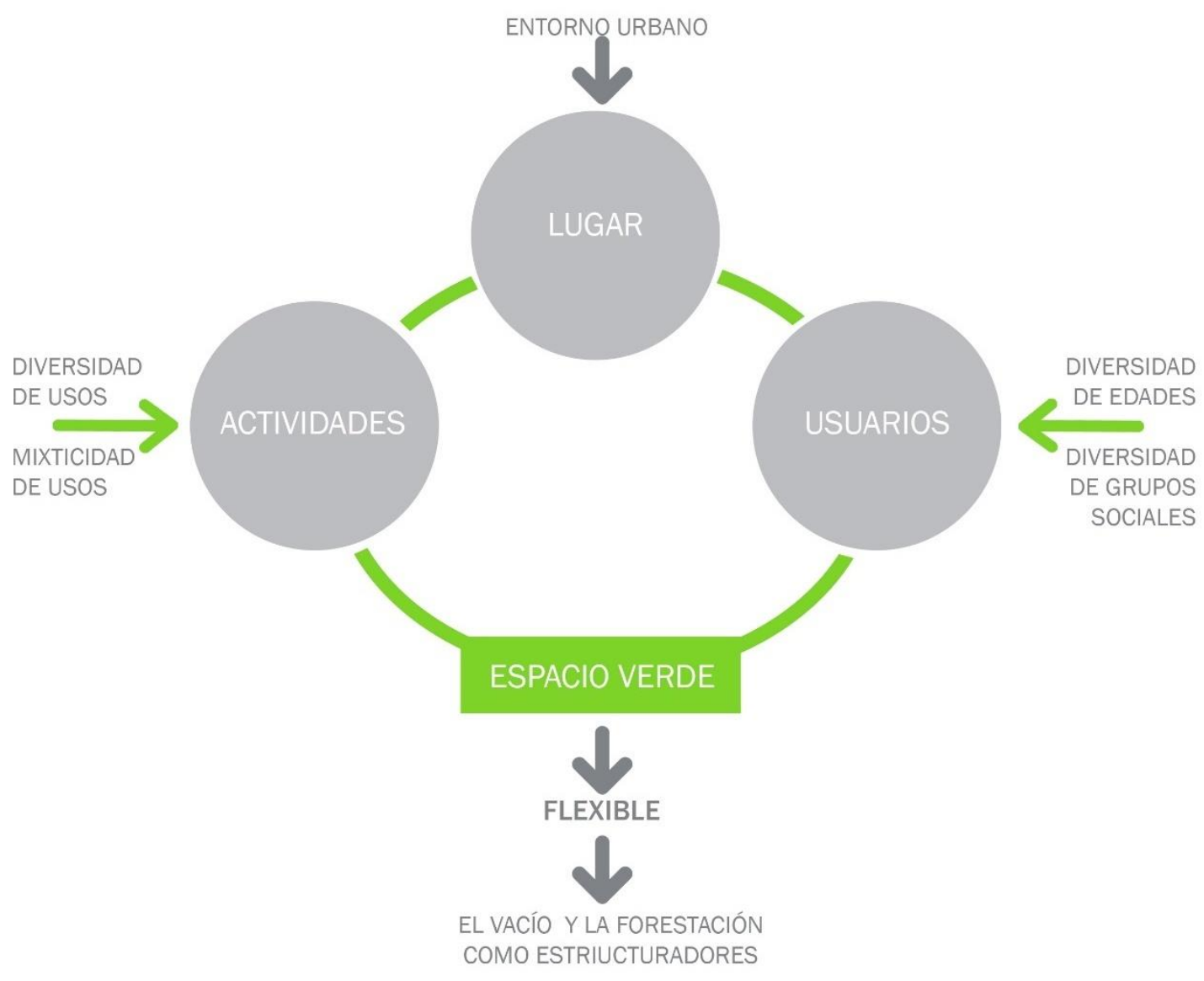

Figura 57. Tipo de espacios verdes flexibles.

Fuente: Elaboración propia, 2018.

La flexibilidad de los espacios verdes públicos es la herramienta para la diversidad de usos como de usuarios. Los espacios han cambiado Delgado (2007) afirma que:

“lo que en realidad era solo un espacio teórico se ha convertido por arte de magia en espacio sensible. Lo que antes era una calle es ahora escenario potencialmente inagotable para la comunicación y el intercambio, ámbito accesible a todos en que se producen constantes negociaciones entre constantes que juegan con los diferentes grados de la aproximación y el distanciamiento, pero siempre sobre la base de la libertad formal y la igualdad de derechos, todo ello en una esfera de la que todos pueden apropiarse, pero que no pueden reclamar como propiedad." (p.1)

La flexibilidad en el espacio verde no solo debería de remitirse a la superficie, sino también al Ilamado urbanismo del subsuelo o urbanismo subterráneo, proyectando infraestructuras que permitan y faciliten la ejecución de las modificaciones que surgirán a lo largo del tiempo, debido a la misma evolución de la ciudad. De este modo, lo cambios no supondrán la demolición y posterior reconstrucción del espacio público. 
El espacio verde público es un ámbito tremendamente cambiante y dinámico donde factores como la inmigración, las nuevas formas de cultura urbana o el envejecimiento de la población exigen del diseño de estos una respuesta flexible. El espacio verde debería ser flexible para permitir que los usuarios lo modifiquen.

Para garantizar que se desarrollen distintas actividades ya sea simultáneamente (mixticidad de usos), o de manera diferida en el tiempo (diversidad de usos) es necesario pensar en un espacio flexible que permita que exista el escenario físico para las actividades proyectadas y las que con el transcurso del tiempo vayan surgiendo. "Para entender una ciudad hemos de ocuparnos abiertamente como su manifestación esencial, de las combinaciones o mezclas de usos, no de estos por separado". (Jacobs, 2011)

Se puede decir entonces que, si bien las actividades que suceden en un determinado lugar lo modifican de una manera temporal o permanente, las características del lugar condicionan las actividades que se pueden desarrollar en él. Esta relación reciproca debe ser flexible para garantizar la complejidad del espacio público. "En esta mezcla de actividades realizadas en el exterior influyen una serie de condiciones. El entorno físico es una de ellas: un factor que influye en las actividades en diversas medidas y de diferentes maneras" (Gehl, 2006). Estos nuevos espacios flexibles deben tener en cuenta el entorno urbano ya que lo van a modificar y deben cumplir con determinados parámetros.

En un barrio deberían existir varios espacios flexibles de distintos tamaños, para que las actividades previstas se realicen en el que más se ajuste a sus necesidades. Independientemente del tipo de actividad propuesto, para poder devolver al espacio urbano su carácter de lugar público es imprescindible reflexionar sobre las características físicas de la propia calle y para ello será necesario una dimensión generosa de la acera como primera recomendación de diseño.

Para dinamizar espacios y facilitar su integración en la ciudad, es importante prever focos de atracción que actúen de "pegamento" entre la ciudad y este tipo de espacios flexibles. "Si las actividades y las personas se agrupan, es posible que los acontecimientos individuales se estimulen mutuamente". (Gehl, 2006)

\section{2 | Las tierras vacantes como Espacios verdes potenciales}

En la región de estudio, la problemática del suelo vacante resulta un elemento clave para la gestión municipal, especialmente luego de la sanción en el año 2013 de la Ley 14449 de Acceso Justo al Hábitat de la Provincia de Buenos Aires que crea una serie de 
mecanismos concretos de intervención del Estado en el mercado de suelo. Sin embargo, los gobiernos municipales no intervienen aun en el proceso de configuración de la ciudad, que está regido casi exclusivamente por la función de mercado, favoreciendo la especulación inmobiliaria y la proliferación de tierras urbanas vacantes. En La Plata más del $70 \%$ de los lotes urbanos en medio periurbano ${ }^{63}$ se encuentran vacantes. Estos espacios, en su mayoría de dominio privado, se ven afectados por una gran variedad de situaciones, asociadas a cuestiones de esparcimiento y recreación, a la acumulación de residuos sólidos urbanos o a la resolución de necesidades básicas como la vivienda, derivando en la toma de dichas tierras para la conformación de asentamientos ilegales.

En este marco, la utilización y refuncionalización ${ }^{64}$ de las tierras vacantes de la región constituirían una oportunidad a aprovechar tendiente a un desarrollo urbano sustentable. El uso o una reutilización racional de estas tierras podría contribuir a recomponer y ordenar la ciudad en su totalidad, favoreciendo la integración socio territorial.

Como afirma Clichevzky (2007) "sólo una porción de esa tierra puede ser utilizada para usos urbanos, en virtud de condiciones urbano-ambientales (algunas de ella, inundable o contaminada) y de restricciones legales", esto sumado a la falta de espacios verdes convierte a las tierras vacantes en espacios verdes públicos potenciales. Entonces estas tierras podrían dotar de espacios verdes de uso público a zonas consolidadas que no cuentan con ellos como así también pensar en una nueva forma de espacio verde que se adapte a la sociedad de hoy en día. Pensar en una respuesta directa a las necesidades de los barrios, de introducción de nuevos usos y funciones, de relaciones espaciales y funcionales no establecidas por el planeamiento.

Consideramos entonces que los vacíos urbanos que contiene la ciudad pueden revertir la falta de espacios verdes de uso público y re-valorizarlo como un espacio de producción y reproducción socio-espacial. Recuperar tierras sin uso, actualmente abandonadas y degradadas, para cubrir las necesidades de la sociedad en su conjunto. Siguiendo a Harvey (2006), “Equilibrando el espacio, se definen nuevas conductas sociales creadoras de igualdad". El estado debería garantizar que la ciudad sea un espacio de sociabilidad y de encuentro y no simplemente un ámbito de acumulación de capital.

\footnotetext{
63 Espacio periurbano es el espacio geográfico que ocupa el espacio intersticial dejado libre por el espacio urbano dentro de una aglomeración urbana.

${ }^{64}$ El objeto se transforma en otro que cumple una función distinta a la original.
} 
La encuesta realizada por Jensen y Birche (2018) (figura 58) revela que en $92 \%$ de la población le gustaría que un espacio en desuso se convierta en un espacio verde, pero a su vez por esta invisibilidad de estos paisajes vacantes un $60 \%$ (respondió que no conoce ninguno, es decir "no lo ve".

\section{¿Le gustaría que algún espacio sin uso sea convertido en un espacio verde?}

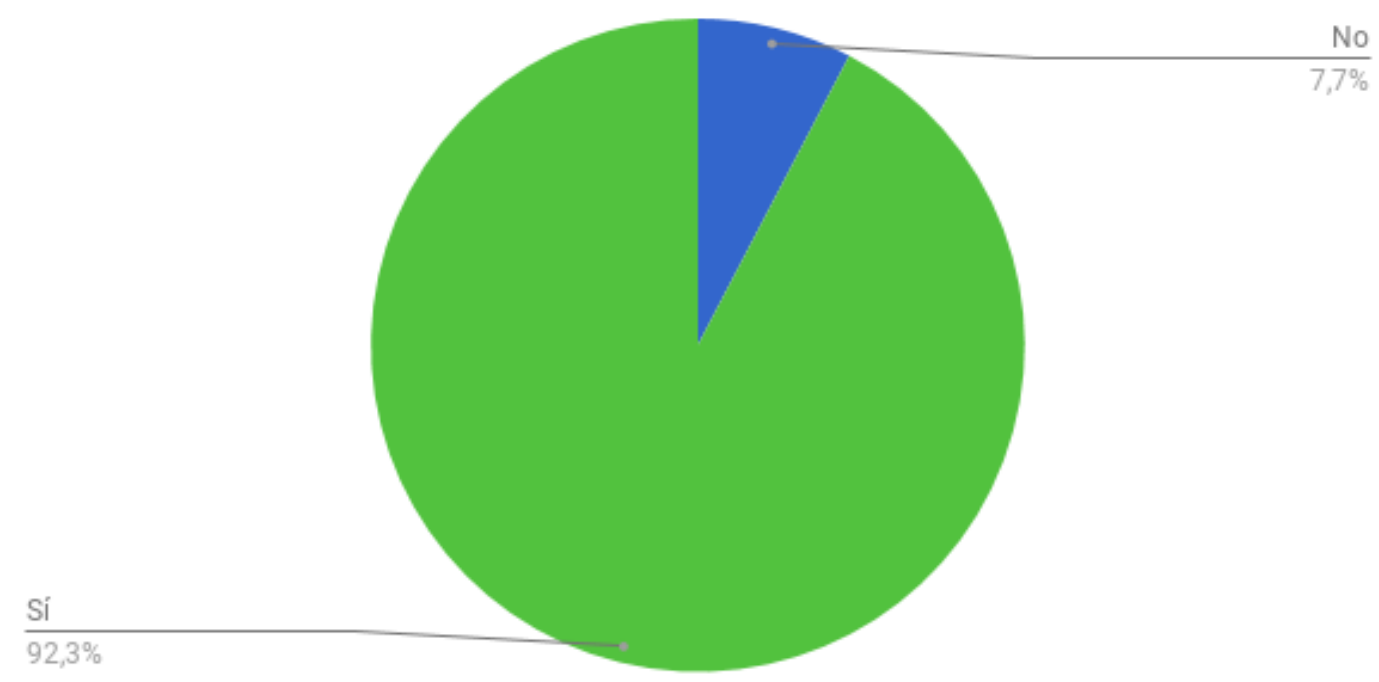

¿Reconoce algún espacio exterior sin uso o abandonado en la ciudad?

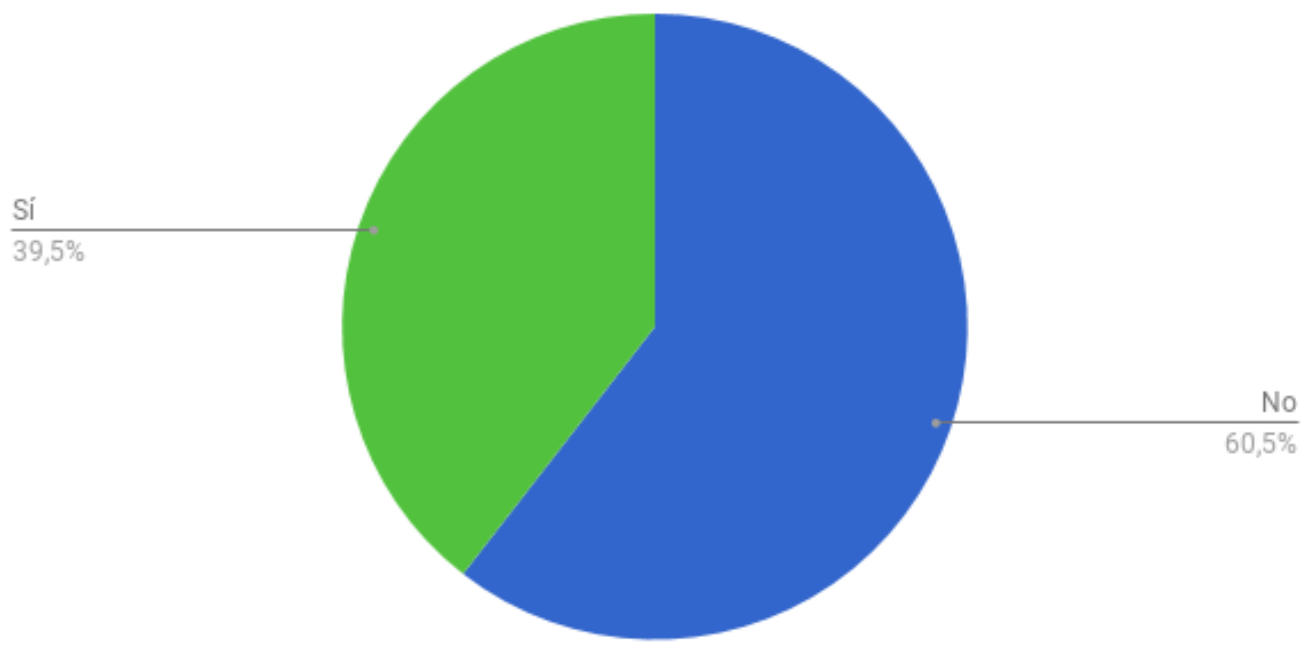

Figura 58. Gráfico de espacios sin uso o vacantes en la ciudad.

Fuente: Datos obtenidos de la encuesta.

A su vez lo que respondieron que si identificaban un espacio en desuso mencionaron tierras vacantes, en su mayoría en la periferia o ligadas a cursos de agua (ver anexo 1). 


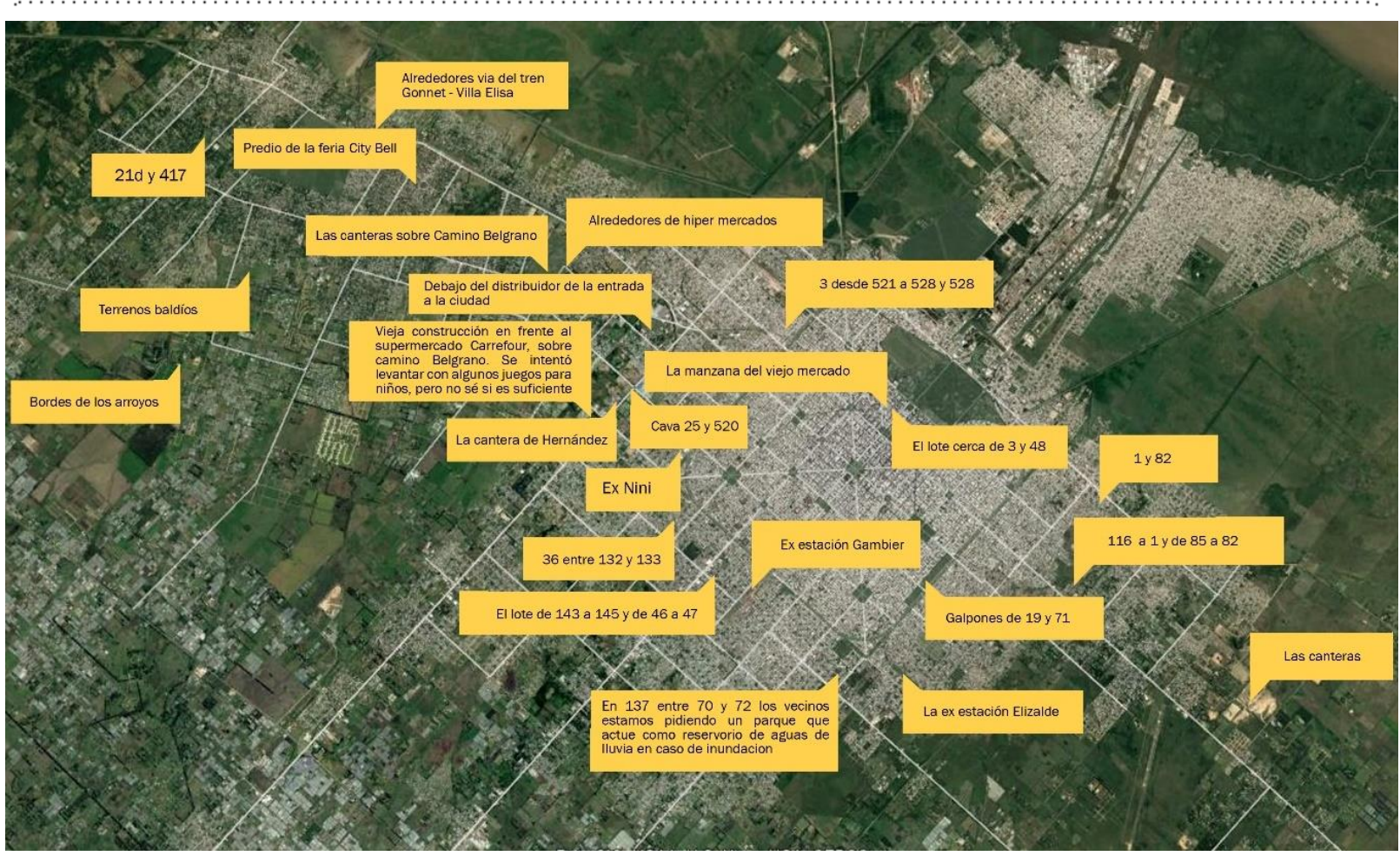

Figura 59. Plano con los espacios sin uso o vacantes en la ciudad reconocidos por los habitantes encuestados.

Fuente: Datos obtenidos de la encuesta, 2018.

Remarcando la necesidad de empezar a pensar las tierras vacantes como una oportunidad a la demanda concreta y necesidad de los habitantes de espacios verdes de uso público (figura 59). Los habitantes que reconocieron espacios sin uso o abandonados hacen referencia a los de su barrio que son los que ven todos los días y que en muchos casos se usan para realizar actividades por la falta de espacios verdes que hay a escala barrial.

Uno de los casos que se puede mencionar como ejemplo es el caso de la cava de 501 y 133 la cual era un paisaje vacante hasta que hubo una propuesta para realizar un espacio verde (figura 60). Esta tierra vacante, degradada y abandonada comenzó a quedar en el medio de una zona donde la ciudad se fue expandiendo, por la falta de espacio verde que hay en la región como vimos en el capítulo anterior convertirla en un espacio verde fue una demanda de los habitantes.

En este predio se iba a llevar a cabo un espacio verde y un conjunto de viviendas, el espacio verde se materializo con vegetación, senderos y puesta en valor, el cual hoy es utilizado no solo por los vecinos, sino que también por habitantes de otras zonas de la ciudad que van a realizar actividades deportivas. Los vecinos de los barrios aledaños se sienten identificados con este espacio y eso se vio reflejado en la encuesta (ver anexo 1). 

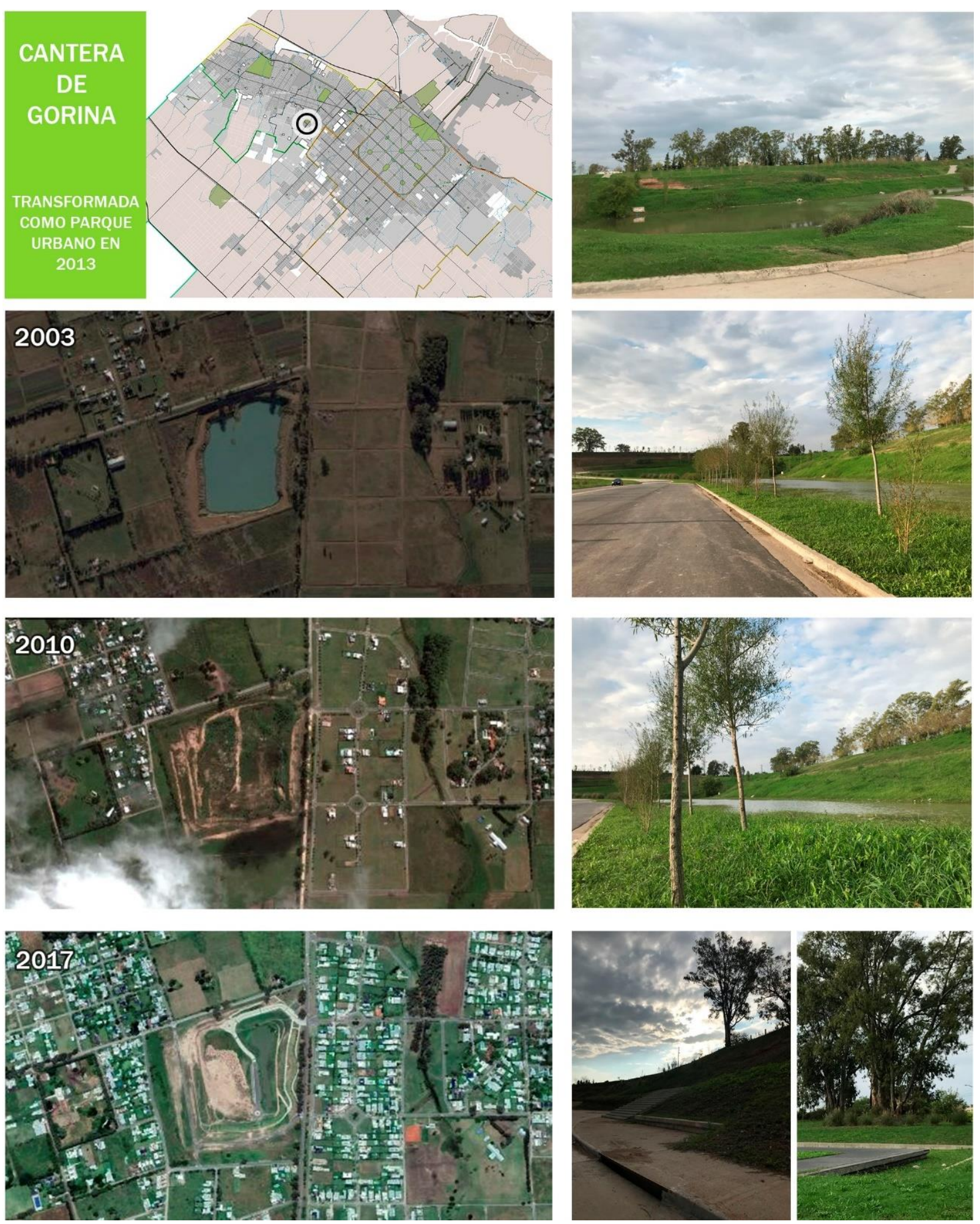

Figura 60. La cantera de Gorina. Fuente: elaboración propia con fotos sacadas por el autor, 2017.

Un paisaje que nadie miraba paso a ser un espacio que tiene uso, vegetación en otras palabras que tiene vida. Este espacio fue diseñado desde el paisaje resaltando su condición natural y pensando cada uno de sus elementos en base a las condiciones que presenta el terreno y aprovechando las líneas del territorio. Este espacio verde está 
diseñado desde el concepto de paisaje haciendo énfasis en esta relación entre cultura y naturaleza, convirtiendo esta tierra vacante en un espacio verde de uso público.

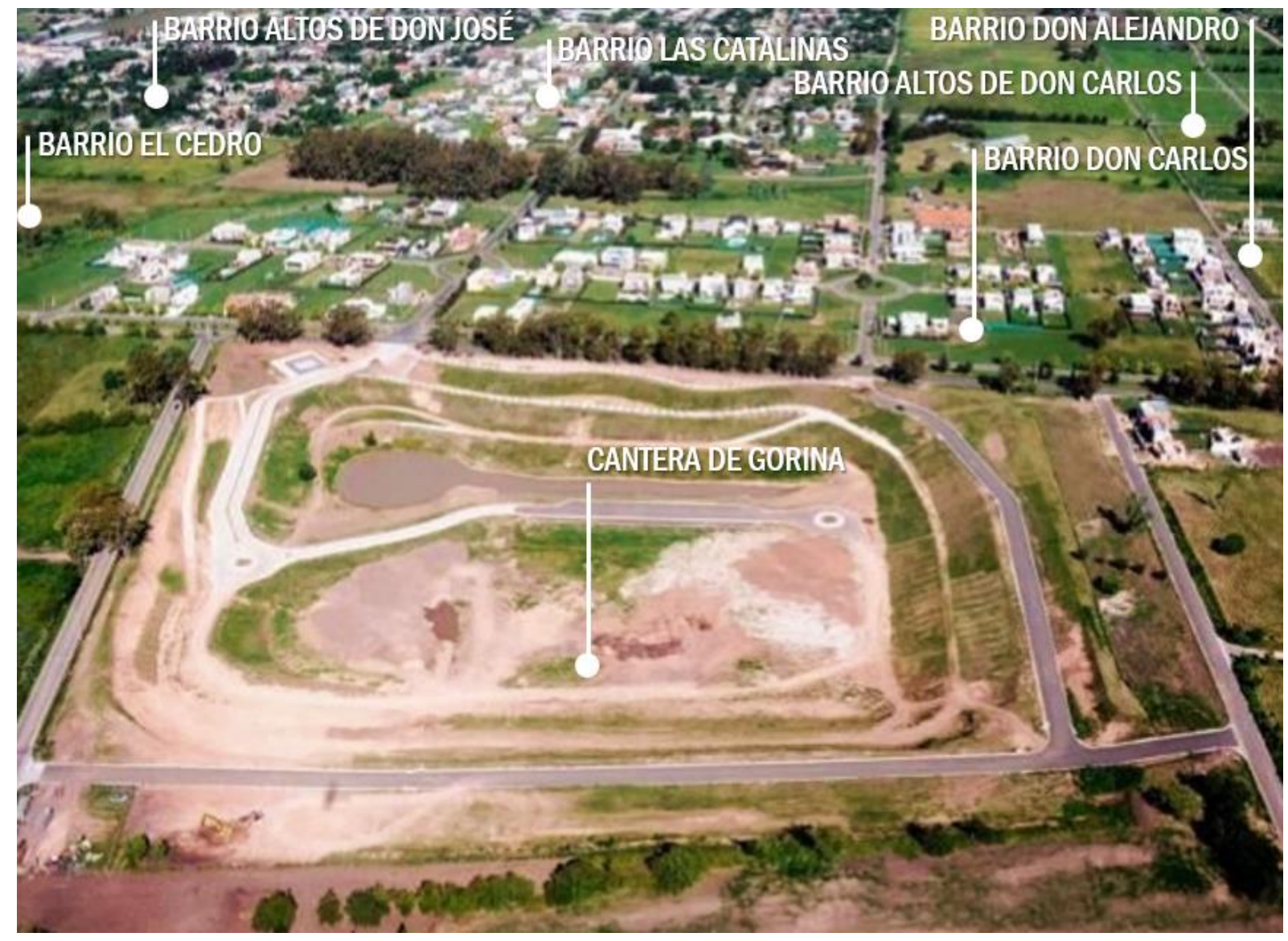

Figura 61. La cantera de Gorina y su entorno.

Fuente: elaboración propia con fotos sacadas por el autor, 2017.

En el entorno de este espacio verde, hoy en día, se localizan diversos barrios y loteos que terminan de localizarlo en una zona residencial y donde se habitualmente por los vecinos de estos barrios como por personas que vienen de otros lugares (figura 61).

\section{Identificación de los espacios verdes potenciales en las áreas críticas}

Una vez relevados los espacios verdes de uso público se relevaron las tierras vacantes clasificándolas y caracterizándolas por tipo. Se determinaron parámetros para identificarlas (capitulo 2 apartado 2.2). La primera discriminación va a realizarse para identificar las que tengan como superficie más de una hectárea, que se encuentren en la periferia, que sean de dominio público, Privado o desconocido, que sean vacíos latentes y que encuentren en área urbana. De este modo, se realizó la primera selección del total de las tierras vacantes de la región. 
En el siguiente plano elaborado en GIS (Figura 62) se marcaron todas las tierras vacantes relevadas con que poseen las características de selección anteriormente descriptas. Es decir, las que posean más de una hectárea, estén en zona urbana, sean vacíos latentes y estén en la periferia.

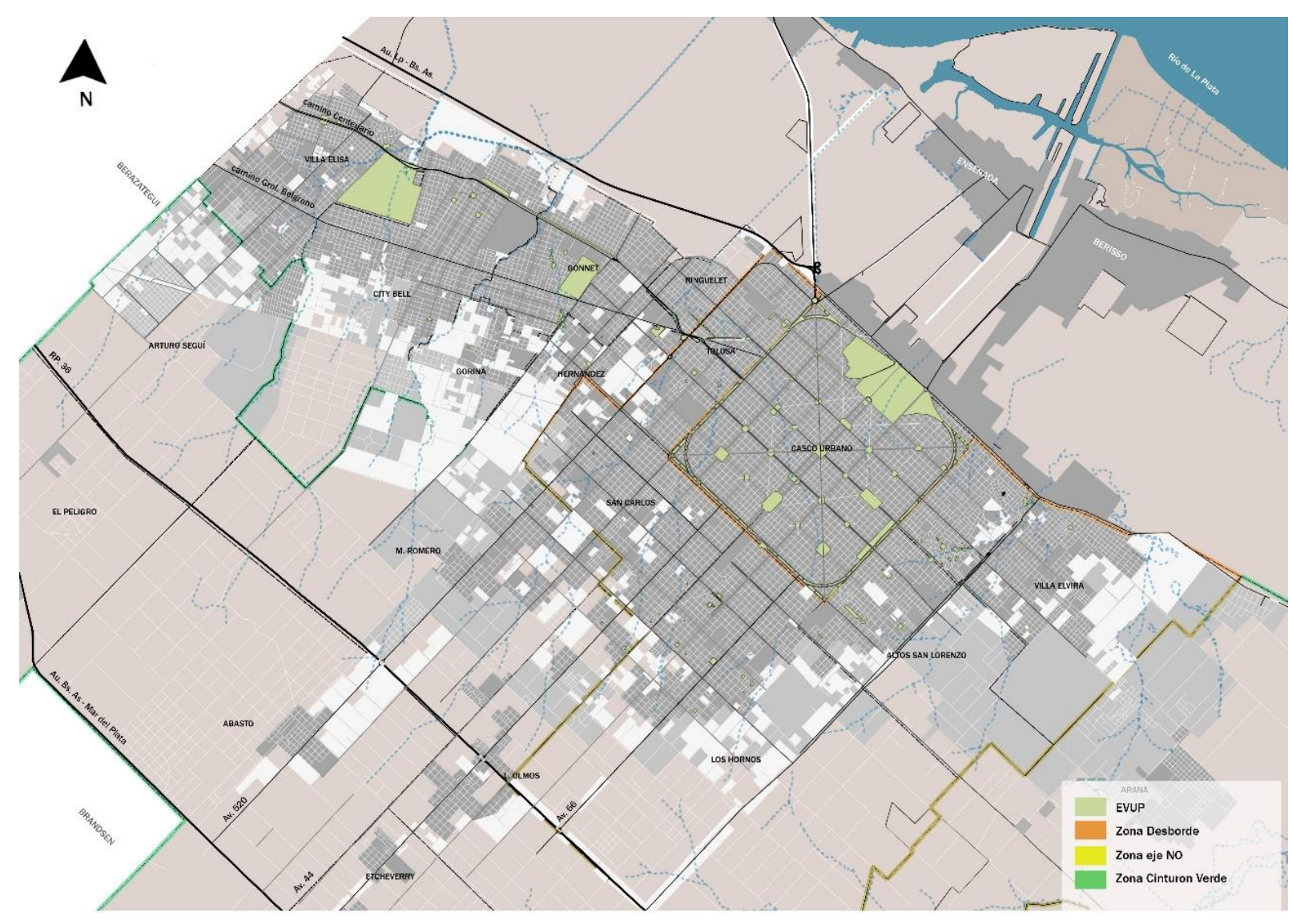

Figura 62. Las TV en zona urbana en la periferia platense.

Fuente: Elaboración propia en GIS en base a Frediani, 2017.

En segundo lugar, para ser incorporadas como espacios verdes en base a los parámetros descriptos en el capítulo 2 (apartado 2.2) los cuales tienen como prioridad seleccionar las tierras que estén en área urbana y son adyacentes a cursos de agua ya que van a permitir aminorar las inundaciones como así también dejar libre de ocupación la planicie de inundación y las cavas (pasivos ambientales). Por otro lado, dentro del área urbana las que se encuentren en áreas críticas donde se va a hacer otra selección donde haya más de una cerca priorizando en este caso las que estén cerca de las principales vías de circulación, las que estén fuera del área de cobertura de parques y las de mayor tamaño. 


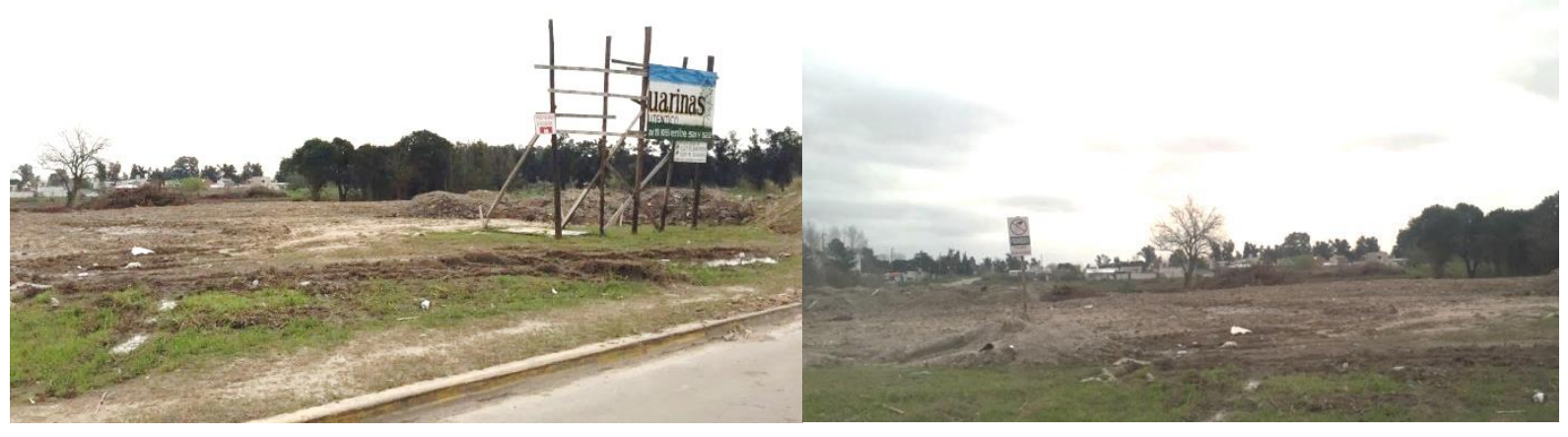

Figura 63. Tierra vacante en 520 y 149.

Fuente: imágenes del autor, 2017.

De este modo, se procedió a establecer parámetros para identificar las que pueden ser potenciales espacios verdes de uso público, estos se establecen en base al tamaño, ubicación, dominio, tipo y el área. Una vez identificadas las T.V. susceptibles a ser incorporadas como espacios verdes se hizo una preselección de las tierras vacantes en base a los parámetros anteriormente descriptos.

En el plano (figura 64) se pueden observar donde se localizan las T.V. seleccionadas, donde en su gran mayoría se encuentran en la zona con más crecimiento y más urbanizada como lo es el eje NO. Es decir, que es posible revertir en estas zonas de crecimiento sin cobertura de espacios verdes la situación. También es posible colaborar desde estas con la absorción del agua ya que en muchos tramos de los arroyos en zona urbana encontramos T.V. adyacentes a los cursos de agua las cuales podrían funcionar como reservorios.

En números estos espacios potenciales en eje NO son 38, en la zona de desborde son 35 y en el cinturón verde son 33. Es decir que se incorporarían en la periferia platense 106 nuevos espacios verdes los cuales se sumarian a los 29465 espacios verdes de uso público de escala barrial donde 103 son plazoletas, 84 son plazas y 107 segmentos que conforman la avenida circunvalación y ex estaciones de ferrocarril como parques lineales. Quedando por fuera de este número los parques que son 14. Se incrementaría en un tercio los espacios verdes de escala barrial.

65 Datos obtenidos del relevamiento realizado para la tesis en el marco del grupo de investigación del IIPAC en el 2016 mediante Google erath y posterior vista de campo. 


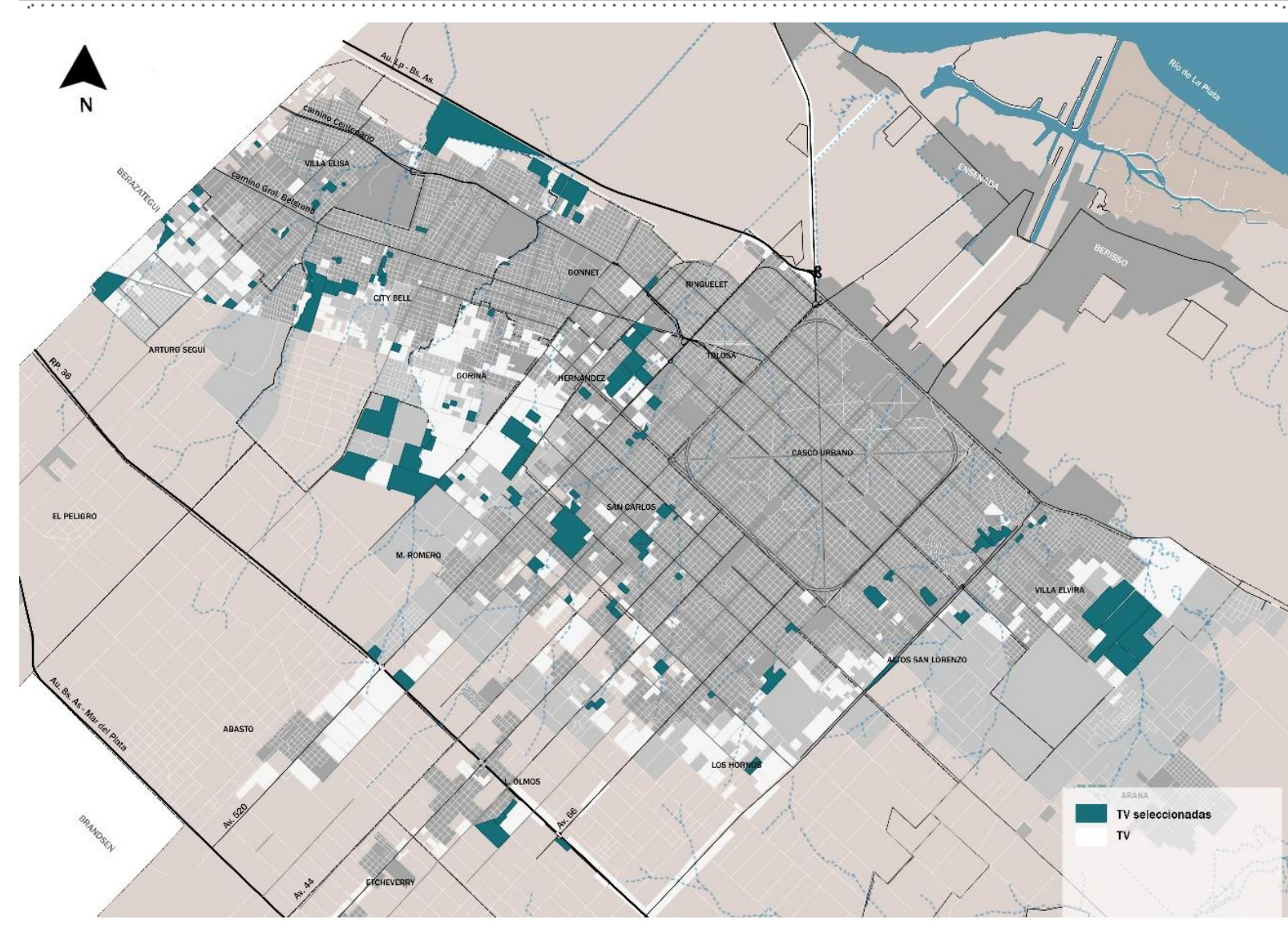

Figura 64. Preselección de las TV.

Fuente: Elaboración propia en GIS, 2017.

De este modo si a los espacios EVUP relevados con sus respectivos radios de cobertura le incorporamos los espacios verdes potenciales con un radio de cobertura de 800m (como las plazas) obtendríamos un incremento de espacios verdes de uso público en la periferia, donde la relación en promedio seria de 30 m2/hab. va a variar de acuerdo a la zona de la periferia.

Como se observa en el plano (figura 65) la periferia quedaría cubierta de espacios verdes casi en su totalidad. Esto Contribuye a mejorar la calidad del paisaje urbano y mejorar la calidad de vida. De este modo, los habitantes de la periferia van a estar a 8 cuadras de un espacio verde de escala barrial y en el caso de que no esté a 8 cuadras estará a no más de 15 cuadras y a su vez está dentro del radio de cobertura de parques. Es decir, que cualquier habitante de la periferia tendrá acceso a un espacio verde de escala barrial a 15 cuadras de su vivienda como máximo. Si bien había zonas cubiertas de espacios verdes estos recibían habitantes de zonas donde no había espacios verdes y con esta nueva distribución espacial estos estarían menos saturados. 


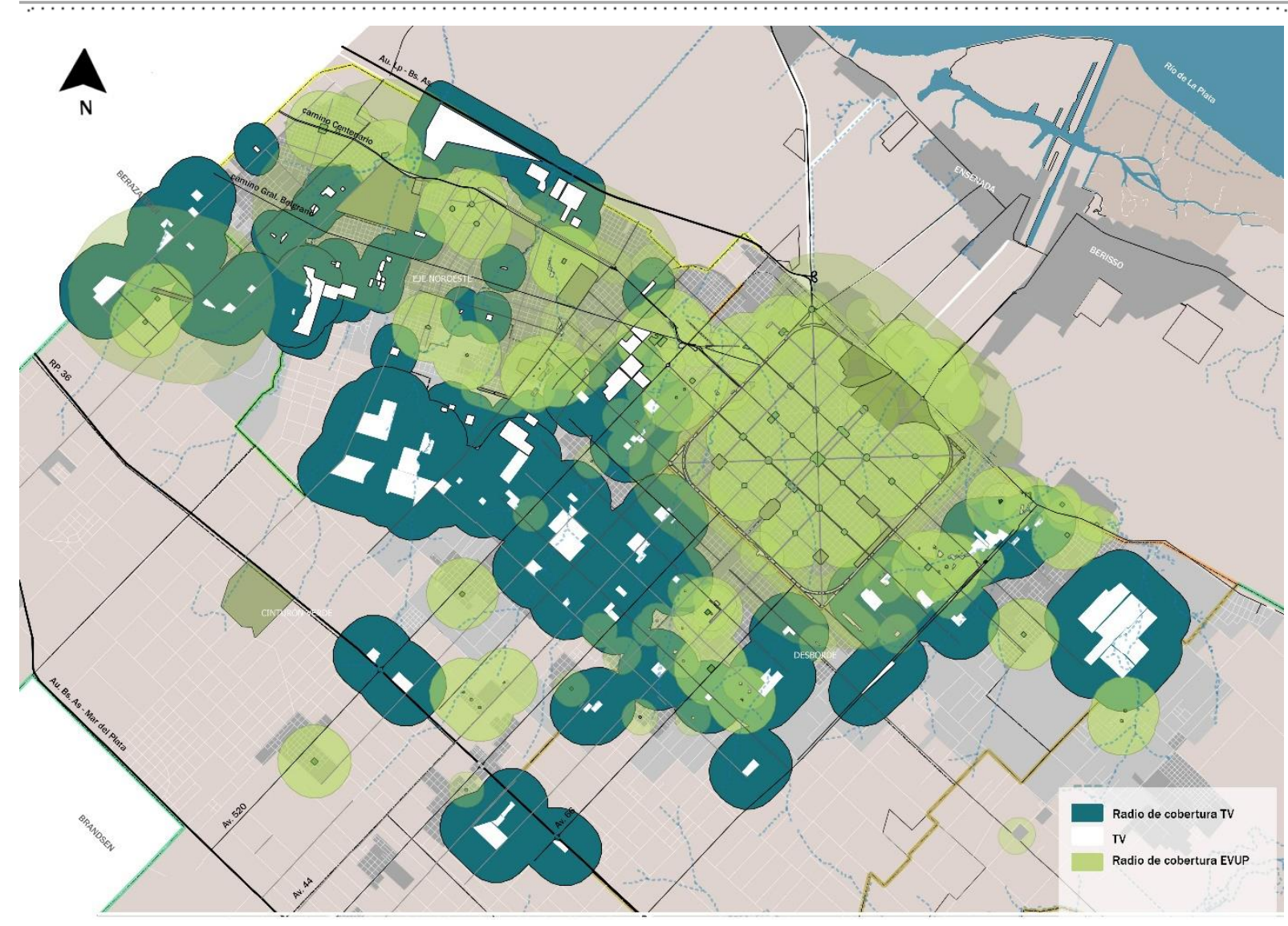

Figura 65. Tierras vacantes como espacios verdes potenciales y radios de cobertura.

Fuente: Elaboración propia en GIS, 2017.

Se puede decir entonces que las condiciones en la periferia en cuanto a los EVUP cambiaría por completo y a su vez estos parques de transición servirían como un fuelle con lo rural y permitirían mediante políticas públicas poner un freno al crecimiento sobre la zona productiva. De esta manera, se podría comenzar a pensar en preservar el cinturón frutihortícola platense del avance de la urbanización.

En síntesis, en la ciudad de La Plata donde había 885,1 Ha. de espacios verdes se incrementarían 1319,1 Ha. de espacios verdes nuevos, donde en total entre el casco y la periferia tendríamos con este sistema de espacios verdes 2204,2 Ha. de EVUP (figura 66). Es decir, que se incrementaría 149,1 \% la superficie los EVUP, a su vez este cambio seria aún mayor si lo dividimos en casco urbano y periferia ya que hoy en día el casco fundacional quedaría igual pero el incremento se vería en la periferia. Es necesario también tener en cuenta la superficie del área urbana que tiene es de $15.710 \mathrm{Ha}$. 


\begin{tabular}{|c|c|c|c|c|}
\hline \multicolumn{2}{|r|}{ DESBORDE } & EJE NOROESTE & CINTURON VERDE & REGIÓN LP \\
\hline \multirow{2}{*}{$\begin{array}{l}\text { EVUP } \\
\text { EXISTENTES } \\
\text { EVUP } \\
\text { PROPUESTOS }\end{array}$} & 70,24 На. & 335,36 Ha. & 18,52 Ha. & $885,1 \mathrm{Ha}$. \\
\hline & 415,7 На. & $452 \mathrm{Ha}$. & 451,4 Ha. & 1319,1Ha. \\
\hline $\begin{array}{c}\% \\
\text { INCREMENTO }\end{array}$ & $591 \% \uparrow$ & $134,7 \% \uparrow$ & $2437 \% \uparrow$ & $149,1 \% \uparrow$ \\
\hline \multicolumn{2}{|c|}{$\begin{array}{l}\text { SUPERRICIE } \\
\text { TOTAL MANCHA } \\
\text { URBANA }\end{array}$} & $\begin{array}{l}\text { SUPERFIIIE } \\
\text { TOTAL EVUP }\end{array}$ & $\begin{array}{l}\text { \% de AREAS VERD } \\
\text { EN RELAACONALL } \\
\text { MANCHA URBAN }\end{array}$ & $14 \%$ \\
\hline \multicolumn{2}{|c|}{ 731.783 Hab. } & $04,2 \mathrm{Ha}$ & 000 m2 & 2 m2/Hab. \\
\hline
\end{tabular}

Figura 66. Tierras vacantes como espacios verdes potenciales y radios de cobertura. El estado actual y el incremento de espacios verdes.

Fuente: elaboración propia, 2017.

Para concluir el incremento en la zona no es del 134,7\% en cambio en la zona desborde o cinturón es de 591\% donde solo un 5\% de la tiene un espacio verde como máximo a 15 cuadras de distancia caminando.

\section{3 | Calidad de paisaje de las tierras vacantes aptas para ser incorporadas como espacios verdes}

Luego del relevamiento y la selección de tierras vacantes viene la fase de caracterización donde se las clasifica según sus características en base a las cuatro dimensiones propuestas: geográfico urbanístico, biofísica, estructural y estética que permitirán determinar la calidad de cada una de las tierras vacantes seleccionadas.

Para la incorporación de tierras vacantes como espacios verdes se las relevo para poder clasificarlas mediante la calidad del paisaje, comprendiéndolas como estos paisajes vacantes que mencionamos anteriormente. Entonces ¿Cuándo hablamos de calidad de paisaje a que nos referimos?, el termino calidad tiene diversas acepciones al igual que el término paisaje.

Según el Diccionario de la Lengua Española de la Real Academia Española, calidad se define como" la propiedad o conjunto de propiedades inherentes a una persona o cosa que permiten apreciarla con respecto a las restantes de su especie", o también como "superioridad o excelencia". 
En cuanto a la planificación del territorio, el término calidad se entiende como el grado de excelencia de un recurso, o de un punto del territorio, que no debe ser destruido, o señalado de otra manera, el mérito para ser conservado, entendiendo su uso sustentable, de forma que se garantice su producción indefinida.

El Convenio Europeo del Paisaje (2000) define la calidad paisajística como: "el encuentro entre las aspiraciones de la ciudadanía, la opinión de los expertos y las políticas públicas en relación al paisaje". Así la calidad del paisaje es un proceso de participación, dialogo, negociación y de expectativas, en donde los habitantes muestran su aspiración hacía un entorno físico atractivo, limpio, afable y estéticamente armonioso que genere bienestar y mejore su calidad de vida. Esta calidad tiene que ver, por tanto, con los sentimientos que despierta la contemplación del paisaje, y si uno toma conciencia de que muchos paisajes cotidianos están deteriorados, carentes de cuidado, sin identidad se pone de manifiesto que eso perjudica la calidad de vida de los ciudadanos. También se puede decir que es "el grado de excelencia de éste, su mérito para no ser alterado o destruido o de otra manera, su mérito para que su esencia y su estructura actual se conserve" (Blanco, 1979). El paisaje como cualquier otro elemento tiene un valor intrínseco, y su calidad se puede definir en función de su calidad visual intrínseca.

Las dimensiones estudiadas conformadas por un conjunto de variables a las cuales se componen de un indicador al cual se le asigna un valor numérico. Las características físicas del paisaje pueden ser identificadas por sus atributos visuales, ya que el planeamiento, las decisiones de manejo, la interacción de la cultura y los procesos naturales llevan a cambios físicos que se verán en el futuro en el paisaje.

La calidad paisajística va a estar ligada a cuatro dimensiones propuestas para el análisis (figura 67), la dimensión geográfico urbanística, biofísica, estructural y estética.

Las tierras vacantes poseen características singulares y distintas entre sí, por eso para poder clasificarlas y catalogarlas es necesario poder identificarlas y agruparlas según los diferentes casos. Se elabora una matriz donde se le asignan valores a cada atributo, estos valores van a permitir ponderar cada una de las tierras vacantes según la característica de cada dimensión en calidad alta, media o baja. Como se explicó en el capítulo 2 apartado 3.2. 


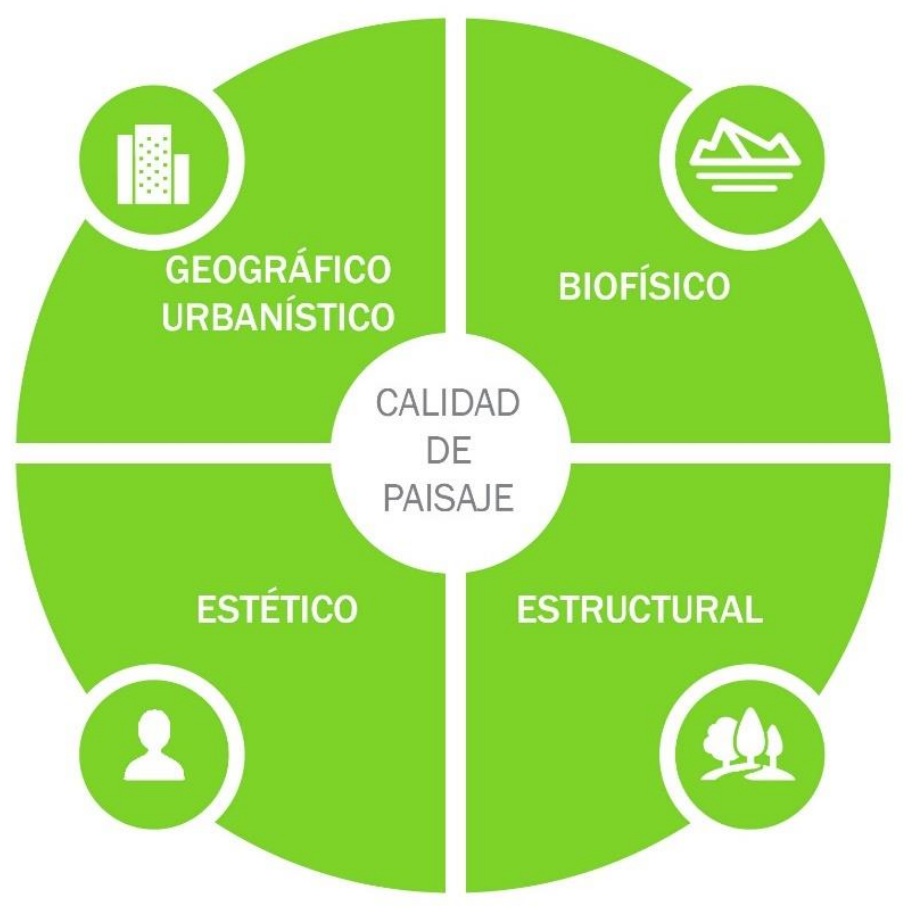

Figura 67. Dimensiones de la calidad de paisaje.

Fuente: elaboración propia, 2018.

Se analizan las tierras vacantes por zona de la periferia, donde se las identifica mediante una imagen satelital y se la referencia con un código, esta matriz luego nos permite elaborar el catálogo de tierras vacantes. (Ver anexo 5)

De cada uno de los atributos, se va a tener un valor numérico que se estableció en la matriz, el cual va a permitir sumarlos y en base a parámetros que explicaremos más adelante se va a determinar el tipo de calidad. Esta tabla me va a permitir tener valores parciales por atributo como el valor total.

Como así también, obtener el tipo de calidad de cada tierra vacante como así también la calidad de cada uno de los atributos geográfico urbanístico, biofísico, estructural y estético.

La calidad de cada una se basa en la noción de paisaje, con el fin de establecer lineamientos para la incorporación como espacios verdes de uso público. Esta se da en función del valor que representan los propios elementos que lo componen (vegetación y usos del suelo, presencia de agua, presencia de singularidades, etc.) o bien como la respuesta que produce en las personas que lo observan.

Se establece entonces que un paisaje va a ser de calidad alta cuando los valores estén entre 53 a 81, un paisaje va a ser de calidad media cuando estos valores estén entre 34 a 52 y de baja calidad cuando estén entre 19 y 33. 
Estos valores se obtuvieron de la suma de los valores máximos de cada uno de los componentes teniendo en cuenta las particularidades de cada atributo y estableciendo un valor medio entre el máximo de cada uno (tabla 13).

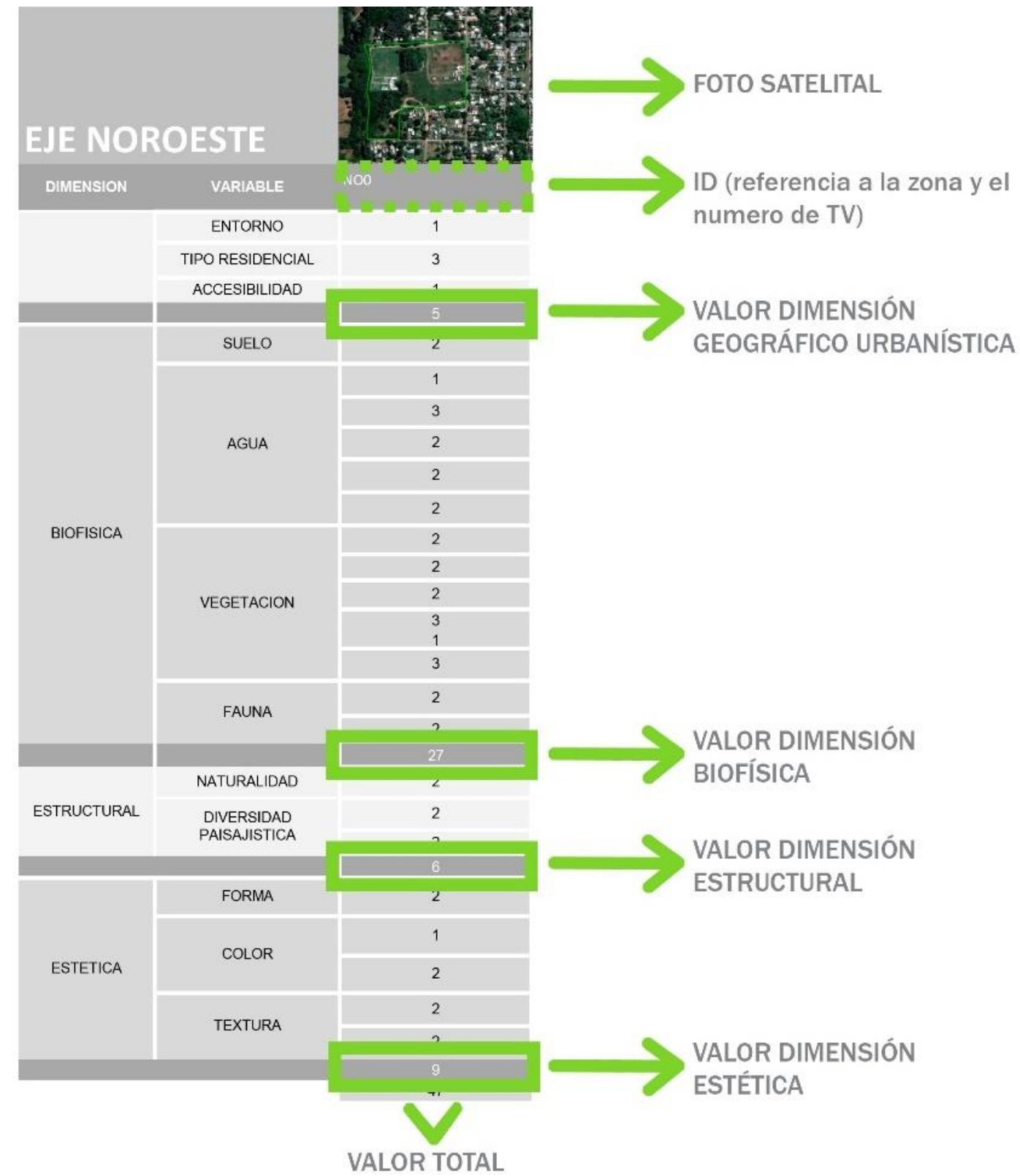

Tabla 13. Ejemplo matriz de atributos (ver anexo 4).

Fuente: Elaboración propia, 2017.

La determinación de la calidad permite obtener un conocimiento más exhaustivo del territorio y, por tanto, facilita la integración de la variable paisajística como un aspecto más a tener en consideración en los procesos de crecimiento urbano.

La calidad será mayor en aquellas tierras vacantes donde el suelo posea rugosidad, vegetación, diversidad de formas y colores, presencia de agua superficial, vegetación y diversidad de tipos, buena accesibilidad y que se encuentre en un entorno singular. La 
calidad va a disminuir a medida que estos atributos se alejen de estas características. La calidad de cada una de las tierras va a permitirnos determinar las categorías de intervención en cada una de ellas.

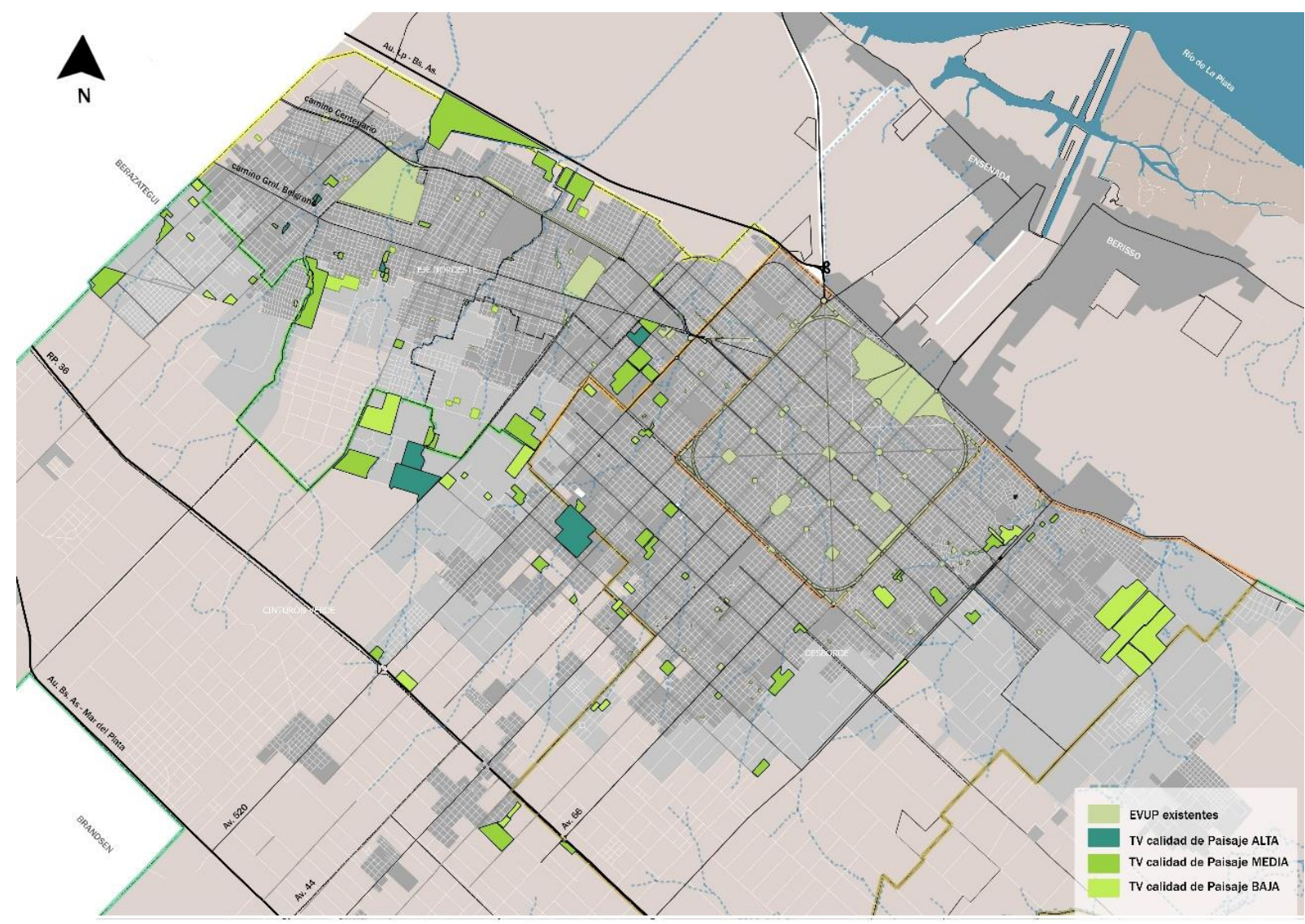

Figura 68. Calidad de paisaje en las tierras vacantes seleccionadas.

Fuente: elaboración propia, 2018.

En el plano se puede ver la distribución espacial de las tierras vacantes en cuanto a su calidad (figura 68). Se puede observar entonces que las tierras de mayor calidad paisajística son las que se encuentran en el sector de desborde y en el eje noroeste y son de las que hay menor cantidad.

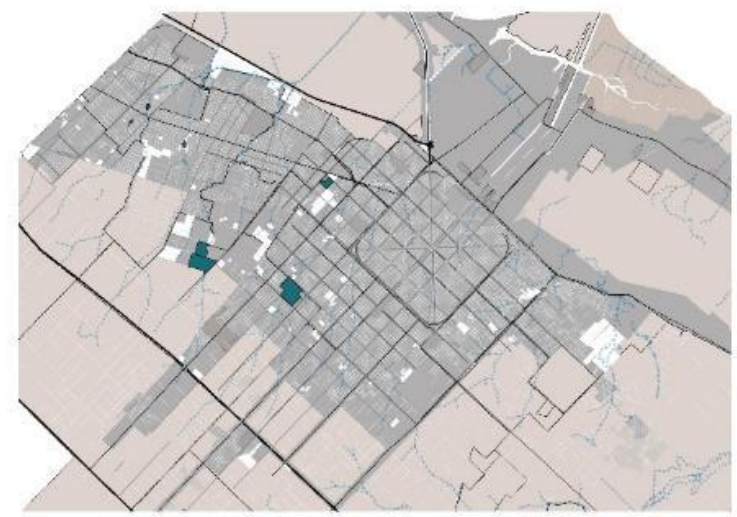


Las tierras de calidad media son de las que mayor cantidad hay, estas se encuentran distribuidas de manera homogénea en todas las zonas.

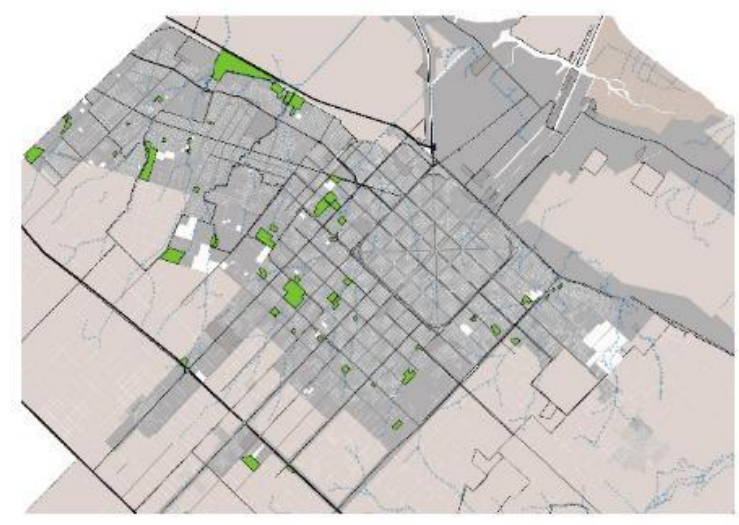

Por último, las de calidad baja, las cuales también se distribuyen en todas las zonas, pero estas en su mayoría se encuentran en los bordes, donde lo urbano se encuentra con lo rural.

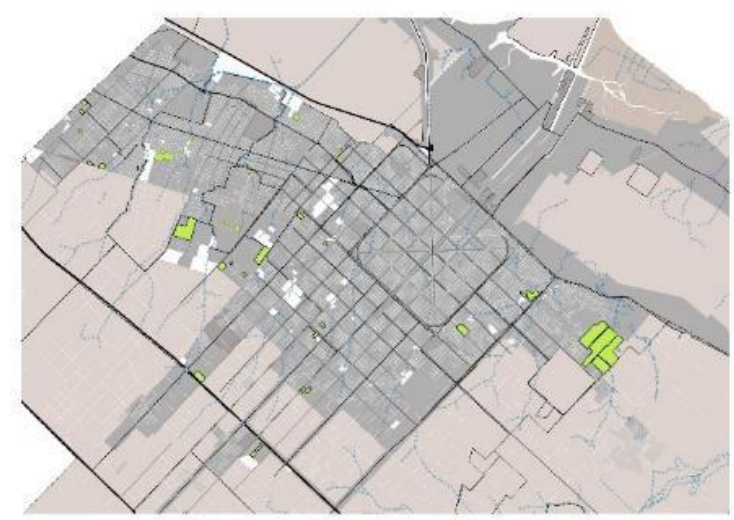

Por otro lado, además de la calidad de cada una de las tierras vacantes se determinaron las características de cada uno de los atributos, la cual nos va a permitir poder establecen criterios de intervención y recuperación.

Se determina entonces que calidad del atributo geográfico urbanístico va a ser alta cuanto este entre 8 y 9 , va a ser media cuando este entre 6 y 7 y bajo cuando este entre 3 y 5 , lo mismo para el atributo estructural. Para el atributo biofísico va a ser alta cuando este entre 24 y 39, media cuando este entre 16 y 23 y baja cuanto este entre 8 y 15 . Por último, el atributo estético va a ser de alta calidad cuando este entre 13 y 15 , de media calidad cuando este entre 9 y 12 y baja calidad cuando este entre 5 y 8 (figura 69). 


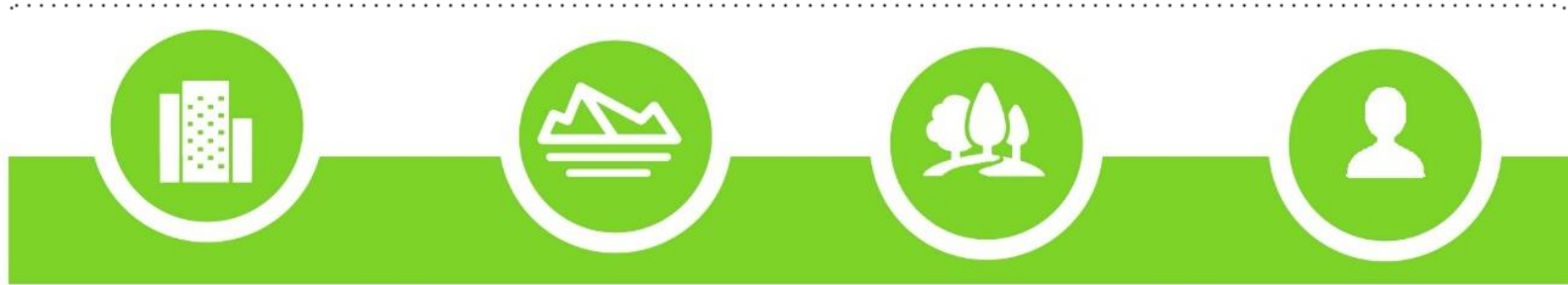

\begin{tabular}{c|c|c|c}
\hline $\begin{array}{c}\text { GEOGRÁFICO } \\
\text { URBANÍSTICO }\end{array}$ & BIOFÍSICO & ESTRUCTURAL & ESTÉTICO \\
ALTA: 8 a 9 & ALTA: 24 a 39 & ALTA: 8 a 9 & ALTA: 13 a 15 \\
MEDIA: 6 a 7 & MEDIA: 16 a 23 & MEDIA: 6 a 7 & MEDIA: 9 a 12 \\
BAJA: 3 a 5 & BAJA: 8 a 15 & BAJA: 3 a 5 & BAJA: 5 a 8 \\
\hline
\end{tabular}

\section{CALIDAD DE PAISAJE TV \\ ALTA: 53 a 81 MEDIA: 34 a 52 BAJA: 19 a 33}

Figura 69. Calidad de paisaje y valores.

Fuente: elaboración propia, 2018.

Para concluir, con esta matriz se permite conocer no solo la calidad de paisaje de cada tierra vacante sino también la calidad de cada uno de sus atributos para poder establecer criterios de intervención sobre cada uno de estos teniendo en cuenta su calidad. Hay paisajes que poseen calidad alta en algún atributo y baja en otro entonces intervenir en todos de la misma manera o con la misma intensidad seria no respetar las cualidades de cada uno particularizadamente. El paisaje hay que trabajarlo desde todas sus dimensiones para que nos permita conocer más de él y contemplar cada uno de sus atributos. 


\section{CAPÍTULO 6}

Hacia un sistema de espacios verdes en la periferia platense

6.2 | Los espacios verdes como resiliencia al cambio climático

6.1 | Categorías de intervención y recuperación para las tierras vacantes

6.3 | Criterios de diseño 


\section{CAPITULO 6}

"Solo en el vacío reside lo verdaderamente esencial...El vacío es todopoderoso, porque puede encerrarlo todo. Únicamente en el vacío es posible el movimiento"

(Tseu en Abalos,2005).

\section{1 | Los espacios verdes como resiliencia al cambio climático.}

Reflexionando acerca de los problemas y consecuencias que genera el cambio climático en los habitantes es necesario pensar como obtener una ciudad más resiliente ¿Por qué no un sistema de espacios verdes?

Como señala Ábalos (2005), repensar el espacio urbano y el territorio desde el paisaje permitirá individualizar estrategias, lugares y programas para equilibrar los déficits medioambientales de la ciudad y su oferta de ocio y productividad, mejorando la calidad de vida y sustentabilidad de la ciudad. Un sistema de espacios verdes espacial el cual se define como un conjunto de espacios verdes planificados de forma estratégica diseñado y gestionado para la prestación de una de servicios ecosistémicos. Es decir, conserva y aporta servicios ecosistémicas claves para la población humana, provisión de agua limpia, mejoramiento de la calidad del aire, mitigación de efectos de isla de calor, biodiversidad, recreación, belleza escénica y protección ante desastres, entre otros beneficios (Benedict y McMahon, 2006).

Un sistema en contraposición a las intervenciones puntuales, el fin es interconectar espacios verdes con el fin de obtener beneficios ecológicos, sociales y económicos funcionando como un marco de referencia para integrar medidas de adaptación de la ciudad. Construir una estrecha relación entre los espacios ocupados y no ocupados, comenzar a articular los distintos tipos de tejidos desde los espacios verdes (Tardín, 2010).

El diseño de estos paisajes vacantes no se proyecta como un jardín estático, como una imagen de la naturaleza, sino que, es un sistema que cambia, evoluciona con la sociedad y sus requerimientos al mismo tiempo que brinda una capacidad de adaptación. Un sistema espacial es un todo dinámico, que varía con el tiempo (Santos, 2002). Milton Santos en 1994, señala que uno de los componentes del espacio es el paisaje "es como 
un palimpsesto, o sea, el resultado de una acumulación, en la cual algunas construcciones permanecen intactas o modificadas, en cuanto otras desaparecen para dar lugar a nuevas edificaciones. A través de este proceso, lo que está delante de nosotros es siempre un paisaje y un espacio..." (p.67)

Este sistema en el tiempo puede ir cambiando mostrando las fortalezas y debilidades de cada uno de los espacios verdes como así también el uso que se da en ellos. Espacios verdes que vinculen la función como espacios públicos, lugar de recreación y encuentro con las funciones ecológicas que brindan como por ejemplo la disminución de los efectos de las precipitaciones que afectan tanto a la región. Un sistema pensado desde el paisaje que articule las diferentes funciones con el fin de ofrecer espacios de uso para los habitantes como funciones en pos de la sustentabilidad y resiliencia urbana. Este sistema va a estar conformado por diferentes espacios verdes en cuanto al tipo y a las actividades que en él se pueden realizar, estas van a estar determinadas por el análisis en base a la calidad que se desarrollara en próximo apartado.

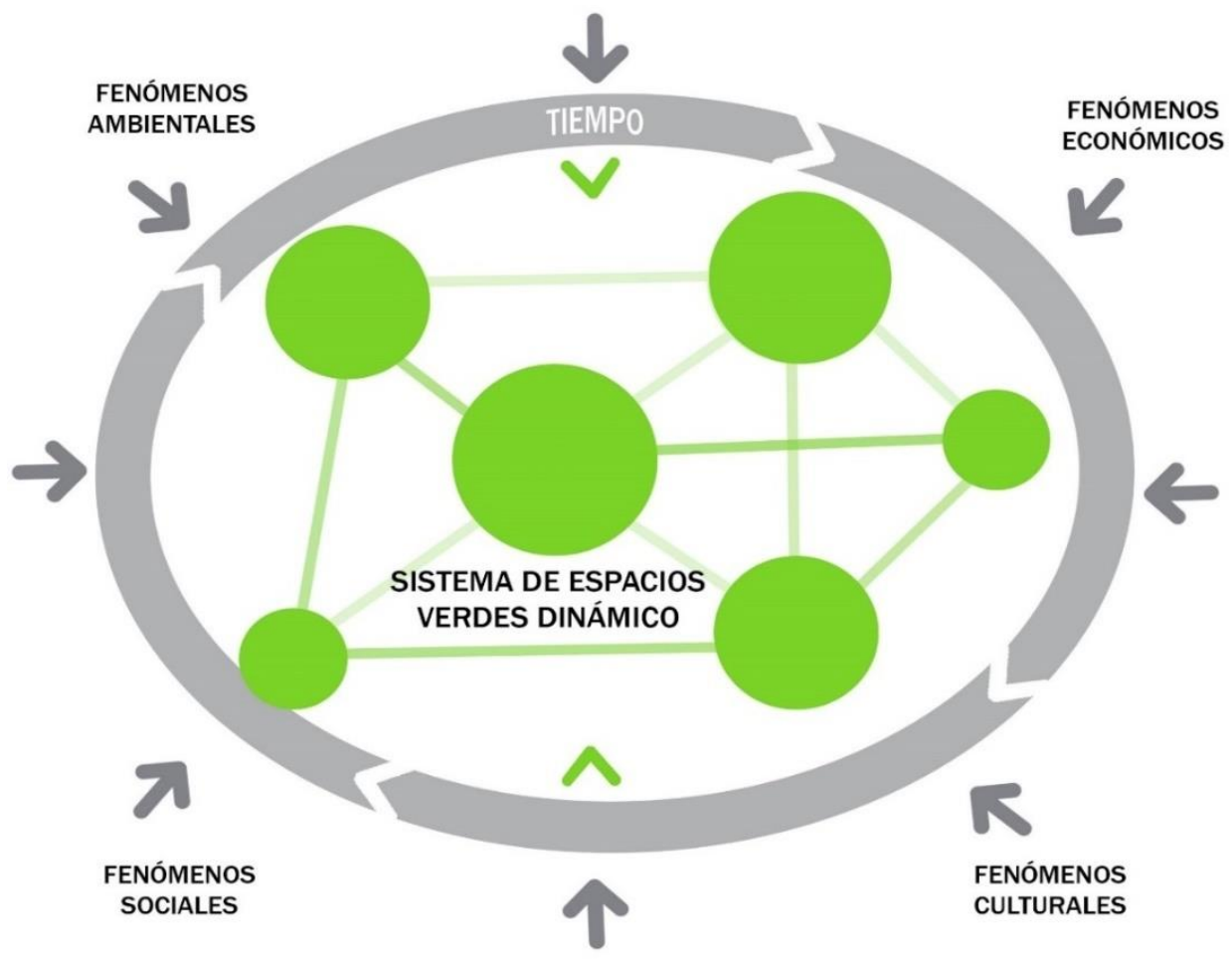

Figura 70. Sistema de espacios verdes dinámico que se adapta a los cambios en el tiempo. Fuente: Elaboración propia, 2017.

Se busca proponer lineamientos y criterios para conformar un sistema de espacios diversos (figura 70) que brinde cobertura a nivel espacial y barrial de espacios verdes a los habitantes. De este modo, los habitantes de la periferia estarían cubiertos de espacios 
verdes de uso público. La función y actividades de estos espacios verdes no va a estar ligada a la forma sino a las cualidades del paisaje, teniendo en cuenta las características y la calidad, como así también las actividades requeridas por los habitantes.

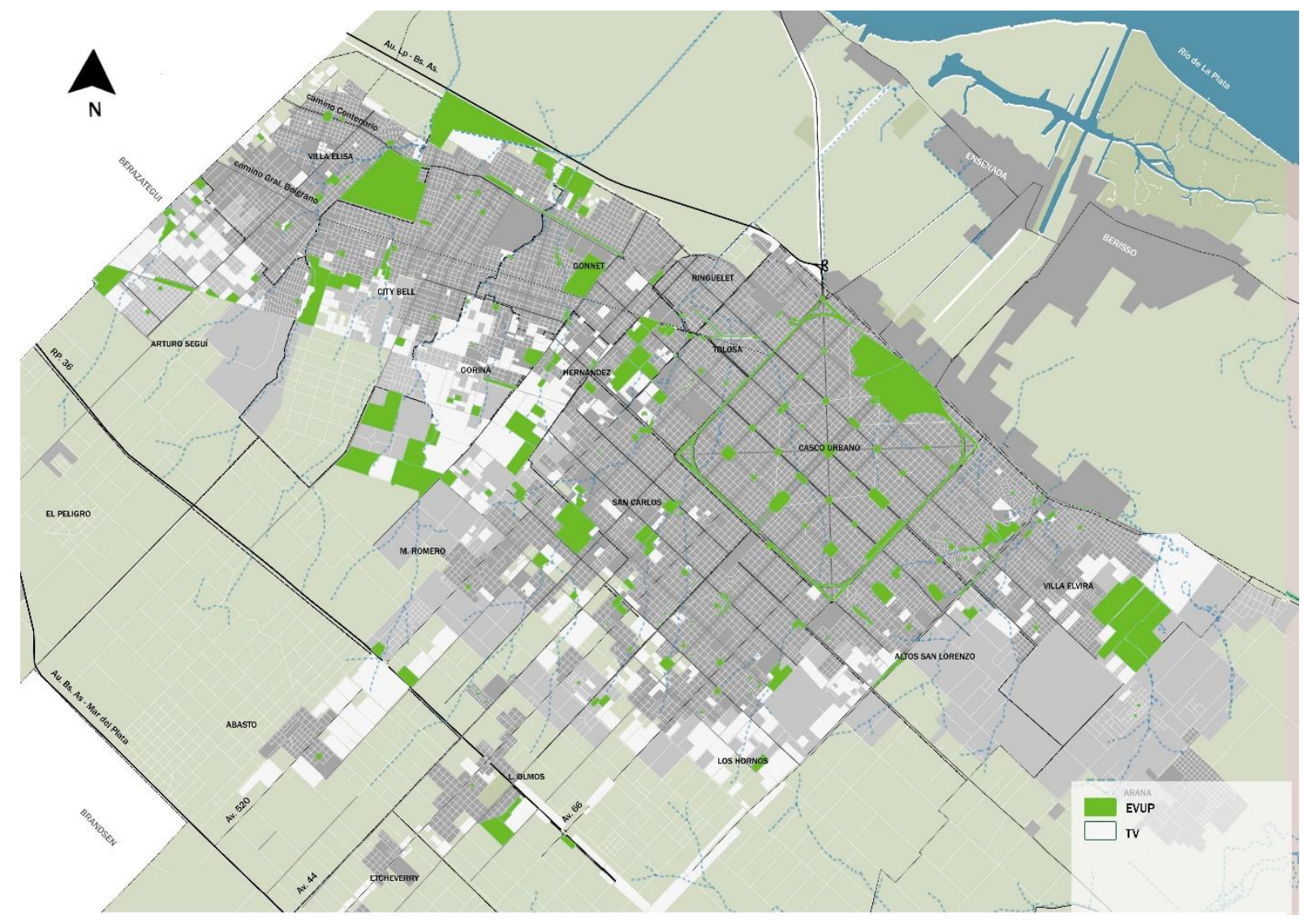

Figura 71. Los espacios verdes propuestos.

Fuente: Elaboración propia en GIS, 2017.

Este es un avance en el planteamiento de dichos espacios ya que siempre las actividades, el diseño, las intervenciones están dadas por la forma no por las características y cualidades del paisaje. La búsqueda de un sistema de espacios verdes (figura 71) es una directriz posible hacia el desarrollo sustentable del territorio, el mantenimiento de la heterogeneidad de los espacios verdes garantiza de esta manera la integridad de los procesos humanos y naturales. Los espacios verdes públicos otorgan cualidad a la ciudad y por ende, constituyen uno de los ejes de las políticas públicas.

\subsection{Categorías de intervención y recuperación para las tierras vacantes}

Las tierras vacantes como mencionamos anteriormente son espacios que pueden revertir la situación que se viene dando de falta de áreas verdes de uso público en la periferia, "La reutilización de tierras vacantes a través de adecuadas políticas de manejo permitiría 
contribuir a la recuperación de la calidad urbana-ambiental de ciudades actualmente dispersas y fragmentadas" (Frediani, 2016)

Las tierras vacantes entendidas como paisajes vacantes a la espera de ser vistos por los habitantes como nuevos paisajes. Espacios de oportunidad, vacíos en la trama urbana como piezas que quedaron estratégicamente desocupadas para darle aire a la ciudad. Estos espacios debieran ser aprovechados, incorporarlos como espacios verdes seria la función más adecuada y a la vez requerida por los habitantes. Se busca “usar la naturaleza como un modelo para diseñar nuestras propias comunidades, estilos de vida y tecnologías y, regresar a la naturaleza grandes espacios para su propio mantenimiento" (Register, 2002).

Para incorporar estas tierras como espacios verdes es indispensable conocer las características de cada una para luego proponer criterios para la recuperación e intervención de las tierras vacantes como se mencionó en el capítulo 5.

Establecer criterios de recuperación e intervención desde la mirada del paisaje va a permitir poder rescatar y valorar las condiciones y características de cada una, como así también poder llevar a cabo acciones en ellas que busquen la recuperación desde todas las dimensiones. Teniendo en cuenta no solo las características geomorfológicas sino también las estéticas, las que hacen a la conformación de ese paisaje, sin perder la identidad del lugar se busca generar una nueva identidad de los habitantes con estos nuevos espacios. Esta mirada nos permite intervenir en el territorio sin perder de vista como son estos lugares este que características tienen y como es la sociedad que los habita.

En base a las características y cualidades desde el paisaje de cada tierra vacante se proponen criterios de intervención. Los criterios se basan en la calidad de cada uno de los atributos en particular, los cuales luego se suman y nos proporcionan la calidad de paisaje de cada una de las tierras vacantes.

Se establece entonces que la calidad de cada atributo condicione las acciones a llevar a cabo teniendo en cuanto a la calidad de paisaje observada de estos (tabla 14). Estas acciones reflejan la intensidad o grado de modificación que se puede realizar como así también acciones ligadas a la preservación y puesta en valor. 


\begin{tabular}{|c|c|c|}
\hline & & Criterios de intervencion \\
\hline \multirow{3}{*}{$\begin{array}{l}\text { Geografico } \\
\text { urbanistico }\end{array}$} & ALTA & Intensidad o grado de modificación posible del entorno baja o nula. \\
\hline & MEDIA & $\begin{array}{l}\text { Intensidad o grado de modificación posible del entorno media. Culminar las obras inacabadas o poner en } \\
\qquad \text { valor las infraestructuras públicas en desuso. }\end{array}$ \\
\hline & BAJA & Intensidad o grado de modificación posible del entorno alta. Recuperar edificios abandonados. \\
\hline \multirow{3}{*}{ Biofisico } & ALTA & Preservación activa \\
\hline & MEDIA & completamiento forestal - purificación del agua \\
\hline & BAJA & forestación - saneamiento curso de agua \\
\hline \multirow{3}{*}{ Estructural } & ALTA & Preservación activa \\
\hline & MEDIA & puesta en valor \\
\hline & BAJA & recuperación - Remediación / mitigación de un hábitat degradado \\
\hline \multirow{3}{*}{ Estetico } & ALTA & Preservación activa \\
\hline & MEDIA & puesta en valor \\
\hline & BAJA & recuperación \\
\hline
\end{tabular}

Tabla 14. Criterios de intervención según calidad de atributos.

Fuente elaboración propia, 2017.

En este contexto, en el caso del atributo geográfico urbanístico la calidad alta, media o baja lo que hace es ver en qué medida se puede modificar el entorno urbano de la tierra vacante en cuestión. Es decir, si el entorno es singular o posee algo en particular preservarlo y no modificarlo, cambio si es la calidad media o mala se busca poner en valor los edificios e infraestructuras públicas en desuso.

En relación al atributo biofísico, la calidad lo que determina es si hay que preservar activamente ese espacio porque tiene una alta calidad en cuanto a la vegetación, en cambio si la calidad es media lo que se propone es un completamiento forestal y la purificación del agua. En caso de que sean de baja calidad se propone un plan de plantación de especies vegetales y el saneamiento del curso de agua.

En cuanto al atributo estructural, lo que se mide en este caso es el grado de antropización, de la tierra vacante y si es un paisaje heterogéneo en relación a la conformación del paisaje y cuan singular es. Es por ello que se propone como criterio de intervención para una calidad alta la preservación activa del paisaje, para una calidad media poner en valor ese hábitat y para una baja calidad recuperar, remediar y mitigar el hábitat degradado. Entendiendo por remediar a la recuperación ambiental de sitios degradados por la actividad y contaminación humana y por mitigar al conjunto de medidas que se pueden tomar para contrarrestar o minimizar los impactos ambientales negativos que pudieran tener algunas intervenciones antrópicas. 
Por último, en relación al atributo estético, lo que se propone como medidas de intervención en relación a la característica más visual del paisaje como la forma, el color y la textura. Donde sí es de calidad alta en relación a la conformación de diferentes tipos de colores, texturas y formas se propone la preservación activa, en cambio si es de calidad media se propone poner en valor los componentes de este paisaje resaltando sus cualidades y si la calidad es mala se busca la recuperación de este paisaje que ha sido degradado buscando llevarlo a su condición original.

Estas calidades de paisaje en base a los diferentes atributos nos permiten caracterizar las tierras vacantes y pensar que acciones se van a llevar a cabo para convertirlas en espacios verdes públicos. A su vez, esto se complementa de los criterios de diseño urbano, donde el tipo o función ya no responde a la forma, sino que se propone que estos sean espacios verdes flexibles donde las actividades que se lleven a cabo van a estar ligadas al diseño de estos en base a las características biofísicas, estructurales y estéticas.

Una vez obtenida la calidad de paisaje por atributo se prosigue con establecer el tipo de EVUP que va a ser y en relación a esto los criterios de diseño. El tipo de espacio verde que va ser depende de la calidad del paisaje que posea. Como se mencionó en el capítulo 5 apartado 5.3.

Estas tierras vacantes que ya tenemos catalogadas en base a la calidad de paisaje, se superponen en un plano gis a los tipos de paisaje que establecimos en el capítulo 2 apartado 2.3. De esta manera, no solo para determinar el tipo de espacio verde que va a ser se tiene en cuenta la calidad, sino que también se tiene en cuenta la ubicación y como es ese tipo de paisaje.

Los tipos de paisaje son importantes para incorporarlos ya que reflejan características del territorio que van a condicionar estos nuevos espacios verdes. Estos entonces tienen que adaptarse al lugar donde se implantan y ser funcionales. De este modo, puede haber espacios de calidad alta en un tipo de paisaje como en otro y la respuesta no puede ser la misma, tenemos que ser sensibles al territorio.

Para delimitar tipos de espacios verdes se tiene en cuenta el porcentaje de suelo absorbente que tiene que poseer, el porcentaje de especies vegetales en relación a la superficie total. Estas dos características son las más importantes ya que en estos espacios va a predominar el verde y van a funcionar como resilientes al cambio climático. 
Para este se elaboraron fichas de catálogos ${ }^{66}$ de T.V. donde en cada una de las fichas se volcó la información de la calidad que poseía y donde se encontraba localizada en base a los tipos de paisaje (figura 72).

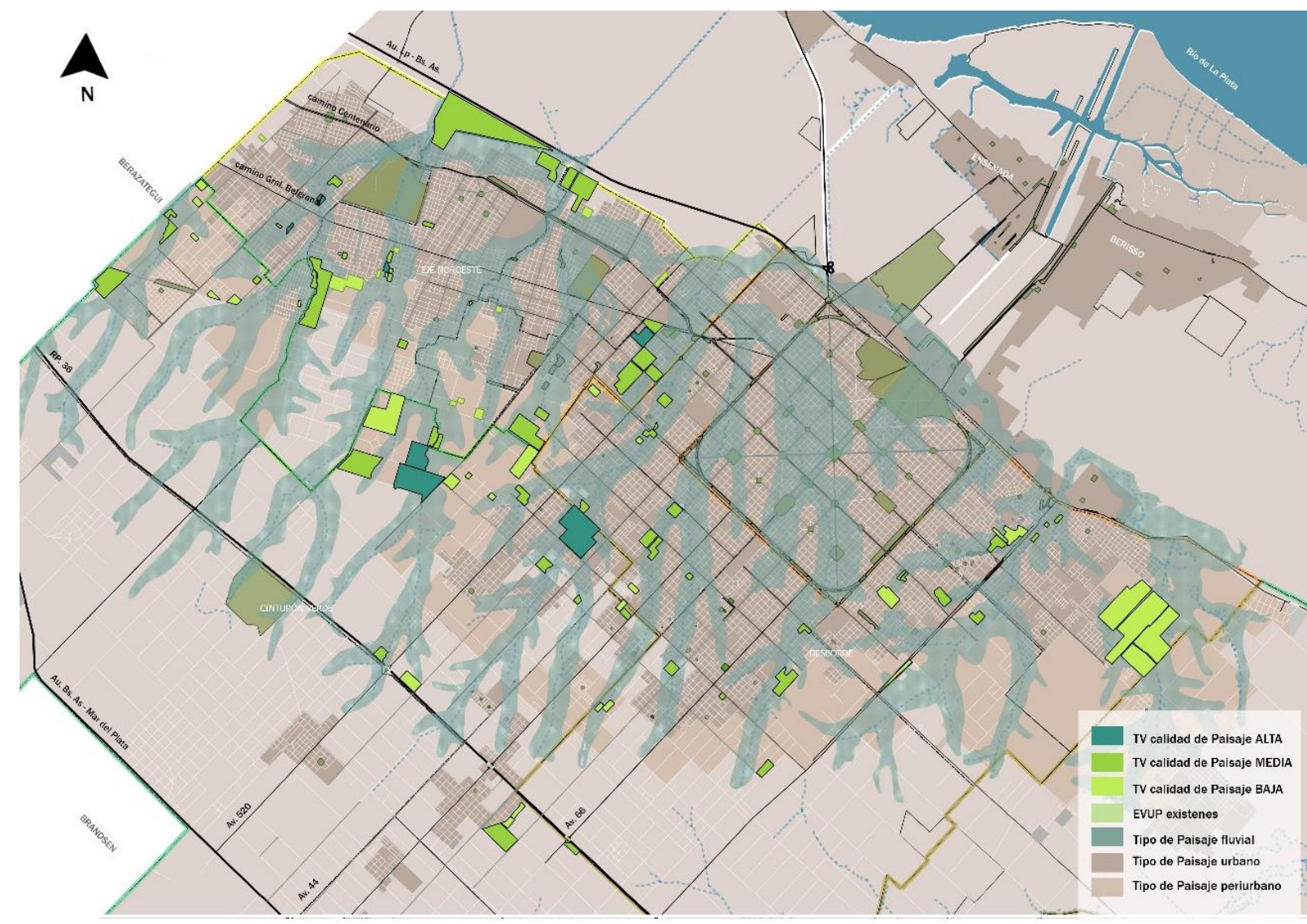

Figura 72. Las tierras vacantes según calidad de paisaje y tipos de paisaje.

Fuente elaboración propia en GIS, 2018.

Estos catálogos se elaboraron a modo de síntesis para poder incorporar toda la información obtenida en la etapa de relevamiento (figura 73). Estos buscan tener descripciones de las tierras vacantes y cuál es el elemento que las vincula desde el paisaje. A su vez, contienen la información necesaria para luego poder determinar el tipo de espacio verde que se va a proponer en ese sector.

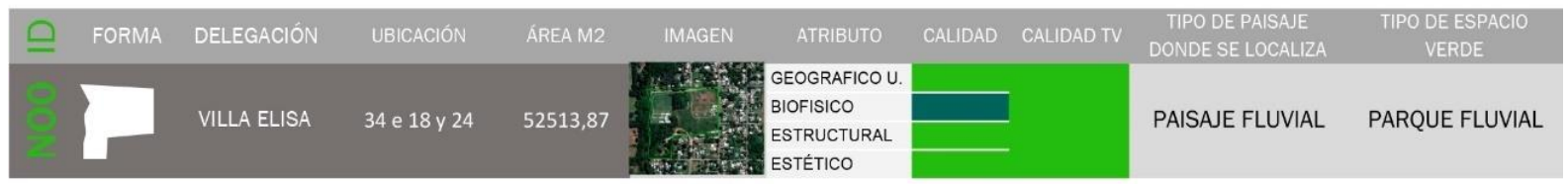

Figura 73. Ejemplo de Catalogo de paisaje y TV. (ver anexo 5).

Fuente elaboración propia, 2018.

${ }^{66}$ Es un registro que presenta, de manera ordenada, descripciones y datos generales. 
Para poder ver qué tipo de espacio verde debería ser en base a la ubicación en relación al tipo de paisaje y la calidad se realizó una tabla de asociaciones, la cual permite a simple vista ver qué tipo de espacio verde seria, cuales serían sus principales características y el uso principal.

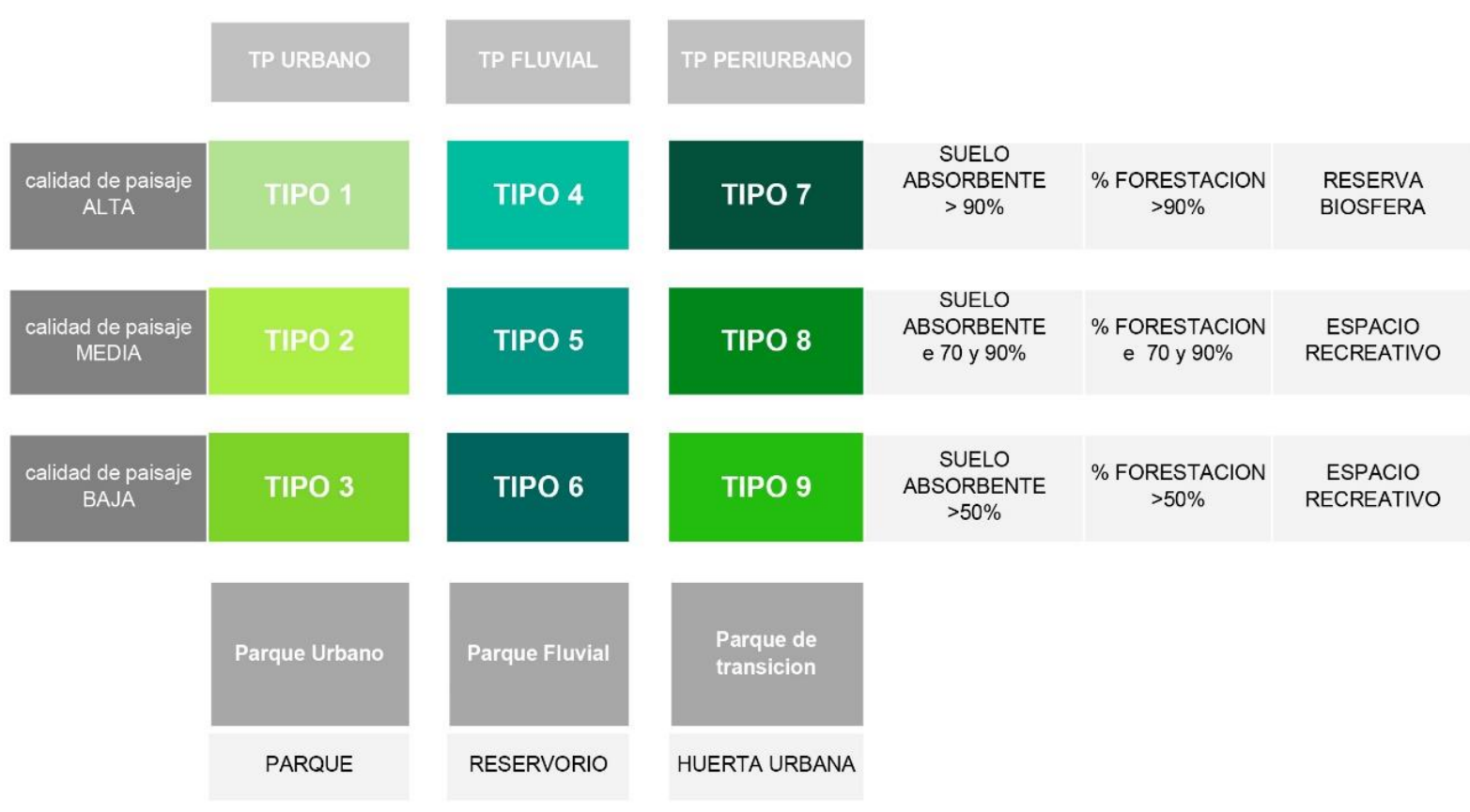

Tabla 15. Ejemplo de aplicación tabla de asociaciones.

Fuente: Elaboración propia, 2018.

Por ejemplo, una tierra vacante que está ubicada en el tipo de paisaje fluvial y es de calidad alta se propone que sea un parque fluvial con un $90 \%$ de suelo absorbente, un $90 \%$ de la superficie total cubierta por especies vegetales y que funcione como una reserva de biosfera.

Esta tabla resulta un insumo muy útil y práctico para aplicar en este caso de estudio como en cualquier otra para que con dos datos obtengamos todos los demás. En la tabla (tabla 15) no solo aparece el tipo de espacio verde que debería ser, sino que también aparece la función principal y el porcentaje mínimo de vegetación y de suelo absorbente que debería poseer. Estos porcentajes mínimos de vegetación y superficie de suelo absorbente nos van a permitir poder absorber el agua de las precipitaciones y contribuir así a mitigar los efectos del cambio climático aumentando la resiliencia a este. 


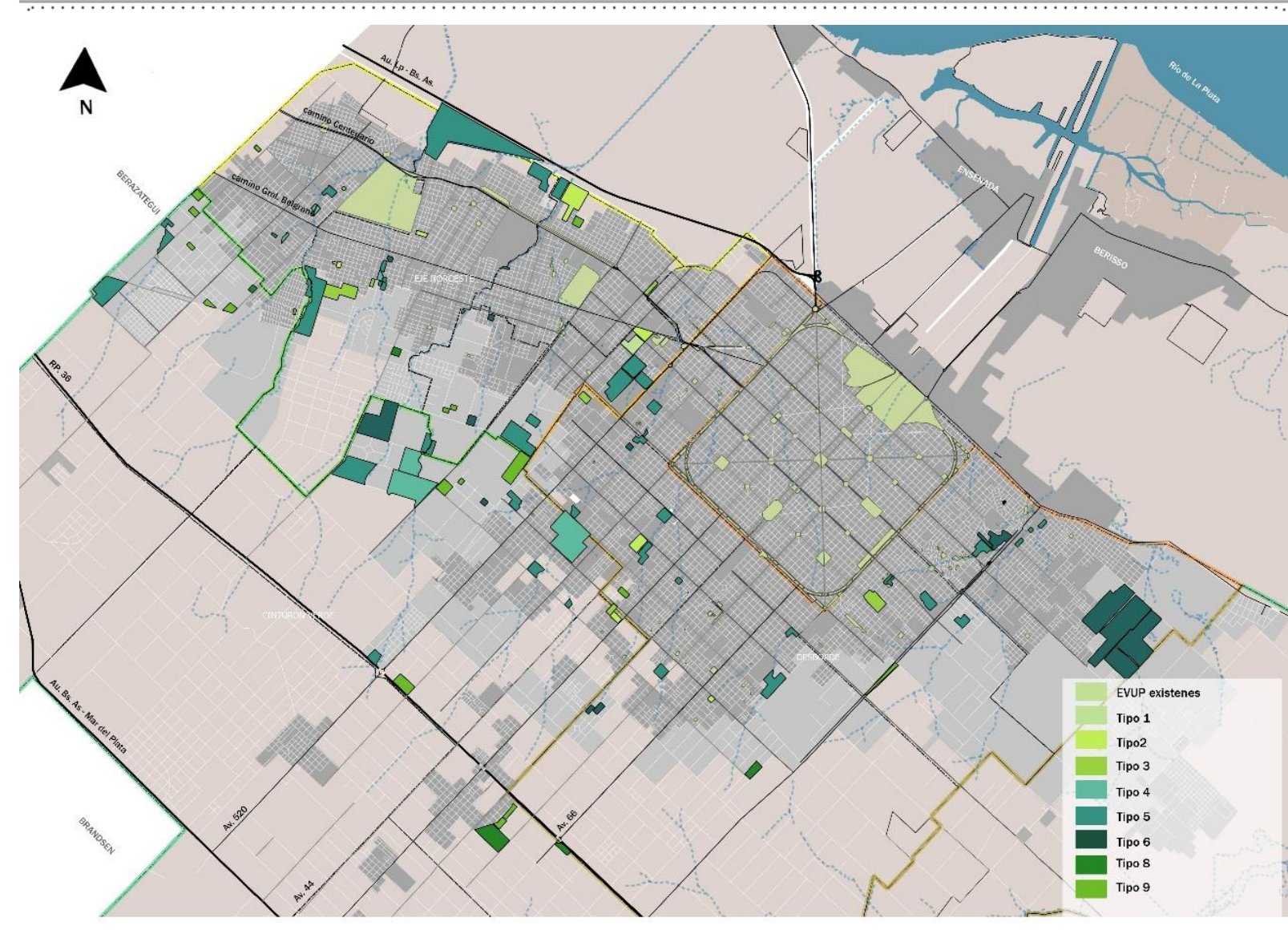

Figura 74. Espacios verdes propuestos por tipo.

Fuente: Elaboración propia, 2018.

Se pueden observar entonces que de los espacios verdes propuestos en la periferia (figura 74) en su mayoría son parques fluviales que funcionan como reservorios. Esto se da porque al ser la región de estudio una llanura alluvional atravesada por valles fluviales encontramos muchos arroyos donde estos espacios adyacentes tienen la función principal de aminorar las inundaciones.

Estas tierras vacantes adyacentes a cursos de agua en su mayoría cuentan con una calidad de paisaje alta ya que el agua le brinda una condición de singularidad. Asimismo, estas poseen diversidad de vegetación y de estratos. Estas tierras adyacentes a cursos de agua deberían ser las áreas prioritarias de intervención para evitar la localización de viviendas y asentamientos informales en las orillas de los arroyos.

Si analizamos la periferia por las zonas definidas anteriormente se puede observar que en todas se da una situación distinta y particular (tabla 16). A su vez, se puede observar que no hay en ninguna de las zonas de la periferia TV de alta calidad en el tipo de paisaje periferia, es decir que no hay parques dl tipo 7. Por otra parte, del tipo que más hay en las tres zonas es del tipo 5 que responde a calidad media en tipo de paisaje fluvial. 


\begin{tabular}{|l|c|c|c|c|c|c|c|c|c|}
\hline & TIPO 1 & TIPO 2 & TIPO 3 & TIPO 4 & TIPO5 & TIPO 6 & TIPO 7 & TIPO 8 & TIPO 9 \\
\hline DESBORDE & & 2 & $\mathbf{2}$ & & $\mathbf{1 9}$ & $\mathbf{9}$ & & $\mathbf{1}$ & $\mathbf{2}$ \\
\hline EJE NO & 1 & 4 & $\mathbf{5}$ & $\mathbf{4}$ & $\mathbf{1 7}$ & $\mathbf{3}$ & & $\mathbf{1}$ & $\mathbf{4}$ \\
\hline CINTURON VERDE & & 1 & 1 & $\mathbf{3}$ & $\mathbf{1 1}$ & $\mathbf{2}$ & & $\mathbf{3}$ & $\mathbf{1 2}$ \\
\hline
\end{tabular}

Tabla 16. Tipos de espacios verdes propuestos y cantidad por zona.

Fuente: Elaboración propia, 2018.

Para finalizar, de los espacios verdes a partir del tipo se determina el porcentaje de suelo absorbente mínimo para cada uno (figura 75). Si analizamos el incremento de espacios verdes y los discriminamos por tipo según los parámetros en cuanto al porcentaje de superficie absorbente vamos a identificar que de esos 1319,1 Ha. que se incorporarían el $66 \%$ sería el mínimo de suelo absorbente y de áreas forestadas. Es decir que se incorporarían un mínimo de 863,1 Ha. de superficie capaz de absorber el agua, aminorar las inundaciones y contribuir a la resiliencia al cambio climático.

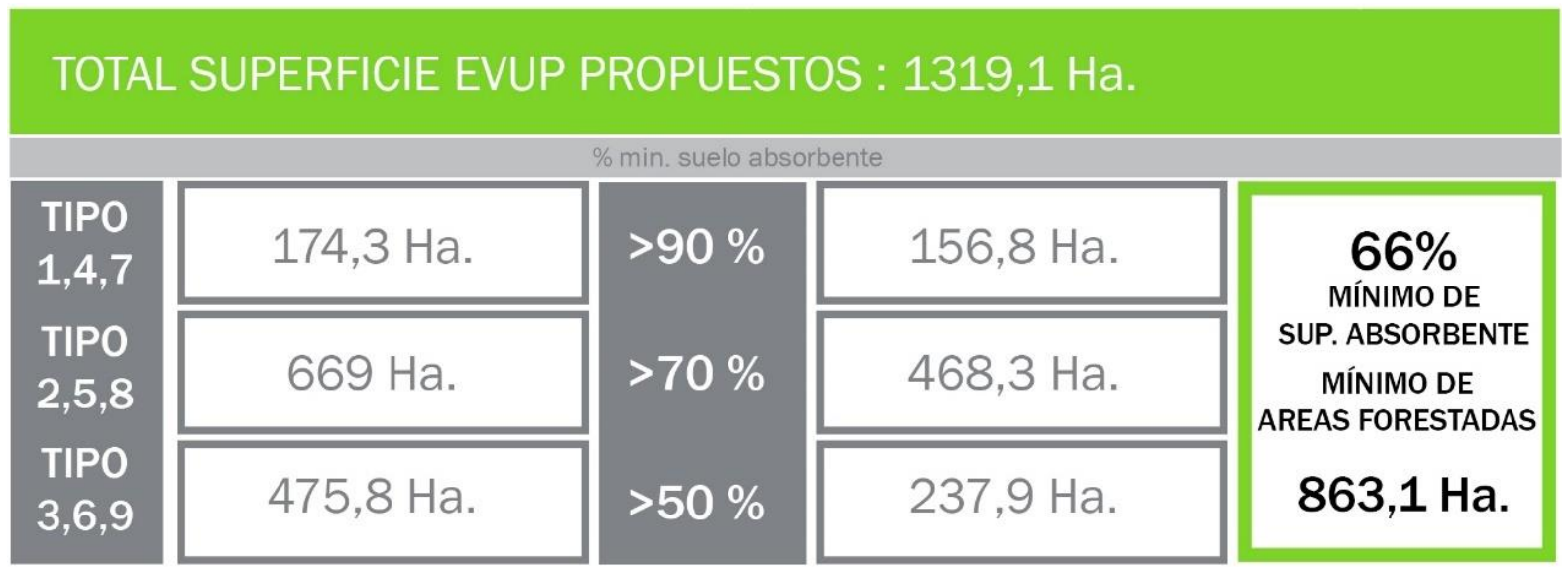

Figura 75. Superficie de suelo absorbente mínima (ver anexo 6).

Fuente: Elaboración propia, 2018.

DESBORDE

En la zona de desborde al ser la zona más urbanizada no encontramos TV de calidad alta, sino que son en su mayoría de calidad media (figura 76). Las adyacentes a cursos fluviales tienen calidad media en la zona más cercana al caso fundacional y baja la calidad a medida que nos alejamos de él. Esto nos da en casi en su totalidad parques fluviales, los cuales serían de suma relevancia ya que esta zona es atravesada por el arroyo el Gato67 y el Maldonado.

\footnotetext{
${ }^{67}$ La cuenca del arroyo el gato es la más antropizada y en la que se asienta la mayor cantidad de población la cual se vio muy afectada en la última gran inundación del 2 de abril de 2013.
} 


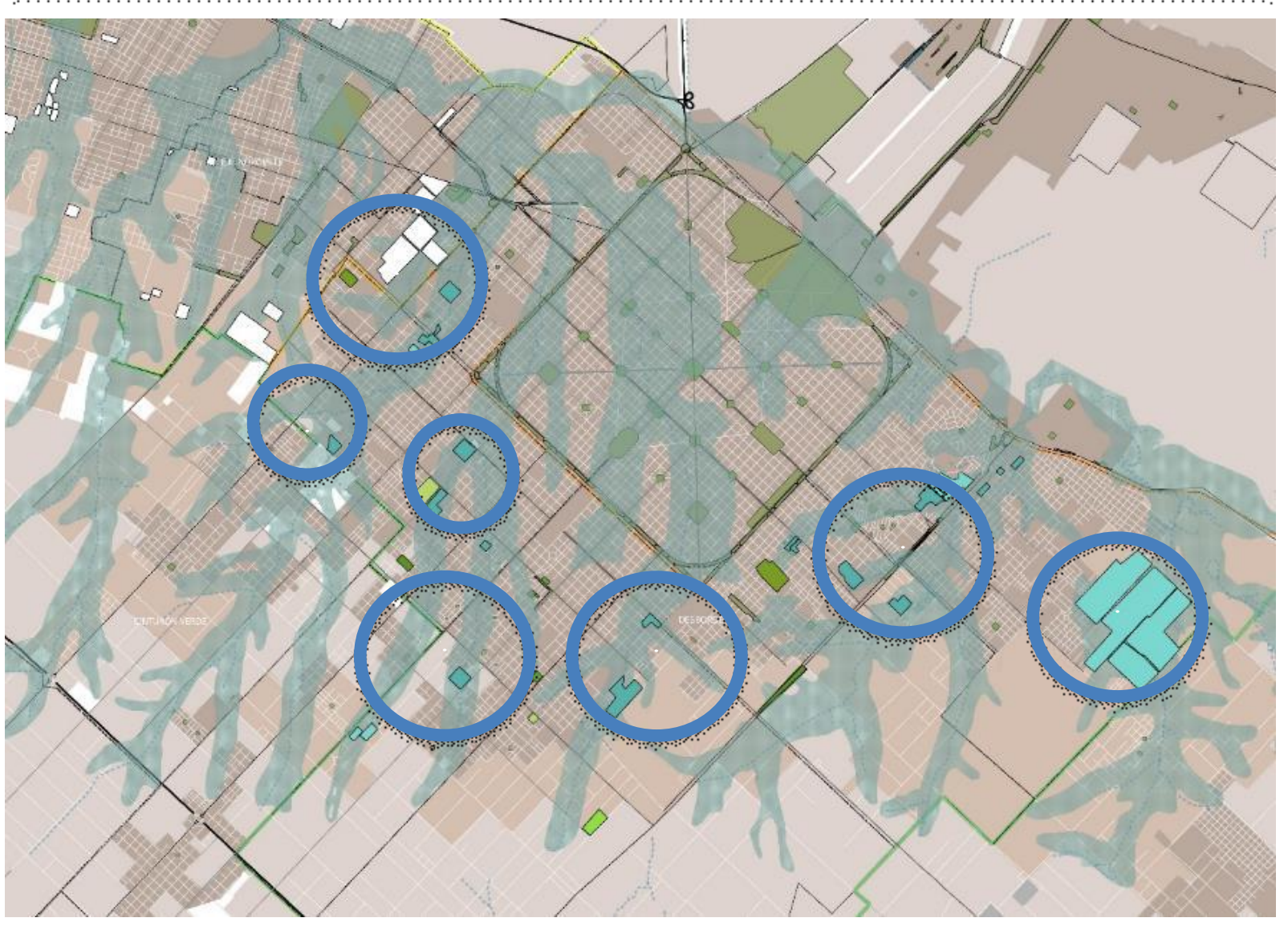

Figura 76. Zona desborde tipos de espacios verdes propuestos.

Fuente elaboración propia en GIS, 2018.

EJE NO

Analizando la zona del eje NO se puede observar que las tierras vacantes en su mayoría poseen calidad media, si bien hay de calidad alta y baja, estas cuadruplican el número. Las tierras vacantes en esta zona se localizan en su mayoría adyacentes a cursos de agua o en zona inundable y son las de mayor tamaño (figura 77). Esta zona entonces estará compuesta en su mayoría por grandes parques fluviales y que a su vez por estar en una condición de borde pueden hacer de límite para la expansión urbana. También posee grandes agrupaciones de espacios verdes que pueden funcionar como parques lineales.

A su vez, en esta zona hay un punto donde hay varias cavas las cuales convertiralas espacios verdes serian de suma importancia por lo que generan a los vecinos. Son espacios que son susceptibles a ser usados como basurales clandestinos como asi también las que poseen agua en su interior de ser usados como espacios para la recreación acuática sin tener en cuenta la peligrosidad para la población que esto genera. 


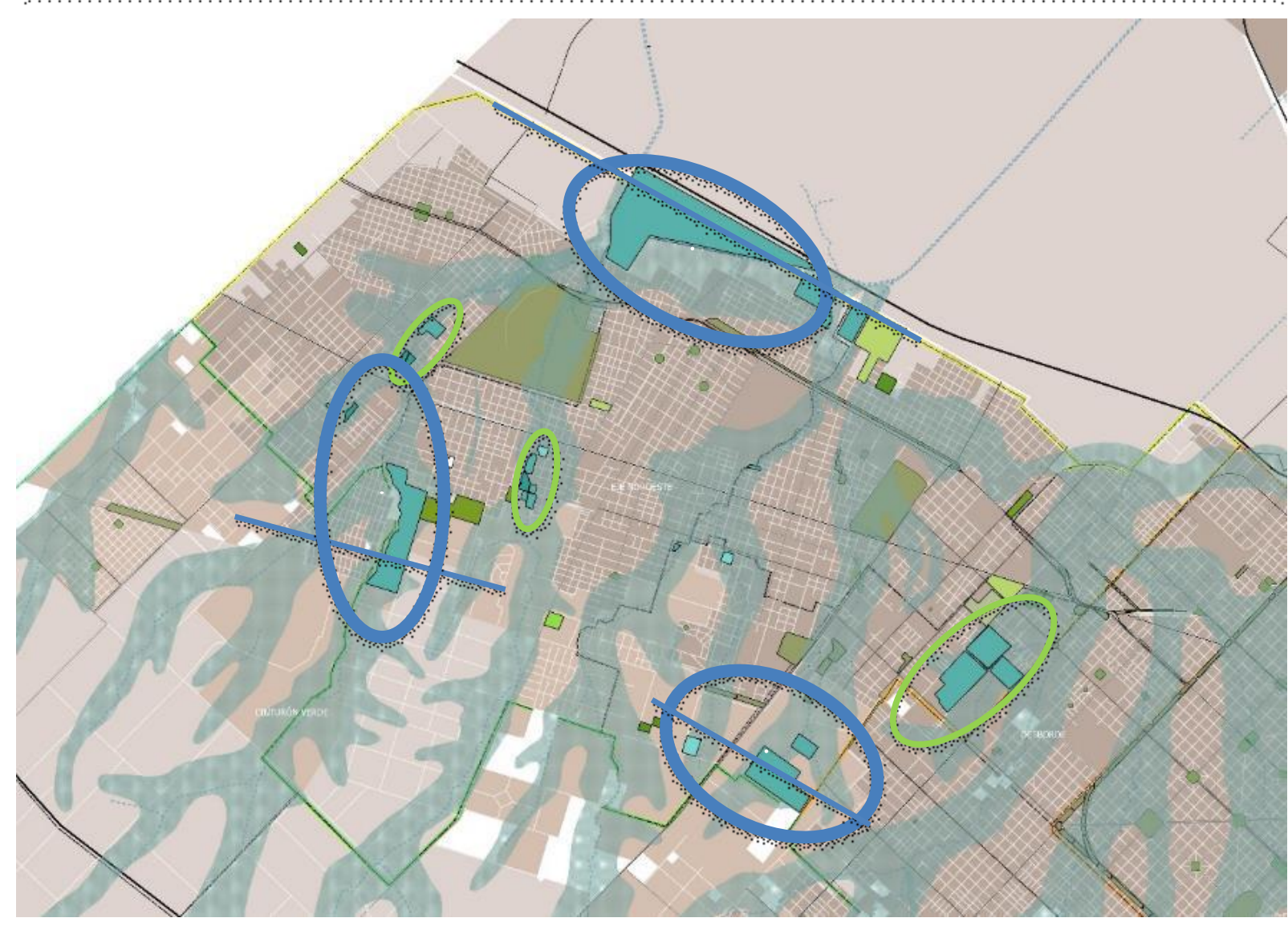

Figura 77. Zona del eje NO tipos de espacios verdes propuestos.

Fuente elaboración propia en GIS, 2018.

CINTURON VERDE

Por último, la zona del cinturón verde es la zona menos antropizada y gran parte de su extensión forma parte del cinturón frutihortícola platense (figura 78). Esta zona posee grandes tierras vacantes con calidad alta las cuales están en zona de paisaje fluvial o periurbano y solo 2 se encuentran en zona urbana las cuales son de menor tamaño. En su mayoría serian parques fluviales y parques de transición con huertas urbanas.

En esta zona, si bien al poseer mayor cantidad de suelo de uso rural el suelo no se encuentra urbanizado son valiosas las escasas tierras vacantes que se encuentran en zona urbana. Estas tierras podrían ser los nuevos espacios verdes de los habitantes de esta zona, los habitantes poseen mayor espacio verde en sus viviendas, pero no hay espacios de encuentro y de uso social.

A su vez, estas tierras que pueden ser convertidas en parques de transición se proponen que funcionen como huertas urbanas fortaleciendo a este cordón frutihortícola platense como una actividad más de la comunidad. 


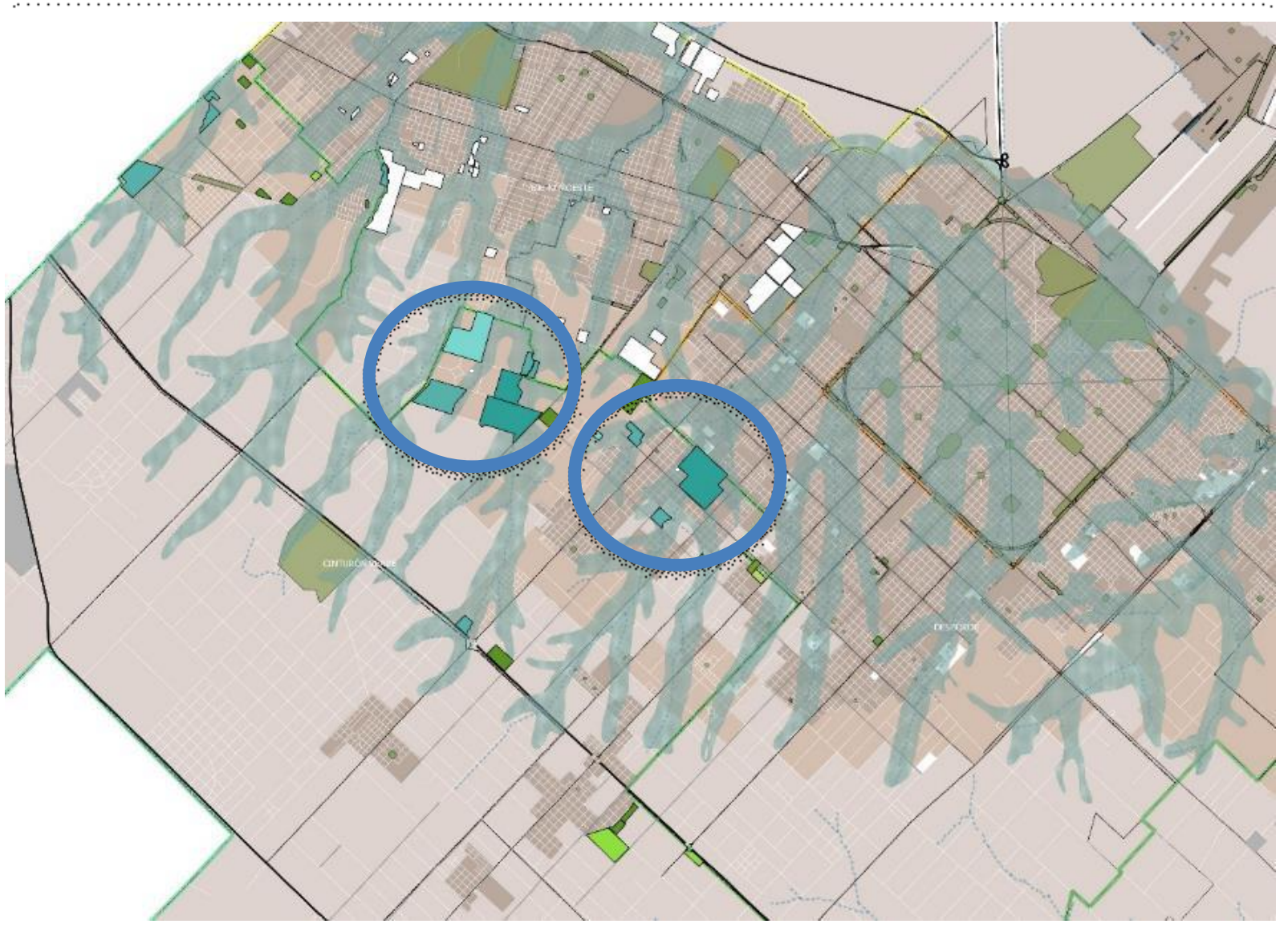

Figura 78. Zona del eje NO tipos de espacios verdes propuestos

Fuente elaboración propia en GIS, 2018.

\section{3 | Criterios de diseño}

Lo natural nunca está exento de la antropización donde todos los sistemas ecológicos han sido, de una u otra manera, afectados por la acción de las personas. Habitamos en entornos antropizados que han tenido que adaptar los ciclos que regulan su funcionamiento a las transformaciones que los humanos han ido realizando en ellos. Esto también significa que las personas han pasado a formar parte de los sistemas ecológicos como agente regulador y la protección o la no actuación sobre estos sistemas ya no es suficiente para lograr su correcto funcionamiento. Es necesario actuar sobre dichos sistemas con operaciones que permitan su reactivación para que éstos recobren su capacidad de recuperación o resiliencia.

Para comenzar a determinar criterios se realizó un análisis de espacios verdes reconocidos distintas ciudades con el fin de poder encontrar herramientas a la hora de diseñar. El relevamiento se realizó buscando a las dimensiones determinadas para la identificación de las tierras vacantes. 
¿Cómo deberían ser estos espacios verdes resilientes? Diseñar espacios verdes para la Resiliencia “implica generar capacidades adaptativas a través de proyectos que permitan la evolución de sus componentes en el tiempo, la integración de funciones múltiples y el desarrollo de programas versátiles, que aun así promuevan la evocación del paisaje y sus valores estéticos y culturales" (Moreno Flores, 2018).

Estos espacios verdes flexibles van a permitir el uso de los habitantes para diversas actividades (figura 79). Los nuevos espacios verdes ponen al ser humano como el elemento principal donde el hombre es el que vive, disfruta, pero también diseña este espacio. Entonces estos espacios tienen que estar pensados en función a él y a sus necesidades.

Estos espacios deben ser pensados para el uso de todos los habitantes, teniendo en cuenta los diferentes posibles usuarios, pensar en espacios accesibles, con actividades para todas las edades, actividades en conjunto o actividades individuales.

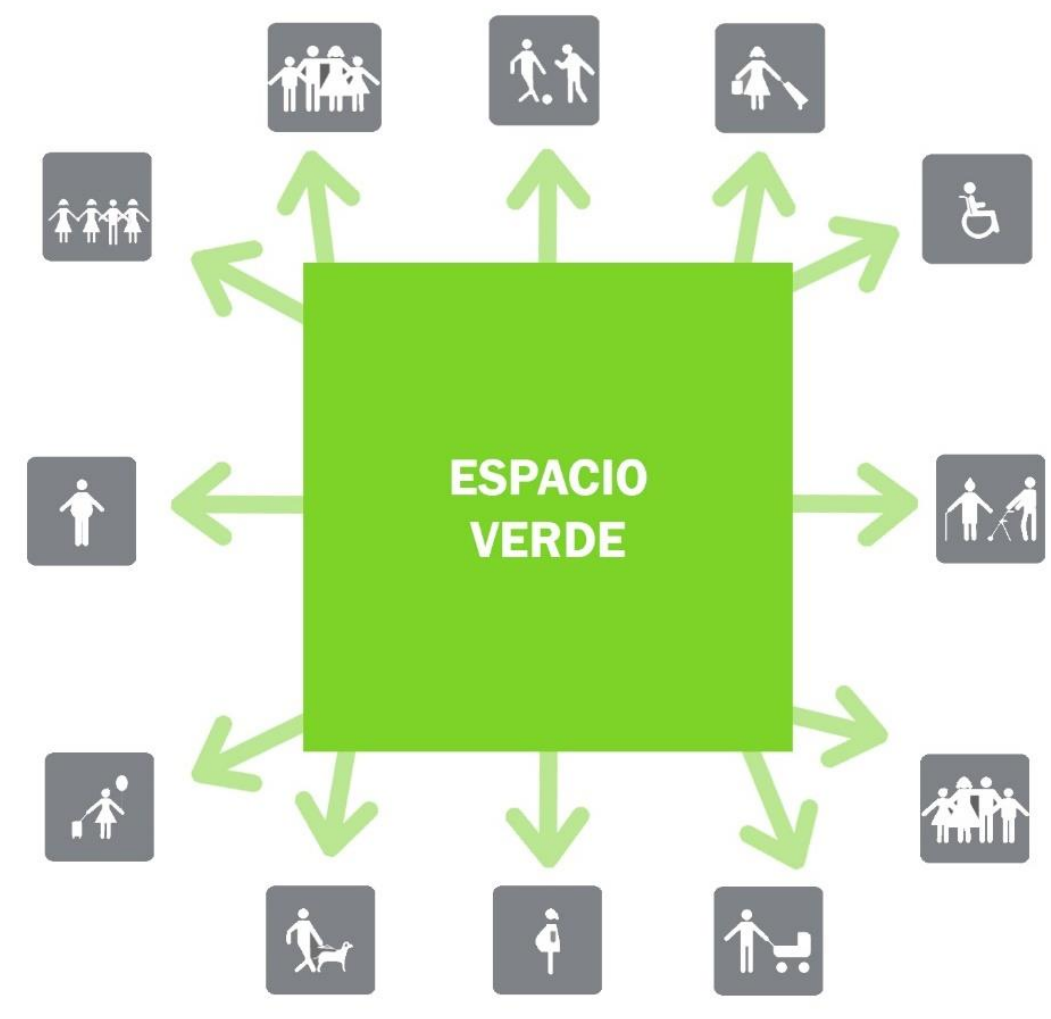

Figura 79. La diversidad de usuarios de los espacios verdes.

Fuente: Elaboración propia, 2018.

Se propone entonces reflexionar acerca de ¿cómo estos espacios pueden ser flexibles en el tiempo y adaptarse a las necesidades de hoy como del futuro? Estos tienen que ser dinámicos y adaptarse en el tiempo a la multiplicidad y diversidad de usos como así 
también a los diferentes grupos sociales. Deben contemplar un gran espacio vacío que permita usarse de diferentes maneras. "Solo en el vacío, afirma, reside lo verdaderamente esencial...El vacío es todopoderoso, porque puede encerrarlo todo. Únicamente en el vacío es posible el movimiento" (Tseu en Abalos,2009). Este concepto del vacío como el espacio donde todo se puede ser es una evolución de lo que siempre busco el hombre

"nunca ha podido vivir sin tramas. Ante el desorden aparente del mundo, tuvo que buscar los términos significantes, aquellos que, asociados entre ellos, hacían que su acción sobre el medio fuese más eficaz, aquellos que le permitían sobrevivir. Ante la infinita abundancia de objetos y seres, busco relaciones entre ellos y, ante la infinita movilidad de las cosas busco invariables." (Laborit, 1974 citado en Ábalos, 2009)

Para pensar en un espacio que se adapte a las diferentes necesidades es necesario indagar en la preponderancia del vacío como espacio donde todo puede ser. Es por ello que se propone un diseño en dos etapas: una primera fase de delimitaciones de ciertos parámetros de intervención y una segunda etapa de zonificación y determinación de actividades en trabajo conjuntos con los habitantes, es decir pensar en un diseño participativo de estos en base criterios de diseño establecidos.

Los elementos vegetales, como elementos de protección colaboran en el confort térmico de los espacios. Esto resulta un factor fundamental a la hora de diseñar las distintas actividades que se prevean en los espacios flexibles. Es importante situar los recorridos peatonales y las zonas de descanso exteriores de forma óptima con respecto a cada lugar concreto. Más aun, habría que centrar los esfuerzos en la pequeña escala para mejorar la situación incorporando cortavientos, árboles y vallas donde más se necesitan (Gehl, 2006).

Se plantea discriminar entre elementos estructurales, elementos de uso y sectores (figura 80). Donde como elementos estructurales se comprende a las especies vegetales como árboles, arbustos, plantas, flores entre otros, estos son fijos e inamovibles y van a ir conformándose a través del tiempo.

Por otro lado, como elementos de uso estos son los relacionados al propio uso en relación a las actividades, como lo es el mobiliario, solados, servicios, entre otros. Por último, los sectores los cuales contemplan sector de sol y de sombra, sectores de juegos, sector de descanso, entre otros. 


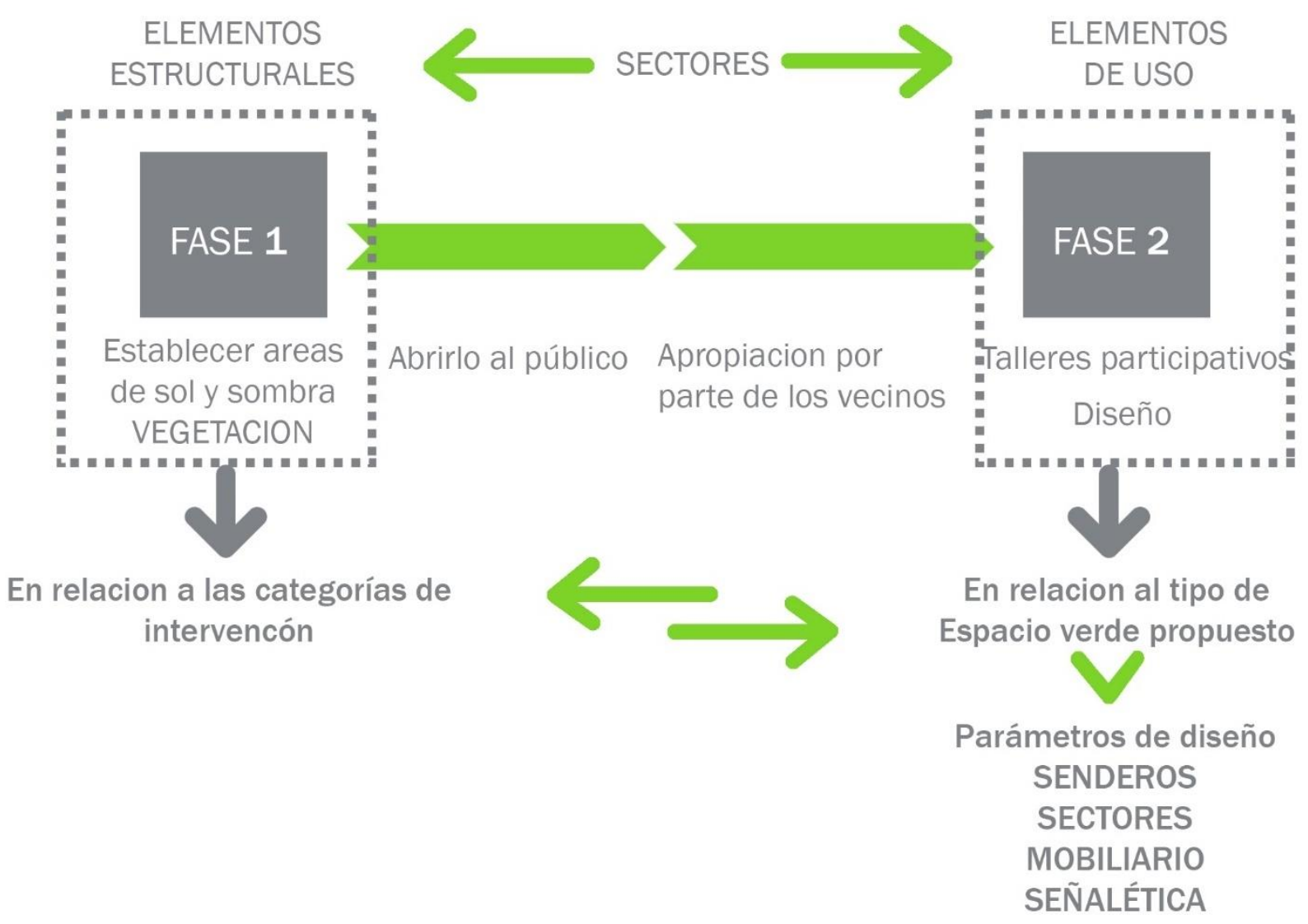

Figura 80. Fases propuestas para la intervención en tierras vacantes.

Fuente: Elaboración propia, 2018

Cuando se trabaja con elementos vegetales donde sobre todo en el caso de los arboles hay que tener en cuenta el tiempo que lleva su crecimiento. Es por ello que el tiempo que va a haber entre una etapa y la otra depende del tiempo de crecimiento del árbol.

El árbol pasa por tres instancias:

Árbol joven: Tiene todas las características de un árbol completamente crecido, y sólo le falta tamaño y la capacidad reproductiva.

Árbol maduro: Un árbol alcanza la madurez cuando se comienza a producir semillas y el polen para la reproducción.

Árbol Viejo: El árbol alcanza la etapa de edad como ralentiza su crecimiento, especialmente en altura, y comienza a producir menos semillas y el polen menos.

Estas instancias dependen de cada especie, pero se considera un valor medio de años para estipular las fases a 1 año, 2 años y a 5 años. 
La diferencia de tiempo entre la primera etapa y la segunda (figura 81) va a estar relacionada con la T.V. y la vegetación que esta posea si es alta, media o baja según el relevamiento realizado. El tipo y estratificación de especies va a estar ligado a las especies la diversidad y el tipo de follaje que posea la vegetación que contiene. Este dato también se va a sacar del relevamiento y caracterización realizado anteriormente.

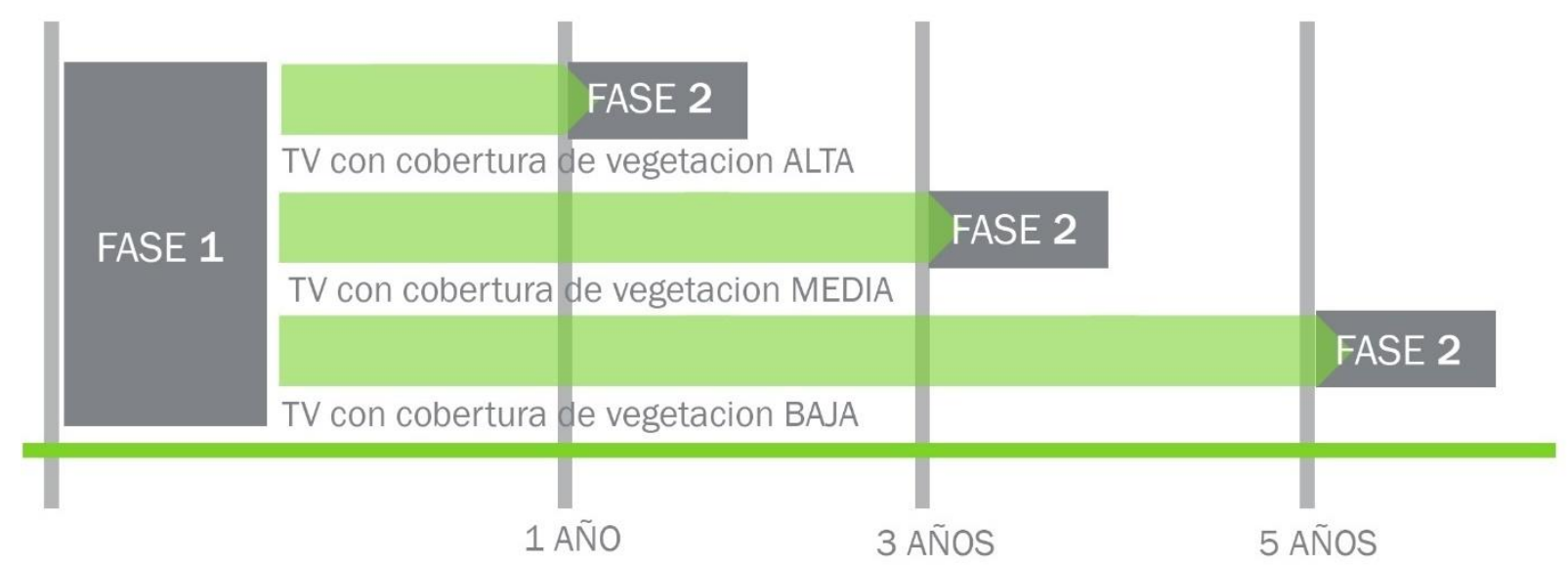

Figura 81. Fases según la cobertura de vegetación en las tierras vacantes y los años.

Fuente: Elaboración propia, 2018.

De esta manera se proponen las siguientes acciones a llevar a cabo en las dos etapas:

\section{FASE 1}

En la primera fase se propone zonificar el espacio tentativamente, organizar áreas de sol y de sombra determinando donde van los árboles y establecer las circulaciones y conectividad.

En esta fase además de los especialistas en vegetación y diseño se puede incorporar a los vecinos para que estos se hagan responsables de cuidar cada uno de los árboles. Es decir, se van a disponer los elementos estructurales vegetales. Estos se diferencian de a acuerdo al tipo. Los arboles de todas las magnitudes son inamovibles, mientras la vegetación arbusta o herbácea (figura 82) podemos colocarla, pero luego podemos moverla si es necesario.

Es decir, la vegetación aparece como estructural en la organización del espacio verde y en base a esta se van a disponer los usos y las diferentes actividades luego de que este alcance un tamaño medio. 


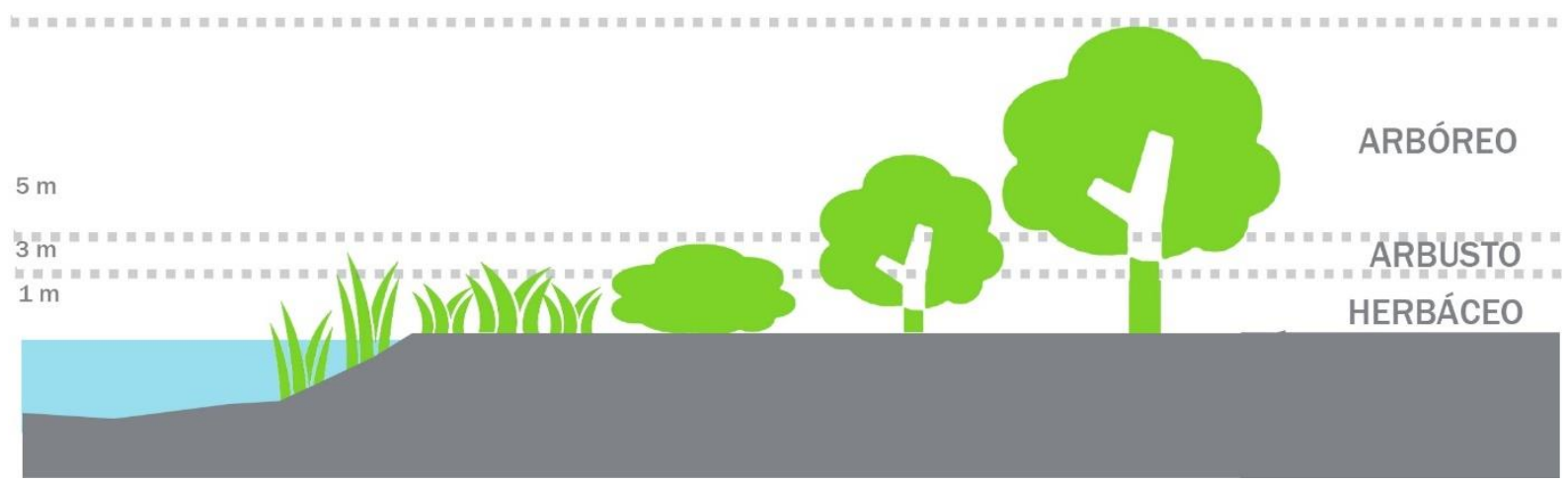

Figura 82. Estratos de la vegetación.

Fuente: Elaboración propia, 2017.

Se propone también colocar luminarias y bancos para el descanso de los que lo comiencen a utilizar.

\section{VEGETACIÓN:}

El árbol, ese otro ser vivo que permanece, quieto, en las calles conquistando las aceras, es un bien de dominio público que a menudo es tratado como elemento mueble. Este patrimonio arbóreo podría ser utilizado como un magnífico indicador cultural y ambiental. Una ciudad que cuida sus árboles, que quiere verlos grandes, viejos, es, sin duda alguna, más respetuosa y sensible. Las prácticas inadecuadas de poda o a destiempo provocan malformaciones en los árboles, acortan su vida y generan un peligro al debilitarlos.

Se propone una vegetación con baja exigencia en los costos de implantación, de consolidación y de manejo, y considerando una sucesión programada, complejidad estructural y biológica, se obtiene por resultado un paisaje de mayor calidad y un proceso de paisaje urbano sustentable. Proveer principalmente de especies arbóreas autóctonas con la finalidad de recuperar la avifauna del lugar.

Los árboles que se van a colocar deben tener en cuenta las siguientes premisas: la época de floración, porte y tipo de copa a fin de dotar a cada espacio o circulación de aquellas especies que más se adecuen ya sea por la sombra que brindan, por ser de hojas caducas y garantizar sol cuando así se lo requiera, o por su altura que acompaña y protege sectores propuestos, teniendo en cuenta la fenología (comportamiento a lo largo del año), que indica cómo se percibirá el paisaje y sus elementos en cada estación y con relación al clima local. Por otro lado, se deberá ver la frecuencia de cada especie, que pone de manifiesto la abundancia de cada organismo en el paisaje como así también. Que contribuyan a la resiliencia del cambio climático. 
También se propone tener en cuenta sectores o circulaciones con múltiples colores, texturas y perfumes, de modo tal de otorgarle identidad a cada uno de los trayectos a recorrer. Combinar especies según época de floración y caducidad. Las especies se van a seleccionar por un especialista en el tema teniendo en cuenta las premisas que determinamos anteriormente.

\section{FASE 2}

La segunda fase está prevista para que sea después de unos años donde la gente del barrio se comience a apropiar del lugar y se identifique con él, un moderador experto en el tema puede establecer junto a los vecinos que actividades se fueron dando espontáneamente en este espacio, que necesidades y actividades requieren y quienes son los encargados de cuidar este espacio. Esta actividad podría incorporar a los chicos de las escuelas donde se gente un compromiso con el nuevo espacio de uso público. En la segunda fase donde los habitantes se hayan apropiado del espacio y hayan delimitado usos en base a las necesidades con la comunidad realizar el diseño final del espacio verde. En esta fase se van a ubicar los usos requeridos en base al tipo de espacios verde según la calidad determinada y parámetros establecidos.

El perímetro de los espacios verdes debe estar un $15 \%$ libre del total del largo de las caras que dan a la calle. Esto va a permitir realizar una circulación por el borde del parque ya sea para peatones, bicicletas o gente que corre.

\section{LOS SENDEROS:}

- En el perímetro: Se deben prever senderos con carriles para los tres tipos de velocidades, la gente que va caminando, la gente que sale a correr y la gente que anda en bicicleta.

- Internos: los senderos deben ser para la gente que camina y eventualmente si algún espacio lo requiriera se podría discriminar en corredor y bicicleta.

El espacio verde es para que la disfruten todos los vecinos más allá de edades, género o particularidades de uso. Pero esencialmente hay dos sectores etáreos que se deben tener en cuenta especialmente, que son los niños y los adultos mayores 68 .

Por cuestiones de movilidad y desplazamiento hasta un espacio verde unos y otros necesitan que la plaza cercana a su domicilio los tenga en cuenta, ya que tienen menos posibilidades de trasladarse a alternativas más lejanas. De estos dos sectores los chicos

\footnotetext{
${ }^{68}$ Niños se les llama a los de 0 a 12 años de edad y adultos mayores son los mayores de 65 años.
} 
son los que más limitados están porque dependen generalmente del acompañamiento de un mayor para llevarlos.

La encuesta realizada (ver anexo 1) pone de manifiesto que la gente mayor de 65 años ante la pregunta ¿hasta cuantas cuadras caminaría ustedes para acceder a un espacio verde contesto que caminaría hasta 6 cuadras. Con lo que se evidencia la necesidad de espacios verdes a escala barrial.

\section{SECTORES:}

Se establecen parámetros para el diseño de estos sectores tan relevantes dentro de un espacio verde (figura 83). Estos parámetros se determinan en base al relevamiento realizado en distintos espacios verdes de uso público (ver anexo 7).

- El sector de juegos para niños: debe estar como mínimo a una distancia del $25 \%$ de la línea municipal del total de las caras que dan a la calle. Tienen que estar cerca de una zona de sombra. Poseer un solado blando.

- Sector adultos mayores: Este sector debe estar a una distancia mínima del $15 \%$ de la línea municipal. Tiene que estar bajo un sector de sombra.

- Sector de ejercicios: Este sector debe ser adyacente a los senderos para caminar o correr permitiendo poder combinar ejercicios.

- Los sanitarios: Deben estar a una distancia mínima del 15\% de la línea municipal del total de la cara que da a la calle. Esto permite que sea utilizado por la gente que pasa por el espacio verde como por el que lo usa.

- Sector de deportes: Este sector debe localizarse a una distancia de un \%25 del sector de juegos de niños y de los adultos mayores. Este espacio según el lugar y la actividad requerida puede estar delimitada o puede ser libre.

- Sector para perros: Es indispensable pensar en un sector para perros que permita a los habitantes llevar a sus mascotas.

- Áreas de descanso: deben poder estar bajo arboles del tipo caduco que en invierno posibiliten el paso del sol y en verano nos den sombra. 


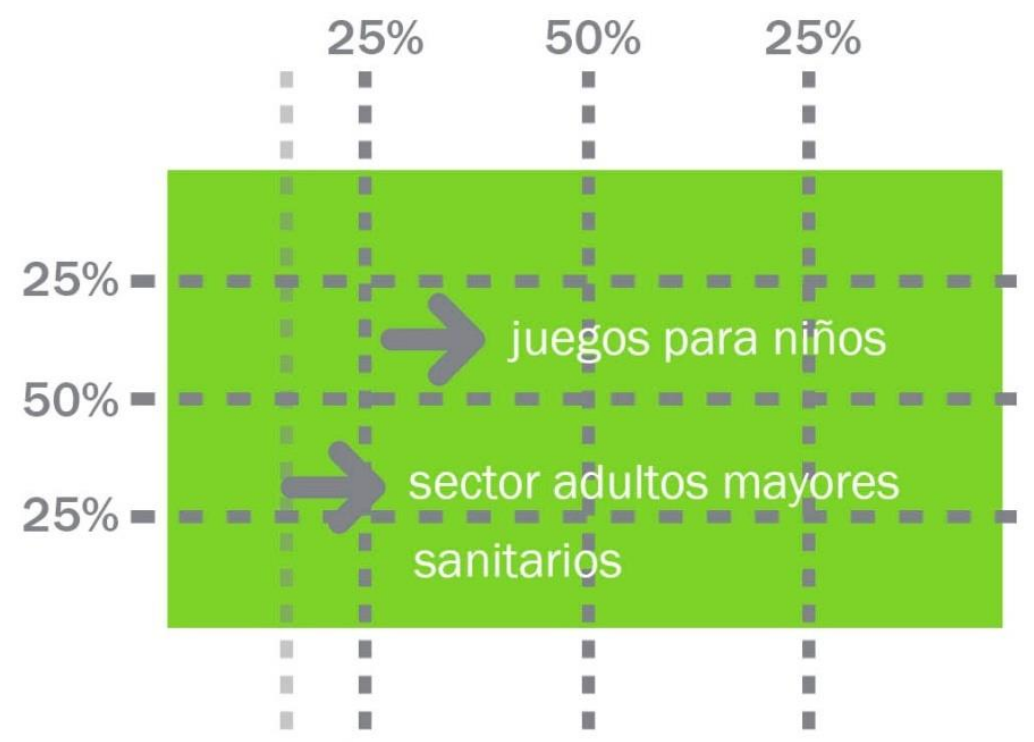

Figura 83. Subdivisión para ubicar sectores.

Fuente: Elaboración propia, 2018.

MOBILIARIO

El mobiliario es uno de componentes principales de un espacio verde es el que permite poder usar esos espacios pensados para el descanso o el ocio, es parte sustancial del confort ofrecido en el uso de un espacio verde. Estos deben adaptarse a las necesidades de los usuarios y poder perdurar en el tiempo. Es por ello que deben ser de materiales duraderos de fácil mantenimiento ya que el problema se plantea cuando ese mobiliario o los elementos que componen los espacios verdes públicos no son mantenidos por los entes responsables.

Estos no están eximidos de actos de vandalismo y poco cuidado por los ciudadanos, sus usuarios. Ello demuestra no sólo un conflicto educacional y cultural, sino también una falta de generación de valor para quienes deberían defenderlos como propios; motivo por el cual la incorporación de la ciudadanía a los procesos de planificación de los espacios verdes es clave para su futuro.

El mobiliario debe tener un hilo conductor es decir pensar cómo se organizan y cuál es la estética de este en relación al lugar.

Según un relevamiento realizado en plazas y parques en distintas ciudades nos permitió reconocer como elementos como un banco se repite y se reitera en distintos espacios generando una identidad particular y una fácil referencia de donde estamos. A su vez, algo 
tan identitario se complementa con algún otro tipo de mobiliario más moderno y coexisten (ver anexo 7).

Esto pone de manifiesto que los componentes pueden ser diversos, pero hay que especificar tipos en relación a usos y sectores. Es decir, se puede tener un tipo de banco para los senderos principales y otro para los secundarios, un tipo de luminaria para los senderos internos y otra para el perímetro, cestos de diferentes tamaños según donde se ubiquen y con separación diferenciada de residuos. En el caso de los juegos de niños deberían preverse juegos en relación a las diferentes edades que permitan el uso por todos los niños. Las máquinas de ejercicio deberán poseer distintas actividades.

Premisas a tener en cuenta:

- Luminaria: Las luces deben acompañar a los diferentes sectores, permitiendo poder usar el espacio verde a partir de que cae el sol y en la noche. Estas deben diferenciarse según las actividades donde puede haber unas en el perímetro las cuales iluminan la vereda, otras de mediana altura en el interior del espacio verde, también puede haber una de las más pequeñas que acompañen senderos secundarios. Estas luces deben ser las más eficientes en cuanto a la energía que consumen.

- Bancos: Los bancos deben ser simples, dobles, múltiples. Debe haber distintos tipos de bancos que conformen diferentes espacios. Bancos solos y bancos con mesas. Así como también en espacios más controlados puede haber bancos móviles que permitan configurar este espacio como más se desee.

- Cestos: estos deben contemplar el clima donde se colocan, poseer tapa y ser fácil recolección. Se debe contemplar la separación de residuos en orgánicos e inorgánicos. Los tamaños pueden variar en relación a la localización. Se deben disponer en el perímetro como en el centro del espacio verde acompañando los sectores de descanso o los recorridos.

- Juegos para niños: Estos deben estar pensados para todas las edades. Es decir, en un sector para niños debe haber diferentes juegos para niños de 2-5 años y para niños de 5 a 12 años. Estos deben ser de materiales amigables con los niños y que no generen riesgo.

- Máquinas de ejercicio: estas máquinas deben ser especializados para que personas de todas las edades y capacidades se ejerciten al aire libre. Deben permitir desarrollar 
diferentes actividades de elongación, musculación y aeróbico. Deben agruparse en sectores.

Estos criterios de diseño están propuestos en base a una encuesta realizada donde la gente pondera positivamente la presencia de árboles y especies vegetales (figura 84).

\section{¿Considera importante que la ciudad tenga arboles en las calles?}

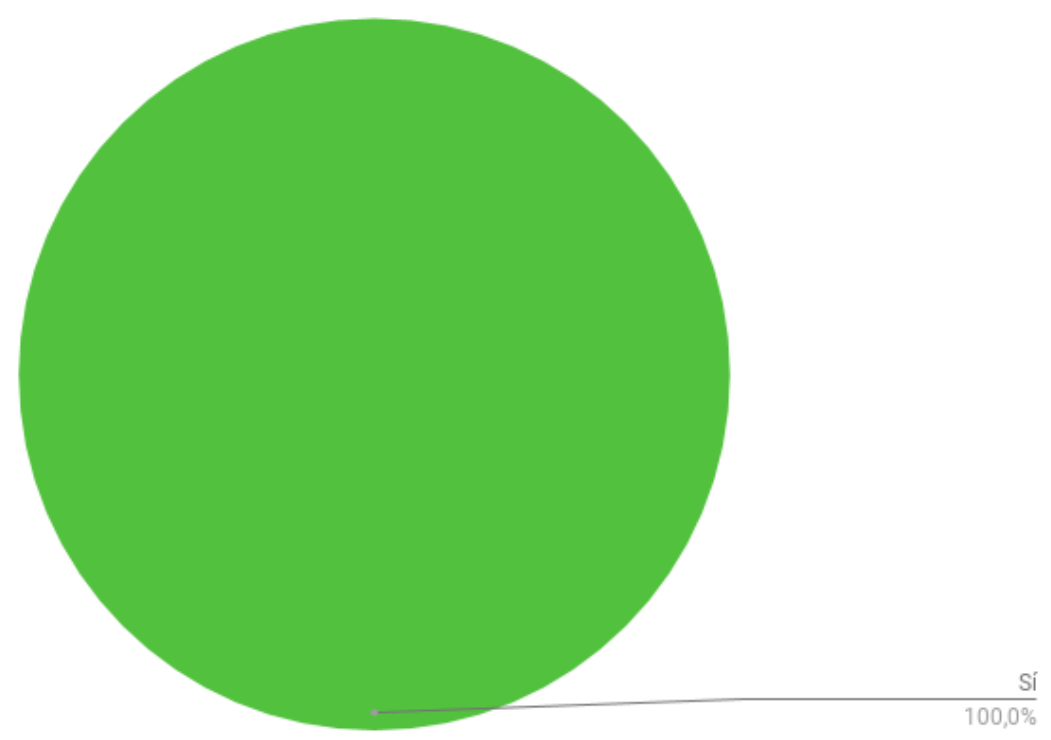

Figura 84. Datos de la encuesta. Fuente: Jensen y Birche, 2018.

Ante la pregunta si considera importante que la ciudad tenga árboles en las calles el 100\% respondió que sí y cuando se le pidió que lo fundamentaran las respuestas hicieron énfasis en la importancia desde la función que cumplen ya sea biológica, estética entre otras (ver anexo 1).

\section{¿PORQUE PENSAR EN UN DISEÑO PARTICIPATIVO?}

Los proyectos que no son pensados y diseñados con la comunidad no generan apropiación colectiva ni identificación de los habitantes con ellos. Hoy en día, la mayor parte de los proyectos salen a concurso los cuales son diseñados por expertos, pero no tienen en cuenta las necesidades de los vecinos.

Los espacios verdes públicos que se encuentran abandonados o sin uso por los habitantes es porque no cumplen con las necesidades de los usuarios, esto se produce por la falta del sentido de pertenencia e identidad con sus espacios publico barrial. Es decir que cuando la ciudad ignora al habitante, el habitante ignora a la ciudad. Por ello es tan importante la participación de la comunidad porque esta necesita de los espacios verdes 
públicos y su participación es fundamental. La participación ciudadana se entiende como una toma de conciencia colectiva de la comunidad, sobre factores que frenan el crecimiento, por medio de la reflexión crítica y la promoción de formas asociativas y organizativas que facilitan el bien común.

Si bien hay diversos autores que hablan la importancia del diseño participativo, en el caso de nuestra región de estudio y en particular de espacios verdes Fabio Márquez (2008) es el referente del tema. El viene trabajando hace unos años en el diseño participativo de los espacios verdes donde pone de manifiesto que:

“el espacio público ha sido percibido como un lugar de nadie, en vez de ser el lugar de todos. El individualismo creciente y la disminución de la solidaridad en la sociedad, se expresa en estos espacios, en los que se han ido incrementando las situaciones altamente conflictivas. Vandalismo, mal uso de los equipamientos, mantenimiento defectuoso, inseguridad, excesiva cantidad de usuarios, conjugado con ineficientes respuestas gubernamentales, han llevado a repensar mecanismos asociativos con los ciudadanos en la búsqueda de soluciones concretas, tanto sea de proyecto como de gestión cotidiana."(p.1)

El diseño Participativo surge como una herramienta para lograr proyectos eficientes, que no conformaran solamente desde el punto de vista del diseño del paisaje, sino que contengan conceptos sociales que favorezcan la construcción de una sociedad mejor (Márquez, 2011). El diseño participativo pone al habitante en el centro de atención, le da el rol protagónico donde es el responsable de su futuro espacio verde, fortaleciendo el vínculo con el espacio público.

Este método busca establecer medios de comunicación entre los que toman las decisiones y los beneficiarios estimulando también la comunicación entre los vecinos con el fin de poder establecer acuerdos. Esto refleja el significado propiamente dicho de estos espacios donde lo que se busca es fomentar el encuentro, la comunicación y la ciudadanía. Es decir: “Es preciso entender que esta metodología colabora para proyectarlos como espacios colectivos, mejorando la calidad de vida de sus habitantes". Esta metodología se inscribe en un marco pedagógico donde los habitantes comprenden que el espacio público o verde es de todos y entre todos debemos cuidarlo. A su vez, es necesario un buen diagnóstico participativo para poder realizar un diseño participativo. 


\section{Fases del diseño participativo (figura 85):}

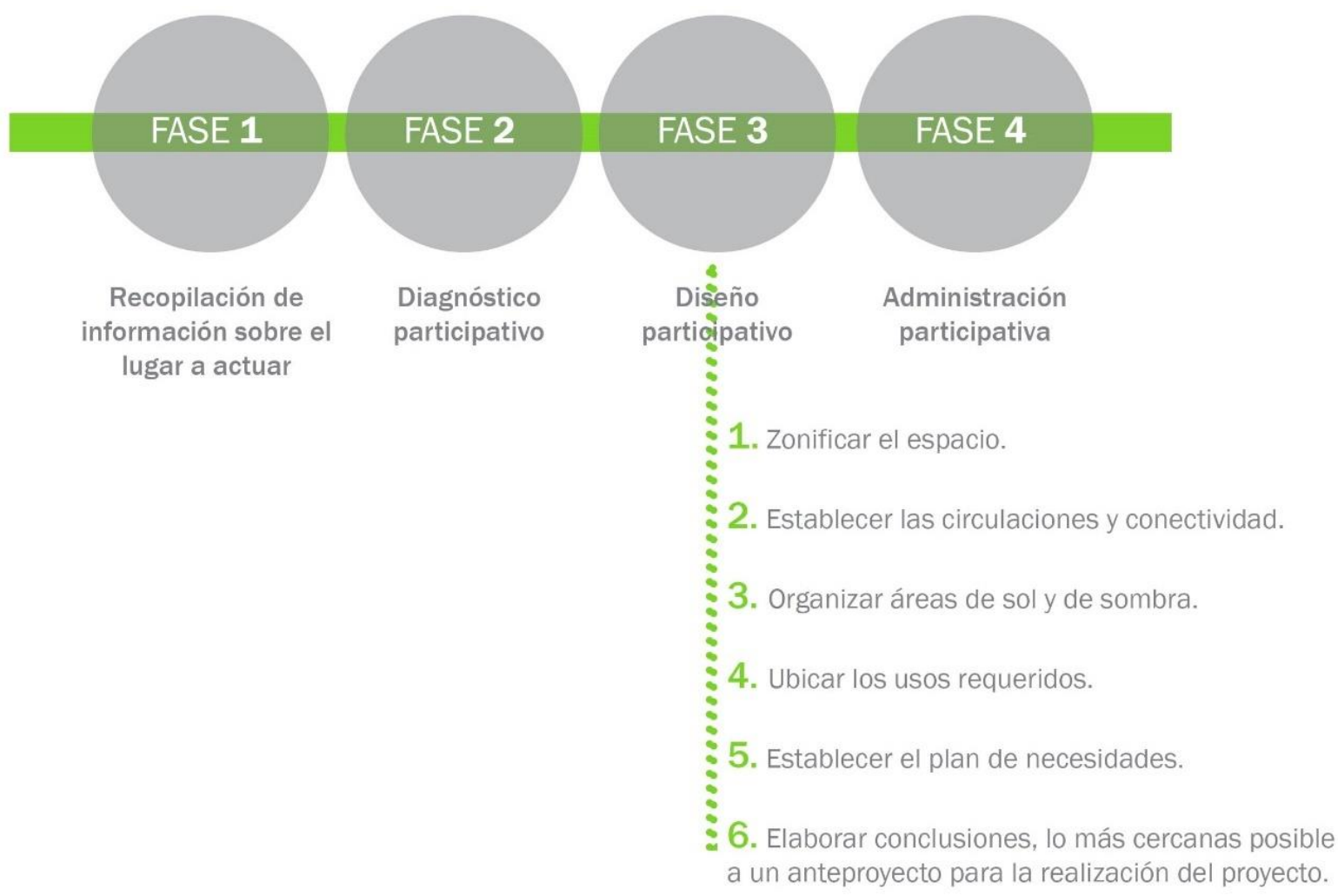

Figura 85. Fases del diseño participativo.

Fuente: esquema elaborado en base a Márquez, 2011.
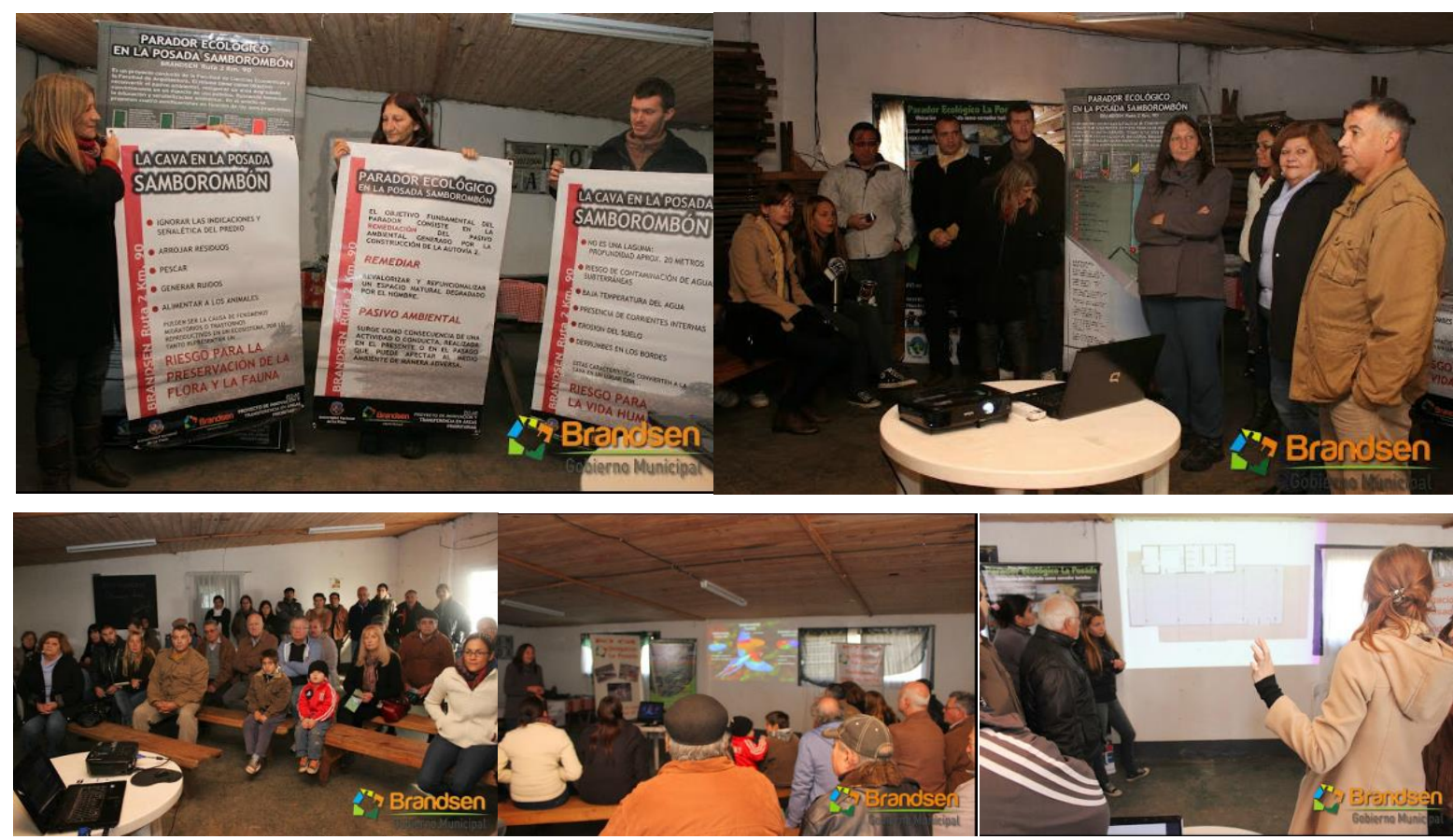

Figura 86. Experiencia de diseño participativo en el 2013 con el grupo de investigación (IIPAC) de un parador ecológico en la posada Samborombón (Brandsen) en el marco del proyecto PIT-AP Parador ecológico en la autovía 2.

Fuente: http://prensabrandsen.blogspot.com.ar/2013/06/avanza-el-proyecto-del-parador.html 
El diseño del espacio público o verde se caracteriza por un tratamiento técnico de modo interdisciplinario y por la participación real de usuarios y vecinos de esos espacios; es decir, por un involucramiento que apunta a la toma de decisiones y control ciudadano. Los especialistas y expertos en paisaje son los que van compartir los conocimientos técnicos y creativos para lograr junto a los vecinos un proyecto coherente.

Vincular a los habitantes en el proceso de diseño de un espacio verde tiene ventajas ya que: Los habitantes tienen una visión de lo que quieren que tenga ese espacio y que luego ellos mismos usarían.

Si se los involucra en el proceso de diseño, toma de decisiones y se contemplan sus requerimientos se va a generar un sentido de pertenencia con ese espacio.

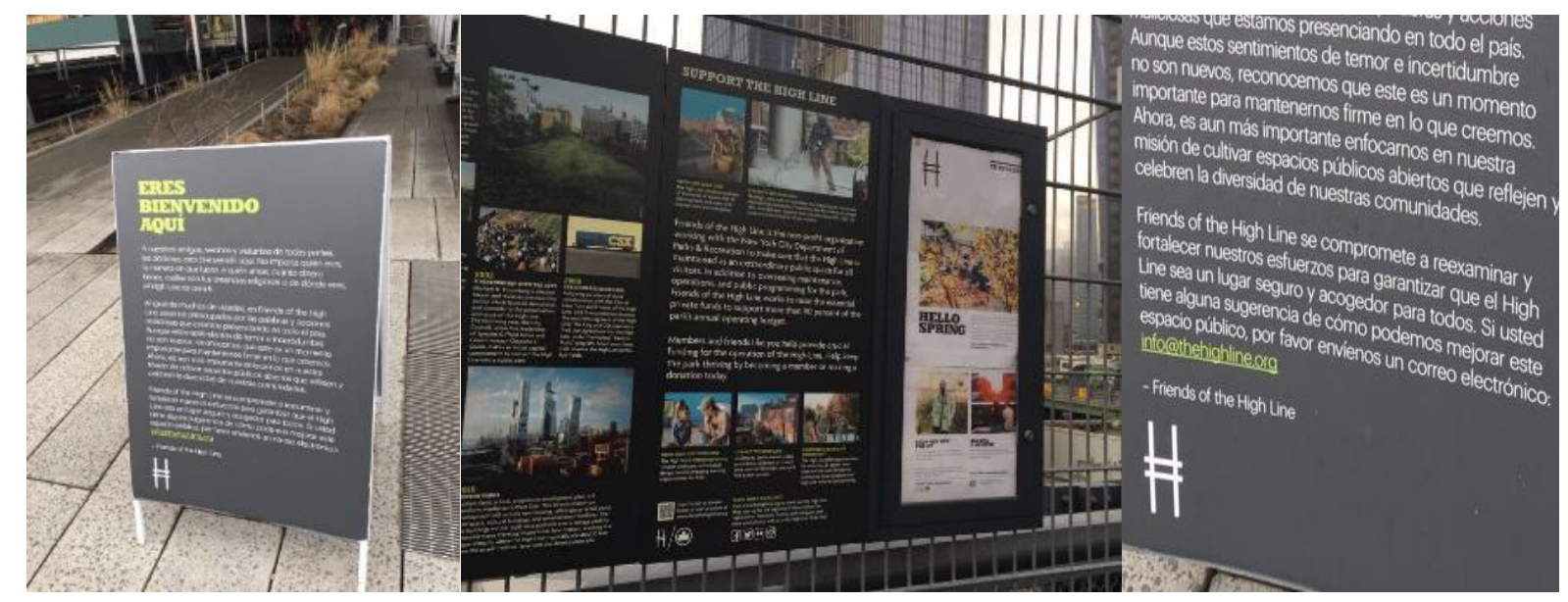

Figura 87. Cartelería en el High Line en Nueva York donde se manifiestan las intenciones de cuidado de la fundación amigos y vecinos de High line. Fuente: Imágenes del autor, 2018.

Al sentirse representados con ese espacio van a colaborar en el control ciudadano, cuidando y manteniendo ese espacio, velando por su conservación (figura 87).

Para la incorporación de todas las edades en la metodología es necesario diferenciar la participación de los niños, ya que ellos no pueden expresarse como los adultos entonces hay que buscar su expresión mediante el juego, los dibujos que les van a permitir expresarse. Lo que se busca con este diseño es transformar la participación de los habitantes, pasando de una participación pasiva a una participación activa. 


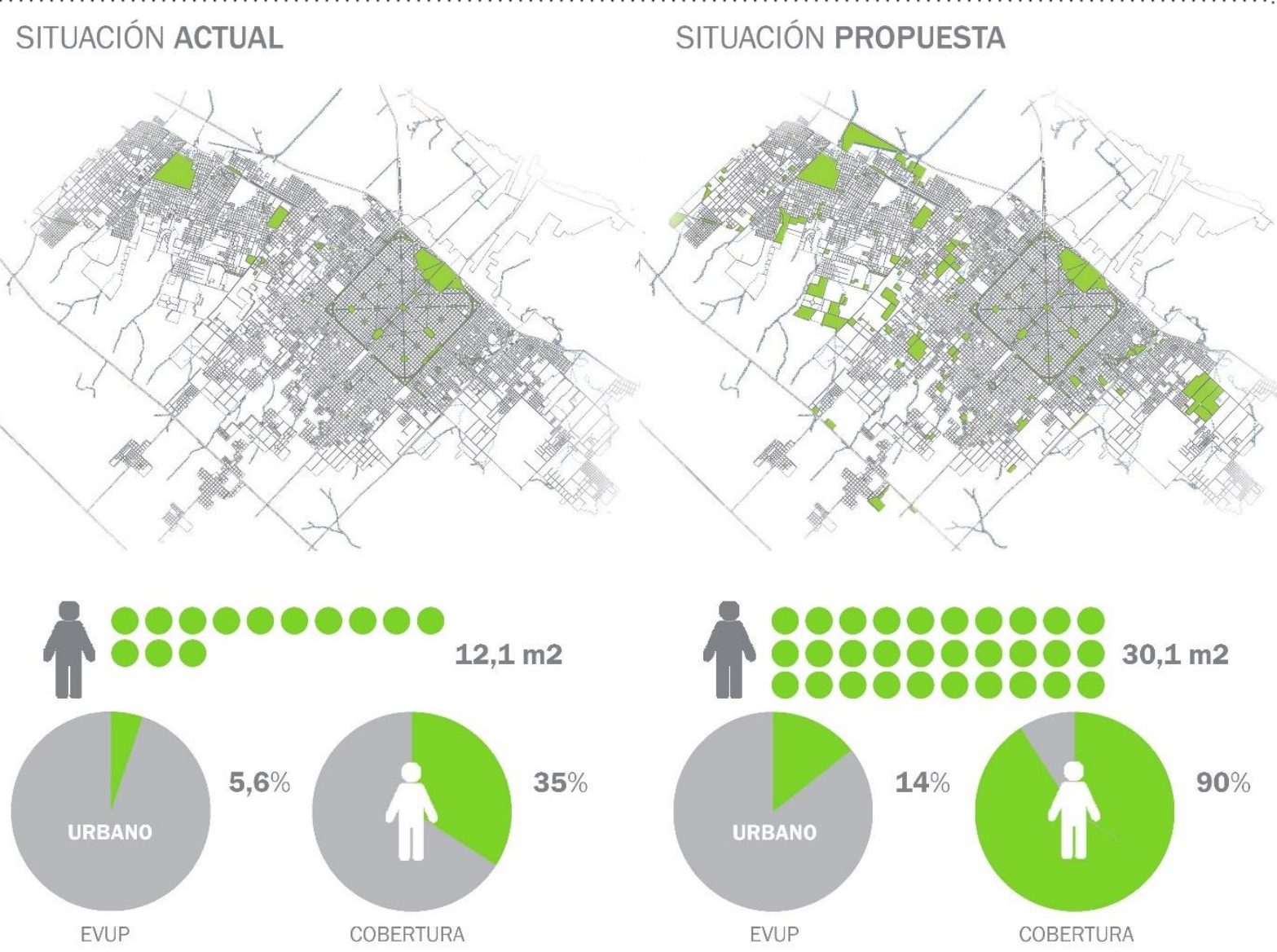

Figura 88. Comparación de la situación actual y la propuesta con el sistema de espacios verdes.

Fuente: elaboración propia en GIS, 2018. 


\section{CAPÍTULO 7 Conclusiones}


CAPITULO 7

\subsection{Consideraciones finales}

En el desarrollo de la investigación surgen las siguientes conclusiones:

Se logró cumplir con el objetivo general y los particulares planteados: Contribuir al conocimiento de los espacios verdes y tierras vacantes desde la noción de paisaje con el fin de establecer lineamientos para conformar un sistema de espacios verdes en pos de mejorar la calidad del paisaje urbano y mitigar los efectos del cambio climático.

En cuanto a los objetivos propuestos se realizaron las siguientes actividades con el fin de alcanzar los objetivos propuestos:

Indagar los diferentes marcos teóricos metodológicos que integren las prácticas urbanísticas y el rol del paisaje.

El proceso de indagación y conformación de un marco teórico conceptual y metodológico de referencia se viene trabajando hace unos años en las anteriores becas de investigación en relación al paisaje. Por lo cual para la tesis la actividad principal fue la de estudiar la cuestión urbana desde esa perspectiva del paisaje que venía trabajando. Elaborando un marco teórico conceptual de referencia incorporando autores clásicos como así también los últimos trabajos en la temática.

\section{Analizar las transformaciones territoriales derivadas del modo de producción} del espacio urbano en busca de comprender los procesos que dan origen a la falta de espacios verdes de uso público.

Se indago acerca de las transformaciones territoriales en Latinoamérica, para luego abordar los procesos de conformación de la ciudad de La Plata y sus cambios a través del tiempo y como el proceso de expansión conformo una periferia con diferentes carencias.

Entre una de ellas se observa la fragmentación del tejido y la falta de espacios verdes de uso público configurando una periferia con baja calidad de paisaje urbano. A su vez, se hace hincapié en la diferencia que hay entre el casco fundacional y la periferia. Se realizó un diagnóstico de la situación de la ciudad desde el paisaje determinando tipos de paisaje. 
Explorar acerca de la percepción de los habitantes de la periferia en relación a la cantidad y calidad de espacios verdes públicos en pos de relacionar las diferentes visiones con la localización espacial según la zona de la periferia.

Con el fin de indagar acerca de la percepción de los habitantes se realizo una encuesta que permitió conocer como perciben los espacios verdes y su calidad en la periferia los habitantes. Como así también se hizo énfasis en el reconocimiento de los espacios vacantes que tiene la población.

Indagar y analizar sobre las nuevas tipologías de espacios públicos en relación a las actividades y funciones requeridas en pos conformar la base del sistema de espacios verdes.

Una vez comprendida la situación y la falta de espacios verdes en la periferia platense surgió como interrogante como deberían ser estos nuevos espacios verdes para adaptarse a los cambios de la sociedad y ser una herramienta para la biodiversidad. Por ello se propuso incorporar el concepto de espacio flexible, un espacio que permita que se realicen todas las actividades requeridas por la gente y a su vez que la premisa sea el predominio del vacío.

Elaborar categorías de intervención y recuperación para la incorporación de tierras vacantes que permitan formular estrategias de intervención paisajística para los nuevos espacios de uso público

Una vez identificada la problemática se prosiguió con relevar, analizar y catalogar las tierras vacantes del tipo vacío latente las cuales estén en área urbana y adyacentes a cursos de agua. Por otro lado, las que sean del mismo tipo y estén en las áreas críticas definidas sin cobertura de espacios verdes. Una vez identificadas se las analizo en relación a las cuatro dimensiones propuestas para determinar la calidad de paisaje de cada una. Se determinaron criterios de intervención y en base a la calidad de cada una de las dimensiones. Esto permitió posteriormente determinar tipos de espacios verdes con características particulares según dos variables la calidad de paisaje y el tipo de paisaje donde se localizan. Se realizo un catálogo de las tierras vacantes.

Formular lineamientos que integren las prácticas urbanísticas referidas a las tierras vacantes y el rol del paisaje tendientes a conformar un sistema de espacios verdes.

Este último objetivo es el resultado del proceso realizado en los objetivos anteriormente descriptos. 
En el trabajo de investigación realizado se constató que:

\section{Aspectos teórico-conceptuales}

- En lugar de utilizar el concepto de superficie cubierta de espacio verde por habitante, que no considera en sus considerandos la relación de distancia entre la población y el área verde, se elabora el concepto de radio de cobertura, donde se pone como elemento principal a la accesibilidad de los habitantes a dichos espacios.

La aplicación de este concepto, radio de cobertura de los espacios verdes, permitió visibilizar una problemática más compleja que la clásica relación de áreas verdes por habitante, dejando al descubierto áreas críticas en el tejido urbano desprovistas de espacios verdes. De esta forma, se pone en manifiesto el carácter espacial de la problemática trabajada. Es por esto que la concepción territorial del paisaje, en general, y de los espacios verdes, en particular, demandan políticas paisajísticas a nivel regional. Asimismo, se considera a la superficie de espacio verde por habitantes como una variable central en los planes territoriales en distintas partes del mundo. Como se menciona en la p. 151 de la tesis, este concepto se ha incorporado en el Plan Verde de Valencia (1992), el Plan especial de indicadores de sostenibilidad ambiental de la actividad urbanística de Sevilla (2010) y se hace referencia en el libro Biodiversidad Urbana de Garay y Fernández (2013).

- Una correcta proporción de superficie de espacios verdes por habitante no garantiza el disfrute de todos los ciudadanos, sino que la ubicación y la distribución espacial de los mismos son las que lo posibilitan. Para eso es importante la determinación de radios de cobertura para cada tipo de espacio, pensando en los espacios verdes como una infraestructura o un servicio más de los que brinda la ciudad. Pensar en la escala urbana y/o barrial en que la mayoría de los usuarios puedan acceder caminando y fomentar el uso diario.

- El concepto de paisaje vacante que propone esta tesis es un concepto nuevo que busca poner en valor esos espacios vacíos que se encuentran en la trama urbana y que los habitantes aun no los pueden ver. La puesta en valor de estas tierras vacantes y la incorporación como espacios verdes de uso público los convertiría en paisaje, es decir, el observador podría generar la imagen de estos.

Esta categoría propuesta permitiría reconocer las tierras vacantes que estén en esta condición y reflexionar ¿cómo se pueden incorporar a la ciudad estos paisajes vacantes? 
o ¿qué deberían ser? En su mayoría estos paisajes aparecen como espacios residuales, abandonados los cuales contribuyen a la fragmentación del tejido. Pero, sin embargo, estos espacios representan una oportunidad para la ciudad, paisajes que esperan ser reconocidos por los habitantes, en otras palabras, paisajes vacantes.

Si bien la problemática de las tierras vacantes resulta fundamental en la planificación del entorno urbano. Es así como el estudio de las dinámicas y gestión de la tierra vacante resulto una línea de investigación fundamental para la tesis ya que estos lugares pueden plantearse como espacios verdes de uso público. Los vacíos urbanos de la ciudad aún pueden revalorizar el espacio verde publico siendo una "oportunidad para producir ciudadanía ya su vez un test de desarrollo de la misma" (Gorelik, 1998).

- La búsqueda de un sistema de espacios verdes es una directriz posible hacia el desarrollo del territorio, el mantenimiento de la heterogeneidad de los espacios verdes garantiza de esta manera la integridad de los procesos humanos y naturales. Los espacios verdes públicos otorgan cualidad a la ciudad y por ende, constituyen o debieran constituir uno de los ejes de las políticas públicas.

En este marco, se considera necesario proponer la recuperación, intervención y diseño de las tierras vacantes como espacios verdes desde el paisaje en su perspectiva integral teniendo en cuenta aspectos económicos, socio-espaciales, ambientales y estéticos. Los criterios de diseño e intervención propuestos en esta tesis intentan constituir un avance en relación al enfoque actual y/o tradicional dado que se plantean desde el paisaje, es decir, desde una mirada integral, y no únicamente considerando al espacio verde en relación a su forma.

\section{Aspectos metodológicos}

- En la matriz de relevamiento de espacios verdes se propone incorporar la dimensión paisajística donde se toma como variables de análisis el arbolado, que está en relación a la proporción de especies vegetales en relación al área total de un espacio verde de uso público, y la presencia de agua superficial, como una variable clave respecto a la calidad paisajística de un sitio. Estas variables si bien en otros estudios son analizadas en este se propone que estén dentro de la dimensión paisajística ya que se entiende que son elementos claves que determinan la calidad de ese paisaje. Es decir, se incorpora en la matriz del relevamiento una dimensión la cual es de relevancia para determinar luego la calidad de estos espacios verdes desde el paisaje. 
- En cuanto a la matriz propuesta para determinar la calidad de paisaje, si bien hay numerosos estudios que proponen dimensiones para evaluar la calidad visual de los paisajes ligadas a lo biofísico o biológico, a lo estético y a la conformación de la estructura del paisaje, se propone desde nuestra disciplina incorporar la dimensión geográfico urbanística. Esta dimensión nos va a permitir conocer el entorno, es decir, no pensar sólo en el espacio en cuestión sino además en aquello que lo rodea. Esta nueva dimensión incorporada para evaluar la calidad de paisaje establece un precedente de interés para futuros estudios de paisaje.

Las variables consideradas y sus respectivos indicadores se pensaron en relación a las principales características de nuestro territorio donde se hace hincapié en la relevancia de la vegetación y la presencia de agua como los elementos que más valor tienen dentro de esta matriz. Como variables e indicadores que se destacan en relación a otros estudios realizados se puede mencionar:

En la variable agua en la dimensión biofísica se tiene en cuenta la presencia de agua y el tipo de cuerpo de agua, pero también su calidad. Teniendo en cuenta la contaminación ambiental ya que es uno de los principales problemas de nuestro territorio.

En la variable naturalidad en la dimensión estructural se hace énfasis en cuan antropizado esta ese paisaje lo que permite incorporar las principales acciones e intervenciones que se han llevado a cabo por parte del hombre en esos espacios.

En la dimensión estética no solo se tiene en cuenta la forma, sino que también los diferentes colores que componen ese paisaje y las texturas dándole importancia tanto a la diversidad de vegetación como a la presencia de elementos que conforman ese paisaje.

\section{Aspectos empíricos o referidos al caso de estudio}

- De los espacios verdes relevados en la totalidad de la región, se identificó que la zona con mayor déficit de espacios verdes es la zona del desborde con un $77 \%$ de la población sin un espacio verde a menos de 8 cuadras.

- En relación a las tierras vacantes analizadas de las 105 seleccionadas para ser incorporadas como espacios verdes 68 están en zona inundable o adyacente a cursos de agua y 11 son cavas. De este modo, se buscó validar la hipótesis general la cual planteaba que "la integración de las tierras vacantes a un sistema de espacios verdes, permite mejorar la calidad del paisaje urbano en el Partido de La Plata". El abordaje teórico 
conceptual y la aplicación de la metodología propuesta fueron los factores claves para verificar esta hipótesis general como así también las hipótesis derivadas. La cual se corrobora en el caso relevado en el marco de la tesis de la cantera de Gorina (ver p. 165 y anexo 8) un paisaje vacante que se convirtió en un espacio verde de uso público diseñado desde el paisaje y su condición de pasivo ambiental el cual mejoro la calidad del paisaje urbano de los barrios aledaños. El espacio verde de uso público no solo contribuye a mejorar el carácter visual, en términos globales, sino que también vigoriza las actividades económicas y mejora la funcionalidad de la ciudad.

- Como se ha mencionado anteriormente, las zonas periféricas de la ciudad han desempeñado un rol protagónico en lo que respecta al crecimiento urbano. Estos procesos de urbanización se hacen visibles no solo a través del aumento poblacional, sino que modifican sustancialmente la relación que mantiene la ciudad con el espacio rural y los elementos naturales. A través de los años, se han configurado grandes zonas periurbanas que adquieren los rasgos particulares de una zona de transición y a la vez sirven de apoyo a la ciudad, pero también son susceptibles de ser absorbidas por el crecimiento urbano. La periferia platense se caracteriza por su dinamismo y su inmersión en los procesos de cambio morfológicos, funcionales y sociales. Esto constituye un valor distintivo del área periférica y la posiciona estratégicamente como un área de oportunidad.

Sin embargo, se puede afirmar que el ritmo de los procesos de ocupación resulta ampliamente superior al de cualquier tipo de planificación por parte del Estado. Esta situación ha derivado en una gran cantidad de espacios fragmentados, desprovistos de ciudad y de paisaje.

Se verifica así entonces que en los últimos 30 años la población creció un 26,9\% mientras que la mancha urbana creció un $45,1 \%$ y la superficie de espacios verdes un $28,7 \%$. Se identificó además que el mayor crecimiento de la población y la mancha urbana se da en el período 2010-2017 y el mayor incremento de espacios verdes se produce en el período 1991-2001.

- Los espacios verdes públicos tienen un rol fundamental en la calidad de vida urbana y por ende en el urbanismo, por ello su estudio es fundamental en las mejoras de las condiciones de habitabilidad de las ciudades actuales. Esto se verifica en los casos de la periferia donde no había espacios verdes constituidos por la normativa de usos de suelo, pero no así en el relevamiento donde se observó que la gente se apropia de espacios que 
son de dominio privado transformándolos en espacios verdes de uso público (ver anexo 1). Esto demuestra que los habitantes necesitan disponer de espacios verdes.

Los resultados de la encuesta realizada reflejan la necesidad de los habitantes de la periferia de espacios verdes, exceptuando los habitantes del eje noroeste que como en este eje se localizan dos grandes parques urbanos como lo son el Parque Ecológico y la Republica de los Niños no expresaron la misma necesidad que los habitantes de la zona de desborde. Pero si expresaron la necesidad de espacios a escala barrial cercanos a sus viviendas para el uso diario, excepto los habitantes de la localidad de City Bell los cuales creen que no necesitan más espacios verdes y que los que tienen están en buenas condiciones haciéndose referencia a las plazas previstas desde el origen del trazado.

A su vez, se investigó acerca de cómo pueden estos espacios verdes colaborar con la capacidad que poseen las poblaciones para adaptarse al impacto del cambio climático. Entendiendo que algunos de los factores más importantes que determina la capacidad de adaptación de las personas, hogares y comunidades, es el acceso y control que puedan tener sobre los recursos naturales, humanos, sociales, físicos y financieros. Es decir, se indagó acerca de ¿cómo pueden estos espacios contribuir a la adaptación o resiliencia como un proceso enfocado en reducir la vulnerabilidad de la población a los efectos de cambio climático? En este caso, y como parte de las medidas de adaptación más importantes al cambio climático, se propone incorporar las tierras vacantes adyacentes a cursos de agua como reservorios contribuyendo a minimizar los efectos de las inundaciones y de las grandes precipitaciones.

Desde el enfoque de esta tesis se puede pensar como estrategia de resiliencia al cambio climático: concebir y dar forma a nuestro entorno pensando de manera integral y con medidas de intervención creativas, ecológicas y sociales, integrando un sistema de espacios verdes de uso público a partir de los espacios vacantes de la ciudad con el fin de optimizar las condiciones de los habitantes.

De lo analizado se corrobora que se dispone de una experiencia acumulada en las instituciones locales en relación a los procesos de generación, acumulación e intercambio de conocimiento. Conocimientos que a través de la incorporación de nuevas metodologías y tecnologías lentamente se van incorporando al análisis de los procesos urbanos, incluyendo enfoques de participación y de desarrollo de capacidades a partir de alianzas entre actores con una visión emprendedora y transformadora de la sociedad. 
En este sentido, creemos que mantener una visión integral de la problemática y trabajar con la amplitud conceptual necesaria resulta clave al momento de estudiar la ciudad. Las nuevas formas de apropiación social y la adaptación de los espacios de esparcimiento y recreación obligan a los investigadores a reformular presupuestos y a reorientar las líneas de trabajo con una mayor conciencia respecto de la realidad urbana. Pensar los nuevos espacios verdes desde la calidad de paisaje y sus características en relación adónde se localizan y no desde la relación forma-función, como se establece hoy en día, plantea un avance en el conocimiento.

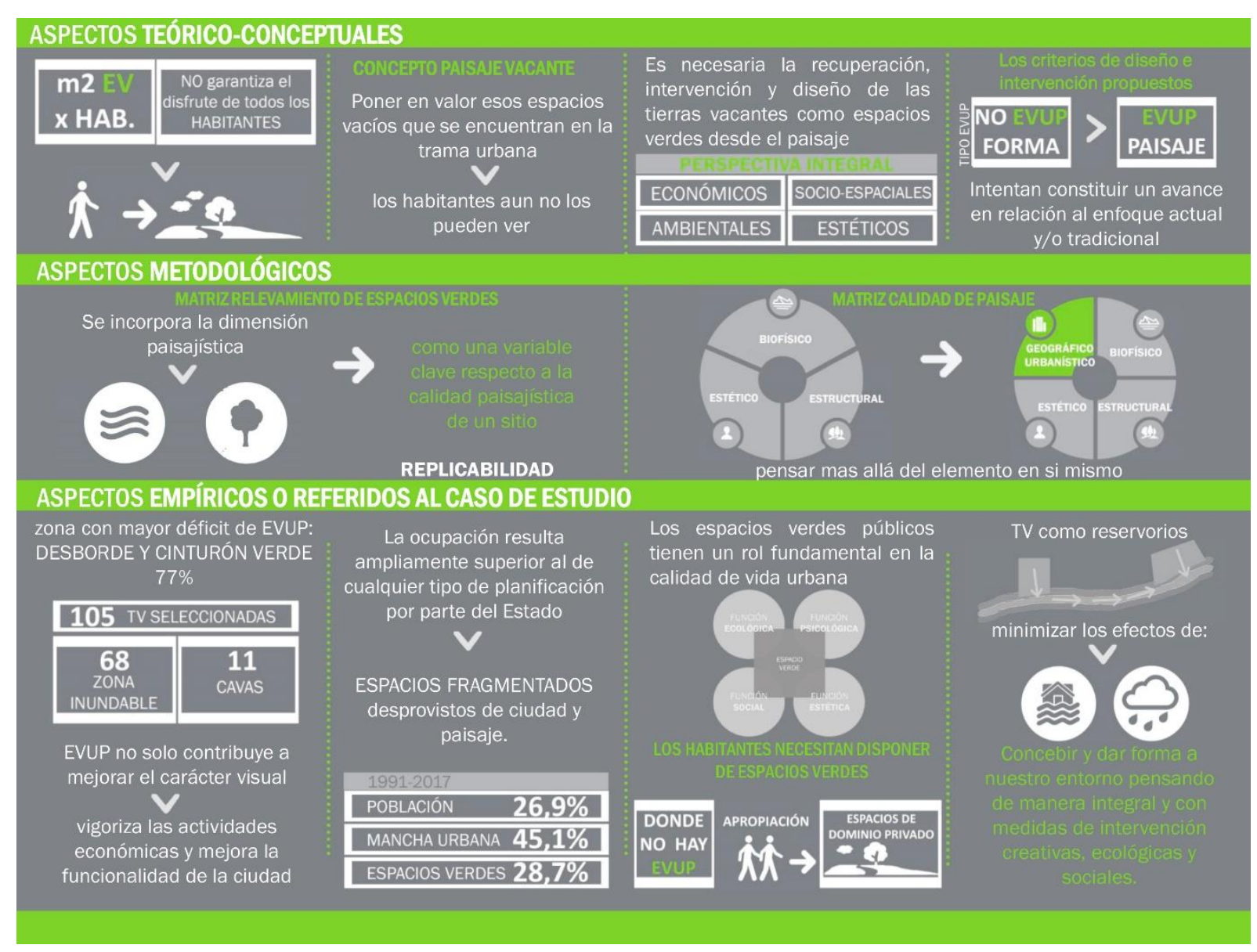

Figura 89. Tabla resumen de conclusiones obtenidas. Fuente: Elaboración propia, 2018.

\subsection{Reflexiones del proceso y futuras líneas de trabajo}

Pudimos constatar en el desarrollo de nuestra investigación, que la ciudad se constituye en un sistema dinámico, puesto que las tierras vacantes, identificadas mediante fotos satelitales al comienzo del trabajo de campo, no fue la misma al momento de terminar con el procesamiento de los datos. Ello determinó un cambio del área de estudio 
Ese cambio implica que los datos expuestos en este trabajo reflejan la foto del momento de realización del estudio y pueden variar en el tiempo, pero a través del abordaje metodológico expuesto podrán actualizarse dichos datos.

Si bien se trabaja en el Partido de La Plata como caso de estudio para poder aplicar la metodología y demostrar los resultados en un caso concreto, la metodología propuesta tanto para el relevamiento de espacios verdes, la determinación de la calidad de paisaje, como para determinar el tipo de espacio verde en relación a la calidad y al tipo de paisaje, podrán replicarse para el abordaje de cualquier otro caso de estudio.

En el devenir de nuestra investigación hemos podido ir respondiendo a los diversos interrogantes originalmente planteados, que motivaron la investigación acerca del paisaje, los espacios verdes y las tierras vacantes. Pero al mismo tiempo el avance en el conocimiento ha contribuido a disparar nuevos interrogantes y temas que necesitarán ser profundizados en otros trabajos e investigaciones. Entre ellos como futuras líneas de trabajo surgen:

1- ¿Cómo abordar el futuro crecimiento de las ciudades a partir de los emergentes de la sociedad, así como los cambios culturales y sociales provocados? ¿Cómo pensar las nuevas formas de crecimiento poblacional a partir de la existencia de las áreas vacantes en relación a su calidad geomorfológica, paisajística y ambiental?

2- ¿Cuál sería la relación entre los espacios verdes y en el entorno urbano en la configuración urbanística de las próximas décadas?? ¿Cómo impedir que los espacios vacantes en torno a los ríos y arroyos sean ocupados por urbanizaciones?

3 - ¿Cómo desde estos nuevos espacios verdes propuestos se podría empezar a modificar el entorno urbano? Un nuevo espacio propone una nueva configuración de ese lugar, la mayoría de estos espacios están en zonas en transición en el periurbano donde todavía se está a tiempo de pensar cómo debería ser ese entorno desde la concepción del paisaje.

4- ¿Qué mecanismos e instrumentos de gestión se pueden aplicar para la incorporar de las tierras vacantes a un sistema de espacios verdes?

5 - ¿Cuáles son las diferencias conceptuales entre las ideas de los diferentes momentos históricos y la representación espacial de las intervenciones en espacios verdes en relación a la variable estética, socio espacial, ambiental y económica? 
Estas líneas de trabajo son interrogantes que surgieron en el proceso de investigación y creemos que resultan claves para seguir pensando las intervenciones en el territorio desde el paisaje. 


\section{BIBLIOGRAFIA}

Ábalos, I. (Ed.). (2009). Naturaleza y artificio. El ideal pintoresco en la arquitectura y el paisajismo contemporáneos. Barcelona, España: G. Gili.

Ábalos, I. (2008). Atlas Pintoresco Vol. 2: Los viajes. Barcelona, España: G. Gilli.

Ábalos, I. (2005). Atlas Pintoresco Vol. 1: el observatorio. Barcelona, España: G. Gili.

Al-Kodmany, K. (1999). Using Visualization Techniques for Enhancing Public Participation in Planning and Design: Process, Implementation and Evaluation. Landscape and Urban Planning (44), 37-45.

Amir, S. y Gidalizon, E. (1990). Expert-based method for the evaluation of visual absorption capacity of the landscape. Journal of Environmental Management, 30, págs. 251-263.

Aón, L.; Bidinost, M. Goenaga V.; Manuel, D.; Michellod, O.; Pinedo, A.; Santinelli, G. y Varela, L. (2001). Paisaje. Reflexiones. La Plata, Argentins: Ediciones Al Margen.

Appleton, J. (1975). The Experience of Landscape. Wiley, London \& New York.

Appleton, J. (1984). Prospects and refuges re-visited. Landscape Journal, 91-103.

Arias Sierra, P. (2003). Periferias y nueva ciudad. Sevilla: Secretariado de publicaciones de la Universidad de Sevilla.

Armenteras, D. y Vargas O. (2016). Patrones del paisaje y escenarios de restauración: acercando escalas. Acta biol. Colomb. 2016, 21(1), 229-239. doi: http://dx.doi.org/10.15446/abc.v21n1sup.5084

Arroyo, J. (2011). Espacio público, entre afirmaciones y desplazamientos. Santa Fe: Centro de Publicaciones UNL.

Auge, M. (1992). Los no lugares. Espacio del anonimato. Barcelona, España: Editorial Gedisa, S.A.

Barsky, A. y Vio, M. (2007) la problemática del ordenamiento territorial en cinturones verdes periurbanos sometidos a Procesos de Valorización Inmobiliaria. El caso del Partido del Pilar, Región Metropolitana de Buenos Aires. IX Coloquio Internacional de Neocrítica. Universidade Federal do Rio Grande do Sul, Porto Alegre.

Barsky, A. (2005). El periurbano productivo, un espacio en constante transformación. Introducción al estado del debate, con referencias al caso de Buenos Aires. Scripta Nova, Revista Electrónica de Geografía y Ciencias Sociales. Universidad de Barcelona, IX (194), 36.

Battle, E. (2011). El jardín de la metrópoli. Del paisaje romántico al espacio libre para una ciudad sostenible. Barcelona, España: GG.

Bedoya, M. (1996). La lectura del jardín paisajista. En C. Añón Feliú. El lenguaje oculto del jardín: jardín y metáfora. Madrid, España: Ed. Complutense.

Blanco, A. A. (1979). La definición de unidades de paisaje y su clasificación en la provincia de Santander. Tesis Doctoral. E.T.S. Ing. de Montes. Univ. Politécnica de Madrid. Belli, E. y 
Benassi, A. (2004). Planeamiento paisajista y medio ambiente. La Plata, Argentina.

Becerra, A. (1997). Investigación en metodología vs. metodología de la investigación. Investigación y Postgrado, 12 (1).

Benedict, M. and McMahon, E. (2006) Green Infrastructure: Linking Landscapes and Communities. Island Press. Washington, USA.

Berque, A. (2006). Trayección y realidad del paisaje, Traducción de Devora Manuel.

Birche, M. y Jensen, K. (2018). Relevamiento y catalogación de los espacios verdes de uso público de la ciudad de La Plata, Argentina. Urbano, (37).

Borsdforf, A. (2003). Cómo modelar el desarrollo y la dinámica de la ciudad latinoamericana.Revista EURE, 29 (86) Santiago.

Borja, J. y Muxí, Z. (2003). El espacio público, ciudad y ciudadanía. Barcela, España: Ed. Electa.

Borja, J. (2001). El gobierno del territorio de las ciudades latinoamericanas. Revista Instituciones y Desarrollo. Barcelona: IIGOV (8 y 9). Capturado de: www.iigov.org/id/index.drt>

Borja J. (1998). Ciudadanía y espacio público. Significat i funció a l'espai urbà modern, "Urbanitats" (7) Centro de Cultura Contemporánea de Barcelona.

Bozzano, H. (1990). Los procesos de estructuración de espacios periurbanos. Hacia una definición del borde metropolitano de Buenos Aires. Revista Interamericana de Planificación, XXIII (89).

Bozzano, H. (2002). El Cinturón Verde Platense: Sistemas de objetos, sistemas de acciones. Foro CIVEBA, Cinturón Verde Metropolitano de Buenos Aires, Argentina (p. 264284).

Cabarrou, Alicia. Hacia una nueva ruralidad urbana: diversidad y pluriactividad en la producción y en el territorio metropolitano. Tesis de Maestría en Desarrollo Sustentable, FLACAM-UNLA-UNESCO. La Plata, 2004.

Cakci-Kaymaz, I. 2012. Landscape perception. In: Ozyavuz M.s (Ed.). Landscape planning. In Tech. Rijeka, CRO, 251-276.

Camilloni, I. y Barros, V. (2016). La Argentina y el cambio climático. Buenos Aires, Argentina: EUDEBA.

Carabajal, Servetti y Souto (2011). "Reciclando vacíos urbanos". Proyecto de Investigación. Facultad de Arquitectura, Universidad de la República, Uruguay. Recuperado desde: http://es.scribd.com/doc/72201829/Vacios-Urbanos-Carpeta-Final

Caron D. (2017) El estudio del paisaje como clave interpretativa del territorio a través de las narrativas para la planificación urbana y territorial Paraty, Río de Janeiro/Brasil como caso de estudio.

Carter, H. (1995). El estudio de la geografía urbana. Madrid, España: Instituto de Estudios de la Administración Local. 
Castelli, L. y Sapallasso, V. (2007). Planificación y conservación del paisaje: Herramientas para la protección del patrimonio natural y cultural. Buenos Aires, Argentina: Fundación Naturaleza para el Futuro.

Castells, M. (1978). La teoría marxista de las crisis económicas y las transformaciones del capitalismo. $2^{\mathrm{a}}$ edición.

Cerasi, M. (1990). El espacio colectivo de la ciudad. Barcelona, España: OikosTau.

Chávez, M., Valladares Anguiano, R. y Aguirre Fuentes, M. (2008). Terrenos baldíos y expansión territorial en la ciudad de Villa de Álvarez, Colima. Palapa. Revista de investigacion cientifica en la arquitectura, III (II), 29-37. Recuperado de: http://www.redalyc.org/pdf/948/94814774005.pdf

Cicollela, P. (2010). Capitalismo global y transformaciones metropolitanas: enfoque e instrumentos para repensar el desarrollo urbano, en Otro desarrollo urbano. Buenos Aires, Argentina: CLACSO

Clement, G. (2007). Manifiesto del tercer paisaje. Barcelona, España: Editorial Gustavo Gili.

Clichevsky, N. (2007). La tierra vacante "revisitada“. elementos explicativos y potencialidades de utilización. Cuaderno urbano, (6), 195-219. ISSN: 1666-6186

Clichevsky, N. (Ed.). (2002). Tierra vacante en ciudades latinoamericanas. Cambridge: Lincoln Institute of Land Policy

Clichevsky, N. (2001). Tres casos de utilización de tierra vacante en el Área Metropolitana de Buenos Aires. Cambridge: Documento de Trabajo, Lincoln Institute of Land Policy.

Clichevsky, N. (1990). Construcción y Administración de la ciudad latinoamericana. Instituto Internacional de Medio Ambiente y Desarrollo. IIED-América Latina. Argentina: Grupo Editor Latinoamericano. Col. Estudios Políticos y Sociales.

Colafranceschi, D. (2007). Landscape+ Cien palabras para habitarlo. Barcelona, España: Gustavo Gilli.

Conselleria de infraestructuras, territorio y medio ambiente (Ed.) (s.f.). Guía metodológica. Estudio de Paisaje. Valencia: La Imprenta CG. Recuperado de: http://www.upv.es/contenidos/CAMUNISO/info/U0670136.pdf

Corraliza, J. (2015). La experiencia humana del verde urbano Universidad Autónoma de Madrid, Percepción y uso humano de los espacios verdes urbanos. XXXVIII Congreso Nacional de Parques y Jardines Públicos. Asociación Española de Parques y Jardines Públicos, España.

Corraliza, J. A. (1987). La experiencia del ambiente. Percepción y significado del medio construido. Madrid, España: Ed. Madrid, Tecnos.

Corraliza, J. A. (2009). Emoción y espacios públicos: La experiencia humana de los escenarios urbanos. Madrid, España: Universidad Autónoma de Madrid.

Corraliza, J. A.(2009). Emoción y espacios públicos: La experiencia humana de los escenarios urbanos.Jornada de El árbol en el diseño urbano. Madrid, España: Universidad Autónoma de Madrid. 
Cosgrove, D. (2002). Observando la naturaleza: el paisaje Geógrafos Españoles. Boletín de la Asociación de geografos españoles, (34), 63-89.

Cotorruelo menta, R. (2001) “Aspectos estratégicos del desarrollo local”, en Vázquez Barquero A. y Madoery O., Transformaciones globales, instituciones y políticas de desarrollo local. Rosario, Argentina: Ediciones Homo Sapiens.

Cowman, S. (1993). Triangulation: a means of reconciliation in nursing research. Journal of Acvanced Nursing.

Dankhe, G. (1976). Investigación y comunicación, en C. Fernández-Collado y G.L., Dankhe (Eds): “La comunicación humana: ciencia social". D.F, México: McGraw Hill.

Del Pozo, C. (2016). SUNLIGHT Landscape Studio. Revista Ciudad Sostenible, (Eenero2016). Recuperado de http://www.ciudadsostenible.eu/

Delgado, M. (2007). Lo común y lo colectivo. Barcelona, España: Universidad de Barcelona.

Dematteis, G. (1996). Suburbanización y periurbanización. Ciudades anglosajonas y ciudades latinas. Revista Urbanitats, (4). Recuperado de: http://wwwcpsv.upc.es/CITiC/documents/ dematteis.pdf

Domenico di Siena (13 de noviembre de 2014). Espacio Público y Participación Ciudadana: ¿administrar, controlar o potenciar?. La ciudad Viva. Recuprado de: http://www.laciudadviva.org/blogs/?p=26593.

Dominguez, M. C. (2013). Valoración del patrimonio cultural platense, plazas platenses. Buenos Aires, Argentina: Nobuko.

Druot, F., Lacaton, A. y Vassal, P. (2007). La vivienda colectiva territorio de Excepción. Barcelona, España: Gustavo Gili.

Duarte, F. y Blascovi, K. (2006). LA desocupación de los centros urbanos y la tipología de las viviendas: el mercado inmobiliario en curitiba desertion of urban centers and housing typology: land market in Curitiba. Revista invi, 21 (58), 11 -25.

Fairbanks, D. H. K. y Benn, G. A. (2000). Indentifying regional landscapes for conservation planning: a case study from KwaZulu-Natal, South Africa. Landscape and Urban Planning, (50), 237-257.

Falcón, A. (2007). Espacios Verdes para una ciudad sostenible: Planificación, proyecto, mantenimiento y gestión. Barcelona, España: Gustavo Gili.

Fariña, J. (27 de junio de 2012). Infraestructura verde urbana. El blog de José Fariña. Urbanismo, Territorio y Paisaje. Recuperado de: https://elblogdefarina.blogspot.com/2012/06/infraestructura-verde-urbana.html.

Fausto Brito, A. (2005). Desarrollo urbano equitativo en las ciudades mexicanas: Consideraciones respecto a los terrenos intersticiales vacantes. El caso del Área Metropolitana de Guadalajara (AMG). Third Urban Research Symposium of the World Bank on "Land Development, Urban Policy and Poverty Reduction". Brasilia.

Fausto Brito, A y Rábago, J. (2001). ¿Vacíos urbanos o vacíos de poder metropolitano?. Revista Ciudad Vacíos urbanos. 
Fernández Áñez, V. (2011). Vacíos urbanos. un derecho. una oportunidad. RNIU, Madrid, (49), 33-39.

Fernández Cañadas, M. (1977). El paisaje en la planificación física. Aproximación sistemática a su valoración. Tesis Doctoral. E.T.S.I.M., Madrid.

Folch (2003). Los conceptos socio ecológicos de partida. El territorio como sistema: conceptos y herramientas de ordenación. Barcelona, España: diputación de Barcelona.

Fontanari, E. (2011). El concepto de paisaje. En, Seminario de paisaje. Maestría en Paisaje, Medio ambiente y Ciudad. Facultad de Arquitectura y Urbanismo. Universidad. Nacional de La Plata.

Frediani, J. C. (2016). La política de manejo de la tierra vacante en el gran La Plata, Buenos Aires. Cuaderno urbano, 20 (20). ISSN 1853-3655

Frediani J. (2014). Las tierras vacantes al interior de un proceso de crecimiento urbano desarticulado y fragmentado. El caso del gran la plata. En 11th Symposium of International Urban Planning and Environment Association - IUPEA. Simposio llevado a cabo en La Plata, Argentina.

Frediani, J. C. (2010). Lógicas y tendencias de la expansión residencial en áreas periurbanas. El Partido de La Plata, Buenos Aires, Argentina, entre 1990 y 2010 (Tesis doctoral). Recuperado de: http://www.memoria.fahce.unlp.edu.ar/tesis/te.355/te.355.pdf

Frediani J. C. y Matti C. (2006). Transformaciones urbanas en el partido de La Plata desde los años '90. ¿Hacia un modelo de ciudad compacta o difusa?. Geograficando: Revista de Estudios Geogr aficos, 2(2). ISSN E 2346-898X. Recuperado de: http://geograficando.fahce.unlp.edu.ar

Gandolfi, F. y. (s/f). La Plata: un trazado inconcluso en tres movimientos. La Plata, Argentina: Mimeo.

Garnier, A. (1992). El cuadrado roto. Sueños y realidades de La Plata. La Plata, Argentina: LINTA, CIC y Municipalidad de La Plata.

García, D. (2009). Educación ambiental: aportes políticos y pedagógicos en la construcción del campo de la educación ambiental. Buenos Aires, Argentina: Jefatura de Gabinete de Ministros. Presidencia de la Nación. Desarrollo sustentable.

Garay, D. y Fernández, L. (2013). Biodiversidad urbana, áreas verdes en la Región Metropolitana de Buenos Aires. Buenos Aires, Argentina: Nobuko.

Garay, A. et. al. (2007). Lineamientos Estratégicos para la Región Metropolitana de Buenos Aires. Recuperado el 27 de Julio de 2014, del sitio web: http://www.mosp.gba.gov.ar/sitios/ urbanoter/planurbana/Lineamientos_RMBA.pdf

Gastó-Coderch, J. M., Gálvez-Navarrete M. C. y Morelos-Arnaiz, P. (2010). Construcción y articulación del paisaje rural. Revista AUS, (7), 6-11.

Gehl, J., (2006). La humanización del Espacio Urbano. La vida social entre los edificios. Barcelona, España: Reverté, S.A. 
Gómez A. A. (2010). El paisaje como patrimonio cultural, ambiental y productivo, análisis e intervención para su sostenibilidad. Revista KEPES, 7 (6), 91-106.

GÓmez Orea, D. (2004). Recuperación de espacios degradados. Madrid, España: Ed. Multiprensa.

Gómez Orea, D. (1979). El medio físico y la planificación. Madrid, España: CIFCA.

Gordon Cullen, T. (1959). El paisaje urbano. Barcelona, España: Ed. Blume.

Gorelik, A. (1998). La grilla y el parque. Espacio público y cultura urbana en Buenos Aires, 1887-1936. Buenos Aires, Argentina: Universidad Nacional de Quilmes.

Gorelik, A. (2004). Miradas sobre Buenos Aires. Historia cultural y crítica urbana. Buenos Aires, Argentina: Siglo XXI.

Gunderson, L. H. and .Holling, C. S. (Ed.) 2002. Panarchy: understanding transformations in human and natural systems. Washington, USA: Island Press,

Halperin, D. T. (1969). Historia Contemporánea de América Latina.

Harvey, D. (2005). Las grietas en la ciudad capitalista. Entrevista con David Harvey. http://nodo50.org/zafra/docu/urb/05121entrevista harvey.pdf

Harvey, D. (2006). La ciudad como un cuerpo político. Revista $\tilde{N},(160)$ edición especial 3er aniversario, Octubre.

Harvey, D. (2004). El nuevo imperialismo. Acumulación por desposesión. Socialist Register 2004, Buenos Aires,Argentina: CLACSO.

Harvey, D. (2003). Espacios de esperanza. Madrid, España: Akal.

Heidegger, M. (1951) construir habitar pensar

Holling, C. S. (1973). Resilience and stability of ecological systems. Annual Review of Ecological Systems, (4), 1-23.

Jacobs, J., 2011. Muerte y vida de las grandes ciudades. Madrid, España: Capitán Swing Libros, S.L.

Janesick, V. (1998). Stretching exercises for qualitative researchers. University of South Florida, USA: Thousand Oaks.

Jensen, K y Birche, M. (2018b). Reconfiguring the urban landscape of La Plata through a green network. Journal of Urban and Landscape Planning, (3).

Jensen, K. y Birche, M. (2018). Vulnerabilidad al cambio climático: las inundaciones. Revista CIS, XIV (23), 77-99.

Jensen, K.y Birche, M. (2017). Espacio verde: elemento clave en la gestión urbana. Revista Ciudades, (115), 10-21.

Johnston, C. A. And Naiman, R. J. (1990). The use of a geographic information system to analyze long term landscape alteration by beaver. Landscape Ecology. 1, 5-19. 
Karol, J., Ravella, O. y Aón, L. (2012). Transporte y ambiente: utopías urbanas, ciudades reales, ciudades posibles. Buenos Aires, Argentina: Transporte y territorio.

Karol. J. (2013). Ciudad como sistema. En, Seminario Maestría en Paisaje, Medio ambiente y Ciudad. Facultad de Arquitectura y Urbanismo. Universidad. Nacional de La Plata.

Kullock, D. (1998). Planificación ambiental urbana. Mar del Plata, Argentina: Programa editorial del centro de investigaciones ambientales.

Kusch, R. (2000). Obras Completas. Tomo III. Rosario, Argentina: Editorial Fundación Ross.

Latour, B. (2007). Nunca fuimos modernos. Buenos Aires, Argentina: Siglo XXI.

Larangeira, A. (2004). Tierra vacante en las ciudades de América Latina: desafíos y oportunidades. Seminario Internacional Tierra Vacante: Nuevos Desafíos y Oportunidades. Lincoln Institute of Land Policy, Cambridge, MA.

Lefevbre, H. (1974). La production de l'espace. Paris, Francia: Ed. Du Minuit.

Linton, D.L. (1968). The Assesment of Scenary as a Natural Resource. Scottish Geogr. Magazine, 84 (3), 219-238.

López Geta, Pulido Bosch, y Baquero Úbeda, (2005). Agua, minería y medio ambiente: libro homenaje al profesor Rafael Fernández Rubio.

Lynch, K. (2005). Echar a perder. Barcelona, España: Gustavo Gilli.

Lynch, K. (1998). La imagen de la ciudad. Barcelona, España: Centro de Editor GG Reprints.

Observatorio del paisaje de Cataluña (2014). La planificación del paisaje en el ámbito local en Europa". Los casos de Alemania, Francia, Países Bajos, Reino Unido, Suiza y la región de Valonia, en Bélgica.

Palomo, P. J. S. (2003). La Planificación verde en las ciudades. Barcelona, España: Gustavo Gili.

Perahia, R. (2007). Los problemas del mundo actual soluciones y alternativas desde la geografía y las ciencias sociales. IX Coloquio Internacional de Geocrítica. Universidade Federal do Rio Grande do Sul, Porto Alegre.

Perahia, R. (1999). El Espacio Público. Los espacios verdes, los espacios libres. Buenos Aires, España: Editorial Belgrano.

Períes, L., Ojeda, B., Kesman, C. y Perazzolo, D. (2016). Catálogo del Paisaje del río Suquía en la ciudad de Córdoba. Cordoba, Argentina: EDUCC.

Períes, L. (2009). Paisajes desdoblados: radiografía de una condición urbana latinoamericana. Arquiteturarevist, 5 (2), 76-83.

McHarg, I. L. (2000). Proyectar con la naturaleza. Barcelona, España: Editorial Gustavo Gilli.

Márquez, F. (2011). Planificación, diseño y gestión participativa del paisaje. Buenos Aires, Argentina: Nobuko. 
Márquez, F. (2008). La correcta implementación de un proceso participativo en el Observatorio Temático DC-UP. Universidad Nacional de Palermo, Facultad de diseño y comunicación. Recuperado de: http://fido.palermo.edu/servicios_dyc/noticiasdc/mas_informacion.php?id_noticia=401

Maderuelo, J. (2010). Paisaje y Patrimonio. Madrid, España: Abada editores.

Meinig, D. W. (1979). Interpretation of Ordinary Landscapes: Geographical Essays. New York, USA: Oxford University Press.

Méndez Mihura, X. (2011). Ciudades: del Higienismo al advenimiento del Toyotismo AMÉRICA LATINA - La planificación urbana, recuperado de: www.alterinfos.org/spip.php?page=spipdf\&spipdf.

Metz, B., Davidson, O., Swart, R. y Pan, J., (Ed.) (2001). IPCC TAR WG3. Climate Change 2001: Mitigation, Contribution of Working Group III to the Third Assessment Report of the Intergovernmental Panel on Climate Change. Cambridge University Press.

Ministerio de Planificación Federal, Inversión Pública y Servicios (2011). Plan Estratégico Territorial Avance II: Argentina Urbana. Buenos Aires, Argentina: Ministerio de Planificación Federal, Inversión Pública y Servicios.

Moreno Flores, O. (2018, abril). Arquitecturas y ecologías del paisaje. Conceptos, estrategias y operatorias del proyecto. Trabajo presentado en conferencia en la FAU UNLP, La Plata, Argentina.

Morosi, J. (1999). Ciudad de La Plata. Tres décadas de reflexiones acerca de un singular espacio urbano. Buenos Aires, Argentina: CIC

Monclús, F. (1997). Ciudad dispersa y ciudad compacta. Perspectivas urbanísticas sobre las ciudades mediterráneas. Cicle de conferències "Ecologia Urbana" Ajuntament de Girona - Universitat de Girona. D`Humanitats (7), 95 - 110.

Morosi, J. y De Teran F. (1983). La Plata: ciudad nueva ciudad antigua: historia, forma y estructura de un espacio urbano singular. Madrid, España: UNLP-IEAL.

Naredo, J. M. y Fariña J. (coord.). (2010). Libro Blanco de la sostenibilidad en el planeamiento urbanístico español. Madrid: Ministerio de Vivienda. Madrid, España: Ministerio de Vivienda.

Navarro, B. G. (2003). Una aproximación al paisaje como patrimonio cultural, identidad y constructo mental de una sociedad. Apuntes para la búsqueda de invariantes que determinen la patrimonialidad de un paisaje. Santiago, Chile: Facultad de Arquitectura y Paisaje- Universidad de Chile.

Nogue, J.y Sala, P. (2008). El paisaje en la ordenación del territorio. Los catálogos de paisaje de Cataluña. Cuadernos Geográficos, (43), 69-98.

Nogué, J. (Ed.) (2008). El paisaje en la cultura contemporánea. Madrid, España: Biblioteca nueva.

Nogué, J. (2007). El paisaje como construcción social. Madrid, España: Editorial Biblioteca Nueva 
Novick, Alicia (2004) “Espacios públicos y proyectos urbanos. Oposiciones, hegemonías e interrogantes. Vitruvius, 11, Recuperado de: http://www.vitruvius.com.br/arquitextos/arq054/arq054_01_e.asp

Orians, G. (1986). An ecological and evolutionary approach to landscape aesthetics. En: Penning-Rowsell, E. C., and Lowenthal, D. (eds.) Landscape meanings and values. Londen etc., Allen and Unwin. 1986.

Punter, J. V. (1982). Landscape aesthetics: a synthesis, and critique.

Ramos, J. A. (2005). El papel del sistema de espacios verdes en la multifuncionalidad del Paisaje Urbano. Aplicacion al Area Metropolitana de Sevilla. En X Colóquio Ibérico de Geografia. Universidade de Évora, Portugal.

Ravella, O. (2010). Pasado, presente y futuro de la planificación urbano-regional. Buenos Aires, Argentina: Nobuko.

Ravella, O. (2013). Contexto histórico y configuración urbana. En, Seminario de Teoría e Historia de la Ciudad. Maestría en Paisaje, Medio ambiente y Ciudad. Facultad de Arquitectura y Urbanismo. Universidad. Nacional de La Plata.

Ravella, O. y Varela, L. (Comp.) (2008). Diseñando el paisaje. Buenos Aires, Argentina: Prometeo.

Ravella, O., Giacobbe, N. y Frediani, J. (2006). El transporte como factor de integración / desintegración de las regiones urbanas. 42nd ISoCaRP Congress. Cities between Integration and Disintegration: Opportunities and Challenges. Estambul, Turquía.

Register, R. (2002) Ecocities. Building cities in balance with nature. Berkeley Hills Books, USA.

Roger, A. (2007). Breve tratado del paisaje. Madrid, España: Editorial Nueva, S.L.

Rueda, S. (1998). La ciudad compacta y diversa frente a la conurbación difusa. Barcelona. Recuperado de: http://habitat.aq.upm.es/cs/p2/a009.html

Rueda, S. (1996). Habitabilidad y calidad de vida. Madrid. Recuperado de: http://habitat.aq.upm.es/select-sost/ac3.html

Rueda, S. (2012). Libro Verde la sostenibilidad urbana y local en la era de la información. Madrid, España: Ministerio de Agricultura, Alimentación y Medio Ambiente y Agencia de Ecología Urbana de Barcelona.

Samaja, Juan (1996). El Proceso de la Ciencia, una breve introducción a la investigación científica. Ed. Serie Difusión. Dirección de Investigaciones. Secretaría de Investigación y Postgrado. FADU. UBA

Santos, M. (2000). La naturaleza de espacio. España: Ariel.

Sassen, S. (2005). The Global City: Introducing a concept. Brown Journal of World Affairs, $\mathrm{XI}(2)$.

Segura, R. (2015). Vivir afuera, antropología de la experiencia urbana. Buenos Aires, Argentina: Universidad de San Martin. 
Segura, R. (2009). La persistencia de la forma (y sus omisiones). Un estudio del espacio urbano de La Plata a través de sus ciudades análogas. Cuad. antropol. soc., (30).

Servicio de evaluación ambiental (2013). Guía de evaluación de impacto ambiental. Valor paisajístico en el SEIA. Chile: Servicio de evaluación ambiental.

Sierra Arias, P., (2003). Periferias y Nueva Ciudad. Sevilla, España.

Silvestri, G. (2011). ARS Publica. Ensayos de crítica e historia de la arquitectura, la ciudad y del paisaje. Buenos Aires, Argentina: Nobuko.

Silvestri, G. y Aliata F. (2001). El paisaje como cifra de armonía. Buenos Aires, Argentina: Edic. Nueva Visión.

Smardon, R. C., Palmer, J. E. and Felleman, J.P. (Eds.) (1986). Foundations for Visual Projects Analysis. Johan Wiley and Sons.

Souto, P. (coord.). (2011). Territorio, Lugar, Paisaje. Buenos Aires, Argentina: Editorial de la facultad de Filosofía y letras. Cap. 3.

Solà-Morales Rubió, I. (1996). Presente y futuros. La arquitectura en las ciudades. En AA. WV., Presente y futuros. Arquitectura en las grandes ciudades. Barcelona, España: Col.legi Oficial d'Arquitectes de Catalunya / Centre de Cultura Contemporània. 10-23.

Tardin, Raquel (2010). Espacios libres: Sistema y proyecto territorial. Buenos Aires, Argentina: Nobuko.

Tella, G. y Potocko, A. (2009). Espacios verdes públicos: Una delicada articulación entre demanda y posibilidades efectivas. Revista Mercado y Empresas para Servicios Públicos, Buenos Aires, (55), 40-55.

Tesser, O. C. (2000). Algunas reflexiones sobre los significados del paisaje para la geografía. Revista de Geografía Norte Grande , (27), 19-26.

Torroja, A. y Camagni, R. (coords.) (2006). Una nueva cultura del territorio: criterios sociales y ambientales en las políticas y el gobierno del territorio. Barcelona, España: Diputació de Barcelona.

URBIS, "Plan Regulador Conjunto de los Partidos de La Plata y Ensenada", 2 Vol. La Plata, 1961

Varela, L. y Sahaniuk, A. (Coord.). (2008) Seminario de Legislación ambiental. Fundamentos para la elaboración de un Proyecto de Ley de Presupuestos Mínimos sobre Paisaje

Verne, J. (2005). Los quinientos millones de la Begún. Madrid, España: Alianza Editorial.

Wright, G.(1974). Appraisal of visual landscape qualities in a region selected for acelerated growth. Landscape Planning, (1), 307-327.

Wylie, j. (2007). landscape. Londres/Nueva York: routledge.

Ynoub, R. (2015). Cuestión de método. Aportes para una metodología crítica. Mexico: Cengage learning 
Zoido Naranjo, F. (2002). El paisaje y su utilidad para la ordenación del territorio. En Congreso, Paisaje y ordenación del territorio. Sevilla, España: servicio de publicaciones de la consejería de obras públicas y transportes de la junta de Andalucía. Duques de Soria. (21-33).

\section{SITIOS WEB}

Banco mundial. Recuperado de: http://www.bancomundial.org/es/. Fecha de captura: $10 / 09 / 2015$

Blog La ciudad viva. Recuperado de: http://www.laciudadviva.org/blogs/?p=26593. Fecha de captura: 15/9/2017

Blog paisaje transversal. Recuperado de: http://www.paisajetransversal.org/2017/11/metamorfosis-sintetica-paisajes-resilienteslandlab.html. Fecha de captura: 28/11/2017

Blog Habitar arq. Recuperado de: https://habitar-arq.blogspot.com.ar/2010/05/ladesestructuracion-de-la-ciudad-de-la.html Fecha de captura: 15/6/2017

Blog prensa Brandsen. Recuperado de: http://prensabrandsen.blogspot.com.ar/2013/06/avanza-el-proyecto-del-parador.html Fecha de captura: 13/5/16

Catálogos de paisaje urbano. https://www.lucasperies.com/catalogos-paisaje-urbano. Fecha de captura: 5/2/2018

CARE Internacional (2010) ¿Qué es adaptación al cambio climático? Documentos sobre Cambio Climático. Recuperado de: http://www.careclimatechange.org/files/adaptation/Que es adaptacion_al_cambio cli matico.pdf.

Consel de l'Europe. Recuperado de: http://www.coe.int/t/dg4/cultureheritage/heritage/Landscape/VersionsConvention/spa nish.p df. Fecha de captura: 10/10/2014

INDEC. Recuperado de: https://www.indec.gob.ar/. Fecha de captura: 15/8/16.

Iniciativa LALI para el Paisaje. Recuperado de: https://lali-iniciativa.com/nodos-lali/ Fecha de captura: 12/06/2015

International federation of federation architects- IFLA. Recuperado de: http://iflaonline.org/ Fecha de captura: 10/09/2015

Lincoln Institute of Land Policy. Recuperado de www.lincolninst.edu Fecha de captura: $10 / 4 / 2017$

Observatorio del Paisaje. Recuperado de: http://www.catpaisatge.net/esp/observatori.php. Fecha de captura: 12/6/2014

Paisaje transversal. Recuperado de: http://www.paisajetransversal.org/2017/11/metamorfosis-sintetica-paisajes-resilienteslandlab.html. Fecha de captura: 22/10/2016 
Parador ecológico en Brandsen. Recuperado de: http://prensabrandsen.blogspot.com.ar/2013/06/avanza-el-proyecto-del-parador.html.

Fecha de captura: 15/10/16

Proyecto AIACC LA26. Impacto del cambio global en las costas del Río de La Plata: Incremento del nivel del mar y sus efectos meteorológicos. Recuperado de: http://www.ina.gov.ar/pdf/LH PHC AIACC.pdf Fecha de captura: 10/10/17

Red argentina del paisaje. Recuperado de: http://www.redargentinadelpaisaje.com/. Fecha de captura: 24/08/2016

The countryside agency (2002). Landscape character assessment Guidance for england and Scotland. Recuperado de:

urBAsig. Servidor de Mapas. Ministerio de Infraestructura y Servicios Públicos. Recuperado de: http://sig.gobierno.gba.gov.ar/urbasig/ Fecha de captura: 14/5/2016.

Urban resilliance. Recuperado de: https://www.resalliance.org capturado: 15/2/2018

UTDT -CIPUV, Centro de Investigación de Políticas Urbanas y de Vivienda (2013). Atlas de Crecimiento Urbano. Recuperado de: http://atlasurbano.herokuapp.com/\#/contacto. Fecha de captura: 03/06/2016

\section{OTROS DOCUMENTOS}

Ley de protección, gestión y ordenación del paisaje (2005). Parlamento de Cataluña. Cataluña, España.

Ley 12704 de Paisaje Protegido De Interés Provincial y/o Espacio Verde De Interés Provincial (2012). Cámara de Diputados de la Provincia de Buenos Aires. Buenos Aires, Argentina.

Ley 12274 (1999). Cámara de Diputados de la Provincia de Buenos Aires. Buenos Aires, Argentina.

Decreto-ley 8912 Ley de Ordenamiento Territorial y Uso del Suelo de la Provincia de Buenos Aires (1977). Buenos Aires, Argentina.

Ley 25.675 (2002). Congreso de la Nación Argentina. Buenos Aires, Argentina.

Ley N¹4.546 Espacio Verde Monte del Hospital Dr. Raúl Alfonsín (2012). Partido de Gral. Rodríguez, Argentina.

Ley 14449 de Acceso Justo al Hábitat (2013). Buenos Aires, Argentina. 
PAISAJES VACANTES

ANEXO 1

Encuesta paisajes platenses 
ANEXO 1

\section{Paisajes platenses}

*Obligatorio

\section{Datos generales}
1. Indique su edad *
Marca solo un óvalo.
menor a 20 años
(C) a 35 años
( 36 a 60 años
más de 60 años

\section{Indique sexo *}
Marca solo un óvalo.
Femenino
Masculino
Otro:

3. Indique la esquina mas cercana a su residencia

\section{Paisajes Platenses}

4. ¿Puede nombrar algún lugar al aire libre reconocido de la ciudad? * Marca solo un óvalo.

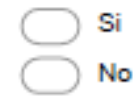

5. ¿Cuál?

6. Indique: ¿cuál imagen le agrada mas? * Marca solo un óvalo.

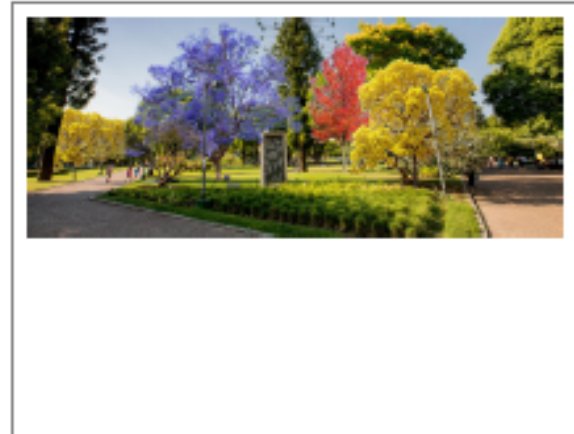

Opción 1

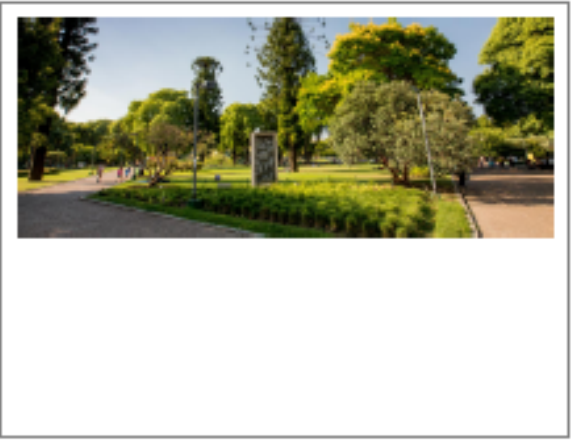

Opción 2 
7. Indique: ¿ cuál imagen le agrada mas? *

Marca solo un óvalo.

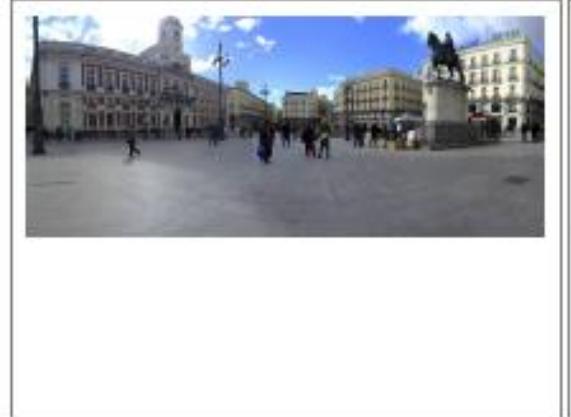

Opción 1

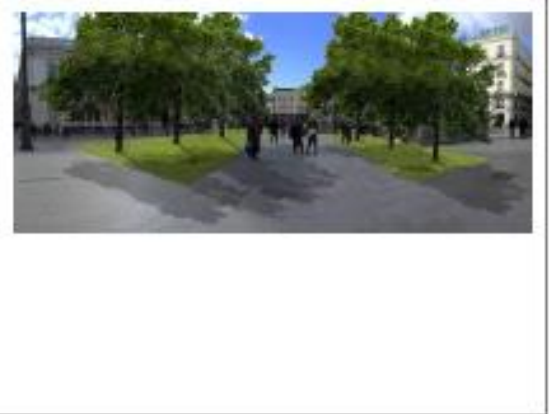

Opción 2

8. Indique: ¿ cuál imagen le agrada mas ? Marca solo un óvalo.

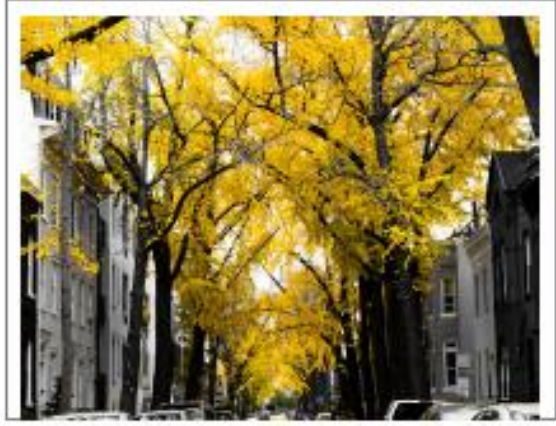

Opción 1

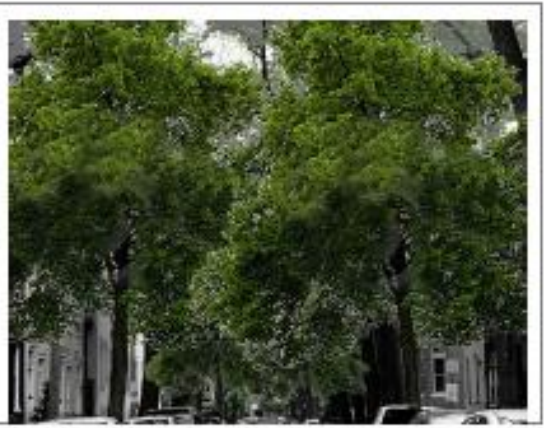

Opción 2

9. Indique: ¿cuál imagen le agrada mas? * Marca solo un óvalo.

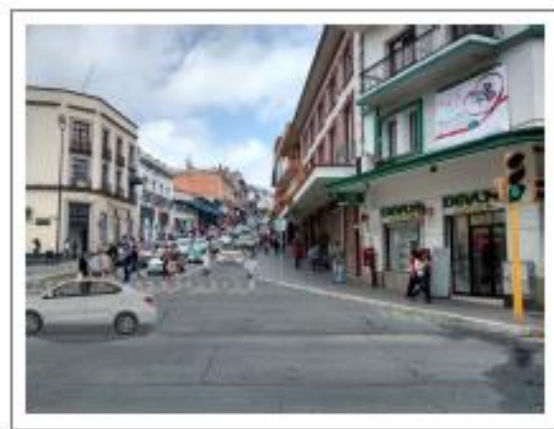

Opción 1

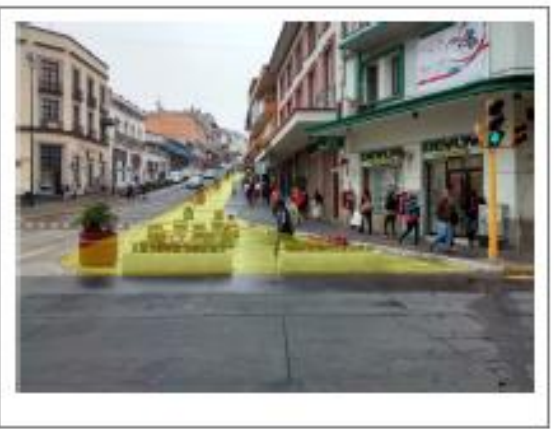

Opción 2

10. ¿Cuál es el espacio al aire libre de la ciudad que más disfruta? *

11. El lugar elegido en la respuesta anterior, ¿Está asociado a algún elemento en particular? * Selecciona todos los que correspondan.
Vegetación característica
Edificio significativo
Amplitud y comodidad del espacio
Presencia de agua
Otro: 
12. ¿Cree que las veredas de la ciudad tienen las condiciones necesarias para una buena circulación de los peatones? *

Marca solo un óvalo.

$\longrightarrow$ Sí

No

13. ¿Porqué?

\section{Espacios verdes platenses}

14. ¿Se siente identificado con algún espacio verde de su barrio? * Marca solo un óvalo.

$($ Si

No

15. ¿Cuál?

16. ¿Para qué usa los espacios verdes?*

Selecciona todos los que correspondan.

$\square$ Descanso y recreación

Deporte

$\square$ Lugar de encuentro

Lugar de paso

Espera de medios de transporte

Otro:

17. ¿Cuál es el espacio verde que más usa? *

18. ¿Utiliza algún espacio verde de noche?* Marca solo un óvalo.

C Si

No

19. Si la respuesta es si:¿Cuál?

20. Si la respuesta es no: ¿Porqué?

21. ¿Hasta cuantas cuadras caminaría usted para llegar a una plaza o parque?*

22. ¿Cree que se usarian más los espacios verdes si estuvieran en mejores condiciones? * Marca solo un óvalo.

C Sí 
23. ¿Qué elementos cree que le faltan a los espacios verdes? * Selecciona todos los que correspondan.

Veredas y solados (rampas, bicisendas, senderos aeróbicos)

Vegetación

Mobiliario (bancos, cestos, bicicleteros etc)

Dlluminación

$\square$ Juegos

\Señalética (Cartelería, planos de ubicación)

$\square$ Sanitarios

1 Otro:

24. ¿Cree que es necesario que existan más espacios verdes en la ciudad? * Marca solo un óvalo.

(C) Si

No

25. ¿Le gustaría que algún espacio sin uso sea convertido en un espacio verde? *

Un espacio sin uso, espacio vacante o espacio libre puede ser un terreno baldio o con alguna

construcción inutilizada. Este espacio puede estar inutilizado en su totalidad o albergar algún uso esporádico como por ejemplo espacios para la práctica de algún deporte Marca solo un óvalo.

Si

No

26. ¿Reconoce algún espacio exterior sin uso o abandonado en la ciudad? * Marca solo un óvalo.

$$
\text { Si }
$$

No

27. ¿Cuál? 


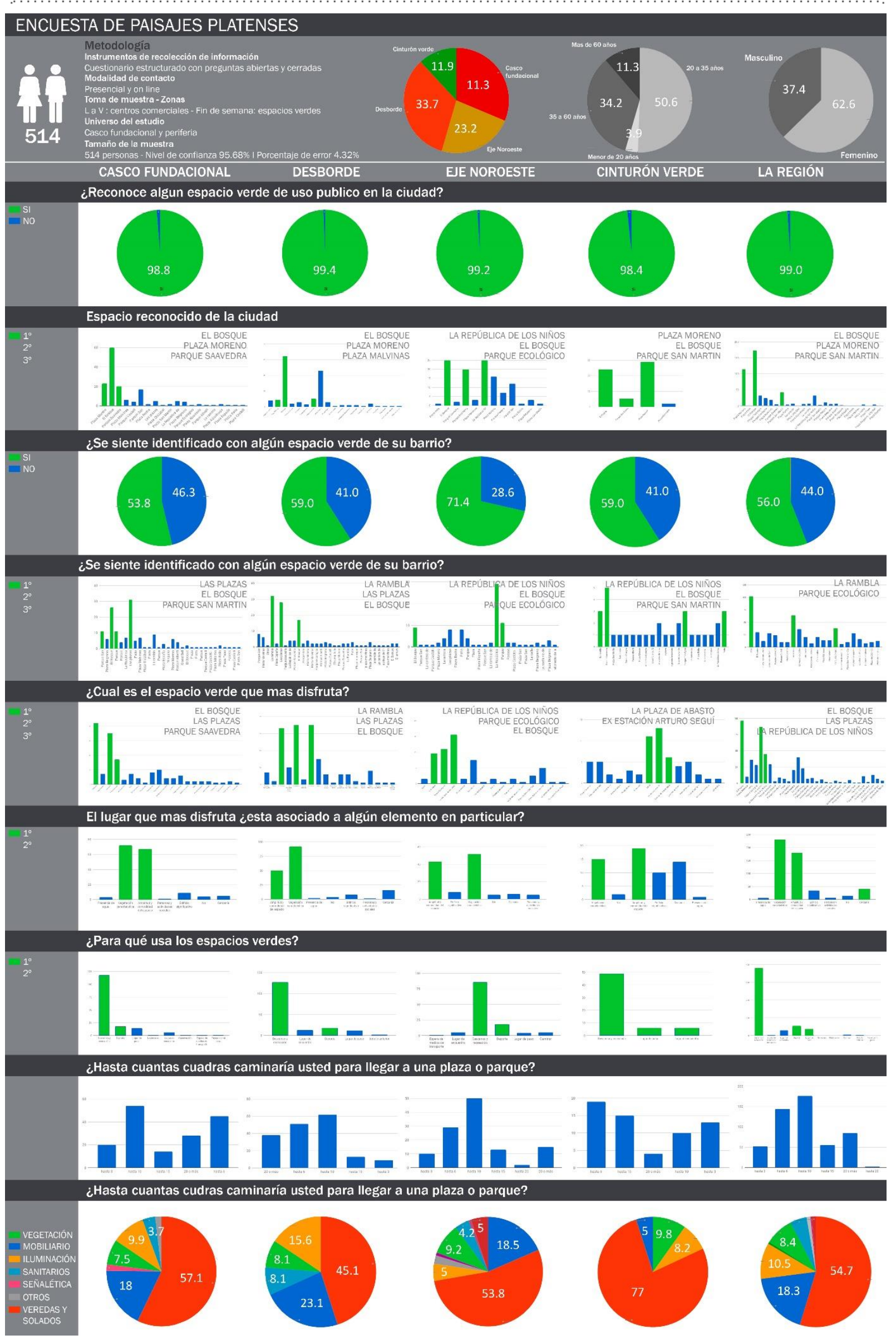




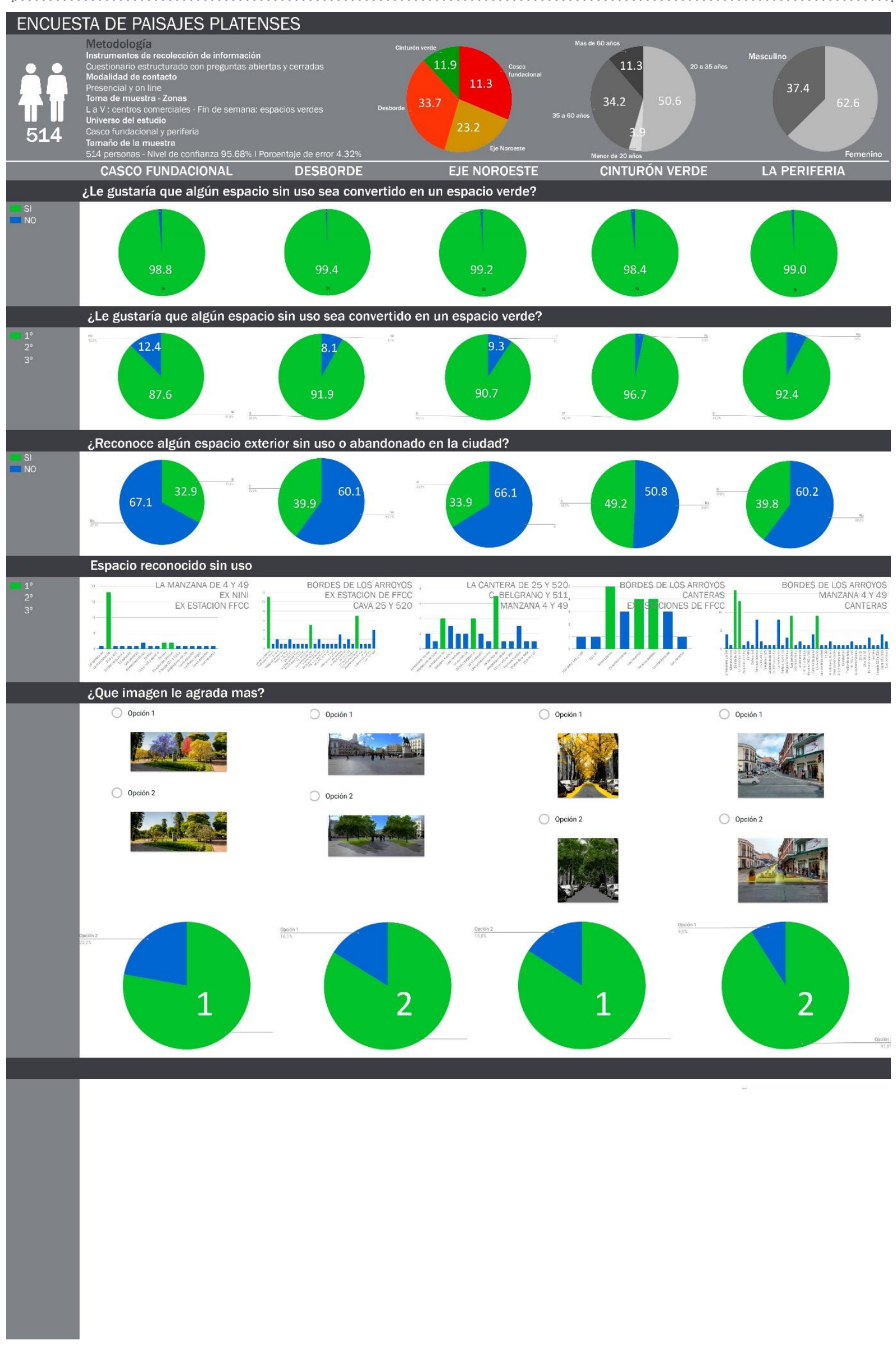




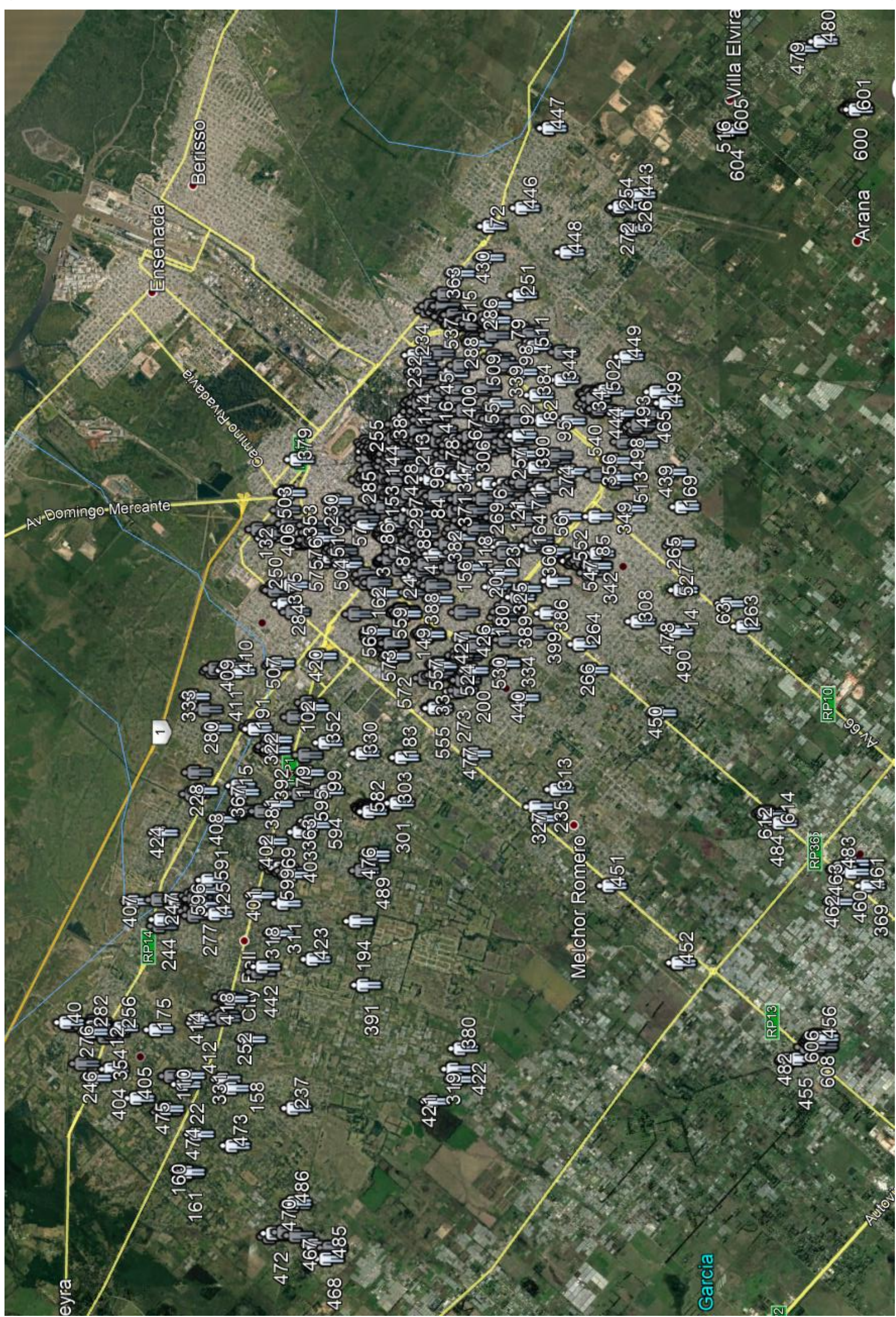

Localización espacial de los habitantes encuestados en base a la esquina más cercana a su residencia. 


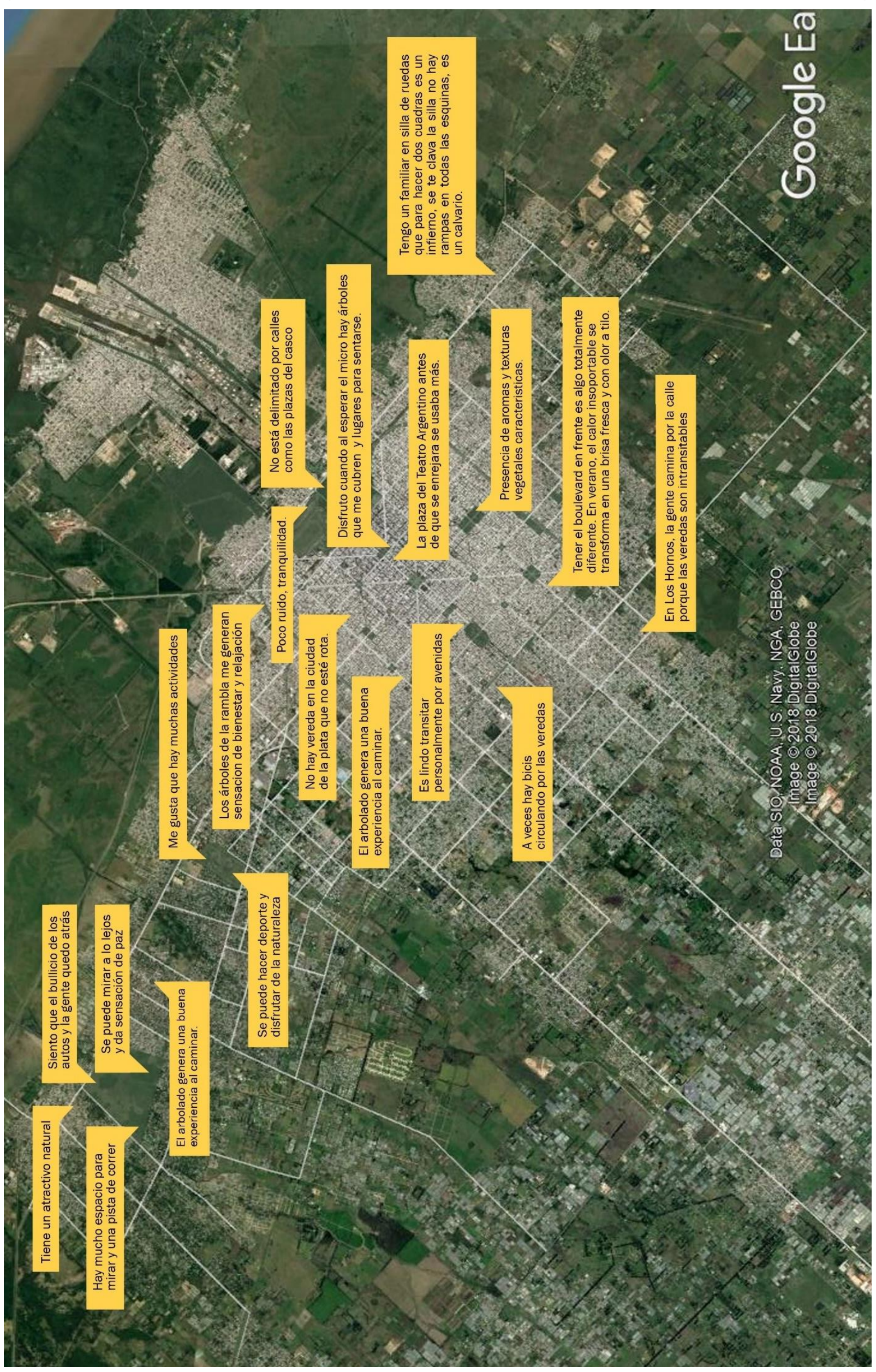




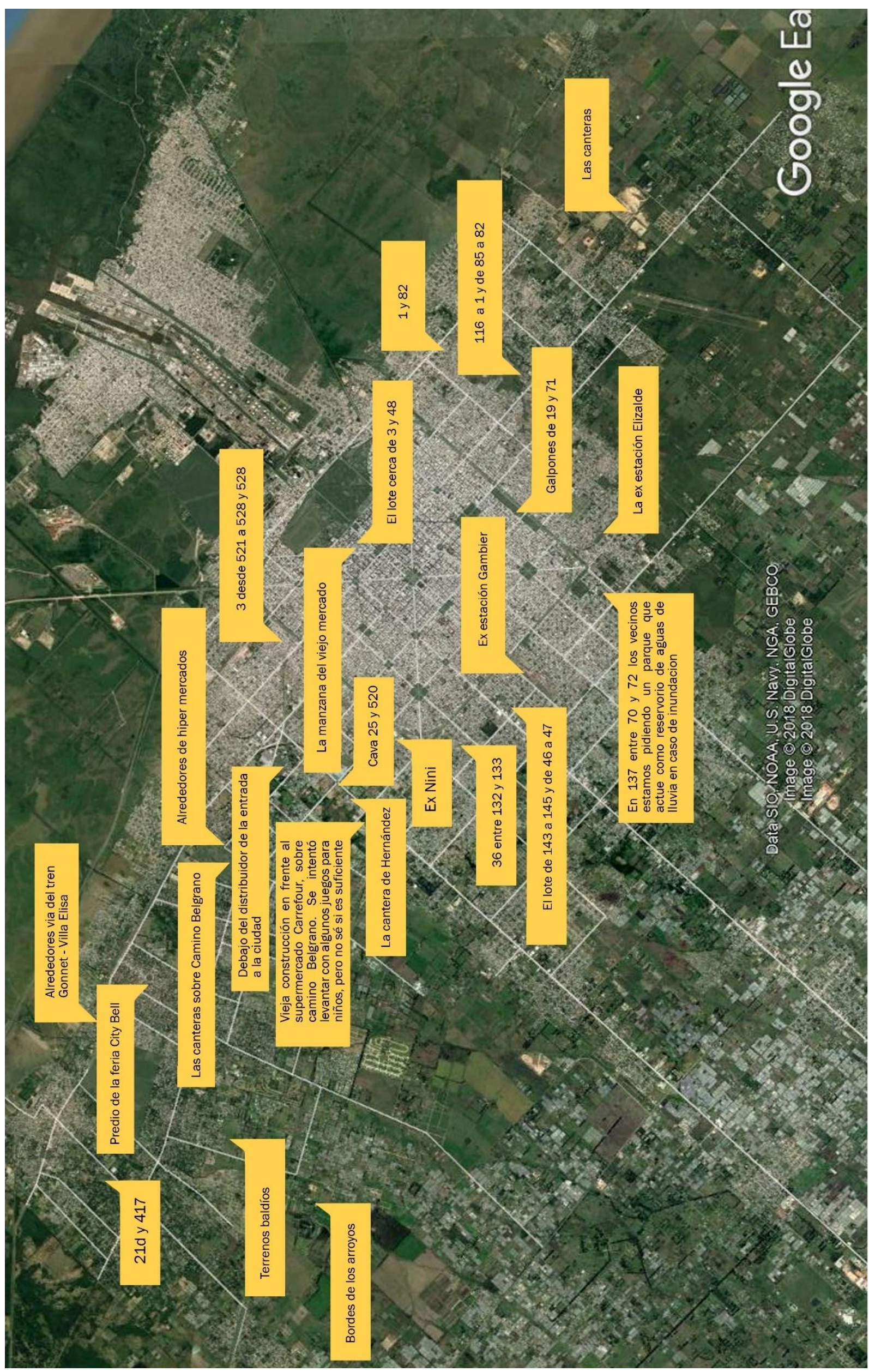




\begin{tabular}{|c|c|c|c|c|c|c|c|c|}
\hline ID & $\begin{array}{c}\text { Indique la } \\
\text { esquina mas } \\
\text { cercana a su } \\
\text { residencla }\end{array}$ & ZONA & Indique su edad & $\begin{array}{c}\text { Indique } \\
\text { sexo }\end{array}$ & 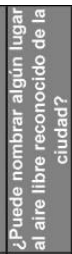 & ¿Cuál? & $\begin{array}{l}\text { ¿Cuál es el espacio al } \\
\text { aire libre de la ciudad } \\
\text { que más disfruta? }\end{array}$ & $\begin{array}{l}\text { El lugar elegido en la respuesta anterior, ¿Está asociado a algún elemento en } \\
\text { particular? }\end{array}$ \\
\hline & & & & & & & & \\
\hline 1 & 3 y 47 & Casco fundacional & 20 a 35 años & Femenino & Si & Plaza Moreno & El Bosque & Presencia de agua \\
\hline 3 & 14 y 35 & Casco fundacional & 20 a 35 años & Femenino & Si & Plaza Moreno & Plaza Belgrano & Vegetación caracteristica, Amplitud y comodidad del espacio \\
\hline 198 & 15 y 502 & Eje Noroeste & menor a 20 años & Masculino & si & Plaza Italia & Otros & Amplitud y comodidad del espacio \\
\hline 10 & 5 y 505 & Eje Noroeste & 36 a 60 años & Masculino & $\mathrm{si}$ & El Bosque & El Bosque & Edificio significativo \\
\hline 6 & esq. 60 y 19 & Eje Noroeste & 20 a 35 años & Femenino & si & Parque Saavedra & Parque Ecológico & Vegetación caracteristica, Amplitud y comodidad del espacio \\
\hline 7 & Diag 79 y 56 & Casco fundacional & 20 a 35 años & Femenino & $\mathrm{Si}$ & El Bosque & El Bosque & Amplitud y comodidad del espacio \\
\hline 19 & 65 & Casco fundacional & 20 a 35 años & Femenino & $\mathrm{Si}$ & Parque Saavedra & Las plazas & Vegetación característica \\
\hline 13 & 44 & Eje Noroeste & 36 a 60 años & Femenino & si & Parque Ecologico & Parque Ecológico & Vegetación caracteristica, Amplitud y comodidad del espacio \\
\hline 8 & 7 y 45 & Casco fundacional & 20 a 35 años & Femenino & $\mathrm{Si}$ & Parque Saavedra & El Bosque & Amplitud y comodidad del espacio, Está cerca de los baños del campo de deportes. \\
\hline 9 & 34 & Casco fundacional & menor a 20 años & Femenino & si & Plaza Malvinas & El Bosque & Vegetación caracteristica, Amplitud y comodidad del espacio, Presencia de agua \\
\hline 131 & 485 y 132 & Eje Noroeste & 36 a 60 años & Femenino & $\mathrm{Si}$ & Parque Ecológico & La República de los Niños & Amplitud y comodidad del espacio \\
\hline 11 & 116 y 68 & Casco fundacional & 20 a 35 años & Femenino & si & El Bosque & Parque Saavedra & actividad feria \\
\hline 410 & 6 y 507 & Eje Noroeste & 36 a 60 años & Femenino & $\mathrm{Si}$ & Plaza Malvinas & El Bosque & Vegetación caracteristica \\
\hline 12 & 5 y 44 villa elis: & SEje Noroeste & 20 a 35 años & Femenino & $\mathrm{si}$ & El Bosque & Plaza San Martín & Vegetación caracteristica, Amplitud y comodidad del espacio \\
\hline 14 & 65 & Casco fundacional & 36 a 60 años & Femenino & si & Parque Castelli & Parque Castelli & Amplitud y comodidad del espacio \\
\hline 15 & 15 bis y 494 & Eje Noroeste & 20 a 35 años & Femenino & $\mathrm{si}$ & El Bosque & La República de los Niños & Amplitud y comodidad del espacio \\
\hline 17 & 11 & Casco fundacional & 20 a 35 años & Femenino & si & Plaza Moreno & Otros & Vegetación característica \\
\hline 18 & 138 & Desborde & 20 a 35 años & Femenino & $\mathrm{Si}$ & Parque San Martin & Parque San Martin & Amplitud y comodidad del espacio \\
\hline 20 & 133 esq 529 & Desborde & 20 a 35 años & Femenino & $\mathrm{Si}$ & Plaza Malvinas & Patio & Amplitud y comodidad del espacio \\
\hline 21 & 122 y 72 & Desborde & 20 a 35 años & Femenino & $\mathrm{Si}$ & El Bosque & El Bosque & Vegetación característica \\
\hline 22 & 21 d y 421 & Eje Noroeste & 36 a 60 años & Femenino & $\mathrm{Si}$ & Parque Ecológico & Parque Ecológico & Vegetación caracteristica \\
\hline 23 & 26 & Casco fundacional & 20 a 35 años & Femenino & si & Parque San Martin & Parque Ecológico & Vegetación caracteristica, Amplitud y comodidad del espacio \\
\hline 24 & 36 Y 19 & Casco fundacional & 20 a 35 años & Femenino & Si & Plaza Moreno & Las plazas & Amplitud y comodidad del espacio \\
\hline 26 & 12 y 64 & Casco fundacional & 20 a 35 años & Femenino & si & El Bosque & Las plazas & Amplitud y comodidad del espacio \\
\hline 28 & $7 y 58$ & Casco fundacional & 20 a 35 años & Femenino & $\mathrm{Si}$ & Plaza Rocha & Las plazas & Vegetación característica \\
\hline 30 & Colpayo & Casco fundacional & 20 a 35 años & Femenino & $\mathrm{Si}$ & Las plazas & Las plazas & Vegetación caracteristica \\
\hline 31 & 8 y 36 & Casco fundacional & 20 a 35 años & Masculino & Si & Plaza Olazábal & Plaza Belgrano & Amplitud y comodidad del espacio \\
\hline 32 & 6 y 56 & Casco fundacional & 20 a 35 años & Masculino & Si & El Bosque & El Bosque & Vegetación caracteristica \\
\hline 33 & 31 y 526 & Desborde & 36 a 60 años & Femenino & si & Plaza Azcuénaga & La República de los Niños & Vegetación caracteristica, Amplitud y comodidad del espacio \\
\hline 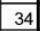 & Calle 81 & Desborde & 20 a 35 años & Femenino & $\mathrm{Si}$ & El Bosque & Las plazas & Vegetación caracteristica \\
\hline 35 & 6 y 64 & Casco fundacional & 20 a 35 años & Femenino & $\mathrm{Si}$ & El Bosque & Plaza España & Amplitud y comodidad del espacio \\
\hline 36 & 32 y 119 & Desborde & menor a 20 años & Femenino & $\mathrm{si}$ & El Bosque & Plaza Belgrano & Vegetación caracteristica, Amplitud y comodidad del espacio \\
\hline 39 & 3 y 65 & Casco fundacional & 20 a 35 años & Masculino & $\mathrm{si}$ & El Bosque & Plaza Moreno & Amplitud y comodidad del espacio \\
\hline 40 & 2 y 43 villa elis: & s:Eje Noroeste & 20 a 35 años & Femenino & si & Parque Ecológico & Parque Ecológico & Vegetación caracteristica, Amplitud y comodidad del espacio \\
\hline 43 & $6 y 64$ & Casco fundacional & 36 a 60 años & Femenino & si & Parque Saavedra & El Bosque & Vegetación caracteristica, Amplitud y comodidad del espacio, Tranquilidad \\
\hline 44 & $2 y 69$ & Casco fundacional & 36 a 60 años & Masculino & $\mathrm{Si}$ & El Bosque & El Bosque & Vegetación caracteristica \\
\hline 45 & 2 y 67 & Casco fundacional & 20 a 35 años & Femenino & $\mathrm{Si}$ & El Bosque & Parque Ecológico & Amplitud y comodidad del espacio \\
\hline 46 & $4 y 66$ & Casco fundacional & 20 a 35 años & Masculino & Si & El Bosque & Parque Saavedra & Vegetación caracteristica, Amplitud y comodidad del espacio \\
\hline 47 & $26 y 58$ & Casco fundacional & 36 a 60 años & Masculino & si & Parque San Martin & Las plazas & Vegetación caracteristica \\
\hline 48 & & Casco fundacional & 20 a 35 años & Femenino & Si & Parque San Martin & El Bosque & Vegetación característica, Edificio significativo, Amplitud y comodidad del espacio, $\mathrm{P}$ \\
\hline 49 & 9 y 531 & Desborde & 36 a 60 años & Masculino & si & La rambla & La rambla & Vegetación caracteristica, Amplitud y comodidad del espacio \\
\hline 50 & 481 y 27 & Eje Noroeste & 20 a 35 años & Femenino & $\mathrm{Si}$ & La República de los Niños & La República de los Niños & Vegetación característica, Edificio significativo \\
\hline 53 & 4 y 49 & Casco fundacional & 20 a 35 años & Femenino & $\mathrm{si}$ & Plaza San Martin & Plaza Malvinas & Edificio significativo, Amplitud y comodidad del espacio \\
\hline 55 & 9 y 68 & Casco fundacional & más de 60 años & Masculino & Si & Parque Saavedra & Otros & Todos están llenos de elementos que no me permiten disfrutar \\
\hline 56 & 62 y 30 & Casco fundacional & 36 a 60 años & Femenino & $\mathrm{Si}$ & Parque San Martin & La República de los Niños & Amplitud y comodidad del espacio \\
\hline 57 & 7 y 36 & Casco fundacional & más de 60 años & Femenino & si & El Bosque & La rambla & Cerca de donde vivo \\
\hline 58 & 16 y 64 & Casco fundacional & más de 60 años & Femenino & Si & Parque Saavedra & Parque Saavedra & Vegetación caracteristica, Amplitud y comodidad del espacio, Presencia de agua \\
\hline 59 & 41 y 131 & Desborde & 20 a 35 años & Masculino & si & Parque Pereyra & Otros & Presencia de agua \\
\hline $61 \mid$ & 8 y 40 & Casco fundacional & 20 a 35 años & Femenino & $\mathrm{Si}$ & EI Bosque & El Bosque & Vegetación caracteristica, Amplitud y comodidad del espacio \\
\hline 62 & $55 \times 7$ & Casco fundacional & más de 60 años & Femenino & $\mathrm{Si}$ & Parque San Martin & El Bosque & Vegetación caracteristica \\
\hline 63 & 68 y 157 & Desborde & 20 a 35 años & Masculino & $\mathrm{si}$ & El Bosque & Plaza Moreno & Vegetación caracteristica \\
\hline 64 & 16 y 66 & Casco fundacional & más de 60 años & Femenino & $\mathrm{Si}$ & Parque Saavedra & Otros & Edificio significativo, Amplitud y comodidad del espacio \\
\hline 65 & 1 y 54 & Casco fundacional & 36 a 60 años & Masculino & si & Parque San Martin & La rambla & Vegetación caracteristica, Amplitud y comodidad del espacio \\
\hline 67 & 11 y 60 & Casco fundacional & 20 a 35 años & Femenino & $\mathrm{Si}$ & EI Bosque & Las plazas & Amplitud y comodidad del espacio \\
\hline 69 & 24 esq 481 & Eje Noroeste & $36 \mathrm{a} 60$ años & Masculino & si & El Bosque & El Bosque & Vegetación caracteristica, Amplitud y comodidad del espacio \\
\hline 70 & 82 bis & Desborde & 36 a 60 años & Femenino & $\mathrm{Si}$ & Parque Saavedra & Las plazas & Vegetación caracteristica \\
\hline 72 & 122 y 89 & Desborde & menor a 20 años & Masculino & $\mathrm{si}$ & Plaza Moreno & Otros & por laburp \\
\hline 73 & 11 y 512 & Eje Noroeste & 36 a 60 años & Masculino & si & Plaza Moreno & Plaza Moreno & Edificio significativo, Amplitud y comodidad del espacio \\
\hline 74 & 16 y 48 & Casco fundacional & 20 a 35 años & Masculino & $\mathrm{si}$ & Parque San Martin & Parque San Martin & Amplitud y comodidad del espacio \\
\hline 75 & 12 y66 & Casco fundacional & 20 a 35 años & Masculino & si & Parque Saavedra & Las plazas & Vegetación caracteristica \\
\hline 76 & 4 y 530 & Desborde & más de 60 años & Femenino & $\mathrm{Si}$ & El Bosque & La rambla & Amplitud y comodidad del espacio \\
\hline 77 . & 13 y 60 & Casco fundacional & 20 a 35 años & Masculino & Si & Parque Saavedra & Las plazas & Vegetación caracteristica, Amplitud y comodidad del espacio, Presencia de agua \\
\hline 78 & 60 y 9 & Casco fundacional & 20 a 35 años & Femenino & $\mathrm{si}$ & Parque Saavedra & Parque Saavedra & Amplitud y comodidad del espacio, Presencia de agua \\
\hline 79 & Calle 1 bis y 78 & 3 Desborde & más de 60 años & Femenino & $\mathrm{Si}$ & La rambla & El Bosque & Vegetación caracteristica, Amplitud y comodidad del espacio \\
\hline 81 & 57 y 22 & Casco fundacional & 20 a 35 años & Masculino & si & La República de los Niños & Parque Saavedra & Amplitud y comodidad del espacio \\
\hline 82 & $20 y 71$ & Casco fundacional & 20 a 35 años & Femenino & si & Plaza Moreno & El Bosque & Amplitud y comodidad del espacio, Presencia de agua \\
\hline 84 & $10 Y 50$ & Casco fundacional & 20 a 35 años & Masculino & No & & Las plazas & Amplitud y comodidad del espacio \\
\hline 85 & 133 y 65 & Desborde & 20 a 35 años & Femenino & $\mathrm{si}$ & El Bosque & El Bosque & Vegetación caracteristica, Amplitud y comodidad del espacio \\
\hline 86 & 11 y 39 & Casco fundacional & 36 a 60 años & Masculino & $\mathrm{Si}$ & Plaza Belgrano & Plaza Belgrano & Cercania \\
\hline 87 & 15 y 38 & Casco fundacional & más de 60 años & Femenino & si & EI Bosque & Las plazas & Cercania \\
\hline 89 & Plaza italia & Casco fundacional & 20 a 35 años & Femenino & Si & Parque Ecologico & Parque Saavedra & Amplitud y comodidad del espacio \\
\hline 90 & 11 y 65 & Casco fundacional & 20 a 35 años & Masculino & $\mathrm{si}$ & Parque Saavedra & Paseos peatonales & Amplitud y comodidad del espacio \\
\hline \begin{tabular}{|c|}
91 \\
\end{tabular} & 8 y 50 & Casco fundacional & 36 a 60 años & Femenino & $\mathrm{Si}$ & Plaza San Martin & Patio & Vegetación caracteristica \\
\hline 92 & 37 y 22 & Casco fundacional & 36 a 60 años & Femenino & $\mathrm{Si}$ & El Bosque & Parque San Martin & Vegetación caracteristica, Amplitud y comodidad del espacio \\
\hline 93 & Mirando hacia & Desborde & 20 a 35 años & Masculino & si & Parque Alberti & Otros & Amplitud y comodidad del espacio \\
\hline 95 & 72 y 21 & Desborde & 36 a 60 años & Femenino & $\mathrm{Si}$ & Parque Castelli & El Bosque & Vegetación caracteristica \\
\hline 96 & 11 y 53 & Casco fundacional & 20 a 35 años & Masculino & Si & Plaza Moreno & Plaza Moreno & Edificio significativo \\
\hline 97 & 7 y 529 & Desborde & 20 a 35 años & Femenino & $\mathrm{si}$ & Plaza Moreno & Las plazas & Vegetación caracteristica, Edificio sign \\
\hline 98 & 78 bis & Desborde & 20 a 35 años & Femenino & $\mathrm{Si}$ & Plaza Moreno & Las plazas & Amplitud y comodidad del espacio, Verde y aire \\
\hline 99 & $501 Y 30$ & Eje Noroeste & 20 a 35 años & Femenino & No & & La República de los Niños & Amplitud y comodidad del espacio \\
\hline 100 & 6 y 43 & Casco fundacional & 20 a 35 años & Masculino & Si & El Bosque & Otros & Amplitud y comodidad del espacio \\
\hline 101 & 655 y 22 & Cinturón verde & 36 a 60 años & Femenino & Si & El Bosque & Parque Saavedra & Biblioteca y árboles \\
\hline 102 & $510 Y 19$ & Eje Noroeste & 20 a 35 años & Femenino & Si & Parque Pereyra & Las plazas & Amplitud y comodidad del espacio \\
\hline 103 & 55 y 19 & Casco fundacional & 20 a 35 años & Femenino & $\mathrm{Si}$ & La República de los Niños & Plaza Malvinas & Amplitud y comodidad del espacio \\
\hline 104 & Calle 44 villa e & Eje Noroeste & 36 a 60 años & Masculino & $\mathrm{si}$ & El Bosque & Parque Ecológico & Vegetación caracteristica, Amplitud y comodidad del espacio \\
\hline 105 & 32 y 131 & Desborde & 36 a 60 años & Femenino & $\mathrm{si}$ & El Bosque & El Bosque & Vegetación caracteristica \\
\hline 106 & $70 Y 131$ & Desborde & 36 a 60 años & Femenino & $\mathrm{Si}$ & El Bosque & Las plazas & Vegetación caracteristica \\
\hline
\end{tabular}




\begin{tabular}{|c|c|}
\hline 108 & Calle 131 y 32 \\
\hline 109 & Esquina diagor \\
\hline 110 & $21 \mathrm{~d}$ \\
\hline 112 & 39 y 22 \\
\hline 113 & 23 \\
\hline 114 & 2 y 62 \\
\hline 116 & 116 \\
\hline 117 & 12 y 44 \\
\hline 118 & 47 \\
\hline 119 & 19 y 48 \\
\hline 120 & 29 \\
\hline 121 & 24 y 59 \\
\hline 122 & 13 y 61 \\
\hline 124 & 635 y 11 \\
\hline 125 & 9 y 47 \\
\hline 126. & 5 y 60 \\
\hline 128 & 74 y 118 \\
\hline 130 & 13 y 32 \\
\hline 132 & 117 y 526 \\
\hline 133 & 20 y 59 \\
\hline 134 & 63 y 24 \\
\hline 135 & 12 \\
\hline 136 & 15 y 68 \\
\hline 137 & 2 y 51 \\
\hline 138 & 45 \\
\hline 140 & 27 y 36 \\
\hline 141 & $7 y 73$ \\
\hline 142 & $26 y 48$ \\
\hline 143 & 67 y 23 \\
\hline 145 & 1 y 46 \\
\hline 146 & 44 esq 9 \\
\hline 147 & 7 y 68 \\
\hline 148 & 26 y 66 \\
\hline 149 & 32 \\
\hline 151 & 2 y 50 \\
\hline 152 & 14 y 42 \\
\hline 154 & 3 y 48 \\
\hline 155 & 3 y 53 \\
\hline 156 & 24 y 42 \\
\hline 157 & diagonal $78 y^{3}$ \\
\hline 158 & 425 esquina 28 \\
\hline 159 & 408 y 31 \\
\hline 160 & 408 y 31 \\
\hline 161 & 408 y 31 \\
\hline 162 & 15 \\
\hline 163 & 47 \\
\hline 164 & 29 y 54 \\
\hline 166 & 14 y 40 \\
\hline 168 & 38 y 11 \\
\hline 169 & 74 y 142 \\
\hline 171 & $73 y 1$ \\
\hline 172 & 501 y 19 \\
\hline 173 & 2 \\
\hline 175 & 50 metros \\
\hline 177 & 7 y 64 \\
\hline 178 & $43 \times 3$ \\
\hline 179 & 25 y 501 \\
\hline 180 & 29 esquina 43 \\
\hline 182 & 59 \\
\hline 183 & 514 bis y 134 \\
\hline 184 & 73 y 120 \\
\hline 186 & 7 y 80 \\
\hline 187 & Con Belgrano \\
\hline 189 & 15 y 526 \\
\hline 190 & 115 y 74 \\
\hline 191 & 15 y 502 \\
\hline 192 & 16 y 66 \\
\hline 194 & 476 y 138 \\
\hline 195 & 4 y 46 \\
\hline 196 & 16 y 40 \\
\hline 197 & 5 y 34 \\
\hline 200 & 530 y 134 \\
\hline 201 & $28 \times 45$ \\
\hline 204 & 4 y 56 \\
\hline 205 & 7 esquina 531 \\
\hline 206 & $46 y^{3}$ \\
\hline 214 & $121 Y 76$ \\
\hline 215 & 3 y 520 \\
\hline 219 & Camino Begrar \\
\hline 220 & 10 y 58 \\
\hline 221 & 5 y 505 \\
\hline 222 & 7 y 32 \\
\hline 224 & 43 \\
\hline 225 & 1 y 47 \\
\hline 226 & 24 y 504 \\
\hline 227 & 61 y 21 \\
\hline 228 & 13 y 486 \\
\hline 229 & 3 y 76 \\
\hline 230 & 37 \\
\hline 231 & 27 y 460 \\
\hline 234 & 65 y 119 \\
\hline 235 & 155 y 521 \\
\hline 236 & 47 y 13 \\
\hline 237 & 436 \\
\hline 238 & 9 y 45 \\
\hline 239 & 3 y 42 \\
\hline 240 & 118 \\
\hline
\end{tabular}




\begin{tabular}{|c|c|}
\hline 244 & 461 cy 14 \\
\hline 245 & 490 \\
\hline 246 & 411 y 13 \\
\hline 247 & 465 y $14 b$ \\
\hline 249 & $2 \times 62$ \\
\hline 250 & 117 \\
\hline 251 & 85 \\
\hline 252 & Gamboa y 28 \\
\hline 253 & 7 y 32 \\
\hline 254 & 4 y 609 \\
\hline 256 & $9 y 421$ villa elis \\
\hline 257 & 19 \\
\hline 258 & Lacrosse y 17 \\
\hline 260 & 59 y 9 \\
\hline 262 & 25 \\
\hline 263 & 66 y 161 \\
\hline 264 & 44 y 144 \\
\hline 265 & 145 y 70 \\
\hline 266 & 44 \\
\hline 267 & 17 y 489 \\
\hline 269 & 18 y 58 \\
\hline 272 & 609 \\
\hline 273 & $\begin{array}{ll}134 \text { y } 527 \\
\end{array}$ \\
\hline 274 & 26 y 67 \\
\hline 275 & 15 a City Bell \\
\hline 276 & 44 v. Elisa \\
\hline 277 & 467 y $15 a$ \\
\hline 278 & $44 \mathrm{v}$. Elisa \\
\hline 279 & 1 y 60 \\
\hline 280 & 498 y 10 \\
\hline 281 & 82 bis \\
\hline 282 & 5 y 43 \\
\hline 283 & 5 y 43 \\
\hline 284 & 4 y 523 \\
\hline 286 & 2 bis y 531 \\
\hline 287 & 44 y 6 villa elis \\
\hline 288 & 2 y 80 \\
\hline 289 & 504 y 134 \\
\hline 290 & 135 y 504 \\
\hline 292 & 38 y 13 \\
\hline 293 & 467 y $14 c$ \\
\hline 299 & 37 y 14 \\
\hline 300 & 125 y 530 \\
\hline 301 & 507 y 137 \\
\hline 303 & 507 y 137 \\
\hline 304 & 51 y 4 villa elis \\
\hline 308 & 57 y 148 \\
\hline 310 & 13 y 32 \\
\hline 311 & 28 y 476 \\
\hline 312 & 51 y 16 \\
\hline 313 & 156 y 526 \\
\hline 314 & 13 y 61 \\
\hline 315 & 5 y 42 Villa Elis \\
\hline 316 & 13 y 63 \\
\hline 317 & 117 y 64 \\
\hline 318 & 28 y 471 \\
\hline 319 & 449 y 160 \\
\hline 320 & 13 b y 464 \\
\hline 321 & 7 y 79 \\
\hline 322 & 503 y 19 \\
\hline 323 & 2 y 59 \\
\hline 324 & 45 y 132 \\
\hline 325 & 10 y 61 \\
\hline 326 & 42 y 131 \\
\hline 327 & 157 y 521 \\
\hline 328 & 10 y 42 \\
\hline 330 & 30 y 510 \\
\hline 331 & 426 y 27 \\
\hline 333 & 4 y 500 \\
\hline 334 & 35 y 14 \\
\hline 335 & 14 y 35 \\
\hline 336 & 12 y 60 \\
\hline 337 & 8 y 520 \\
\hline 338 & 35 y 132 \\
\hline 339 & $10 y 74$ \\
\hline 340 & 45 y 19 \\
\hline 341 & 38 y 19 \\
\hline 342 & 60 y 137 \\
\hline 343 & 122 y 72 \\
\hline 344 & 16 y 78 \\
\hline 345 & 47 y 115 \\
\hline 347 & 14 y 58 \\
\hline 348 & 31 \\
\hline 349 & 69 y 136 \\
\hline 352 & 25 y 508 \\
\hline 353 & 529 y 2 \\
\hline 354 & 8 y 419 villa eli \\
\hline 355 & 419 y 8 \\
\hline 356 & 29 y 73 \\
\hline 357 & 7 y 60 \\
\hline 358 & 1 y 77 \\
\hline 359 & Calle 19 Bis y \\
\hline 360 & 526 y 119 \\
\hline 361 & 55 y 131 \\
\hline 362 & 13 y 43 \\
\hline 363 & 30 y 491 \\
\hline 364 & 122 y 80 \\
\hline
\end{tabular}




\begin{tabular}{|c|c|}
\hline 365 & 4 y 43 \\
\hline 366 & $2 y 47$ \\
\hline 367 & 16 bis y 493 \\
\hline 369 & 45 y 201 \\
\hline 370 & 11 y 58 \\
\hline 371 & 13 y 55 \\
\hline 375 & 6 bis y 520 \\
\hline 377 & 1 y 37 \\
\hline 379 & 122 y 38 \\
\hline 380 & 464 y 160 \\
\hline 381 & 493 bis y Belgr \\
\hline 382 & 45 y 19 \\
\hline 383 & 18 y 41 \\
\hline 385 & 53 y 22 \\
\hline 386 & 134 y 50 \\
\hline 388 & 23 y35 \\
\hline 389 & 44 y 132 \\
\hline 390 & 64 y 21 \\
\hline 391 & 467 y 144 \\
\hline 392 & 502 y 19 \\
\hline 393 & 13 y 531 \\
\hline 394 & 19 y 60 \\
\hline 395 & 38 y 135 \\
\hline 396 & 16 y 47 \\
\hline 397 & 44 y 3 \\
\hline 398 & 46 y 11 \\
\hline 399 & 45 y 137 \\
\hline 400 & $67 y 7$ \\
\hline 401 & 476 y Belgrano \\
\hline 402 & 487 y Belgrano \\
\hline 403 & $27 y 489$ \\
\hline 404 & 51 y 17 villa eli \\
\hline 405 & 24 y 55 villa eli \\
\hline 406 & 529 y 115 \\
\hline 407 & 463 y 11 \\
\hline 408 & 486 y 15 \\
\hline 409 & 6 y507 \\
\hline & \\
\hline 411 & 6 y 507 \\
\hline 412 & 21 y 449 \\
\hline \begin{tabular}{|l|}
413 \\
\end{tabular} & Belgrano y 450 \\
\hline 414 & 449 y 21 a \\
\hline 415 & 450 y Belgrano \\
\hline \begin{tabular}{|l|}
416 \\
\end{tabular} & $63 y^{6}$ \\
\hline \begin{tabular}{|l|}
417 \\
\end{tabular} & 531 y 21 \\
\hline \begin{tabular}{|l|}
418 \\
\end{tabular} & Belgrano y 454 \\
\hline 419 & 489 y 10 \\
\hline 420 & 15 y Belgrano \\
\hline 421 & 160 y 445 \\
\hline \begin{tabular}{|l|}
422 \\
\end{tabular} & 160 y 450 \\
\hline \begin{tabular}{|l|}
423 \\
\end{tabular} & 477 y 133 bis \\
\hline 424 & 477 y 10 \\
\hline 425 & 17 y 467 \\
\hline 426. & 132 y 37 \\
\hline \begin{tabular}{|l|}
427 \\
\end{tabular} & 34 y 31 \\
\hline 429 & 42 y 138 \\
\hline 430 & 85 y 118 bis \\
\hline 431 & 508 y 19 \\
\hline \begin{tabular}{|l|}
432 \\
\end{tabular} & 60 y 24 \\
\hline 433 & 30 y diag 74 \\
\hline 434 & $6 y 45$ \\
\hline 435 & 20 y 43 \\
\hline 436 & 40 y 14 \\
\hline 438 & 501 y 6 \\
\hline 439 & 137 y 14 \\
\hline 440 & 33 y 143 \\
\hline 441 & 485 y 138 \\
\hline \begin{tabular}{|l|}
442 \\
\end{tabular} & 461 y 27 \\
\hline 443 & 614 y 6 bis \\
\hline 444 & 80 y 25 \\
\hline 446 & 97 y 121 \\
\hline \begin{tabular}{|l|}
447 \\
\end{tabular} & 26 y 612 \\
\hline 448 & 2 y 96 \\
\hline 449 & 87 y 21 \\
\hline 450 & 44 y 160 \\
\hline 451 & 451 \\
\hline 452 & 418 y 187 \\
\hline \begin{tabular}{|l|}
453 \\
\end{tabular} & 521 y 210 \\
\hline 454 & 522 y 211 \\
\hline 455 & 210 y 518 \\
\hline 456 & 523 y 211 \\
\hline 457 & 522 y 210 \\
\hline 458 & 522 y 210 \\
\hline 459 & 517 y 209 \\
\hline 460 & 197 y 45 \\
\hline 461 & 196 y 46 \\
\hline \begin{tabular}{|l|}
462 \\
\end{tabular} & 40 y 199 \\
\hline 463 & 44 y 196 bis \\
\hline 464 & 182 y 44 \\
\hline \begin{tabular}{|l|}
4655 \\
\end{tabular} & 28 y 86 \\
\hline 466 & 413 y 146 \\
\hline \begin{tabular}{|l|}
467 \\
\end{tabular} & 153 y 415 \\
\hline 468 & 157 y 14 bis \\
\hline 469 & 416 y 156 \\
\hline 470 & 418 y 143 \\
\hline 471 & 149 y 414 \\
\hline 472 & 145 y 411 \\
\hline
\end{tabular}




\begin{tabular}{|c|c|}
\hline \begin{tabular}{|l|}
473 \\
\end{tabular} & 419 y 132 bis \\
\hline 474 & 416 y 20 \\
\hline 475 & 21 y 415 \\
\hline \begin{tabular}{|l|}
476 \\
\end{tabular} & 488 y 138 \\
\hline 477 & 143 y 521 \\
\hline 478 & 153 y 69 \\
\hline 479 & 657 y 10 \\
\hline 480 & 661 y 12 \\
\hline 481 & 522 y 210 \\
\hline 482 & 517 y 209 \\
\hline 483 & 44 y 196 bis \\
\hline 484 & 182 y 44 \\
\hline 485 & 157 y 14 bis \\
\hline 486 & 418 y 143 \\
\hline 487 & 145 y 411 \\
\hline 488 & 21 y 415 \\
\hline 489 & 488 y 138 \\
\hline 490 & 153 y 59 \\
\hline 493 & 29 y 80 \\
\hline 494 & 29 y 80 \\
\hline 495 & 29 y 80 \\
\hline 496 & 29 y 80 \\
\hline 497. & 76 y 29 \\
\hline 498 & 78 y 131 \\
\hline 499 & 30 y 86 \\
\hline 500 & 133 esq 529 \\
\hline 501 & 31 y 526 \\
\hline 502 & Calle 81 \\
\hline 503 & 32 y 119 \\
\hline 504 & 9 y 531 \\
\hline 505 & 41 y 131 \\
\hline 506 & 82 bis \\
\hline 507 & 11 y 512 \\
\hline 508 & 4 y 530 \\
\hline 509 & Mirando hacia \\
\hline 510 & 7 y 529 \\
\hline 511 & 78 bis \\
\hline 512 & 32 y 131 \\
\hline 513 & 70 Y 131 \\
\hline 514 & Calle 131 y 32 \\
\hline 515 & 116 \\
\hline 516 & 635 y 11 \\
\hline 517 & 74 y 118 \\
\hline 518 & 117 y 526 \\
\hline 519 & $7 y 73$ \\
\hline 520 & 32 \\
\hline 521 & $73 y 1$ \\
\hline 522 & 73 y 120 \\
\hline 523 & 115 y 74 \\
\hline 524 & 530 y 134 \\
\hline 525 & 3 y 520 \\
\hline 526 & 4 y 609 \\
\hline 527 & 145 y 70 \\
\hline 528 & 134 y 527 \\
\hline 533 & 72 y 119 \\
\hline 534 & 73 y 118 \\
\hline 535 & 73 y 120 \\
\hline 536 & 72 y 117 \\
\hline 537 & 72 y 117 \\
\hline 538 & 79 y 21 \\
\hline 539 & 78 y 21 \\
\hline 540 & 77 y 21 \\
\hline 541 & 78 y 23 \\
\hline 542 & 79 y 23 \\
\hline 543 & $20 \times 79$ \\
\hline 544 & 20 y 79 \\
\hline 545 & $20 \times 79$ \\
\hline 546 & 137 y 59 \\
\hline 547 & 138 y 59 \\
\hline 548 & 135 y 58 \\
\hline 549 & 135 y 59 \\
\hline 550 & 136 y 58 \\
\hline 551 & 134 y 57 \\
\hline 552 & 135 y 57 \\
\hline 553 & 525 bis $y 30$ \\
\hline 554 & 523 y 133 \\
\hline 555 & 523 y 133 \\
\hline 556 & 528 y 30 \\
\hline 557 & 528 y 30 \\
\hline 558 & 531 y 21 \\
\hline 559 & 531 y 21 \\
\hline 560 & 531 y 21 \\
\hline 561 & 531 y 21 \\
\hline 562 & 531 y 21 \\
\hline 563 & 524 bis y 20 \\
\hline 564 & 524 bis y 20 \\
\hline 565 & 525 bis y 19 \\
\hline \begin{tabular}{|l|}
566 \\
\end{tabular} & 525 bis y 19 \\
\hline 567 & 21 bis y 525 \\
\hline 568 & 21 bis y 525 \\
\hline 569 & 21 bis y 525 \\
\hline 570 & 22 bis y 526 \\
\hline 571 & 22 bis y 526 \\
\hline 572 & 24 y 524 \\
\hline 573 & 24 y 524 \\
\hline 574 & 529 y 2 bis \\
\hline 575 & 529 y 2 bis \\
\hline
\end{tabular}




\begin{tabular}{|c|c|c|c|c|c|c|c|c|}
\hline 576 & 529 y 2 bis & Desborde & menor a 20 años & Femenino & $\mathrm{Si}$ & El Bosque & La rambla & Cerca de donde vivo \\
\hline 577 & 528 bis $\mathrm{y} 2$ & Desborde & 20 a 35 años & Femenino & $\mathrm{Si}$ & Plaza Moreno & La rambla & Cerca de donde vivo \\
\hline 578 & 528 bis $y 2$ & Desborde & 36 a 60 años & Femenino & $\mathrm{Si}$ & Plaza Moreno & La rambla & Cerca de donde vivo \\
\hline 579 & 115 y 529 & Desborde & 36 a 60 años & Masculino & Si & Plaza Iraola & La rambla & Cerca de donde vivo \\
\hline 580 & 504 y 134 & Eje Noroeste & 20 a 35 años & Femenino & Si & Parque San Martin & La República de los Niños & Amplitud y comodidad del espacio \\
\hline 581 & 504 y 134 & Eje Noroeste & 36 a 60 años & Masculino & $\mathrm{Si}$ & Parque San Martin & La República de los Niños & Amplitud y comodidad del espacio \\
\hline 582 & 504 y 134 & Eje Noroeste & 20 a 35 años & Femenino & $\mathrm{Si}$ & Parque San Martin & La República de los Niños & Amplitud y comodidad del espacio \\
\hline 583 & 504 y 134 & Eje Noroeste & 20 a 35 años & Femenino & Si & Parque San Martin & La República de los Niños & Amplitud y comodidad del espacio \\
\hline 584 & 504 y 134 & Eje Noroeste & menor a 20 años & Masculino & $\mathrm{Si}$ & Parque San Martin & La República de los Niños & Amplitud y comodidad del espacio \\
\hline 585 & 504 y 134 & Eje Noroeste & 20 a 35 años & Femenino & $\mathrm{Si}$ & Parque San Martin & La República de los Niños & Amplitud y comodidad del espacio \\
\hline 586 & 481 y 27 & Eje Noroeste & 20 a 35 años & Femenino & $\mathrm{si}$ & La República de los Niños & La República de los Niños & Vegetación caracteristica, Edificio significativo \\
\hline 587 & 24 esq 481 & Eje Noroeste & 36 a 60 años & Masculino & $\mathrm{Si}$ & El Bosque & EI Bosque & Vegetación caracteristica, Amplitud y comodidad del espacio \\
\hline 588 & 501 y 19 & Eje Noroeste & 20 a 35 años & Masculino & $\mathrm{Si}$ & Parque San Martin & Las plazas & Amplitud y comodidad del espacio \\
\hline 589 & 15 a City Bell & Eje Noroeste & más de 60 años & Femenino & $\mathrm{Si}$ & La República de los Niños & Parque Ecológico & Vegetación caracteristica \\
\hline 590 & 461 cy 14 & Eje Noroeste & 36 a 60 años & Femenino & $\mathrm{Si}$ & Parque Pereyra & Parque Ecológico & Vegetación caracteristica \\
\hline 591 & 15 a City Bell & Eje Noroeste & más de 60 años & Femenino & Si & La República de los Niños & Parque Ecológico & Vegetación caracteristica \\
\hline 592 & 467 y $14 \mathrm{c}$ & Eje Noroeste & 36 a 60 años & Femenino & Si & La República de los Niños & El Bosque & Vegetación caracteristica \\
\hline 593 & 467 y $14 \mathrm{c}$ & Eje Noroeste & 36 a 60 años & Femenino & Si & La República de los Niños & El Bosque & Vegetación caracteristica \\
\hline 594 & 30 y 491 & Eje Noroeste & 20 a 35 años & Masculino & Si & La República de los Niños & La República de los Niños & Amplitud y comodidad del espacio \\
\hline 595 & 30 y 491 & Eje Noroeste & 20 a 35 años & Femenino & Si & La República de los Niños & La República de los Niños & Amplitud y comodidad del espacio \\
\hline 596 & 15 a City Bell & Eje Noroeste & más de 60 años & Femenino & Si & La República de los Niños & Parque Ecológico & Vegetación caracteristica \\
\hline 597 & 501 y 19 & Eje Noroeste & 20 a 35 años & Masculino & Si & Parque San Martin & Las plazas & Amplitud y comodidad del espacio \\
\hline 598 & 24 esg 481 & Eje Noroeste & 36 a 60 años & Masculino & $\mathrm{Si}$ & El Bosque & El Bosque & Vegetación caracteristica, Amplitud y comodidad del espacio \\
\hline 599 & 481 y 27 & Eje Noroeste & 20 a 35 años & Masculino & $\mathrm{Si}$ & La República de los Niños & La República de los Niños & Vegetación característica, Edificio significativo \\
\hline 600 & 655 y 22 & Cinturón verde & 36 a 60 años & Femenino & $\mathrm{Si}$ & El Bosque & Parque Saavedra & Biblioteca y árboles \\
\hline 601 & 655 y 22 & Cinturón verde & 36 a 60 años & Femenino & Si & El Bosque & Parque Saavedra & Biblioteca y árboles \\
\hline 602 & 655 y 22 & Cinturón verde & 36 a 60 años & Femenino & $\mathrm{Si}$ & El Bosque & Parque Saavedra & Biblioteca y árboles \\
\hline \begin{tabular}{|c|}
603 \\
\end{tabular} & 635 y 11 & Cinturón verde & 36 a 60 años & Femenino & $\mathrm{Si}$ & Parque San Martin & Paseos peatonales & Vegetación característica \\
\hline 604 & 635 y 11 & Cinturón verde & 36 a 60 años & Femenino & $\mathrm{Si}$ & Parque San Martin & Paseos peatonales & Vegetación caracteristica \\
\hline 605 & 635 y 11 & Cinturón verde & 36 a 60 años & Femenino & $\mathrm{Si}$ & Parque San Martin & Paseos peatonales & Vegetación caracteristica \\
\hline 606 & 522 y 210 & Cinturón verde & 36 a 60 años & Masculino & Si & El Bosque & La plaza de Abasto & porque esta enfrente \\
\hline \begin{tabular}{|l|}
607 \\
\end{tabular} & 522 y 210 & Cinturón verde & 36 a 60 años & Masculino & $\mathrm{Si}$ & El Bosque & La plaza de Abasto & porque esta enfrente \\
\hline \begin{tabular}{|l|l|}
608 \\
\end{tabular} & 522 y 210 & Cinturón verde & 36 a 60 años & Masculino & $\mathrm{Si}$ & El Bosque & La plaza de Abasto & porque esta enfrente \\
\hline \begin{tabular}{|l|}
609 \\
\end{tabular} & 522 y 210 & Cinturón verde & 36 a 60 años & Masculino & $\mathrm{Si}$ & El Bosque & La plaza de Abasto & porque esta enfrente \\
\hline 610 & 522 y 211 & Cinturón verde & más de 60 años & Femenino & Si & Plaza Moreno & La plaza de Abasto & cercania \\
\hline 611 & 522 y 211 & Cinturón verde & más de 60 años & Femenino & $\mathrm{Si}$ & Plaza Moreno & La plaza de Abasto & cercania \\
\hline 612 & 182 y 44 & Cinturón verde & 36 a 60 años & Masculino & $\mathrm{Si}$ & El Bosque & Plaza Malvinas & Edificio significativo \\
\hline 613 & 182 y 44 & Cinturón verde & 36 a 60 años & Masculino & Si & El Bosque & Plaza Malvinas & Edificio significativo \\
\hline 614 & 184 y 44 & Cinturón verde & 36 a 60 años & Masculino & Si & El Bosque & Plaza Malvinas & Edificio significativo \\
\hline \begin{tabular}{|c|}
617 \\
\end{tabular} & 48 & Casco fundacional & 20 a 35 años & Femenino & $\mathrm{Si}$ & Plaza Malvinas & Plaza Malvinas & Amplitud y comodidad del espacio \\
\hline
\end{tabular}




\begin{tabular}{|c|c|c|c|c|c|}
\hline 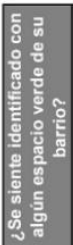 & ¿Cuál? & ¿Para qué usa los espacios verdes? & $\begin{array}{c}\text { ¿Cuál es el espacio verde } \\
\text { que más usa? }\end{array}$ & 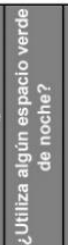 & $\begin{array}{l}\text { Si la respuesta es } \\
\text { si: ¿Cuál? }\end{array}$ \\
\hline \begin{tabular}{|l} 
No \\
\end{tabular} & & Descanso y recreación & Parque San Martin & No & \\
\hline $\mathrm{Si}$ & Plaza Belgrano & Descanso y recreación, Deporte, Lugar de paso, Espera de medios de transporte & Plaza Belgrano & No & \\
\hline No & & Espera de medios de transporte & & No & \\
\hline No & & Lugar de encuentro & El Bosque & No & \\
\hline No & & Descanso y recreación & Parque San Martin & No & \\
\hline Si & El Bosque & Deporte, Lugar de paso, Espera de medios de transporte & El Bosque & No & \\
\hline No & & Descanso y recreación & Parque Saavedra & No & \\
\hline Si & Plaza Castells - Villa Elisa & Deporte, Lugar de paso, Espera de medios de transporte & & No & \\
\hline No & Plaza Italia & Descanso y recreación, Deporte, Lugar de encuentro & El Bosque & $\mathrm{Si}$ & \\
\hline No & & Descanso y recreación, Lugar de encuentro, Lugar de paso & El Bosque & Si & \\
\hline $\mathrm{Si}$ & La cantera de Gorina & Descanso y recreación, Deporte & La cantera de Gorina & No & \\
\hline Si & Parque Saavedra & Descanso y recreación & Parque Saavedra & No & \\
\hline No & & Descanso y recreación, Deporte & & No & \\
\hline No & & Descanso y recreación, Lugar de paso, Espera de medios de transporte & Parque Ecológico & No & \\
\hline Si & Parque Castelli & Descanso y recreación, Deporte & Parque Castelli & No & \\
\hline No & & Descanso y recreación & La República de los Niños & No & \\
\hline No & & & & No & \\
\hline No & & Descanso y recreación, Deporte, Lugar de encuentro & Parque San Martin & No & \\
\hline No & & Lugar de encuentro & Plaza Malvinas & No & \\
\hline No & & Descanso y recreación, Lugar de paso & El Bosque & No & \\
\hline SI & & Descanso y recreación, Deporte, Lugar de encuentro, Espera de medios de transporte & Las plazas & No & \\
\hline $\mathrm{Si}$ & Parque San Martin & Descanso y recreación, Deporte, Lugar de encuentro & Las plazas & Si & \\
\hline Si & Plaza Güemes & Descanso y recreación, Deporte & Patio & No & \\
\hline Si & Parque Saavedra & Descanso y recreación, Deporte & Parque Saavedra & No & \\
\hline Si & & Descanso y recreación, Lugar de encuentro & Plaza Malvinas & $\mathrm{Si}$ & \begin{tabular}{|l} 
Plaza Malvinas \\
\end{tabular} \\
\hline $\mathrm{Si}$ & & Lugar de paso & & No & \\
\hline Si & Plaza Olazábal & Descanso y recreación & Plaza Olazábal & Si & Plaza Belgrano \\
\hline $\mathrm{Si}$ & Plaza San Martin & Descanso y recreación, Lugar de encuentro & Jardin de la memoria Facult & tSi & \begin{tabular}{|l|l} 
Plaza Moreno \\
\end{tabular} \\
\hline No & & Deporte, Lugar de paso & La rambla & No & \\
\hline $\mathrm{Si}$ & & Descanso y recreación, Lugar de encuentro & Plaza malvinas & $\mathrm{si}$ & Plaza Malvinas \\
\hline $\mathrm{Si}$ & Plaza España & Descanso y recreación & Plaza España & No & \\
\hline Si & La rambla & Deporte & La rambla & No & \\
\hline No & & Descanso y recreación, Deporte & Plaza Moreno & No & \\
\hline No & & Descanso y recreación, Lugar de encuentro & Parque Ecológico & No & \\
\hline Si & Plaza España & Descanso y recreación, Lugar de encuentro & Las plazas & No & \\
\hline No & & Lugar de paso & Las plazas & No & \\
\hline Si & Parque Saavedra & Descanso y recreación, Lugar de encuentro & Parque saavedra & No & \\
\hline Si & Plaza España & Descanso y recreación, Lugar de paso, Espera de medios de transporte & Plaza España & $\mathrm{Si}$ & Plaza España \\
\hline $\mathrm{Si}$ & Parque San Martin & Descanso y recreación, Lugar de encuentro & Parque San Martin & No & \\
\hline Si & La República de los Niños & Deporte, Lugar de encuentro & Las plazas & No & \\
\hline Si & La rambla & Descanso y recreación, Deporte & La rambla & No & \\
\hline No & & Descanso y recreación, Lugar de encuentro, Lugar de paso & La República de los Niños & No & \\
\hline Si & Paseos peatonales & Lugar de paso, Espera de medios de transporte & Ninguno & No & \\
\hline No & & No los uso & & No & \\
\hline $\mathrm{Si}$ & Parque Castelli & Descanso y recreación & La República de los Niños & No & \\
\hline No & & Deporte & La rambla & No & \\
\hline Si & Parque Saavedra & Deporte & Parque saavedra & No & \\
\hline No & & Descanso y recreación & Parque Saavedra & No & \\
\hline $\mathrm{Si}$ & Plaza Olazábal & Descanso y recreación & Plaza Belgrano & No & \\
\hline Si & El Bosque & Lugar de encuentro & Las plazas & No & \\
\hline No & & Descanso y recreación, Lugar de paso & Las plazas & $\mathrm{Si}$ & \\
\hline $\mathrm{Si}$ & La rambla & Descanso y recreación, pasear mi mascota & Las plazas & No & \\
\hline Si & Zona de calle 1 , de 54 a 50, plaza Rivada & Observacion. & & No & \\
\hline No & & Descanso y recreación & Las plazas & No & \\
\hline Si & El Bosque & Descanso y recreación, Deporte & La República de los Niños & Si & La República de los Niños \\
\hline Si & Las plazas & Descanso y recreación & Las plazas & No & \\
\hline Si & & laburo & Plaza Rocha & $\mathrm{Si}$ & Plaza Rocha \\
\hline No & & Lugar de paso, Espera de medios de transporte & Plaza Moreno & No & \\
\hline No & & Deporte & Parque San Martin & Si & Pque San Martin \\
\hline Si & Parque Saavedra & Descanso y recreación, Deporte, Lugar de encuentro, Lugar de paso & Parque Saavedra & Si & Parque Saavedra \\
\hline $\mathrm{SI}$ & Plaza Iraola - Tolosa & Descanso y recreación & La rambla & No & \\
\hline Si & Parque Saavedra & Descanso y recreación, Deporte, Lugar de encuentro, Espera de medios de transporte & Parque Saavedra & Si & Plaza Hipólito Yrigoyen \\
\hline No & & Descanso y recreación, Lugar de encuentro, Espera de medios de transporte & El Bosque & $\mathrm{si}$ & El Bosque \\
\hline $\mathrm{Si}$ & La rambla & Descanso y recreación, Deporte & El Bosque & No & \\
\hline No & & Descanso y recreación, Deporte, Lugar de encuentro & Las plazas & No & \\
\hline No & & Descanso y recreación, Lugar de encuentro & El Bosque & No & \\
\hline No & & Descanso y recreación, Lugar de encuentro, Lugar de paso & Las plazas & No & \\
\hline No & & Descanso y recreación, Deporte & El Bosque & No & \\
\hline Si & Plaza Belgrano & Descanso y recreación, Deporte, Espera de medios de transporte & Plaza Belgrano & Si & Plaza Belgrano \\
\hline Si & Plaza Belgrano & Deporte & Parque Alberti & No & \\
\hline $\mathrm{Si}$ & Plaza Italia & Descanso y recreación, Lugar de paso & Parque Saavedra & $\mathrm{Si}$ & Plaza italia \\
\hline Si & Parque Saavedra & Descanso y recreación, Lugar de encuentro & Parque Saavedra & Si & Parque Saavedra \\
\hline No & & Lugar de paso & & No & \\
\hline Si & Parque Alberti & Deporte & Parque San Martin & No & \\
\hline No & & Descanso y recreación, Lugar de encuentro & La rambla & No & \\
\hline $\mathrm{SI}$ & La rambla & Descanso y recreación, Deporte, Lugar de encuentro, Lugar de paso, Espera de medios & sLa rambla & Si & Plaza Malvinas \\
\hline No & & Lugar de paso & Plaza Moreno & No & \\
\hline Si & Plaza Iraola - Tolosa & Descanso y recreación, Deporte, Lugar de encuentro, Lugar de paso & Plaza Malvinas & No & \\
\hline Si & La rambla & Descanso y recreación, Lugar de encuentro & Patio & $\mathrm{Si}$ & Patio \\
\hline No & & Deporte, Lugar de paso & Las plazas & No & \\
\hline No & & Descanso y recreación, Deporte, Lugar de encuentro & La rambla & Si & Plaza Italia \\
\hline Si & & Descanso y recreación, Lugar de encuentro & Parque Saavedra & Si & Plaza Malvinas \\
\hline No & & Descanso y recreación & Plaza Moreno & No & \\
\hline SI & Plaza Malvinas & Descanso y recreación & Las plazas & No & \\
\hline Si & El Bosque & Descanso y recreación, Deporte & Parque Ecológico & Si & Plaza Castells - Villa Elisa \\
\hline $\mathrm{SI}$ & La rambla & Deporte, Espera de medios de transporte & Parque Alberti & $\mathrm{si}$ & Parque Alberti \\
\hline No & & Lugar de encuentro & Las plazas & No & \\
\hline
\end{tabular}




\begin{tabular}{|c|c|}
\hline $\mathrm{Si}$ & Parque Alberti \\
\hline No & \\
\hline Si & Plaza Castells - Villa Elisa \\
\hline Si & \\
\hline No & \\
\hline Si & El Bosque \\
\hline Si & \\
\hline Si & Plaza Paso \\
\hline Si & Parque San Martin \\
\hline Si & Plaza Malvinas \\
\hline Si & Parque San Martin \\
\hline Si & Parque San Martin \\
\hline Si & Parque Saavedra \\
\hline Si & Plaza Moreno \\
\hline No & \\
\hline No & \\
\hline Si & La rambla \\
\hline No & \\
\hline Si & \\
\hline Si & Parque San Martin \\
\hline$S i$ & Parque Castelli \\
\hline No & \\
\hline Si & Parque Saavedra \\
\hline Si & Plaza Rivadavia \\
\hline No & \\
\hline Si & Parque Alberti \\
\hline No & \\
\hline Si & Parque San Martin \\
\hline No & \\
\hline No & \\
\hline Si & Las plazas \\
\hline Si & Plaza España \\
\hline Si & Parque Castelli \\
\hline Si & La rambla \\
\hline No & \\
\hline No & Plaza belgrano \\
\hline Si & Paseos peatonales \\
\hline Si & El Bosque \\
\hline No & \\
\hline Si & Plaza Rivadavia \\
\hline Si & \begin{tabular}{|l|} 
Parque Ecológico \\
\end{tabular} \\
\hline Si & \\
\hline Si & \\
\hline Si & \\
\hline No & \\
\hline$S i$ & Plaza Moreno \\
\hline Si & Parque San Martin \\
\hline Si & Plaza Belgrano \\
\hline Si & Plaza Malvinas \\
\hline No & \\
\hline No & \\
\hline Si & La República de los Niños \\
\hline No & \\
\hline Si & Las plazas \\
\hline No & \\
\hline No & \\
\hline Si & La República de los Niños \\
\hline Si & Parque Alberti \\
\hline Si & \\
\hline No & \\
\hline Si & La rambla \\
\hline No & \\
\hline Si & $\begin{array}{l}\text { Parque Ecológico } \\
\end{array}$ \\
\hline No & \\
\hline $\mathrm{Si}$ & Plaza Matheu \\
\hline Si & La República de los Niños \\
\hline Si & Parque Saavedra \\
\hline No & \\
\hline No & \\
\hline Si & Plaza Belgrano \\
\hline No & \\
\hline No & \\
\hline $\mathrm{Si}$ & Parque San Martin \\
\hline No & \\
\hline No & \\
\hline No & \\
\hline Si & El terraplen costero \\
\hline No & \\
\hline Si & La República de los Niños \\
\hline No & \\
\hline Si & La rambla de calle 13 - Villa Castells \\
\hline No & \\
\hline No & \\
\hline Si & EI Bosque \\
\hline Si & La República de los Niños \\
\hline Si & Las plazas \\
\hline Si & La rambla de calle 13 - Villa Castells \\
\hline Si & \\
\hline No & \\
\hline $\mathrm{Si}$ & \\
\hline No & \\
\hline No & \\
\hline Si & Plaza Moreno \\
\hline No & \\
\hline No & \\
\hline Si & Plaza Alsina \\
\hline No & \\
\hline
\end{tabular}




\begin{tabular}{|c|c|}
\hline Si & Parque Ecológico \\
\hline Si & La República de los Niños \\
\hline Si & Parque Ecológico \\
\hline Si & Las plazas \\
\hline Si & El Bosque \\
\hline Si & El Bosque \\
\hline Si & Las plazas \\
\hline Si & Patio \\
\hline No & \\
\hline No & \\
\hline Si & Parque Ecológico \\
\hline No & \\
\hline Si & La República de los Niños \\
\hline No & \\
\hline Si & \\
\hline No & \\
\hline No & \\
\hline No & \\
\hline No & \\
\hline Si & La República de los Niños \\
\hline No & \\
\hline No & \\
\hline Si & Parque Alberti \\
\hline Si & Parque Castelli \\
\hline Si & Parque Ecológico \\
\hline Si & Parque Ecológico \\
\hline Si & Plaza San Martin \\
\hline Si & Parque Ecológico \\
\hline No & \\
\hline Si & La rambla de calle 13 - Villa Castells \\
\hline No & \\
\hline No & \\
\hline No & \\
\hline No & \\
\hline Si & La Rambla \\
\hline SI & Plaza Castells - Villa Elisa \\
\hline Si & La Rambla \\
\hline Si & La cantera de Gorina \\
\hline Si & La cantera de Gorina \\
\hline No & \\
\hline Si & Plaza San Martin \\
\hline No & \\
\hline No & \\
\hline Si & Parque del Arroyo Don carlos \\
\hline Si & La cantera de Gorina \\
\hline Si & la plaza de villa elisa \\
\hline No & \\
\hline No & \\
\hline No & \\
\hline Si & Plaza Malvinas \\
\hline No & \\
\hline Si & Parque Saavedra \\
\hline Si & Parque Ecológico \\
\hline Si & Parque Saavedra \\
\hline No & \\
\hline No & \\
\hline Si & \\
\hline Si & Plaza San Martin - City Bell \\
\hline No & \\
\hline Si & \\
\hline No & \\
\hline No & \\
\hline Si & Plaza Máximo Paz \\
\hline Si & Las plazas \\
\hline No & \\
\hline No & \\
\hline Si & La cantera de Gorina \\
\hline Si & Parque Ecologico \\
\hline No & \\
\hline No & \\
\hline No & \\
\hline No & \\
\hline No & \\
\hline No & \\
\hline No & \\
\hline Si & Plaza Azcuenaga \\
\hline Si & Las plazas \\
\hline No & \\
\hline Si & Paseos peatonales \\
\hline No & \\
\hline Si & El bosque \\
\hline No & \\
\hline No & \\
\hline Si & La rambla \\
\hline Si & La República de los Niños \\
\hline No & \\
\hline Si & Plazoleta caidos malvinas \\
\hline Si & La plaza centenario y el arroyo \\
\hline Si & El Bosque \\
\hline No & \\
\hline Si & La rambla \\
\hline Si & Paseos peatonales \\
\hline No & \\
\hline No & \\
\hline Si & Plaza Paso \\
\hline Si & La República de los Niños \\
\hline No & \\
\hline
\end{tabular}




\begin{tabular}{|c|c|}
\hline No & \\
\hline No & \\
\hline Si & La República de los Niños \\
\hline No & \\
\hline No & \\
\hline No & \\
\hline No & \\
\hline No & \\
\hline Si & El Bosque \\
\hline No & \\
\hline Si & La República de los Niños \\
\hline SI & Plaza Azcuenaga \\
\hline No & \\
\hline $\mathrm{Si}$ & Plaza Malvinas \\
\hline Si & Plaza Malvinas \\
\hline Si & Parque Alberti \\
\hline No & \\
\hline No & \\
\hline No & \\
\hline SI & La República de los Niños \\
\hline No & \\
\hline Si & El Bosque \\
\hline No & \\
\hline $\mathrm{Si}$ & Las plazas \\
\hline No & \\
\hline No & \\
\hline No & \\
\hline Si & Plaza España \\
\hline No & \\
\hline No & \\
\hline No & \\
\hline Si & Plaza Castells - Villa Elisa \\
\hline Si & Plaza Castells - Villa Elisa \\
\hline No & \\
\hline Si & La costa \\
\hline No & \\
\hline No & \\
\hline & \\
\hline No & \\
\hline SI & Parque Ecológico \\
\hline No & \\
\hline Si & Parque Ecológico \\
\hline No & \\
\hline No & \\
\hline SI & La rambla \\
\hline Si & \begin{tabular}{|l|} 
Parque Ecológico \\
\end{tabular} \\
\hline No & \\
\hline No & \\
\hline SI & Club la banderita \\
\hline SI & Club la banderita \\
\hline Si & Plaza Belgrano - City Bell \\
\hline Si & \begin{tabular}{|l|} 
Parque Ecológico \\
\end{tabular} \\
\hline $\mathrm{Si}$ & Parque Ecológico \\
\hline Si & Parque Alberti \\
\hline Si & Parque Alberti \\
\hline No & \\
\hline No & \\
\hline No & \\
\hline Si & Parque San Martin \\
\hline $\mathrm{Si}$ & La rambla \\
\hline No & \\
\hline Si & \\
\hline No & \\
\hline No & \\
\hline No & \\
\hline No & \\
\hline Si & La cantera de gorina \\
\hline No & \\
\hline No & \\
\hline No & \\
\hline No & \\
\hline No & \\
\hline No & \\
\hline SI & el terreno baldio \\
\hline Si & con la plaza de 43 y 160 \\
\hline Si & plaza de 521 y 172 \\
\hline Si & el borde del arroyo \\
\hline SI & la plaza de abasto \\
\hline Si & la plaza de abasto \\
\hline Si & la ex estacion \\
\hline $\mathrm{Si}$ & la plaza de abasto \\
\hline Si & la plaza de abasto \\
\hline Si & la plaza de abasto \\
\hline Si & la plaza de abasto \\
\hline Si & la plaza de olmos \\
\hline Si & la plaza de olmos \\
\hline No & \\
\hline Si & la plaza de olmos \\
\hline No & \\
\hline No & \\
\hline Si & con el prefio de la ex estacion de trenes \\
\hline Si & con el predio de la ex estación de trenes \\
\hline Si & la plaza \\
\hline No & \\
\hline Si & el predio de la ex estacion de trenes \\
\hline Si & el predio de la ex estacion de ferrocarril \\
\hline Si & la ex estacion del ferrocarril \\
\hline
\end{tabular}




\begin{tabular}{|c|c|}
\hline No & \\
\hline No & \\
\hline No & \\
\hline Si & La cantera de Gorina \\
\hline No & \\
\hline Si & Plaza de 61 y 154 \\
\hline No & \\
\hline No & \\
\hline Si & la plaza de abasto \\
\hline Si & la plaza de abasto \\
\hline Si & la plaza de olmos \\
\hline No & \\
\hline $\mathrm{Si}$ & la plaza \\
\hline Si & el predio de la ex estacion de trenes \\
\hline Si & la ex estacion del ferrocarril \\
\hline No & \\
\hline Si & La cantera de Gorina \\
\hline Si & Plaza de 61 y 154 \\
\hline No & \\
\hline No & \\
\hline No & \\
\hline No & \\
\hline No & \\
\hline No & \\
\hline No & \\
\hline No & \\
\hline No & \\
\hline Si & \\
\hline Si & La rambla \\
\hline Si & La rambla \\
\hline No & \\
\hline Si & Las plazas \\
\hline No & \\
\hline Si & Plaza Iraola - Tolosa \\
\hline No & \\
\hline Si & Plaza Iraola - Tolosa \\
\hline Si & La rambla \\
\hline Si & La rambla \\
\hline No & \\
\hline Si & Parque Alberti \\
\hline $\mathrm{Si}$ & \\
\hline Si & Plaza Moreno \\
\hline Si & La rambla \\
\hline Si & \\
\hline No & \\
\hline Si & La rambla \\
\hline No & \\
\hline Si & La rambla \\
\hline Si & Plaza Matheu \\
\hline No & \\
\hline No & \\
\hline No & \\
\hline No & \\
\hline Si & Parque Alberti \\
\hline Si & La rambla \\
\hline Si & La rambla \\
\hline Sí & La rambla \\
\hline Si & La rambla \\
\hline Si & La rambla \\
\hline Si & \\
\hline Si & \\
\hline Si & \\
\hline Si & \\
\hline Si & \\
\hline Si & El arroyo Maldonado \\
\hline Si & El arroyo Maldonado \\
\hline No & \\
\hline No & \\
\hline No & \\
\hline No & \\
\hline \begin{tabular}{|l} 
No \\
\end{tabular} & \\
\hline No & \\
\hline \begin{tabular}{|l|} 
No \\
\end{tabular} & \\
\hline No & \\
\hline No & \\
\hline No & \\
\hline No & \\
\hline No & \\
\hline No & \\
\hline Si & La rambla \\
\hline Si & La rambla \\
\hline Si & La rambla \\
\hline No & \\
\hline No & \\
\hline Si & Plaza de 525 y 20 \\
\hline Si & Plaza de 525 y 20 \\
\hline Si & Plaza de 525 y 20 \\
\hline$S i$ & Plaza de 525 y 20 \\
\hline Si & Plaza de 525 y 22 \\
\hline Si & Plaza de 525 y 22 \\
\hline Si & Plaza de 525 y 23 \\
\hline Si & Plaza de 525 y 24 \\
\hline Si & Plaza de 525 y 25 \\
\hline Si & Plaza de 525 y 26 \\
\hline Si & Plaza de 525 y 27 \\
\hline No & \\
\hline No & \\
\hline
\end{tabular}




\begin{tabular}{|c|c|c|c|c|c|}
\hline No & & Descanso y recreación, Lugar de encuentro, Lugar de paso & La rambla & No & \\
\hline No & & Descanso y recreación, Lugar de encuentro, Lugar de paso & La rambla & No & \\
\hline No & & Descanso y recreación, Lugar de encuentro, Lugar de paso & La rambla & No & \\
\hline Si & La cantera de Gorina & Descanso y recreación & La República de los Niños & No & \\
\hline Si & La cantera de Gorina & Descanso y recreación & La Repüblica de los Niños & No & \\
\hline Si & La cantera de Gorina & Descanso y recreación & La República de los Niños & No & \\
\hline Si & La cantera de Gorina & Descanso y recreación & La República de los Niños & No & \\
\hline Si & La cantera de Gorina & Descanso y recreación & La República de los Niños & No & \\
\hline Si & La República de los Niños & Descanso y recreación & Plaza Belgrano & Si & Plaza Belgrano \\
\hline Si & Parque Ecológico & Caminar & Parque Ecológico & No & \\
\hline Si & Parque Ecológico & Deporte & La República de los Niños & Si & República de los niños \\
\hline Si & Parque Ecológico & Caminar & Parque Ecológico & No & \\
\hline Si & Plaza San Martín & Descanso y recreación, Lugar de encuentro & La República de los Niños & No & \\
\hline Si & Plaza San Martin & Descanso y recreación, Lugar de encuentro & La República de los Niños & No & \\
\hline Si & La República de los Niños & Descanso y recreación, Lugar de encuentro & La República de los Niños & No & \\
\hline Si & & Descanso y recreación, Lugar de encuentro & Parque Saavedra & Si & Plaza Malvinas \\
\hline Si & & Descanso y recreación, Lugar de encuentro & Parque Saavedra & Si & Plaza Malvinas \\
\hline Si & & Descanso y recreación, Lugar de encuentro & Parque Saavedra & Si & Plaza Malvinas \\
\hline Si & Plaza Moreno & Lugar de paso & Patio & No & \\
\hline Si & Plaza Moreno & Lugar de paso & Patio & No & \\
\hline Si & Plaza Moreno & Lugar de paso & Patio & No & \\
\hline Si & la plaza de abasto & Descanso y recreación, Deporte, Lugar de encuentro & & $\mathrm{Si}$ & la plaza de abasto \\
\hline Si & la plaza de abasto & Descanso y recreación, Deporte, Lugar de encuentro & & Si & la plaza de abasto \\
\hline Si & la plaza de abasto & Descanso y recreación, Deporte, Lugar de encuentro & & Si & la plaza de abasto \\
\hline Si & la plaza de abasto & Descanso y recreación, Deporte, Lugar de encuentro & & Si & la plaza de abasto \\
\hline Si & la plaza de abasto & Lugar de encuentro & & No & \\
\hline Si & la plaza de abasto & Lugar de encuentro & & No & \\
\hline No & & Descanso y recreación & & No & \\
\hline No & & Descanso y recreación & & No & \\
\hline
\end{tabular}




\begin{tabular}{|c|c|c|}
\hline Sil la respuesta es no: ¿Porqué? & 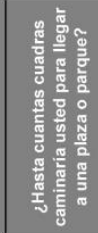 & 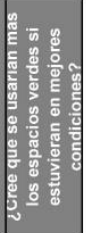 \\
\hline & hasta 3 & si \\
\hline & hasta 3 & Si \\
\hline & hasta 3 & No \\
\hline Solo a veces. Seguridad quizas & hasta 6 & Si \\
\hline \multirow[t]{2}{*}{ inseguridad y falta de atractivos } & hasta 10 & si \\
\hline & hasta 10 & si \\
\hline Xla seguridad & hasta 15 & Si \\
\hline$X$ seguridad & hasta 10 & Si \\
\hline \multirow[t]{2}{*}{ La respuesta es la plaza de 1 y 50 . Frente al ministerio de seguridad } & 20 o más & No \\
\hline & hasta 10 & Si \\
\hline inseguridad & hasta 15 & Si \\
\hline Porque no tienen el equipamiento necesario & hasta 6 & Si \\
\hline Inseguridad & hasta 20 & Si \\
\hline Porque es inseguro & 20 o más & No \\
\hline Por seguridad y tiempos de mi vida diaria & hasta 10 & Si \\
\hline Duermo de noche y es peligroso & hasta 3 & si \\
\hline No me gustan los espacios verdes & hasta 10 & Si \\
\hline \begin{tabular}{|l|} 
Por la inseguridad \\
\end{tabular} & 20 o más & Si \\
\hline Poca seguridad & hasta 6 & Si \\
\hline porque es inseguro y estan mal iluminados & hasta 10 & Si \\
\hline \multirow[t]{2}{*}{ Por inseguridad } & hasta 10 & Si \\
\hline & 20 o más & Si \\
\hline Porque salgo cansada del trabajo & 20 o más & Si \\
\hline \multirow[t]{2}{*}{ Por seguridad } & hasta 15 & Si \\
\hline & hasta 3 & Si \\
\hline Peligroso & hasta 6 & si \\
\hline & 20 o más & si \\
\hline & hasta 3 & Si \\
\hline & hasta 6 & Si \\
\hline & hasta 15 & Si \\
\hline Está muy inseguro, hace unos años atrás si salia a correr todas las noch & 20 o más & Si \\
\hline No está muy ilusionado & hasta 6 & Si \\
\hline Seguridad & hasta 10 & Si \\
\hline No lo creo seguro & 20 o más & Si \\
\hline Por la seguridad & hasta 6 & Si \\
\hline Inseguridad & hasta 6 & Si \\
\hline Por seguridad & hasta 10 & Si \\
\hline & hasta 6 & Si \\
\hline No esta en condiciones ni es seguro & hasta 10 & si \\
\hline No están lo suficientemente iluminados ni poseen seguridad & 20 o más & Si \\
\hline inseguridad & hasta 6 & Si \\
\hline & hasta 15 & Si \\
\hline Inseguridad & hasta 3 & Si \\
\hline Por ser completamente inseguros & hasta 10 & Si \\
\hline & hasta 10 & Si \\
\hline Inseguridad & hasta 3 & Si \\
\hline Por seguridad las que hagan falta & hasta 6 & Si \\
\hline Por trabajo & hasta 6 & Si \\
\hline Porque es peligroso & hasta 10 & Si \\
\hline No son seguros & hasta 3 & Si \\
\hline & hasta 15 & Si \\
\hline Por inseguridad & hasta 10 & Si \\
\hline Lamentablemente la noche está asociada a la inseguridad. & hasta 10 & Si \\
\hline Porque estan poco iluminados,por lo general & hasta 10 & Si \\
\hline & hasta 10 & Si \\
\hline Falta de iluminación y seguridad & hasta 10 & Si \\
\hline & 20 o más & Si \\
\hline Inseguridad & hasta 6 & Si \\
\hline & hasta 10 & No \\
\hline & hasta 10 & Si \\
\hline es inseguro & hasta 3 & No \\
\hline & hasta 6 & Si \\
\hline & hasta 10 & si \\
\hline No salgo de noche & hasta 10 & Si \\
\hline Por la inseguridad & 20 o más & si \\
\hline Por la inseguridad & hasta 6 & Si \\
\hline & hasta 6 & Si \\
\hline Inseguridad & hasta 6 & Si \\
\hline & hasta 15 & Si \\
\hline Por la inseguridad & 20 o más & Si \\
\hline & hasta 10 & Si \\
\hline & hasta 10 & Si \\
\hline Mucha, gente rara en plaza San Martin & 20 o más & Si \\
\hline Por inseguridad & hasta 6 & Si \\
\hline Por la inseguridad & hasta 6 & Si \\
\hline & 20 o más & Si \\
\hline \begin{tabular}{|l|} 
Inseguridad \\
\end{tabular} & hasta 6 & si \\
\hline Inseguridad & hasta 10 & Si \\
\hline & 20 o más & Si \\
\hline & hasta 6 & Si \\
\hline & hasta 3 & Si \\
\hline & hasta 6 & Si \\
\hline \begin{tabular}{|l|} 
Son peligrosos \\
\end{tabular} & hasta 15 & Si \\
\hline Inseguridad & hasta 6 & Si \\
\hline & hasta 10 & si \\
\hline & hasta 6 & $\mathrm{si}$ \\
\hline
\end{tabular}




\begin{tabular}{|c|c|}
\hline No salgo de noche & hasta 10 \\
\hline & hasta 6 \\
\hline Por inseguridad & hasta 10 \\
\hline Por más iluminada que este la plaza, elMiedo a la inseguridad siempre esta & 20 o más \\
\hline & hasta 15 \\
\hline Porque no encuentro actividades para desarrollar ahi & hasta 10 \\
\hline Por inseguridad & hasta 10 \\
\hline Es muy inseguro, no hay control, no hay iluminación & hasta 6 \\
\hline inseguridad & 20 o más \\
\hline inseguridad & hasta 3 \\
\hline Por miedo, inseguridad & 20 o más \\
\hline moreno & hasta 15 \\
\hline Por la inseguridad & hasta 3 \\
\hline Vivo en las afueras & hasta 15 \\
\hline Por hábitos diurnos & hasta 10 \\
\hline Porque es inseguro & hasta 15 \\
\hline & hasta 6 \\
\hline Inseguridad & hasta 10 \\
\hline Falta de seguridad e iluminación & 20 o más \\
\hline so marchas & hasta 15 \\
\hline Plaza & hasta 10 \\
\hline Inseguridad & hasta 10 \\
\hline No los siento seguros & hasta 6 \\
\hline & 20 o más \\
\hline No salgo a la calle de noche por los peligros que representa para las mujer & hasta 15 \\
\hline No suelo juntarme en parques o plazas de noche & 20 o más \\
\hline El Bosque & hasta 10 \\
\hline De noche me da miedo & hasta 3 \\
\hline & hasta 10 \\
\hline Seguridad & hasta 10 \\
\hline No son seguros & hasta 10 \\
\hline No me inspiran seguridad & hasta 6 \\
\hline Inseguridad & hasta 6 \\
\hline Peligroso & hasta 10 \\
\hline No me llama la atencion & hasta 3 \\
\hline Me siento insegura & hasta 10 \\
\hline & hasta 6 \\
\hline Por inseguridad. generalmente son lugares oscuros & hasta 6 \\
\hline No acostumbro & hasta 15 \\
\hline & hasta 6 \\
\hline $10 \mathrm{Paz}$ & 20 o más \\
\hline & hasta 6 \\
\hline & hasta 6 \\
\hline & hasta 6 \\
\hline NO LO FRECUENTO DE NOCHE & 20 o más \\
\hline inseguridad & hasta 6 \\
\hline & hasta 6 \\
\hline nas. & 20 o más \\
\hline & hasta 6 \\
\hline Por inseguridad & hasta 10 \\
\hline Seguridad & 20 o más \\
\hline & hasta 6 \\
\hline & hasta 10 \\
\hline Porque no tengo un espacio verde público cerca de mi domicilio & hasta 15 \\
\hline & 20 o más \\
\hline & hasta 15 \\
\hline & hasta 10 \\
\hline seguridad & hasta 10 \\
\hline Son peligrosos durante la noche, me genera desconfianza & hasta 10 \\
\hline inseguridad & hasta 10 \\
\hline & hasta 3 \\
\hline Inseguridad & hasta 15 \\
\hline Porque la época del año & hasta 6 \\
\hline Por seguridad & hasta 10 \\
\hline & 20 o más \\
\hline Inseguridad & hasta 10 \\
\hline Inseguridad, falta de luminarias, etc & hasta 6 \\
\hline Frio. Inseguridad. Poca iluminación & hasta 10 \\
\hline Me da miedo. & hasta 10 \\
\hline & hasta 3 \\
\hline Por la inseguridad & hasta 15 \\
\hline No suelo salir mucho de noche y si lo hago, es a algún lugar cerrado como & hasta 10 \\
\hline Te roban y violentan & hasta 10 \\
\hline Como por lo general ando sola, no suelo ir de noche a estos lugares donde & hasta 15 \\
\hline Inseguridad & 20 o más \\
\hline Peligro...falta de control & hasta 10 \\
\hline Por la inseguridad & hasta 10 \\
\hline Inseguridad & hasta 3 \\
\hline Por la inseguridad & hasta 3 \\
\hline inseguridad & hasta 6 \\
\hline tengo escasa actividad nocturna & hasta 6 \\
\hline Inseguridad & 20 o más \\
\hline Inseguridad & hasta 6 \\
\hline Inseguridad & hasta 10 \\
\hline No salgo de noche & hasta 10 \\
\hline Seguridad & hasta 10 \\
\hline Tiempo & 20 o más \\
\hline & hasta 10 \\
\hline No salgo & 20 o más \\
\hline & hasta 3 \\
\hline Porque ya estoy en mi casa & hasta 6 \\
\hline Creo que no estamos en un momento sociocultural apropiado como para p & 20 o más \\
\hline Por miedo, inseguridad & hasta 6 \\
\hline Por la inseguridad & 20 o más \\
\hline Inseguridad & 20 o más \\
\hline Primero, porque uno no disfruta la vista ni nada a esa hora, y & 20 o más \\
\hline Por la inseguridad & hasta 10 \\
\hline
\end{tabular}




\begin{tabular}{|c|c|}
\hline Deporte & hasta 10 \\
\hline & 20 o más \\
\hline Seguridad & 20 o más \\
\hline No me gusta & hasta 3 \\
\hline Inseguridad & hasta 6 \\
\hline Por la inseguridad & hasta 10 \\
\hline Inseguridad & hasta 3 \\
\hline & hasta 6 \\
\hline & hasta 6 \\
\hline Por la inseguridad & 20 o más \\
\hline Seguridad & hasta 10 \\
\hline & hasta 6 \\
\hline & hasta 10 \\
\hline & hasta 10 \\
\hline & hasta 10 \\
\hline & hasta 6 \\
\hline Peligroso & hasta 3 \\
\hline Porque no hay seguridad & hasta 10 \\
\hline & 20 o más \\
\hline & hasta 10 \\
\hline por inseguridad & hasta 10 \\
\hline Porque no suelo salir a la noche & 20 o más \\
\hline & hasta 6 \\
\hline & hasta 6 \\
\hline Por seguridad & hasta 6 \\
\hline Seguridad 15 & hasta 15 \\
\hline seguridad & 20 o más \\
\hline Seguridad15 & hasta 15 \\
\hline & hasta 3 \\
\hline & hasta 6 \\
\hline Inseguridad & hasta 6 \\
\hline Seguridad & hasta 6 \\
\hline No me da seguridad & hasta 6 \\
\hline Por la inseguridad & 20 o más \\
\hline Por que me gusta mas de dia & hasta 3 \\
\hline Inseguridad & hasta 10 \\
\hline No es seguro & hasta 15 \\
\hline por seguridad & hasta 10 \\
\hline porque me da miedo & hasta 15 \\
\hline Por la inseguridad & 20 o más \\
\hline seguridad & 20 o más \\
\hline Porque de noche no salgo a caminar & hasta 3 \\
\hline Miedo. Si bien están iluminando muchos espacios verdes, a la noche sigo & hasta 6 \\
\hline porque no salgo de noche & hasta 10 \\
\hline porque me da miedo & hasta 15 \\
\hline hago otras cosas de noche & hasta 3 \\
\hline Porque vivo en los hornos & hasta 6 \\
\hline Duermo & 20 o más \\
\hline & hasta 6 \\
\hline & hasta 10 \\
\hline Porque vivo en la periferia & hasta 15 \\
\hline & hasta 10 \\
\hline Por que está cerrado de noche & hasta 10 \\
\hline inseguridad & hasta 10 \\
\hline porque soy mujer, basicamente por eso, inseguridad, y en segunda medide & hasta 10 \\
\hline Inseguridad & hasta 10 \\
\hline & hasta 10 \\
\hline & hasta 10 \\
\hline Inseguridad & 20 o más \\
\hline & hasta 10 \\
\hline Inseguridad & hasta 6 \\
\hline Por falta de seguridad & hasta 3 \\
\hline inseguridad & hasta 3 \\
\hline Inseguridad, poca illuminación. Suelen ser solitarias. & hasta 6 \\
\hline & hasta 10 \\
\hline Poca iluminacion y control & hasta 3 \\
\hline Por inseguridad & hasta 3 \\
\hline En verano hay mosquitos en invierno hace frío & hasta 6 \\
\hline & hasta 10 \\
\hline & hasta 6 \\
\hline Miedo a q m choreen & hasta 10 \\
\hline inseguridad & hasta 6 \\
\hline Inseguridad & hasta 6 \\
\hline & hasta 10 \\
\hline Inseguridad & hasta 15 \\
\hline Porque es peligroso & hasta 10 \\
\hline No salgo de noche & hasta 6 \\
\hline Inseguridad & 20 o más \\
\hline La inseguridad & hasta 6 \\
\hline & hasta 10 \\
\hline & hasta 10 \\
\hline la inseguridad y la policia, van de la mano & hasta 15 \\
\hline Inseguridad, condiciones climáticas & hasta 10 \\
\hline & 20 o más \\
\hline & 20 o más \\
\hline Presentan peligro & hasta 6 \\
\hline Porque hago otras cosas de noche & hasta 10 \\
\hline Soy grande & hasta 10 \\
\hline & 20 o más \\
\hline Por seguridad & hasta 10 \\
\hline Porque es peligroso de noche & 20 o más \\
\hline Porque a la noche no salgo de mi casa, al menos que vaya con familiares, & 20 o más \\
\hline Delincuencia & hasta 6 \\
\hline inseguridad & hasta 10 \\
\hline Prefiero alguna calle peatonal o calle comercial & hasta 10 \\
\hline Por razones de seguridad & hasta 10 \\
\hline me parecen peligrosos y oscuros & hasta 6 \\
\hline
\end{tabular}




\begin{tabular}{|c|c|c|}
\hline Es peligroso & hasta 3 & si \\
\hline Por la inseguridad & hasta 6 & si \\
\hline Inseguridad & hasta 10 & si \\
\hline No tengo cercania a uno & hasta 10 & si \\
\hline por la inseguridad mayormente, pero sino si, y en el verano & hasta 10 & si \\
\hline Inseguridad & hasta 10 & si \\
\hline Inseguridad & 20 o más & si \\
\hline Por costumbre & hasta 10 & si \\
\hline Falta de tiempo & hasta 6 & si \\
\hline & hasta 6 & si \\
\hline Por la inseguridad & hasta 3 & si \\
\hline Porque no salgo de noche & hasta 10 & si \\
\hline Por peligro & hasta 6 & $\mathrm{si}$ \\
\hline & hasta 6 & $\mathrm{si}$ \\
\hline Por inseguridad & 20 o más & si \\
\hline Inseguridad & hasta 10 & $\mathrm{No}$ \\
\hline Miedo & hasta 10 & si \\
\hline Inseguridad & hasta 6 & Si \\
\hline No hay un lugar seguro & hasta 10 & si \\
\hline & hasta 6 & $\mathrm{Si}$ \\
\hline inseguridad & hasta 6 & Si \\
\hline Inseguridad & hasta 10 & si \\
\hline pocas luces, poca seguridad & 20 o más & si \\
\hline Inseguridad & hasta 6 & si \\
\hline Inseguridad & 20 o más & si \\
\hline \begin{tabular}{|l|} 
Por la inseguridad \\
\end{tabular} & hasta 15 & $\mathrm{si}$ \\
\hline por seguridad & hasta 10 & $\mathrm{si}$ \\
\hline Inseguridad & hasta 6 & si \\
\hline Por la inseguridad & hasta 6 & si \\
\hline & hasta 15 & $\mathrm{Nc}$ \\
\hline Por inseguridad & 20 o más & si \\
\hline & 20 o más & $\mathrm{si}$ \\
\hline & hasta 6 & si \\
\hline Duerme & 20 o más & si \\
\hline is & hasta 6 & $\mathrm{si}$ \\
\hline Inseguridad & hasta 6 & si \\
\hline & hasta 20 & Si \\
\hline & hasta 20 & si \\
\hline & hasta 10 & $\mathrm{si}$ \\
\hline Por cercania & hasta 10 & $\mathrm{si}$ \\
\hline & hasta 10 & No \\
\hline Lejos & hasta 15 & $\mathrm{si}$ \\
\hline & hasta 10 & si \\
\hline & hasta 10 & $\mathrm{si}$ \\
\hline & hasta 15 & si \\
\hline Por seguridad & hasta 10 & si \\
\hline & 20 o más & si \\
\hline Hace frii & hasta 3 & $\mathrm{si}$ \\
\hline & hasta 3 & si \\
\hline & hasta 10 & $\mathrm{Si}$ \\
\hline No hay tiempo & hasta 6 & si \\
\hline Por cansancio & hasta 10 & si \\
\hline Inseeguridad & 20 o más & si \\
\hline Insrfuridad & 20 o más & si \\
\hline & hasta 10 & No \\
\hline Peligroso & 20 o más & $\mathrm{si}$ \\
\hline No salgo a caminar de noche & hasta 6 & $\mathrm{No}$ \\
\hline \begin{tabular}{|l|} 
Inseguridad \\
\end{tabular} & hasta 10 & $\mathrm{si}$ \\
\hline Peligrosos & hasta 6 & si \\
\hline Es peligroso & 20 o más & si \\
\hline Por inseguridad & hasta 3 & $\mathrm{No}$ \\
\hline Tengo una nena de dos años y otro en camino... ni al cine voy & hasta 6 & $\mathrm{No}$ \\
\hline porque ya estoy adentro & hasta 10 & si \\
\hline & hasta 6 & si \\
\hline Porque está no lejos & hasta 10 & si \\
\hline Es inseguro & hasta 10 & si \\
\hline Porque me da miedo & 20 o más & si \\
\hline Porque están muy lejos & hasta 10 & si \\
\hline Ya no salgo & hasta 10 & si \\
\hline porque me da miedo & hasta 10 & si \\
\hline porque me queda muy lejos & hasta 10 & si \\
\hline porque duermo & hasta 6 & si \\
\hline porque no salgo de noche & hasta 6 & si \\
\hline no salgo & hasta 3 & si \\
\hline duermo & hasta 6 & si \\
\hline porque me da miedo que me roben & hasta 10 & si \\
\hline no salgo de noche & hasta 6 & si \\
\hline es muy tarde para salir & hasta 3 & si \\
\hline me da miedo & hasta 6 & Si \\
\hline & hasta 3 & si \\
\hline & hasta 6 & si \\
\hline & hasta 3 & si \\
\hline me da miedo & hasta 6 & si \\
\hline & hasta 10 & $\mathrm{si}$ \\
\hline & hasta 15 & si \\
\hline me da miedo & hasta 10 & si \\
\hline no salgo de noche & hasta 6 & si \\
\hline estan muy lejos & hasta 15 & $\mathrm{si}$ \\
\hline por seguridad & hasta 10 & si \\
\hline le trenes & hasta 6 & $\mathrm{Si}$ \\
\hline miedo & hasta 10 & $\mathrm{si}$ \\
\hline porque no hay luz & hasta 6 & si \\
\hline porque me da miedo & hasta 15 & si \\
\hline miedo & hasta 3 & si \\
\hline por segurida & hasta 6 & si \\
\hline por miedo a que me roben & hasta 6 & si \\
\hline
\end{tabular}




\begin{tabular}{|c|c|}
\hline porque esta lejos y me inseguridad & hasta 10 \\
\hline seguridad & hasta 10 \\
\hline seguridad & hasta 10 \\
\hline miedo & 20 o más \\
\hline por seguridad & hasta 15 \\
\hline porque no salgo de noche & hasta 10 \\
\hline porque no salgo de noche me da miedo & hasta 15 \\
\hline no a esa hora no & hasta 6 \\
\hline & hasta 3 \\
\hline me da miedo & hasta 6 \\
\hline no salgo de noche & hasta 6 \\
\hline estan muy lejos & hasta 15 \\
\hline porque no hay luz & hasta 6 \\
\hline miedo & hasta 3 \\
\hline por miedo a que me roben & hasta 6 \\
\hline seguridad & hasta 10 \\
\hline miedo & 20 o más \\
\hline porque no salgo de noche & hasta 10 \\
\hline Inseguridad & 20 o más \\
\hline Inseguridad & hasta 10 \\
\hline Inseguridad & hasta 15 \\
\hline Inseguridad & hasta 10 \\
\hline Inseguridad & hasta 15 \\
\hline Inseguridad & hasta 15 \\
\hline Inseguridad & 20 o más \\
\hline Poca seguridad & hasta 6 \\
\hline Por inseguridad & hasta 6 \\
\hline & hasta 15 \\
\hline No está muy ilusionado & hasta 6 \\
\hline inseguridad & hasta 6 \\
\hline Por trabajo & hasta 6 \\
\hline Falta de iluminación y seguridad & hasta 10 \\
\hline Inseguridad & hasta 6 \\
\hline es inseguro & hasta 3 \\
\hline Por la inseguridad & hasta 6 \\
\hline Inseguridad & hasta 10 \\
\hline & 20 o más \\
\hline & hasta 6 \\
\hline Por la inseguridad & hasta 10 \\
\hline No salgo de noche & hasta 10 \\
\hline Por inseguridad & hasta 10 \\
\hline \begin{tabular}{|l|} 
Vivo en las afueras \\
\end{tabular} & hasta 15 \\
\hline & hasta 6 \\
\hline Falta de seguridad e iluminación & 20 o más \\
\hline El Bosque & hasta 10 \\
\hline Peligroso & hasta 10 \\
\hline Seguridad & 20 o más \\
\hline & hasta 3 \\
\hline & 20 o más \\
\hline No suelo salir mucho de noche y si lo hago, es a algún lugar cerrado com & hasta 10 \\
\hline Inseguridad & hasta 3 \\
\hline Por la inseguridad & 20 o más \\
\hline Porque no hay seguridad & hasta 10 \\
\hline & hasta 6 \\
\hline & hasta 6 \\
\hline & hasta 6 \\
\hline & hasta 6 \\
\hline & hasta 6 \\
\hline & hasta 6 \\
\hline & hasta 15 \\
\hline & 20 o más \\
\hline & hasta 15 \\
\hline & hasta 15 \\
\hline & hasta 10 \\
\hline & hasta 10 \\
\hline & 20 o más \\
\hline & hasta 15 \\
\hline Por la inseguridad & 20 o más \\
\hline Por la inseguridad & 20 o más \\
\hline Por la inseguridad & 20 o más \\
\hline Por la inseguridad & 20 o más \\
\hline Por la inseguridad & 20 o más \\
\hline Por la inseguridad & 20 o más \\
\hline Por la inseguridad & 20 o más \\
\hline Por inseguridad & hasta 6 \\
\hline Por inseguridad & hasta 6 \\
\hline Por inseguridad & hasta 6 \\
\hline Por inseguridad & hasta 6 \\
\hline Por inseguridad & hasta 6 \\
\hline & hasta 10 \\
\hline & hasta 10 \\
\hline & hasta 10 \\
\hline & hasta 10 \\
\hline & hasta 10 \\
\hline & hasta 10 \\
\hline & hasta 10 \\
\hline & hasta 10 \\
\hline & hasta 10 \\
\hline & hasta 10 \\
\hline & hasta 10 \\
\hline & hasta 10 \\
\hline & hasta 10 \\
\hline & hasta 10 \\
\hline & hasta 10 \\
\hline & hasta 10 \\
\hline \begin{tabular}{|l|} 
Presentan peligro \\
\end{tabular} & hasta 6 \\
\hline entan peli & hasta 6 \\
\hline
\end{tabular}




\begin{tabular}{|c|c|c|}
\hline Presentan peligro & hasta 6 & Si \\
\hline \begin{tabular}{|l|} 
Presentan peligro \\
\end{tabular} & hasta 6 & si \\
\hline Presentan peligro & hasta 6 & Si \\
\hline Presentan peligro & hasta 6 & Si \\
\hline por seguridad & hasta 10 & Si \\
\hline por seguridad & hasta 10 & si \\
\hline por seguridad & hasta 10 & si \\
\hline por seguridad & hasta 10 & Si \\
\hline por seguridad & hasta 10 & Si \\
\hline \multirow[t]{4}{*}{ por seguridad } & hasta 10 & Si \\
\hline & hasta 15 & si \\
\hline & hasta 10 & Si \\
\hline & hasta 6 & Si \\
\hline Por seguridad & hasta 6 & si \\
\hline Deporte & hasta 10 & Si \\
\hline Por seguridad & hasta 6 & si \\
\hline seguridad & 20 o más & si \\
\hline seguridad & 20 o más & Si \\
\hline Por razones de seguridad & hasta 10 & Si \\
\hline Por razones de seguridad & hasta 10 & si \\
\hline \multirow[t]{7}{*}{ Por seguridad } & hasta 6 & si \\
\hline & hasta 6 & Si \\
\hline & hasta 10 & Si \\
\hline & hasta 15 & Si \\
\hline & hasta 6 & Si \\
\hline & hasta 6 & si \\
\hline & hasta 6 & si \\
\hline Vivo en las afueras & hasta 15 & Si \\
\hline \begin{tabular}{|l|} 
Vivo en las afueras \\
\end{tabular} & hasta 15 & Si \\
\hline \multirow[t]{5}{*}{ Vivo en las afueras } & hasta 15 & Si \\
\hline & hasta 3 & si \\
\hline & hasta 3 & Si \\
\hline & hasta 3 & si \\
\hline & hasta 3 & Si \\
\hline es muy tarde para salir & hasta 3 & si \\
\hline es muy tarde para salir & hasta 3 & si \\
\hline estan muy lejos & hasta 15 & si \\
\hline estan muy lejos & hasta 15 & si \\
\hline \multirow[t]{2}{*}{ estan muy lejos } & hasta 15 & Si \\
\hline & hasta 10 & si \\
\hline
\end{tabular}


Veredas y solados (rampas, bicisendas, senderos aeróbicos), Vegetación, Mobiliario (bancos, cestos, bicicleteros etc), lluminación, Sanitarios

Veredas y solados (rampas, bicisendas, senderos aeróbicos), Vegetación, Mobiliario (bancos, cestos, bicicleteros etc), lluminación, Juegos, Señalética (Carteleria, planos de ubicación), Sanitarios Mobiliario (bancos, cestos, bicicleteros etc)

Veredas y solados (rampas, bicisendas, senderos aeróbicos), Vegetación, Mobiliario (bancos, cestos, bicicleteros etc), lluminación, Juegos, Señalética (Carteleria, planos de ubicación), Sanitarios Veredas y solados (rampas, bicisendas, senderos aeróbicos), Vegetación, Mobiliario (bancos, cestos, bicicleteros etc), lluminación

Veredas y solados (rampas, bicisendas, senderos aeróbicos), Mobiliario (bancos, cestos, bicicleteros etc), lluminación, Señalética (Carteleria, planos de ubicación), Sanitarios

Veredas y solados (rampas, bicisendas, senderos aeróbicos), lluminación

Veredas y solados (rampas, bicisendas, senderos aeróbicos), Mobiliario (bancos, cestos, bicicleteros etc), lluminación, Juegos, Señalética (Carteleria, planos de ubicación), Sanitarios

Mobiliario (bancos, cestos, bicicleteros etc), Sanitarios

Mobiliario (bancos, cestos, bicicleteros etc), lluminación, Señalética (Carteleria, planos de ubicación), Sanitarios

Veredas y solados (rampas, bicisendas, senderos aeróbicos), Mobiliario (bancos, cestos, bicicleteros etc), lluminación, Sanitarios

Veredas y solados (rampas, bicisendas, senderos aeróbicos), Mobiliario (bancos, cestos, bicicleteros etc), Sanitarios, activdades

lluminación

Veredas y solados (rampas, bicisendas, senderos aeróbicos), Vegetación, Mobiliario (bancos, cestos, bicicleteros etc)

Señalética (Carteleria, planos de ubicación), Sanitarios, Controles serios de las deposiciones de nuestras mascotas. No dejarlas ahi!!!

Veredas y solados (rampas, bicisendas, senderos aeróbicos), Mobiliario (bancos, cestos, bicicleteros etc), lluminación, Juegos

Veredas y solados (rampas, bicisendas, senderos aeróbicos), Vegetación, Mobiliario (bancos, cestos, bicicleteros etc), lluminación, Señalética (Cartelería, planos de ubicación), Sanitarios

Veredas y solados (rampas, bicisendas, senderos aeróbicos), Mobiliario (bancos, cestos, bicicleteros etc), lluminación, Sanitarios

Veredas y solados (rampas, bicisendas, senderos aeróbicos), Vegetación, Mobiliario (bancos, cestos, bicicleteros etc), lluminación, Juegos, Sanitarios

Mobiliario (bancos, cestos, bicicleteros etc), lluminación, Señalética (Carteleria, planos de ubicación), Sanitarios

Veredas y solados (rampas, bicisendas, senderos aeróbicos), Vegetación, Mobiliario (bancos, cestos, bicicleteros etc), lluminación, Juegos, Sanitarios

Veredas y solados (rampas, bicisendas, senderos aeróbicos), Vegetación, Mobiliario (bancos, cestos, bicicleteros etc), lluminación, Juegos, Señalética (Carteleria, planos de ubicación), Sanitarios, Agua para consu veredas y solados (rampas, bicisendas, senderos aeróbicos), lluminación, Sanitarios

Mobiliario (bancos, cestos, bicicleteros etc), lluminación, Sanitarios

Veredas y solados (rampas, bicisendas, senderos aeróbicos), Vegetacion, Mobiliario (bancos, cestos, bicicleteros etc), Sanitarios

Vegetación, lluminación, Señalética (Carteleria, planos de ubicación)

Vegetación, Mobiliario (bancos, cestos, bicicleteros etc), lluminación

Mobiliario (bancos, cestos, bicicleteros etc), lluminación, Sanitarios

Veredas y solados (rampas, bicisendas, senderos aeróbicos), Vegetación, Iluminación, Juegos, Sanitarios

Sanitarios

Veredas y solados (rampas, bicisendas, senderos aeróbicos), Vegetación, lluminación

Vegetación, Mobiliario (bancos, cestos, bicicleteros etc), lluminación

lluminación

Veredas y solados (rampas, bicisendas, senderos aeróbicos), Vegetación, Mobiliario (bancos, cestos, bicicleteros etc), lluminación, Juegos, Sanitarios

Veredas y solados (rampas, bicisendas, senderos aeróbicos), Vegetación, Mobiliario (bancos, cestos, bicicleteros etc), lluminación, Juegos, Señalética (Carteleria, planos de ubicación)

Veredas y solados (rampas, bicisendas, senderos aeróbicos), Vegetación, Mobiliario (bancos, cestos, bicicleteros etc), lluminación, Juegos, Señalética (Carteleria, planos de ubicación), Sanitarios

Veredas y solados (rampas, bicisendas, senderos aeróbicos), Mobiliario (bancos, cestos, bicicleteros etc), lluminación, Sanitarios

Veredas y solados (rampas, bicisendas, senderos aeróbicos), Vegetación, Mobiliario (bancos, cestos, bicicleteros etc), lluminación, Señalética (Cartelería, planos de ubicación), Sanitarios

Veredas y solados (rampas, bicisendas, senderos aeróbicos), Mobiliario (bancos, cestos, bicicleteros etc), lluminación, Señalética (Carteleria, planos de ubicación), Sanitarios

Veredas y solados (rampas, bicisendas, senderos aeróbicos), Sanitarios

Veredas y solados (rampas, bicisendas, senderos aeróbicos), Mobiliario (bancos, cestos, bicicleteros etc), lluminación

Mobiliario (bancos, cestos, bicicleteros etc), lluminación

Veredas y solados (rampas, bicisendas, senderos aeróbicos), Vegetación, Mobiliario (bancos, cestos, bicicleteros etc), lluminación, Señalética (Carteleria, planos de ubicación)

Veredas y solados (rampas, bicisendas, senderos aeróbicos), Vegetación, Mobiliario (bancos, cestos, bicicleteros etc), lluminación, Juegos, Señalética (Carteleria, planos de ubicación), Sanitario

Mobiliario (bancos, cestos, bicicleteros etc)

Veredas y solados (rampas, bicisendas, senderos aeróbicos), Mobiliario (bancos, cestos, bicicleteros etc), Señalética (Carteleria, planos de ubicación)

Veredas y solados (rampas, bicisendas, senderos aeróbicos), Mobiliario (bancos, cestos, bicicleteros etc), lluminación, Sanitarios

Veredas y solados (rampas, bicisendas, senderos aeróbicos), Sanitarios, Seguridad

Veredas y solados (rampas, bicisendas, senderos aeróbicos), lluminación, Señalética (Cartelería, planos de ubicación), Sanitarios

Veredas y solados (rampas, bicisendas, senderos aeróbicos)

Veredas y solados (rampas, bicisendas, senderos aeróbicos), lluminación, Señalética (Carteleria, planos de ubicación)

Mobiliario (bancos, cestos, bicicleteros etc), lluminación, Juegos, Sanitarios

Sanitarios, Mantenimiento y condiciones de seguridad. Presencia persuasiva de autoridad policial

Vegetación, Mobiliario (bancos, cestos, bicicleteros etc), lluminación, Sanitarios

Diseño principalmente e inicialmente para completarlos con todos los elementos antes mencionados

Veredas y solados (rampas, bicisendas, senderos aeróbicos), lluminación, Señalética (Carteleria, planos de ubicación

Sanitarios

Mobiliario (bancos, cestos, bicicleteros etc), lluminación, Señalética (Carteleria, planos de ubicación

Veredas y solados (rampas, bicisendas, senderos aeróbicos), Vegetación, lluminación, Sanitarios

Veredas y solados (rampas, bicisendas, senderos aerobicos), Vegetación, Mobiliario (bancos, cestos, bicicleteros etc), lluminación, Juegos, Sefialética (Cartelería, planos de ubicación), Sanitarios

lluminación

Vegetación, lluminación, Señalética (Carteleria, planos de ubicación), agua para tomar

Veredas y solados (rampas, bicisendas, senderos aeróbicos), Mobiliario (bancos, cestos, bicicleteros etc), lluminación, Seńalética (Carteleria, planos de ubicación), Sanitarios

Veredas y solados (rampas, bicisendas, senderos aeróbicos), Mobiliario (bancos, cestos, bicicleteros etc), lluminación, Sanitarios

Veredas y solados (rampas, bicisendas, senderos aeróbicos), Vegetación lluminación

Veredas y solados (rampas, bicisendas, senderos aeróbicos), Vegetación, Mobiliario (bancos, cestos, bicicleteros etc), lluminación, Sanitarios

luminación, Sanitarios

Veredas y solados (rampas, bicisendas, senderos aeróbicos), Vegetación, Mobiliario (bancos, cestos, bicicleteros etc), lluminación, Juegos, Sanitarios

Vegetación, Mobiliario (bancos, cestos, bicicleteros etc), Limpieza de residuos animales

Veredas y solados (rampas, bicisendas, senderos aeróbicos), Mobiliario (bancos, cestos, bicicleteros etc), Sanitarios

Veredas y solados (rampas, bicisendas, senderos aeróbicos), lluminación, Sanitarios

Veredas y solados (rampas, bicisendas, senderos aeróbicos), Mobiliario (bancos, cestos, bicicleteros etc), lluminación, Juegos, Señalética (Carteleria, planos de ubicación), Sanitarios

Veredas y solados (rampas, bicisendas, senderos aeróbicos)

Veredas y solados (rampas, bicisendas, senderos aeróbicos), Vegetación, Iluminación, Más seguridad

Sanitarios

Veredas y solados (rampas, bicisendas, senderos aeróbicos), Vegetación, Mobiliario (bancos, cestos, bicicleteros etc), lluminación, Juegos, Señalética (Cartelería, planos de ubicación), Sanitarios

Vegetación, Señalética (Carteleria, planos de ubicación)

Veredas y solados (rampas, bicisendas, senderos aeróbicos), Mobiliario (bancos, cestos, bicicleteros etc), Sanitarios

Veredas y solados (rampas, bicisendas, senderos aeróbicos), lluminación, Señalética (Carteleria, planos de ubicación

Veredas y solados (rampas, bicisendas, senderos aeróbicos), Mobiliario (bancos, cestos, bicicleteros etc) lluminación

lluminación

Vegetación, Mobiliario (bancos, cestos, bicicleteros etc), lluminación, Sanitarios

Veredas y solados (rampas, bicisendas, senderos aeróbicos)

Mobiliario (bancos, cestos, bicicleteros etc), lluminación, Sanitarios

luminación, Juegos, Sanitarios

Veredas y solados (rampas, bicisendas, senderos aeróbicos), Mobiliario (bancos, cestos, bicicleteros etc), lluminación

Mobiliario (bancos, cestos, bicicleteros etc), lluminación 


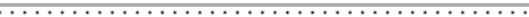

Vegetación, Mobiliario (bancos, cestos, bicicleteros etc), lluminación

Illuminación

Vobiliario (bancos, cestos, bicicleteros etc) Iluminacion, sanitios

Mobiliario (bancos, cestos, bicicleteros etc), lluminación, Sanitarios

Veredas y solados (rampas, bicisendas, senderos aerobicos), Mobiliario (bancos, cestos, bicicleteros etc), lluminación, Juegos, Sef́alética (Cartelería, planos de ubicación), Sanitarios

Veredas y solados (rampas, bicisendas, senderos aeróbicos), Mobiliario (bancos, cestos, bicicleteros etc), Sanitarios

Veredas y solados (rampas, bicisendas, senderos aeróbicos), Mobiliario (bancos, cestos, bicicleteros etc), lluminación, Señalética (Cartelería, planos de ubicación), Sanitarios

Veredas y solados (rampas, bicisendas, senderos aeróbicos), Mobiliario (bancos, cestos, bicicleteros etc), lluminación, Sanitarios

Mobiliario (bancos, cestos, bicicleteros etc)

Veredas y solados (rampas, bicisendas, senderos aeróbicos), Mobiliario (bancos, cestos, bicicleteros etc), lluminación, Sanitarios

Veredas y solados (rampas, bicisendas, senderos aeróbicos), Mobiliario (bancos, cestos, bicicleteros etc), lluminación, Sanitario

Veredas y solados (rampas, bicisendas, senderos aeróbicos), Mobiliario (bancos, cestos, bicicleteros etc), lluminación, Sanitarios

lluminación, Sanitarios

Veredas y solados (rampas, bicisendas, senderos aeróbicos), Mobiliario (bancos, cestos, bicicleteros etc), lluminación, Sanitarios

Veredas y solados (rampas, bicisendas, senderos aeróbicos), Vegetación, Mobiliario (bancos, cestos, bicicleteros etc), lluminación, Señalética (Carteleria, planos de ubicación), Sanitarios

Mobiliario (bancos, cestos, bicicleteros etc), lluminación

Mobiliario (bancos, cestos, bicicleteros etc)

Mobiliario (bancos, cestos, bicicleteros etc), lluminación, Sanitarios

le faltan ser más democráticos y no concentrare en el casco urbano, el espacio verde debe llegar ala periferia.

Veredas y solados (rampas, bicisendas, senderos aeróbicos), Mobiliario (bancos, cestos, bicicleteros etc), lluminación

Mobiliario (bancos, cestos, bicicleteros etc), Sanitarios

lluminación, Señalética (Carteleria, planos de ubicación), Sanitarios

Mobiliario (bancos, cestos, bicicleteros etc), Bicicletas tipo las de buenos aires. Donde cada ciudadano pueda agarrar una y dejarla en otro puesto

Vegetación, Mobiliario (bancos, cestos, bicicleteros etc), lluminación, Señalética (Cartelería, planos de ubicación)

Mobiliario (bancos, cestos, bicicleteros etc), lluminación, Sanitarios

Mobiliario (bancos, cestos, bicicleteros etc), lluminación, Señalética (Cartelería, planos de ubicación), Sanitarios

Veredas y solados (rampas, bicisendas, senderos aeróbicos), Vegetación, Mobiliario (bancos, cestos, bicicleteros etc), lluminación, Juegos, Señalética (Carteleria, planos de ubicación)

Veredas y solados (rampas, bicisendas, senderos aeróbicos), Mobiliario (bancos, cestos, bicicleteros etc), lluminación, Sanitarios

Veredas y solados (rampas, bicisendas, senderos aeróbicos), Vegetación, Mobiliario (bancos, cestos, bicicleteros etc), lluminación, Sanitarios

Vegetación, Mobiliario (bancos, cestos, bicicleteros etc), Sanitarios

lluminación, Señalética (Carteleria, planos de veredas y solados (rampas bicisendas, senderos aes) Vegetación. lluminación

Veredas y solados (rampas, bicisendas, senderos aeróbicos), Mobiliario (bancos, cestos, bicicleteros etc), lluminación

Sanitarios

Veredas y solados (rampas, bicisendas, senderos aeróbicos), Vegetación, Mobiliario (bancos, cestos, bicicleteros etc), lluminación, Juegos, Señalética (Carteleria, planos de ubicación), Sanitarios, Aparatos aeróbic

Veredas y solados (rampas, bicisendas, senderos aeróbicos), Vegetación, lluminación, Sanitarios

Sanitarios

Veredas y solados (rampas, bicisendas, senderos aeróbicos), Mobiliario (bancos, cestos, bicicleteros etc), lluminación, Juegos, Señalética (Carteleria, planos de ubicación)

Veredas y solados (rampas, bicisendas, senderos aeróbicos), Vegetación, Sanitarios

Veredas y solados (rampas bicisendas senderos aerobicos). lluminación Sanitarios

Veredas y solados (rampas bicisendas, senderos aeróbicos) Uluminación, Sanitarios

Veredas y solados (rampas, bicisendas, senderos aeróbicos), lluminación, Sanitarios

lluminación, Juegos, Sanitarios

Veredas y solados (rampas, bicisendas, senderos aeróbicos), Mobiliario (bancos, cestos, bicicleteros etc), lluminación, Sanitarios

Veredas y solados (rampas, bicisendas, senderos aeróbicos), Vegetación, Mobiliario (bancos, cestos, bicicleteros etc), lluminación, Sanitarios

Veredas y solados (rampas, bicisendas, senderos aeróbicos), Mobiliario (bancos, cestos, bicicleteros etc), Sanitarios

Veredas y solados (rampas, bicisendas, senderos aeróbicos), Mobiliario (bancos, cestos, bicicleteros etc), lluminación, a pesar de los puestos de control, más seguridad

Vegetación, Mobiliario (bancos, cestos, bicicleteros etc), lluminación, Juegos, Señalética (Cartelería, planos de ubicación)

Sanitarios

Vegetación, Mobiliario (bancos, cestos, bicicleteros etc), lluminación, Juegos

Vegetación, Sanitarios

Veredas y solados (rampas, bicisendas, senderos aeróbicos), Vegetación, Mobiliario (bancos, cestos, bicicleteros etc), Señalética (Carteleria, planos de ubicación), Sanitarios

Vegetación, lluminación, Sanitarios

Veredas y solados (rampas, bicisendas, senderos aeróbicos), Vegetación, Mobiliario (bancos, cestos, bicicleteros etc), lluminación, Sanitarios

Vegetación, Mobiliario (bancos, cestos, bicicleteros etc), lluminación

Señalética (Cartelería, planos de ubicación), Sanitarios

Veredas y solados (rampas, bicisendas, senderos aeróbicos), lluminación, Señalética (Carteleria, planos de ubicación), Sanitarios

Veredas y solados (rampas, bicisendas, senderos aeróbicos), Vegetación, Mobiliario (bancos, cestos, bicicleteros etc), lluminación, Juegos, Sef́alética (Carteleria, planos de ubicación), Sanitarios

Sanitarios

Veredas y solados (rampas, bicisendas, senderos aeróbicos), Vegetación, Mobiliario (bancos, cestos, bicicleteros etc), Juegos, Señalética (Carteleria, planos de ubicación), Sanitarios

Veredas y solados (rampas, bicisendas, senderos aeróbicos), Mobiliario (bancos, cestos, bicicleteros etc), lluminación, Sanitarios

Veredas y solados (rampas, bicisendas, senderos aeróbicos), lluminación, Sanitarios

Veredas y solados (rampas, bicisendas, senderos aeróbicos), Vegetación, Mobiliario (bancos, cestos, bicicleteros etc), lluminación

Veredas y solados (rampas, bicisendas, senderos aeróbicos), Vegetación, Mobiliario (bancos, cestos, bicicleteros etc), lluminación, Juegos, Señalética (Cartelería, planos de ubicación), Sanitarios

Iluminación, Sanitarios

Mobiliario (bancos, cestos, bicicleteros etc), lluminación, Sanitarios

Veredas y solados (rampas, bicisendas, senderos aeróbicos), Mobiliario (bancos, cestos, bicicleteros etc), lluminación, Juegos, Sanitarios

Señalética (Carteleria, planos de ubicación), Sanitarios

Veredas y solados (rampas, bicisendas, senderos aeróbicos), lluminación, Bebederos de agua

lluminación, Señalética (Carteleria, planos de ubicación), Sanitarios

Veredas y solados (rampas, bicisendas, senderos aeróbicos), lluminación, Sanitarios

Veredas y solados (rampas, bicisendas, senderos aeróbicos), lluminación, Sef́alética (Carteleria, planos de ubicación), Sanitarios

Vegetación, Mobiliario (bancos, cestos, bicicleteros etc), lluminación, Juegos

Veredas y solados (rampas, bicisendas, senderos aeróbicos), Vegetación, Mobiliario (bancos, cestos, bicicleteros etc), lluminación, Juegos

Vegetación, Mobiliario (bancos, cestos, bicicleteros etc), lluminación

Veredas y solados (rampas, bicisendas, senderos aeróbicos), Vegetación, Mobiliario (bancos, cestos, bicicleteros etc), lluminación, Señalética (Carteleria, planos de ubicación), Sanitarios

Veredas y solados (rampas, bicisendas, senderos aeróbicos), Vegetación, Mobiliario (bancos, cestos, bicicleteros etc), lluminación, Sanitarios

Veredas y solados (rampas, bicisendas, senderos aeróbicos), Vegetación, Mobiliario (bancos, cestos, bicicleteros etc), lluminación, Juegos, Señalética (Cartelería, planos de ubicación), Sanitarios

Veredas y solados (rampas, bicisendas, senderos aeróbicos), Vegetación, Mobiliario (bancos, cestos, bicicleteros etc), lluminación, Juegos, Señalética (Carteleria, planos de ubicación), Sanitarios

Veredas y solados (rampas, bicisendas, senderos aeróbicos), Vegetación, Mobiliario (bancos, cestos, bicicleteros etc), lluminación

Veredas y solados (rampas, bicisendas, senderos aeróbicos), Vegetación, lluminación, Sanitarios

Veredas y solados (rampas, bicisendas, senderos aeróbicos), lluminación, Juegos, Sanitarios

Veredas y solados (rampas, bicisendas, senderos aeróbicos), lluminación, Sanitarios

Veredas y solados (rampas, bicisendas, senderos aeróbicos), Mobiliario (bancos, cestos, bicicleteros etc), lluminación, Sanitarios

Vegetación, lluminación, Sanitarios

Veredas y solados (rampas, bicisendas, senderos aeróbicos), Vegetación, Mobiliario (bancos, cestos, bicicleteros etc), Juegos, Sanitarios

lluminación, Sanitarios, Aparatos de gym

Veredas y solados (rampas, bicisendas, senderos aeróbicos), Vegetación, Mobiliario (bancos, cestos, bicicleteros etc), Sanitarios

Veredas y solados (rampas, bicisendas, senderos aeróbicos)

Veredas y solados (rampas, bicisendas, senderos aeróbicos), Vegetación, Mobiliario (bancos, cestos, bicicleteros etc), lluminación, Juegos, Señalética (Cartelería, planos de ubicación), Sanitarios

Veredas y solados (rampas, bicisendas, senderos aeróbicos), lluminación, Sanitarios

lluminación, Señalética (Carteleria, planos de ubicación)

Sanitarios

Veredas y solados (rampas, bicisendas, senderos aerobicos), Mobiliario (bancos, cestos, bicicleteros etc), lluminación, Sanitarios

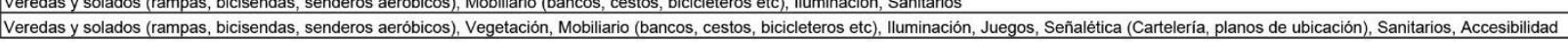


Mobiliario (bancos, cestos, bicicleteros etc), lluminación, Bolsas para residuos de los perros

Veredas y solados (rampas, bicisendas, senderos aeróbicos), Mobiliario (bancos, cestos, bicicleteros etc), lluminación

Veredas y solados (rampas, bicisendas, senderos aeróbicos), Vegetación, Mobiliario (bancos, cestos, bicicleteros etc), lluminación, Juegos, Señalética (Carteleria, planos de ubicación), Sanitarios, Seguridad, pues

Veredas y solados (rampas, bicisendas, senderos aeróbicos)

Veredas y solados (rampas, bicisendas, senderos aeróbicos), Sanitarios

Veredas y solados (rampas, bicisendas, senderos aeróbicos), Vegetación, Mobiliario (bancos, cestos, bicicleteros etc), lluminación, Juegos

Veredas y solados (rampas, bicisendas, senderos aeróbicos), Vegetación, Mobiliario (bancos, cestos, bicicleteros etc)

Mobiliario (bancos, cestos, bicicleteros etc), lluminación, Sanitarios

Veredas y solados (rampas, bicisendas, senderos aeróbicos), lluminación, Sanitarios

Veredas y solados (rampas, bicisendas, senderos aeróbicos), Vegetación, Mobiliario (bancos, cestos, bicicleteros etc), lluminación, Señalética (Carteleria, planos de ubicación), Sanitarios

Veredas y solados (rampas, bicisendas, senderos aeróbicos), Mobiliario (bancos, cestos, bicicleteros etc), lluminación, Sanitarios

Veredas y solados (rampas, bicisendas, senderos aeróbicos), lluminación, Señalética (Carteleria, planos de ubicación)

lluminación, Sanitarios

Mobiliario (bancos, cestos, bicicleteros etc), lluminación

Vegetación

Mobiliario (bancos, cestos, bicicleteros etc), lluminación

Veredas y solados (rampas, bicisendas, senderos aeróbicos), Vegetación, Mobiliario (bancos, cestos, bicicleteros etc), lluminación

Mobiliario (bancos, cestos, bicicleteros etc), lluminación, Juegos, Sanitarios

Veredas y solados (rampas, bicisendas, senderos aeróbicos), Vegetación, lluminación

Veredas y solados (rampas, bicisendas, senderos aeróbicos), lluminación

Sanitarios

Mobiliario (bancos, cestos, bicicleteros etc)

Vegetación, Mobiliario (bancos, cestos, bicicleteros etc), lluminación, Sanitarios

Mobiliario (bancos, cestos, bicicleteros etc), lluminación

Veredas y solados (rampas, bicisendas, senderos aeróbicos), Mobiliario (bancos, cestos, bicicleteros etc), lluminación, Señalética (Carteleria, planos de ubicación), Seguridad

Mobiliario (bancos, cestos, bicicleteros etc), lluminación

Iluminación, Sanitarios

Veredas y solados (rampas, bicisendas, senderos aeróbicos), Vegetación, Juegos

Mobiliario (bancos, cestos, bicicleteros etc)

No

Mobiliario (bancos, cestos, bicicleteros etc), Sanitarios

lluminación

Mobiliario (bancos, cestos, bicicleteros etc), Sanitarios

Mobiliario (bancos, cestos, bicicleteros etc)

Mobiliario (bancos, cestos, bicicleteros etc)

Veredas y solados (rampas, bicisendas, senderos aeróbicos), Mobiliario (bancos, cestos, bicicleteros etc)

luminación, Seguridad

Vegetación, lluminación

La plaza de citybell esta bien

Ninguno

Xx

lluminación, Seguridad

lluminación, Sanitarios, Seguridad

Sanitarios

Mobiliario (bancos, cestos, bicicleteros etc), Sanitarios

Mobiliario (bancos, cestos, bicicleteros etc)

lluminación

lluminación, Sanitarios

Vegetación, Mobiliario (bancos, cestos, bicicleteros etc)

Veredas y solados (rampas, bicisendas, senderos aeróbicos), Mobiliario (bancos, cestos, bicicleteros etc)

Veredas y solados (rampas, bicisendas, senderos aeróbicos), Vegetación, Mobiliario (bancos, cestos, bicicleteros etc), lluminación, Juegos, Señalética (Carteleria, planos de ubicación)

lluminación

lluminación, Sanitarios

Vegetación

Mobiliario (bancos, cestos, bicicleteros etc), lluminación, Sanitarios

Iluminación

lluminación, Sanitarios

Mobiliario (bancos, cestos, bicicleteros etc)

Veredas y solados (rampas, bicisendas, senderos aeróbicos), Mobiliario (bancos, cestos, bicicleteros etc), Juegos, Sanitarios

Vegetación, Mobiliario (bancos, cestos, bicicleteros etc)

Vegetación, Mobiliario (bancos, cestos, bicicleteros etc), lluminación, Juegos

Veredas y solados (rampas, bicisendas, senderos aeróbicos), Mobiliario (bancos, cestos, bicicleteros etc), Sanitarios

Veredas y solados (rampas, bicisendas, senderos aeróbicos), Vegetación, Mobiliario (bancos, cestos, bicicleteros etc)

Veredas y solados (rampas, bicisendas, senderos aeróbicos)

Mobiliario (bancos, cestos, bicicleteros etc), lluminación

Veredas y solados (rampas, bicisendas, senderos aeróbicos), Vegetación, Mobiliario (bancos, cestos, bicicleteros etc), lluminación, Juegos, Señalética (Cartelería, planos de ubicación), Sanitarios

Veredas y solados (rampas, bicisendas, senderos aeróbicos), Mobiliario (bancos, cestos, bicicleteros etc), lluminación, Sanitarios

Veredas y solados (rampas, bicisendas, senderos aeróbicos), Vegetación, Mobiliario (bancos, cestos, bicicleteros etc), lluminación, Juegos, Señalética (Cartelería, planos de ubicación), Sanitarios

Veredas y solados (rampas, bicisendas, senderos aeróbicos), Vegetación, Mobiliario (bancos, cestos, bicicleteros etc), lluminación, Juegos, Señalética (Carteleria, planos de ubicación), Sanitarios

Veredas y solados (rampas, bicisendas, senderos aeróbicos), Vegetación, Mobiliario (bancos, cestos, bicicleteros etc), lluminación, Juegos, Señalética (Carteleria, planos de ubicación), Sanitarios

Veredas y solados (rampas, bicisendas, senderos aeróbicos), Vegetación, Mobiliario (bancos, cestos, bicicleteros etc), lluminación, Juegos, Señalética (Cartelería, planos de ubicación), Sanitarios

Veredas y solados (rampas, bicisendas, senderos aeróbicos), Vegetación, Mobiliario (bancos, cestos, bicicleteros etc), lluminación, Juegos, Señalética (Carteleria, planos de ubicación), Sanitarios

Veredas y solados (rampas, bicisendas, senderos aeróbicos), Vegetación, Mobiliario (bancos, cestos, bicicleteros etc), lluminación, Juegos, Señalética (Carteleria, planos de ubicación), Sanitarios

Veredas y solados (rampas, bicisendas, senderos aeróbicos), Vegetación, Mobiliario (bancos, cestos, bicicleteros etc), lluminación, Juegos, Señalética (Carteleria, planos de ubicación), Sanitarios Veredas y solados (rampas, bicisendas, senderos aeróbicos), Vegetación, Mobiliario (bancos, cestos, bicicleteros etc)

Veredas y solados (rampas, bicisendas, senderos aeróbicos), Vegetación, Mobiliario (bancos, cestos, bicicleteros etc), lluminación, Juegos, Señalética (Carteleria, planos de ubicación), Sanitarios Veredas y solados (rampas, bicisendas, senderos aeróbicos), Mobiliario (bancos, cestos, bicicleteros etc)

Veredas y solados (rampas, bicisendas, senderos aeróbicos), Vegetación, Mobiliario (bancos, cestos, bicicleteros etc), lluminación, Juegos, Señalética (Carteleria, planos de ubicación), Sanitarios Veredas y solados (rampas, bicisendas, senderos aeróbicos), Vegetación, Mobiliario (bancos, cestos, bicicleteros etc), lluminación, Juegos, Señalética (Cartelería, planos de ubicación), Sanitarios Veredas y solados (rampas, bicisendas, senderos aeróbicos), Vegetación, Mobiliario (bancos, cestos, bicicleteros etc), lluminación, Señalética (Carteleria, planos de ubicación), Sanitarios

Veredas y solados (rampas, bicisendas, senderos aeróbicos), Vegetación, Mobiliario (bancos, cestos, bicicleteros etc), Señalética (Carteleria, planos de ubicación), Sanitarios

Veredas y solados (rampas, bicisendas, senderos aeróbicos), Vegetación, Mobiliario (bancos, cestos, bicicleteros etc), lluminación, Juegos, Señalética (Carteleria, planos de ubicación), Sanitarios Vegetación, Mobiliario (bancos, cestos, bicicleteros etc), lluminación

Veredas y solados (rampas, bicisendas, senderos aeróbicos), Vegetación, Mobiliario (bancos, cestos, bicicleteros etc), lluminación, Señalética (Carteleria, planos de ubicación), Sanitarios

Veredas y solados (rampas, bicisendas, senderos aeróbicos), Vegetación, Mobiliario (bancos, cestos, bicicleteros etc), lluminación, Juegos, Señalética (Cartelería, planos de ubicación), Sanitarios

Veredas y solados (rampas, bicisendas, senderos aeróbicos), Vegetación, Mobiliario (bancos, cestos, bicicleteros etc), lluminación, Señalética (Carteleria, planos de ubicación), Sanitarios

Veredas y solados (rampas, bicisendas, senderos aeróbicos), Vegetación, Mobiliario (bancos, cestos, bicicleteros etc), lluminación, Juegos, Señalética (Carteleria, planos de ubicación), Sanitarios

Veredas y solados (rampas, bicisendas, senderos aeróbicos), Vegetación, Mobiliario (bancos, cestos, bicicleteros etc), lluminación, Juegos, Señalética (Carteleria, planos de ubicación), Sanitarios

Veredas y solados (rampas, bicisendas, senderos aeróbicos), Vegetación, Mobiliario (bancos, cestos, bicicleteros etc), lluminación, Juegos, Señalética (Carteleria, planos de ubicación), Sanitarios

Veredas y solados (rampas, bicisendas, senderos aeróbicos), Vegetación, Mobiliario (bancos, cestos, bicicleteros etc), lluminación, Señalética (Carteleria, planos de ubicación), Sanitarios

Veredas y solados (rampas, bicisendas, senderos aeróbicos), Vegetación, Mobiliario (bancos, cestos, bicicleteros etc), lluminación, Juegos, Señalética (Carteleria, planos de ubicación), Sanitarios

Veredas y solados (rampas, bicisendas, senderos aeróbicos), Mobiliario (bancos, cestos, bicicleteros etc), lluminación, Señalética (Carteleria, planos de ubicación), Sanitarios

Veredas y solados (rampas, bicisendas, senderos aeróbicos), Vegetación, Mobiliario (bancos, cestos, bicicleteros etc), lluminación, Juegos, Señalética (Carteleria, planos de ubicación), Sanitarios 
Veredas y solados (rampas, bicisendas, senderos aerobicos), Vegetacion, Mobiliario (bancos, cestos, bicicleteros etc), lluminación, Juegos, Señaletica (Carteleria, planos de ubicacion), Sanitarios Veredas y solados (rampas, bicisendas, senderos aeróbicos), Mobiliario (bancos, cestos, bicicleteros etc), Sanitarios

Veredas y solados (rampas, bicisendas, senderos aerobicos), Vegetación, Sanitarios

Mobiliario (bancos, cestos, bicicleteros etc), Juegos, Señalética (Carteleria, planos de ubicación), Sanitarios

Veredas y solados (rampas, bicisendas, senderos aerobicos), Mobiliario (bancos, cestos, bicicleteros etc)

Veredas y solados (rampas, bicisendas, senderos aeróbicos), Vegetación, Mobiliario (bancos, cestos, bicicleteros etc), Señaletica (Cartelerí, planos de ubicación), Sanitarios

Veredas y solados (rampas, bicisendas, senderos aeróbicos), Vegetación, Mobiliario (bancos, cestos, bicicleteros etcc

Veredas y solados (rampas, bicisendas, senderos aerobicos), Mobiliario (bancos, cestos, bicicleteros etc), Sanitarios

Veredas y solados (rampas, bicisendas, senderos aeróbicos), Vegetación, Mobiliario (bancos, cestos, bicicleteros etc), lluminación, Juegos, Señalética (Carteleria, planos de ubicación), Sanitarios

Veredas y solados (rampas, bicisendas, senderos aeróbicos), Vegetación, Mobiliario (bancos, cestos, bicicleteros etc), lluminación, Señalética (Carteleria, planos de ubicación), Sanitarios

Veredas y solados (rampas, bicisendas, senderos aeróbicos), Vegetación, Mobiliario (bancos, cestos, bicicleteros etc), lluminación, Señalética (Cartelería, planos de ubicación), Sanitarios

Veredas y solados (rampas, bicisendas, senderos aeróbicos), Vegetación, Mobiliario (bancos, cestos, bicicleteros etc), lluminación, Juegos, Señaleticica (Carteleria, planos de ubicación), Sanitarios

Veredas y solados (rampas, bicisendas, senderos aeróbicos), Vegetación, Mobiliario (bancos, cestos, bicicleteros etc), lluminación, Juegos, Señalética (Carteleria, planos de ubicación), Sanitarios

Veredas y solados (rampas, bicisendas, senderos aerobicos), Vegetación, Mobiliario (bancos, cestos, bicicleteros etc), lluminación, Juegos, Señaletica (Cartelerlia, planos de ubicación), Sanitarios

Veredas y solados (rampas, bicisendas, senderos aeróbicos), Vegetación, Mobiliario (bancos, cestos, bicicleteros etc), lluminación, Juegos, Señalética (Carteleria, planos de ubicación), Sanitarios

Veredas y solados (rampas, bicisendas, senderos aerobicos), Vegetacion, Sanitarios

Mobiliario (bancos, cestos, bicicleteros etc), Juegos, Señaletitica (Carteleria, planos de ubicación), Sanitarios

Veredas y solados (rampas, bicisendas, senderos aerobicos), Vegetación, Mobiliario (bancos, cestos, bicicleteros etc), Señalética (Carrelería, planos de ubicación), Sanitarios

Veredas y solados (rampas, bicisendas, senderos aeróbicos)

Veredas y solados (rampas, bicisendas, senderos aeróbicos)

Mobiliario (bancos, cestos, bicicleteros etc)

Mobiliario (bancos, cestos, bicicleteros etc), Veredas y solados (rampas, bicisendas, senderos aerobicos)

Mobiliario (bancos, cestos, bicicleteros etc

Mobiliario (bancos, cestos, bicicleteros etc

Veredas y solados (rampas, bicisendas, senderos aeróbicos)

Veredas y solados (rampas, bicisendas, senderos aeróbicos), Vegetación, Mobiliario (bancos, cestos, bicicleteros etc), lluminación, Juegos, Sanitarios

veredas y solados (rampas, bicisendas, senderos aerobicos), Vegetación, Iluminación, Juegos, Sanitarios

Sanitarios

Vegetacion, Mobiliario (bancos, cestos, bicicleteros etc), lluminación

veredas y solados (rampas, bicisendas, senderos aeróbicos), Mobiliario (bancos, cestos, bicicleteros etc), lluminación

Veredas y solados (rampas, bicisendas, senderos aerobicos), Sanitarios, Seguridac

Veredas y solados (rampas, bicisendas, senderos aeróbicos), Iluminación, Señalética (Carteleria, planos de ubicación)

Mobiliario (bancos, cestos, bicicleteros etc), lluminación, Señaletica (Carteleria, planos de ubicación)

lluminación

Veredas y solados (rampas, bicisendas, senderos aeróbicos), Mobiliario (bancos, cestos, bicicleteros etc), Sanitarios

Veredas y yolados (rampas, bicisendas, senderos aeróbicos), Iluminación, Señaletetica (Carteleria, planos de ubicación

Veredas y solados (rampas, bicisendas, senderos aeróbicos), Mobiliario (bancos, cestos, bicicleteros etc), lluminación

Mobiliario (bancos, cestos, bicicleteros etc), lluminación

Vegetación, Mobiliario (bancos, cestos, bicicleteros etc), lluminación

Veredas y solados (rampas, bicisendas, senderos aeróbicos), Mobiliario (bancos, cestos, bicicleteros etc), Sanitarios

lluminación, Sanitarios

Mobiliario (bancos, cestos, bicicleteros etc), lluminación

Mobiliario (bancos, cestos, bicicleteros etc), lluminación, Sanitarios

Mobiliario (bancos, cestos, bicicleteros etc), lluminación, Sanitarios

veredas y solados (rampas, bicisendas, senderos aeróbicos), Vegetación, lluminación

Sanitarios

Sanitarios

Veredas y solados (rampas, bicisendas, senderos aeróbicos), Vegetación, Mobiliario (bancos, cestos, bicicleteros etc), lluminación

lluminación, Señalética (Cartelería, planos de ubicación), Sanitarios

Veredas y solados (rampas, bicisendas, senderos aeróbicos), Vegetación, Mobiliario (bancos, cestos, bicicleteros etc), lluminación, Señalética (Carteleria, planos de ubicación), Sanitarios

Veredas y solados (rampas, bicisendas, senderos aeróbicos), Mobiliario (bancos, cestos, bicicleteros etc), lluminación, Sanitarios

Mobiliario (bancos, cestos, bicicleteros etc), lluminación, Sanitarios

Mobiliario (bancos, cestos, bicicleteros etc), lluminación

Mobiliario (bancos, cestos, bicicleteros etc), lluminación

Mobiliario (bancos, cestos, bicicleteros etc), lluminación

Mobiliario (bancos, cestos, bicicleteros etc), lluminación

Mobiliario (bancos, cestos, bicicleteros etc), lluminación

Mobiliario (bancos, cestos, bicicleteros etc). lluminacion

Sanitarios

Veredas y solados (rampas, bicisendas, senderos aeróbicos), Vegetación, lluminación

Sanitarios

Veredas y solados (rampas, bicisendas, senderos aeróbicos), Vegetación, lluminación

Sanitarios

Mobiliario (bancos, cestos, bicicleteros etc), lluminación

Mobiliario (bancos, cestos, bicicleteros etc), lluminación

Mobiliario (bancos, cestos, bicicleteros etc) Illuminación

Veredas y solados (rampas, bicisendas, senderos aeróbicos), Mobiliario (bancos, cestos, bicicleteros etc), lluminación, Sanitarios

Veredas y solados (rampas, bicisendas, senderos aeróbicos), Mobiliario (bancos, cestos, bicicleteros etc), lluminación, Sanitarios

Veredas y solados (rampas, bicisendas, senderos aeróbicos), Mobiliario (bancos, cestos, bicicleteros etc), lluminación, Sanitarios

Veredas y solados (rampas, bicisendas, senderos aeróbicos), Mobiliario (bancos, cestos, bicicleteros etc), lluminación, Sanitario

Veredas y solados (rampas, bicisendas, senderos aerobicos), Mobiliario (bancos, cestos, bicicleteros etc), lluminación, Sanitario

Veredas y solados (rampas, bicisendas, senderos aeróbicos), Mobiliario (bancos, cestos, bicicleteros etc), lluminación, Sanitario

Veredas y solados (rampas, bicisendas, senderos aeróbicos), Mobiliario (bancos, cestos, bicicleteros etc), lluminación, Sanitarios

Veredas y solados (rampas, bicisendas, senderos aeróbicos), Vegetación, lluminación, Juegos, Sanitarios

Veredas y solados (rampas, bicisendas, senderos aeróbicos), Vegetación, lluminación, Juegos, Sanitarios

Veredas y solados (rampas, bicisendas, senderos aeróbicos), Vegetación, lluminación, Juegos, Sanitarios

Veredas y solados (rampas, bicisendas, senderos aeróbicos), Vegetación, lluminación, Juegos, Sanitarios

Veredas y solados (rampas, bicisendas, senderos aeróbicos), Vegetación, lluminación, Juegos, Sanitarios

lluminación, Sanitarios, Seguridad

lluminación, Sanitarios, Seguridad

luminación, Sanitarios, Seguridad

lluminación, Sanitarios, Seguridad

luminación Sanitarios, Segurid

umminar, Santos, suridad

uminacion, Sanlanios, Segurida

luminación, Sanitarios, Segurida

lluminación, Sanitarios, Seguridad

lluminación, Sanitarios, Seguridad

luminación, Sanitarios, Seguridad

lluminación, Sanitarios, Seguridad

luminación, Sanitarios, Seguridad

luminación Sanitarios Segurid

uminacion, Sanitas, seguria

Iuminacion, Sanilarios, Seguridad

lluminación, Sanitarios, Seguridad

luminación, Sanitarios, Seguridad

Mobiliario (bancos, cestos, bicicleteros etc), lluminación, Señalética (Cartelería, planos de ubicación), Sanitarios

Mobiliario (bancos, cestos, bicicleteros etc), lluminación, Señalética (Cartelería, planos de ubicación), Sanitarios 


\begin{tabular}{|c|c|c|c|c|c|c|c|c|c|}
\hline 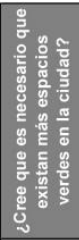 & 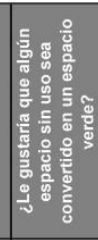 & 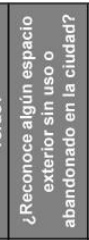 & ¿Cuál? & 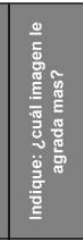 & 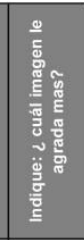 & 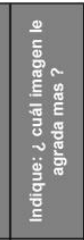 & 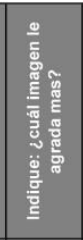 & \begin{tabular}{|c} 
¿Cuál es el medio \\
de transporte que \\
más utiliza?
\end{tabular} & 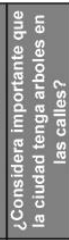 \\
\hline & & & & & & & & & \\
\hline Si & $\mathrm{Si}$ & si & la cantera de hernandez & Opción 2 & Opción 2 & Opción 2 & Opción 2 & Camino & Si \\
\hline Si & si & No & & Opción 1 & Opción 2 & Opción 1 & Opción 2 & Bicicleta & Si \\
\hline No & No & No & & Opción 1 & Opción 2 & Opción 1 & Opción 2 & Bicicleta & Si \\
\hline Si & $\mathrm{si}$ & si & Paralelo a la via del tren gonnet- villa elisa & Opción 2 & Opción 2 & Opción 1 & Opción 2 & Camino & si \\
\hline Si & si & Si & espacios de alrededores de hiper mercados & Opción 1 & Opción 2 & Opción 1 & Opción 2 & Transporte público & Si \\
\hline No & No & No & & Opción 2 & Opción 1 & Opción 2 & Opción 1 & Transporte público & si \\
\hline No & si & No & & Opción 1 & Opción 2 & Opción 1 & Opción 2 & Camino & si \\
\hline Si & si & No & & Opción 1 & Opción 2 & Opción 1 & Opción 2 & Bicicleta & si \\
\hline No & Si & No & & Opción 1 & Opción 2 & Opción 1 & Opción 2 & Vehiculo particular & $\mathrm{Si}$ \\
\hline Si & Si & No & & Opción 1 & Opción 2 & Opción 1 & Opción 1 & Camino & Si \\
\hline No & si & No & & Opción 1 & Opción 2 & Opción 1 & Opción 2 & Camino & Si \\
\hline Si & $\mathrm{si}$ & Si & muchos tramos de la rambla de circunvalacion & Opción 1 & Opción 2 & Opción 1 & Opción 2 & Camino & Si \\
\hline Si & No & No & & Opción 1 & Opción 2 & Opción 1 & Opción 2 & Transporte público & si \\
\hline Si & si & si & Hay un estacionamiento de una manzana en calle 48 y 3 , tiene uso porque estacionan autos de dia, pero de & Opción 1 & Opción 2 & Opción 1 & Opción 2 & Vehiculo particular & $\mathrm{Si}$ \\
\hline No & $\mathrm{Si}$ & si & Plaza en Los Hornos 150 y 66 & Opción 1 & Opción 2 & Opción 1 & Opción 2 & Bicicleta & Si \\
\hline No & $\mathrm{si}$ & Si & & Opción 1 & Opción 2 & Opción 1 & Opción 2 & Transporte público & Si \\
\hline No & No & No & & Opción 1 & Opción 1 & Opción 1 & Opción 1 & Transporte público & Si \\
\hline Si & $\mathrm{si}$ & No & & Opción 1 & Opción 2 & Opción 1 & Opción 2 & Vehiculo particular & $\mathrm{si}$ \\
\hline Si & si & No & & Opción 1 & Opción 1 & Opción 1 & Opción 1 & Camino & si \\
\hline No & Si & No & & Opción 1 & Opción 2 & Opción 1 & Opción 2 & Transporte público & Si \\
\hline Si & si & Si & Terreno baldio en 21d y 417 & Opción 1 & Opción 2 & Opción 2 & Opción 2 & Vehiculo particular & si \\
\hline Si & si & No & & Opción 1 & Opción 2 & Opción 1 & Opción 2 & Camino & Si \\
\hline Si & si & No & & Opción 2 & Opción 2 & Opción 1 & Opción 1 & Vehiculo particular & Si \\
\hline No & No & No & & Opción 1 & Opción 2 & Opción 1 & Opción 2 & Bicicleta & Si \\
\hline No & si & Sí & Silos de 1 y 57 . En 44 y 4 . Estacionamiento en 4 y 48. & Opción 1 & Opción 2 & Opción 2 & Opción 2 & Transporte público & Si \\
\hline Si & si & No & & Opción 1 & Opción 2 & Opción 1 & Opción 2 & Camino & si \\
\hline Si & $\mathrm{si}$ & si & El lote cerca de 3 y 48 & Opción 1 & Opción 1 & Opción 1 & Opción 1 & Vehiculo particular & $\mathrm{si}$ \\
\hline No & Si & No & & Opción 2 & Opción 2 & Opción 1 & Opción 2 & Bicicleta & $\mathrm{si}$ \\
\hline Si & Si & si & Los costados del arroyo el gato. Rambla de 520 & Opción 1 & Opción 2 & Opción 1 & Opción 2 & Bicicleta & $\mathrm{Si}$ \\
\hline No & si & No & & Opción 2 & Opción 1 & Opción 1 & Opción 2 & Transporte público & Si \\
\hline Si & si & No & & Opción 2 & Opción 2 & Opción 1 & Opción 2 & Transporte público & Si \\
\hline No & si & No & & Opción 1 & Opción 2 & Opción 1 & Opción 2 & Transporte público & $\mathrm{si}$ \\
\hline No & si & No & & Opción 1 & Opción 2 & Opciön 1 & Opción 2 & Camino & $\mathrm{si}$ \\
\hline Si & $\mathrm{Si}$ & si & & Opción 1 & Opción 2 & Opción 1 & Opción 2 & Transporte público & Si \\
\hline Si & si & Si & Gambier. Estacion Tolosa. Avenida 90. Aeropuerto. & Opción 1 & Opción 2 & Opción 1 & Opción 2 & Camino & si \\
\hline Si & si & No & & Opción 1 & Opción 2 & Opción 2 & Opción 2 & Camino & si \\
\hline Si & si & No & & Opción 1 & Opción 2 & Opción 1 & Opción 2 & Camino & Si \\
\hline Si & $\mathrm{si}$ & No & & Opciōn 2 & Opción 1 & Opción 2 & Opción 2 & Vehiculo particular & $\mathrm{si}$ \\
\hline Si & si & Sí & Las plazoletas & Opción 1 & Opción 1 & Opción 1 & Opción 1 & Bicicleta & Si \\
\hline Si & si & sí & Los margenes de los arroyos y vias & Opción 1 & Opción 2 & Opción 1 & Opción 2 & Bicicleta & Si \\
\hline Si & si & si & el viejo mercado & Opción 1 & Opción 2 & Opción 2 & Opción 2 & Transporte público & si \\
\hline Si & si & No & & Opción 1 & Opción 2 & Opción 1 & Opción 2 & Transporte público & si \\
\hline Si & Si & Si & Estacionamiento del viejo mercado ( 4 y 49 ) & Opción 1 & Opción 2 & Opción 1 & Opción 2 & Bicicleta & Si \\
\hline Si & si & si & Todos & Opción 1 & Opción 2 & Opción 1 & Opción 2 & Transporte público & si \\
\hline No & si & No & & Opción 1 & Opción 2 & Opción 1 & Opción 2 & Transporte público & Si \\
\hline No & No & No & & Opción 1 & Opción 2 & Opción 1 & Opción 2 & Transporte público & si \\
\hline Si & $\mathrm{si}$ & si & Galpones de 19 y 71 & Opción 1 & Opción 2 & Opción 2 & Opción 2 & Vehiculo particular & Si \\
\hline Si & $\mathrm{si}$ & No & & Opción 2 & Opción 1 & Opción 1 & Opción 2 & Camino & Si \\
\hline Si & si & si & Hay varios edificios abandonados alrededor del casco centrico & Opción 1 & Opción 2 & Opción 2 & Opción 2 & Transporte público & Si \\
\hline No & No & No & & Opción 1 & Opción 2 & Opción 1 & Opción 1 & Vehiculo particular & Si \\
\hline Si & si & No & & Opción 2 & Opción 1 & Opción 1 & Opción 2 & Camino & si \\
\hline Si & si & No & & Opción 2 & Opción 2 & Opción 2 & Opción 2 & Camino & si \\
\hline No & si & si & la manzana de $48,49,3$ y 4 . & Opción 1 & Opción 2 & Opción 1 & Opción 2 & Vehiculo particular & si \\
\hline Si & si & No & & Opción 2 & Opción 2 & Opción 1 & Opción 1 & Bicicleta & SI \\
\hline Si & si & si & En La periferia, un montón & Opción 2 & Opción 1 & Opción 1 & Opción 2 & Vehiculo particular & si \\
\hline Si & No & No & & Opción 1 & Opción 2 & Opción 2 & Opción 2 & Bicicleta & Si \\
\hline Si & Si & No & & Opción 2 & Opción 2 & Opción 2 & Opción 2 & Transporte público & Si \\
\hline No & si & Si & Las canteras & Opción 2 & Opción 1 & Opción 2 & Opción 1 & Transporte público & Si \\
\hline Si & si & si & Antiguo Mercado & Opción 1 & Opción 2 & Opción 1 & Opción 1 & Transporte público & Si \\
\hline Si & si & No & & Opción 1 & Opción 2 & Opción 1 & Opción 2 & Vehiculo particular & si \\
\hline No & si & sí & la zona ferroviaria de la estacion de tolosa & Opción 1 & Opción 2 & Opción 1 & Opción 1 & Camino & Si \\
\hline Si & $\mathrm{si}$ & si & el ex nini sobre calle 32 & Opción 1 & Opción 2 & Opción 1 & Opción 2 & Camino & $\mathrm{Si}$ \\
\hline No & si & No & & Opción 2 & Opción 2 & Opción 1 & Opción 2 & Camino & Si \\
\hline Si & si & No & & Opción 1 & Opción 2 & Opción 2 & Opción 2 & Vehiculo particular & si \\
\hline Si & si & No & & Opción 1 & Opción 1 & Opción 1 & Opción 2 & \begin{tabular}{|l|} 
Bicicleta \\
\end{tabular} & si \\
\hline Si & si & si & El ex mercado y todos los vacios ferroviarios & Opción 1 & Opción 2 & Opción 2 & Opción 2 & Transporte público & si \\
\hline Si & $\mathrm{si}$ & No & & Opción 1 & Opción 1 & Opción 1 & Opción 2 & Transporte público & $\mathrm{Si}$ \\
\hline Si & si & No & & Opción 1 & Opción 2 & Opción 1 & Opción 2 & Vehiculo particular & $\mathrm{si}$ \\
\hline Si & si & No & & Opción 2 & Opción 2 & Opción 2 & Opción 2 & Camino & $\mathrm{Si}$ \\
\hline Si & $\mathrm{si}$ & si & La manzana de 49 y 48 entre 4 y 5 & Opción 1 & Opción 2 & Opción 1 & Opción 2 & Camino & Si \\
\hline Si & Si & No & & Opción 1 & Opción 2 & Opción 1 & Opción 2 & Vehiculo particular & Si \\
\hline Si & si & No & & Opción 1 & Opción 2 & Opción 1 & Opción 2 & Vehiculo particular & Si \\
\hline Si & Si & Si & calles. 143 a 145 y de 46 a 47 & Opción 1 & Opción 2 & Opción 2 & Opción 2 & Vehiculo particular & Si \\
\hline No & si & si & La plaza San Martin & Opción 1 & Opcion 2 & Opción 1 & Opción 2 & Camino & si \\
\hline Si & Si & Si & El viejo NINI 32/ 26y27 & Opción 1 & Opción 2 & Opción 2 & Opción 2 & Vehiculo particular & Si \\
\hline Si & $\mathrm{si}$ & si & 72 e 19 y 22 & Opción 2 & Opción 2 & Opción 1 & Opción 2 & Bicicleta & Si \\
\hline No & si & No & & Opción 1 & Opción 1 & Opción 2 & Opción 2 & Transporte público & Si \\
\hline No & No & No & & Opción 2 & Opción 1 & Opción 1 & Opción 2 & Transporte público & Si \\
\hline Si & Si & si & & Opción 1 & Opción 2 & Opción 1 & Opción 2 & Transporte público & si \\
\hline Si & si & No & & Opción 1 & Opción 2 & Opción 1 & Opción 2 & Vehiculo particular & si \\
\hline No & No & No & & Opción 1 & Opción 1 & Opción 1 & Opción 2 & Camino & Si \\
\hline Si & si & Si & En mi loteo hay un espacio destinado a espacio verde & Opción 1 & Opción 2 & Opción 1 & Opción 2 & Camino & $\mathrm{Si}$ \\
\hline No & si & No & & Opción 2 & Opción 2 & Opción 1 & Opción 2 & Vehiculo particular & Si \\
\hline No & si & No & & Opción 1 & Opción 1 & Opción 1 & Opción 2 & Camino & $\mathrm{si}$ \\
\hline Si & si & si & Debajo del distribuidor de la entrada a la ciudad & Opción 1 & Opción 2 & Opción 2 & Opción 2 & Vehiculo particular & Si \\
\hline Si & si & Sí & rambla a la altura de 32 y 115,116 aprox. esta abandonado. & Opción 1 & Opción 2 & Opción 1 & Opción 2 & Bicicleta & Si \\
\hline Si & Si & No & & Opción 1 & Opción 2 & Opción 2 & Opción 1 & Bicicleta & Si \\
\hline
\end{tabular}




\begin{tabular}{|c|c|}
\hline $\mathrm{SI}$ & SI \\
\hline No & $\mathrm{Si}$ \\
\hline $\mathrm{Si}$ & $\mathrm{Si}$ \\
\hline No & $\mathrm{SI}$ \\
\hline Si & $\mathrm{Si}$ \\
\hline $\mathrm{Si}$ & $\mathrm{Si}$ \\
\hline No & $\mathrm{Si}$ \\
\hline No & $\mathrm{si}$ \\
\hline $\mathrm{Si}$ & $\mathrm{Si}$ \\
\hline No & $\mathrm{Si}$ \\
\hline $\mathrm{Si}$ & $\mathrm{SI}$ \\
\hline Si & $\mathrm{Si}$ \\
\hline $\mathrm{SI}$ & $\mathrm{Si}$ \\
\hline $\mathrm{Si}$ & $\mathrm{Si}$ \\
\hline $\mathrm{SI}$ & $\mathrm{Si}$ \\
\hline $\mathrm{Si}$ & $\mathrm{Si}$ \\
\hline Si & $\mathrm{Si}$ \\
\hline $\mathrm{Si}$ & $\mathrm{Si}$ \\
\hline No & $\mathrm{Si}$ \\
\hline $\mathrm{SI}$ & Si \\
\hline $\mathrm{Si}$ & $\mathrm{Si}$ \\
\hline $\mathrm{Si}$ & No \\
\hline No & $\mathrm{Si}$ \\
\hline No & No \\
\hline No & $\mathrm{si}$ \\
\hline $\mathrm{Si}$ & $\mathrm{Si}$ \\
\hline Si & No \\
\hline $\mathrm{SI}$ & $\mathrm{SI}$ \\
\hline $\begin{array}{l}\text { No } \\
\end{array}$ & \begin{tabular}{|l|} 
No \\
\end{tabular} \\
\hline No & $\mathrm{Si}$ \\
\hline $\mathrm{Si}$ & Si \\
\hline Si & $\mathrm{Si}$ \\
\hline No & $\mathrm{Si}$ \\
\hline No & Si \\
\hline No & $\mathrm{SI}$ \\
\hline No & $\mathrm{Si}$ \\
\hline $\mathrm{SI}$ & SI \\
\hline No & $\mathrm{Si}$ \\
\hline $\mathrm{Si}$ & No \\
\hline No & No \\
\hline $\mathrm{Si}$ & $\mathrm{Si}$ \\
\hline $\mathrm{Si}$ & $\mathrm{Si}$ \\
\hline Si & Si \\
\hline $\mathrm{Si}$ & Si \\
\hline $\mathrm{Si}$ & $\mathrm{Si}$ \\
\hline $\mathrm{Si}$ & $\mathrm{Si}$ \\
\hline $\mathrm{Si}$ & No \\
\hline Si & Si \\
\hline $\mathrm{SI}$ & $\mathrm{Si}$ \\
\hline $\mathrm{Si}$ & $\mathrm{Si}$ \\
\hline Si & $\mathrm{Si}$ \\
\hline \begin{tabular}{|l} 
No \\
\end{tabular} & $\mathrm{Si}$ \\
\hline $\mathrm{Si}$ & $\mathrm{Si}$ \\
\hline $\mathrm{Si}$ & Si \\
\hline $\mathrm{Si}$ & $\mathrm{Si}$ \\
\hline Si & Si \\
\hline \begin{tabular}{|l} 
No \\
\end{tabular} & $\mathrm{Si}$ \\
\hline \begin{tabular}{|l} 
No \\
\end{tabular} & $\mathrm{Si}$ \\
\hline $\mathrm{Si}$ & Si \\
\hline $\mathrm{SI}$ & $\mathrm{si}$ \\
\hline \begin{tabular}{|l} 
No \\
\end{tabular} & Si \\
\hline \begin{tabular}{|l} 
No \\
\end{tabular} & $\mathrm{Si}$ \\
\hline \begin{tabular}{|l} 
No \\
\end{tabular} & $\mathrm{Si}$ \\
\hline \begin{tabular}{|l} 
No \\
\end{tabular} & $\mathrm{Si}$ \\
\hline $\mathrm{Si}$ & $\mathrm{Si}$ \\
\hline \begin{tabular}{|l} 
No \\
\end{tabular} & Si \\
\hline \begin{tabular}{|l} 
No \\
\end{tabular} & $\mathrm{Si}$ \\
\hline $\mathrm{Si}$ & $\mathrm{Si}$ \\
\hline $\mathrm{Si}$ & $\mathrm{Si}$ \\
\hline $\begin{array}{ll}\mathrm{Si} \\
\end{array}$ & $\mathrm{Si}$ \\
\hline \begin{tabular}{|l} 
No \\
\end{tabular} & Si \\
\hline No & $\mathrm{SI}$ \\
\hline $\mathrm{Si}$ & No \\
\hline SI & $\mathrm{SI}$ \\
\hline $\mathrm{Si}$ & $\mathrm{si}$ \\
\hline Si & Si \\
\hline $\mathrm{Si}$ & $\mathrm{Si}$ \\
\hline $\mathrm{Si}$ & Si \\
\hline $\mathrm{Si}$ & $\mathrm{Si}$ \\
\hline $\mathrm{Si}$ & Si \\
\hline SI & $\mathrm{Si}$ \\
\hline \begin{tabular}{|l} 
No \\
\end{tabular} & $\mathrm{Si}$ \\
\hline \begin{tabular}{|l} 
No \\
\end{tabular} & $\mathrm{Si}$ \\
\hline $\mathrm{Si}$ & $\mathrm{Si}$ \\
\hline $\begin{array}{l}\text { No } \\
\end{array}$ & $\mathrm{Si}$ \\
\hline $\begin{array}{l}\text { No } \\
\end{array}$ & $\mathrm{Si}$ \\
\hline $\mathrm{Si}$ & Si \\
\hline \begin{tabular}{|l} 
Si \\
\end{tabular} & Si \\
\hline $\mathrm{Si}$ & Si \\
\hline $\mathrm{Si}$ & $\mathrm{Si}$ \\
\hline \begin{tabular}{|l} 
No \\
\end{tabular} & $\mathrm{Si}$ \\
\hline $\mathrm{Si}$ & $\mathrm{Si}$ \\
\hline SI & Si \\
\hline $\mathrm{Si}$ & Si \\
\hline $\mathrm{Si}$ & $\mathrm{si}$ \\
\hline No & Si \\
\hline Si & Si \\
\hline
\end{tabular}




\begin{tabular}{|c|c|}
\hline $\mathrm{SI}$ & $\mathrm{SI}$ \\
\hline Si & $\mathrm{Si}$ \\
\hline$S i$ & No \\
\hline No & $\mathrm{Si}$ \\
\hline No & Si \\
\hline Si & Si \\
\hline$S i$ & Si \\
\hline$S i$ & $\mathrm{si}$ \\
\hline Si & Si \\
\hline Si & Si \\
\hline Si & Si \\
\hline \begin{tabular}{|l} 
No \\
\end{tabular} & $\mathrm{Si}$ \\
\hline Si & $\mathrm{Si}$ \\
\hline $\begin{array}{l}\text { No } \\
\end{array}$ & $\mathrm{SI}$ \\
\hline \begin{tabular}{|l|}
$S i$ \\
\end{tabular} & $\mathrm{Si}$ \\
\hline \begin{tabular}{|l|} 
No \\
\end{tabular} & No \\
\hline No & $\mathrm{Si}$ \\
\hline Si & Si \\
\hline Si & $\mathrm{Si}$ \\
\hline \begin{tabular}{|l|} 
No \\
\end{tabular} & $\mathrm{si}$ \\
\hline \begin{tabular}{|l} 
No \\
\end{tabular} & $\mathrm{Si}$ \\
\hline \begin{tabular}{|l|}
$S I$ \\
\end{tabular} & $\mathrm{si}$ \\
\hline $\mathrm{Si}$ & $\mathrm{Si}$ \\
\hline$S i$ & $\mathrm{Si}$ \\
\hline Si & Si \\
\hline Si & $\mathrm{Si}$ \\
\hline No & $\mathrm{SI}$ \\
\hline $\mathrm{Si}$ & $\mathrm{Si}$ \\
\hline$S i$ & $\mathrm{Si}$ \\
\hline $\mathrm{Si}$ & $\mathrm{Si}$ \\
\hline Si & Si \\
\hline Si & Si \\
\hline Si & $\mathrm{SI}$ \\
\hline \begin{tabular}{|l|} 
No \\
\end{tabular} & No \\
\hline $\mathrm{Si}$ & $\mathrm{Si}$ \\
\hline$S i$ & $\mathrm{si}$ \\
\hline $\mathrm{Si}$ & $\mathrm{Si}$ \\
\hline Si & $\mathrm{Si}$ \\
\hline $\mathrm{Si}$ & Si \\
\hline $\mathrm{Si}$ & $\mathrm{Si}$ \\
\hline No & Si \\
\hline $\mathrm{Si}$ & Si \\
\hline \begin{tabular}{|l|} 
No \\
\end{tabular} & $\mathrm{si}$ \\
\hline $\mathrm{Si}$ & $\mathrm{Si}$ \\
\hline Si & $\mathrm{Si}$ \\
\hline $\mathrm{Si}$ & Si \\
\hline Si & $\mathrm{Si}$ \\
\hline $\mathrm{Si}$ & $\mathrm{Si}$ \\
\hline $\mathrm{Si}$ & $\mathrm{Si}$ \\
\hline Si & $\mathrm{Si}$ \\
\hline $\mathrm{Si}$ & $\mathrm{si}$ \\
\hline Si & Si \\
\hline No & Si \\
\hline \begin{tabular}{|l} 
No \\
\end{tabular} & $\mathrm{Si}$ \\
\hline $\mathrm{Si}$ & $\mathrm{Si}$ \\
\hline \begin{tabular}{|l} 
No \\
\end{tabular} & $\mathrm{Si}$ \\
\hline$S i$ & $\mathrm{si}$ \\
\hline \begin{tabular}{|l} 
No \\
\end{tabular} & $\mathrm{Si}$ \\
\hline $\mathrm{Si}$ & $\mathrm{Si}$ \\
\hline \begin{tabular}{|l|} 
No \\
\end{tabular} & $\mathrm{Si}$ \\
\hline Si & $\mathrm{Si}$ \\
\hline Si & Si \\
\hline $\mathrm{Si}$ & si \\
\hline Si & $\mathrm{Si}$ \\
\hline Si & Si \\
\hline Si & $\mathrm{Si}$ \\
\hline Si & $\mathrm{si}$ \\
\hline $\mathrm{Si}$ & $\mathrm{Si}$ \\
\hline Si & No \\
\hline $\mathrm{Si}$ & $\mathrm{Si}$ \\
\hline $\mathrm{Si}$ & $\mathrm{Si}$ \\
\hline No & $\mathrm{si}$ \\
\hline Si & $\mathrm{Si}$ \\
\hline Si & Si \\
\hline $\mathrm{Si}$ & $\mathrm{Si}$ \\
\hline Si & $\mathrm{Si}$ \\
\hline Si & $\mathrm{Si}$ \\
\hline$S i$ & si \\
\hline No & $\mathrm{Si}$ \\
\hline $\mathrm{Si}$ & $\mathrm{si}$ \\
\hline No & $\mathrm{si}$ \\
\hline Si & $\mathrm{Si}$ \\
\hline Si & si \\
\hline Si & $\mathrm{si}$ \\
\hline \begin{tabular}{|l|} 
No \\
\end{tabular} & No \\
\hline $\mathrm{Si}$ & $\mathrm{si}$ \\
\hline $\mathrm{Si}$ & $\mathrm{Si}$ \\
\hline $\mathrm{Si}$ & $\mathrm{Si}$ \\
\hline $\mathrm{Si}$ & $\mathrm{Si}$ \\
\hline No & No \\
\hline $\mathrm{Si}$ & Si \\
\hline$S i$ & $\mathrm{Si}$ \\
\hline $\mathrm{Si}$ & si \\
\hline No & $\mathrm{Si}$ \\
\hline \begin{tabular}{|l|} 
No \\
\end{tabular} & Si \\
\hline Si & Si \\
\hline \begin{tabular}{|l|} 
No \\
\end{tabular} & Si \\
\hline
\end{tabular}




\begin{tabular}{|c|c|}
\hline No & $\mathrm{SI}$ \\
\hline No & No \\
\hline $\mathrm{Si}$ & si \\
\hline No & Si \\
\hline No & $\mathrm{Si}$ \\
\hline $\mathrm{Si}$ & $\mathrm{Si}$ \\
\hline No & $\mathrm{si}$ \\
\hline No & $\mathrm{si}$ \\
\hline $\mathrm{Si}$ & $\mathrm{Si}$ \\
\hline No & Si \\
\hline $\mathrm{Si}$ & Si \\
\hline$S i$ & Si \\
\hline No & No \\
\hline No & Si \\
\hline No & si \\
\hline No & No \\
\hline No & No \\
\hline No & Si \\
\hline $\mathrm{Si}$ & No \\
\hline No & si \\
\hline $\mathrm{Si}$ & Si \\
\hline SI & Si \\
\hline Si & Si \\
\hline No & Si \\
\hline No & $\mathrm{si}$ \\
\hline $\mathrm{Si}$ & No \\
\hline Si & $\mathrm{Si}$ \\
\hline$S i$ & Si \\
\hline No & Si \\
\hline No & No \\
\hline No & $\mathrm{Si}$ \\
\hline $\mathrm{Si}$ & $\mathrm{Si}$ \\
\hline Si & Si \\
\hline $\mathrm{Si}$ & si \\
\hline No & $\mathrm{Si}$ \\
\hline No & si \\
\hline No & No \\
\hline & \\
\hline $\mathrm{Si}$ & No \\
\hline No & $\mathrm{Si}$ \\
\hline No & si \\
\hline No & No \\
\hline $\mathrm{SI}$ & Si \\
\hline No & Si \\
\hline$S i$ & si \\
\hline $\mathrm{Si}$ & si \\
\hline $\mathrm{Si}$ & $\mathrm{Si}$ \\
\hline $\mathrm{Si}$ & $\mathrm{Si}$ \\
\hline Si & No \\
\hline $\mathrm{Si}$ & si \\
\hline No & $\mathrm{Si}$ \\
\hline No & $\mathrm{si}$ \\
\hline No & $\mathrm{Si}$ \\
\hline$S i$ & $\mathrm{Si}$ \\
\hline No & Si \\
\hline No & Si \\
\hline No & $\mathrm{SI}$ \\
\hline No & No \\
\hline No & No \\
\hline No & No \\
\hline No & No \\
\hline No & si \\
\hline $\mathrm{Si}$ & Si \\
\hline $\mathrm{Si}$ & si \\
\hline $\mathrm{Si}$ & $\mathrm{si}$ \\
\hline Si & $\mathrm{Si}$ \\
\hline Si & Si \\
\hline Si & Si \\
\hline$S i$ & Si \\
\hline $\mathrm{Si}$ & $\mathrm{Si}$ \\
\hline $\mathrm{Si}$ & $\mathrm{Si}$ \\
\hline $\mathrm{Si}$ & Si \\
\hline Si & Si \\
\hline $\mathrm{Si}$ & $\mathrm{Si}$ \\
\hline $\mathrm{Si}$ & $\mathrm{Si}$ \\
\hline Si & $\mathrm{Si}$ \\
\hline $\mathrm{Si}$ & $\mathrm{Si}$ \\
\hline Si & $\mathrm{si}$ \\
\hline$S i$ & $\mathrm{Si}$ \\
\hline $\mathrm{Si}$ & $\mathrm{si}$ \\
\hline $\mathrm{SI}$ & $\mathrm{si}$ \\
\hline Si & Si \\
\hline $\mathrm{Si}$ & Si \\
\hline$S i$ & si \\
\hline $\mathrm{Si}$ & $\mathrm{si}$ \\
\hline $\mathrm{Si}$ & $\mathrm{Si}$ \\
\hline $\mathrm{Si}$ & Si \\
\hline $\mathrm{SI}$ & $\mathrm{Si}$ \\
\hline$S i$ & $\mathrm{si}$ \\
\hline $\mathrm{Si}$ & $\mathrm{si}$ \\
\hline $\mathrm{SI}$ & $\mathrm{Si}$ \\
\hline $\mathrm{Si}$ & Si \\
\hline Si & $\mathrm{Si}$ \\
\hline $\mathrm{Si}$ & Si \\
\hline $\mathrm{Si}$ & si \\
\hline Si & Si \\
\hline $\mathrm{Si}$ & si \\
\hline
\end{tabular}




\begin{tabular}{|c|c|}
\hline $\mathrm{SI}$ & $\mathrm{SI}$ \\
\hline Si & Si \\
\hline Si & $\mathrm{Si}$ \\
\hline Si & $\mathrm{Si}$ \\
\hline$S i$ & $\mathrm{Si}$ \\
\hline $\mathrm{Si}$ & $\mathrm{Si}$ \\
\hline Si & Si \\
\hline Si & $\mathrm{Si}$ \\
\hline Si & Si \\
\hline Si & $\mathrm{Si}$ \\
\hline Si & Si \\
\hline Si & Si \\
\hline $\mathrm{Si}$ & Si \\
\hline$S i$ & $\mathrm{Si}$ \\
\hline \begin{tabular}{|l|}
$S i$ \\
\end{tabular} & $\mathrm{Si}$ \\
\hline $\mathrm{Si}$ & $\mathrm{Si}$ \\
\hline$S i$ & $\mathrm{Si}$ \\
\hline Si & Si \\
\hline$S i$ & Si \\
\hline$S i$ & Si \\
\hline Si & Si \\
\hline Si & Si \\
\hline $\mathrm{Si}$ & $\mathrm{Si}$ \\
\hline$S i$ & $\mathrm{Si}$ \\
\hline$S i$ & si \\
\hline $\mathrm{Si}$ & $\mathrm{Si}$ \\
\hline$S i$ & $\mathrm{Si}$ \\
\hline \begin{tabular}{|l} 
No \\
\end{tabular} & $\mathrm{Si}$ \\
\hline No & Si \\
\hline$S i$ & $\mathrm{Si}$ \\
\hline Si & Si \\
\hline Si & No \\
\hline No & $\mathrm{Si}$ \\
\hline \begin{tabular}{|l|} 
No \\
\end{tabular} & $\mathrm{si}$ \\
\hline $\mathrm{Si}$ & Si \\
\hline No & No \\
\hline Si & $\mathrm{Si}$ \\
\hline Si & Si \\
\hline$S i$ & $\mathrm{Si}$ \\
\hline$S i$ & Si \\
\hline \begin{tabular}{|l|} 
No \\
\end{tabular} & $\mathrm{Si}$ \\
\hline Si & Si \\
\hline$S i$ & $\mathrm{Si}$ \\
\hline No & $\mathrm{si}$ \\
\hline$S i$ & No \\
\hline No & $\mathrm{Si}$ \\
\hline $\mathrm{Si}$ & $\mathrm{Si}$ \\
\hline \begin{tabular}{|l|} 
No \\
\end{tabular} & $\mathrm{si}$ \\
\hline$S i$ & $\mathrm{Si}$ \\
\hline No & Si \\
\hline$S i$ & $\mathrm{Si}$ \\
\hline Si & Si \\
\hline$S i$ & $\mathrm{Si}$ \\
\hline Si & $\mathrm{Si}$ \\
\hline$S i$ & No \\
\hline$S i$ & No \\
\hline Si & No \\
\hline$S i$ & No \\
\hline $\mathrm{Si}$ & No \\
\hline \begin{tabular}{|l|} 
No \\
\end{tabular} & $\mathrm{Si}$ \\
\hline No & Si \\
\hline No & Si \\
\hline No & si \\
\hline \begin{tabular}{|l|} 
No \\
\end{tabular} & $\mathrm{si}$ \\
\hline \begin{tabular}{|l|} 
No \\
\end{tabular} & $\mathrm{si}$ \\
\hline \begin{tabular}{|l|} 
No \\
\end{tabular} & $\mathrm{Si}$ \\
\hline No & si \\
\hline$S i$ & $\mathrm{si}$ \\
\hline Si & $\mathrm{Si}$ \\
\hline$S i$ & $\mathrm{si}$ \\
\hline $\mathrm{Si}$ & si \\
\hline$S i$ & Si \\
\hline Si & Si \\
\hline $\mathrm{Si}$ & Si \\
\hline$S i$ & Si \\
\hline $\mathrm{Si}$ & Si \\
\hline$S i$ & $S i$ \\
\hline $\mathrm{Si}$ & si \\
\hline Si & $\mathrm{Si}$ \\
\hline $\mathrm{Si}$ & Si \\
\hline $\mathrm{Si}$ & $\mathrm{Si}$ \\
\hline \begin{tabular}{|l|}
$S i$ \\
\end{tabular} & si \\
\hline $\mathrm{Si}$ & si \\
\hline Si & Si \\
\hline Si & Si \\
\hline $\mathrm{Si}$ & Si \\
\hline $\mathrm{Si}$ & Si \\
\hline$S i$ & Si \\
\hline $\mathrm{Si}$ & $\mathrm{Si}$ \\
\hline $\mathrm{Si}$ & Si \\
\hline$S i$ & $\mathrm{si}$ \\
\hline$S i$ & $\mathrm{si}$ \\
\hline$S I$ & Si \\
\hline Si & Si \\
\hline Si & Si \\
\hline SI & $\mathrm{si}$ \\
\hline$S i$ & Si \\
\hline
\end{tabular}




\begin{tabular}{|c|c|c|c|c|c|c|c|c|c|}
\hline Si & Sí & No & & Opción 2 & Opción 2 & Opción 1 & 1 Opción 2 & Transporte público & si \\
\hline Si & si & No & & Opción 2 & Opción 2 & Opción 1 & 1 Opción 2 & Transporte público & si \\
\hline Si & Si & No & & Opción 2 & Opción 2 & Opción 1 & 1 Opción 2 & Transporte público & Si \\
\hline Si & Si & No & & Opción 2 & Opción 2 & Opción 1 & 1 Opción 2 & Transporte público & si \\
\hline Si & Si & Si & la cantera de hernandez & Opción 1 & Opción 2 & Opción 1 & 1 Opción 2 & Vehiculo particular & Si \\
\hline Si & Si & Si & la cantera de hernandez & Opción 1 & Opción 2 & Opción 1 & 1 Opción 2 & Vehiculo particular & $S i$ \\
\hline Sí & Si & Si & la cantera de hernandez & Opción 1 & Opción 2 & Opción 1 & 1 Opción 2 & Vehiculo particular & Si \\
\hline Si & si & si & la cantera de hernandez & Opción 1 & Opción 2 & Opción 1 & 1 Opción 2 & Vehiculo particular & Si \\
\hline Si & Si & Si & la cantera de hernandez & Opción 1 & Opción 2 & Opción 1 & 1 Opción 2 & Vehiculo particular & Si \\
\hline Si & Sí & Si & la cantera de hernandez & Opción 1 & Opción 2 & Opción 1 & 1 Opción 2 & Vehiculo particular & Si \\
\hline Si & Si & No & & Opción 1 & Opción 2 & Opción 1 & 1 Opción 2 & Transporte público & Si \\
\hline Si & Si & Si & En La periferia, un montón & Opción 2 & Opción 1 & Opción 1 & 1 Opción 2 & Vehiculo particular & Sí \\
\hline No & Si & Si & El.viejo mercado & Opción 2 & Opción 1 & Opción 1 & 1 Opción 2 & Camino & Si \\
\hline Si & si & $\mathrm{si}$ & Camino Belgrano y 513 & Opción 1 & Opción 2 & Opción 1 & 1 Opción 2 & Transporte público & Si \\
\hline Si & Si & Si & Cava de gorina & Opción 1 & Opción 2 & Opción 2 & 2 Opción 2 & Bicicleta & Si \\
\hline Si & Si & Si & Camino Belgrano y 513 & Opción 1 & Opción 2 & Opción 1 & 1 Opción 2 & Transporte público & Si \\
\hline No & si & si & Teatro del Lago del Bosque & Opción 1 & Opción 2 & Opción 1 & 1 Opción 2 & Bicicleta & Si \\
\hline No & Si & Si & Teatro del Lago del Bosque & Opción 1 & Opción 2 & Opción 1 & 1 Opción 2 & Bicicleta & Si \\
\hline Si & Si & No & & Opción 2 & Opción 2 & Opción 1 & 1 Opción 2 & Vehiculo particular & Si \\
\hline Si & si & No & & Opción 2 & Opción 2 & Opción 1 & 1 Opción 2 & Vehiculo particular & Si \\
\hline Si & Si & $\mathrm{si}$ & Camino Belgrano y 513 & Opción 1 & Opción 2 & Opción 1 & 1 Opción 2 & Transporte público & Si \\
\hline No & Si & Si & El.viejo mercado & Opción 2 & Opción 1 & Opción 1 & 1 Opción 2 & Camino & Si \\
\hline $\mathrm{Si}$ & Si & $\mathrm{Si}$ & En La periferia, un montón & Opción 2 & Opción 1 & Opción 1 & 1 Opción 2 & Vehiculo particular & $\mathrm{Si}$ \\
\hline Sí & Si & No & & Opción 1 & Opción 2 & Opción 1 & 1 Opción 2 & Transporte público & Sí \\
\hline Si & Si & Si & En mi loteo hay un espacio destinado a espacio verde & Opción 1 & Opción 2 & Opción 1 & 1 Opción 2 & Camino & Si \\
\hline Si & Si & Si & En mi loteo hay un espacio destinado a espacio verde & Opción 1 & Opción 2 & Opción 1 & 1 Opción 2 & Camino & Si \\
\hline Si & Si & Si & En mi loteo hay un espacio destinado a espacio verde & Opción 1 & Opción 2 & Opción 1 & 1 Opción 2 & Camino & Si \\
\hline Si & Si & Si & La manzana del viejo mercado es un buen ejemplo de mal utilización. En las afueras hay muchos espacios d & Opción 2 & Opción 2 & Opción 1 & 1 Opción 2 & Bicicleta & Si \\
\hline Si & Si & Si & La manzana del viejo mercado es un buen ejemplo de mal utilización. En las afueras hay muchos espacios d & Opción 2 & Opción 2 & Opción 1 & 1 Opción 2 & Bicicleta & Si \\
\hline Si & Sí & Sí & La manzana del viejo mercado es un buen ejemplo de mal utilización. En las afueras hay muchos espacios df & Opción 2 & Opción 2 & Opción 1 & 1 Opción 2 & Bicicleta & Sí \\
\hline Si & Si & No & & Opción 1 & Opción 2 & Opción 1 & 1 Opción 2 & Bicicleta & Si \\
\hline Si & Si & No & & Opción 1 & Opción 2 & Opción 1 & 1 Opción 2 & Bicicleta & $\mathrm{Si}$ \\
\hline Si & Si & No & & Opción 1 & Opción 2 & Opción 1 & 1 Opción 2 & Bicicleta & $\mathrm{si}$ \\
\hline Si & Si & No & & Opción 1 & Opción 2 & Opción 1 & 1 Opción 2 & Bicicleta & Si \\
\hline Si & Si & No & & Opción 1 & Opción 2 & Opción 1 & 1 Opción 2 & Vehiculo particular & Si \\
\hline Si & Si & No & & Opción 1 & Opción 2 & Opción 1 & 1 Opción 2 & Vehiculo particular & Si \\
\hline Si & Si & $\mathrm{Si}$ & las canteras & Opción 1 & Opción 2 & Opción 2 & 2 Opción 2 & Vehiculo particular & $S i$ \\
\hline Si & $\mathrm{Si}$ & $\mathrm{Si}$ & las canteras & Opción 1 & Opción 2 & Opción 2 & 2 Opción 2 & Vehiculo particular & $\mathrm{Si}$ \\
\hline Si & Si & $\mathrm{Si}$ & las canteras & Opción 1 & Opción 2 & Opción 2 & 2 Opción 2 & Vehiculo particular & $S i$ \\
\hline Si & $\mathrm{Si}$ & Si & En realidad se usa de estacionamiento, pero estaría bueno que en 3 y 49 hubiera un espacio verde & Opción 1 & Opción 1 & Opción 1 & 1) Opción 1 & Vehiculo particular & $\mathrm{Si}$ \\
\hline
\end{tabular}


PAISAJES VACANTES

ANEXO 2 Arbolado urbano en La ciudad de La Plata 
A continuación, se identifican los tipos de árboles y las vías donde se encuentran.

Acacia Blanca: En calle 9 de 51 a 60 .

Aguaribay: Frente a la Universidad por avenida 7.

Alcanforero: Está en Plaza San Martín, Casa de Gobierno y facultad de Agronomía.

Árbol de lo 40 Escudos: En Avenida Iraola hasta el museo de Ciencias Naturales.

Árbol del Cielo: En calle 55 y zona céntrica de la ciudad.

Árbol de Judea: Calle 8 de 33 a 44.

Arce: En muchas Plazas de la ciudad.

Castañas de la India: En Avenida 51 de 1 a 2, en Plaza San Martín y jardines del Ministerio de Educación.

Ceibo: En el Lago del Bosque, Plaza San Martín y Plaza Moreno. Cabe mencionar que la flor del Ceibo es la flor Nacional de Argentina.

Eucaliptos: En los alrededores del Lago del Bosque y en todo el Paseos del Bosque y Jardín Zoológico.

Ibapoy: Frente al Museo de Ciencias Naturales.

Jacarandá: Diagonal 73 desde Plaza Rocha hasta plaza Azcuénaga.

Lapacho: En la calle 10 y en los ex Jardines del Teatro Argentino.

Magnolia: Plaza San Martín, Plaza Rivadavia y otros lugares.

Naranjos Amargos: En la Calle 47.

Olmo Europeo: Calle 5 de 44 a 60.

Ombú: Dos grandes ejemplares en Plaza Italia y Ministerio de Educación.

Patito Dulce: Calle 10 y frente al Museo de Ciencias Naturales.

Plátano: En calle 56, avenidas 13, 51, 53, 60 y Plaza Moreno.

Paraíso o Árbol de Paraíso: Plaza Belgrano, 38 y 13, Parque Castelli.

Parasol de China: Calle 56 de 1 a 3 y 8 de 45 a 51 .

Palo Borracho: Plaza Alte. Brown, Ministerio de Educación y otros lugares.

Pata de Vaca: Alrededor de la escuela Normal № 1, 50 y 15.

Roble: Parque Castelli, Museo de Ciencias Naturales, Plaza Rivadavia.

Tilo: En la avenida 7 y en otras calles de la ciudad.

Tipas: Diagonal 73 de Plaza Rocha a Plaza Matheu.

Tulipanero: Calle 10 de 49 a 60 .

Fuente:

Recuperado

de:

http://catalogo.datos.laplata.gov.ar/dataviews/241394/especies-de-arboles-en-la-

ciudad-de-la-plata/ . Fecha de captura: 15/08/17

Además de estas especies anteriormente mencionas existen variedades de pinos, cedros, cipreses, tuyas, abetos, álamos, etc. 
PAISAJES VACANTES

ANEXO 3

Relevamiento de los espacios verdes 
ANEXO 3

\begin{tabular}{|c|c|c|c|c|c|c|c|c|}
\hline \multicolumn{9}{|c|}{ EVUP CASCO FUNDACIONAL } \\
\hline ID & TIPO & ALCANCE & DOMINIO & $\begin{array}{c}\text { SUELO } \\
\text { ABSORBENTE }\end{array}$ & $\begin{array}{l}\text { PRESENCIA DE } \\
\text { AGUA }\end{array}$ & MOBILIARIO & ARBOLADO & AREA M12 \\
\hline 371 & 4 & 3 & 1 & 1 & 2 & 3 & 4 & 3827.673828 \\
\hline 372 & 4 & 3 & 1 & 1 & 2 & 3 & 4 & 3500,472658 \\
\hline 373 & 4 & 3 & 1 & 1 & 2 & 3 & 4 & 3610.923828 \\
\hline 374 & 4 & 3 & 1 & 1 & 2 & 3 & 4 & 3300,064453 \\
\hline 118 & 3 & 3 & 1 & 1 & 2 & 2 & 4 & 15483,84141 \\
\hline 140 & 4 & 3 & 1 & 1 & 2 & 2 & 2 & 18975,36523 \\
\hline 141 & 4 & 3 & 1 & 1 & 2 & 2 & 2 & 33896,00586 \\
\hline 142 & 4 & 3 & 1 & 1 & 2 & 3 & 4 & 12680,37108 \\
\hline 143 & 4 & 2 & 1 & 1 & 2 & 3 & 3 & 4394.226563 \\
\hline 144 & 4 & 2 & 1 & 1 & 2 & 2 & 2 & 30404,98828 \\
\hline 145 & 4 & 2 & 1 & 1 & 2 & 1 & 3 & 4430,611328 \\
\hline 146 & 4 & 2 & 1 & 1 & 2 & 2 & 3 & 5483,458984 \\
\hline 147 & 4 & 2 & 1 & 1 & 2 & 2 & 2 & 22739,30468 \\
\hline 148 & 4 & 2 & 1 & 1 & 2 & 2 & 1 & 6278.892578 \\
\hline 148 & 4 & 2 & 1 & 1 & 2 & 2 & 4 & 7282.226563 \\
\hline 150 & 3 & 3 & 1 & 1 & 2 & 1 & 4 & 3867.224600 \\
\hline 151 & 4 & 3 & 1 & 1 & 2 & 1 & 2 & 27048,56641 \\
\hline 152 & 4 & 3 & 1 & 1 & 2 & 2 & 3 & 6382,701172 \\
\hline 153 & 4 & 3 & 1 & 1 & 2 & 2 & 3 & 6703,576172 \\
\hline 154 & 4 & 3 & 1 & 1 & 2 & 3 & 3 & 27525,75 \\
\hline 155 & 4 & 3 & 1 & 1 & 2 & 3 & 3 & 6258.724600 \\
\hline 156 & 4 & 3 & 1 & 1 & 2 & 3 & 3 & 6393.134768 \\
\hline 157 & 4 & 3 & 1 & 1 & 2 & 1 & 3 & 17783,72852 \\
\hline 158 & 4 & 3 & 1 & 1 & 2 & 2 & 1 & 5601,086408 \\
\hline 158 & 4 & 3 & 1 & 1 & 2 & 2 & 1 & 5488,154297 \\
\hline 160 & 4 & 3 & 1 & 1 & 2 & 3 & 3 & 24533.07617 \\
\hline 181 & 4 & 3 & 1 & 1 & 2 & 3 & 3 & 5017,680453 \\
\hline 162 & 4 & 3 & 1 & 1 & 2 & 3 & 3 & 5022.435547 \\
\hline 163 & 4 & 3 & 1 & 1 & 2 & 3 & 2 & 16323,8457 \\
\hline 164 & 4 & 3 & 1 & 1 & 2 & 2 & 3 & 17067,78516 \\
\hline 166 & 4 & 3 & 1 & 1 & 2 & 2 & 3 & 33502,57617 \\
\hline 187 & 4 & 3 & 1 & 1 & 2 & 2 & 3 & 7453,044822 \\
\hline 168 & 4 & 3 & 1 & 1 & 2 & 2 & 3 & 6033,166016 \\
\hline 168 & 4 & 2 & 1 & 1 & 2 & 3 & 3 & 22028,99600 \\
\hline 170 & 4 & 2 & 1 & 1 & 1 & 1 & 1 & 13583,19822 \\
\hline 171 & 4 & 3 & 1 & 1 & 2 & 3 & 3 & 8462.244141 \\
\hline 172 & 4 & 2 & 1 & 1 & 2 & 3 & 3 & 32018,31838 \\
\hline 173 & 4 & 3 & 1 & 1 & 2 & 2 & 3 & 7524,632813 \\
\hline 174 & 4 & 3 & 1 & 1 & 2 & 2 & 3 & 7546,650381 \\
\hline 175 & 4 & 3 & 1 & 1 & 2 & 3 & 3 & 28264,98805 \\
\hline 176 & 3 & 3 & 1 & 1 & 2 & 3 & 3 & 32001,2793 \\
\hline 177 & 4 & 3 & 1 & 1 & 2 & 3 & 2 & 7507.544922 \\
\hline 178 & 4 & 2 & 1 & 1 & 2 & 3 & 2 & 3681,763672 \\
\hline 178 & 4 & 3 & 1 & 1 & 2 & 3 & 3 & 3182,361328 \\
\hline 180 & 4 & 3 & 1 & 1 & 2 & 3 & 3 & 2980,505850 \\
\hline 181 & 4 & 3 & 1 & 1 & 2 & 3 & 3 & 28333,31055 \\
\hline 182 & 4 & 3 & 1 & 1 & 2 & 2 & 4 & 8956,332031 \\
\hline 183 & 4 & 3 & 1 & 1 & 2 & 2 & 3 & 32423,00781 \\
\hline 184 & 4 & 3 & 1 & 1 & 2 & 3 & 2 & 14958,74805 \\
\hline 185 & 4 & 3 & 1 & 1 & 2 & 2 & 3 & 15004,02148 \\
\hline 186 & 4 & 3 & 1 & 1 & 2 & 2 & 4 & 5020,121094 \\
\hline 187 & 4 & 3 & 1 & 1 & 2 & 3 & 3 & 22127,10742 \\
\hline 188 & 4 & 3 & 1 & 1 & 2 & 3 & 4 & 7228,548828 \\
\hline 190 & 4 & 3 & 1 & 1 & 2 & 2 & 4 & 3650,955078 \\
\hline 181 & 4 & 3 & 1 & 1 & 2 & 2 & 4 & 3610,736328 \\
\hline 192 & 4 & 3 & 1 & 1 & 2 & 1 & 2 & 24894,46875 \\
\hline 193 & 4 & 3 & 1 & 1 & 2 & 2 & 2 & 4154,138672 \\
\hline 194 & 4 & 2 & 1 & 1 & 2 & 1 & 3 & 37528.20888 \\
\hline 185 & 4 & 3 & 1 & 1 & 2 & 2 & 4 & 4200,812100 \\
\hline 196 & 4 & 3 & 1 & 1 & 2 & 2 & 4 & 4017,611328 \\
\hline 197 & 4 & 3 & 1 & 1 & 2 & 2 & 3 & 34097,1875 \\
\hline 197 & 4 & 3 & 1 & 1 & 2 & 2 & 3 & 4850,515625 \\
\hline 198 & 4 & 3 & 1 & 1 & 2 & 3 & 4 & 4424,710938 \\
\hline 198 & 4 & 3 & 1 & 1 & 2 & 1 & 4 & 5820,890625 \\
\hline 200 & 4 & 3 & 1 & 1 & 2 & 2 & 4 & 24845,17578 \\
\hline 201 & 4 & 3 & 1 & 1 & 2 & 3 & 4 & 3950,118141 \\
\hline 202 & 4 & 3 & 1 & 1 & 2 & 3 & 4 & 33379.28711 \\
\hline 203 & 4 & 3 & 1 & 1 & 2 & 3 & 3 & 8303,083984 \\
\hline 204 & 4 & 3 & 1 & 1 & 2 & 2 & 1 & 13848,07227 \\
\hline 205 & 4 & 3 & 1 & 1 & 2 & 3 & 1 & 4790,363281 \\
\hline
\end{tabular}




\begin{tabular}{|c|c|c|c|c|c|c|c|c|}
\hline 206 & 4 & 3 & 1 & 1 & 2 & 3 & 1 & 5775,636718 \\
\hline 207 & 4 & 3 & 1 & 1 & 2 & 2 & 2 & 8450,072268 \\
\hline 208 & 4 & 3 & 1 & 1 & 2 & 3 & 1 & 8968,789063 \\
\hline 200 & 4 & 3 & 1 & 1 & 2 & 3 & 1 & 8441,048828 \\
\hline 210 & 4 & 3 & 1 & 1 & 2 & 3 & 1 & $7516,710 Q 38$ \\
\hline 211 & 4 & 3 & 1 & 1 & 2 & 3 & 1 & 18902,48242 \\
\hline 213 & 4 & 3 & 1 & 1 & 2 & 1 & 3 & 15428,69338 \\
\hline 214 & 4 & 3 & 1 & 2 & 2 & 4 & 1 & 0567.255850 \\
\hline 215 & 1 & 2 & 1 & 1 & 2 & 2 & 4 & 54011,26563 \\
\hline 218 & 2 & 2 & 1 & 1 & 2 & 1 & 1 & 18743.21288 \\
\hline 217 & 1 & 2 & 1 & 1 & 2 & 1 & 3 & 107122,502 \\
\hline 218 & 4 & 3 & 1 & 1 & 2 & 3 & 4 & 8623,152344 \\
\hline 218 & 2 & 2 & 1 & 1 & 2 & 1 & 2 & 16746,8418 \\
\hline 220 & 1 & 2 & 1 & 1 & 1 & 1 & 1 & 139346,0352 \\
\hline 221 & 2 & 3 & 1 & 2 & 1 & 1 & 1 & 15785,90218 \\
\hline 222 & 1 & 2 & 1 & 1 & 2 & 1 & 3 & 81797,85032 \\
\hline 223 & 2 & 2 & 1 & 1 & 2 & 1 & 1 & 14190,50185 \\
\hline 224 & 2 & 2 & 1 & 1 & 2 & 1 & 1 & 24121,40038 \\
\hline 225 & 2 & 2 & 1 & 1 & 2 & 1 & 1 & 13063.29492 \\
\hline 228 & 2 & 2 & 1 & 1 & 2 & 1 & 1 & 22888,60938 \\
\hline 227 & 1 & 2 & 1 & 1 & 2 & 1 & 2 & 180415,1738 \\
\hline 228 & 2 & 2 & 1 & 2 & 2 & 1 & 2 & 42433,99414 \\
\hline 228 & 2 & 1 & 1 & 3 & 2 & 1 & 2 & 81317.53711 \\
\hline 230 & 2 & 2 & 1 & 1 & 2 & 1 & 1 & 24784,70117 \\
\hline 231 & 2 & 2 & 1 & 2 & 2 & 1 & 3 & 10786,80078 \\
\hline 232 & 2 & 2 & 1 & 2 & 2 & 1 & 2 & 19506,45117 \\
\hline 233 & 1 & 2 & 1 & 1 & 2 & 1 & 2 & 80851,32813 \\
\hline 234 & 2 & 2 & 1 & 1 & 2 & 2 & 3 & 21050,73047 \\
\hline 235 & 2 & 2 & 1 & 1 & 2 & 1 & 2 & 18827,83398 \\
\hline 236 & 2 & 2 & 1 & 1 & 2 & 1 & 2 & 18134,75586 \\
\hline 237 & 2 & 2 & 1 & 1 & 2 & 1 & 2 & 7975,482422 \\
\hline 238 & 2 & 2 & 1 & 1 & 2 & 1 & 2 & 7201,121004 \\
\hline $23 \theta$ & 2 & 2 & 1 & 1 & 2 & 1 & 1 & 7321,095703 \\
\hline 240 & 2 & 2 & 1 & 1 & 2 & 1 & 1 & 7500,154297 \\
\hline 241 & 4 & 3 & 1 & 1 & 2 & 3 & 2 & 50187,75977 \\
\hline 242 & 4 & 3 & 1 & 1 & 2 & 3 & 2 & 18937.90625 \\
\hline 243 & 4 & 3 & 1 & 1 & 2 & 3 & 2 & 8186,972656 \\
\hline 244 & 3 & 3 & 1 & 1 & 2 & 3 & 3 & 14463,62305 \\
\hline 245 & 1 & 2 & 1 & 2 & 2 & 1 & 3 & 751258,8828 \\
\hline 246 & 1 & 1 & 1 & 1 & 1 & 1 & 1 & 1833181,514 \\
\hline 247 & 3 & 2 & 1 & 1 & 2 & 2 & 4 & 4782,712881 \\
\hline 248 & 3 & 2 & 1 & 1 & 2 & 2 & 4 & 2064,804888 \\
\hline 250 & 3 & 2 & 1 & 1 & 2 & 1 & 1 & 9856,759768 \\
\hline 251 & 2 & 2 & 1 & 1 & 2 & 1 & 1 & 17137,95508 \\
\hline 252 & 2 & 2 & 1 & 1 & 2 & 1 & 1 & 13502,67188 \\
\hline 253 & 2 & 2 & 1 & 2 & 2 & 1 & 1 & 41835,43555 \\
\hline 386 & 4 & 3 & 1 & 1 & 2 & 3 & 3 & 11582,72286 \\
\hline
\end{tabular}

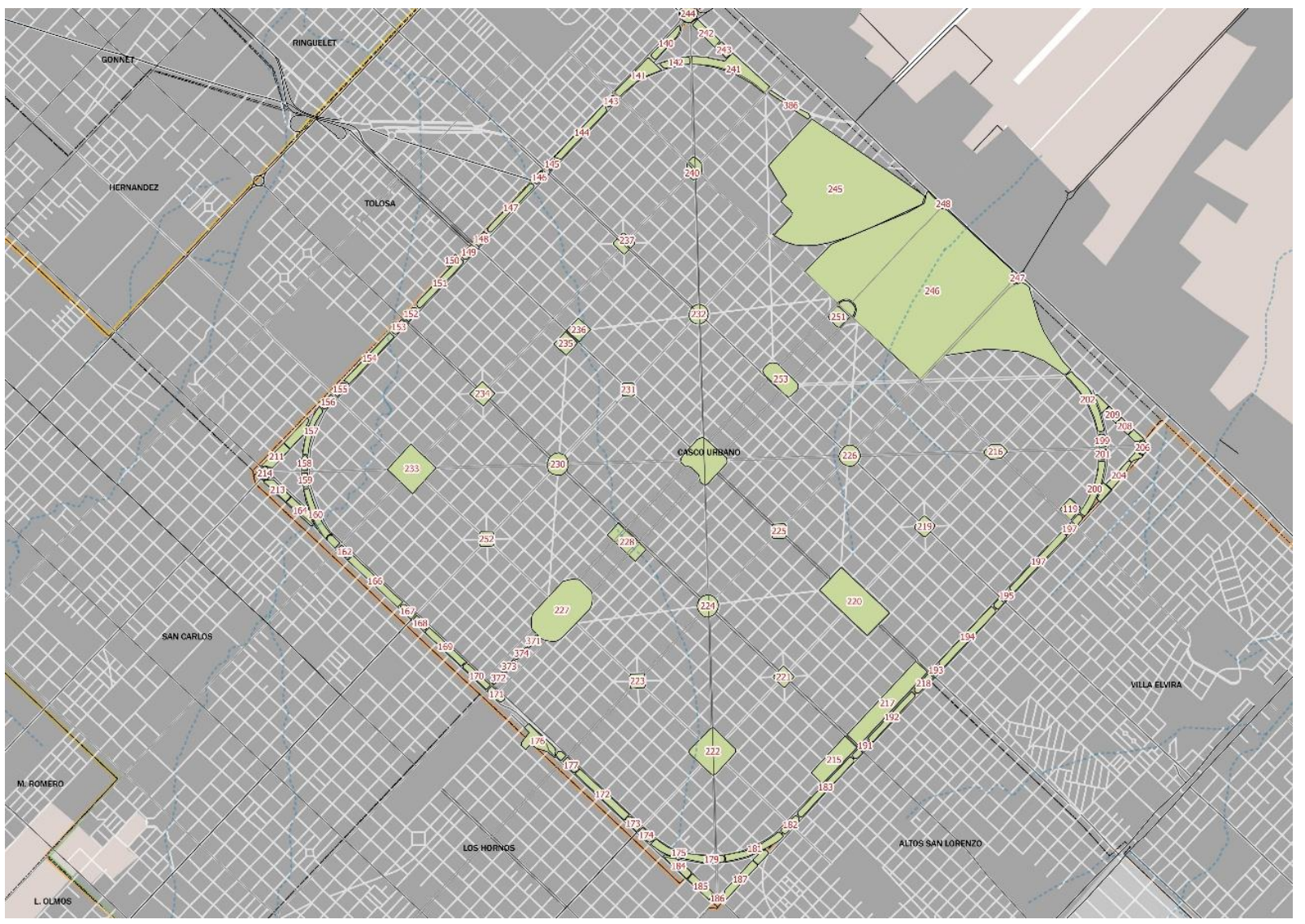




\begin{tabular}{|c|c|c|c|c|c|c|c|c|}
\hline \multicolumn{9}{|c|}{ EVUP DESBORDE } \\
\hline ID & TIPO & ALCANCE & DOMINIO & $\begin{array}{c}\text { SUELO } \\
\text { ABSORBENTE }\end{array}$ & $\begin{array}{l}\text { PRESENCIA DE } \\
\text { AGUA }\end{array}$ & MOBILIARIO & ARBOLADO & AREA M12 \\
\hline 325 & 3 & 3 & 1 & 3 & 2 & 3 & 3 & 2362,339844 \\
\hline 326 & 2 & 3 & 1 & 1 & 2 & 3 & 4 & 4142,189922 \\
\hline 327 & 3 & 3 & 1 & 1 & 2 & 3 & 1 & 5228,486328 \\
\hline 328 & 3 & 3 & 1 & 3 & 2 & 3 & 3 & 1258,601563 \\
\hline 328 & 3 & 3 & 1 & 3 & 2 & 3 & 3 & 388,037109 \\
\hline 330 & 3 & 3 & 1 & 3 & 2 & 3 & 3 & 301,683594 \\
\hline 331 & 3 & 3 & 1 & 3 & 2 & 3 & 3 & $850,28710 \theta$ \\
\hline 332 & 3 & 3 & 1 & 3 & 2 & 3 & 3 & 1635,351563 \\
\hline 333 & 2 & 3 & 1 & 1 & 2 & 3 & 3 & 1798.298828 \\
\hline 338 & 2 & 3 & 1 & 1 & 2 & 2 & 3 & 10175,07813 \\
\hline 330 & 1 & 3 & 1 & 1 & 2 & 3 & 3 & 18080,35156 \\
\hline 340 & 1 & 3 & 1 & 1 & 1 & 3 & 1 & 14290,12891 \\
\hline 341 & 4 & 2 & 1 & 1 & 2 & 3 & 1 & 0562,605460 \\
\hline 342 & 3 & 3 & 1 & 1 & 2 & 3 & 4 & 905,236328 \\
\hline 343 & 4 & 2 & 1 & 1 & 2 & 3 & 4 & 5328,087891 \\
\hline 344 & 4 & 2 & 1 & 1 & 2 & 3 & 4 & 5832,685547 \\
\hline 345 & 4 & 2 & 1 & 1 & 2 & 3 & 4 & 2248,447268 \\
\hline 346 & 4 & 2 & 1 & 1 & 2 & 3 & 4 & 1562,823828 \\
\hline 347 & 4 & 2 & 1 & 1 & 2 & 3 & 4 & 1313,455078 \\
\hline 348 & 4 & 2 & 1 & 1 & 2 & 3 & 4 & 683,978518 \\
\hline 348 & 4 & 2 & 1 & 1 & 2 & 3 & 4 & 836,603516 \\
\hline 350 & 4 & 2 & 1 & 1 & 2 & 3 & 4 & 1118.287102 \\
\hline 351 & 4 & 2 & 1 & 1 & 2 & 3 & 4 & 454,427734 \\
\hline 352 & 4 & 2 & 1 & 1 & 2 & 3 & 4 & 240,98875 \\
\hline 353 & 4 & 2 & 1 & 1 & 1 & 3 & 4 & 18154,43945 \\
\hline 354 & 2 & 3 & 1 & 1 & 2 & 2 & 3 & 8689,546875 \\
\hline 367 & 3 & 2 & 1 & 1 & 2 & 3 & 4 & 3603,683584 \\
\hline 368 & 3 & 2 & 1 & 1 & 2 & 3 & 4 & 2815.285158 \\
\hline 368 & 3 & 2 & 1 & 1 & 2 & 3 & 4 & 2043.248047 \\
\hline 370 & 3 & 3 & 1 & 4 & 2 & 3 & 3 & 2095,0625 \\
\hline 375 & 3 & 3 & 1 & 2 & 2 & 3 & 1 & 1951,404297 \\
\hline 376 & 3 & 3 & 1 & 2 & 2 & 3 & 1 & 2484,53125 \\
\hline 377 & 3 & 3 & 1 & 2 & 2 & 3 & 1 & 2494,367188 \\
\hline 001 & 4 & 2 & 1 & 1 & 2 & 3 & 4 & 6081,306641 \\
\hline 002 & 4 & 2 & 1 & 1 & 2 & 3 & 4 & 10689,01172 \\
\hline 005 & 2 & 3 & 1 & 1 & 2 & 1 & 4 & 12870,75185 \\
\hline 014 & 2 & 3 & 1 & 1 & 2 & 1 & 4 & 2892.396484 \\
\hline 015 & 2 & 3 & 1 & 1 & 2 & 1 & 3 & 2830,111328 \\
\hline 035 & 3 & 2 & 1 & 1 & 2 & 3 & 4 & 2201,304688 \\
\hline 120 & 2 & 3 & 1 & 1 & 2 & 1 & 1 & 11035,97852 \\
\hline 121 & 2 & 3 & 1 & 1 & 2 & 2 & 1 & 10747,38281 \\
\hline 122 & 4 & 3 & 1 & 1 & 2 & 3 & 3 & 10040,17773 \\
\hline 123 & 2 & 3 & 1 & 2 & 2 & 3 & & 8548,601408 \\
\hline 124 & 3 & 3 & 1 & 1 & 2 & 3 & 3 & 911,833984 \\
\hline 125 & 4 & 2 & 1 & 1 & 2 & 3 & 2 & 2918,021484 \\
\hline 126 & 4 & 2 & 1 & 1 & 2 & 3 & 2 & 5310,757813 \\
\hline 127 & 4 & 2 & 1 & 1 & 2 & 3 & 2 & 4607,21875 \\
\hline 128 & 4 & 2 & 1 & 1 & 2 & 3 & 4 & 4650,558504 \\
\hline 132 & 4 & 3 & 1 & 1 & 2 & 3 & 3 & 2237,279297 \\
\hline 133 & 4 & 3 & 1 & 1 & 2 & 2 & 3 & 1989,470703 \\
\hline 134 & 4 & 3 & 1 & 1 & 2 & 3 & 3 & 2084,328125 \\
\hline 135 & 4 & 3 & 1 & 1 & 2 & 3 & 3 & 1958,876053 \\
\hline 136 & 4 & 3 & 1 & 1 & 2 & 3 & 4 & 5626,349602 \\
\hline 150 & 3 & 3 & 1 & 1 & 2 & 1 & 4 & 3857.224602 \\
\hline 185 & 3 & 3 & 2 & 1 & 2 & 3 & 4 & 7812,28125 \\
\hline 254 & 2 & 3 & 1 & 1 & 2 & 2 & 1 & 20721,82031 \\
\hline 255 & 3 & 3 & 2 & 1 & 2 & 2 & 4 & 1848,474608 \\
\hline 256 & 3 & 3 & 2 & 1 & 2 & 2 & 4 & 18405,41408 \\
\hline 250 & 3 & 3 & 2 & 1 & 2 & 2 & 4 & 1948,474608 \\
\hline 262 & 2 & 3 & 2 & 1 & 2 & 2 & 4 & 10286,39063 \\
\hline 263 & 4 & 3 & 1 & 1 & 2 & 2 & 3 & 18940,44822 \\
\hline 264 & 3 & 3 & 1 & 1 & 2 & 2 & 4 & 9759.964844 \\
\hline 285 & 3 & 3 & 2 & 1 & 2 & 2 & 4 & 2389,650381 \\
\hline 286 & 4 & 3 & 1 & 1 & 2 & 2 & 4 & 3791,644531 \\
\hline 268 & 3 & 3 & 1 & 1 & 2 & 2 & 4 & 7758,823828 \\
\hline 270 & 1 & 3 & 2 & 2 & 2 & 2 & 4 & 3353,90025 \\
\hline 271 & 3 & 3 & 1 & 1 & 2 & 2 & 4 & 4111,337881 \\
\hline 273 & 3 & 3 & 2 & 1 & 2 & 2 & 4 & 1848,474602 \\
\hline 276 & 2 & 3 & 1 & 1 & 2 & 2 & 2 & 20721,82031 \\
\hline 277 & 2 & 3 & 2 & 1 & 2 & 2 & 4 & 10286,39063 \\
\hline
\end{tabular}




\begin{tabular}{|c|c|c|c|c|c|c|c|c|}
\hline 278 & 3 & 3 & 1 & 1 & 2 & 2 & 4 & 9759,864844 \\
\hline 278 & 4 & 3 & 1 & 1 & 2 & 2 & 3 & 16840,44822 \\
\hline 280 & 4 & 3 & 1 & 1 & 2 & 2 & 4 & 3791,644531 \\
\hline 281 & 3 & 3 & 2 & 1 & 2 & 2 & 4 & 2389,650391 \\
\hline 282 & 4 & 3 & 1 & 1 & 2 & 2 & 1 & 1935,322268 \\
\hline 283 & 4 & 3 & 1 & 1 & 2 & 2 & 3 & 1780,267578 \\
\hline 288 & 2 & 3 & 2 & 1 & 2 & 2 & 2 & 20721,82031 \\
\hline 287 & & & & & & & & 10268,39063 \\
\hline 288 & 3 & 3 & 2 & 1 & 2 & 2 & 4 & 8759,864844 \\
\hline 288 & 4 & 3 & 1 & 1 & 2 & 2 & 3 & 16940,44922 \\
\hline 290 & 3 & 3 & 2 & 1 & 2 & 2 & 4 & 2389,650391 \\
\hline 291 & 4 & 3 & 1 & 1 & 2 & 2 & 4 & 3791,644531 \\
\hline 282 & 4 & 3 & 1 & 1 & 2 & 2 & 1 & 1935,322268 \\
\hline 283 & 4 & 3 & 1 & 1 & 2 & 2 & 3 & 1780,287578 \\
\hline 284 & 3 & 3 & 1 & 1 & 2 & 2 & 3 & 4112,511718 \\
\hline 285 & 3 & 3 & 1 & 2 & 2 & 2 & 4 & 4458,818350 \\
\hline 297 & 3 & 3 & 2 & 1 & 2 & 2 & 4 & 4976,613281 \\
\hline 298 & 4 & 3 & 1 & 1 & 2 & 2 & 4 & 46884,08008 \\
\hline $29 \theta$ & 3 & 3 & 2 & 1 & 2 & 2 & 3 & 14192,04922 \\
\hline 300 & 3 & 3 & 2 & 1 & 1 & 2 & 4 & 45353,80408 \\
\hline 301 & 2 & 3 & 2 & 1 & 2 & 2 & 4 & 18570,81838 \\
\hline 302 & 3 & 3 & 1 & 1 & 2 & 2 & 4 & 15010,68845 \\
\hline 303 & 3 & 3 & 1 & 1 & 1 & 2 & 4 & 9817,105460 \\
\hline 304 & 3 & 3 & 2 & 1 & 1 & 2 & 3 & 6030,142578 \\
\hline 305 & 3 & 3 & 2 & 1 & 1 & 2 & 4 & 17284,35158 \\
\hline 308 & 3 & 3 & 2 & 1 & 2 & 1 & 4 & 5703,101563 \\
\hline 307 & 3 & 3 & 2 & 1 & 2 & 3 & 4 & 2228,328125 \\
\hline 308 & 3 & 3 & 1 & 1 & 2 & 2 & 4 & 5113,59375 \\
\hline 300 & 4 & 3 & 1 & 1 & 1 & 2 & 3 & 5113,59375 \\
\hline 385 & 3 & 3 & 1 & 1 & 2 & 3 & 4 & 1840,518531 \\
\hline 384 & 3 & 3 & 1 & 1 & 2 & 3 & 4 & 2017,214844 \\
\hline 383 & 3 & 3 & 1 & 1 & 2 & 3 & 4 & 2872,28125 \\
\hline 382 & 3 & 3 & 1 & 1 & 2 & 3 & 4 & 1932,574218 \\
\hline 380 & 3 & 3 & 1 & 1 & 2 & 3 & 4 & 2426,428688 \\
\hline
\end{tabular}

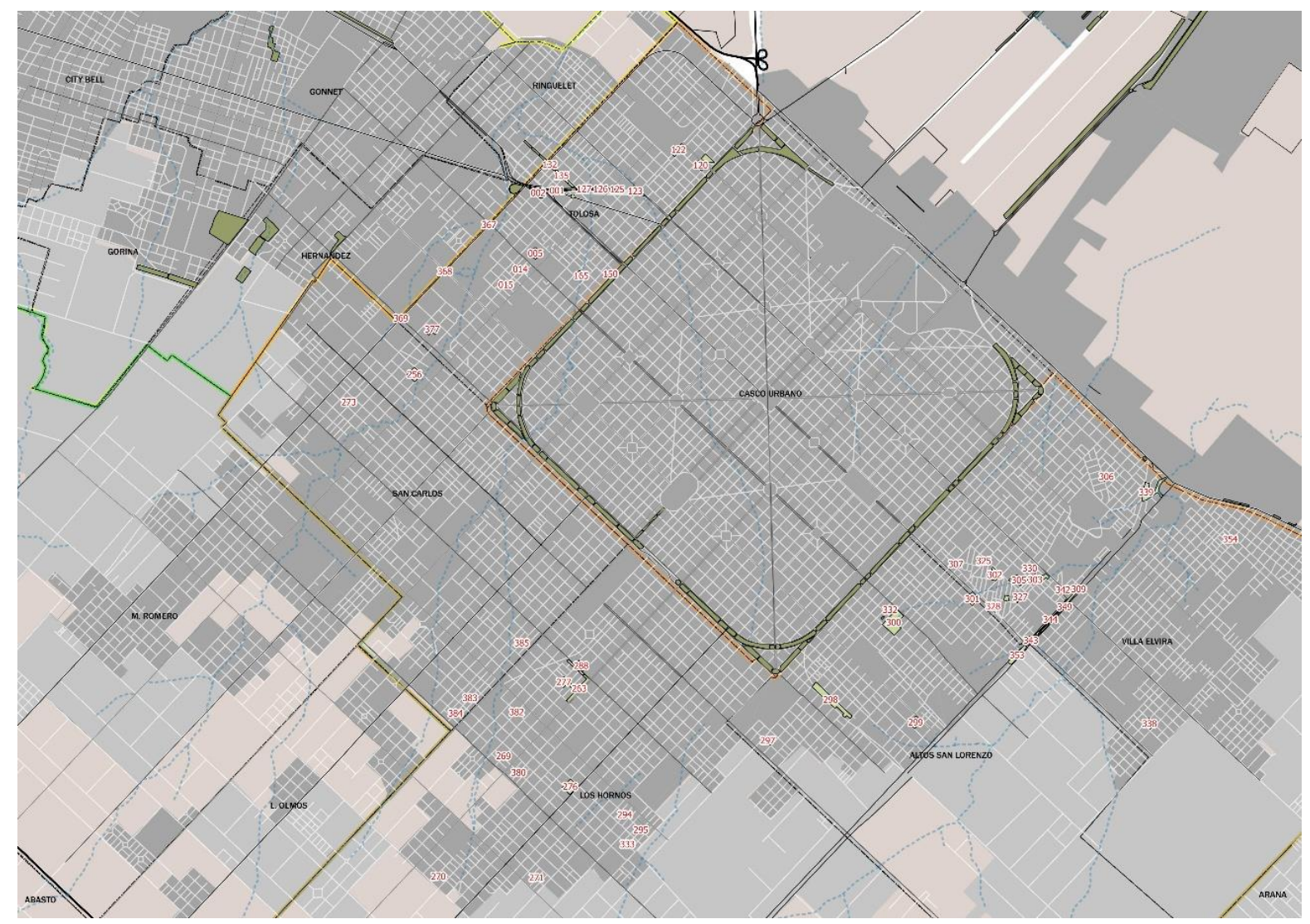




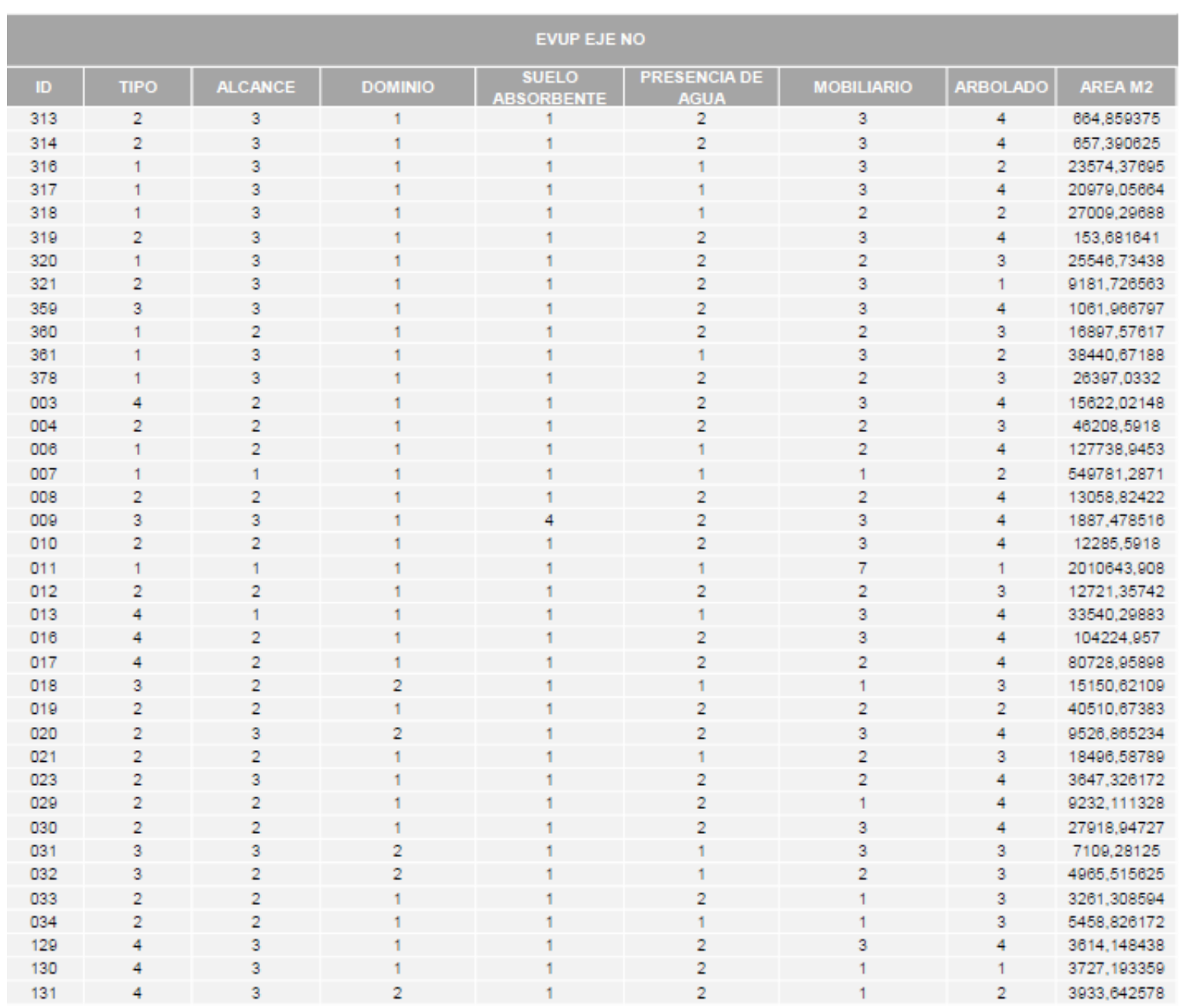

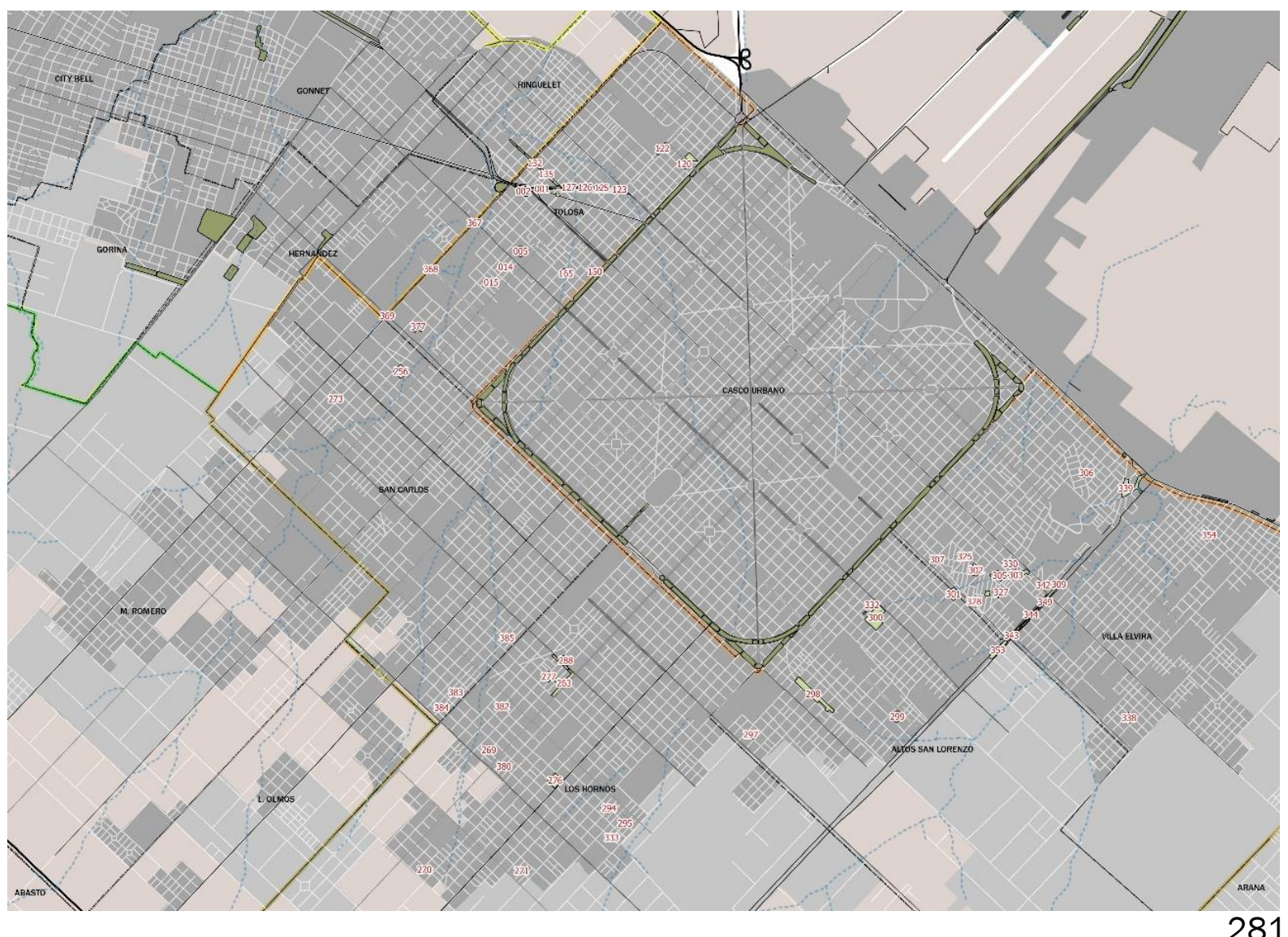




\begin{tabular}{|c|c|c|c|c|c|c|c|c|}
\hline \multicolumn{9}{|c|}{ EVUP CINTURON VERDE } \\
\hline ID & TIPO & ALCANCE & DOMINIO & $\begin{array}{c}\text { SUELO } \\
\text { ABSORBENTE }\end{array}$ & $\begin{array}{c}\text { PRESENCIA DE } \\
\text { AGUA }\end{array}$ & MOBILIARIO & ARBOLADO & AREA M2 \\
\hline 310 & 2 & 3 & 1 & 1 & 2 & 1 & 2 & 17750,93359 \\
\hline 311 & 1 & 2 & 1 & 3 & 2 & 2 & 3 & 97549,7207 \\
\hline 312 & 2 & 3 & 1 & 1 & 2 & 3 & 4 & 9979,816406 \\
\hline 315 & 2 & 3 & 1 & 1 & 2 & 3 & 4 & 9089,011719 \\
\hline 322 & & & & & & & & 1239,740234 \\
\hline 323 & 2 & 3 & 1 & 1 & 2 & 3 & 4 & 1806,056641 \\
\hline 324 & 2 & 3 & 1 & 1 & 2 & 3 & 4 & 1438,707031 \\
\hline 336 & 2 & 3 & 1 & 1 & 2 & 3 & 2 & 3763,863281 \\
\hline 337 & 2 & 3 & 1 & 1 & 2 & 3 & 2 & 3781,652344 \\
\hline 137 & 2 & 1 & 1 & 1 & 2 & 2 & 4 & 3269,373047 \\
\hline 138 & 2 & 1 & 1 & 1 & 2 & 2 & 4 & 3002,458984 \\
\hline 139 & 2 & 3 & 2 & 1 & 2 & 1 & 4 & 11041,56836 \\
\hline 267 & 3 & 3 & 2 & 1 & 2 & 2 & 4 & 2625,660156 \\
\hline 268 & 3 & 3 & 1 & 1 & 2 & 2 & 4 & 7919,037109 \\
\hline 272 & 3 & 3 & 2 & 1 & 2 & 2 & 3 & 4789,277344 \\
\hline 296 & 3 & 3 & 1 & 1 & 2 & 2 & 1 & 3986,0625 \\
\hline 381 & 3 & 3 & 1 & 1 & 2 & 3 & 4 & 2115,800781 \\
\hline
\end{tabular}

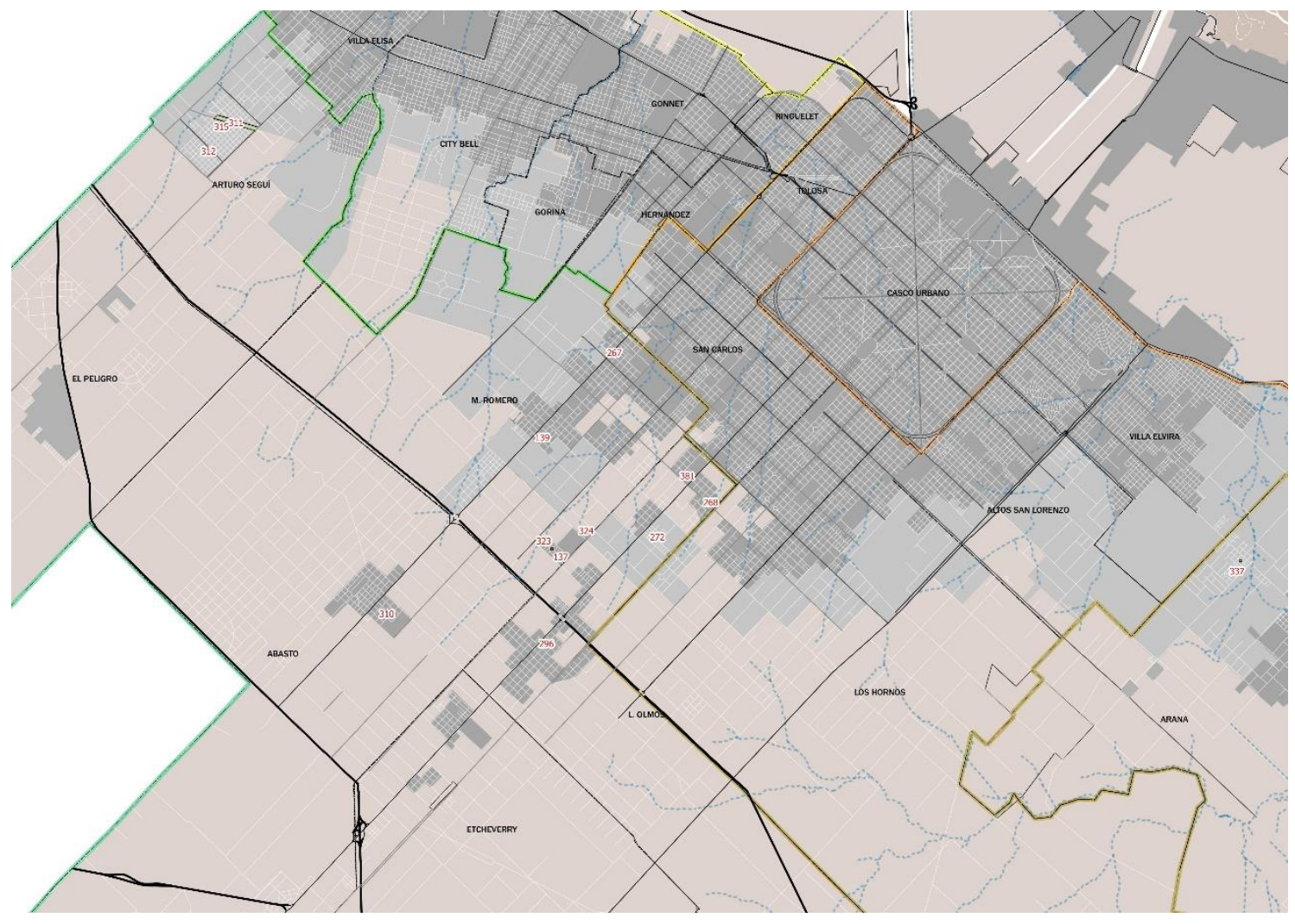


PAISAJES VACANTES

ANEXO 4

Relevamiento tierras vacantes 
ANEXO 4

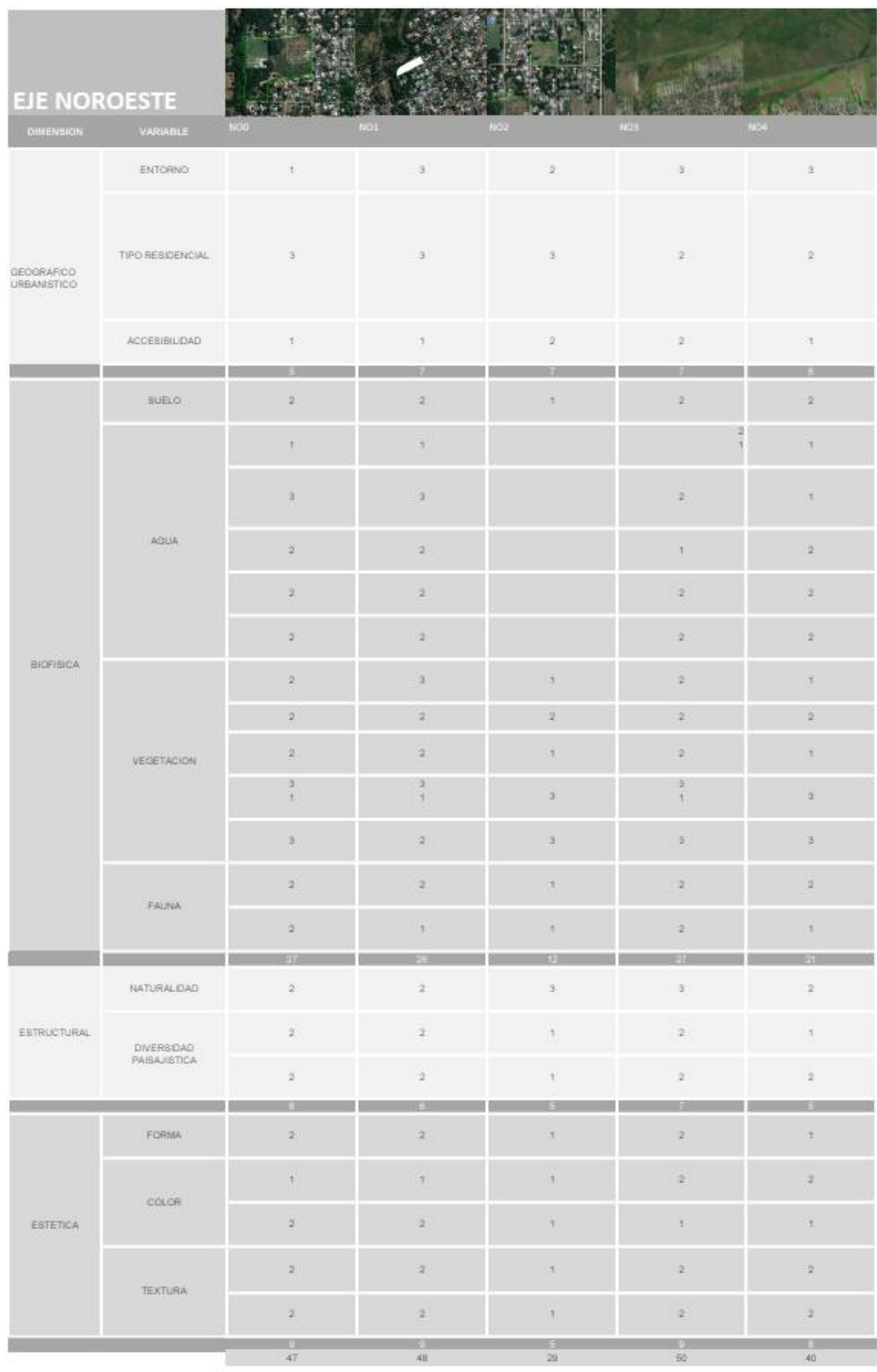



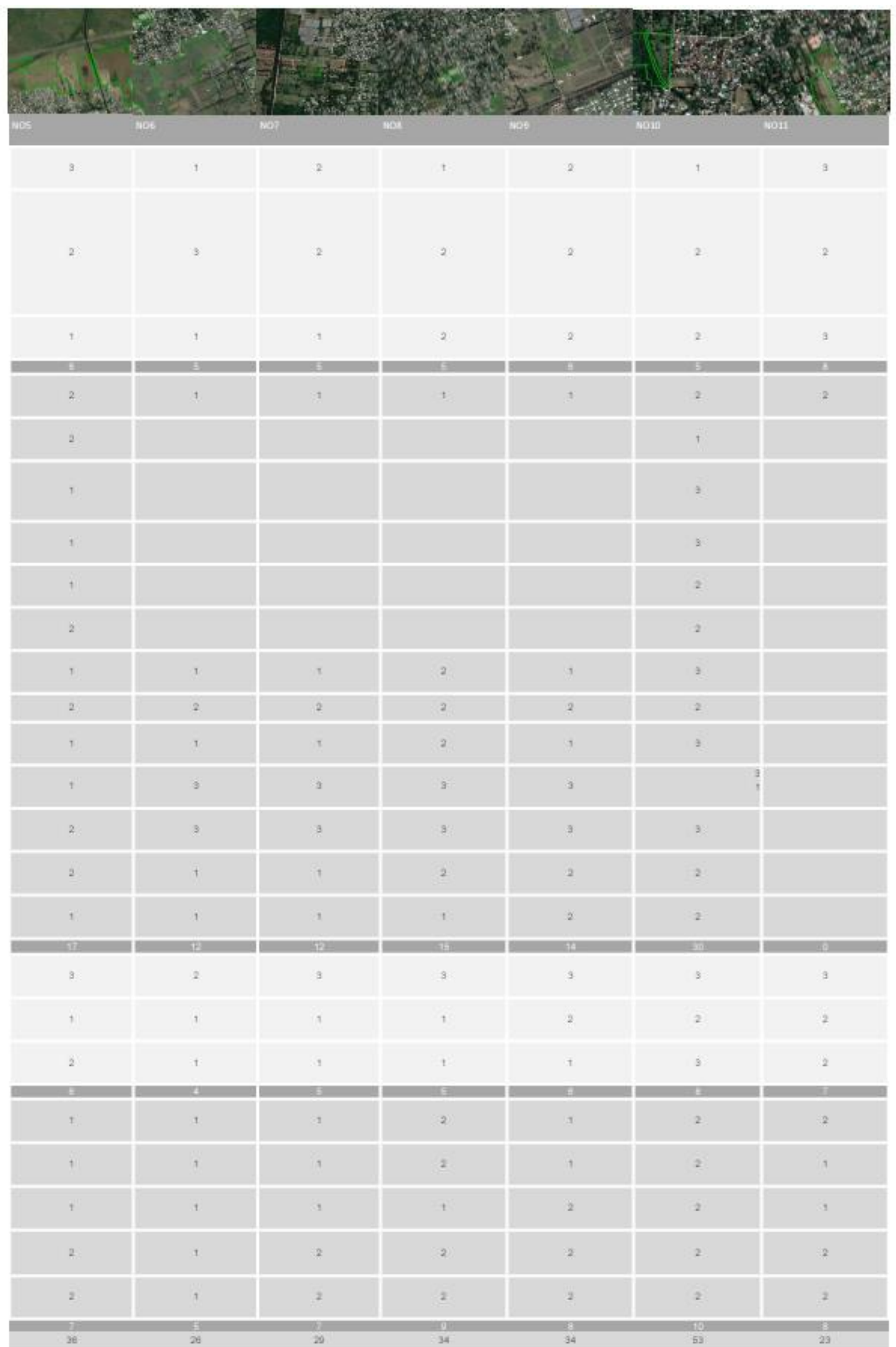


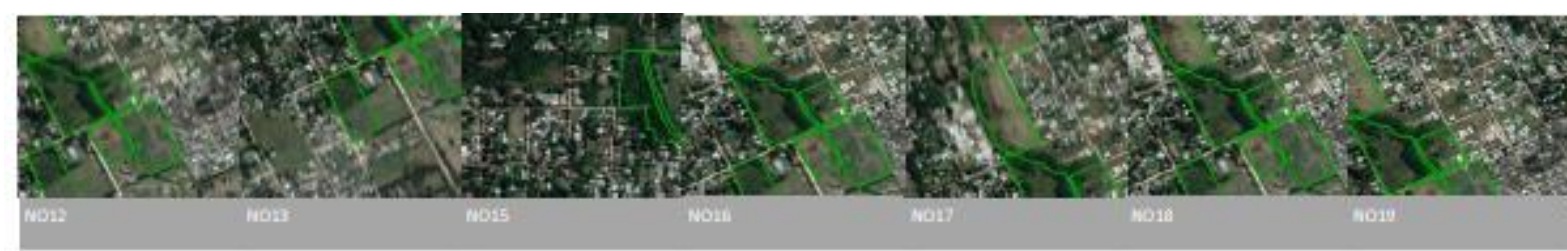

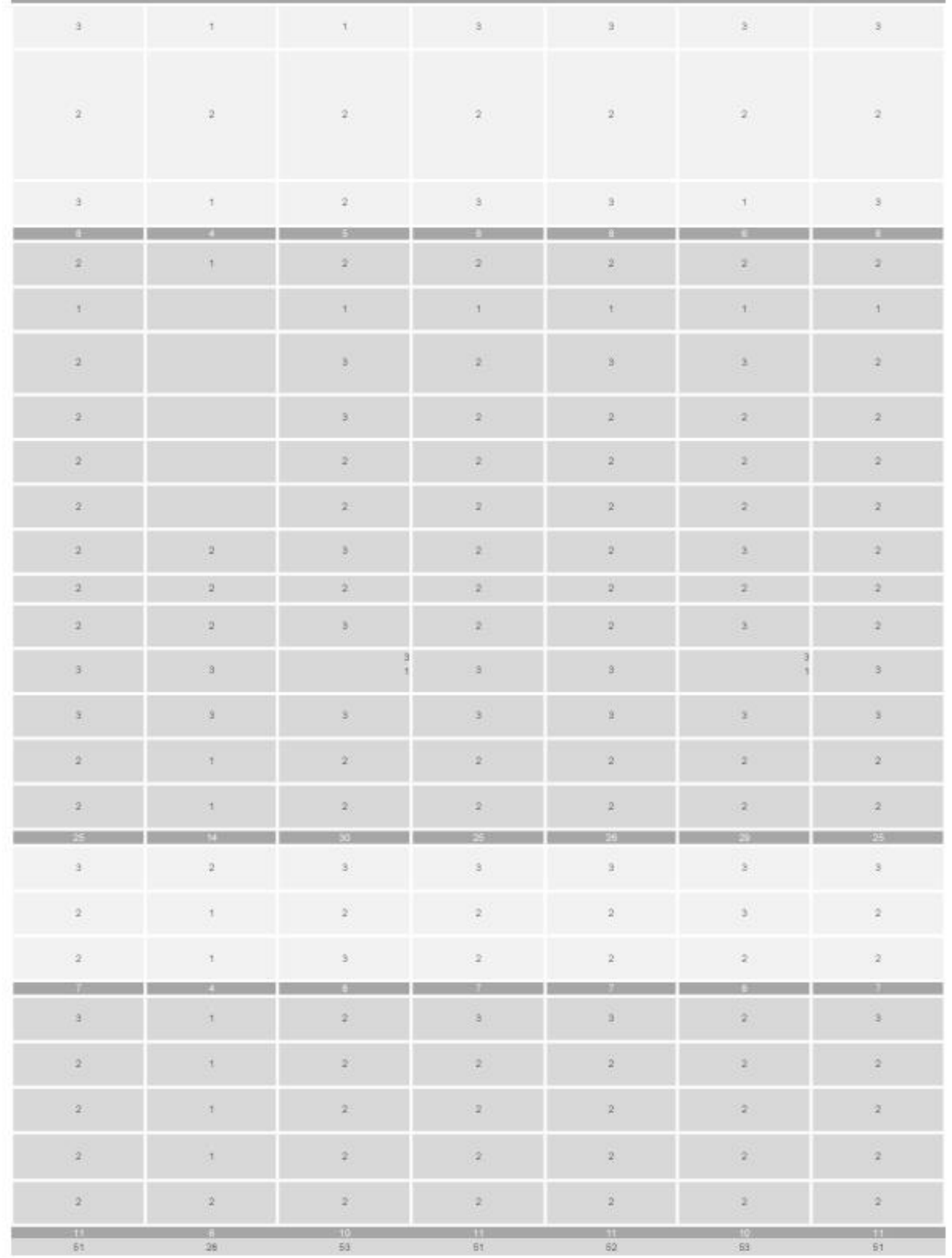



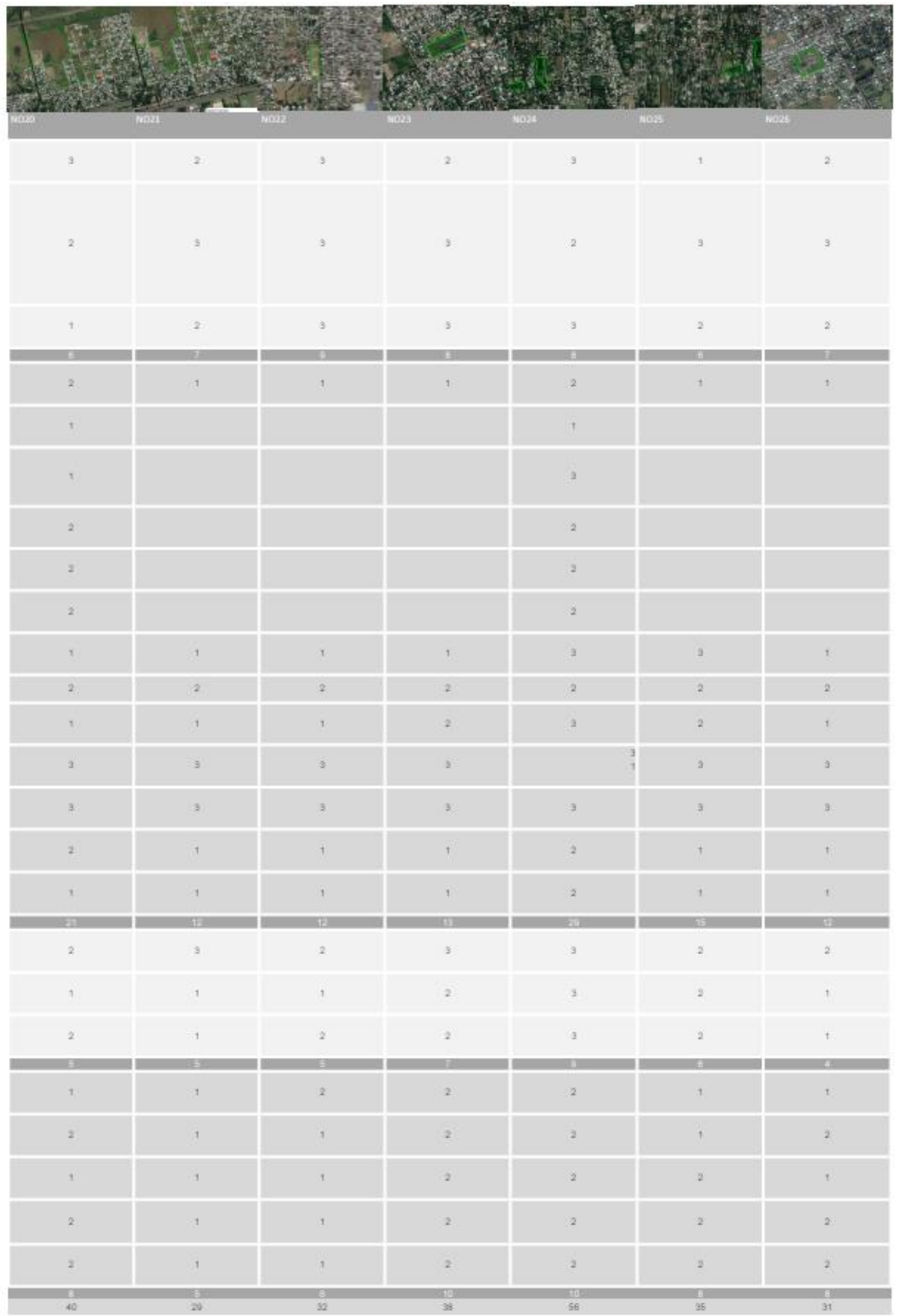


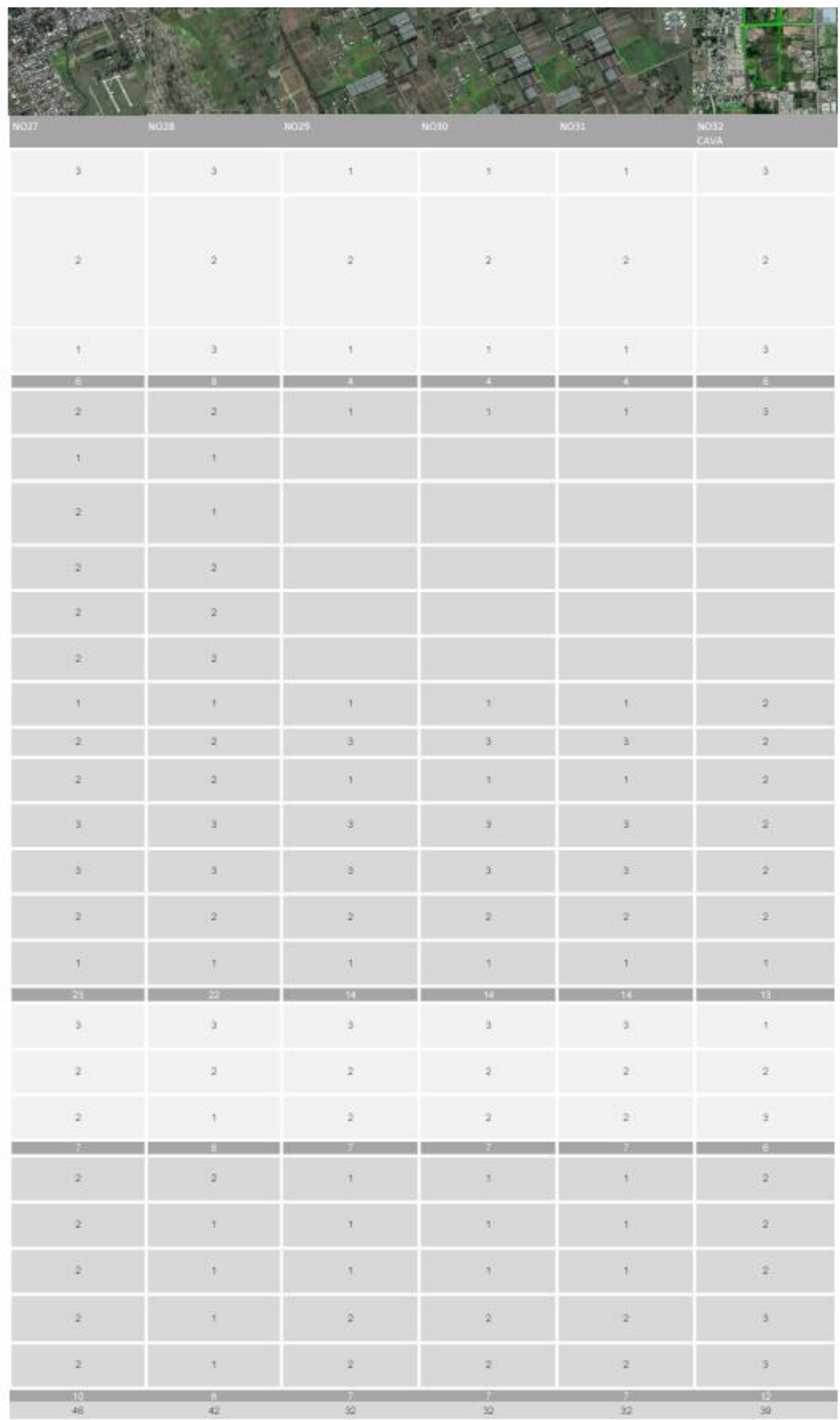




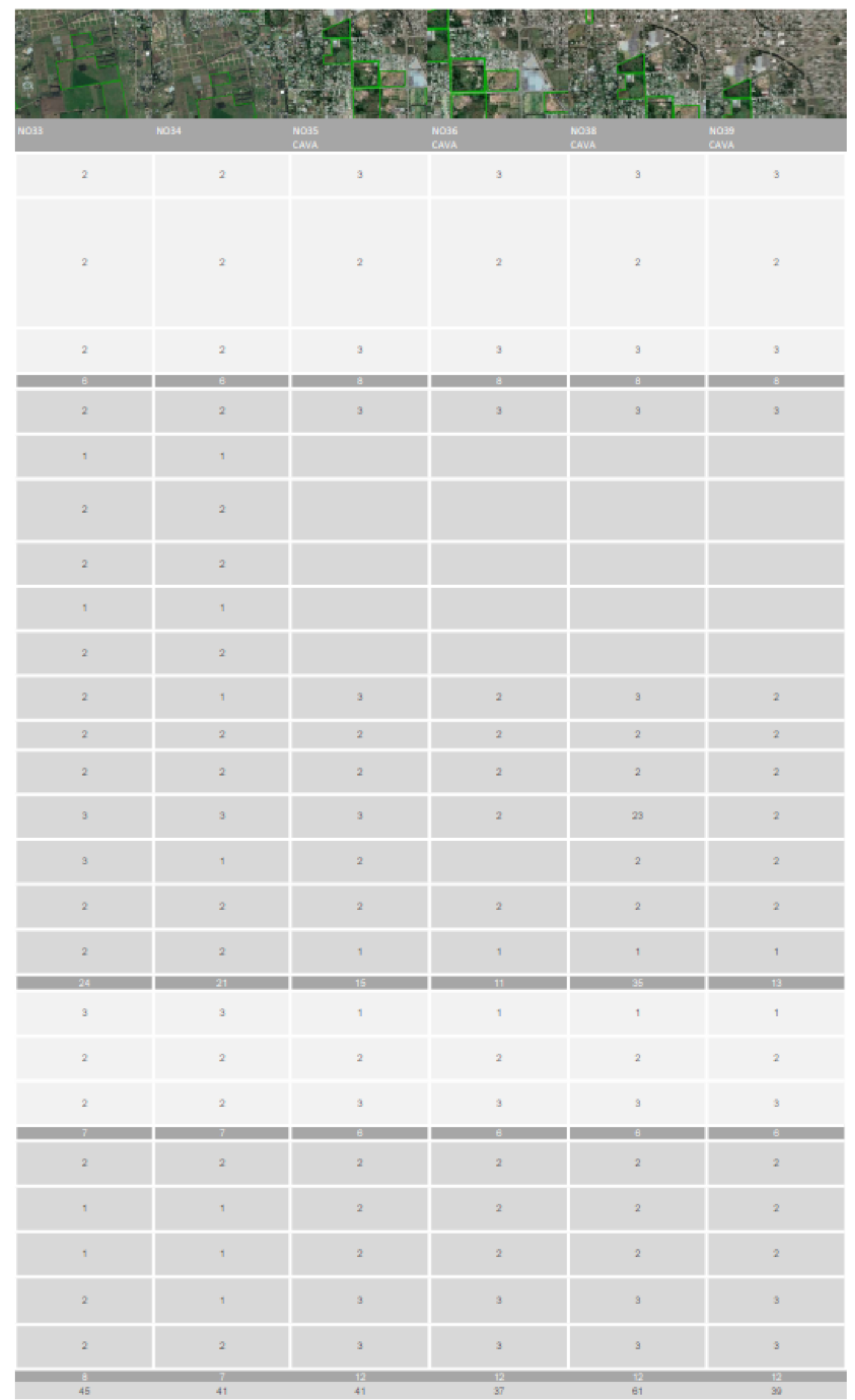




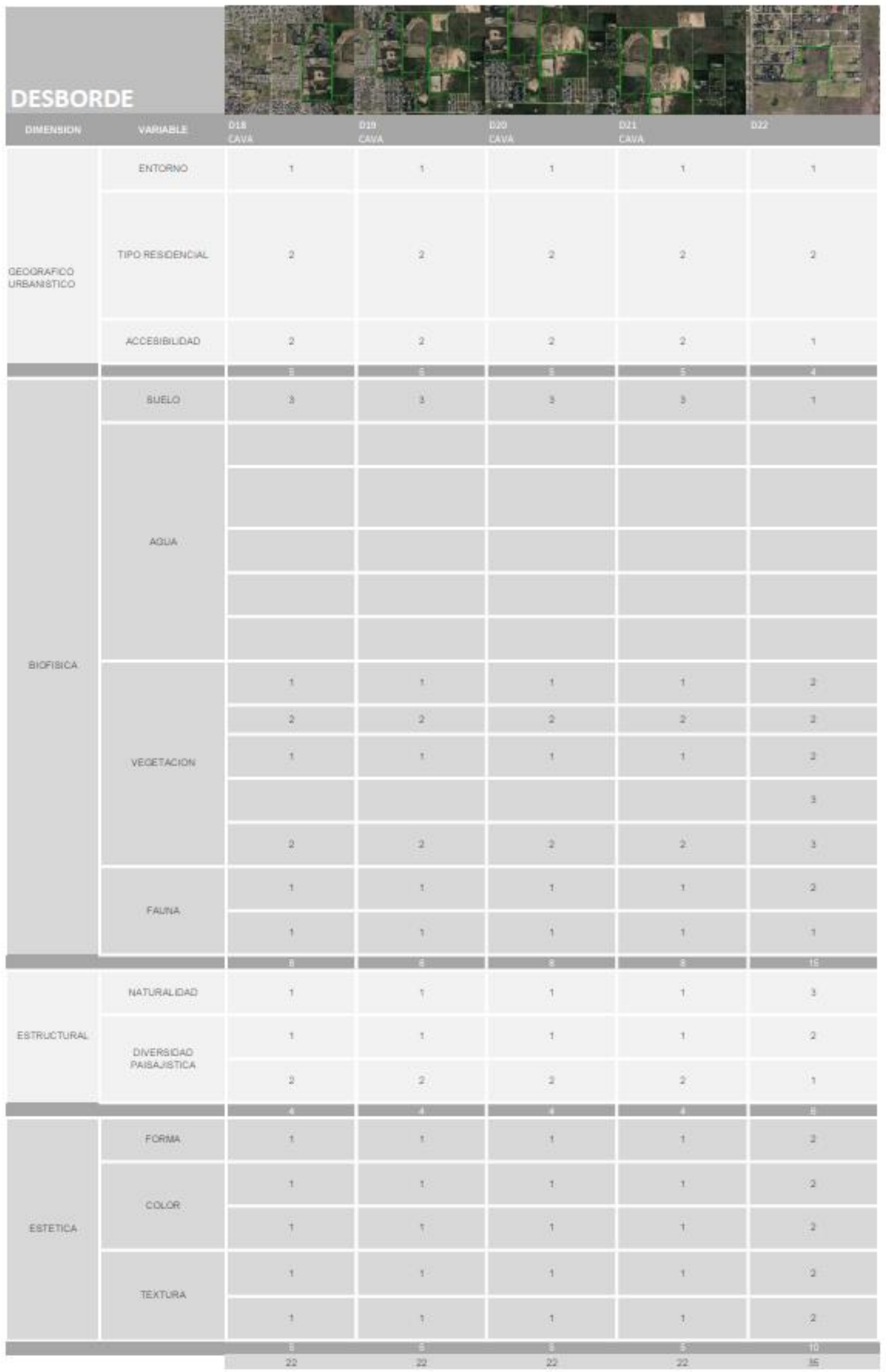



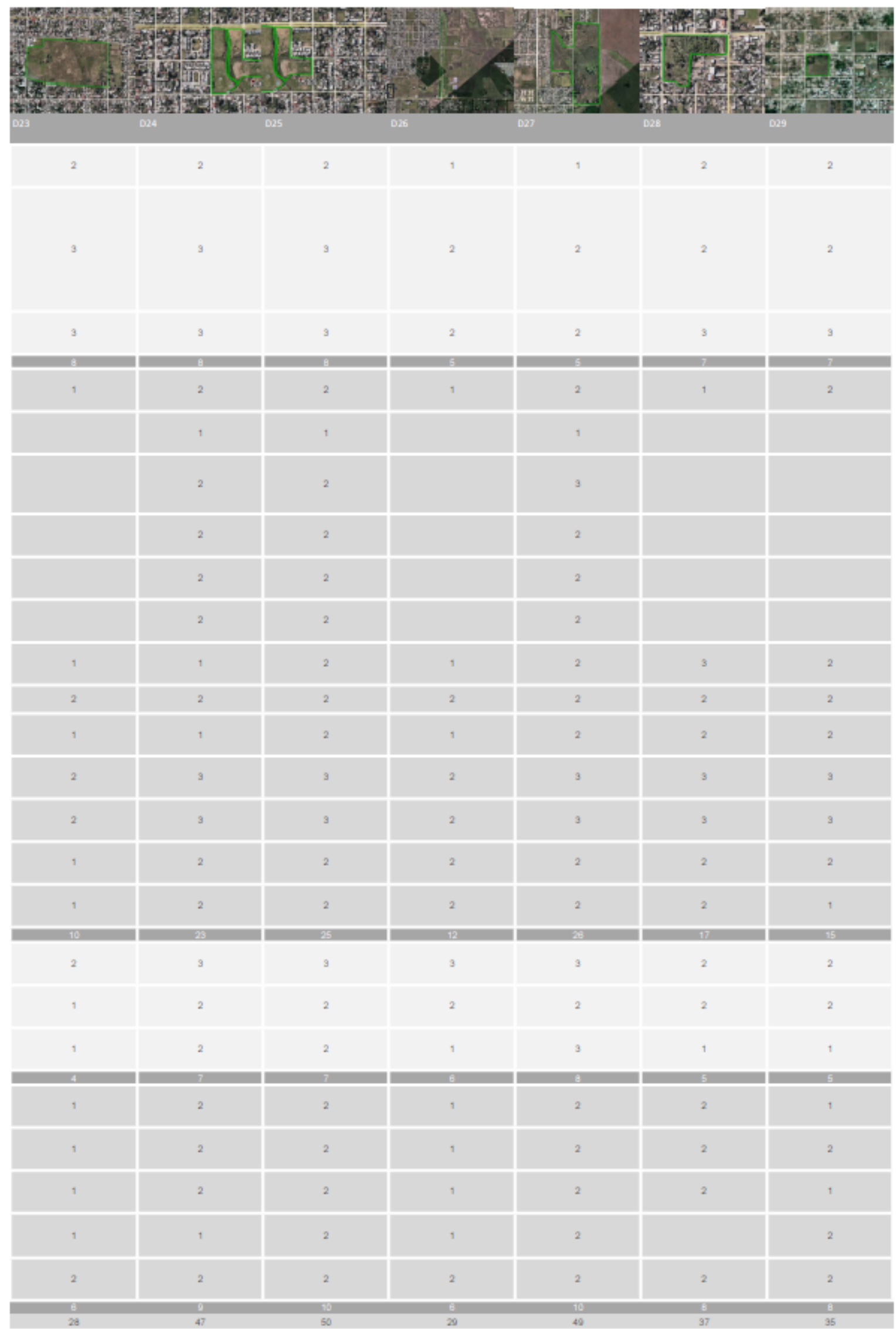

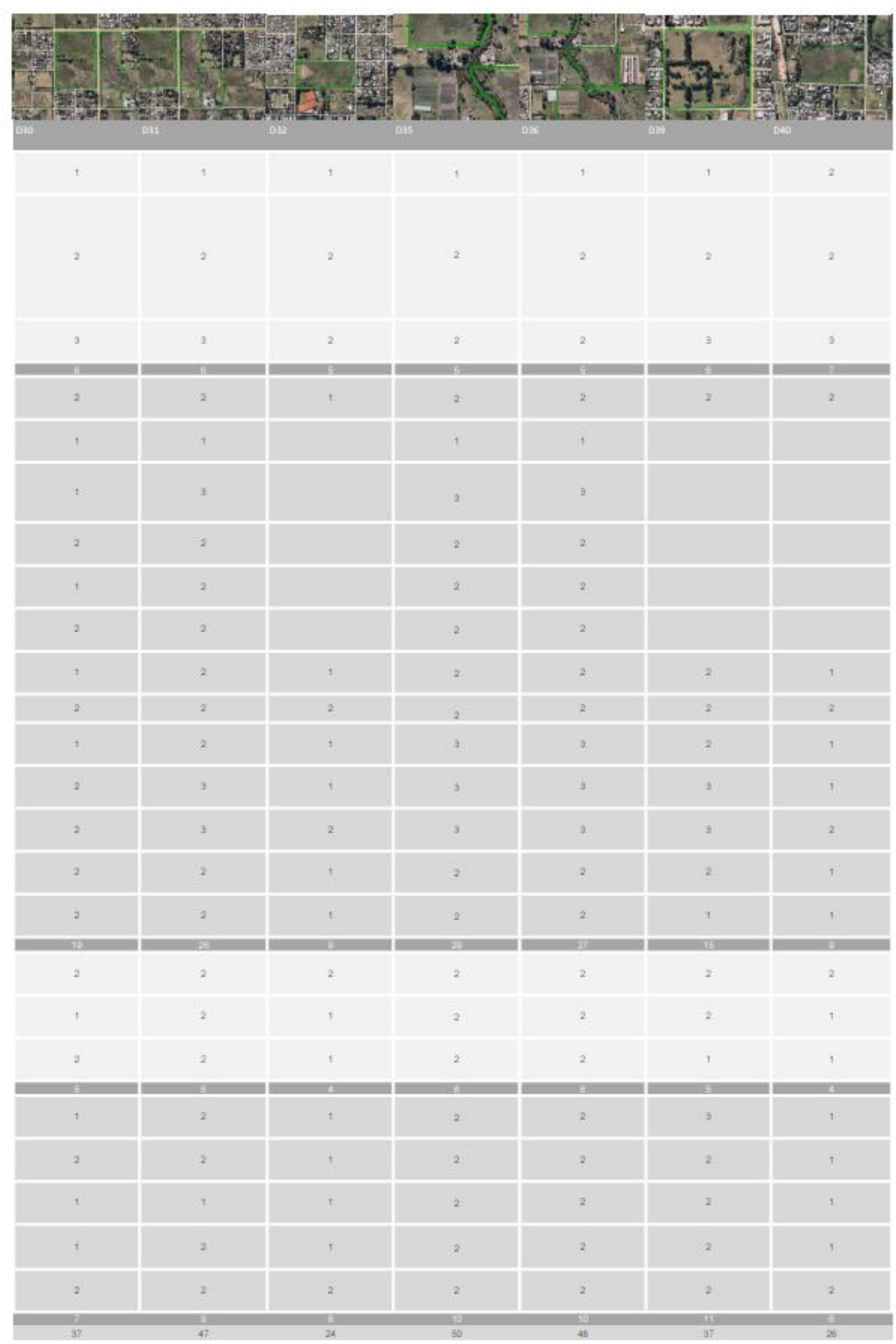

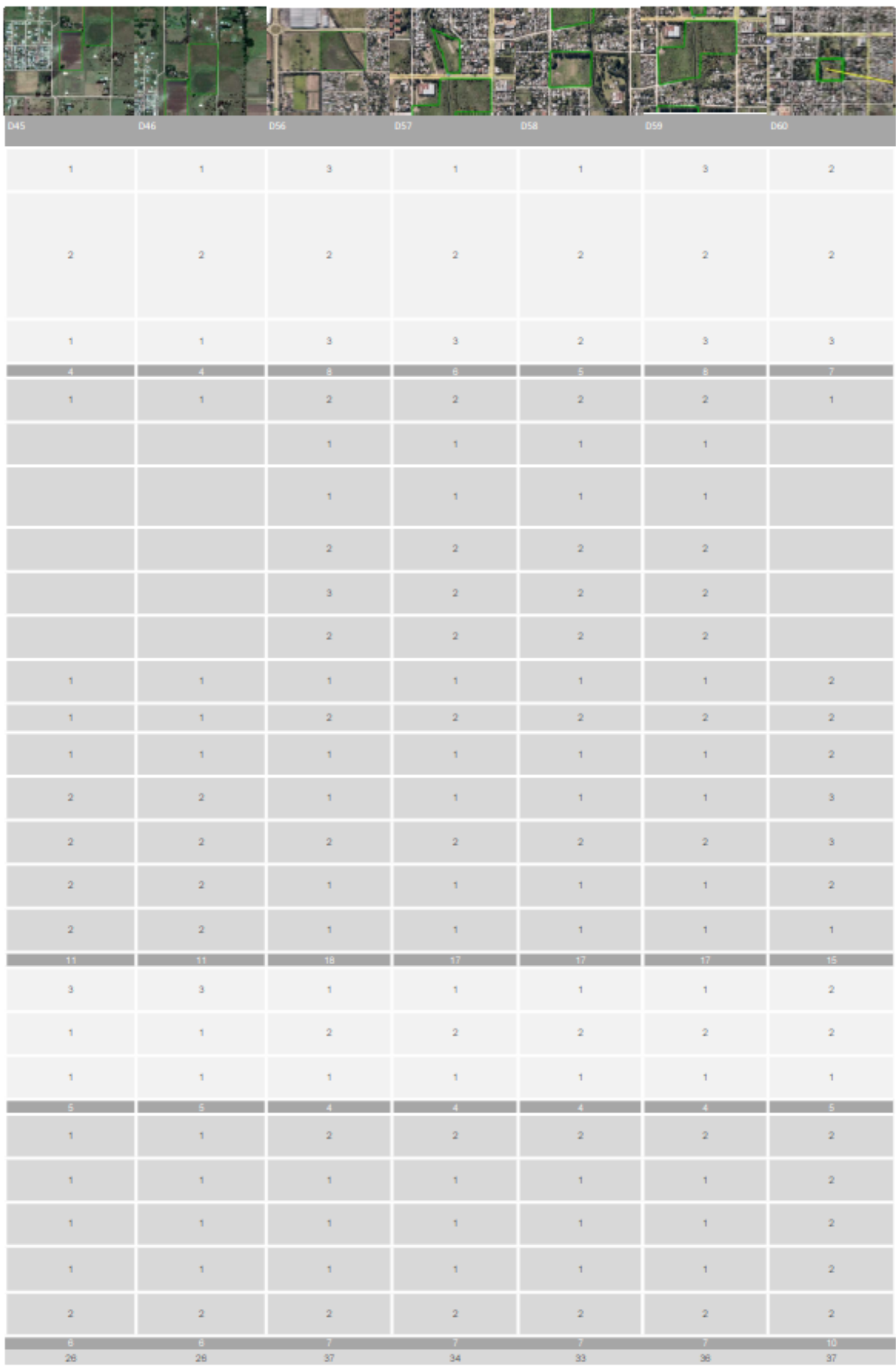


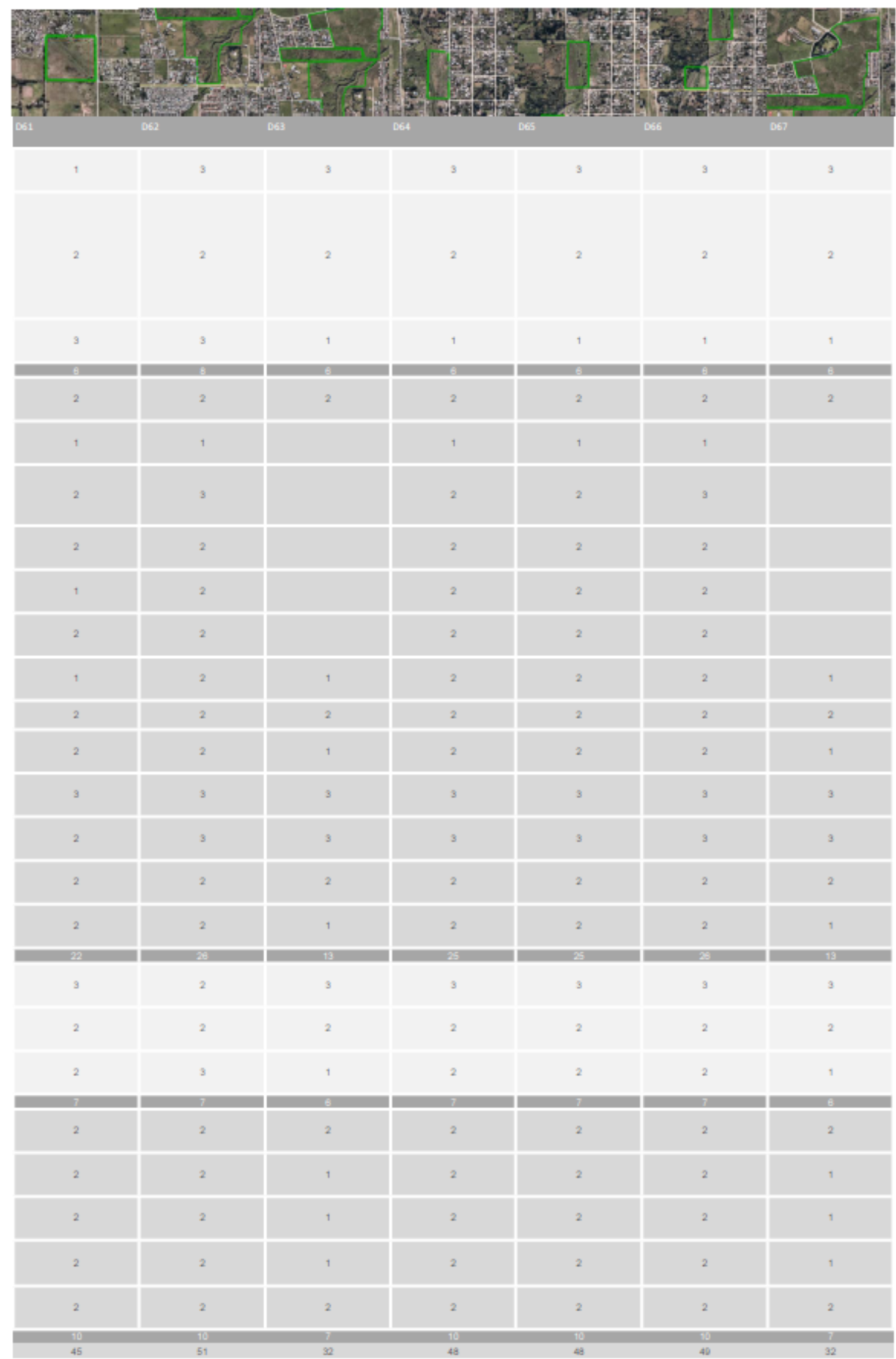




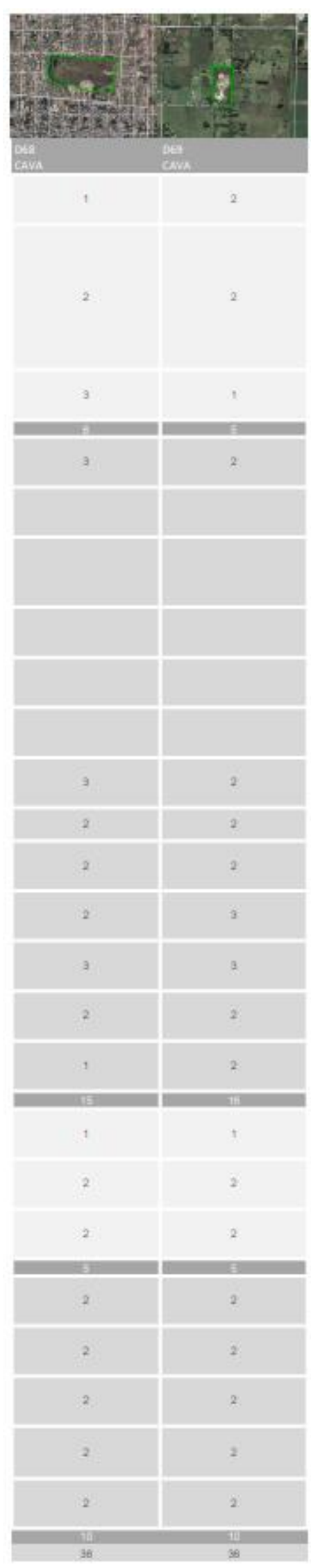



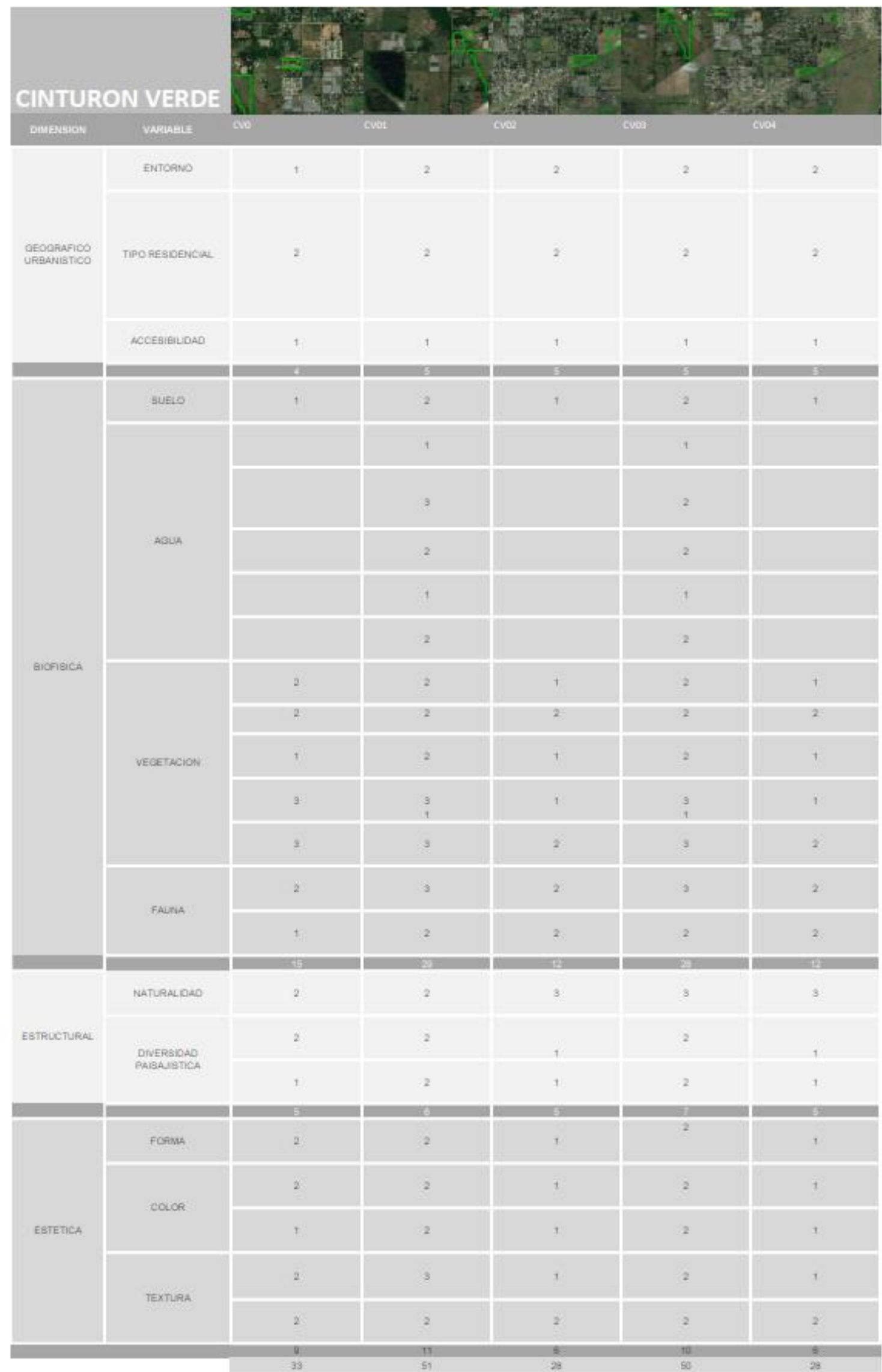


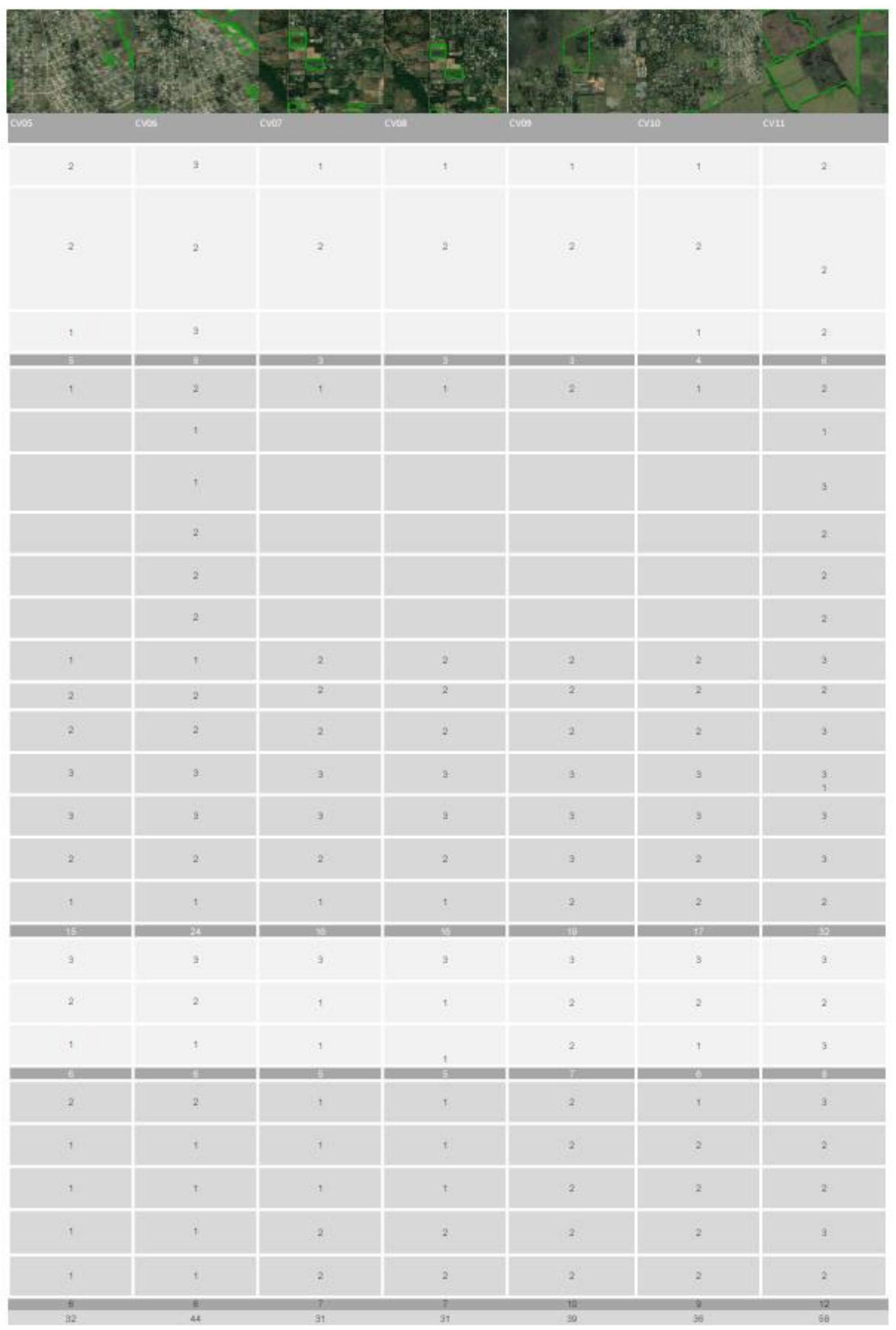



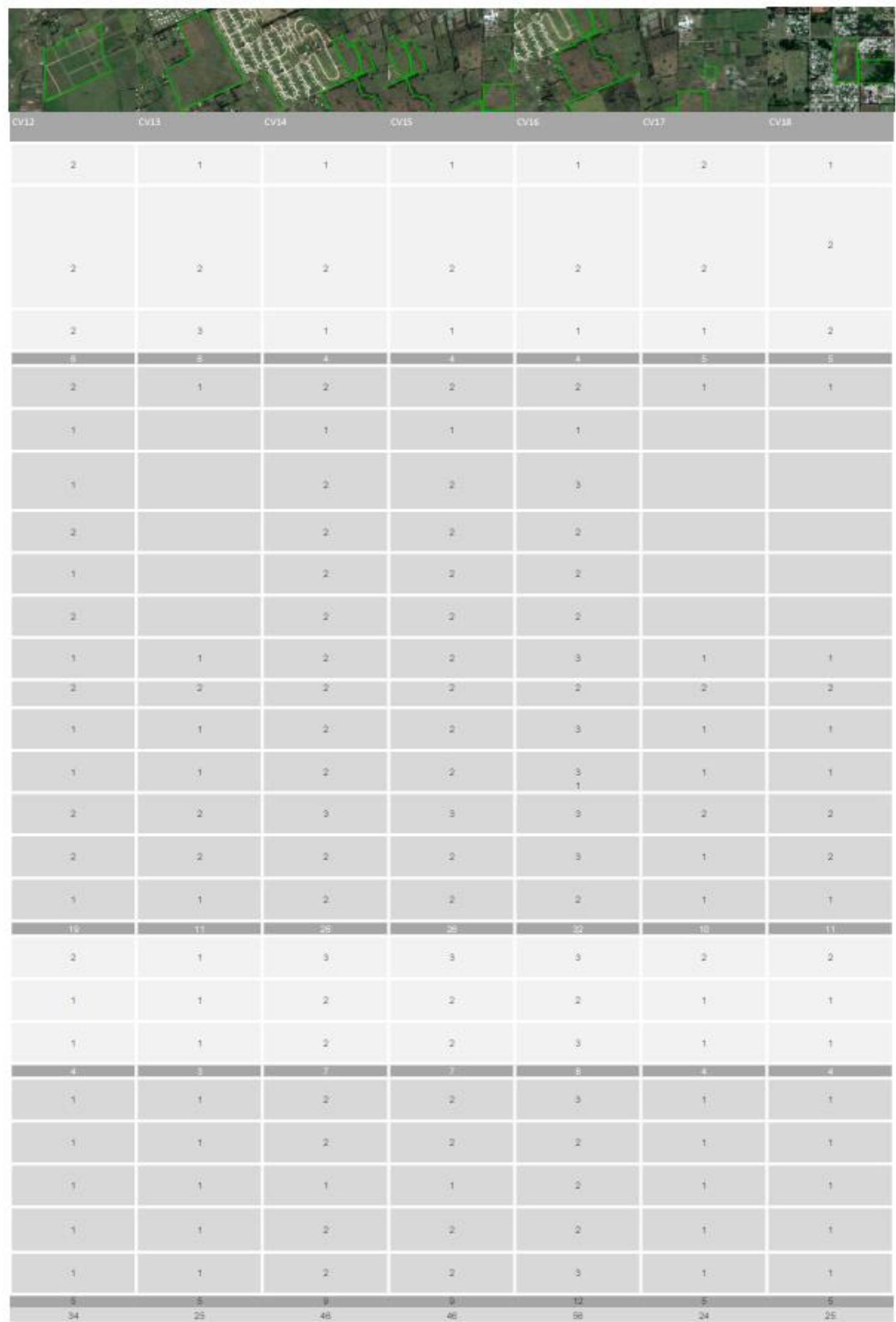


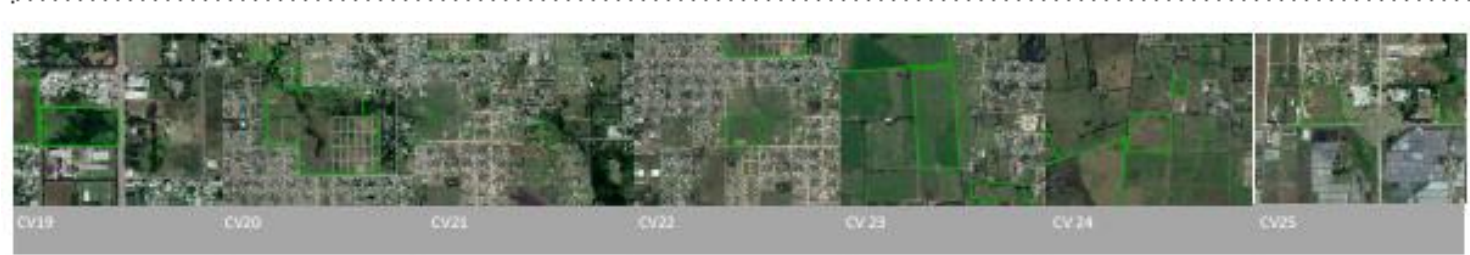

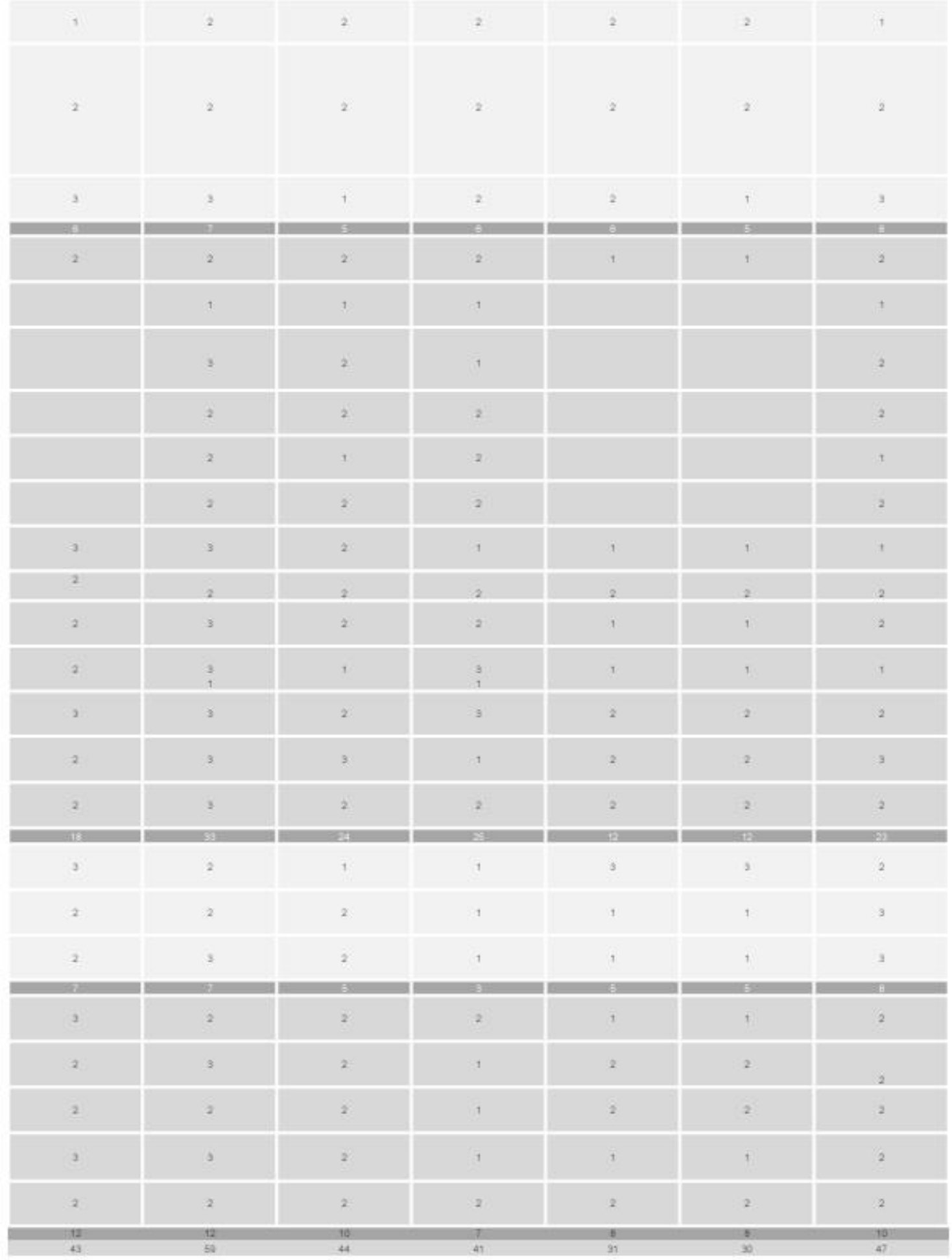




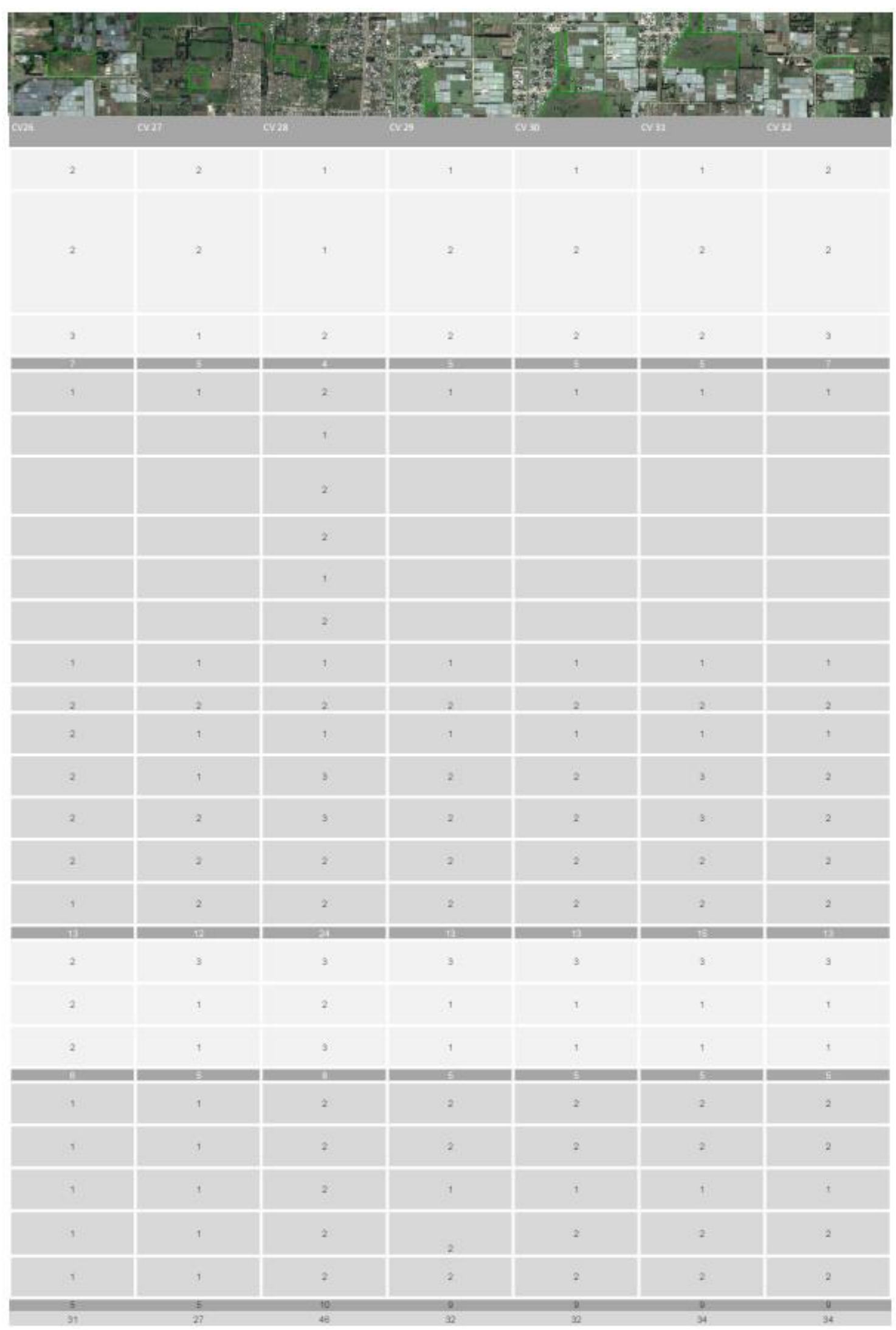


PAISAJES VACANTES

ANEXO 5

Catálogo de las tierras vacantes 
ANEXO 5

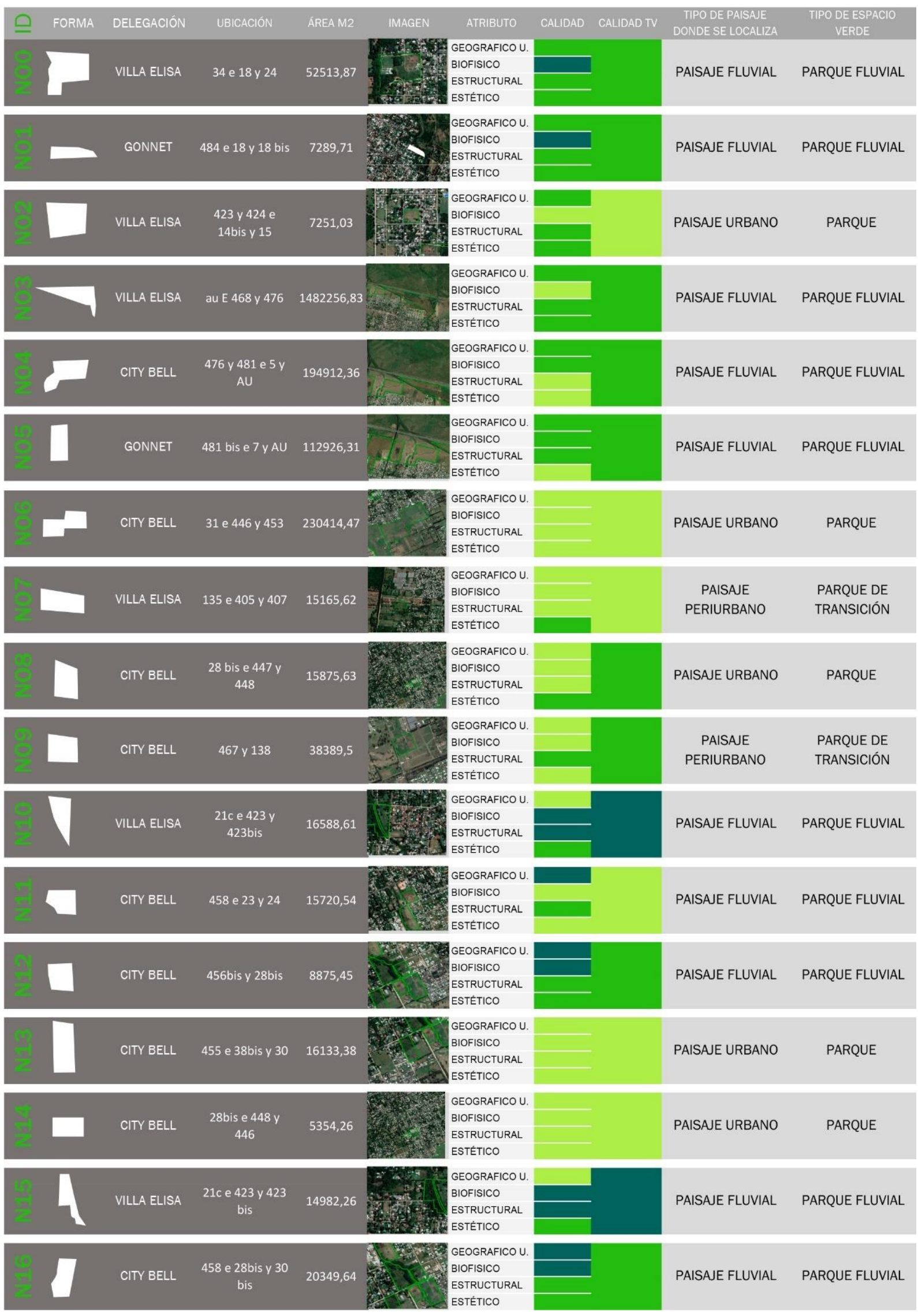




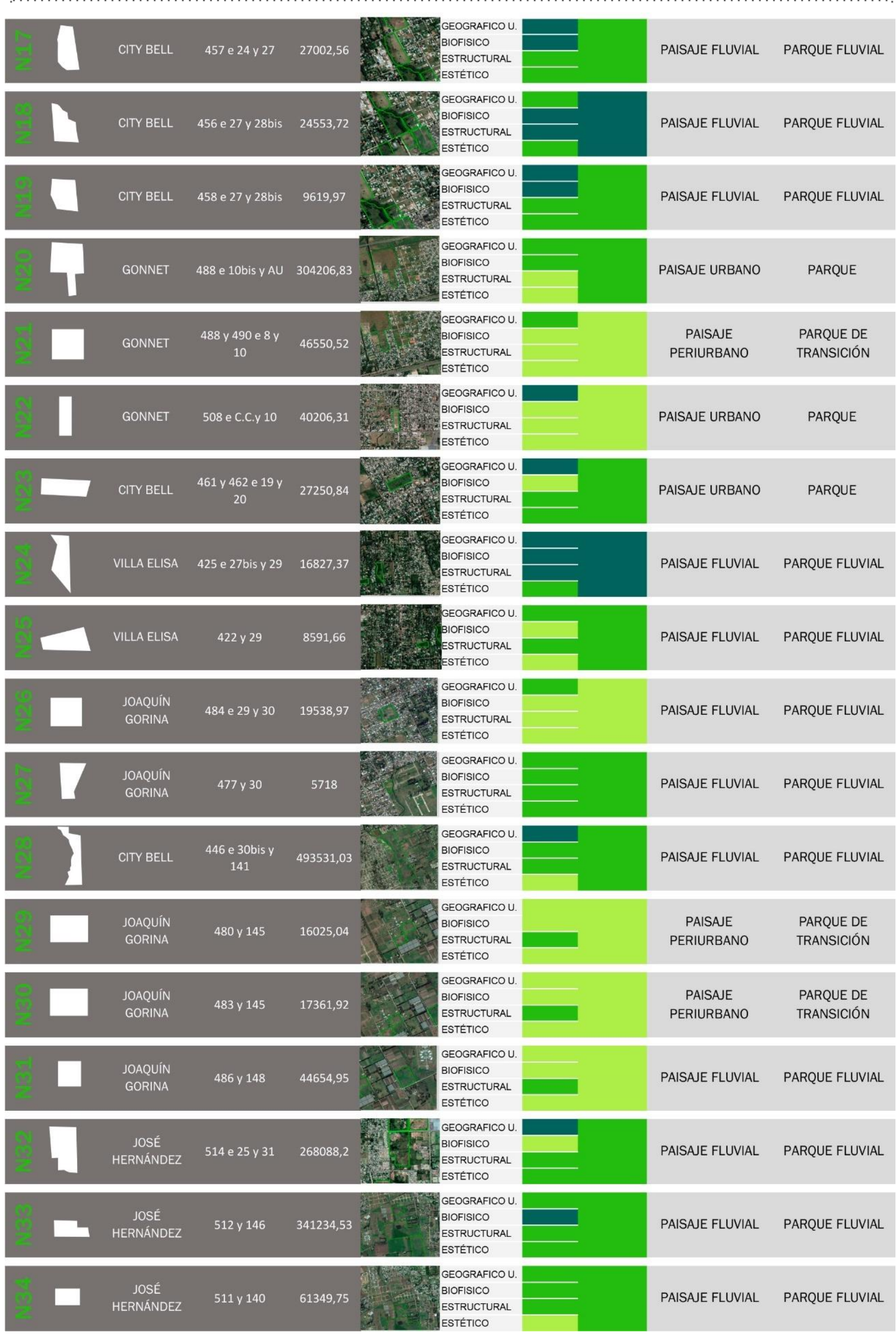




\begin{tabular}{|c|c|c|c|c|c|}
\hline $\begin{array}{c}\text { JOSÉ } \\
\text { HERNÁNDEZ }\end{array}$ & 25 e 514 y 517 & 170580,92 & $\begin{array}{l}\text { GEOGRAFICOU. } \\
\text { BIOFISICO } \\
\text { ESTRUCTURAL } \\
\text { ESTÉTICO }\end{array}$ & PAISAJE FLUVIAL & PARQUE FLUVIAL \\
\hline $\begin{array}{c}\text { JOSÉ } \\
\text { HERNÁNDEZ }\end{array}$ & 520 y 25 & 97911,26 & $\begin{array}{l}\text { BIOFISICO } \\
\text { ESTRUCTURAL } \\
\text { ESTÉTICO }\end{array}$ & PAISAJE FLUVIAL & PARQUE FLUVIAL \\
\hline $\begin{array}{c}\text { JOSÉ } \\
\text { HERNÁNDEZ }\end{array}$ & 514 e 19 y 22 & 137228,95 & $\begin{array}{l}\text { GEOGRAFICOU. } \\
\text { BIOFISICO } \\
\text { ESTRUCTURAL } \\
\text { ESTÉTICO }\end{array}$ & PAISAJE URBANO & PARQUE \\
\hline $\begin{array}{c}\text { JOSÉ } \\
\text { HERNÁNDEZ }\end{array}$ & $\begin{array}{c}511 \text { y } 514 \text { e C.B. } \\
\text { y } 19\end{array}$ & 91203 & $\begin{array}{l}\text { GEOGRAFICOU. } \\
\text { BIOFISICO } \\
\text { ESTRUCTURAL } \\
\text { ESTÉTICO }\end{array}$ & PAISAJE URBANO & PARQUE \\
\hline
\end{tabular}




\begin{tabular}{|c|c|c|c|c|c|c|c|c|c|}
\hline$\supseteq$ FORMA & DELEGACIÓN & UBICACIŌN & ÁREA M2 & IMAGEN & ATRIBUTO & CALIDAD & CALIDAD TV & $\begin{array}{l}\text { TIPO DE PAISAJE } \\
\text { DONDE SE LOCALIZA }\end{array}$ & $\begin{array}{l}\text { TIPO DE ESPACIO } \\
\text { VERDE }\end{array}$ \\
\hline & VILLA ELVIRA & 122 y 613 & 619559,59 & & $\begin{array}{l}\text { GEOGRAFICO U. } \\
\text { BIOFISICO } \\
\text { ESTRUCTURAL } \\
\text { ESTÉTICO }\end{array}$ & & & PAISAJE FLUVIAL & PARQUE FLUVIAL \\
\hline & VILLA ELVIRA & 617 e 122 y 7 & 804113,59 & $=$ & $\begin{array}{l}\text { GEOGRAFICO U. } \\
\text { BIOFISICO } \\
\text { ESTRUCTURAL } \\
\text { ESTÉTICO }\end{array}$ & & & PAISAJE FLUVIAL & PARQUE FLUVIAL \\
\hline & VILLA ELVIRA & 122 y 626 & 328147,57 & & $\begin{array}{l}\text { GEOGRAFICO U. } \\
\text { BIOFISICO } \\
\text { ESTRUCTURAL } \\
\text { ESTÉTICO }\end{array}$ & & & PAISAJE FLUVIAL & PARQUE FLUVIAL \\
\hline & VILLA ELVIRA & 122 y 626 & 626238,79 & & $\begin{array}{l}\text { GEOGRAFICO U. } \\
\text { BIOFISICO } \\
\text { ESTRUCTURAL } \\
\text { ESTÉTICO }\end{array}$ & & & PAISAJE FLUVIAL & PARQUE FLUVIAL \\
\hline & $\begin{array}{l}\text { ALTOS DE SAN } \\
\text { LORENZO }\end{array}$ & 16 e 93 y 96 & 66067,15 & & $\begin{array}{l}\text { GEOGRAFICOU. } \\
\text { BIOFISICO } \\
\text { ESTRUCTURAL } \\
\text { ESTETICO }\end{array}$ & & & PAISAJE FLUVIAL & PARQUE FLUVIAL \\
\hline & $\begin{array}{l}\text { ALTOS DE SAN } \\
\text { LORENZO }\end{array}$ & 17 e 83 y 88 & 153445,31 & & $\begin{array}{l}\text { GEOGRAFICOU. } \\
\text { BIOFISICO } \\
\text { ESTRUCTURAL } \\
\text { ESTETICO }\end{array}$ & & & PAISAJE URBANO & PARQUE \\
\hline & $\begin{array}{l}\text { ALTOS DE SAN } \\
\text { LORENZO }\end{array}$ & $\begin{array}{c}19 \text { y } 21 \text { e } 77 \text { y } \\
78 \text { bis }\end{array}$ & 17722,67 & & $\begin{array}{l}\text { GEOGRAFICOU. } \\
\text { BIOFISICO } \\
\text { ESTRUCTURAL } \\
\text { ESTÉTICO }\end{array}$ & & & PAISAJE FLUVIAL & PARQUE FLUVIAL \\
\hline & $\begin{array}{l}\text { ALTOS DE SAN } \\
\text { LORENZO }\end{array}$ & $\begin{array}{c}19 \text { y } 21 \text { e } 77 \text { y } \\
78 \text { bis }\end{array}$ & 17789,6 & & $\begin{array}{l}\text { GEOGRAFICO U. } \\
\text { BIOFISICO } \\
\text { ESTRUCTURAL } \\
\text { ESTÉTICO }\end{array}$ & & & PAISAJE FLUVIAL & PARQUE FLUVIAL \\
\hline & $\begin{array}{l}\text { ALTOS DE SAN } \\
\text { LORENZO }\end{array}$ & 9 у 137 & 70226,06 & & $\begin{array}{l}\text { GEOGRAFICOU. } \\
\text { BIOFISICO } \\
\text { ESTRUCTURAL } \\
\text { ESTÉTICO }\end{array}$ & & & $\begin{array}{c}\text { PAISAJE } \\
\text { PERIURBANO }\end{array}$ & $\begin{array}{l}\text { PARQUE DE } \\
\text { TRANSICIÓN }\end{array}$ \\
\hline & LOS HORNOS & $\begin{array}{l}144 \text { y } 149 \\
\text { e } 73 \text { y } 76\end{array}$ & 188507,25 & & $\begin{array}{l}\text { GEOGRAFICO U. } \\
\text { BIOFISICO } \\
\text { ESTRUCTURAL } \\
\text { ESTÉTICO }\end{array}$ & & & PAISAJE FLUVIAL & PARQUE FLUVIAL \\
\hline & LOS HORNOS & 13 y 72 & 38612,94 & & $\begin{array}{l}\text { GEOGRAFICO U. } \\
\text { BIOFISICO } \\
\text { ESTRUCTURAL } \\
\text { ESTÉTICO }\end{array}$ & & & PAISAJE FLUVIAL & PARQUE FLUVIAL \\
\hline & LOS HORNOS & 155 e 68 y 70 & 17855,9 & & $\begin{array}{l}\text { GEOGRAFICO U. } \\
\text { BIOFISICO } \\
\text { ESTRUCTURAL } \\
\text { ESTÉTICO }\end{array}$ & & & PAISAJE FLUVIAL & PARQUE FLUVIAL \\
\hline & SAN CARLOS & 38 e 143 y 146 & 101041,07 & & $\begin{array}{l}\text { GEOGRAFICO U. } \\
\text { BIOFISICO } \\
\text { ESTRUCTURAL } \\
\text { ESTÉTICO }\end{array}$ & & & PAISAJE URBANO & PARQUE \\
\hline & SAN CARLOS & 38 e 143 y 147 & 86524,53 & & $\begin{array}{l}\text { GEOGRAFICO U. } \\
\text { BIOFISICO } \\
\text { ESTRUCTURAL } \\
\text { ESTÉTICO }\end{array}$ & & & PAISAJE FLUVIAL & PARQUE FLUVIAL \\
\hline & SAN CARLOS & 42 e 152 y 153 & 36768,76 & & $\begin{array}{l}\text { GEOGRAFICO U. } \\
\text { BIOFISICO } \\
\text { ESTRUCTURAL } \\
\text { ESTÉTICO }\end{array}$ & & & $\begin{array}{c}\text { PAISAJE } \\
\text { PERIURBANO }\end{array}$ & $\begin{array}{l}\text { PARQUE DE } \\
\text { TRANSICIÓN }\end{array}$ \\
\hline & SAN CARLOS & 526 y 147 & 30787,18 & & $\begin{array}{l}\text { GEOGRAFICO U. } \\
\text { BIOFISICO } \\
\text { ESTRUCTURAL } \\
\text { ESTETICO }\end{array}$ & & & PAISAJE FLUVIAL & PARQUE FLUVIAL \\
\hline & SAN CARLOS & 526 y 147 & 42904,43 & & $\begin{array}{l}\text { GEOGRAFICOU. } \\
\text { BIOFISICO } \\
\text { ESTRUCTURAL } \\
\text { ESTÉTICO }\end{array}$ & & & PAISAJE FLUVIAL & PARQUE FLUVIAL \\
\hline
\end{tabular}




\begin{tabular}{|c|c|c|c|c|c|c|}
\hline SAN CARLOS & 137 e 36 y 38 & 75179,57 & $\frac{1}{4}$ & $\begin{array}{l}\text { BIOFISICO } \\
\text { ESTRUCTURAL } \\
\text { ESTÉTICO }\end{array}$ & PAISAJE FLUVIAL & PARQUE FLUVIAL \\
\hline TOLOSA & 514 y 133 & 48534,93 & 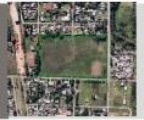 & $\begin{array}{l}\text { GEOGRAFICOU. } \\
\text { BIOFISICO } \\
\text { ESTRUCTURAL } \\
\text { ESTÉTICO }\end{array}$ & PAISAJE URBANO & PARQUE \\
\hline LOS HORNOS & 52 y 172 & 24838,35 & & $\begin{array}{l}\text { GEOGRAFICOU. } \\
\text { BIOFISICO } \\
\text { ESTRUCTURAL } \\
\text { ESTÉTICO }\end{array}$ & PAISAJE FLUVIAL & PARQUE FLUVIAL \\
\hline LOS HORNOS & 55 y 169 & 39642,31 & ide $-4 e^{-1}$ & $\begin{array}{l}\text { GEOGRAFICOU. } \\
\text { BIOFISICO } \\
\text { ESTRUCTURAL } \\
\text { ESTÉTICO }\end{array}$ & PAISAJE FLUVIAL & PARQUE FLUVIAL \\
\hline TOLOSA & $\begin{array}{c}25 \text { e } 522 \text { y } \\
523 \text { bis }\end{array}$ & 71407,49 & 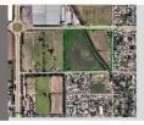 & $\begin{array}{l}\text { GEOGRAFICOU. } \\
\text { BIOFISICO } \\
\text { ESTRUCTURAL } \\
\text { ESTÉTICO }\end{array}$ & PAISAJE FLUVIAL & PARQUE FLUVIAL \\
\hline TOLOSA & 31 y 525 & 9464,53 & 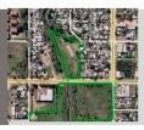 & $\begin{array}{l}\text { GEOGRAFICOU. } \\
\text { BIOFISICO } \\
\text { ESTRUCTURAL } \\
\text { ESTÉTICO }\end{array}$ & PAISAJE FLUVIAL & PARQUE FLUVIAL \\
\hline SAN CARLOS & 138 y 524 & 19555,86 & $\frac{4}{32}-\frac{1}{32}$ & $\begin{array}{l}\text { GEOGRAFICOU. } \\
\text { BIOFISICO } \\
\text { ESTRUCTURAL } \\
\text { ESTÉTICO }\end{array}$ & PAISAJE FLUVIAL & PARQUE FLUVIAL \\
\hline SAN CARLOS & 31 e 524 y 526 & 41645,13 & 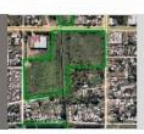 & $\begin{array}{l}\text { GEOGRAFICOU. } \\
\text { BIOFISICO } \\
\text { ESTRUCTURAL } \\
\text { ESTÉTICO }\end{array}$ & PAISAJE FLUVIAL & PARQUE FLUVIAL \\
\hline SAN CARLOS & 144 e 46 y 47 & 18701,35 & 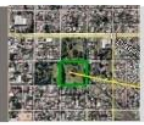 & $\begin{array}{l}\text { GEOGRAFICOU. } \\
\text { BIOFISICO } \\
\text { ESTRUCTURAL } \\
\text { ESTÉTICO }\end{array}$ & PAISAJE FLUVIAL & PARQUE FLUVIAL \\
\hline LOS HORNOS & 155 e 68 y 69 & 71271,18 & tus axting & $\begin{array}{l}\text { GEOGRAFICO U. } \\
\text { BIOFISICO } \\
\text { ESTRUCTURAL } \\
\text { ESTÉTICO }\end{array}$ & PAISAJE FLUVIAL & PARQUE FLUVIAL \\
\hline VILLA ELVIRA & 7 y 85 & 91538,14 & & $\begin{array}{l}\text { GEOGRAFICOU. } \\
\text { BIOFISICO } \\
\text { ESTRUCTURAL } \\
\text { ESTÉTICO }\end{array}$ & PAISAJE FLUVIAL & PARQUE FLUVIAL \\
\hline VILLA ELVIRA & 3 y 84 & 34042,54 & 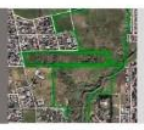 & $\begin{array}{l}\text { GEOGRAFICO U. } \\
\text { BIOFISICO } \\
\text { ESTRUCTURAL } \\
\text { ESTÉTICO }\end{array}$ & PAISAJE FLUVIAL & PARQUE FLUVIAL \\
\hline VILLA ELVIRA & 92 e 115 y 116 & 20381,5 & (3) & $\begin{array}{l}\text { GEOGRAFICOU. } \\
\text { BIOFISICO } \\
\text { ESTRUCTURAL } \\
\text { ESTÉTICO }\end{array}$ & PAISAJE FLUVIAL & PARQUE FLUVIAL \\
\hline VILLA ELVIRA & 93 e 119 y 121 & 20976,12 & 19. & $\begin{array}{l}\text { GEOGRAFICO U. } \\
\text { BIOFISICO } \\
\text { ESTRUCTURAL } \\
\text { ESTETICO }\end{array}$ & PAISAJE FLUVIAL & PARQUE FLUVIAL \\
\hline VILLA ELVIRA & 117 y 92 & 10248,06 & 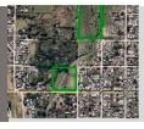 & $\begin{array}{l}\text { GEOGRAFICOU. } \\
\text { BIOFISICO } \\
\text { ESTRUCTURAL } \\
\text { ESTÉTICO }\end{array}$ & PAISAJE FLUVIAL & PARQUE FLUVIAL \\
\hline VILLA ELVIRA & 90 e 115 y 3 & 140184,42 & 2). & $\begin{array}{l}\text { GEOGRAFICOU. } \\
\text { BIOFISICO } \\
\text { ESTRUCTURAL } \\
\text { ESTÉTICO }\end{array}$ & PAISAJE FLUVIAL & PARQUE FLUVIAL \\
\hline $\begin{array}{l}\text { ALTOS DE SAN } \\
\text { LORENZO }\end{array}$ & 183 e 17 y 19 & 96895,58 & mets & $\begin{array}{l}\text { GEOGRAFICOU. } \\
\text { BIOFISICO } \\
\text { ESTRUCTURAL } \\
\text { ESTÉTICO }\end{array}$ & PAISAJE FLUVIAL & PARQUE FLUVIAL \\
\hline LOS HORNOS & 161 y 83 & 78135,12 & $\frac{2}{4}=$ & $\begin{array}{l}\text { GEOGRAFICOU. } \\
\text { BIOFISICO } \\
\text { ESTRUCTURAL } \\
\text { ESTÉTICO }\end{array}$ & $\begin{array}{c}\text { PAISAJE } \\
\text { PERIURBANO }\end{array}$ & $\begin{array}{l}\text { PARQUE DE } \\
\text { TRANSICIÓN }\end{array}$ \\
\hline
\end{tabular}




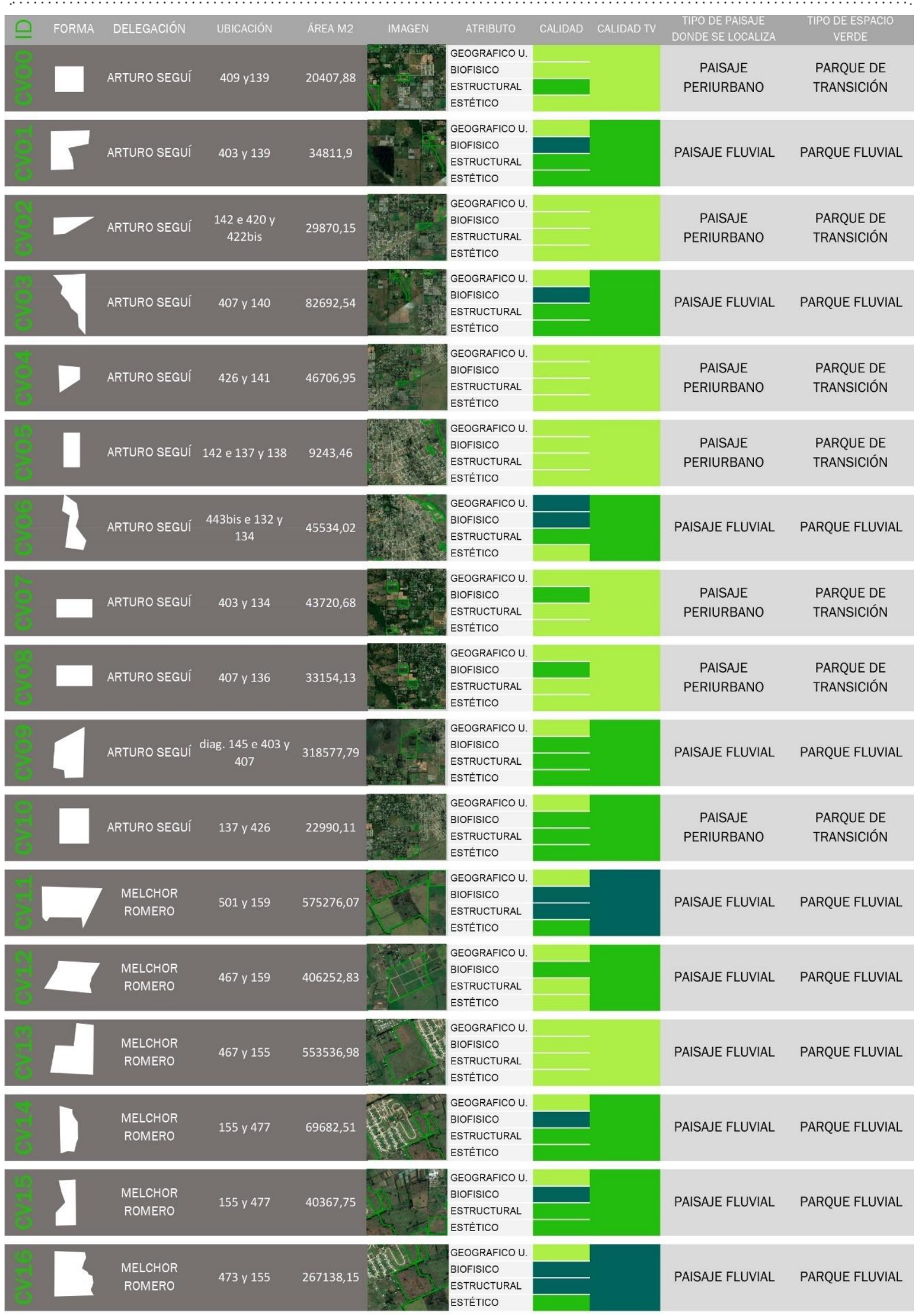




\begin{tabular}{|c|c|c|c|c|c|c|}
\hline $\begin{array}{l}\text { MEL CHOR } \\
\text { ROMERO }\end{array}$ & 507 y 157 & 14369,56 & 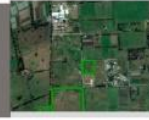 & $\begin{array}{l}\text { GEOGRAFICOU. } \\
\text { BIOFISICO } \\
\text { ESTRUCTURAL } \\
\text { ESTÉTICO }\end{array}$ & $\begin{array}{c}\text { PAISAJE } \\
\text { PERIURBANO }\end{array}$ & $\begin{array}{l}\text { PARQUE DE } \\
\text { TRANSICIÓN }\end{array}$ \\
\hline $\begin{array}{l}\text { LISANDRO } \\
\text { OLMOS }\end{array}$ & 155 y 42 & 36897,6 & $206-3 a^{5}$ & $\begin{array}{l}\text { BIOFISICO } \\
\text { ESTRUCTURAL } \\
\text { ESTÉTICO }\end{array}$ & PAISAJE URBANO & PARQUE \\
\hline $\begin{array}{l}\text { LISANDRO } \\
\text { OLMOS }\end{array}$ & 57 y 44 & 39267,47 & 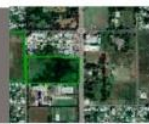 & $\begin{array}{l}\text { GEOGRAFICOU. } \\
\text { BIOFISICO } \\
\text { ESTRUCTURAL } \\
\text { ESTÉTICO }\end{array}$ & PAISAJE URBANO & PARQUE \\
\hline $\begin{array}{l}\text { MELCHOR } \\
\text { ROMERO }\end{array}$ & 32 e 149 y 155 & 692542,73 & se $y+x^{2}$ & $\begin{array}{l}\text { GEOGRAFICO U. } \\
\text { BIOFISICO } \\
\text { ESTRUCTURAL } \\
\text { ESTÉTICO }\end{array}$ & PAISAJE FLUVIAL & PARQUE FLUVIAL \\
\hline $\begin{array}{l}\text { MELCHOR } \\
\text { ROMERO }\end{array}$ & 161 y 36 & 22895,94 & & $\begin{array}{l}\text { GEOGRAFICOU. } \\
\text { BIOFISICO } \\
\text { ESTRUCTURAL } \\
\text { ESTÉTICO }\end{array}$ & PAISAJE FLUVIAL & PARQUE FLUVIAL \\
\hline $\begin{array}{l}\text { MELCHOR } \\
\text { ROMERO }\end{array}$ & 526 y 161 & 76763,2 & & $\begin{array}{l}\text { GEOGRAFICO U. } \\
\text { BIOFISICO } \\
\text { ESTRUCTURAL } \\
\text { ESTÉTICO }\end{array}$ & PAISAJE FLUVIAL & PARQUE FLUVIAL \\
\hline $\begin{array}{l}\text { MELCHOR } \\
\text { ROMERO }\end{array}$ & 511 y 146 & 233935,89 & 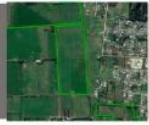 & $\begin{array}{l}\text { GEOGRAFICOU. } \\
\text { BIOFISICO } \\
\text { ESTRUCTURAL } \\
\text { ESTÉTICO }\end{array}$ & $\begin{array}{c}\text { PAISAJE } \\
\text { PERIURBANO }\end{array}$ & $\begin{array}{l}\text { PARQUE DE } \\
\text { TRANSICIÓN }\end{array}$ \\
\hline $\begin{array}{l}\text { MELCHOR } \\
\text { ROMERO }\end{array}$ & 159 y 501 & 87487,69 & & $\begin{array}{l}\text { GEOGRAFICOU. } \\
\text { BIOFISICO } \\
\text { ESTRUCTURAL } \\
\text { ESTÉTICO }\end{array}$ & $\begin{array}{c}\text { PAISAJE } \\
\text { PERIURBANO }\end{array}$ & $\begin{array}{l}\text { PARQUE DE } \\
\text { TRANSICIÓN }\end{array}$ \\
\hline $\begin{array}{l}\text { MELCHOR } \\
\text { ROMERO }\end{array}$ & 191 y 520 & 67365,77 & is arex & $\begin{array}{l}\text { GEOGRAFICOU. } \\
\text { BIOFISICO } \\
\text { ESTRUCTURAL } \\
\text { ESTÉTICO }\end{array}$ & PAISAJE FLUVIAL & PARQUE FLUVIAL \\
\hline $\begin{array}{l}\text { MEICHOR } \\
\text { ROMERO }\end{array}$ & 191 y 520 & 127905,77 & $1^{2}-1=$ & $\begin{array}{l}\text { GEOGRAFICOU. } \\
\text { BIOFISICO } \\
\text { ESTRUCTURAL } \\
\text { ESTÉTICO }\end{array}$ & $\begin{array}{c}\text { PAISAJE } \\
\text { PERIURBANO }\end{array}$ & $\begin{array}{l}\text { PARQUE DE } \\
\text { TRANSICIÓN }\end{array}$ \\
\hline $\begin{array}{l}\text { MELCHOR } \\
\text { ROMERO }\end{array}$ & 157 y 510 & 20038,33 & & $\begin{array}{l}\text { GEOGRAFICOU. } \\
\text { BIOFISICO } \\
\text { ESTRUCTURAL } \\
\text { ESTÉTICO }\end{array}$ & PAISAJE FLUVIAL & PARQUE FLUVIAL \\
\hline $\begin{array}{l}\text { MEICHOR } \\
\text { ROMERO }\end{array}$ & 155 y 515 & 88498,28 & & $\begin{array}{l}\text { GEOGRAFICOU. } \\
\text { BIOFISICO } \\
\text { ESTRUCTURAL } \\
\text { ESTÉTICO }\end{array}$ & PAISAJE FLUVIAL & PARQUE FLUVIAL \\
\hline $\begin{array}{l}\text { LISANDRO } \\
\text { OLMOS }\end{array}$ & 52 y 191 & 43875,37 & 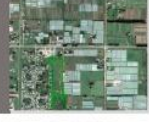 & $\begin{array}{l}\text { GEOGRAFICOU. } \\
\text { BIOFISICO } \\
\text { ESTRUCTURAL } \\
\text { ESTÉTICO }\end{array}$ & $\begin{array}{c}\text { PAISAJE } \\
\text { PERIURBANO }\end{array}$ & $\begin{array}{l}\text { PARQUE DE } \\
\text { TRANSICIÓN }\end{array}$ \\
\hline $\begin{array}{l}\text { LISANDRO } \\
\text { OLMOS }\end{array}$ & 52 y 191 & 40501,56 & 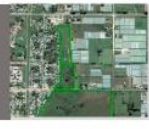 & $\begin{array}{l}\text { GEOGRAFICOU. } \\
\text { BIOFISICO } \\
\text { ESTRUCTURAL } \\
\text { ESTÉTICO }\end{array}$ & $\begin{array}{c}\text { PAISAJE } \\
\text { PERIURBANO }\end{array}$ & $\begin{array}{l}\text { PARQUE DE } \\
\text { TRANSICIÓN }\end{array}$ \\
\hline $\begin{array}{l}\text { LISANDRO } \\
\text { OLMOS }\end{array}$ & 52 y 191 & 277288,05 & 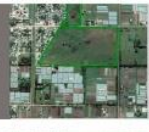 & $\begin{array}{l}\text { GEOGRAFICOU. } \\
\text { BIOFISICO } \\
\text { ESTRUCTURAL } \\
\text { ESTÉTICO }\end{array}$ & $\begin{array}{c}\text { PAISAJE } \\
\text { PERIURBANO }\end{array}$ & $\begin{array}{l}\text { PARQUE DE } \\
\text { TRANSICIÓN }\end{array}$ \\
\hline $\begin{array}{l}\text { LISANDRO } \\
\text { OLMOS }\end{array}$ & 66 y 191 & 47929,53 & 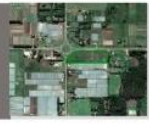 & $\begin{array}{l}\text { GEOGRAFICOU. } \\
\text { BIOFISICO } \\
\text { ESTRUCTURAL } \\
\text { ESTÉTICO }\end{array}$ & $\begin{array}{c}\text { PAISAJE } \\
\text { PERIURBANO }\end{array}$ & $\begin{array}{l}\text { PARQUE DE } \\
\text { TRANSICIÓN }\end{array}$ \\
\hline
\end{tabular}


Espacios verdes propuestos por tipo y zona. Superficies incorporadas según el tipo 
ANEXO 6

\begin{tabular}{|c|c|c|c|c|c|c|c|c|c|c|c|c|c|c|c|c|}
\hline \multicolumn{17}{|c|}{ DESBORDE } \\
\hline \multicolumn{6}{|c|}{ TP URBANO } & \multicolumn{6}{|c|}{ TP FLUVIAL } & \multicolumn{5}{|c|}{ TP PERIURBANO } \\
\hline & \multirow[t]{2}{*}{ TIPO 1} & \multicolumn{2}{|r|}{ TIPO 2} & \multicolumn{2}{|r|}{ TIPO 3} & \multicolumn{2}{|r|}{ TIPO 4} & & TIPO 5 & & TIPO 6 & TIPO 7 & & TIPO 8 & & TIPO 9 \\
\hline & & D30 & 101041,07 & D23 & 153445,31 & & & D22 & 66067,15 & D18 & 619559,59 & & D69 & 78135,12 & D32 & 36768,76 \\
\hline & & D29 & 17855,9 & D40 & 48534,93 & & & D24 & 17722,67 & D19 & 804113,59 & & & & D26 & 70226,06 \\
\hline & & & & & & & & D25 & 17789,6 & D20 & 328147,57 & & & & & \\
\hline & & & & & & & & D27 & 188507,25 & $\mathrm{D} 21$ & 626238,79 & & & & & \\
\hline & & & & & & & & D28 & 38612,94 & $\mathrm{D} 45$ & 24838,35 & & & & & \\
\hline & & & & & & & & D31 & 86524,53 & D46 & 39642,31 & & & & & \\
\hline & & & & & & & & D39 & 75179,57 & D58 & 19555,86 & & & & & \\
\hline & & & & & & & & D56 & 71407,49 & D63 & 34042,54 & & & & & \\
\hline & & & & & & & & D57 & 9464,53 & $\mathrm{D} 67$ & 140184,42 & & & & & \\
\hline & & & & & & & & D59 & 41645,13 & & & & & & & \\
\hline & & & & & & & & $\mathrm{D} 60$ & 18701,35 & & & & & & & \\
\hline & & & & & & & & D61 & 71271,18 & & & & & & & \\
\hline & & & & & & & & D62 & 91538,14 & & & & & & & \\
\hline & & & & & & & & D64 & 20381,5 & & & & & & & \\
\hline & & & & & & & & D65 & 20976,12 & & & & & & & \\
\hline & & & & & & & & D66 & 10248,06 & & & & & & & \\
\hline & & & & & & & & D35 & 30787,18 & & & & & & & \\
\hline & & & & & & & & D36 & 42904,43 & & & & & & & \\
\hline & & & & & & & & D68 & 96895,58 & & & & & & & \\
\hline & & $\mathrm{m} 2$ & 118896,97 & $\mathrm{~m} 2$ & 201980,24 & & & $\mathrm{~m} 2$ & 1016624,4 & m2 & 2636323,02 & & m2 & 78135,12 & $\mathrm{~m} 2$ & 106994,82 \\
\hline & & $\mathrm{Ha}$. & 11,8 & $\mathrm{Ha}$. & 20,2 & & & $\mathrm{Ha}$. & 101,6 & Ha. & 263,6 & & Ha. & 7,8 & $\mathrm{Ha}$. & 10,7 \\
\hline & & & & & & & & & & & & & & TOTAL: & 415,7 & $\mathrm{Ha}$. \\
\hline & & & & & & & & & EJE NO & & & & & & & \\
\hline & & & URBANO & & & & & & FLUVIAL & & & & TP Pt: & ERIURBANO & & \\
\hline & TIPO 1 & & TIPO 2 & & TIPO 3 & & TIPO 4 & & TIPO 5 & & TIPO 6 & TIPO 7 & & TIPO 8 & & TIPO 9 \\
\hline NO38 & 137228,95 & $\mathrm{NO} 20$ & 304206,83 & $\mathrm{NO} 2$ & 7251,03 & NO10 & 16588,61 & NOO & 52513,87 & NO11 & 15720,54 & & NO9 & 38389,5 & NO7 & 15165,62 \\
\hline & & $\mathrm{NO} 23$ & 27250,84 & NO6 & 230414,47 & NO15 & 14982,26 & $\mathrm{NO} 3$ & 1482256,83 & NO26 & 19538,97 & & & & NO21 & 46550,52 \\
\hline & & NO39 & 91203 & NO13 & 16133,38 & NO18 & 24553,72 & NO4 & 194912,36 & NO31 & 44654,95 & & & & NO29 & 16025,04 \\
\hline & & NO8 & 15875,63 & NO22 & 40206,31 & NO24 & 16827,37 & NO5 & 112926,31 & & & & & & NO3O & 17361,92 \\
\hline & & & & NO14 & 5354,26 & & & NO12 & 8875,45 & & & & & & & \\
\hline & & & & & & & & NO16 & 20349,64 & & & & & & & \\
\hline & & & & & & & & NO17 & 27002,56 & & & & & & & \\
\hline & & & & & & & & NO19 & 9619,97 & & & & & & & \\
\hline & & & & & & & & NO28 & 493531,03 & & & & & & & \\
\hline & & & & & & & & NO32 & 268088,2 & & & & & & & \\
\hline & & & & & & & & NO33 & 341234,53 & & & & & & & \\
\hline & & & & & & & & NO34 & 61349,75 & & & & & & & \\
\hline & & & & & & & & NO35 & 170580,92 & & & & & & & \\
\hline & & & & & & & & NO36 & 97911,26 & & & & & & & \\
\hline & & & & & & & & NO1 & 7289,71 & & & & & & & \\
\hline & & & & & & & & NO25 & 8591,66 & & & & & & & \\
\hline & & & & & & & & NO27 & 5718 & & & & & & & \\
\hline $\mathrm{m} 2$ & 137228,95 & $\mathrm{~m} 2$ & 438536,3 & $\mathrm{~m} 2$ & 299359,45 & $\mathrm{~m} 2$ & 72951,96 & $\mathrm{~m} 2$ & 3362752,05 & $\mathrm{~m} 2$ & 79914,46 & & m2 & 38389,5 & $\mathrm{~m} 2$ & 95103,1 \\
\hline $\mathrm{Ha}$. & 13,7 & Ha. & 43,8 & $\mathrm{Ha}$. & 29,9 & $\mathrm{Ha}$. & 7,2 & $\mathrm{Ha}$. & 336,2 & $\mathrm{Ha}$. & 7,9 & & Ha. & 3,8 & $\mathrm{Ha}$. & 9,5 \\
\hline & & & & & & & & & & & & & & TOTAL: & 452 & $\mathrm{Ha}$. \\
\hline & & & & & & & & CINTU & URON VERDE & & & & & & & \\
\hline & & TP & URBANO & & & & & & FLUVIAL & & & & TP PL & ERIURBANO & & \\
\hline & TIPO 1 & & TIPO 2 & & TIPO 3 & & TIPO 4 & & TIPO 5 & & TIPO 6 & TIPO 7 & & TIPO 8 & & TIPO 9 \\
\hline & & CV19 & 39267,47 & CV18 & 36897,6 & CV11 & 575276,07 & CV01 & 34811,9 & CV13 & 553536,98 & & CV10 & 22990,11 & CV0o & 20407,88 \\
\hline & & & & & & CV16 & 267138,15 & CV03 & 82692,54 & CV27 & 20038,33 & & CV31 & 277288,05 & CV02 & 29870,15 \\
\hline & & & & & & CV20 & 692542,73 & cv06 & 45534,02 & & & & CV32 & 47929,53 & CV04 & 46706,95 \\
\hline & & & & & & & & CV09 & 318577,79 & & & & & & CV05 & 9243,46 \\
\hline & & & & & & & & CV12 & 406252,83 & & & & & & CV07 & 43720,68 \\
\hline & & & & & & & & CV14 & 69682,51 & & & & & & CV08 & 33154,13 \\
\hline & & & & & & & & CV15 & 40367,75 & & & & & & CV17 & 14369,56 \\
\hline & & & & & & & & CV21 & 22895,94 & & & & & & CV 23 & 233935,89 \\
\hline & & & & & & & & $\mathrm{CV} 22$ & 76763,2 & & & & & & CV24 & 87487,69 \\
\hline & & & & & & & & & & & & & & & CV 26 & 127905,77 \\
\hline & & & & & & & & CV25 & 67365,77 & & & & & & CV29 & 43875,37 \\
\hline & & & & & & & & CV28 & 88498,28 & & & & & & CV30 & 40501,56 \\
\hline & & $\mathrm{m} 2$ & 39311,27 & $\mathrm{~m} 2$ & 36927,5 & m2 & 1534964,15 & $\mathrm{~m} 2$ & 1253778,73 & $\mathrm{~m} 2$ & 573583,21 & & m2 & 348211,49 & & 731179,09 \\
\hline & & $\mathrm{Ha}$. & 3,9 & $\mathrm{Ha}$. & 3,6 & $\mathrm{Ha}$. & 153,4 & $\mathrm{Ha}$. & 125,3 & $\mathrm{Ha}$. & 57,3 & & $\mathrm{Ha}$. & 34,8 & & 73,1 \\
\hline & & & & & & & & & & & & & & TOTAL: & 451,4 & $\mathrm{Ha}$. \\
\hline
\end{tabular}


Fichas de relevamiento de espacios verdes 


\section{HIGH LINE I NUEVA YORK}

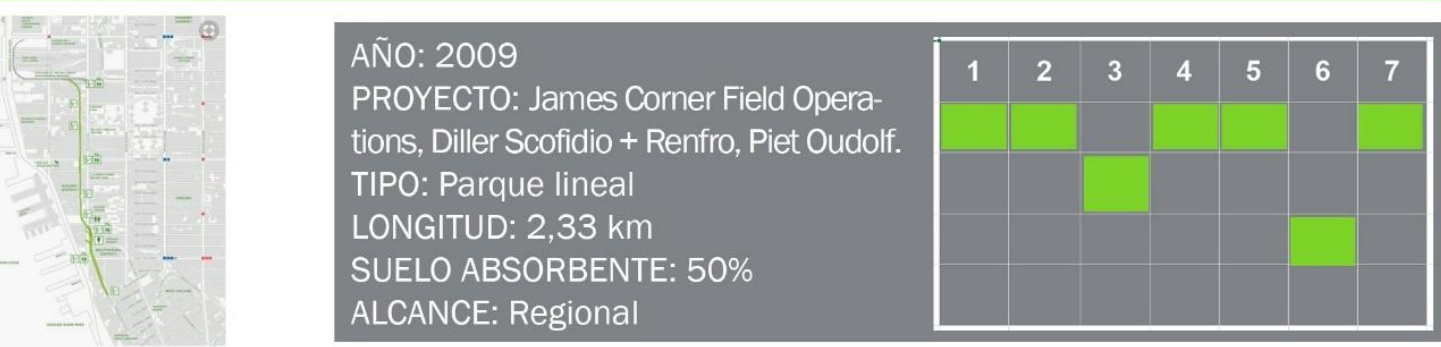

SENDEROS Y VEGETACIÓN
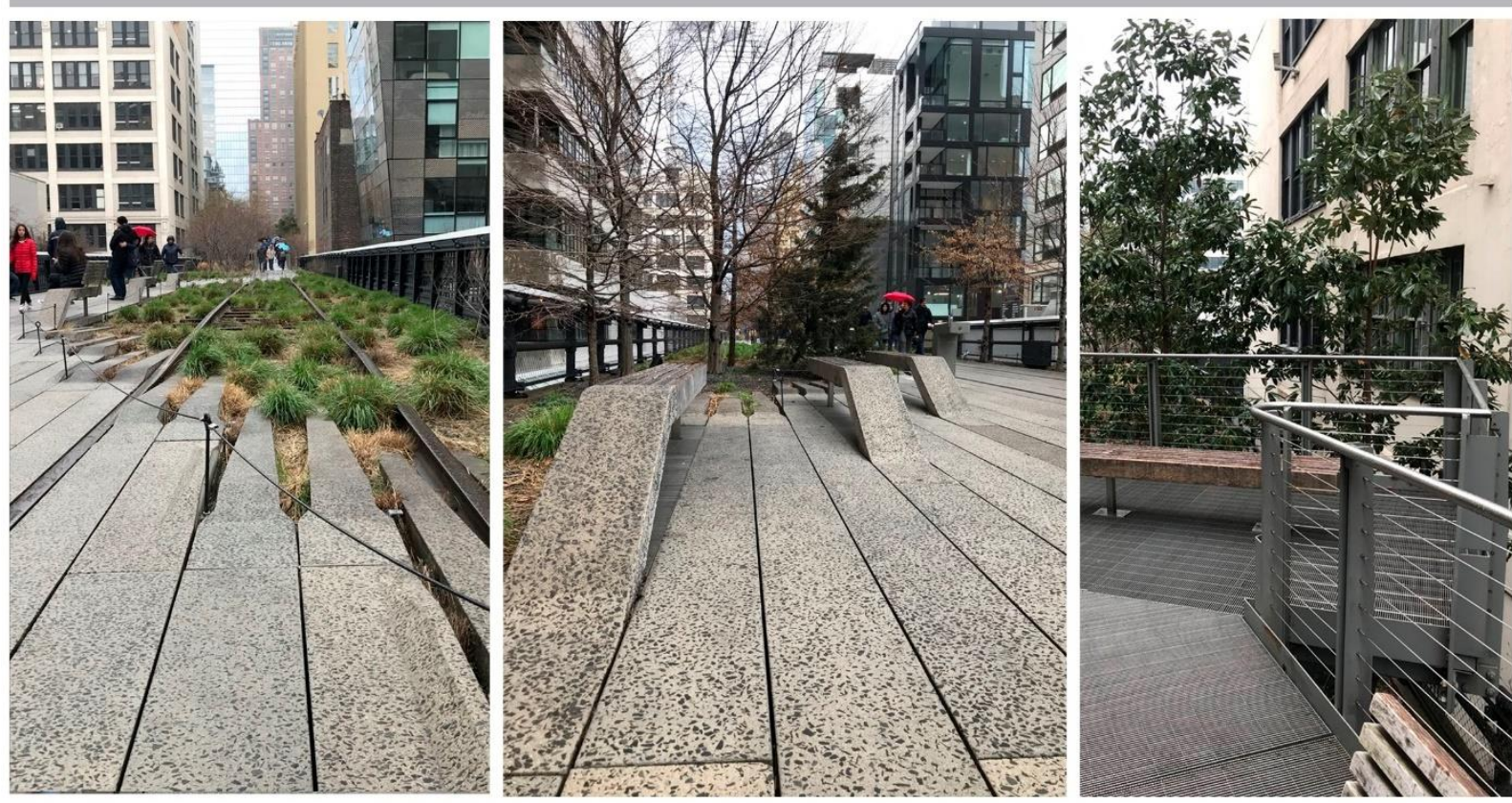

SEÑALÉTICA

MOBILIARIO
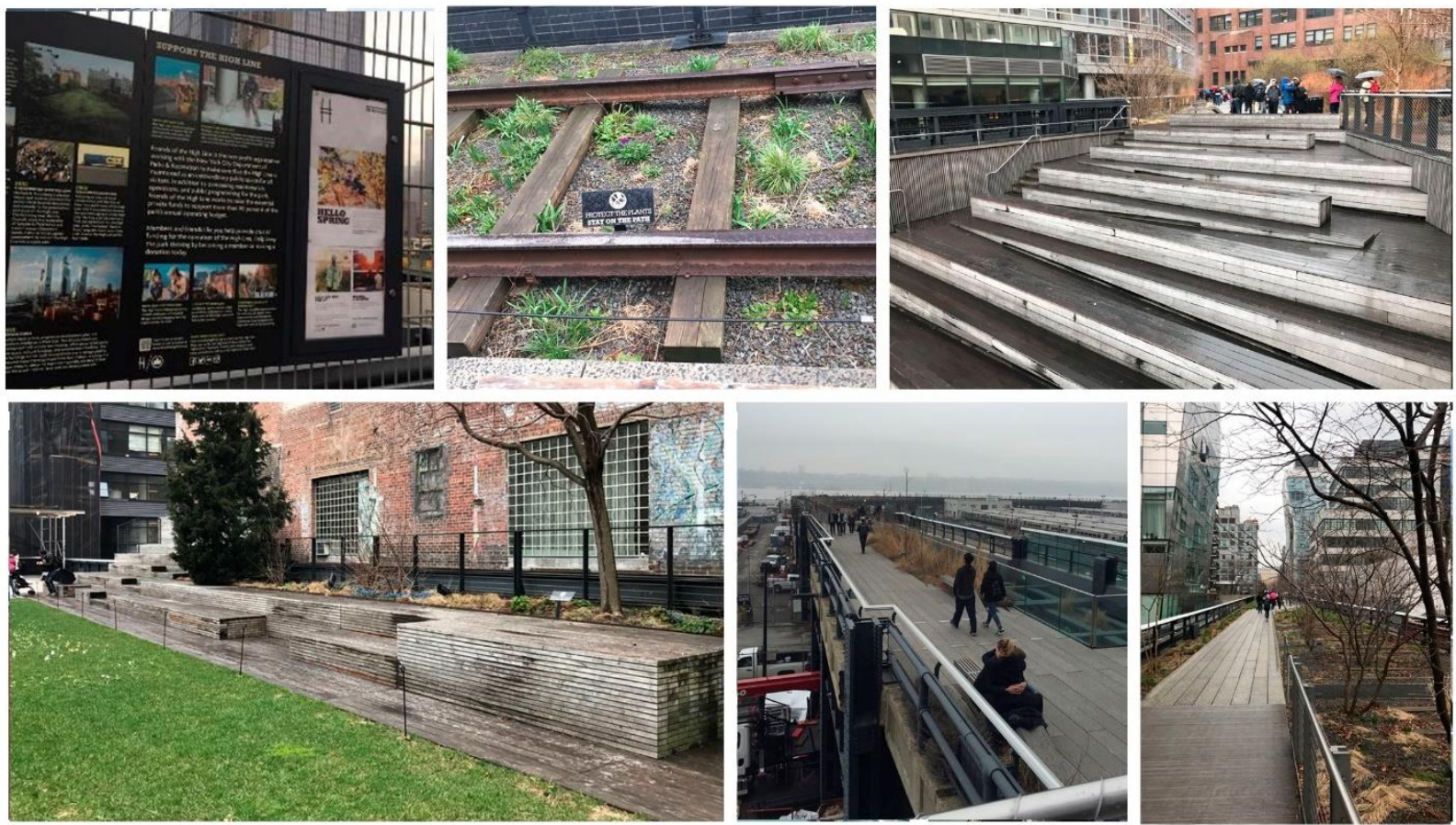

FICHA 1 I PARQUE PUBLICO - Relevado en base a la matriz propuesta para el relevamiento de espacios verdes.312 Fuente: imágenes del autor, 2018 


\section{PARQUE DE LA VILLETTE I PARIS}

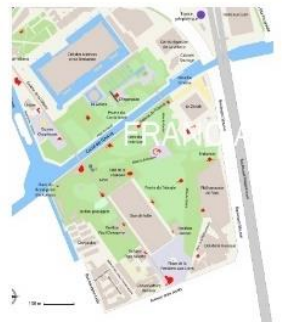

MOBILIARIO

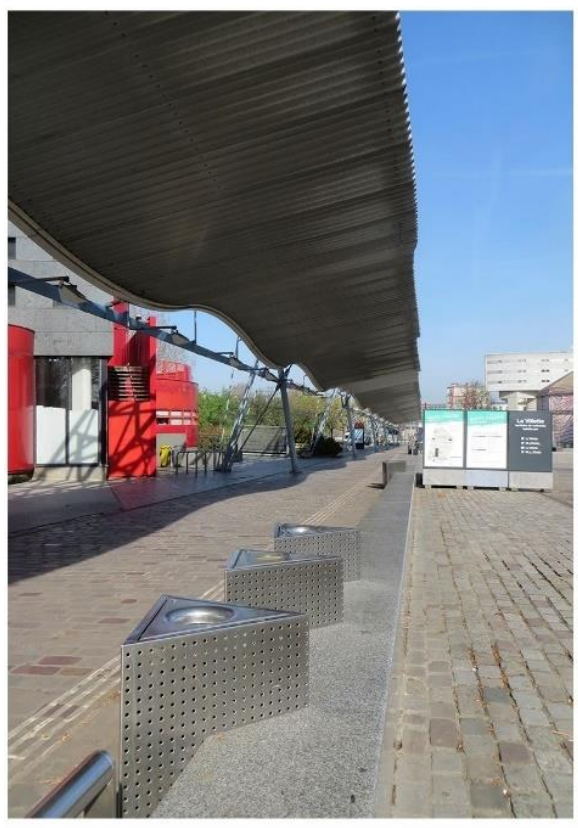

\section{SENDEROS Y VEGETACIÓN}

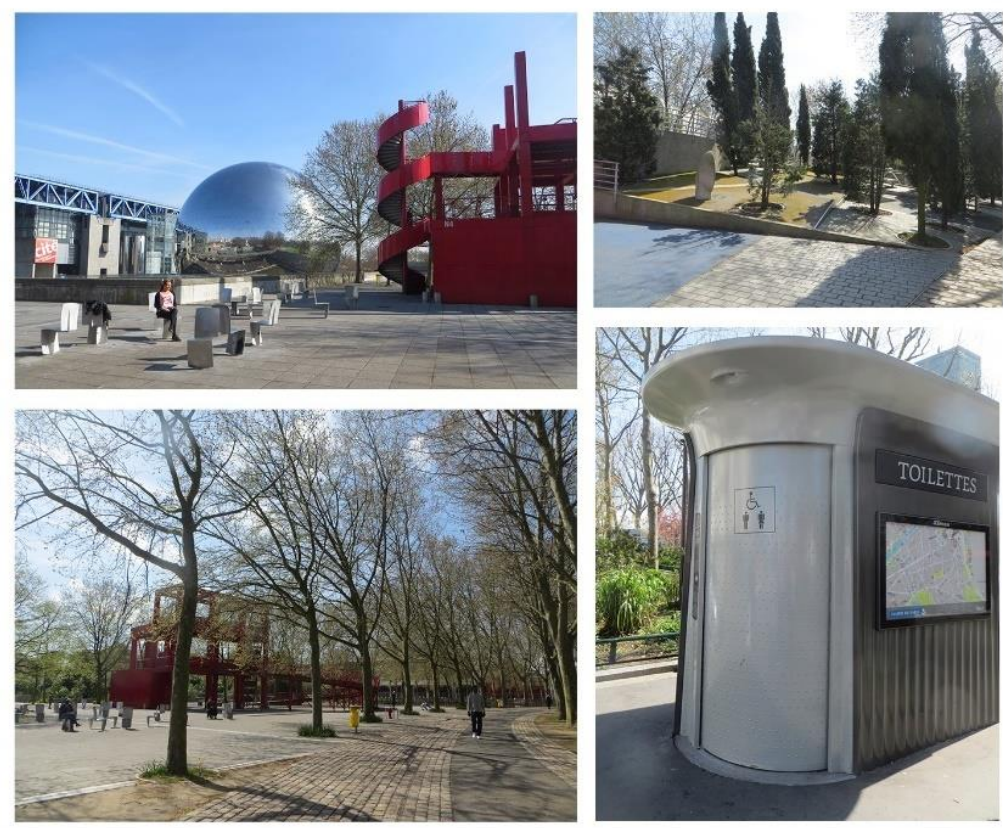

\section{SEÑALÉTICA PRESENCIA DE AGUA}
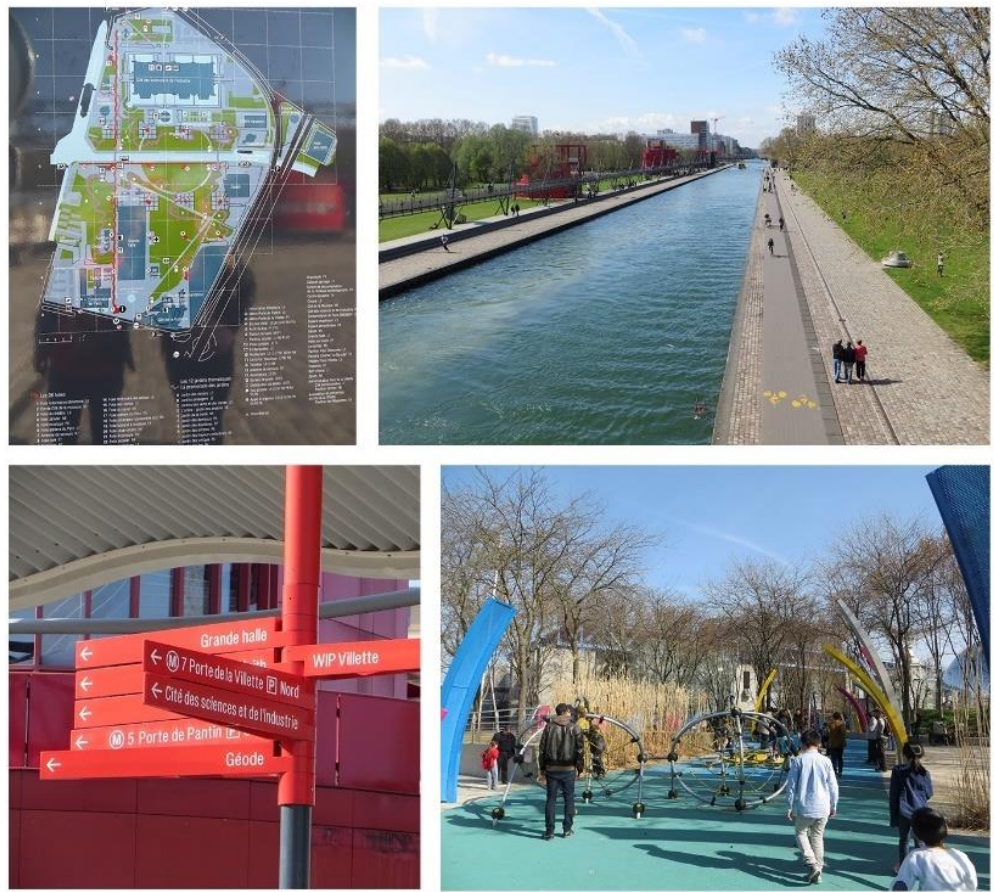

JUEGOS PARA NIÑOS

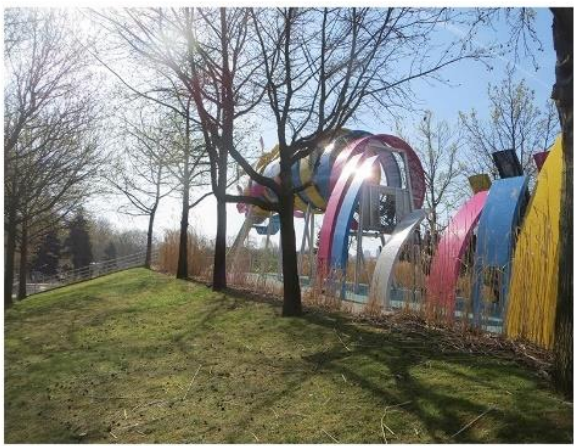

FICHA 2 I PARQUE PUBLICO - Relevado en base a la matriz propuesta para el relevamiento de espacios verdes

Fuente: imágenes del autor, 2015

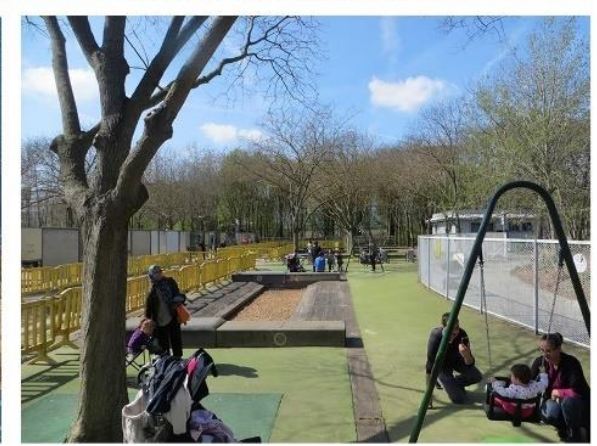




\section{PARQUE GÜELL I BARCELONA}
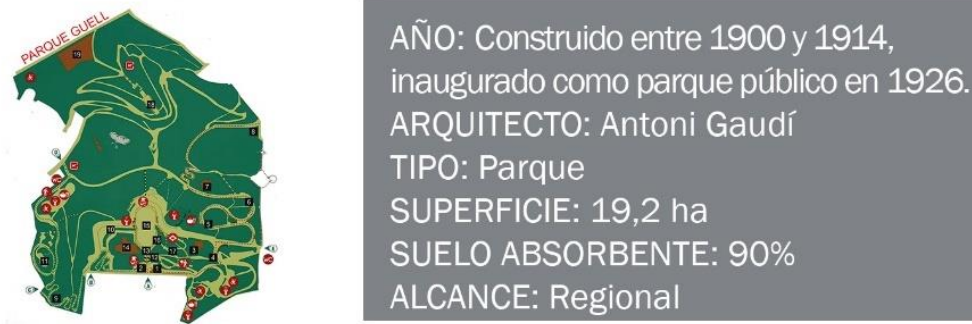

AÑO: Construido entre 1900 y 1914 inaugurado como parque público en 1926. ARQUITECTO: Antoni Gaudí TIPO: Parque

SUPERFICIE: 19,2 ha

SUELO ABSORBENTE: $90 \%$

ALCANCE: Regional

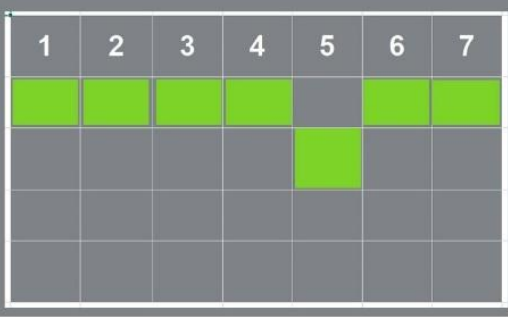

\section{SENDEROS Y VEGETACIÓN}
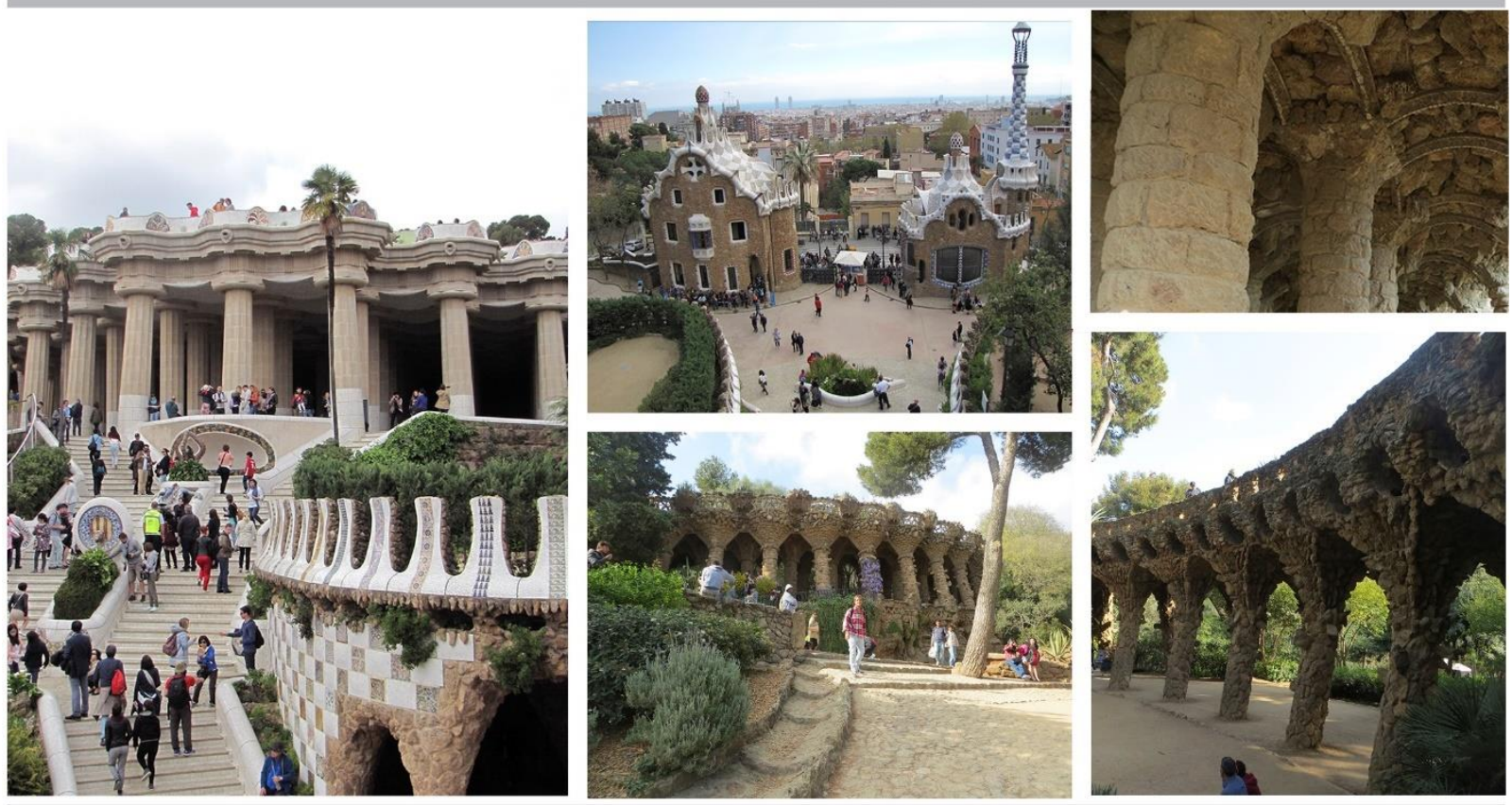

\section{SEÑALÉTICA PRESENCIA DE AGUA MOBILIARIO}
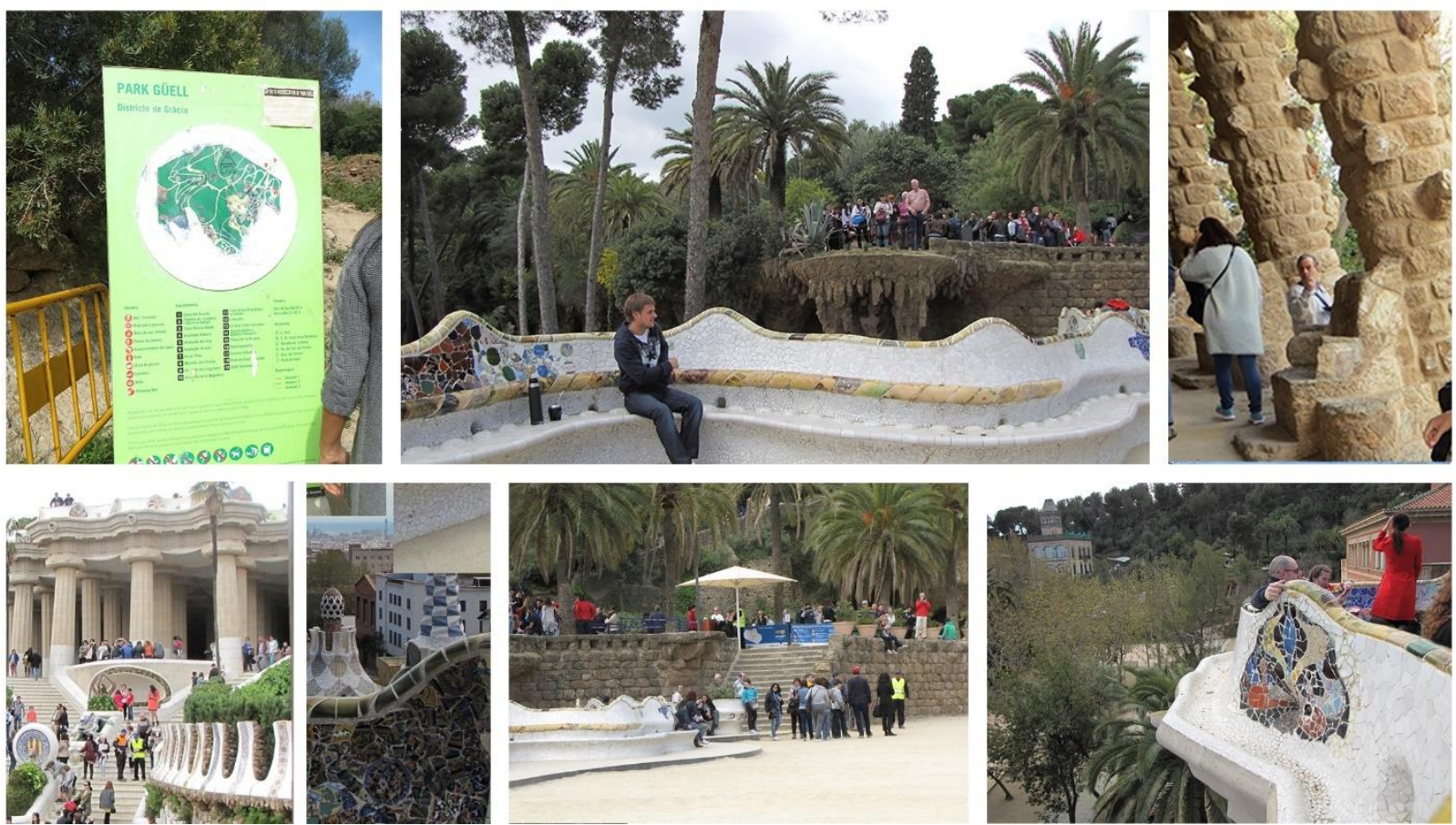

FICHA 3 I PARQUE PUBLICO - Relevado en base a la matriz propuesta para el relevamiento de espacios verdes 314

Fuente: imágenes del autor, 2015 


\title{
JARDINES DEL BUEN RETIRO I MADRID
}

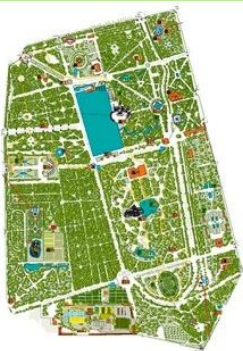

\author{
AÑO: 1868 \\ TIPO: Parque \\ SUPERFICIE: 118 ha. \\ SUELO ABSORBENTE: $80 \%$ \\ ALCANCE: Regional
}

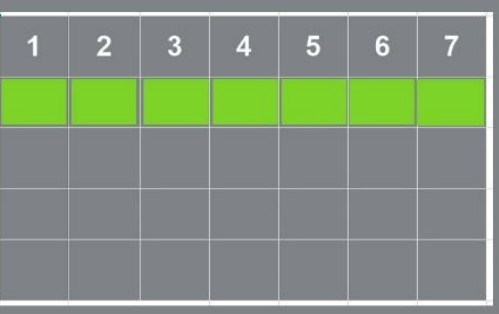

\section{SENDEROS Y VEGETACIÓN}
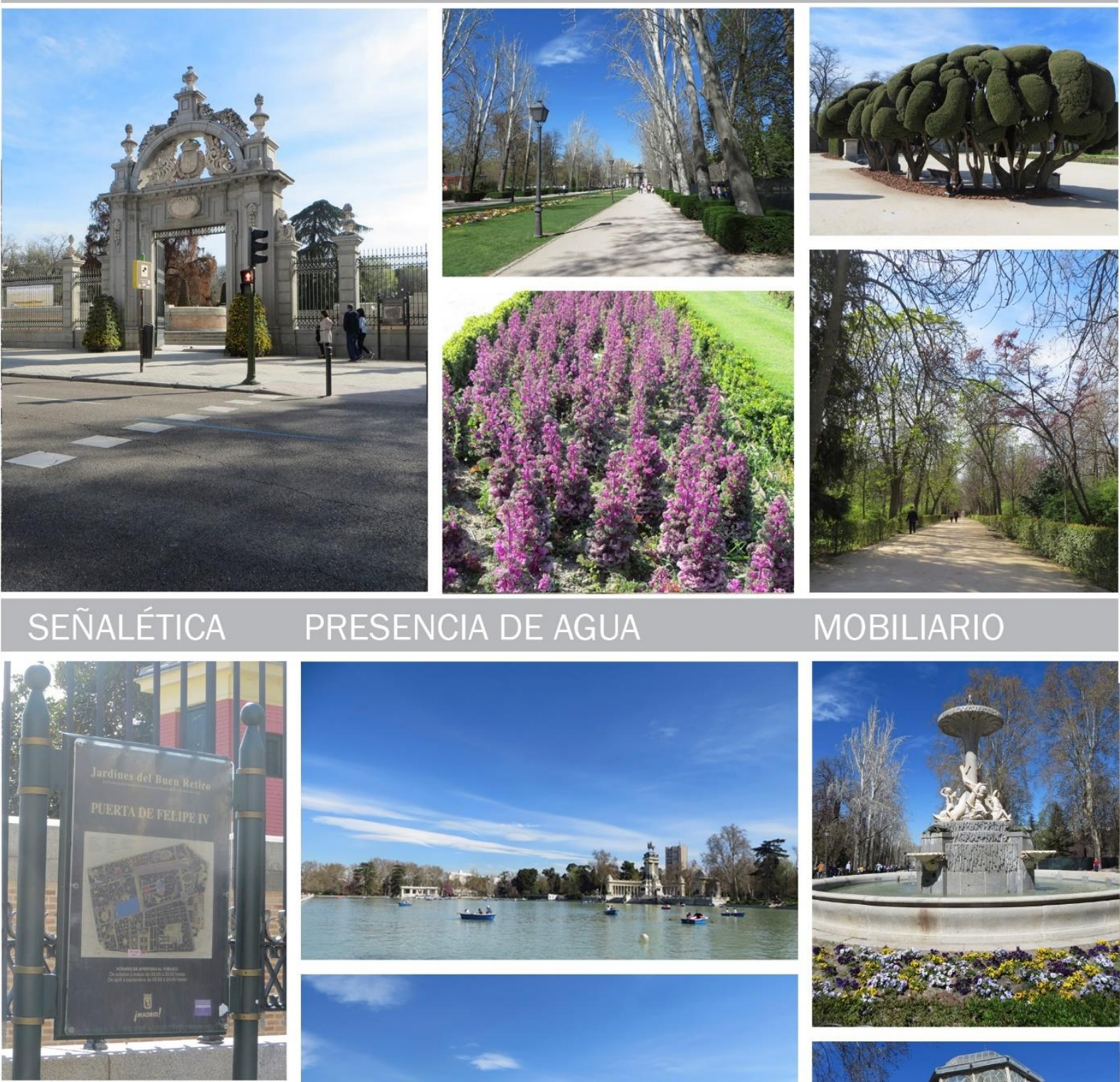

PRESENCIA DE AGUA

MOBILIARIO
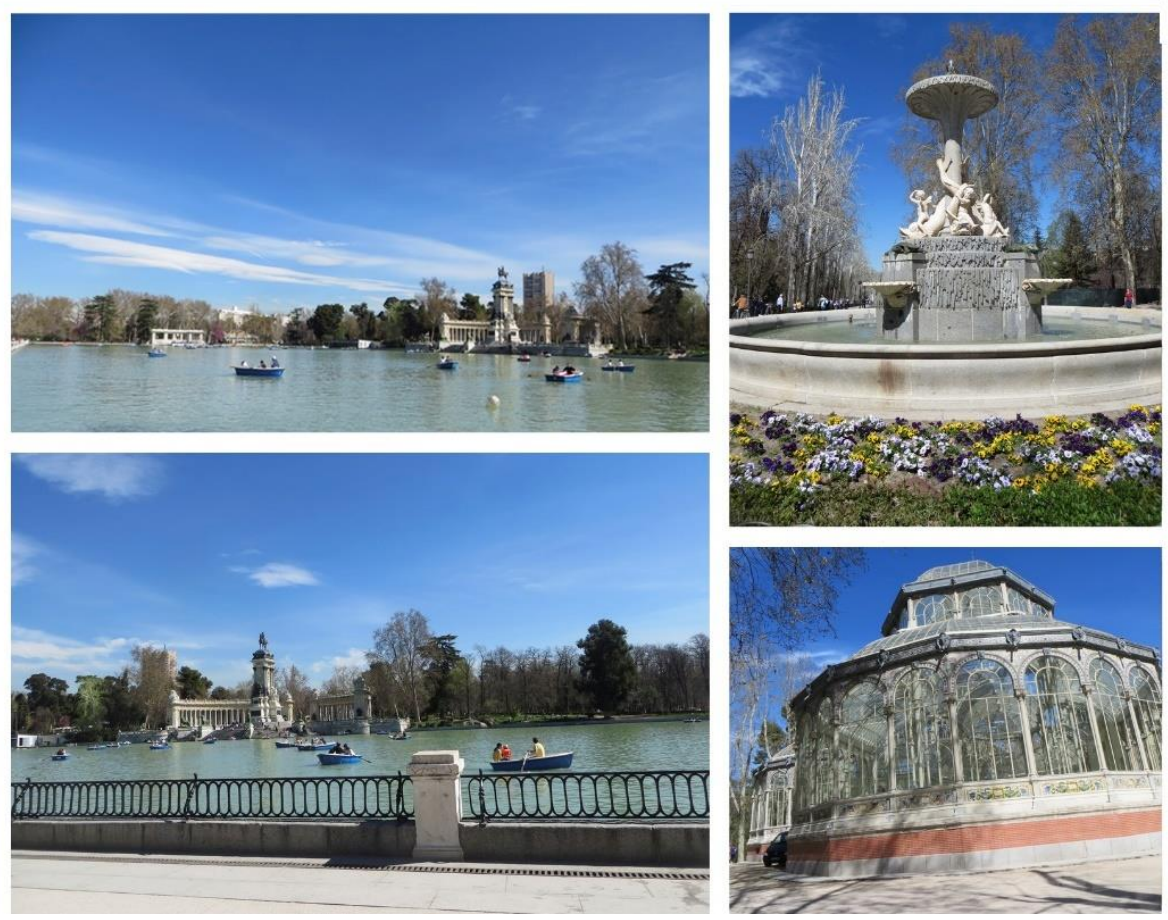

FICHA 4 I PARQUE PUBLICO - Relevado en base a la matriz propuesta para el relevamiento de espacios verdes 315

Fuente: imágenes del autor, 2015 


\section{CENTRAL PARK I NUEVA YORK}

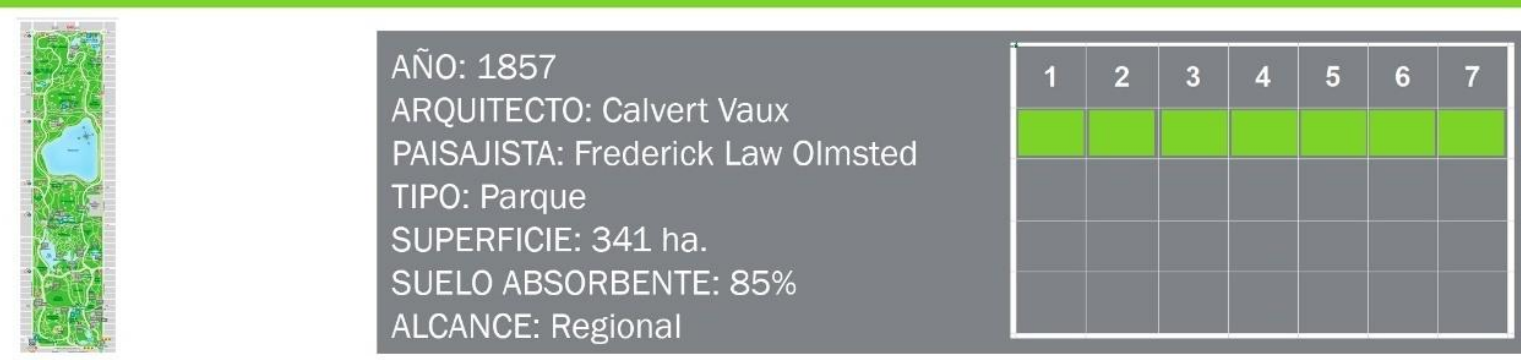

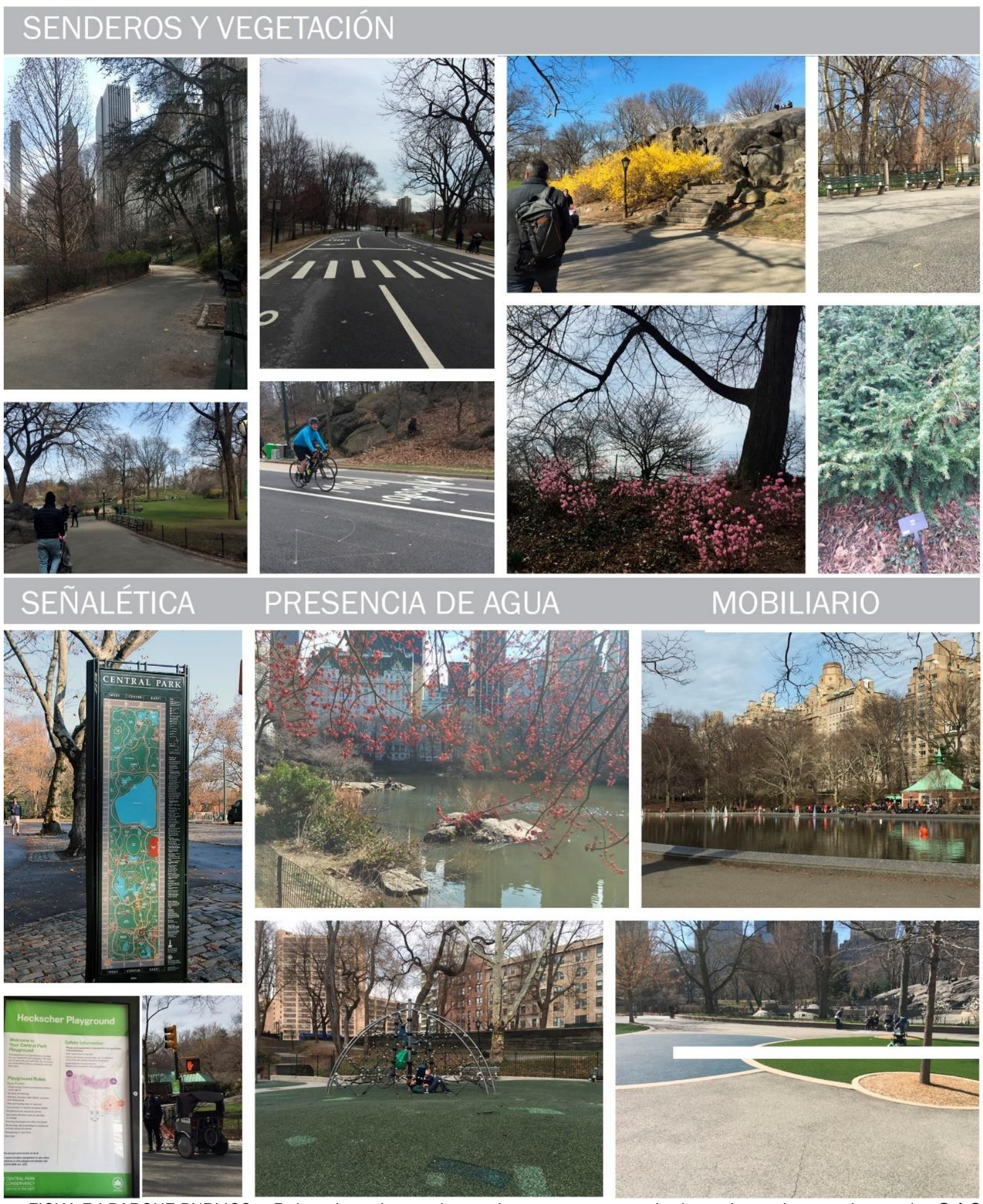

FICHA 5 I PARQUE PUBLICO - Relevado en base a la matriz propuesta para el relevamiento de espacios verdes 316

Fuente: imágenes del autor, 2018 


\section{HYDE PARK I LONDRES}

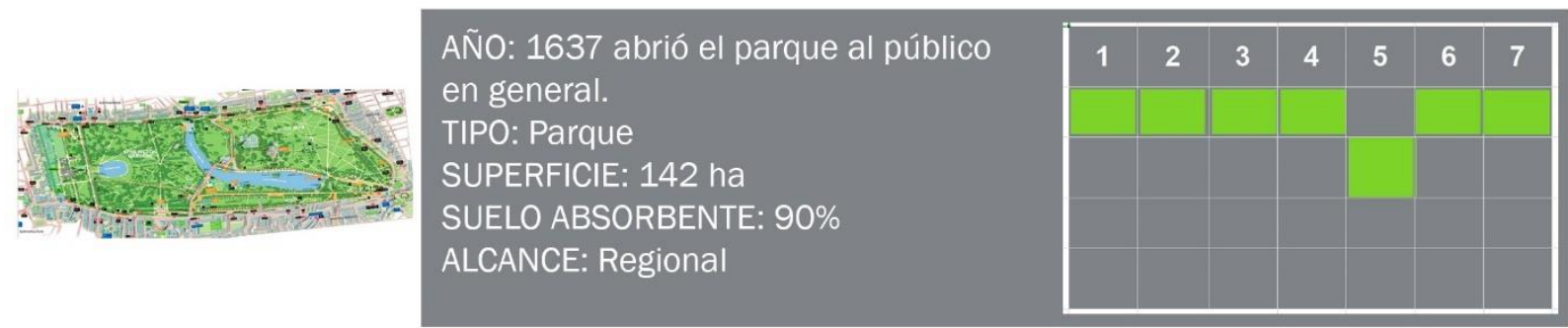

\section{SENDEROS Y VEGETACIÓN \\ PRESENCIA DE AGUA}
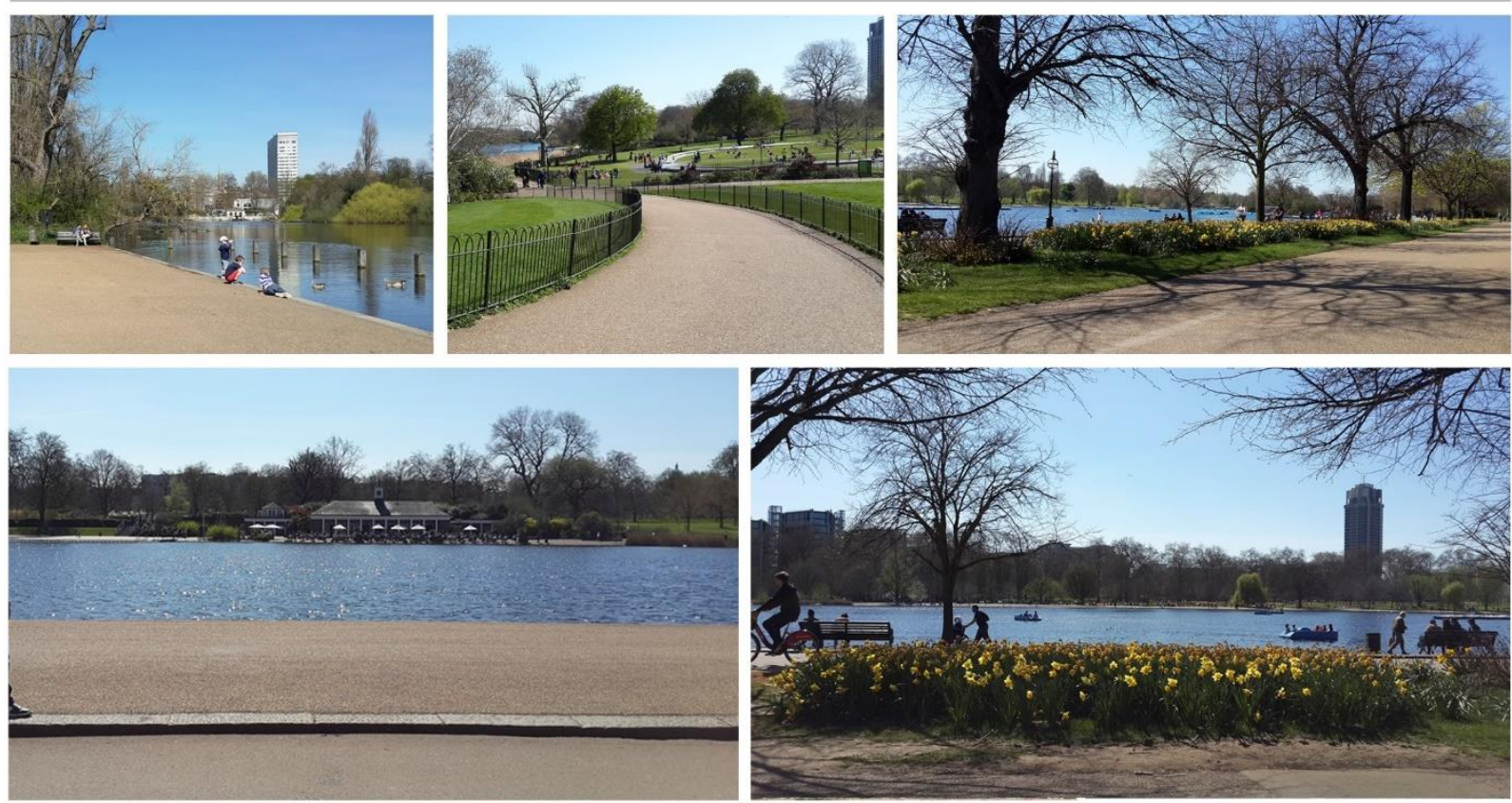

SEÑALÉTICA

MOBILIARIO
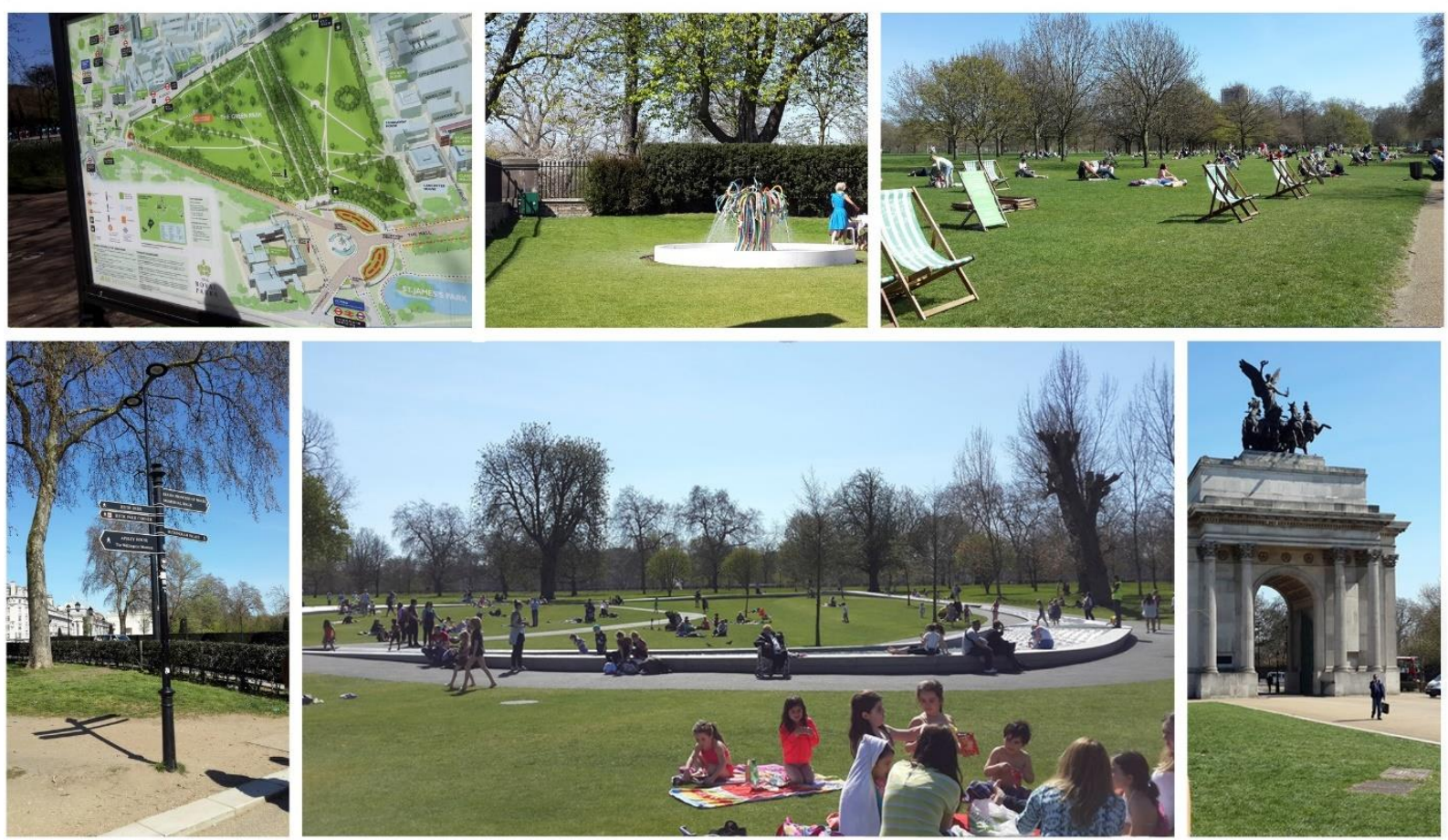

FICHA 6 I PARQUE PUBLICO - Relevado en base a la matriz propuesta para el relevamiento de espacios verdes 317 Fuente: imágenes del autor, 2018 
PAISAJES VACANTES

ANEXO 8

Ficha de relevamiento de la cantera de Gorina 


\section{CANTERA DE GORINA I LA PLATA}

ANEXO 8

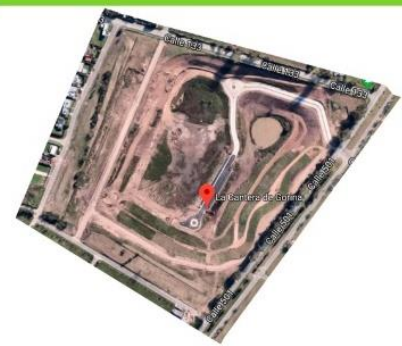

AÑO: 2013

TIPO: Parque

SUPERFICIE: 13 ha.

SUELO ABSORBENTE: 90\%

ALCANCE: URBANO

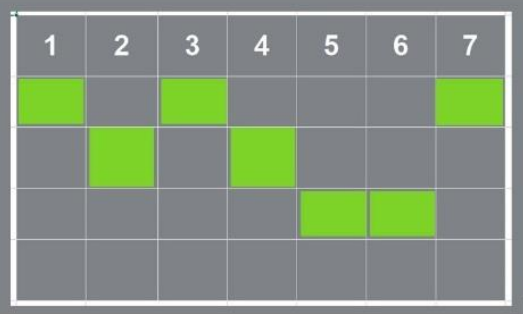

SENDEROS Y VEGETACIÓN
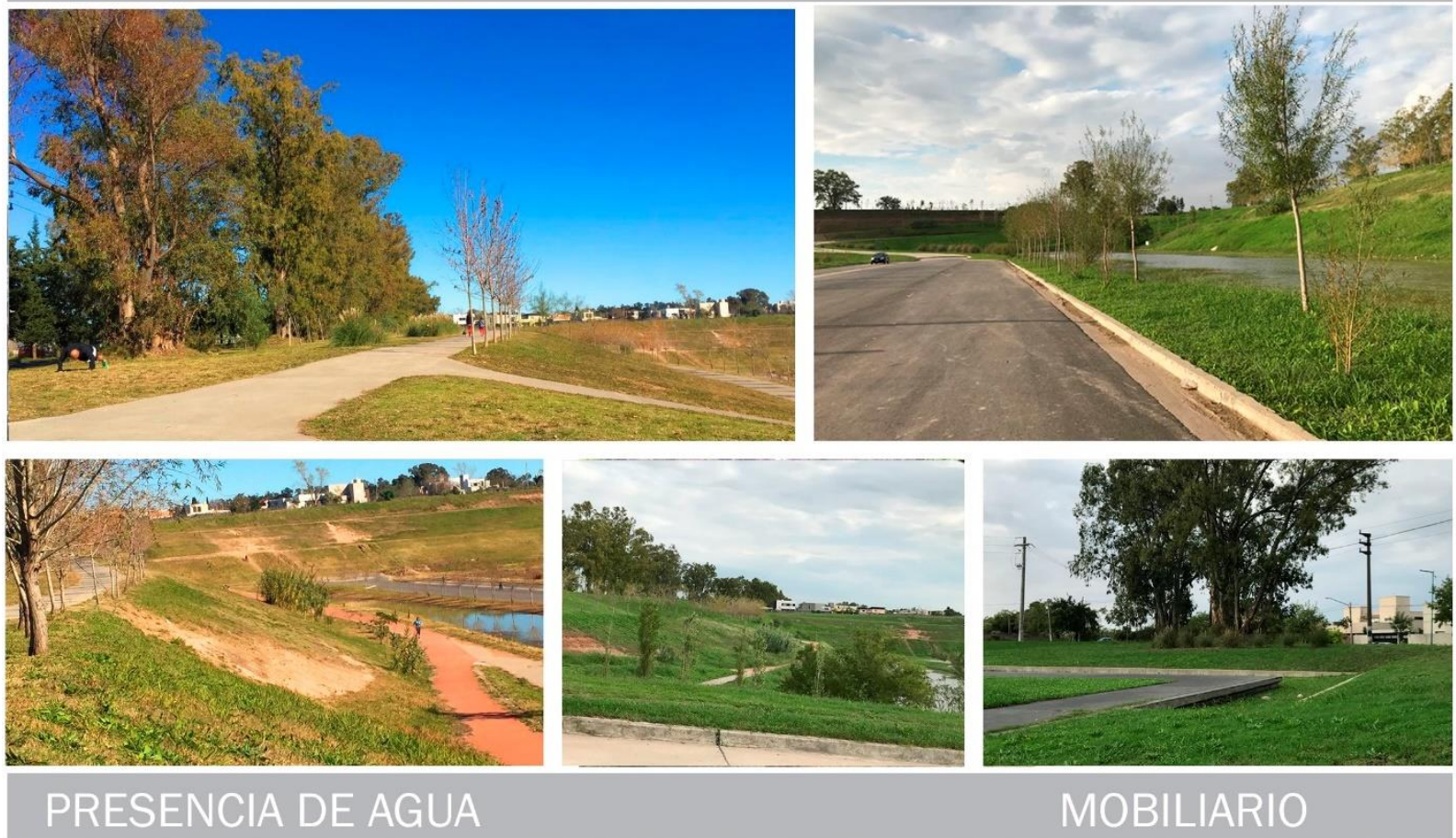

MOBILIARIO
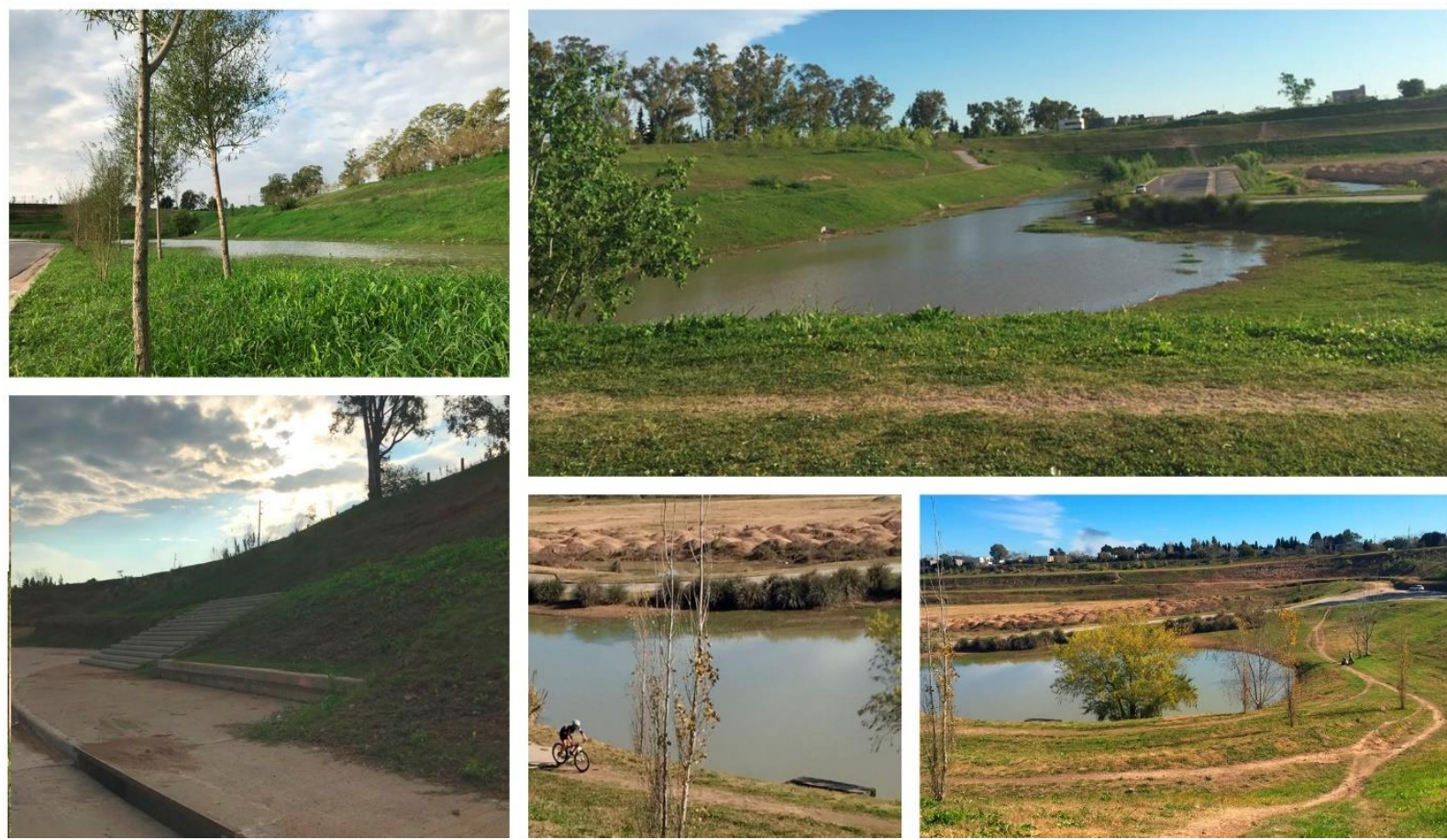

FICHA CANTERA GORINA - Relevado en base a la matriz propuesta para el relevamiento de espacios verdes.

Fuente: imágenes del autor, 2018 


\section{CANTERA DE GORINA I LA PLATA}
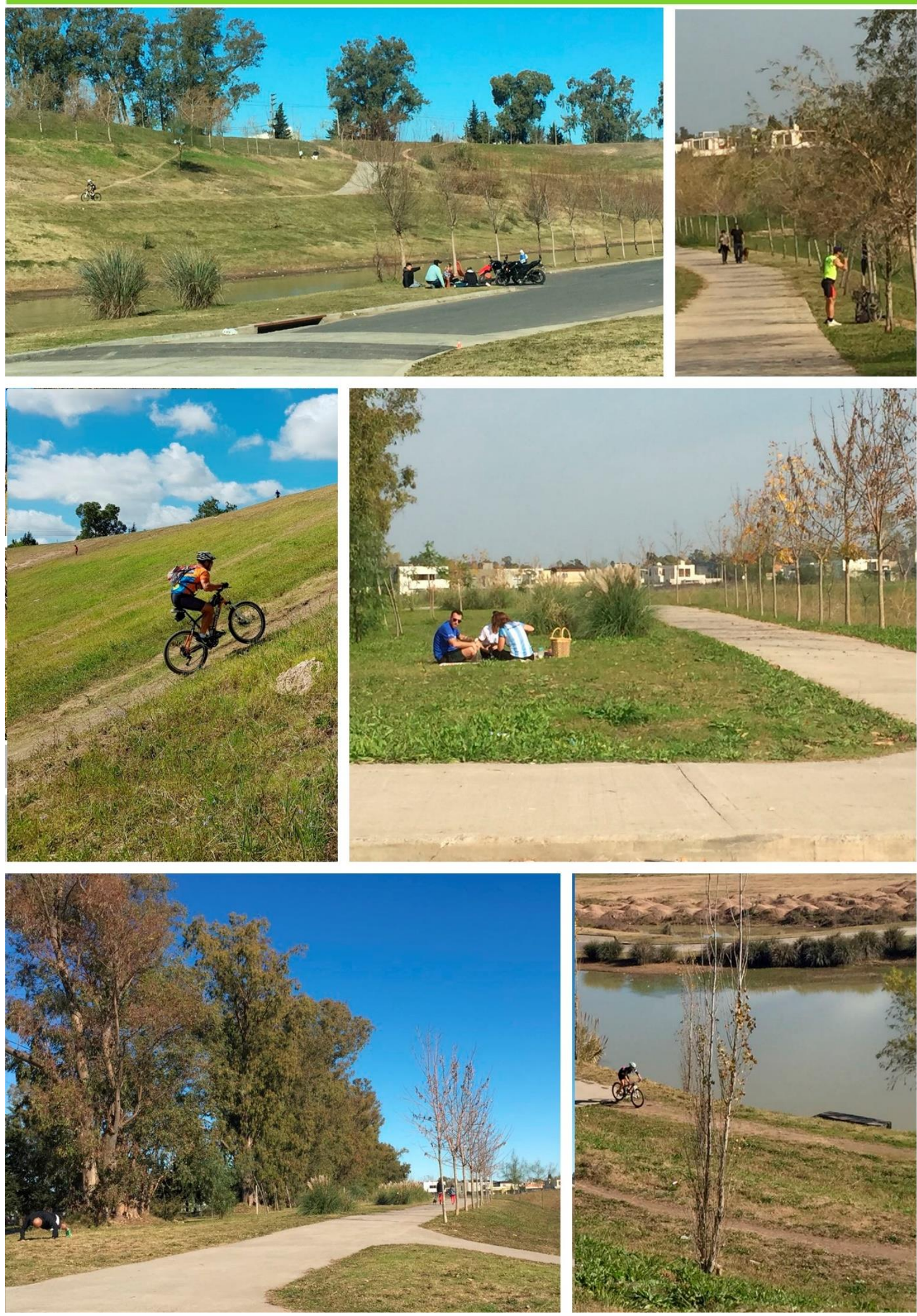


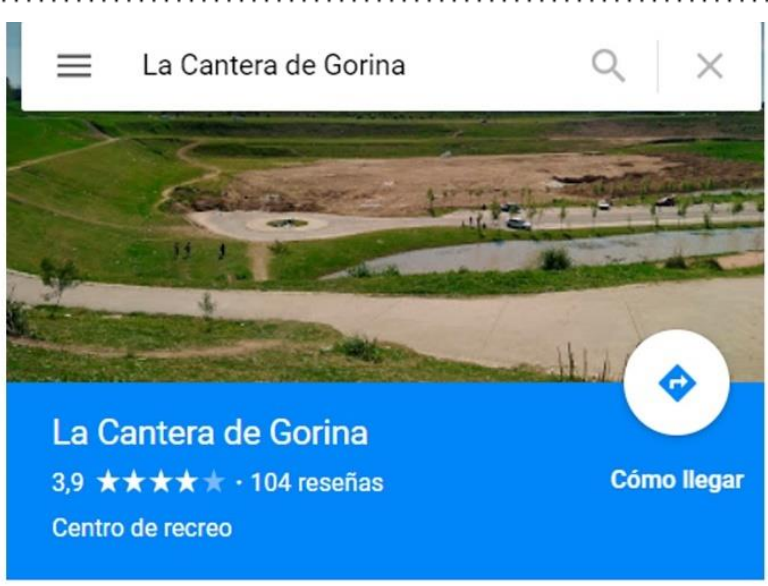

(2) the

ocal Guide $\cdot 56$ reseñas $\cdot 16$ fotos

:

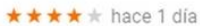

Lugar familiar, tranquilo para compartir

I 1 Megusta $<$ compartir

(2)

Pablo Schaaf

Local Guide $\cdot 83$ reseñas $\cdot 150$ fotos

$\star \star \star \star \star \star * 3$ semanas atrás

Hermoso lugar para pasar la tarde y quemar energia con los niños andando en bicicleta. A veces copan el lugar los wachitos motomel y hacen explosiones con las motos...por lo demás es un lugar único en la

zona.

It $1<$ compartir

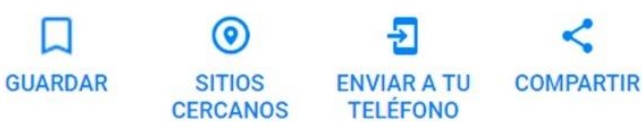
- B1897FTM, Calle 501 3899-4117, B1897FTE Gonnet, Buenos Aires
$\checkmark$ Reclamar esta empresa
- Añadir una etiqueta
SUGERIR UNA CORRECCIÓN

Añadir la información que falta (?)
C. Añadir número de teléfono
() Añadir horario
(4) Añadir sitio web

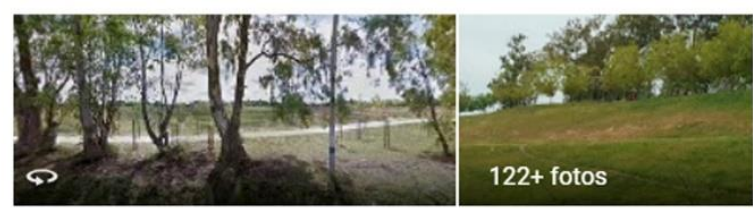

O Añadir una foto

Resumen de reseñas
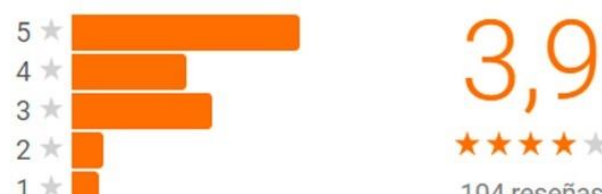

$\star \star \star \star \star$

104 reseñas

"Excelente lugar para entrenar para los deportistas."

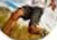

"Fuimos con el grupo de entrenamiento y nos encantó"

"Muy bueno para divertirse con la bicicleta, poca sombra y nada para comprar"

2. ESCRIBIR UNA RESEÑA
Mariano Bertholet

Local Guide - 96 reseñas - 89 fotos

$\star \star \star \star \star 44$ meses atrás

Excelente lugar para practicar deportes al aire libre, sobre todo mountain bike y correr

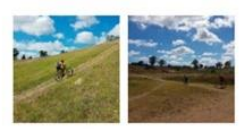

It) Megusta $<$ Compartir

Peci Cam

Local Guide $\cdot 3$ reseñas $\cdot 20$ fotos

$\star \star \star \star \star 4$ meses atrás

Excelente espacio donde podemos entrenar de

forma segura para quienes buscan mejorar su forma de vida

It Megusta $<$ compartir

Martin Sanchez
Local Guide $\cdot 58$ reseñas $\cdot 5$ fotos

$\star \star \star \star \star \star * 2$ meses atrás

Un lugar a la espera de urbanización. Posee un

parque de uso público. La particularidad y novedad

es la refuncionalización de una antigua cantera

como parte de la ciudad.

It Me gusta $<$ compartir

(n)

Dina Ravana

Local Guide $\cdot 13$ reseñas $\cdot 238$ fotos

$\star \star \star \star \star \star 2$ meses atrảs

Linda vista y tranquilo para caminar

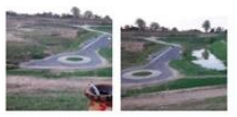

Me gusta $<$ compartir

D Dario Fajre

13 reseñas

$\star \star \star \star \star 4$ semanas atrás Muy bueno para practicar deporte aerobico.

It Me gusta $<$ Compartir

MARIA ALEJANDRA MANSILLA

Local Guide $\cdot 26$ reseñas $\cdot 76$ fotos

$\star \star \star \star \star$ un mes atrás

Excelente para nuestros entrenamientos! Aguante el

TEAM E.M.!I!

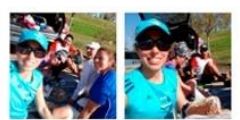

Reseña de los usuarios de la cantera en Google. Fuente: www.google.com.ar, 2018 
PAISAJES VACANTES

ANEXO 9 Información en GIS 


\section{SISTEMA DE INFORMACION GEOGRAFICA}

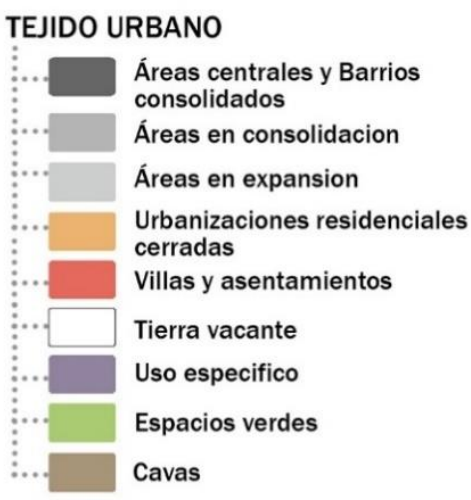

HIDROLOGÍA

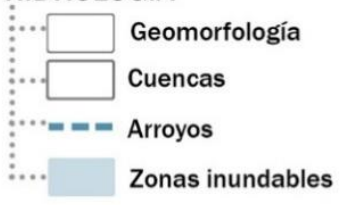

RED VIAL

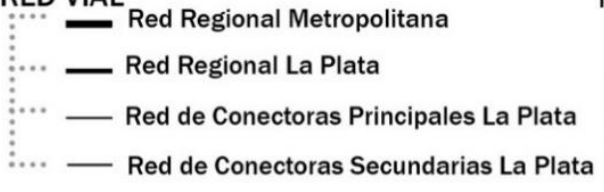

USOS DEL SUELO - COU

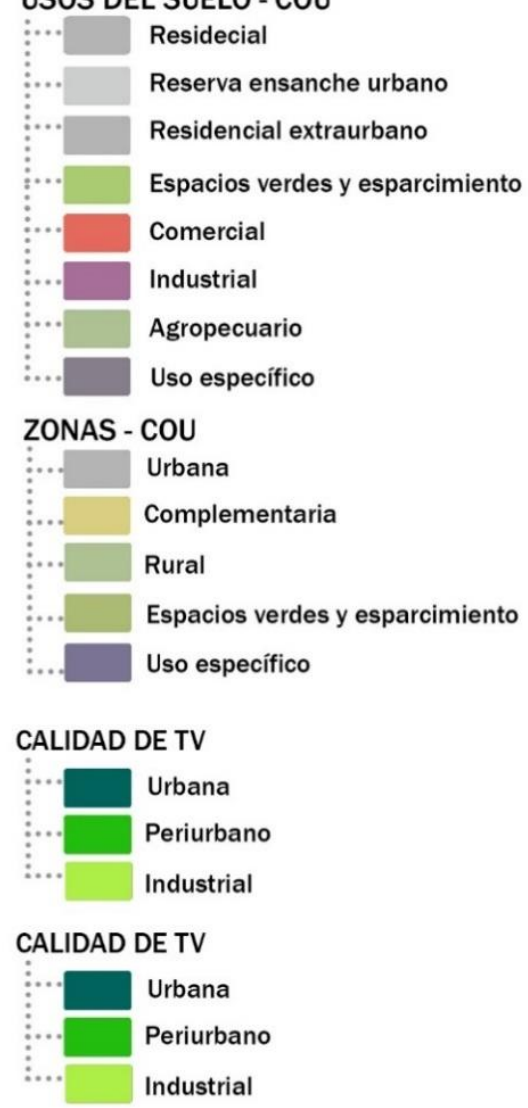

LÍMITES JURISDICCIONALES

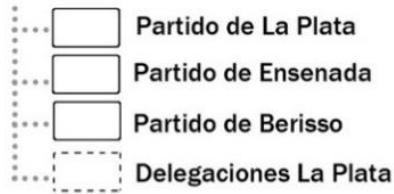

CENSO NACIONAL DE POBLACIÓN

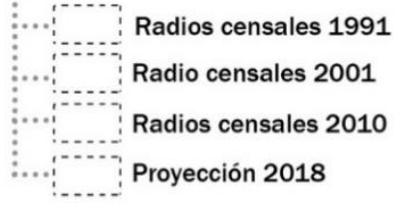

ZONAS DE ANÁLISIS

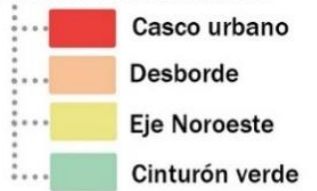

MANCHA URBANA

:... Según COU

Según ARBA

Según relevamiento por Google

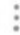

\section{ESPACIOS VERDES}
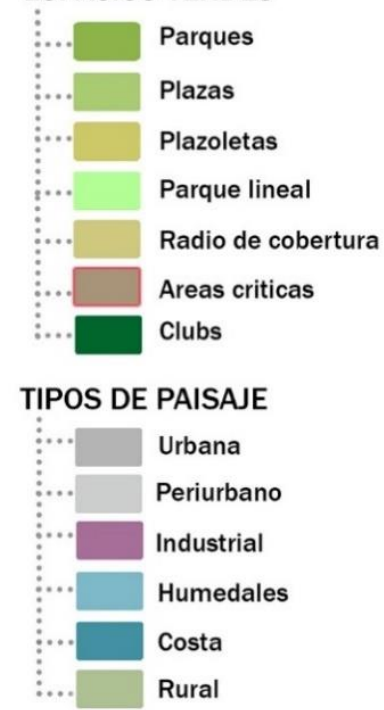

TIPO DE ESPACIO VERDE PROPUESTO

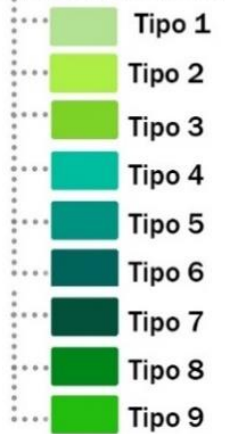




\section{MAPAS ELABORADOS EN GIS}

Figura 18. Plano de la ciudad de La Plata con la mancha urbana que propone el código y la mancha urbana real.

\section{Fuente de la información:}

Mancha urbana relevada mediante foto satelital 2016.

Uso urbano del Código de ordenamiento urbano (2010) www.consejodeliberante.laplata.gov.ar

Parcelas urbanas según ARBA obtenidas de www.carto.arba.gov.ar

Figura 19. El corrimiento del cinturón frutihortícola platense.

Fuente de la información:

Mancha urbana elaborada mediante foto satelital de 2016.

Tendencia de corrimiento en base a relevamiento realizado.

Figura 35. Las zonas de la periferia platense.

Fuente de la información:

Mancha urbana relevada mediante foto satelital.

Zonas de la periferia delimitadas en base a las delegaciones y el código de espacio público (2010).

Figura 20. Estructura urbana.

Fuente de la información:

Areas consolidadas establecidas en base a la zona con cobertura de servicios y la densidad.

Barrios cerrados, asentamientos informales, tierras vacantes y espacios verdes relevados mediante fotos satelitales de 2016.

Figura 37. Plano de áreas

Fuente de la información:

Areas establecidas según el código de ordenamiento urbano (2010)

Tierras vacantes y espacios verdes relevados mediante foto satelital 2016 y verificadas en campo. Tendencia de crecimiento en base a relevamiento de la región realizado mediante fotos satelitales.

Figura 39. Espacios verdes de uso público.

Fuente de la información:

Espacios verdes relevados mediante foto satelital 2016 y verificadas en campo.

Figura 40. $\mathrm{m} 2$ de área verde por habitante según zona de la periferia.

Fuente de la información:

Mancha urbana relevada mediante foto satelital.

Zonas de la periferia delimitadas en base a las delegaciones y el código de espacio público.

M2 de espacio verde relevados mediante foto satelital 2016 y verificadas en campo.

Figura 43. Tipos de paisaje.

Fuente de la información:

Tipos de paisaje definidos en base al uso predominante de cada área relevado mediante foto satelital (2016) y verificado según el uso.

Figura 45. Plano con las zonas de la periferia y los EVUP total y a escala urbana.

\section{Fuente de la información:}

Mancha urbana relevada mediante foto satelital 2016.

Zonas de la periferia delimitadas en base a las delegaciones y el código de espacio público (2010). Espacios verdes relevados mediante foto satelital 2016 y verificadas en campo.

Figura 21. Radios de cobertura de áreas verdes en la periferia.

Fuente de la información:

Mancha urbana relevada mediante foto satelital 2016.

Espacios verdes relevados mediante foto satelital 2016 y verificadas en campo.

Radios de cobertura realizados mediante un buffer de cada espacio verde con la distancia propuesta como mínima.

Figura 22. Zonas sin cobertura de áreas verdes en la periferia.

Fuente de la información:

Mancha urbana relevada mediante foto satelital 2016.

Espacios verdes relevados mediante foto satelital 2016 y verificados en campo.

Radios de cobertura realizados mediante un buffer de cada espacio verde con la distancia propuesta como mínima.

Áreas sin cobertura de espacios verdes delimitadas en base a los buffers realizados. 
Figura 23. Las TV en zona urbana en la periferia platense.

Fuente de la información:

Uso urbano del Código de ordenamiento urbano (2010)

Tierras vacantes relevadas mediante foto satelital 2016 y verificadas en campo.

Figura 24. Preselección de las TV.

Fuente de la información:

Uso urbano del Código de ordenamiento urbano (2010)

Tierras vacantes relevadas mediante foto satelital 2016 y verificadas en campo.

Figura 60 . Tierras vacantes como espacios verdes potenciales y radios de cobertura.

Uso urbano del Código de ordenamiento urbano (2010)

Tierras vacantes relevadas mediante foto satelital 2016 y verificadas en campo.

Radios de cobertura realizados mediante un buffer de cada espacio verde con la distancia propuesta como mínima.

Figura 63. Calidad de paisaje en las tierras vacantes seleccionadas.

Fuente de la información:

Uso urbano del Código de ordenamiento urbano (2010)

Tierras vacantes relevadas mediante foto satelital 2016 y verificadas en campo.

Calidad de paisaje en base al relevamiento realizado mediante foto satelital 2016 y verificación en campo.

Figura 25. Los espacios verdes propuestos.

Fuente de la información:

Mancha urbana relevada mediante foto satelital 2016.

Espacios verdes relevados mediante foto satelital 2016 y verificados en campo.

Figura 26. Las tierras vacantes según calidad de paisaje y tipos de paisaje.

Fuente de la información:

Mancha urbana relevada mediante foto satelital 2016.

Tierras vacantes relevadas mediante foto satelital 2016 y verificadas en campo.

Calidad de paisaje en base al relevamiento realizado mediante foto satelital 2016 y verificación en campo.

Tipos de paisaje definidos en base al uso predominante de cada área relevado mediante foto satelital (2016) y verificado según el uso.

Figura 70. Espacios verdes propuestos por tipo.

Fuente de la información:

Mancha urbana relevada mediante foto satelital 2016.

Tierras vacantes relevadas mediante foto satelital 2016 y verificadas en campo.

Tipo de espacio verde propuesto en base a relevamiento realizado.

Todos los mapas anteriormente descriptos fueron realizados en QGIS versión 2.10.1

Vías principales y secundarias: relevamiento mediante foto satelital 2016 (Google earth y Maps).

Parcelario y manzanas: ARBA www.carto.arba.gov.ar

Límites provinciales, municipales, arroyos y cursos de agua: información obtenida de IGN (2017) www.ign.gob.ar 
Julio 2018

La Plata, Buenos Aires 